$$
\text { UNIVERSIDADE DE S̃̃O PAULO }
$$

MUSEU DE ARQUEOLOGIA E ETNOLOGIA

PROGRAMA DE PÓS-GRADUAÇÃO EM ARQUEOLOGIA

\title{
A flora nos vasos de linha fina Moche: marcadores ambientais e localizadores
}

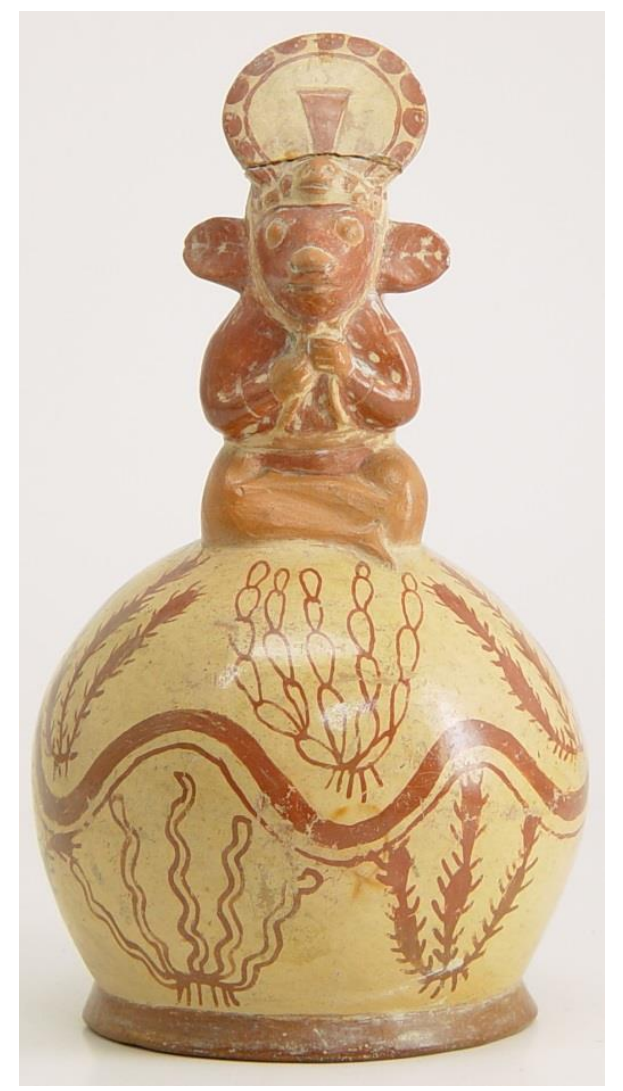

Bruno Tripode Bartaquini

São Paulo 


\section{UNIVERSIDADE DE SÃO PAULO \\ MUSEU DE ARQUEOLOGIA E ETNOLOGIA \\ PROGRAMA DE PÓS-GRADUAÇÃO EM ARQUEOLOGIA}

\section{A flora nos vasos de linha fina Moche: marcadores ambientais e localizadores}

Dissertação de Mestrado apresentada ao Programa de Pós-Graduação em Arqueologiado Museus de Etnologia e Arqueologia da Universidade de São Paulo.

Orientador: Prof.Dr. Rui Sérgio S. Murrieta

Linha de pesquisa: Arqueologia e sociedade 


\section{RESUMO}

Os Moche, cultura arqueológica existente na costa norte peruana entre os séculos I e VIII d.C, desenvolveram uma tradição ceramista de produção de vasos com pictografias de "linha-fina". Um motivo constante nos vasos de linha fina são o que o estudioso Cristopher Donnan chamou de "localizadores": determinadas plantas, animais e outros signos, como ondas, por exemplo, que serviriam como marcadores de paisagem, indicando o cenário onde a ação representada dos vasos estariam se dando.

Porém, apesar de muito referidos os "localizadores" jamais foram objeto de um estudo sistemático. Este estudo busca mapear a flora nativa regional a fim de refinar as associações das espécies com a cerâmica e produzir olhar detalhado sobre função semântica da flora nas composições de linha fina Moche, aproximando os "localizadores" ao conceito de ecótopos, como "tipos de lugares" e "unidades mínimas de paisagem" como definido por Jhonson \& Hunn (2010)

Palavras-chave: Moche, iconografia, paisagem, localizadores, ecótopos 


\begin{abstract}
The Moche, an archaeological culture that existed on the north coast of Peru between the first and nineth centuries A.D, have developed a pottery tradition with "fine-line" pictographs. A constant motif in the fine line vessels is what the scholar Christopher Donnan has called "locators": certain plants, animals, and other signs, such as waves, for example, that would serve as markers of landscape, indicating the setting where the actionr represented on the vessels would be developing.

However, although much referred, the "locators" have never been the subject of a systematic study. This study aims to map regional native flora in order to refine species associations with pottery and to produce a detailed look at the semantic function of the flora in the Moche fine line compositions, bringing the "locators" closer to the concept of ecotopes, such as "types of places" and "Minimum landscape units" as defined by Jhonson \& Hunn (2010)
\end{abstract}

Key-words: Moche, iconography, landscape, locators, ecotopes 


\section{DEDICATÓRIA}

Amico mio che stai/Guardando intorno a te Non credi algli occhi tuoi/Tu piangi e so' il perche' Quel che provi tu/Lo sto provando anch'io Non cambiare mai/Ti fa paura il mondo Amico mio coraggio/ Io, io piango come te.

Giannni Morandi

Dedico este trabalho à memória de meu pai, Joel Bartaquini. Sua alegria e generosidade fazem muita falta neste mundo de sombras. 


\section{AGRADECIMENTOS}

Agradeço aos meus pais Joel e Angelina pelo sangue e suor incalculáveis dedicados na minha criação. Agradeço a minha companheira Mariana por ter suportado com determinação a injusta condição de mulher trabalhadora, criando uma criança ao lado de alguém que teve de dedicar um tempo que não tinha para completar uma tarefa fascinante, mas socialmente desvalorizada. Agradeço a minha amada filha, Catarina, por, mesmo sem saber, arcar com as ausências de seu pai e continuar sendo uma criança alegre e radiante. Agradeço ao meu irmão Renan por ter aguentado minha personalidade pentelha desde que nasceu. Vocês são minha família e nada pode ser mais sublime do que a resistência enraizada na batalha cotidiana. Se me sinto amado no mundo é por causa de vocês.

Agradeço ao meu orientador Rui Murrieta que não apenas me incentivou como me recebeu de braços abertos em todos os momentos de necessidade. Sua generosidade, inteligência afiadíssima e perspicácia são $90 \%$ do que há de bom neste trabalho. Agradeço a minha co-orientadora "não declarada no IR", Márcia Arcuri, que se dedica incansavelmente a criar um jardim já com muitos frutos neste terrenão pedregoso da arqueologia pré-colombiana no Brasil. Ao professor Walter Neves pelas lições em campo. Agradeço também aos funcionários e professores do MAE que proporcionam nossa formação e estudos.

Agradeço aos bons amigos que fiz neste período de formação. Ao Diego Mañas pela amizade, consultoria botânica et.al. Ao João Augusto Rodrigues pelo companheirismo de um igual nas aulas e nas opiniões musicais. À Daniela La Chioma pela ajuda, mesmo à distância, oriunda de um profundo conhecimento sobre os mochica. À Flávia Brasil pelas ajudas e conversas sobre a "vida, o universo e tudo mais". Ao Márcio Figueiredo pela paciência que teve com as minha ignorância do tamanho de Chan Chan. À Debora Soares pela troca de ideias sobre xamanismo e correlatos.

Agradeço aos amigos peruanos Walter Alva e Ignacio Alva Menezes pela sempre generosa acolhida. Ao Victor e Tereza Vasquez que me acolheram em Trujillo e me ofereceram orientações ambientais importantíssimas para este trabalho, além do Pisco Sour. Ao Edgard Bracamonte e a equipe do Museu Tumbas Reales de Sipán pela estrutura e o apoio nas pesquisas da equipe brasileira. Ao Junior Prado por me guiar na subida do cerro Campana com paciência e rap peruano. Aos trabalhadores peruanos da escavação de Ventarrón/2017, particularmente Manuel. Aos funcionários do Museu Larco Herrera pelo fornecimento das imagens e manutenção desse museu maravilhoso. Do mesmo modo ao Museu Etnológico de Berlin por receberem o professor Rui com grande gentileza. 
Aos meus amigos da vida. Ao Guilhermo e Gleicy por terem me apresentado à antropologia e me desviado de uma carreira de investidor financeiro em ascensão (esta parte é mentira). Ao Fabio e Yara, companheiros de longa data e muitas risadas. Ao Raoni, Gabriel, Heber e Vitão, companheiros de MUB e ensaios sem música. Ao Maurício, Galli, Douglão, Heitor, Anna Paola, Rita, Carolzinha, Daniel, Andrey, Lili. Marcio, Thiaguinho, Jaymão, Raquel, Érica, Rodriguinho, Rodrigo Rezende e todos os amigos que se embrenharam no mundo do jornalismo e hoje compensam as agruras da profissão produzindo em escala industrial comentários com PH máximo de 6,5. 


\section{ÍNDICE}

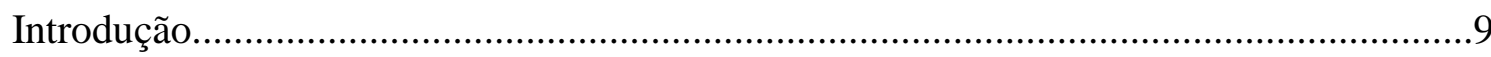

CAPÍTULO I: OS MOCHE NO CONTEXTO ANDINO.............................................11

I.I A natureza como elemento estruturante.......................................................11

I.II- Complexificação social e a costa norte peruana..........................................15

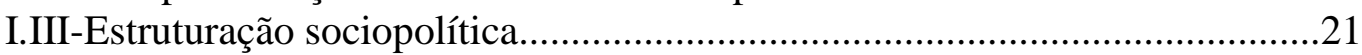

I.IV- Produção cerâmica e controle ideológico..................................................28

CAPÍTULO II: COSMOLOGIA, ICONOGRAFIA E SEMASIOGRAFIA......................31

II.I-A iconografia Moche como objeto de estudo.................................................31

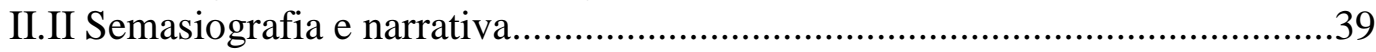

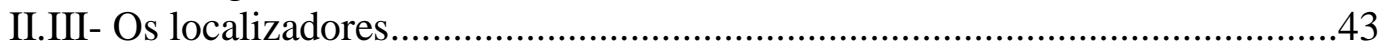

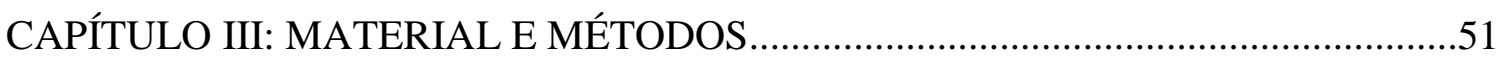

III.I - Pesquisa Bibliográfica............................................................................. 51

III.II-Análise da paisagem e identificação da flora in loco.................................53

III.III- Análise cerâmica.................................................................................61

CAPÍTULO IV : RESULTADOS I -ESTUDO DE AMBIENTE E SUGESTÃO DE

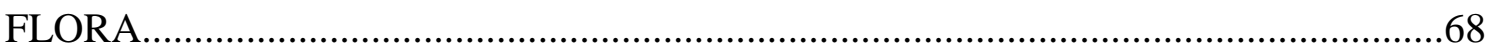

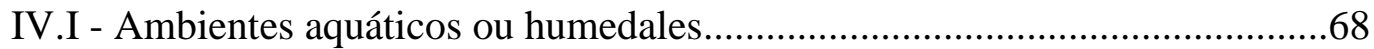

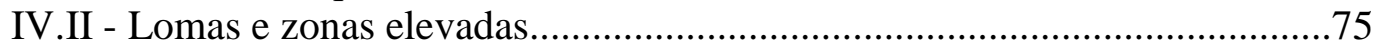

IV.III-Bosques, regiões desérticas e plantas xerófitas: árvores e arbustos..........110

CAPÍTULO V - RESULTADOS - II : ANÁLISE ICONOGRÁFICA..........................121

V.I MACRO GRUPO SINGULARES: Mundo horroroso, Panóplia...................121

V.II - MACRO GRUPO-RITOS: Badminton, Coca/músico, Sacrifício, Batalha, Corrida, Ave guerreira, Guerreiro vigilante......................................................126

V.III-MACRO GRUPO NATURALISTAS: flora, montanha, caça de aves , ave, pantano, raposa, veado, felino, caracois..........................................................148

V.IV-MACROGRUPO SERES MÍTICOS: aia paec, serpiente, monstro strombus,

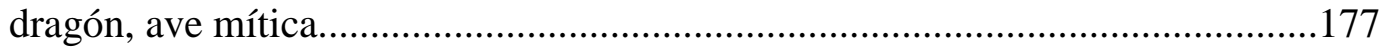

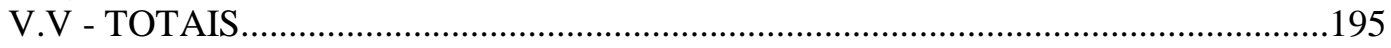

CAPÍTULO VI - INTERPRETAÇÃO DOS DADOS E CONCLUSÃO .......................................202

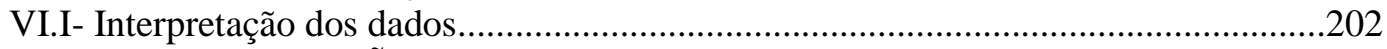

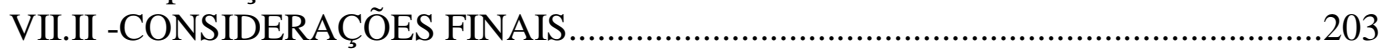

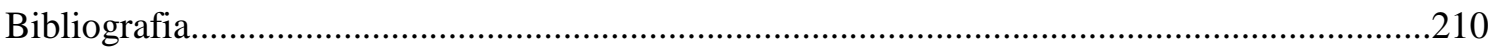

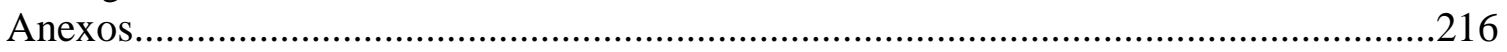




\section{INTRODUÇÃO}

A cultura arqueológica conhecida por Mochica ou Moche desenvolveu-se na costa norte dos andes centrais durante um período de cerca de 700 anos, que se inicia no fim do século I d.C e segue até meados do século VIII. Durante este período disseminaram-se por 10 vales na região, divididos entre muitas unidades políticas, mas unidos por uma cultura material de elite claramente reconhecível pela recorrência de seus temas, produção e estilo (Benson, 2012; Billman, 2010). Partindo de tradições cerâmicas anteriores os mochica produziram um grande salto de complexidade em sua cerâmica ao ponto de trazerem partes identificáveis de grandes "narrativas" cosmológicas contendo muita informação sobre seu mundo físico e ideológico (Golte, 2009; Makowski, 2008). Após décadas de estudos foram identificados personagens e seus atributos, "temas" que apareciam sistematicamente e finalmente grandes "narrativas", nesta ordem (Quilter, 1997).

Nos vales do sul da costa norte desenvolveu-se uma tradição ceramista de produção de vasos com pictografias de "linha-fina", mais tarde incorporada pelo vale de Jequepeteque, localizado na parte norte. Um motivo constante nos vasos de linha fina são o que o estudioso Cristopher Donnan chamou de "localizadores": determinadas plantas, animais e outros signos, como ondas, por exemplo, que serviriam como marcadores de paisagem, indicando o cenário onde a cena dos vasos estariam se dando (Donnan \& Mcllelland, 1999).

Porém, apesar de muito referidos os localizadores jamais foram objeto de um estudo sistemático. Uma abordagem configuracional com olhar detalhado para sua função semântica, sua frequência, localização entre quadrantes, fase e contexto de produção da cerâmica bem como identificação das espécies dentro do contexto etnobotânico e no contexto de paisagem poderia lançar luz às funções destes elementos nas composições mochica bem como na cultura mochica como um todo.

No Capítulo I são abordadas questões contextuais como a geografia nos quais se desenvolveram as sociedades moche além de sua evolução socio-política e econômica. Em quais ambientes surgiram os Moche? Em que período? Em que tipo de sociedade viviam os Moche?

No Capítulo II questões envolvendo ideologia, cosmologia e seu uso na iconografia são desenvolvidas. Neste sentido, intentou-se compreender melhor o desenvolvimento da iconografia como expressão da ideologia e cosmologia para então caminhar no sentido de elucidar o papel dos localizadores dentro do grande esquema iconográfico. Após a delimitação do estado da arte do conhecimento sobre os localizadores, as duas questoes 
centrais do trabalho foram postas na fronteira.

O capítulo III traz os materiais e métodos utilizados nesta dissertação. As análises biliografica, de ambiente e flora e cerâmica são explicadas detalhadamente.

No capítulo IV é apresentada a primeira parte de resultados deste trabalho. Nela buscou-se sugerir algumas espécies e gêneros que estariam sendo representados na cerâmica Moche como localizadores bem como produzir uma breve contextualização dos ambientes ecológicos nos quais essa flora é encontrada.

O capítulo V contém a segunda parte dos resultados. As cenas, personagens e seus localizadores são analisadas buscando-se compreender como a frequencia, localização e tipo de localizadores estão influenciando a composição da cerâmica Moche.

Finalmente, no capítulo VI, há uma breve síntese das direções apontadas pelos resultados, suas possíveis interpretações além de uma discussão sobre a utilizade do conceito de ecótopos como ferramenta interpretativa para os localizadores. 


\section{CAPÍTULO I: OS MOCHE NO CONTEXTO ANDINO}

\section{I.I- A natureza como elemento estruturante}

A geografia andina é elemento essencial na compreensão do desenvolvimento das sociedades nativas. O geógrafo peruano Javier Puldar Vidal (1940), usando como critério o clima, altitude e o uso indígena da terra (Sandweiss \& Richardson III, 2008), dividiu o Peru em oito "regiões naturais": Chala, Yunga, Quechua, Suni, Puna, Janca e Rupa-rupa ((Figura I.I.A). Estas, por sua vez podem ser divididas em três grandes regiões ambientais: Costa, Montanhas e Floresta Tropical (Costa, Sierra y Selva) . Nessa classificação a altitude talvez seja o eixo mais importante pois ela marca as divisões crescentes Chala ou costa (até $500 \mathrm{~m}$ acima do nível do mar), Yunga (500 a 2300 metros a.n.m), Quechua (2.300 a 3.500 metros a.n.m), Suni (3.500 a 4.000 metros a.n.m), Puna (acima de 3.800 metros a.n.m.) e Janca, (montanhas nevadas acima de 4.800 metros a.n.m.. Do lado leste da cordilheira temos também a Selva alta ou Rupa Rupa (de mil a 400 metros) e Selva Baixa ou Omagua (abaixo de 400 metros).

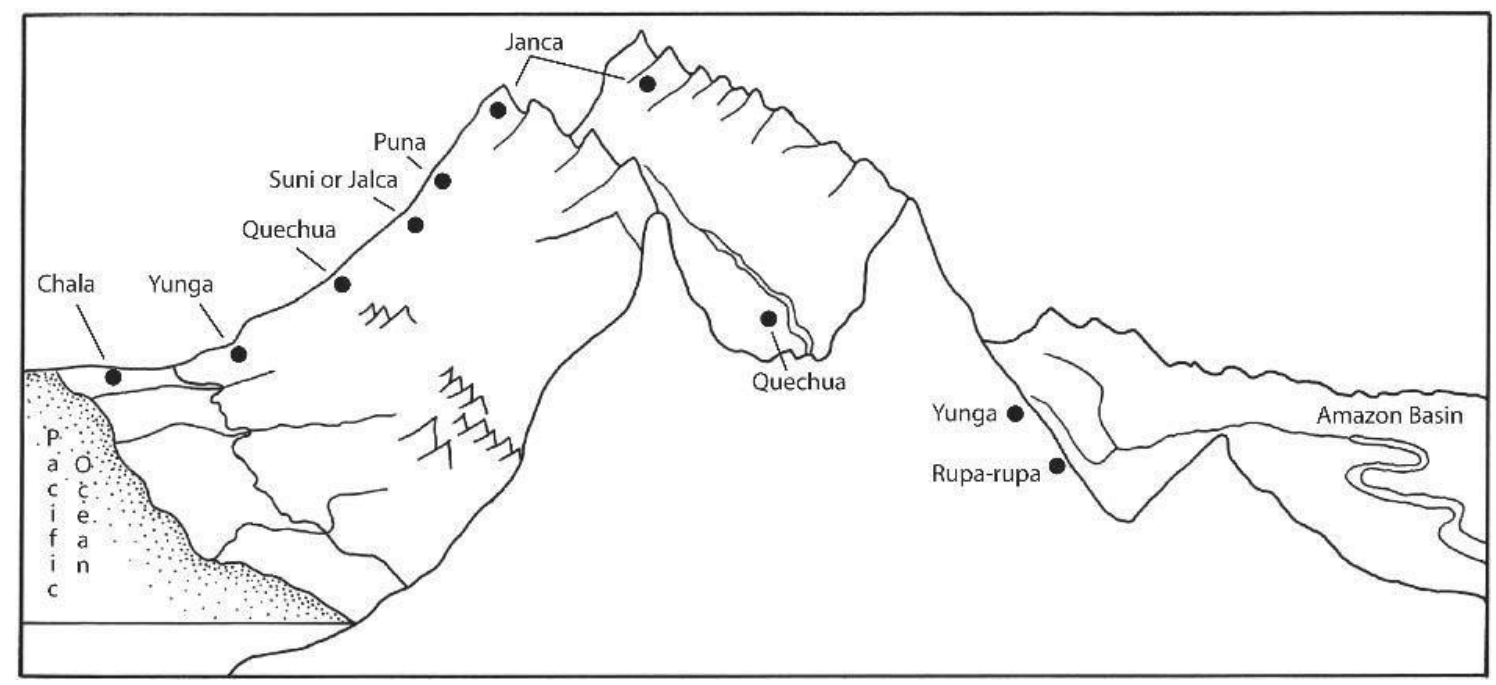

(Figura I.I.A)As oito regiões naturais de Pulgar Vidal (1987) de acordo Sanweiss \& Richradson III, 2008:95

Alternativamente Antônio Brack dividiu o território peruano em 11 denominadas "ecorregiões" (figura I.I.B) que levariam em conta fatores mais diversos do que o esquema de Pulgar Vidal, como tipo de vegetação e fauna, dinâmica climática hidrológica. Estes fatores deveriam ser interdependentes, delimitáveis e distinguíveis de outras ecorregiões. Segundo Hocquenghem (2001) "El concepto de ecorregión se superpone a los de bioma, zona de vida, 
región biogeográfica, provincia biótica y regiones florísticas y faunísticas, que son sólo visiones parciales de él".

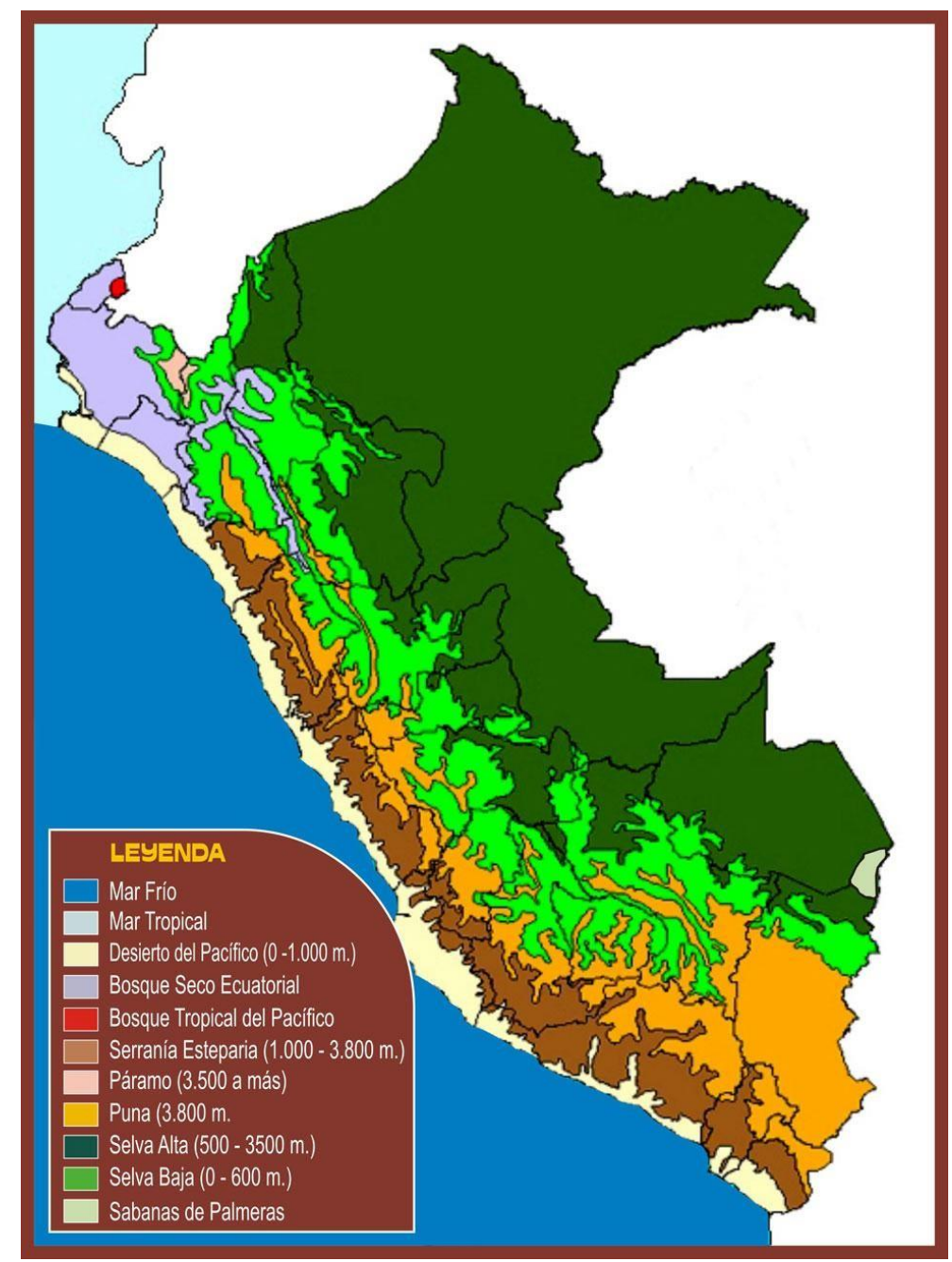

(Figura I.I.B) As ecorregiões peruanas de Brack de acordo com Hocquenhen, 2001 
A região da costa norte peruana que mais tarde seria habitada pelos Mochica comporta 3 das Ecorregiões de Brack: O Mar frio da corrente de Humbolt, o deserto costeiro e o bosque seco equatorial Rios com a exceção dos vales do extremo norte como Lambayeque e Piura que fluem o ano todo, originados do degelo dos picos andinos correm das montanhas para a costa e formam vales férteis circundados por regiões extremamente áridas. Ao redor dos vales surgem nos desertos costeiros regiões mais elevadas e úmidas denominadas Lomas que formam importantes repositórios de vida vegetal e animal.

A história da ocupação humana na região da costa norte peruana se principia com ocupação da América, que pode ter mais de 15 mil anos (Dillehay, 2008:29). Localizado no sul do atual Chile o sítio arqueológico de Monte Verde, possivelmente o mais antigo das Américas com ocupações humanas datadas de 16,500 a.C, atesta a ancestralidade da ocupação humana não apenas nas Américas, mas especificamente na região costeira dos Andes. Curiosamente é no Departamento de Ancash (Costa Norte), onde está localizada a Cueva del Guitarerro, sitio humano mais antigo conhecido no Peru (Aldenderfer, 2008:133), a cerca de 200 quilômetros da costa e 2.500 metros a.nm.

Essas primeiras populações de caçadores-coletores provavelmente exploravam uma gama bem vasta de plantas e animais que incluíam grãos, frutas, talos, raízes e tubérculos. Em Monte Verde, por exemplo, foram encontradas mais de sessenta espécies de plantas junto a ferramentas usadas para a exploração do bioma de florestas e zonas alagadas (Pearsall, 2008: 112). Entre 9.000 e 7.000 a.c , o fim do Pleistoceno e o início do Holoceno trouxeram um clima mais estável e quente, porém também mais árido. Boa parte dos glaciares dos andes encolheu criando a oportunidade de exploração humana em altitudes acima de 2.500 metros.

As populações que viviam na costa norte peruana o faziam nos vales férteis onde manejavam e exploravam a fauna e a flora dos muitos microclimas, principalmente os bosques de galeria às margens dos rios, além de se proverem da pesca e coleta as margens dos rios e do mar. O uso extensivo dos recursos marinhos já é constatado há 13 mil anos (Sandweiss et al, 1998) e mantém-se importante até o presente. Já há evidências de trocas entre populações de diferentes pisos ecológicos (Golte, 2009: 5). Esse tipo de troca se acentua e torna-se elemento essencial da economia dos povos da costa andina após a sedentarização durante os milênios posteriores .

Apesar da relativa estabilidade trazida pelo Holoceno, o clima andino continuava sujeito a bruscas alterações. As populações humanas seguiam se adensando e mergulhavam em um processo de sedentarização que as tornavam mais suscetíveis aos câmbios climáticos (Sandweiss e Richardson, 2008 :95). A costa norte peruana viu um aumento na precipitação 
anual no período do holoceno médio que se inicia por volta de 7.000 a.C (Idem :98) que pode ter propiciado condições favoráveis para a experimentação no sentido da domesticação com algumas espécies de plantas. Entre 5.700 e 2.400 a.C há evidências de cultivo de cabaça e abóbora, ambas do genus cucurbita, goiaba (Psdidium guajava) e Phaseolus, versões selvagens dos feijões de lima (Pearsall, 2008, 112). Deste modo, a partir da segunda metade do Holoceno médio, foram se estabelecendo populações sedentárias de horticultores nos vales férteis e pescadores especializados na costa.

A complementaridade ${ }^{1}$ econômica dessas duas populações foi evidenciada pelo arqueólogo Michael Moseley em The maritime Foundations of Andean Civilization (1975). No período pré-cerâmico tardio (3.000-2100 a.C) a pesca abundante trazida pela corrente marítima de humboldt era trocada por produtos agrícolas produzidos nos vales, que, por sua vez, produzia, abóboras (Curcupita), lúcuma (Pouteria lucuma), feijão de lima (Phaseolus lunatus), abacates (Persea americana), pimentas (genus capsicum) e duas plantas industriais; cabaças (curcubita) e algodão (Gossipum barbadense) (Pozorski \& Pozorski, 2008) além de pacae, pacae (Inga feuillei), achira (Canna edulis), batata doce (Ipomoea batatas ) e amendoins (A.hypogaea) (Sandweiss et. al, 2008). Há sinais de cultivo do milho, mas a pequena quantidade sugere que não tenha sido utilizado como pilar da base alimentar até o período Intermediário Inicial (de I a 800 d.C) talvez por ainda não estar adaptado ao clima andino (Pearsall, 2008:113).

Da lista acima a cabaça e o algodão se destacam por não terem utilidade nutricional, mas industrial. A cabaça servia para o transporte e cozimento de alimentos enquanto o algodão, para além da confecção de têxteis, servia para a confecção de redes de pesca. Com adição da cabaça como boia, as redes eram trocadas com as vilas marítimas por produtos do mar. Nos sítios localizados nos vales da costa norte e central constata-se um aumento substancial nos produtos de origem marítima, principalmente mariscos das espécies de maior tamanho (Pozorski \& Pozorski, 2005).

\footnotetext{
${ }^{\mathbf{1}}$ Apesar deste trabalho focar na região da costa dos Andes Centrais, é necessário apontar o conceito de Arquipelagos Verticais criado por Jhon Murra (1972). Segundo o antropólogo, se o terreno acidentado e extremamente verticalizado dos Andes é desafiadore do ponto de vista da produção de comida, também oferece oportunidade, pois a variação de altitude faz com que várias "zonas ecológicas" ocorram num raio de poucas centenas de quilômetros. Assim, haveria uma grande diversidade complementar de produção de alimentos com pescados sendo providos pelo mar, algodão e frutas pela região costeira, milho da região quechua, batatas e outros tubercúlos da região Suni, animais de pastoreio da Puna e coca e pimentas da Yunga. Na ausência de moeda ou comunidades mercantis, os andinos assegurariam o assesso aos produtos de diferentes zonas ecológicas por meio do estabelecimento de colônias, permanentes ou temporárias, com controle social fortemente baseado no parentesco (Contreras, 2007).
} 
Desse modo a agricultura incipiente, e aqui devemos lembrar que que a distribuição de plantas na costa peruana é extremamente antropogênica, chegando a $90 \%$ de alteração pelos seres humanos (Hastorf, 2006:91) com a ajuda de estruturas simples de irrigação, por volta de 1.800 a.C já se encontram evidências de irrigação artificial na costa norte peruana (Billman, 2002), e das proteínas marítimas teria impulsionado as populações dos vales.Torna-se claro o papel fundamental que as vilas costeiras tiveram na complexificação social emergente dos vales.

\section{I.II- Complexificação social e a costa norte peruana}

Os estudos sobre costa norte peruana tem especial importância no debate arqueológico pois a região é notável por ter sido palco de uma das mais precoces emergências das chamadas "sociedades complexas", evento que marca a passagem dos seres humanos de comunidades simples, não estratificadas e, em geral, formadas por pequenas unidades sociopolíticas, para sociedades estratificadas, com certo nível de especialização e controle laboral e social. Já no pré cerâmico tardio a costa peruana torna-se palco e sociedades deste tipo (Shady, Billman, Moseley, Quilter). Todavia, a discussão sobre a emergência destas sociedades tem ela mesma um histórico complexo e meandros que precisam ser pontuados antes que a caracterização dos moche prossiga.

Os modelos de evolucionismo social surgem no final do século XIX. Inspirados nas ideias de Charles Darwin publicadas em A Origem das espécies (1859) advogavam um paralelo simétrico entre a evolução biológica e evolução social. Herbet Spencer é possivelmente o mais importante autor desta corrente. Em Principles of Sociology publicado em três volumes entre 1875 e 1896, apresentava o conceito de Darwinismo Social que implicava na ideia da "sobrevivência do mais apto" assim como uma diferenciação entre sociedades mais ou menos aptas à sobrevivência. Este tipo de comparação evolucionista cai em descrédito com o surgimento da antropologia como campo autônomo, com a produção de grandes etnografias (Durkheim, Boas, Malinowsky) e a recusa destes primeiros antropólogos de criarem bases comparativas entre as sociedades. A discussão e produção de estudos comparativos só terá seu fôlego retomado às vésperas da segunda metade do século XX (Smith e Peregrine, 2011).

Há neste período, fim do século XIX, uma intensa participação de estudiosos alemães no deciframento da cultura material peruana. No fim do século XIX o engenheiro Hans Henrich Brüning (1848-1928) trabalhando nos engenhos de cana do vale de Lambayeque torna-se um etnólogo e arqueólogo amador tendo sido um dos primeiros fotógrafos das populações 
tradicionais da costa norte peruana e defensor da cultura arqueológica daquela área. O filólogo e arqueólogo Max Uhle (1856-1944), convidado por Brüning em 1888, principiou a identificação da cultura material mochica (chamada então de Proto-Chimu) além um primeira tentativa de cronologia andina.

Com a retomada do debate comparativo novos pilares para a compreensão das trajetórias universais de complexificação social foram lançados por Childe (1936 e 1951), Service (1962) e Carneiro (1970), Childe teve importância crucial como sintetizador das grandes teorias sobre Europa e Oriente médio. Sua abordagem culturalista transportou o conceito de cultura da antropologia para os vestígios arqueológicos e permitiu a aplicação da ideia de difusionismo a grupos que iam muito além das definições de "raça". Por meio do embasamento teórico funcionalista de base marxista, Childe considerava que os progressos tecnológicos eram de alguma forma correlatos aos socioculturais e que poderiam ser rastreados pela analise diacrônica dos vestígios arqueológicos.

Em Man makes himself (1936), e posteriormente em Social Evolucion (1951), Childe sistematiza suas ideias de evolução cultural. Para ele, as civilizações eram o produto de duas "revoluções": a neolítica, que tira o homem do nomadismo e cria, de uma certa forma, o conceito de propriedade, e a chamada "revolução urbana", na qual o processo de nucleação resultado do acúmulo dos excedentes agrícolas teria possibilitado a estratificação social e o sustento de classes não diretamente ligadas à produção agrícola. A despeito da sistemática desconstrução de muitos de seus argumentos, Childe é hoje considerado um dos fundadores da arqueologia moderna. É notável que a noção de densidade populacional é ainda um dos norteadores das explicações sobre o desenvolvimento das sociedades complexas, além do conceito de classes, ainda hoje em disputa na discussão.

Em um segundo momento, durante a metade do século XX o arqueólogo Julio C. Tello (1880-1947) constrói uma cronologia pan-andina que refutava a ideia de Uhle. Este afirmava que as sociedades complexas andinas haviam se originado na centro-américa e se difundido posteriormente para os Andes. Para Tello o epicentro inicial das civilizações andinas teria sido o centro cerimonial de Chavin de Huantar, localizado a 3.100 metros na serra da província nortenha de Ancash e construído a partir de 1.500 a.C. O "difusionismo" de Childe pautava o debate teórico na arqueologia andina uma vez que havia uma disputa na busca de um centro civilizacional pristino irradiador dos modos de vida civilizados, urbanos e hierarquizados.

Da mesma forma, Rafael Larco Hoyle (1901-1966) constrói sua divisão de fases moche baseado na cronologia de Tello. Apesar de apoiar a ideia de desenvolvimento civilizacional 
autóctone nos Andes, Larco acreditava que havia sido a costa e não a serra o locus de desenvolvimento da civilização pristina. Descobridor da cultura arqueológica denominada Cupisnique, localizada entre os vales de Virú em Lambayeque e datada entre 1.500 e 1.000 a.C, advogava que a irradiação cultural teria o sentido costa-serra e não o contrário (Pozorski \& Pozorski, 2008:612).

A arqueologia andina, como se vê, seguiu os paradigmas de sua discussão arqueológica contemporânea no resto do mundo. Buscavam-se centros urbanos nos quais as "revoluções" de Childe teriam impulsionado a civilização, como uma força centrífuga impulsionando rapidamente as comunidades vizinhas a adotá-la. Entretanto, um modelo gradual etapista iria mudar os bastiões deste pensamento a partir da segunda metade do século XX.

Elman Service buscou em Primitive Social Organization (1962), detalhar a forma como as sociedades se organizariam na medida em que o adensamento populacional fosse crescente. Para tanto, produziu uma escala com 4 etapas relativas à crescente complexificação social cujo foco são os modos de produção e de controle social. A escala inicia-se com bandos nômades (representantes de sociedades pequenas e igualitárias), passa por tribos, pelas chefias, onde o poder coercitivo torna-se patente, e culmina na criação de Estados, quando os laços de privilégio das grandes linhagens dão lugar a cargos e posições burocráticas (figura I.II.a).

Uma escala comparável, também com 4 estágios, foi proposta por Morton Fried (1967), iniciando-se em sociedades igualitárias, passando por sociedades de ranking, complexificandose em sociedades estratificadas e finalmente chegando aos Estados. Assim como a escala proposta por Fried o esquema de Service engloba aspectos diversos da dinâmica social como população, estratégia de subsistência, economia, estrutura social, formas de descendência e parentesco. O funcionalismo de Service, entretanto, considera a adaptação à escassez de recursos como a principal força motriz da evolução social enquanto na visão de Fried o processo de complexificação depende muito mais de forças das dinâmicas sociais do que das condições ambientais. É digno de nota que Julian Steward em Handbook of South American Indians (1948) adota um modelo tipológico correlato ao classificar as sociedades amazônicas como "simples" em contraposição aos desenvolvidos Estados centralizados dos Andes. 


\begin{tabular}{|c|c|c|c|c|}
\hline & BANDS & TRIBES & CHIEFDOMS & STATES \\
\hline Population & $25-50$ & 100 's to 1000 's & 1000 's & 100,000 's \\
\hline Settlements & $\begin{array}{l}\text { mobile } \\
\text { low population } \\
\text { densities }\end{array}$ & semi-permanent & $\begin{array}{l}\text { more than one } \\
\text { permanent } \\
\text { comm. }\end{array}$ & $\begin{array}{l}\text { many } \\
\text { permanent } \\
\text { communities }\end{array}$ \\
\hline $\begin{array}{l}\text { Subsistence } \\
\text { Strategy }\end{array}$ & food collecting & $\begin{array}{l}\text { horticulture, } \\
\text { pastoralism }\end{array}$ & $\begin{array}{l}\text { non-mechanized } \\
\text { agriculture }\end{array}$ & $\begin{array}{l}\text { intensive } \\
\text { agriculture, } \\
\text { trade }\end{array}$ \\
\hline Economy & $\begin{array}{l}\text { generalized } \\
\text { reciprocity }\end{array}$ & $\begin{array}{l}\text { reciprocity, } \\
\text { some } \\
\text { redistribution }\end{array}$ & redistribution & market \\
\hline $\begin{array}{l}\text { Social } \\
\text { Structure }\end{array}$ & \begin{tabular}{|l|} 
egalitarian \\
no institutionalized \\
legal or political \\
structure;situational \\
leadership
\end{tabular} & $\begin{array}{l}\text { incipient status } \\
\text { differences, but } \\
\text { not } \\
\text { rigid or } \\
\text { permanent }\end{array}$ & ranked lineages & $\begin{array}{l}\text { clearly defined } \\
\text { classes; highly } \\
\text { stratified }\end{array}$ \\
\hline Descent & cognatic & lineal & lineal & cognatic, lineal \\
\hline $\begin{array}{l}\text { Political } \\
\text { System }\end{array}$ & $\begin{array}{l}\text { non-centralized; } \\
\text { decision by } \\
\text { consensus; } \\
\text { power by } \\
\text { influence; } \\
\text { informal and } \\
\text { temporary } \\
\text { leaders }\end{array}$ & $\begin{array}{l}\text { non-centralized; } \\
\text { some part-time } \\
\text { officials such as } \\
\text { big-men or age- } \\
\text { grades; } \\
\text { power by skills, } \\
\text { knowledge; } \\
\text { "achieved } \\
\text { status" }\end{array}$ & $\begin{array}{l}\text { centralized, but } \\
\text { general } \\
\text { authority; based } \\
\text { on birth with } \\
\text { divine } \\
\text { legitimacy; } \\
\text { "ascribed } \\
\text { status" }\end{array}$ & $\begin{array}{l}\text { centralized } \\
\text { authority, with } \\
\text { formal offices } \\
\text { and multiple } \\
\text { governing } \\
\text { bodies; } \\
\text { power based on } \\
\text { law }\end{array}$ \\
\hline Examples & $\begin{array}{l}\text { Dobe Ju/hoansi } \\
\text { (IKung), } \\
\text { Inuit (Eskimo) }\end{array}$ & $\begin{array}{l}\text { Sambia; } \\
\text { Melanesian big- } \\
\text { man societies; } \\
\text { Yanomamo of } \\
\text { Venezuela and } \\
\text { Brazil }\end{array}$ & $\begin{array}{l}\text { Trobrianders of } \\
\text { Papua New } \\
\text { Guinea; } \\
\text { Polynesia, } \\
\text { including } \\
\text { Hawaii } \\
\end{array}$ & $\begin{array}{l}\text { Most countries, } \\
\text { including the } \\
\text { United States; } \\
\text { and peasants }\end{array}$ \\
\hline
\end{tabular}

(Figura 1.II.a) Tabela baseada no esquema de Service (1962) retirado de : http://abuss.narod.ru/Biblio/service.htm

Para Robert Carneiro, as teorias de evolução social de base voluntarista, como as de Fried, para quem desenvolvimento de Estados trazia benefícios a todas as classes, são improváveis, pois apenas a coerção, estimulada pelas disputas por recursos limitados e circunscritos, faria com que as populações derrotadas das guerras submetiam-se ao jugo de seus conquistadores. Ele exemplifica sua teoria do mecanismo coercitivo do Estado a partir do caso andino, onde, segundo ele "em nenhum lugar, talvez, pode-se encontrar vales agrícolas 
mais acentuadamente circunscritos" (Carneiro, 1970:736). Com a tecnologia neolítica as vilas dos vales peruanos tornavam-se mais populosas e dividiam-se quando o crescimento populacional tornava-se um fator de tensão. O número de vilas teria crescido até que as terras aráveis dos vales tivessem todas sido ocupadas quando, a partir de então, iniciariam-se a exploração intensiva das terras apoiadas pelos primeiros projetos de irrigação. Com a pressão populacional crescente as guerras tornam-se meios para a anexação de terras e vilarejos. Grupos conquistados perdem direito políticos e os conquistadores tornam-se elite. Assim teriam se desenvolvido as chefias, reinos e impérios, cuja expressão final seria o império inca. Segundo Carneiro, a circunscrição ambiental é fator essencial para o desenvolvimento precoce dos Estados pois em ambientes abertos e fluidos ( Carneiro aqui contrapõe os Andes à Amazônia) os grupos derrotados ao invés de aceitarem o domínio alheio simplesmente fugiriam para outro lugar capaz de sustentá-los.

Os esquemas neoevolucionistas surgidos na segunda metade do século $\mathrm{XX}$ foram bastante resilientes e ainda figuram como base para o desenvolvimento correntes do pensamento arqueológico contemporâneo, como a teoria dos sistemas, um desenvolvimento do processualismo (Feinman et al. 2000:450). Valendo-se da crescente capacidade de análise dos computadores pessoais a partir dos anos 70 coadunada a uma enxurrada de dados advindos dos números crescentes de pesquisas arqueológicas os adeptos dessa corrente, como Gary Feinman, Joyce Marcus e Kent Flannery, buscam modelos explanatórios de desenvolvimento social mais heterogêneos e refinados que os anteriores, inspirados pelas modelagens dos sistemas ecológicos na biologia e nas teorias dos sistemas, originárias da matemática. Assim, lançam mão de conceitos com base em dados comparativos sobre estratégias do desenvolvimento sociocultural. Apesar de uma determinada sociedade precisar passar por etapas, até tornar-se estatal, tais etapas dependerão das "estratégias" de desenvolvimento que podem coexistir simultaneamente, como formas de socialização em redes ou corporativas na organização de sociedades antes caracterizadas apenas como "chefias" (Feinman, Lightfoot e Upham, 2000).

A analise comparativa mais abrangente feita pelos adeptos das teorias do sistema não os absteve de formularem algumas "regras" para os desenvolvimento políticos e sociais, Assim, para identificar e analisar os ditos "Estados Arcaicos", lançam mão de análises em diversos campos como arquitetura de tempos e palácios e seu uso, os ciclos de consolidação e dissolução dos Estados, hierarquia entre assentamentos, escalas e demografia, entre outros (Feinman \& Marcus ed, 1998). Não obstante as tentativas de definição sobre o que é um Estado “ estados arcaicos eram sociedades com (no mínimo) dois estratos endogâmicos (uma classe governante 
profissional e uma classe de comuns) e um governo que era tanto altamente centralizado quanto internamente especializado.’[3] (Feinman \& Marcus, 1998), as fronteiras entre Estados e Cacicados são, nesta escola de pensamento, bastante movediças e mesmo a própria definição do que seria uma "sociedade complexa" é objeto de disputas constantes.

O peruano Luis G. Lumbreras, talvez o arqueólogo marxista mais notório segunda metade do século XX considera que o deslocamento do debate de "Origem dos Estados" para "origens das sociedades complexas" não passa de um modismo de reenvernizamento de uma velha questão já definida por Childe. As complexas e pomposas análises sistêmicas advindas principalmente dos arqueólogos estadunidenses estariam evitando a questão chave do desenvolvimento do Estado. Para Lumbreras, uma sociedade Estatal é uma sociedade de classes. "a estratificação pode dever-se à diferenças pelo ranking etário, por razões sexuais ou fatores de prestígio, enquanto as classes se devem diretamente à diferente participação das pessoas no processo de produção" (Lumbrelas, 2005:190) . Ou seja, as classes, diferentemente dos outros tipos de ranqueamento, existem apenas no momento em que há apropriação do trabalho de uma classe por sua classe superior. E Estado seria aparato jurídico necessário para fazê-lo.

A organização do trabalho ao redor da produção agrícola, seus requerimento de maior ou menor complexidade e a articulação do homem com o meio ambiente, é, paraLumbreras, a determinação causal que criará disparidades ou similitudes nas organizações sociais de comunidades distintas (Lumbreras, 2015:215. Desse modo a base comparativa entre sociedades é muito clara "a multicausalidade dos processos singulares está contida na universalidade do trabalho, que é onde a determinação causal adquire sua qualidade holística e nomotética"(Lumbrelas, 2005:216). O trabalho seria, portanto, um um processador que transforma as infinitas variáveis ambientais e sociais em algo comparável: o valor de uso e o valor de troca.

Entretanto, esses grandes sistemas classificatórios vêm sustentando pesadas críticas desde, principalmente, a década de 1980. A principal delas, de certa forma já incorporada e assimilada ao debate, é a necessidade de se ir além de hierarquias e considerar o peso das heterarquias (Crumley, 1987), ou seja, como associações não verticalizadas podem ser determinantes na complexidade nas organização das mais diversas esferas das comunidades. Inúmeras críticas sobre a forma interpretação do enorme fluxo de dados advindos das mais variadas pesquisa e como conceituá-los, se são passíveis de inferências globalizadoras ou não, estão sempre em voga. Mais na vanguarda e ainda não completamente aceito é o esforço na 
atualidade de se tentar incorporar as formas de organização socioeconômica com as mentalidades, cosmovisões e estruturas de parentesco das sociedades estudadas (Arcuri, 2011).

\section{I.III-Estruturação sociopolítica}

Poucos indicadores arqueológicos de violência grupal, coerção ou diferenciação social foram encontrados, contrariando a tese de Carneiro, até o início do Horizonte inicial (900 a.C), mesmo com evidências seguras de habitação da costa norte a partir de 15 mil anos a.C. e sociedades sedentárias são constatadas na região a partir de 6 mil a.C . Por outro lado, parece ter ocorrido uma rápida complexificação social organizada pela promoção de cultos conduzidos por sacerdotes especializados (aqui podemos pensar em um tipo mais sutil de coerção por meio de aspectos rituais) juntamente com o controle dos recursos hídricos ampliados pelas obras iniciais de irrigação. A partir do terceiro milênio a.C diversos centros cerimoniais espalharamse pela costa central e norte, talvez difundindo-se a partir do Vale de Supe, onde, segundo Ruth Shady (2006) pelo menos 18 centros urbanos se formaram.

Todas as nucleações dos centros urbanos se deram ao redor de centros cerimoniais divididos em duas grande metades que, de acordo com Shade, representavam as divisões cosmológicas estruturais tradicionais nos Andes. Hanan, o mundo acima, e Hurin, o mundo abaixo, atuavam como princípios naturais de forças opostas, complementares e assimétricas compartilhados por inúmeras sociedades amazônicas. Por serem tão comuns nas mitologias ameríndias, alguns estudiosos sugerem que estruturações cosmológicas ou mitológicas binárias podem ser tão antigas quanto as primeiras migrações para o continente sul americano (Arcuri, 2011). As plataformas piramidais, denominadas de huacas, estruturas das mais impressionantes, que exigiam grande esforço de coordenação da enorme força laboral necessária a sua construção, representariam Hanan e as quadras em forma de anfiteatro em formato côncavo, estariam no lugar do mundo de Hurin. Semelhanças nas estruturas das huacas espalhadas pela costa central e norte do Peru, como fachada, estilo arquitetônico e a presença santuários para água e para o fogo, levaram os arqueólogos a crerem na difusão de um culto de base única a qual denominaram Kotoshi. Parece evidente, portanto, um compartilhamento bastante precoce de estruturas cosmológicas entre as sociedades andinas, e mais intensamente entre os vales da costa norte e central.

Pensar um modelo de estruturação sociopolítica de uma sociedade passada demanda um esforço dialógico entre os modelos de desenvolvimento sociopolítico que o pensamento 
atual oferece, as particularidades da sociedade estudada e as direções e leituras que os vestígios arqueológicos apresentam. O caso mochica, assim como as sociedades pré-hispânicas das américas têm sido bastante desafiadores aos modelos de evolução social pensados na maioria das vezes a partir de exemplos eurasiáticos. Boa parte das pistas do que seriam as formas relacionais sociais e de poder nos Andes surgem de relatos dos primeiros europeus colonizadores e de dados por pesquisas etnoarqueológicas posteriores. Se interpretadas com cautela, essas narrativas podem servir de bússola na interpretação dos vestígios arqueológicos andinos, cujo corpo de dados vêm aumentando exponencialmente desde a segunda metade do século XX.

As sociedades mochica começam a se estruturar identitariamente 4 séculos depois do começo do período cultural peruano conhecido como Intermediário Inicial iniciado em 200 a.C, que marcou o declínio das culturas do Período inicial e Horizonte precoce (figura I.III.A). Foi um período que marcou uma mudança no estilo de vida da maioria dos habitantes dos Andes já que "Habitats facilmente explorados estavam agora completamente ocupados e surgem hostilidades na medida em que longa e recorrentes secas desencadeavam a competição por recursos" (Moseley \& Heckenberg, 2013:655). O novo cenário viu surgir uma classe de elite bem estabelecida conhecida pelos espanhóis do século XVI como Kuracas. De acordo com Moseley, a partir de 200 d.C. tempos mais úmidos e prósperos levaram as classes kurakas a adotar uma ideologia que racionalizava seu domínio a partir de mitos e cerimônias capturadas em iconografias realistas produzidas por artesãos subsidiados (Moseley \& Heckenberg, 2013:655)

A cultura material Moche pode ser identificada dentro de fronteiras relativamente claras (Quilter, 2002) entre os vales de Piura ao norte e Casma, ao sul, áreas antes ocupadas por populações cujas culturais materiais são conhecidas como Cupisnique, Virú e Salinar e Galinazzo. Arquitetura, práticas funerárias e, principalmente a cerâmica de natureza única são principais indicadores arqueológicos utilizados para a classificação desta cultura que é dividida em três fases: Mochica Inicial ( 100-300 d.C) ou fase I, que marca o início da cultura; Mochica médio (300-600, d.C) ou fase II, quando se observa sua expansão; e Mochica Tardio ( 500-750 d.C) ou fase III, marcado por um movimento de forte nucleação e colapso social, ao final do período.

Entre 200 e 400 d.C milhares de pessoas deixaram o centro urbano de Cerro Oreja, no vale de Moche, para fundar o sítio de Moche, $7 \mathrm{~km}$ a sudeste (Billman, 2010:17). Logo iniciaram a construção de novos templos que diferiam radicalmente dos anteriores tanto em forma como em função e iniciavam novos ritos com sacrifício humano e quantidades inéditas 
de bens funerários encontrados nos enterros das elites (Idem). É possível que esse tenha sido o movimento inicial de um processo que ao longo dos séculos IV e V d.C fundaria um Estado centralizado baseado no vale de Moche que teria conquistado e unificado os outros vales do sul da costa norte, enquanto os vales de Chicama a Piura teriam permanecido independentes. No caso dos Mochica não podemos descartar a flexibilização do que se considera "domínio" de uma unidade política, sob uma ideia de intenso controle territorial, e considerar algum tipo de "hegemonia" ou suserania negociada entre as unidades sociopolíticas submetidas (Shimada, 2010:77).

Os mochica se desenvolveram sobre as bases socio-econômicas e culturais herdadas de seus antepassados. A pesca se manteve como a principal fonte de proteína animal, mas possivelmente houve o complemento da carne de lhama. Importantes avanços ocorrem na agricultura. Apesar de se utilizarem das mesmas plantas conhecidas há séculos, o desenvolvimento e complexificação das redes de irrigação permitiram a plantação intensiva do milho, antes subjugado a um cultivo menor, o que pode ter levado a um incremento populacional considerável, principalmente a partir do século VI d.C. As redes de comércio intensificaram-se pelas rotas intervales, com populações dos andes centrais, pelas vias marítimas, com o atual Equador e através das montanhas, com as regiões de floresta. A troca de bens de prestígio tornou-se mais acentuada por meio do uso de balsas para o comércio marítimo e caravanas com o auxílio da lhama. A metalurgia atinge um alto grau de desenvolvimento e sofisticação, principalmente nos itens trabalhados em ouro e cobre (Quilter, 2011, Shimada, 2013 ).

A partir do século IV d.C se observa nos assentamentos mochica o início de uma forte tendência para nucleação e formação de verdadeiros centros urbanos, com milhares de pessoas ocupando as cidades de forma sazonal ou permanente. Isso pode ter ocorrido por conta da perda de terras e endividamento de pequenos agricultores após uma sequência de fortes El Ninõs (Billman e Huckleberry, 2009), fenômenos climáticos que mudam o padrão de chuvas, inundando os vales, diminuindo as chuvas nas montanhas e inibindo as ricas correntes marítimas. A estratificação nesse período se torna intensa e pode-se reconhecer três camadas sociais bastante distintas: a nobreza, os comuns e os pobres (Quilter. 2009).

Apesar de não haver consenso, os Mochica são, em geral, considerados as primeiras sociedades a atingirem o "nível de estado" nos Andes. Os mochica poderiam cair na categoria de Estados ou Chefias, dependendo de qual unidade política e de qual estágio estaríamos nos referindo. De acordo com Billman (2010:12), diferentemente dos precedentes governantes Galinazzo e Salinar "Moche rulers were able to collect large quantities of goods and labor on 
a regular basis from commoner households, which they used to finance a broad range of political activities". Ou seja, a costa norte no início do período mochica observa um salto na verticalização social com muito mais poder concentrado nas elites do que seus antecessores.

\begin{tabular}{|c|c|}
\hline PERÍODO & DATAS RELATIVAS \\
\hline Período Pré-cerâmico & Anterior a 2000 a.C. \\
\hline Período Inicial & $2000-900$ a.C. \\
\hline Horizonte Inicial & 900 - 200 a.C. \\
\hline Intermediário Inicial & 200 a. C. -600 d.C. \\
\hline Horizonte Médio & 600 - 1000 d.C. \\
\hline Intermediário Tardio & 1000 - 1400 d.C. \\
\hline Horizonte Tardio & $1400-1532$ d.C. \\
\hline
\end{tabular}

(Figura I.III.a) Cronologia Andina baseada em variações estilísticas com base em John Rowe ${ }^{2}$ (retirado de Figueiredo, 2014)

Entretanto a natureza do que seria o Estado nas sociedades andinas e mesmo a definição de um "Estado arcaico", além da utilização da categoria "Chefia" como uma arcabouço conceitual de critérios flexíveis onde se depositam as sociedades complexas que não preenchem todos os requisitos para atingir o status de "Estado" (Yoffe, 2013:55), são ainda objeto de divergências irreconciliáveis entre os estudiosos.

O avanço na compreensão da cosmologia e dinâmica social dos mochica durante a segunda metade do século XX não veio encompassado com o entendimento da magnitude e diversidade de suas unidades sociopolíticas. Durante décadas era subententido que teria existido um "Estado mochica", englobando todas as regiões sob a esfera cultural daquele povo, cuja capital teria se situado no Vale de Moche ao redor das Huacas del Sol e de La Luna. Apenas em meados dos anos 90 os trabalhos de arqueólogos como Shimada, Donnan e Castillo propõem uma divisão política entre as partes norte e sul da costa norte peruana.

\footnotetext{
2 O arqueólogo estadunidense John Rowe propôs uma cronologia pan-Andina em 1945, baseado em documentos históricos, conhecimento estratigráfico e, principalmente, análise comparativa cerâmica e arquitetônica. Rowe notou períodos de maior homogeneização estilítica nestes itens, o que parecia indicar maior integração ideológica e social entre as muitas culturas e regiões andinas. A estes períodos ele nomeou "Horizontes" enquanto períodos em que os estilos tornavam-se mais idiossincráticos em cada cultura e região foram chamados de "Intermediários". Apesar de ter recebido alguns ajustes e contribuições ao longo dos anos, a cornologia de Rowe é ainda a mais aceita e utilizada para o mundo Andino (Figueiredo, 2014:42).
} 
Rafael Larco Hoyle (1901 - 1966) foi figura chave na identificação da cultura moche ou mochica; a primeira denominação surge do Vale de Moche e, portanto, é de base geográfica, enquanto a segunda se baseia na língua falada na costa norte do Perú no evento da conquista espanhola. Ao realizar escavações intensivas em suas fazendas na costa norte peruana ele pode constituir um acervo considerável formado, principalmente, por peças de cerâmica e constatar a singularidade daquela estilo cerâmico antes denominado de proto-chimu (Quilter, 2002:149). Larco produziu uma sequência de estilos cerâmicos em 5 fases, I, II, III, IV, V, compreendendo de 50. d.C a 800 d.C, aproximadamente, ainda hoje largamente utilizada na datação de peças dos vales nos domínio moche ao sul do rio Jequetepe.

Segundo o arqueólogo Luis Jaime Castillo (2007 ) a sequência cerâmica dividida em cinco fases por Larco não seria compatível com os achados no vale de Jequetepeque. Para aquele vale, Castillo propôs uma divisão dos períodos cerâmicos em 3 partes; precoce, médio e tardio (figura I.III.B). A não conformidade dos estilos cerâmicos, considerando a forma de produção corporativa (como indicada por Moseley, 1982) e o controle "estatal" da produção, indicaria uma disparidade também na unidade política das regiões. Assim, as análises de cerâmica, auxiliada por análises de padrões funerários e arquitetônicos, indicam que a parte sul da costa norte peruana, do vale Chicama ao vale de Casma, teria sido unificada sob um governo durante a fase moche III e IV ( equivalente a mochica médio e tardio na parte norte), por volta do século IV d.C, algo que não ocorreu com os vales da parte norte ( nos vales Jequetepe, Lambayeque e Piura). Para Castillo, houve a centralização política na parte sul por um período, enquanto na parte norte as unidades sociopolíticas eram divididas em pequenos reinos com maior ou menor centralização, mas que jamais controlaram territórios para além de seu vale de origem. 


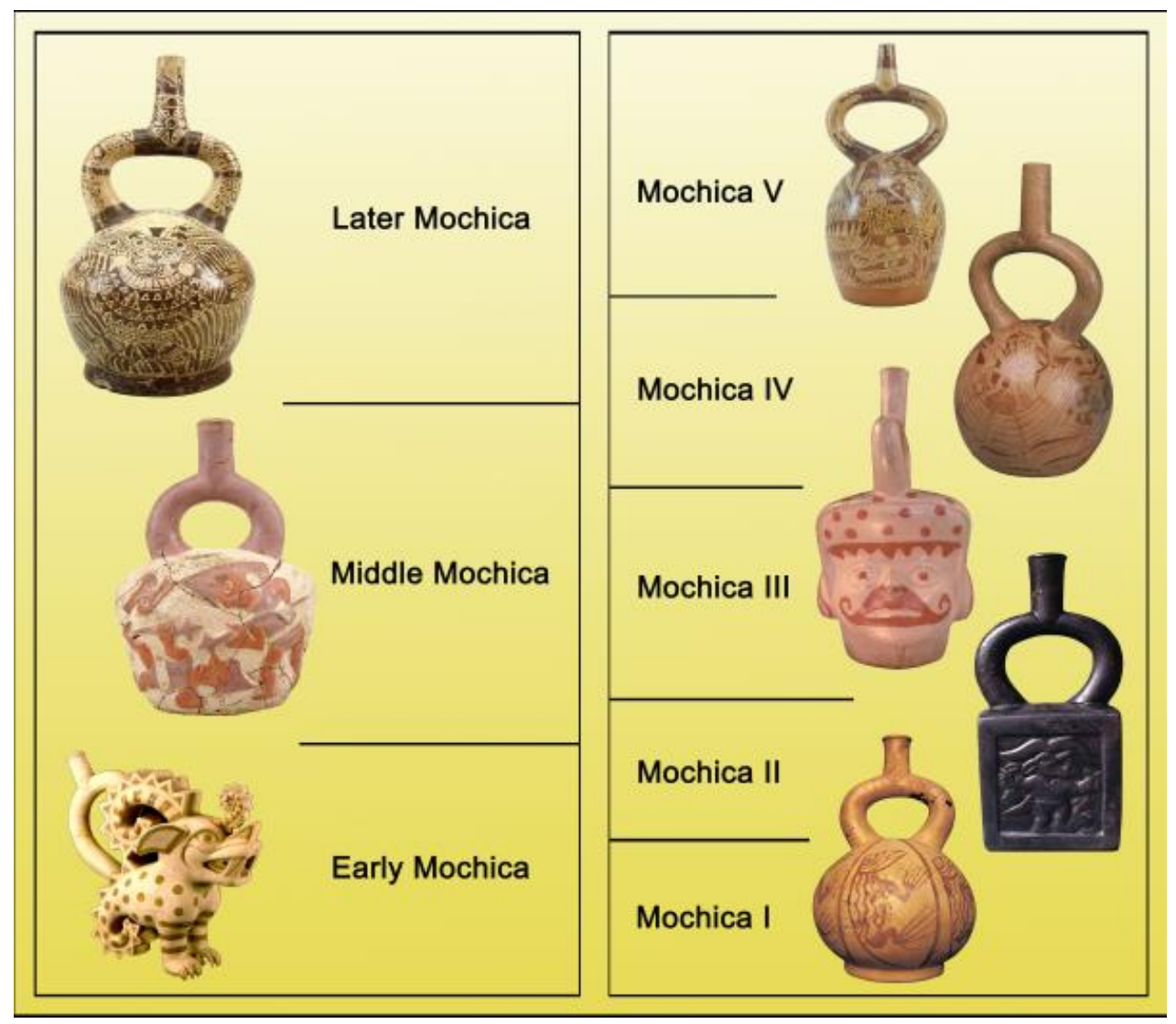

(Figura I.III.b) Divisão das fases da cerâmica norte e sul (retirado de Castilho \& Uceda, 2007)

Shimada (2010) nos alerta para o perigos de considerarmos mesmo o possível "Estado" Moche Sul como uma unidade política monolítica. Enquanto as primeiras interpretações para os avanços da cerâmica e construções corporativas de clara origem mochica nos domínios dos Galinazzo, ao sul do vale de Moche (Shimada, 2010:71) eram de um estado intrusivo em conflito com a população nativa, o arqueólogo japonês parece pontuar os meandros , sutilezas e negociações que qualquer tipo de "dominação" política exige:

“Eu sugiro que não era uma progressão linear suave ou aquele em que o Estado Moche centrado no local de Moche, sozinho, ditou todas as decisões importantes. Em vez disso, o processo envolveu muitas negociações, conquistas, reconquistas $e$ aproximações entre os Moche e as populações locais (Shimada nd); em outras palavras, uma relação política que foi constantemente testada e oscilou por, pelo menos, uma ou duas gerações. "(Shimada, 2010:71) 
Os Incas podem indicar um exemplo de como tais negociações entre o poder central e local podem manifestar-se na cultura material. Em sua dissertação de mestrado, que visava analisar a expressão das relações centro $x$ periferia na cerâmica da costa norte andina no período Inca, Márcio B. Figueiredo (2014) sugere uma aparente correlação entre a frequência e variedades das representações iconográficas na cerâmica e uma maior centralização política. Segundo ele, a cerâmica da costa norte peruana apresenta mudanças notáveis no padrão do que é representado após a conquista Inca do reino de Chimor, no fim do séc. XV. Entre elas estão: 1. Aumento nas representações de figuras abstratas, fitomorfas e zoomorfas. 2. A redução significativa das representações de figuras antropomorfas com atributos de poder evidentes 3 . Diminuição na frequência das representações do panteão chimú. 4. Simplificação nas representações antropomorfas e a retirada de seus atributos de poder. (Figueiredo,2014:176)

Ainda segundo Figueiredo os Incas não necessariamente destituíam o caráter sagrado das deidades Chimú, mas rompiam com as relações institucionais dessas deidades com o Estado, privilegiando seu próprio panteão. (Figueiredo, 2014:173). Logo, a conquista e expansão de territórios dos conquistadores buscava suprimir a representação de divindades regionais, pois elas estavam ligadas à resistência das elites locais ante seus conquistadores, e ao mesmo tempo se esforçava em promover figuras do panteão ligadas a sua região de origem (D’altroy, 2014), passíveis de representação cerimonial por seus líderes.

É importante lembrar, entretanto, que a dinâmica social de cada sociedade não segue necessariamente nas mesmas estruturas. Além disso, o panteão mochica parece ser muito mais diversificado do que o de seus sucessores. Se não devemos esperar exatamente o mesmo padrão da conquista Inca para o Estado mochica, acreditamos que o expansionismo dos sul-mochica durante os séculos IV e $\mathrm{V}$ possa ter criado similaridades na forma de legitimação dos conquistadores.

Se a homogeneidade política dos moche do sul é contestada, variando de um domínio multivale a vale a vale, os mochica do norte, residentes nos vales de Zaña, Jequetepeque, Lambayeque e Piura são formados claramente por distintas unidades políticas dentro de cada vale. A extrema variedade vale a vale e a falta de indícios coercitivos na inserção da cultura material moche nesses vales, além da coexistência entre cerâmica material Galinazzo e Moche, parece reforçar a hipótese de que a chamada "cultura material mochica" surge como uma variante elitista das culturas regionais, por vezes afirmando um grande discurso comum mochica, por vezes reforçando as identidades locais (Shimada, 2010:81). Se o fenômeno moche 
se tratou realmente de uma elite apropriando-se de um discurso para justificar e solidificar seu privilégios de ranking, ou quem sabe estruturar sociedades de classe, os resultados de tal experimento foram extremamente variados, com maior ou menor resistência em cada período e em cada unidade política. Deixaram, entretando, marcas e preceitos com os quais os sucessores dos mochica, os Chimú e os Lambayeque, com certeza tiveram de dialogar.

\section{I.IV- Produção cerâmica e controle ideológico}

Havia uma especialização interna tanto de parte dos comuns quanto das elites mochica. Estas estavam umbilicalmente ligadas ao poder simbólico das huacas, os centros cerimoniais religiosos que se mantiveram como essenciais à dinâmica social, assim como os objetos sagrados representando o poder divino e dos ancestrais, também denominados huacas ou huacos. Foi a partir desses centros que se espalhou a ideologia observável hoje nos vestígios de cultura material. A cultura material, por sua vez, não servia apenas de suporte para a impressão das ideias, mas agia, influenciava e fixava as grandes narrativas que surgiam. Um aspecto importante é que talvez a cultura material seja um aspecto chave para entendermos as alianças de grande escala dos seres humanos, entendidas como verticais ou horizontais. Durante o processo de difusão da cultura mochica as elites tornaram- se cada vez mais poderoras e distintas dos comuns. Um testemunho material da intensa estratificação parece ter sido a explosão de objetos carregados de valor simbólico utilizados como distintivos ou rituais.

Para Jurgen Golte (2009: 17) :

...nos parece provável que a mesma hierarquização, e o aumento da quantidade de pessoas politicamente interconectadas mediante ela, requeria o distanciamento simbólico entre os atores hierarquicamente distanciados.

Ou seja, na medida em que os atores políticos se distanciam hierarquicamente as formas de regulação tradicionais das relações entre esses atores se tornam insuficientes e a produção de uma parafernália de prestígio com normas claras torna-se necessária.

O antropólogo Timothy Earle (1992) concorda com Golte sobre uma maior necessidade de padronização na comunicação na medida em que os atores sociais tornam-se mais distanciados. Partindo da definição de estilo como "variações padronizadas de aparência" o autor vê dois usos da palavra conceitualmente diferentes. Um seria passivo, algo como um 
template mental internalizado, promovido pela socialização e aprendizagem cultural; útil para definir culturas arqueológicas. O outro seria ativo: o estilo seria um meio de comunicação com o qual indivíduos e grupos sociais definem relações e associações. Desta forma, elementos do estilo são selecionados para enviar determinadas "mensagens" e desenrolar o "drama social". A produção estilístisca, portanto, é portadora de um significado.

Apesar de não arbitrária, Earle vê como pouco producentes as tentativas de explicar processos culturais através de atribuição de significado ou busca da subjetividade do artesão. Como alternativa a este problema, ele propõe o reconhecimento de propriedades formais e funcionais dos sistemas ideológicos, utilizando-se de recursos como natureza da aparência de um objeto, contexto de seus usos e o padrão de sua distribuição. A antropólogo é ainda um forte defensor dos estudos inter culturais (cross-cultural) como forma de se determinar possíveis relações entre formas e funções simbólicas.

Ao propor uma clara e declarada abordagem (framework) evolucionista, Earle crê em uma progressão da formalidade simbólica e estética encompassada com o aumento na complexidade social. Para o ele, grupos familiares pequenos têm pouca necessidade de formalização estética ou simbólica em seus artefatos, mais frequentemente encontrada justamente em objetos reservados à trocas com outros grupos, ou seja, em contextos em que a unidade familiar é extrapolada.

Já em unidades políticas maiores e mais complexas a necessidade de projeção da identidade do grupo corporativos locais, como linhagens e clãs, nos artefatos intensifica-se, principalmente nas interações cerimoniais, nas quais são delimitadas questões de regionalidade ligadas à posse da terra e os mitos de origens das famílias. Isso poderia ser observado arqueologicamente observando-se a regionalização estilística de artefatos domésticos, o que teria acontecido no explosão criativa do paleolítico superior.

No caso dos mochica a forma de como pode ter ocorrido a distinção de classes ainda é muito discutida e parece ter sido particular em cada vale. Entretanto, as similaridades na cultura material dos vales de dentro da esfera mochica indicam uma grande homogeneização na cultura das elites ( Quilter, 1990, Castilho, 1998). Uma possível explicação para a aproximação cultural de grande parte da costa norte é o compartilhamento de ritos integradores, cerimônias, parentesco e de uma poderosa ideologia entre as classes altas da região, podendo o fenômeno mochica ser classificado como um "fenômeno da elite" (Butters e Castillo, 2008: 724 ). De fato, a cerâmica regional parece ter convergido a partir de tradições locais próprias de cada vale ou região, como Salinar ou Gallinazo, para o estilo mochica. 
Determinadas "escolas" ou "estilos corporativos" são reconhecidos dentro da totalidade da produção de cerâmica, com oficinas particulares e "estatais" tendo sido identificadas nas escavações dos assentamentos mochica. Isso se deve ao fato de que "a produção de artefatos rituais era uma das atividades mais proeminentes entre os mochica" (Butters \& Castillo, 2008:715). As elites utilizavam-se de corporações de artesãos sob a tutela de líderes urbanos, muito provavelmente ligados a linhagens proeminentes (Berniére, 2010:2) para a produção de seu artefatos rituais, cuja importância seria crucial para a propagação ideológica.

Observa-se que tamanho controle ideológico tinha um papel essencial para a manutenção do estatus quo dessa sociedade elitista com acesso a recursos bastante desigual e sujeita a irrupções populares violentas. A ideologia ainda empoderava as elites no controle da economia planificada e na tentativa do uso e monopólio da violência. Esta, por sua vez pode ter tido importante papel na legitimação das elites por meio de batalhas rituais ou de conquista que possivelmente figuravam guerreiros nobres (Quilter, 2008).

A cerâmica de linha fina, especificamente, foi um meio privilegiado e pode servir como janela excepcional para as narrativas míticas e cotidianas, levando em conta seu papel como objetos rituais de produção corporativa essenciais para os displays de controle ideológico do "Estado". Ou seja, sua produção deve ter seguido uma "agenda" pautada intencionalmente pelas elites dessas sociedades (Bernière, 2010 :16).

O resgate de uma série de objetos com representação iconográfica além de vestimentas e parafernália ritual nos leitos funerários da elite mochica levam a crer que membros da elite não apenas participavam, mas protagonisavam as cerimônias recriações de narrativas míticas (Butters \& Castillo, 2007 ) (Golte, 2009), sendo possível distinguir a representação das mesmas elites na cerâmica ritual através de atributos indicativos de poder. Dessa forma, na sociedade mochica as elites se tornaram expressões materiais de seus sistema ideológico, personificando as principais divindades e seres sobrenaturais em performances rituais (Butters e Castillo, 2008: 715). 


\section{Capítulo II: COSMOLOGIA, ICONOGRAFIA E SEMASIOGRAFIA}

\section{II.I-A iconografia Moche como objeto de estudo}

Todas as sociedades andinas pré-colombianas eram sociedades ágrafas, isto é, não possuíam um sistema de representação simbólica comunicativa equivalente ao que no ocidente chamamos de escrita. Não possuir escrita, entretanto, não significa estar destituído de sistemas de comunicação e significação; pelo contrário, desde o advento do homo sapiens e

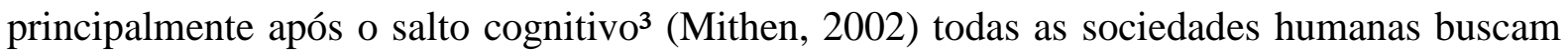
representar, organizar e narrar suas visões de mundo. Porém, a ausência de escrita nos moldes ocidentais faz com que os estudos da cultura material tenham importância especial no desvelamento dos costumes, crenças e práticas dessas sociedades.

Algumas das sociedades chamadas ágrafas construíram sistemas extremamente complexos de representação visual. Entre elas os mochica, que se desenvolveram entre os vales de Piura e Casma ao longo da costa norte peruana durante cerca de 700 anos, entre os séc. II e VIII d.C, são um exemplo. Mesmo se comparados com sociedades predecessoras os mochica atingiram grau de sofisticação inédito em sua produção iconográfica, expressa principalmente em seus murais, metalurgia, mas acima de tudo, em sua produção cerâmica. Há uma diversidade impressionante de formatos e propósitos dentro da cerâmica ritual. Floreros, com uma larga borda extrovertida, cancheros com um único apêndice e vasos de alça estribo, ou vasos escultóricos cada qual com sua função são exemplos dessa diversidade (figura II.I.A).

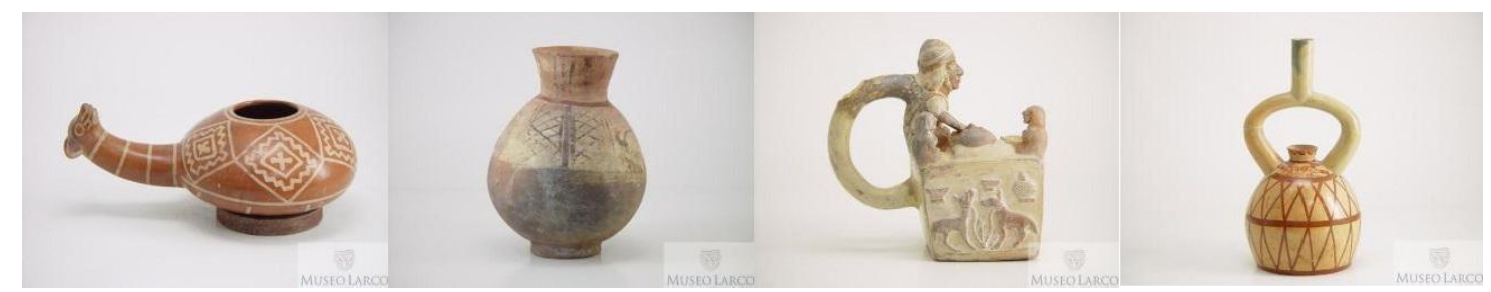

(Figura II.I.A) Da esquerda para a direita: Canchero, Cântaro, Asa estribo lateral escultórica, Asa estribo de linha fina (cortesia Museu Larco)

\footnotetext{
${ }^{3}$.Entre 100 mil e 40 mil a.C teria havido um salto qualitativo na cognição do homo sapiens no qual a espécie passa a produzir artefatos com valor simbólico ou, em outras palavras, "arte". Mithen propõe que neste período regiões cerebrais antes encapsuladas se conectaram, dando condições à nossa atual capacidade criativa, mas há inúmeras outras hipóteses em discussão.
} 
Nos vales de Moche, Virú e Chicama (figura II.I.B), onde teria se desenvolvido um estado ou chefia mochica proeminente ( Castillo, 1990 ) também surge, a partir da cultura Galinazzo anterior, a tradição dos vasos desenhados com linha fina. Neles, a iconografia é pictografada em imagens bidimensionais por meio de pinceis, provavelmente a base de cabelo humano (Donnan \& Mcllelland, 1999), geralmente em tinta ocre sobre uma vase de cor creme. Estes vasos trazem uma série de cenas ou composições que incluem plantas e animais, personagens fantásticos, guerreiros em ação, cena de rituais ou mesmo partes complementares de grandes narrativas cosmológicas que teriam orientado a sociedade mochica.

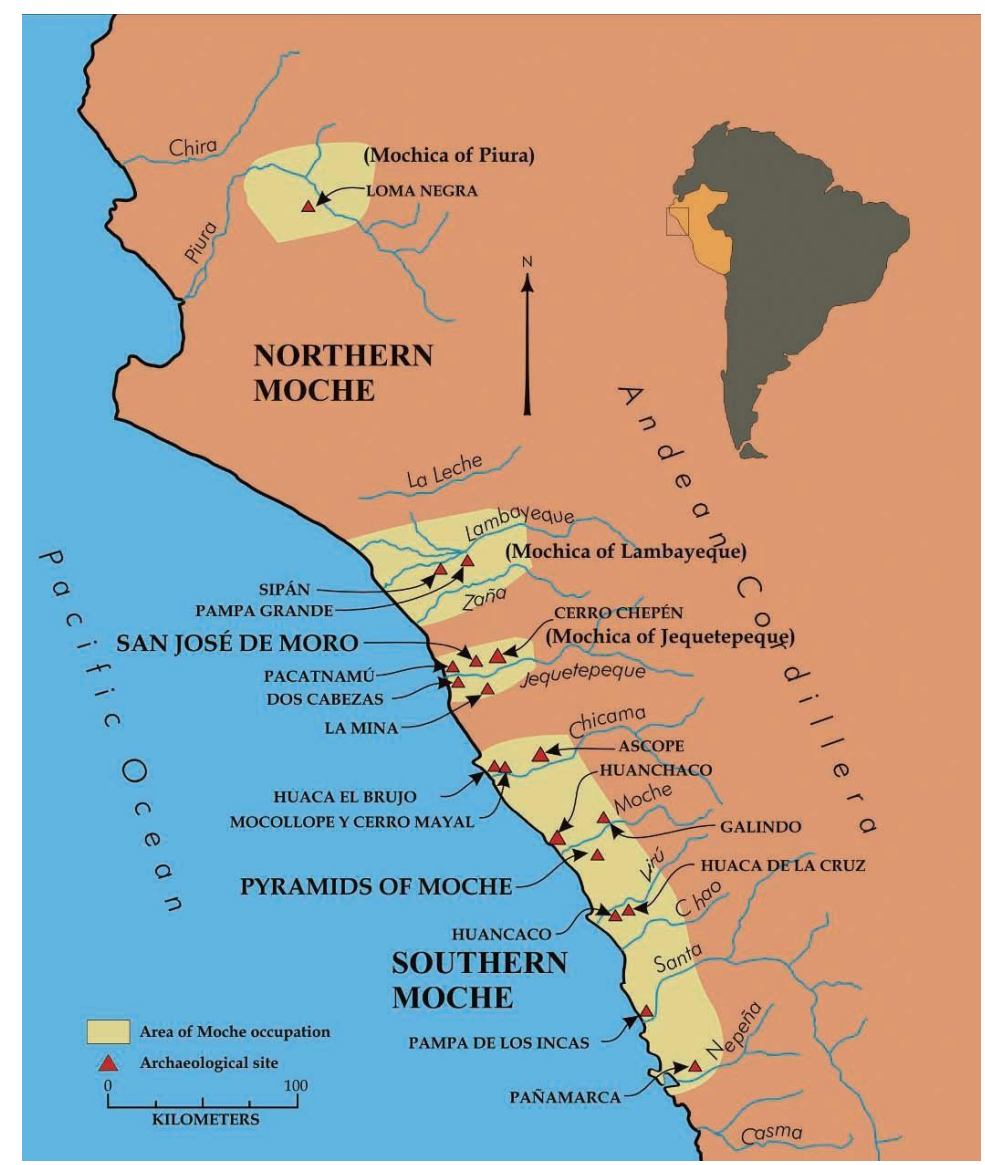

(Figura II.I.B)Área de ocupação Mochica de acordo com Castillo (2008)

4. A cultura Gallinazo também é conhecida por Virú por ser altamente associada a aquele vale. Foi objeto do primeiro grande estudo sobre padrões de assentamento de um vale completo , o Virú Valley Project, cujos resultados são publicados por diversos pesquisadores, mais notoriamento por Willey em 1953. 
Durante todo o século XX e mais intensamente nos últimos 40 anos a complexa teia significativa que liga os personagens representados nos vasos de linha fina vem sendo desvelada em um esforço intensivo e contínuo. Baseando-se nos estudos de pioneiros compatriotas alemães como o arqueólogo Max Uhle (1856 - 1944) e utilizando-se nos desenhos produzidos pelo artista Wilhelm Von den Steinen (1859-1934) através de uma técnica conhecida por roll out ${ }^{5}$, o antropólogo Gerdt Kutsher (1913-1979) concluiu, em meados do século XX, que a iconografia mochica revelava uma forma de arte "canônica, na qual se repetiam cenas pautadas" (Golte, 2009: 418). Uma das cenas identificadas e nomeadas por Kutscher teria sido a cena de arremesso de lótus, conhecida até hoje em inglês por "cerimonial badminton", pois lembrava o badminton, jogo muito popular entre elites europeias à época ( Donnan \& Mcllelland, 1999). Assim, já nos anos 1950 havia se criado a consciência de que as cenas representadas nos vasos de linha fina se tratavam de recorrências temáticas com regulações formais bastante rigorosas.

Rafael Larco Hoyle (1901 - 1966) foi figura chave na identificação da cultura moche ou mochica (a primeira denominação surge do Vale de Moche e, portanto, é de base geográfica, enquanto a segunda se baseia na língua falada na costa norte do Perú no evento da conquista espanhola). Ao realizar escavações intensivas em suas fazendas na costa norte peruana ele pode constituir um acervo formidável constituído, principalmente, por peças de cerâmica. Seus estudos o permitiram constatar singularidade daquele estilo cerâmico antes denominado de Proto-chimu (Quilter, 2002:149). Como já citado no capítulo anterior, Larco produziu, utilizando-se principalmente da comparação entre vasos de alça estribo, uma sequência de estilos cerâmicos em 5 fases, I, II, III, IV, V, (figura II.I.C) compreendendo de 50. d.C a 800 d.C, aproximadamente. Cada fase dura cerca de um século e meio e ainda hoje largamente utilizada na datação de peças dos vales nos domínio moche ao sul do vale do rio Jequetepe.

Roll out é uma técnica que "desenrola" ou transpõe para uma superfície plana a imagem contida em uma superfície cilíndrica como um vaso. É muito utilizada pelos estudiosos dos vasos de linha fina pois permite uma identificação mais clara dos elementos da composição. Apesar disso é uma técnica limitada pois nela perde-se a tridimensionalidade e muito da localização relativa entre os elementos da composição. 

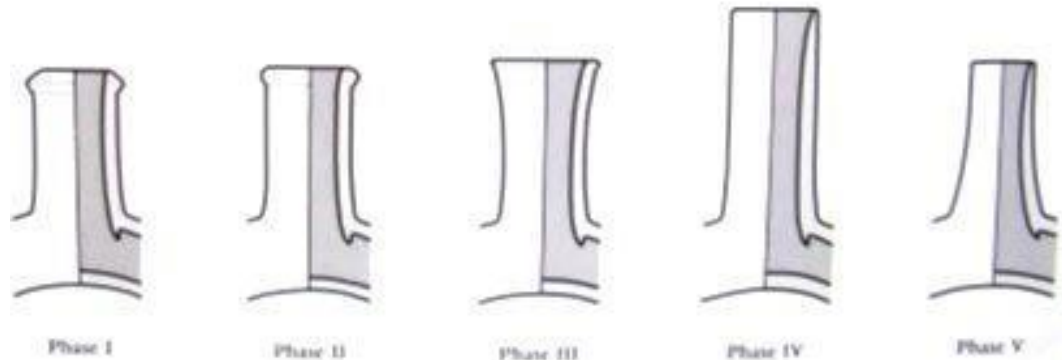

Phus it
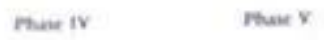

(FIGURA II.I.c)As diferenças morfológicas das 5 fases de Larco na alça estribo de acordo com Donnan \&Mcllelalnd (1999:21)

Nas décadas de 1960 e 1970 houve grande esforço de identificação dos principais personagens representados na cerâmica ritual mochica, buscando recorrências em composições diversas, algo não tão fácil, pois a mesma entidade pode ser representada com diferentes atributos em diferentes momentos da narrativa. Este é um fenômeno conhecido aos ocidentais familiarizados com a história de Jesus Cristo, que "al nacer en Belén muestra otros atributos que cuando está crucificado en el Gólgota." (Golte, 2009:70). Assim, ainda hoje há muitas discordâncias quanto aos personagens apresentados, suas ações, seus atributos e principalmente em como deveríamos nomeá-los, mas houve, sem dúvida um progresso considerável neste campo.

Um grande avanço foi iniciado pelo antropólogo Cristopher Donnan (1975) com o uso da "abordagem temática" (Quilter, 1990:42), capaz de relacionar os elementos contextuais por meio de uma semântica comum. Este tipo de análise utiliza-se das imagens dos vasos de linha fina projetados em roll out e foca grupos recorrentes de figuras e suas variantes, chamados de temas (Quilter, 1997: 113). Assim:

"Specific individuals can be identified by noting the consistent combination of features associated with them - their physical form, distinctive clothing, and objects being held - in the same way that Santa Claus can be distinguished from all other figurines in Western art... the meaning of a specific figure can be determined.... by noting the range of activities in which he is engaged, and the consistent setting in which he is represented." (Donnan, 1976:8 Apud Quilter, 1997:114)

Uma das razões do sucesso deste tipo de abordagem foi a identificação de temas recorrentes em diversos vasos e murais, como o "Tema de apresentação", "O tema funerário", 
"O tema do sacrifício" e o "Tema da Revolta dos Objetos", muitas vezes expressos por meio de apenas um elemento simbólico na composição (Quilter, 1997:114). Como complemento na análise das composições cerâmicas, Donnan também se vale da incorporação de narrativas etnohistóricas, como por exemplo as crônicas do padre peruano Antonio de Calancha como base interpretativa para as cenas do "Tema Funerário" (Donnan \& Mclelland, 1979: 11).

Apesar de inovadora e profícua a abordagem temática traz limitações intrínsecas à sua própria metodologia. O arqueólogo Jeffrey Quilter afirma que a tendência quantitativa da abordagem temática pode apontar certas tendências ao longo do tempo na iconografia, como o aumento ou queda da frequência no uso de certas figuras, mas tende a ignorar causas e mecanismos de criação e difusão de narrativas nas sociedades humanas utilizando-se de elementos etnohistóricos apenas em casos extremamente específicos (Quilter, 1997:115). Além disso, a falta de uma definição rigorosa do que seria um "tema" acaba por proliferar "temas" infinitos, uma vez que haveria um grau considerável de composição nas mãos do artesão mochica, o que produziria incontáveis variações composicionais.

Para superar estes problemas Quilter propõe uma "abordagem narrativa", que consistiria em identificar e inserir os temas dentro de grandes narrativas que deviam ser contadas, lembradas e reencenadas no contexto social mochica (Quilter 1997:116). Segundo Quilter, a partir dos estudos de Weitzmann (1947), as narrativas apareceriam na cultura material de três formas: 1. Simultaneamente, com muitas ações sequenciais da narrativa aparecendo concomitantemente na obra de arte. 2. Selecionando apenas uma cena danarrativa na representação. 3. De forma cíclica na qual o artista apresenta uma série de quadros indicando a sequência de cenas narrativas interligadas.

Mais do que uma antítese, a abordagem narrativa de Quilter funciona como complementar à abordagem temática de Donnan. Reconhecer que os temas fazem partes de narrativas traz uma estruturação mais enraizada aos estudos iconográficos, mas demanda a articulação destes estudos, que se tornam menos autossuficientes, com a produção arqueológica e etnológica da região estudada. O aumento exponencial de pesquisas arqueológicas na região da costa norte andina durante os últimos 40 anos trouxe as condições para essa compreensão mais integrada entre cosmologias, organização social expressas nas narrativas, temas e composições das produções mochica.

A busca para além do tema também impulsionou outras formas de abordagem sobre a pesquisa iconográfica e a interpretação arqueológica como um todo. A arqueóloga Anne-Marie Hocquenghem talvez tenha sido o primeiro exemplo dessa nova leva interpretativa buscando ligar estruturalmente uma forma de organização social sabidamente agrícola e tradicional ao 
material etnológico de sociedades tradicionais andinas disponíveis desde o século XVI. Sua obra mais completa e pioneira neste sentido é Iconografia Mochica (1987), na qual analisa a iconografia utilizando-se o método do estudo de conjuntos iconográficos desenvolvido pelo historiador da arte Erwin Panofsky (1892-1968), também utilizado por Donnan em sua "abordagem temática". Tal iconografia, principalmente as "cenas" das composições de linha fina, são articuladas a eixos explanatórios ligados aos ciclos naturais e ritos de revitalização sazonais extremamente importantes para sociedades agrícolas, como o solstício e equinócio, zênite e nadir do sol (figura 4) e a aparição e reaparição da constelação das plêiades (Hocquenhen, 1987).

Tais ciclos adquirem significações subjetivas ligadas ao ciclo de vida humano e sóciocosmológicas, ligadas à estrutura quadripartida de ordenação do universo andino. Hocquenghem faz isso utilizando-se de relatos etnohistóricos obtidos principalmente no período colonial e descreviam os diversos ritos do império Inca, além de relatos etnográficos posteriores, sobre as práticas de sociedades andinas tradicionais (figura II.I.d)

\section{EL CICLO DE LOS ASTROS}

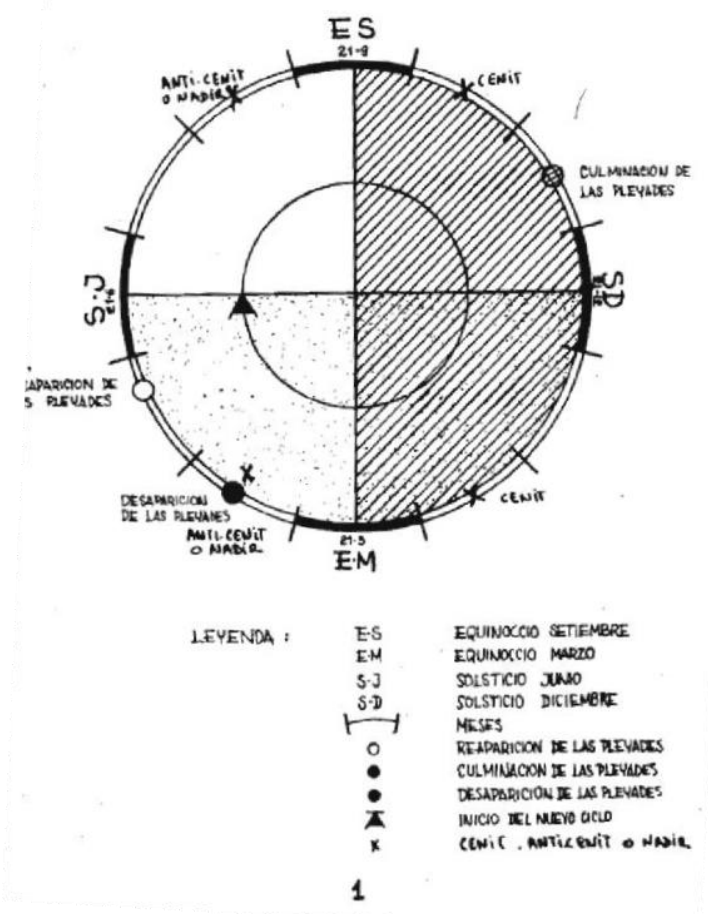

(FIGURA II.I.d)Divisão cosmológica andina de acordo com o ciclo solar e da constelação das Plêiades utilizado por Hocquenghen, 1987:37 
Esta tentativa de reconstruir a iconografia do mundo mochica a partir de uma história social foi continuada e desenvolvida por autores como Steve Bourget e principalmente Jurgen Golte. Enquanto Bourget trabalha principalmente com evidências arqueológicas ligadas à temática dos sacrifícios cerimoniais e violência nos andes, Golte, muito como Hocquenghen, traz uma visão panóptica da iconografia mesclada a um profundo conhecimento da cosmologia etnológica andina. Seu magnus opus "Moche: cosmologia y sociedad (2009)" é uma obra ambiciosa de 466 páginas na qual Golte cria uma costura entre os significados atribuídos à toda iconografia mochica, utilizando-se principalmente da cerâmica, ritos e narrativas embasados em observações etnográficas. Sua leitura da iconografia articula milhares de peças a partir da ordem cosmológica binária quadripartida de ondem surgem se estruturam os significados de personagens, ritos e narrativas. Golte critica Donnan pelo uso indiscriminado dos Roll outs uma vez que mesmo os vasos de linha fina teriam sido criados para operar numa ordem de significação que leva em conta todo o corpo tridimensional do vaso. Ele considera significativo, por exemplo, o quadrante em que determinadas figuras se apresentam como indicadores de associações aos mundos de hanan ou urin $^{6}$ (figura II.I.e) e seus desdobramentos, ou a proximidade de uma determinada figura à alça estribo do vaso, ambos aspectos negligenciados quando analisados pelos roll outs.

Golte divide seu livro em três partes: 1.Cosmovisão, onde pontua elementos básicos na compreensão da gramática visual mochica como elementos cosmológicos, principais personagens e suas funções bem como divisões sazonais significativas e divisões entre as instâncias do mundo como mundo dos mortos, o mundo dos vivos, o mundo de cima, o mundo marinho etc. 2 . Ritos, no qual explica três ritos que estão claramente representados na iconografia. 3. Narrações, onde descreve e interpreta três sequências narrativas recorrentes na cerâmica mochica. O livro se destaca pela abrangência, atualidade e pela erudição e domínio do autor na cosmovisão andina e será utilizado como marco teórico nas questões relacionadas à cosmologia das cenas.

\footnotetext{
Hanan e Hurin são termos retirados de documentos coloniais que descrevem uma classificação que dividia a dinastia Inca em duas metades assimetricas: hanan, relacionada ao mundo de acima e solar e hurin, relacionada ao mundo tectonico, de abaixo. Segundo os relatos, os grupos se alternavam no comando do imperio sendo a primeira dinastia da metade hurin e a segunda, que governava no período da invasão espanhola, hanan. De acordo com Yaya (2013) todavia, a visão de alternancia no poder pode ter sido contaminada pela visão eurocentrica dos colonizadores e há indícios de uma possivel diarquia, com representantes de ambas as metades governando concomitantemente. De qualquer forma, há um consenso entre arqueólogos, historiadores e antropólogos de que uma espécie de divisão cosmológica entre duas metades assimétricas é encontrada ainda hoje nas populações tradicionais, bem como no registro da cultura material a partir do horizonte inicial, por volta de 1.200 a.C e, possivelmente até antes.
} 


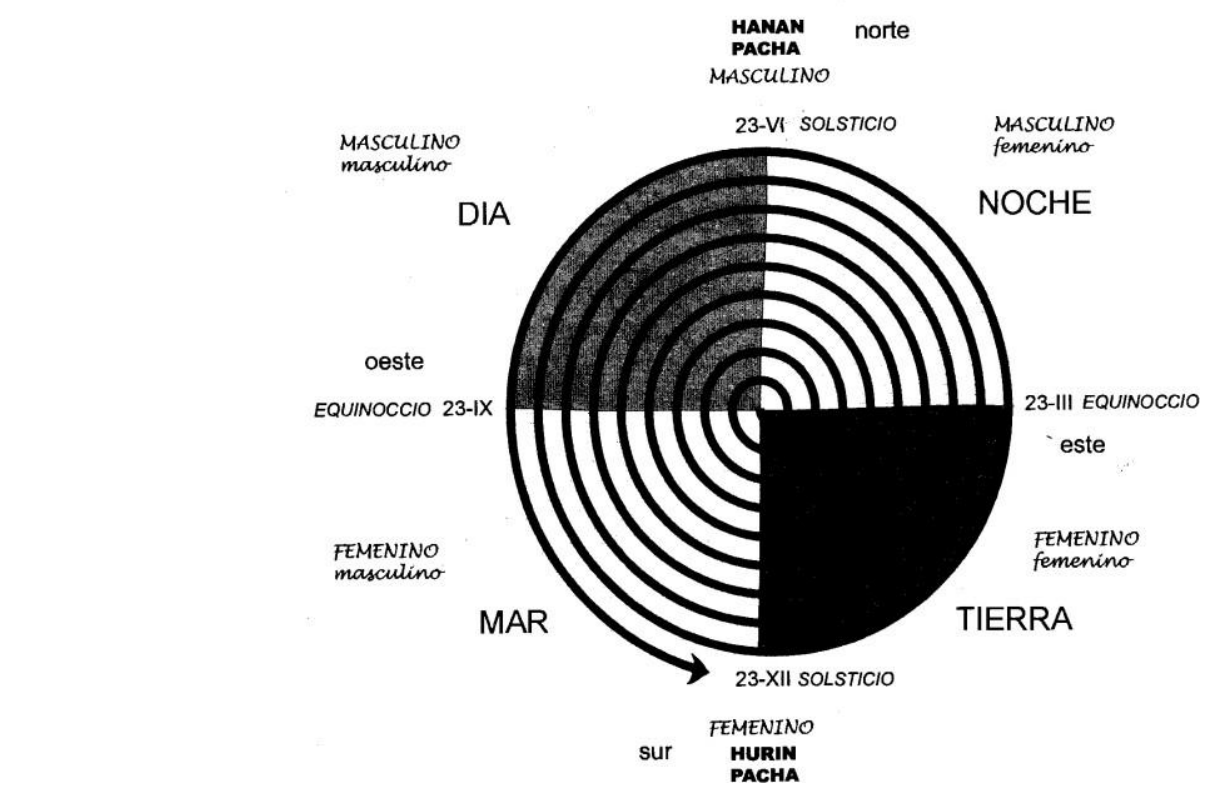

(Figura II.I.e)Esquema cosmológico binário quadripartido andino de acordo com Golte, 2009: 59

Para Golte a cerâmica parece ter sido um meio especialmente privilegiado na representação das narrativas, havendo, por vezes, mais de uma dezena de vasos pintados com o mesmo tema. Enquanto podemos observar manifestações heterogêneas da cosmovisão mochica e de seus personagens principais, nossa compreensão das narrativas é particularmente dependente dos vasos de linha fina. Segundo Golte:

"Neste sentido pode-se supor que as imagens expressavam as ideias preponderantes sobre o cosmos, a natureza e a sociedade. Ainda mais porque as imagens naqueles séculos nunca são obras únicas, pois sempre se trata de composições que se repetiam por mãos diferentes em seus elementos constitutivos" (Golte, 2009:18)

Ainda de acordo com Golte (1998:11), o número de cenas representadas nos vasos gira ao redor de cem com um número ainda mais limitado de atores. Apesar de apontar três grandes sequências, a ver, a sequência do enterro, a sequência das lutas do deus intermediador contra os monstros marinhos e a sequência conhecida como "rebelião dos objetos", Golte crê que todas cenas fariam parte de uma grande narrativa única que trata de uma confrontação entre divindades maiores do panteão mochica e suas cortes que teria posto em perigo a existência da própria humanidade. 


\section{II.II Semasiografia e narrativa}

Concomitantemente ao trabalho de Hocquenhem e Golte desenvolveu-se de maneira paralela, porém dialógica à abordagem histórica social, uma linha de investigação focada na análise semiótica pautada na gramática visual como principal ordenador na compreensão da cultura pictográfica. Para este tipo de abordagem nos basearemos principalmente nos trabalhos da historiadora da arte Margaret A. Jackson e do arqueólogo James Vernon Knight. Ambos, de certa forma, continuam, desenvolvem e expandem o trabalho temático iniciado por Donnan.

A proposta de Margaret A. Jackson se condensa no livro Moche Art and Visual Culture in Ancient Peru, 2008. Para ela a arte mochica como um todo teria se sistematizado a partir de uma cultura visual milenar na costa norte peruana a ponto de poder ser considerada um sistema de 'notação' (Jackson, 2008: 9) ou seja um sistema que "emprega sintaticamente caracteres separados possuindo níveis de certeza semântica" (Jackson, 2008:86). Algo como um mapa, onde os elementos apesar de possuírem uma significação própria, só adquirem um significado inequívoco quando pensados em relação ao todo. Porém, baseada na classificação de Elkins, (1999) para ela a pictografia mochica não seria um sistema de notação simples, mas mista, incorporando elementos notacionais, pictográficos e logográficos a ver, um sistema semasiográfico. A semasiografia significa simplesmente "semasio", o que quer dizer sígnica ou, em outras palavras, com signos + "graphos", isto é, escrita. Ou seja semasiografia seria uma escrita por meio de signos ou significados sem uma correlação linguístico/verbal necessária. Jackson, baseada no esquema de James Elkins a posiciona como um nodo entre três formas representacionais: a escrita propriamente dita, com sua estrutura convencional e sintaxe interna coerente, seja glotográfica, seja ideográfica (figura II.II.a). A pictografia, sem uma sintaxe interna necessária e a notação, como o exemplo do mapa já ilustrado. 


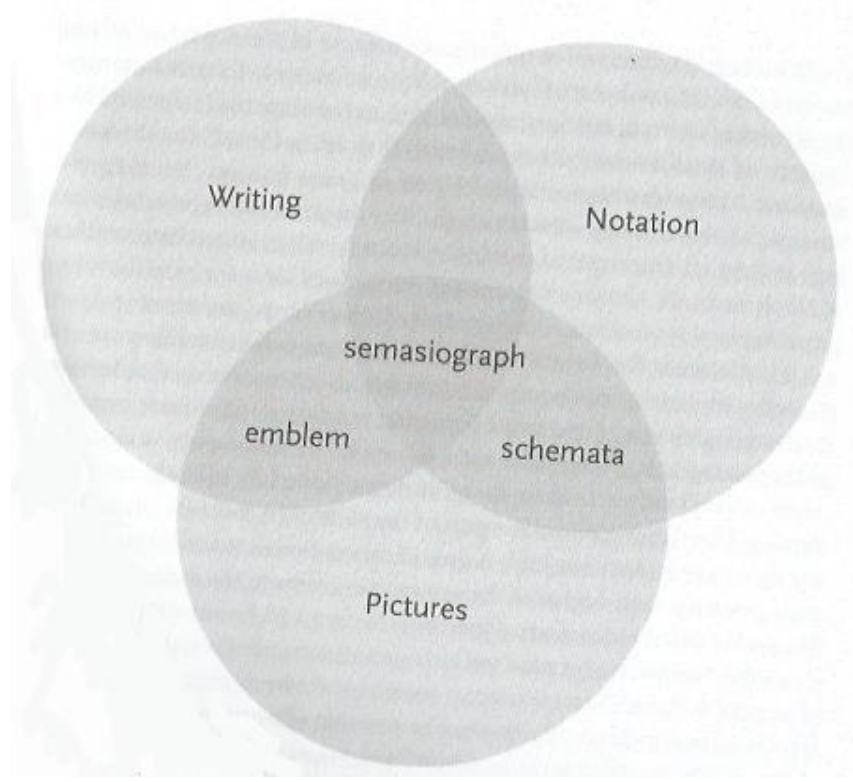

(Figura II.II.a)Esquema triádico de domínio imagético utilizado por Jackson, 2008:87 baseado em Elker, 1999:86

A autora crê que sistemas representacionais mistos são a regra nas Américas préColombianas e que o sistema mochica seria equivalente a escrita pictográfica mixteca (Jackson, 2008:87). Sistemas semasiográficos funcionariam melhor dentro de contextos limitados ou restritos e o caráter canônico da arte mochica parece propiciar o ambiente ideal para este tipo de comunicação. Haveria também níveis diferentes de compreensão da semântica visual de acordo com o domínio das convenções, cânones e narrativas. Para a autora:

The findings suggest that, although the graphic system was not a reiteration of spoken language, it was capable of communication relatively specific information to those trained in esoteric matters. To the larger population, the imagery doubtless held a mnemonic component keyed to prevalent social metanarratives. It possessed an internal logic and specificity that ordered and governed its use, while the iconographic vocabulary was framed by encompassing, pervasive ideological conventions and social habits. Although many of its internal structures are analogous to the patterns typically displayed in oral rhetoric, such as rhythm, repetition, and use of set phrases, Moche iconography constituted an independent visual language that operated in separate symbolic register. (Jackson, 2008:11) 
Jackson considera como linguagem visual independente todas as formas de comunicação visual como cerâmica ritual, metalurgia e murais. Neles seria possível elementos convencionais serem reconfigurados de acordo com a vontade do emissor, de modo a criarem novas mensagem a partir dos mesmos elementos, mesmo que dentro de um campo de possibilidades restritos aos cânones. Ou seja, existiria um mecanismo de organização interna desses elementos que faz com que seus significados mudem de acordo com suas configurações que seguiriam regras próprias. Logo, tais elementos não seriam apenas pictográficos, mas carregariam consigo conotações convencionais que extrapolariam o significado representacional direto 1/1. Em outras palavras, uma flor nem sempre quer dizer apenas flor, assim como um charuto pode não ser apenas um charuto, mas a flor ou o charuto poderiam remeter sistematicamente a outro objeto representado que não o mais óbvio.

Como evidência de que haveria ao menos uma tendência para o uso convencional de signos, a autora aponta o uso de símbolos nas olarias de produção de vasos moldados (os moldes teriam sido um avanço na tecnologia cerâmica criado pelos mochica, Donnan, 1999). Em muitos destes moldes há, na parte exterior, símbolos que indicariam ao artesão o formato interno do molde, utilizados para dar celeridade no seu uso e armazenamento. Neles, alguns símbolos simplesmente não assemelham semelhança alguma com o formato interno do molde. Jackson nos apresenta por exemplo, com moldes de mulheres dando à luz indicados pelo símbolo de um apito, ao que a autora pensa haver uma ligação linguística, ou moldes de rostos com indicações geométricas (Jackson, 2008:104). Ela acredita que haveria indícios nas composições dos vasos de linha fina de que alguns aglomerados de figuras ou nominativos modificados como estariam exercendo a função de verbos nas narrativas, função esta que estaria mimetizando a estrutura da língua Muchic, falada na costa norte do Peru até o fim do século XIX (Jackson, 2008:140). Daí surgiria sua equivalência com a escrita mixteca, mas ao contrário desta última, o conhecimento do Muchic que teria chegado aos dias atuais apenas por gramáticas incompletas e dicionários não seria suficiente para compreendermos por completo os paralelos linguísticos contidos na "Sintaxe de Apresentação Híbrida" (Jackson, 2008:144).

James Vernon Knight por outro lado é mais conservador quanto à estruturação da gramática visual mochica. Seu manual Iconographic Method in New World Prehistory, 2013, versa sobre métodos e princípios para analise iconográfica das culturas americana préColombiana. Seu eixo central é uma divisão metodológica entre estilo, forma significante e correlações etnográficas que apesar de auxiliares entre si devem se manter "analiticamente separadas" (Knight, 2013: XV). Apesar de abrangente Knight se apoia intensamente no trabalho de análise temática de Donnan (que é referido 49 vezes ao longo do livro) e, assim 
como este último e Anne Marie Hocquenghen, baseia boa parte de seu trabalho nos métodos analíticos de Panofsky.

Knight acredita que os mochica não desenvolveram uma semasiografia no sentido completo, mas uma pictografia com elementos semasiográficos. Isto é, para Knight não era todo o conjunto de produção iconográfica mochica que teria uma estruturação interna coerente, convencional e rearranjável, mas apenas algumas partes de sua pictografia. Para ele, a iconografia mochica seria algo equivalente ao que se vê nos murais de Teotihuacan, no atual México, muito anteriores à conhecida escrita glífica maia ou mesmo à escrita desenhada mixteca. O esquema representacional utilizado por Knight (figura II.II.b) é ligeiramente diferente do usado por Jackson porque considera como eixo central de classificação a arbitrariedade vs iconicidade dos signos, onde a semasiografia estaria no meio entre opostos.

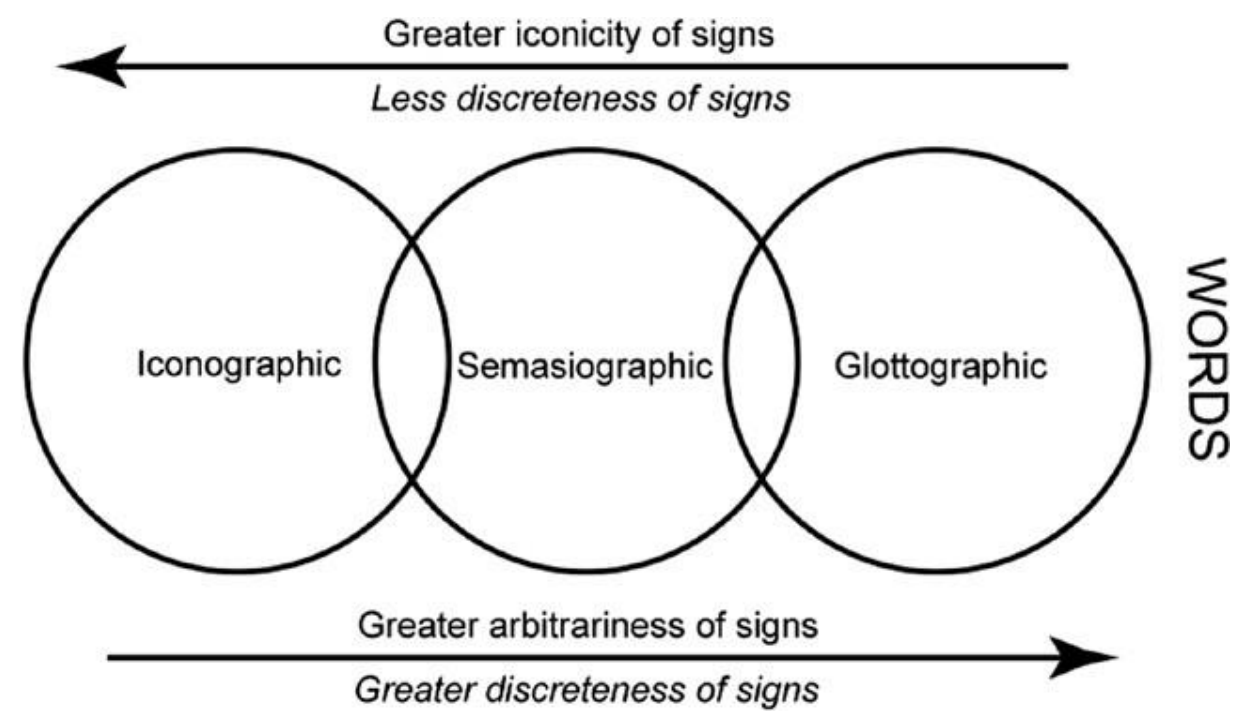

(FIGURA II.II.B)Escala proposta por Knight considerando arbitrariedade e iconicidade dos signos (Knight,2013)

Devemos notar que em ambos os autores há o consenso de que na semasiografia é possível comunicar uma gama de convenções dentro de um sistema canônico. Isso aparentemente acontece na produção da cerâmica Moche, convencional, com um número limitado de temas e personagens, e com elementos de composição numerosos, mas com uso regrado dentro de certas convenções. 


\section{II.III- Os localizadores}

Alguns motivos aparecem de forma discreta mas constante na composição das cenas representadas nos vasos de linha fina (figura II.III.a). São exemplares de vegetação como cactos (família cactaceae), tillandisias (família bromeliácea), alguns tipos de árvores e arbustos, mais comumente o algarrobo (prosopis jutiflora), assim como de fauna marinha como leões marinhos (Otaria byronia) e estrelas do mar (classe Asteroidea) ou mesmo símbolos sintetizados como linhas em s figurando ondas. Estes motivos foram denominados de "localizadores" por Cristopher Donnan (Donnan \& Mcllelland, 1999) e teriam a função de indicar em qual ambiente ou "cenário" no qual a ação representada estaria ocorrendo (Donnan \& Mcllelland, 1999: 59). Deste modo, um cacto indicaria que a cena estaria se passando no deserto entre os vales enquanto uma onda indicaria um cenário marinho e um totoral (Schoenoplectus californicus) indicaria uma região lacustre, assim como um templo estabeleceria a cena dentro de um dos centros cerimoniais, comuns na região.

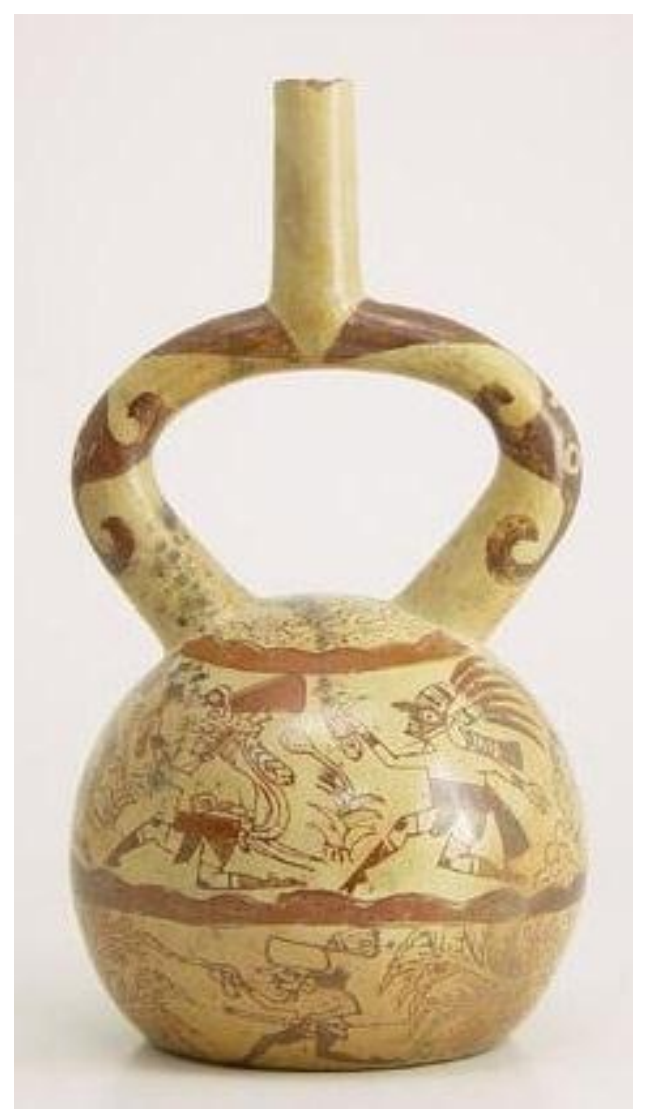

(Figura II.III.a)Vaso figurando cena da corrida dos feijões com tilandisias e arbustos como localizadores(cortesia Museu Larco) 
Knight se refere aos localizadores como locativos e aponta que são encontrados em outros contextos da arte pré-colobiana:

These 'locatives' might indicate the realm of the cosmos in which the subject or action resides, such as crocodile feet in Izapa stonework as a locative for water (Smith 1984:13) or a petaloid motif in Mississippian images as a locative for the celestial realm (Reilly 2007). (Knight, 2013:100).

Partindo de sua análise configuracional, os localizadores seriam elementos do nível subcomposicional com atributos "salientes", pois contribuiriam para a identificação do objeto representado. Também seriam classificados como "motivos" pois carregam significados em si mesmos, podendo ser destacados da ação principal sem que a ação perca sentido (Knight, 2013:117). Em outras palavras, os localizadores seriam "motivos salientes" pois, apesar de adicionarem informação à cena principal eles teriam um significado em si mesmos (um cacto será reconhecido como tal independente do contexto em que aparece) e servem como auxiliares "destacáveis" da cena principal.

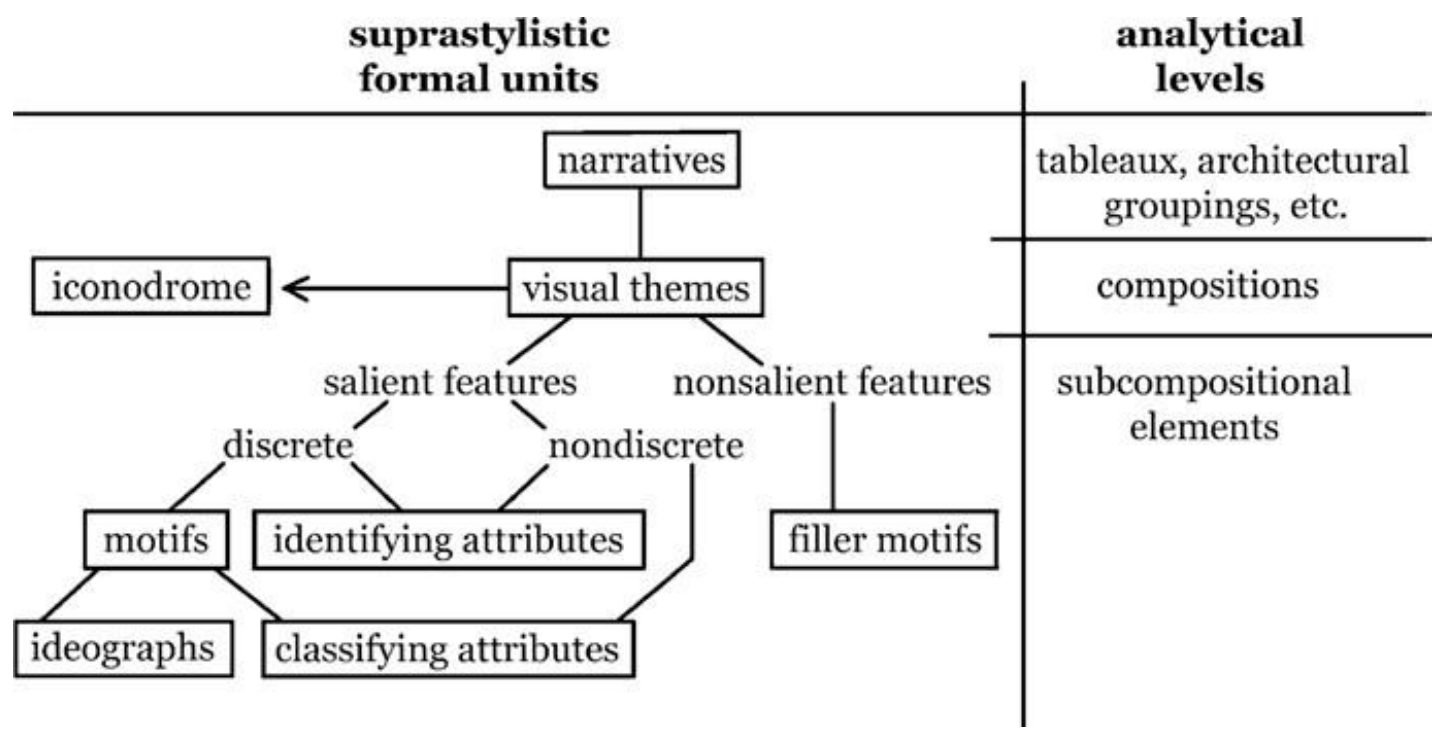

(FIGURA II.III.b)Esquema da analise configuracional de Knight(Knight, 2013: 93)

Margaret Jackson aborda o problema dos localizadores a partir do método de estruturação narrativa de Rolland Barthes (1915-1980), mais próximo da linguística. Haveria nas cenas dos vasos de linha fina uma estrutura narrativa que poderia ser decomposta em partes correspondentes a elementos gramaticais (Jackson, 2008:137). Deste modo determinada parte das cenas poderiam ser decompostas em, por exemplo sujeito, verbo, objeto direto, etc. Os 
localizadores corresponderiam ao caso locativo em preposições como "em” + o nome do local. Assim, o exemplo de Jackson abaixo a cena poderia ser lida como "O guerreiro derrota um adversário no deserto"(Jackson, 2008:136). O montículo de areia da figura corresponderia à contração "em+o" mais o nome deserto (figura II.III.c).

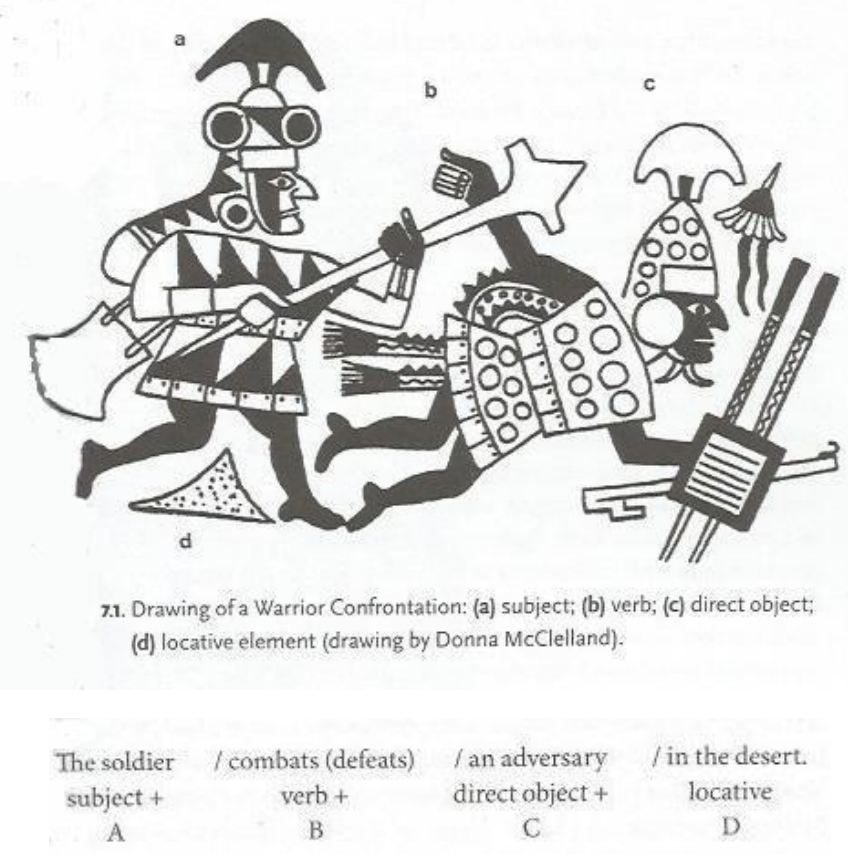

(Figura II.III.c)Exemplo de correspondência pictórica-narrativa Jackson, 2008:137. (As letras signifcam elementos da sentença. A seria o sujeito "o soldado”, b seria o verbo "combate”, c seria o objeto direto "um adversário" e d seria o locativo "no deserto".

É importante destacar que os localizadores não devem ser confundidos, pois possuem função diversa do que Donnan \& Mcllelland nomearam de "símbolos" e "artistic modifiers", ou modificadores artísticos. Estes são elementos da iconografia profundamente convencionalizados que serviriam para expressar ações ou ideias abstratas como ranking, morte, luta ou velocidade. (Donnan\&Mcllelland, 1999 :63). Um exemplo seriam os beija-flores que aparecem nas cenas dos vasos indicando ação rápida, frenética. Beija-flor diferiria do uso dos localizadores, pois a associação dos beija-flores com ação rápida seria indireta. O caminho significativo seria beija-flor $=$ rápido $\rightarrow$ rapidez. Se Donnan estiver certo, nem o artesão nem qualquer mochica versado na gramática visual pensaria que de fato um beija-flor participa da cena, mas o beija-flor é, de certo modo a rapidez. No caso dos localizadores o indicador estaria representado o objeto que estaria presente na cena. Logo, ondas representariam de fato ondas, cactus seriam cactus e leões marinho seriam leões marinhos. Cactus não são o deserto, mas desertos possuem cactus, logo os cactus sugerem o deserto. $\mathrm{O}$ fato de os localizadores estarem 
indicando outra coisa não os abstrai da cena.

Knight crê que a denominação criada por Donnan é ambígua e confusa e propõe nos referirmos a estes modificadores simplesmente como símbolos (Knight, 2013:137). De fato, se utilizarmos a classificação semiótica de Charles Sanders Peirce (1839-1914) baseada na tríade de signos Ícone, Índice e Símbolo (Santaella, 1983) o beija-flor como utilizado nas composições de linha fina seria um elemento simbólico já que a única coisa que liga o significante (beija-flor) de seu significado final (rapidez) seria o compartilhamento de uma lei ou convenção compreendida tanto pelo emissor quanto pelo receptor da mensagem.

Não obstante serem elementos "auxiliares" da composição tanto localizadores quanto símbolos podem trazer não apenas detalhamento para as cenas mas, em casos raros, podem exprimir "sentenças" completas. Jackson apresenta a cena abaixo (figura II.III.d) onde símbolos como a panóplia e o beija flor são considerados verbo e advérbio e a planta o locativo.

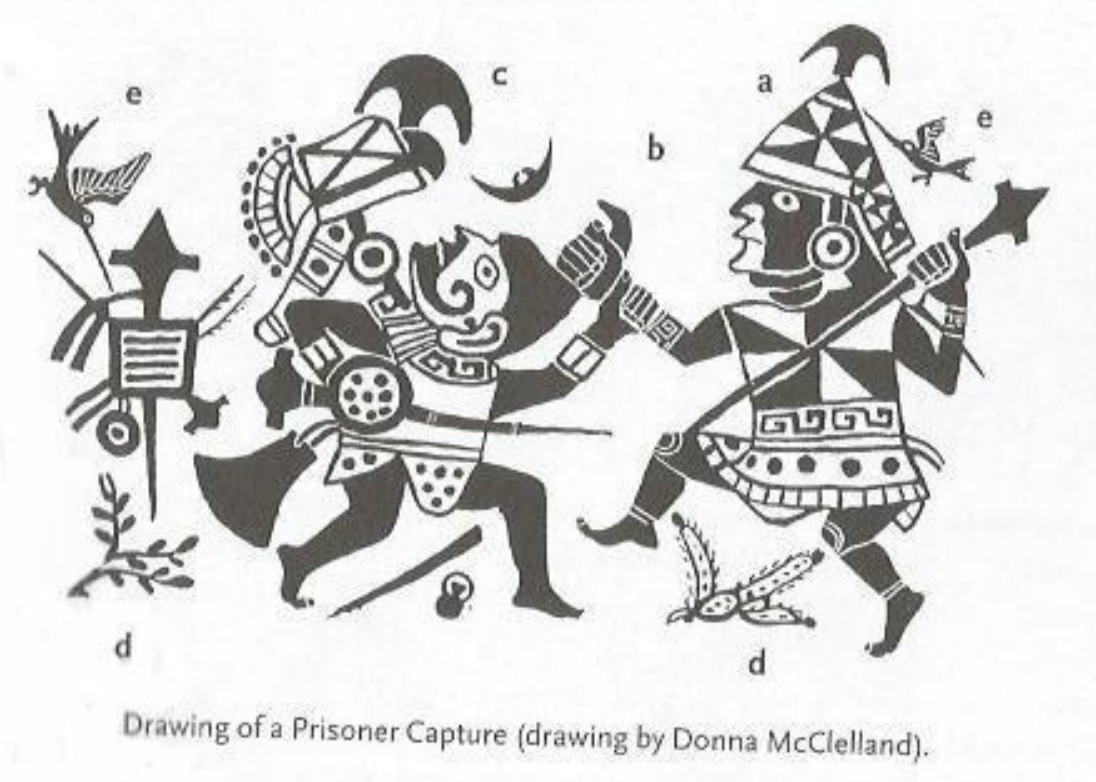

(Figura II.III.d) “Frase” completa com seus elementos indicados por letras (Jackson, 2008:140)

Entretanto se retirássemos a cena principal dos dois guerreiros e mantivéssemos apenas os "auxiliares" haveria uma sentença completa, algo como "luta" (panóplia) "rápida, frenética" (beija-flor) "no bosque" (planta típica dos bosques). Perderíamos a informação dos toucados e vestes indicando qual guerreiro é o vencedor e qual o derrotado mas haveria uma sentença completa apenas através de signos bastante convencionalizados (figura II.III.e). 


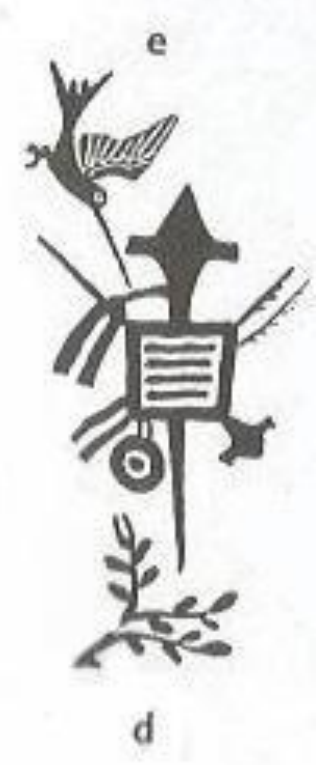

(FIGURA II.III.e) "Símbolos" e "locativos" isolados. Apenas com estes elementos observamos o “verbo” (panóplia) “advérbio” (beija-flor) e "locativo” (planta).

Não queremos afirmar, todavia que os localizadores são tão convencionalizados quanto os "símbolos" como a panóplia. O que podemos dizer é que os localizadores apresentados nos vasos de linha fina são "altamente motivados" segundo Jackson ou "miméticos" segundo Knight ou "realistas" segundo Donnan. Isso quer dizer que possuem alto grau de semelhança com o objeto representado, uma característica também conhecida por naturalismo, ao menos no que diz respeito às espécies vivas (ondas não entrariam nessa afirmação). Tal naturalismo, motivação, realismo ou mimetismo possibilita que mesmo oriundos de uma tradição cultural totalmente diferente, ocidentais do século XXI consigam identificar e distinguir as espécies representadas como localizadores nos vasos de cerâmica mochica, algo que provavelmente seria muito mais improvável caso o desenvolvimento estético mochica fosse em uma direção menos mimética.

Isso não quer dizer, porém, que os localizadores não estariam sendo utilizados de forma altamente convencional. O beija-flor é um signo mimético, mas convencionalizado. Contudo, fossem os localizadores apenas formas totalmente convencionais para indicar ambiente, esperaríamos uma relação $1=1$, como, por exemplo cactus $=$ deserto. Ao invés disso percebemos nas composições espécies diversas de plantas que aparecem indicando o ambiente. Algumas vezes as mesmas espécies de plantas parecem estar indicando ambientes diferentes como lomas, regiões elevadas e úmidas na costa, ou desertos. Segundo a classificação peirceana os localizadores seriam ícones, pois possuem semelhança de forma com o objeto representado, indiciários, pois o objeto representado é parte "planta" de um todo "ambiente". 
Se as plantas estariam indicando um "ambiente" podemos dizer que estão, de certa forma, para além de apenas um indicador convencional sobre o local onde estaria se passando a ação da composição. Mesmo se considerarmos as regras canônicas da composição mochica podemos inferir que as plantas poderiam estar sendo utilizadas como elementos paisagísticos, ou seja, estariam expressando uma ideia de ambiente ou paisagem.

Uma vez que o conceito de paisagem é extremamente polissêmico utilizaremos a definição de Jhonson e Hunn, 2011, de "paisagens etnoecológicas”. Para eles:

Three broad approaches to landscape have ethnoecological significance: landscape as perspective or view and, related to this: landscape as representation; landscape patterns, structures, and the significance of scale; and landscape as foundation of land management. (Jhonson \& Hunn, 2001:268)

Nesta definição a ênfase é na paisagem "como percebida e imaginada pelo povo que vive nela. (...) É uma paisagem cultural” (Jhonson \& Hunn, 2011, 170). Isso não quer dizer que elementos que consideramos "naturais" não sejam levados em conta. É no processo interação e categorização dos povos com o ambiente que encontramos a "paisagem" etnoecológica. Segundo os autores, dentro desta abordagem, ecótopos são as menores unidades paisagísticas. Estes não seriam determinados pelo estudioso, mas sim pelos próprios nativos que a partir de suas categorias indicariam como diferenciam os "tipos de lugares" ou ecótopos (Jhonson \& Hunn, 2010,187).

Ora, é possível que os localizadores estejam justamente nos indicando como os mochica classificavam seus ecótopos. Segundo Jhonson \& Hunn, essas etnocategorias raramente são aleatóreas e estão muitas vezes intrinsicamente ligadas a princípios cosmológicos e a conhecimentos ecológicos essenciais para a população. Ou seja, poderíamos assumir que os ecótopos estejam cosmologicamente estruturados e permeados de um conhecimento ecológico, possivelmente sensível às variações ambientas vividas pela população produtora dos artefatos. Um exemplo de uma possível compreensão ecológica embebida na cosmologia mochica é dado por Golte ao propor que, ao menos em algumas nas cenas rituais da corrida dos feijões as tilandisias estariam indicando não apenas o lugar, mas também a época do ano nas quais os rituais seriam performados, uma vez que sua floração ocorre na época seca, pois têm um ciclo reprodutivo contrário ao da vegetação dos bosques secos. 
Donnan \& Mcllelland também parecem apontar para essa direção quando afirma que os localizadores, que se iniciam na fase III na classificação de Larco, incorporam mais elementos vegetais indicando outros ambientes como pântanos e margens ribeirinhas na fase IV. Há ainda uma aparente mudança da fase IV para a fase V, quando os motivos das composições de linha fina trazem mais temáticas divinas e ambientam-se mais frequentemente no mar. Donnan insinua que tal mudança nos temas e nos elementos subcomposicionais poderia estar indicando uma crise ecológica que teria dado fim ao moche do sul e já se prenunciaria na arte da fase V. Os localizadores indicando pântanos, muito comuns durante a fase IV somem, enquanto surgem dois novos localizadores marinhos (Donnan \&Mcllellan, 1999, 177) Entretanto, aparentemente são os animais o maior indicador de mudança nos elementos subcomposicionais:

\begin{abstract}
Many natural animals were discontinued in Phase $V$, including the feline, fox, lizard, land snail, snake, and most insects. Most of those that remained are marine creatures, such as crabs, fish, rays, and sea lions. They often simply serve as locators - indication that the activity is taking place in or near the ocean. (Donnan \& Mcllellan, 1999: 180)
\end{abstract}

De fato, de acordo com Moseley et. Al (2008) há indícios de que, por volta do ano 650 d.C, há uma aparente convergência de catástrofes naturais no sítio de Dos Cabeças, no vale de Jequetepeque, onde grandes deslizamentos de terra teriam ocorrido por conta de chuvas torrenciais. Este fato tem particular importância uma vez que era no o vale de Jequetepeque que eram produzidas as cerâmicas de linha fina da fase V. Há ainda a convergência da data da catástrofe com a data de produção da fase V. Se não podemos afirmar uma relação de causalidade entre este evento, ou outros distúrbios climáticos, e a escolha de motivos da cerâmica de linha fina mochica, acreditamos que há aí ao menos uma correlação passível de ser investigada mais minuciosamente. 
Apesar de sua ubiquidade e mesmo muito referidos, os localizadores não foram objeto de estudo sistemático. Mesmo assumindo-se que estariam indicando locais de ação não há um estudo aprofundado sobre se a função dos localizadores na composição seria somente esta. Acreditamos que um estudo aprofundado sobre o seria de interesse a todos os estudiosos do contexto da costa norte peruana. Desta forma, este trabalho centrou-se em duas questões:

1. O que podemos inferir sobre o meio ambiente em que viveram os moche estudando os localizadores?

2. Como o refinamento na classificação dos localizadores nos ajuda na compreensão da cultura iconográfica?

Logo, buscamos:

1. Identificar as correspondências morfológicas e sistematizar as possíveis espécies e gêneros de plantas representados na função de localizadores.

2. Entender o uso desses localizadores florísticos no contexto canônico da arte Moche de acordo com sua localização, frequência e associação aos principais personagens representados. 


\section{CAPÍTULO III: MATERIAL E MÉTODOS}

Partindo das questões assinaladas foi decidido produzir uma análise baseada em três abordagens complementares: a análise cerâmica com o intuito de mapeamento e identificação dos elementos florísticos das cerâmicas pictóricas; a visita a locus naturais de importância estratégica, nos quais a paisagem seria percebida de um ponto de vista privilegiado, além de observar a flora in natura; e a revisão bibliográfica, que além de abarcar os estudos arqueológicos sobre os Moche teve de ser aprofundada na bibliografia sobre a flora e ambiente dos vales da costa norte peruana.

Por conta da natureza dupla da questão e dos objetivos, dividiremos os resultados em duas seções. A primeira relativa a identificação de flora e análise de ambiente e a segunda relativa à analise iconográfica (utilizando os dados da primeira seção).

\section{III.I - Pesquisa Bibliográfica}

Esta pesquisa e revisão bibliográfica pode ser dividida basicamente em dois grandes blocos: os estudos sobre os Mochica e sua cultura e os estudos sobre o ambiente, flora e fauna da costa norte peruana, particularmente entre os vales de Chicama e Moche.

A literatura é vasta no que tange a cultura Mochica. Seu histórico de investigação aparece no capítulo I, porém cabe aqui uma breve revisão. A princípio é preciso dizer que a estrutura central do trabalho foi fiada a partir dos conceitos de "localizadores" nos vasos de linha fina encontrados em Donnan \& Mclellan (1999). Do começo ao fim há um diálogo com a obra ao redor do conceito de localizadores com a proposta de observar suas nuances e possíveis ambientes representados.

Para a análise da cerâmica pictórica mochica dentro de um esquema classificatório que considera configuração e semântica foi utilizado Knight (2013) e Jackson (2008). Nas análises mais voltadas à questões socioeconômicas, artigos diversos, com destaque ao trabalho de Quilter, Billman, Shimada, Uceda e Castilho e Benson.

Nas análises sócio-culturais mais totalizadoras foi Golte (2009) foi o principal guia ao lado de Hocquenghem (1989). Ambos os autores buscam ligar os sentidos da 
iconografia com os ritmos naturais sentidos por sociedades agrícolas como dia/noite, período seco/chuvoso e fertilidade. No caso de Golte, as análises cerâmicas e mitológicas giram essencialmente em torno do conceito de Tinku, um encontro muitas vezes conflitivo entre duas partes complementares que produz futuro (Golte, 2009: 95). Benson (2012), também foi muito utilizada nas análises por sua obra que traz uma contextualização clara que ata iconografia a evidências arqueológicas. Makowski edit. (2000) traz esclarecimentos essenciais sobre a cosmologia mochica e seu histórico de estudo. Bourget edit. (2008) e Uceda \& Mujica edit. (1993) também aparecem em menor intensidade.

Quase todos os autores citados em algum momento abordam as representações e o uso da flora pelos mochica com destaque para Golte, Hocquenghem e Benson. Todavia, foi a falta de um estudo sistemático sobre a flora utilizada como localizadores que nos levou a levar a cabo esta dissertação. Para tanto precisávamos no aprofundar na literatura botânica regional.

Towle (2007 [1961]) foi a espinha dorsal das investigações sobre os usos etnobotanicos das populações peruanas juntamente com Bussman \& Sharon (2009) além de Hornung-Leoni (2011).

Para plantas aquáticas e ecologia das zonas alagadas utilizamos principalmente Altivez et. al, (2012), Ângulo-Patrolongo et. Al (2010), Aponte \& Cano (2013), Aponte (2009) Monzón \& Pelaes (2013), Aponte \& Ramiréz (2012) e Rodríguez et. al (2014).

Para identificação espécies de tillandsias e bromeliáceas em geral, suas características fisiológicas e anatômicas, habitats e distribuição regional foi utilizado Aponte \& Flores (2013), León (2008), Zanella et. al (2012), Rundel \& Dillon (1997), Rundel. et. al (1991). Para uma visão panorâmica do ecossistema do deserto do pacífico o principal texto foi de Rundel et. al. (2007) seguido dos dois volumes do Guia de Biodiversidade de Lambayeque (Llamas edit., 2010), além do guia de biodiversidade da região de La libertad (2011).

Para a definição das espécies e gêneros de cactos utilizamos os guias de Ostalaza (2011, 2014) e, em menor grau, o de Osmich (2006) e de Nobel (2001). Ostalaza em particular apresenta uma lista completa de cactos peruanos com sua classificação taxonômica e seus habitats típicos. Rihá \& Subik (1981) foi de grande utilidade nas detalhadas esquematizações anatômicas e Cullman, Götz \& Gröner (1986) traz classificações morfológicas que nos foram bastante úteis na reafirmação dos tipos morfológicos que estabelecemos pelo estudo da cerâmica. Os estudo de Galán de Mera 
et al. (2012) sobre o padrão de distribuição das cactáceas também nos foi particularmente util. Assim, estabelecemos de acordo o manual quais seriam os gêneros e espécies de cactos ocorrentes nas zonas de ocupação moche, mais especificamente nas zonas de ocupação Moche-sul (vales de Chicama, Moche e Virú), produtoras da grande maioria dos vasos de linha fina ou com elementos pictóricos. Desta forma, considerando as zonas de ocorrência e altitude foram selecionas as espécies com diferentes níveis de probabilidade de estarem sendo representadas nos vasos.

Para o estudo da composição florística de lomas foi muito útil o catálogo florístico das lomas peruanas de Dillon et. al (2011), além de Galán de Mera et. al (2010) e Zapana \& Montesino (2016). Para as lomas específicas da região de La Libertad nos surpreendeu a abundância de literatura sobre o cerro Campana em contraste com a escassez de abordagens sobre as outras lomas da região. Mesmo pesquisando com afinco não pudemos encontrar nenhum artigo sobre a flora das lomas do cerro Cabezón, próximo ao cerro campana. Tivemos acesso apenas a um artigo sobre a flora do cerro Ochiputur (Corcuera, 2017) no vale de Moche, enquanto para o Cerro Campana pudemos contar com Leiva Gonzales et. al. (2014), Rodriguez (2012) e ainda os artigos sobre os vestígios culturas de Valladares (2012) e Franco (2012).

A lista aqui apresentada nem de longe abarca a totalidade da literatura, que está apresentada na seção de referências bibliográficas, mas visa esclarecer quais foram as principais referências que influenciaram nosso caminho de investigação.

\section{III.II-Análise da paisagem e identificação da flora in loco}

Em paralelo ao trabalho com cerâmica foram feitas visitas ao cerro Ventarrón no Vale o rio Reque $(2015,2017)$, Cerro Campana, entre o vale de Moche e Chicama (2017), os sítios de Túcume e Batán Grande próximos ao Bosque de Pomac (2015, 2017), e Huaca Rajada, ainda no vale do rio Reque. As zonas da praia do Pacífico foram visitadas em Pimentel (Lambayeque) e Huanchaco (Moche) e a zona arqueológica de Chan Chan, todas em 2017.

No rio Reque não foi possível observar grande quantidade de flora ribeirinha já que ambas as margens são tomadas pela plantação de cana de açúcar ( Figura III.II.a). Se bem que também os mochica faziam uso das margens do rio para o cultivo e pudemos observar canais de irrigação que de acordo com o arqueólogo Ignácio Alva, datam provavelmente do período moche (Figura III.II.b) Todavia, é plausível que 
houvesse mais mata ribeirinha no período pré-hispânico, uma discussão levantada por Hocquencghen (2001), uma vez que ela pode estar sendo retratada nos vasos analisados. De qualquer forma, são visíveis ao longo das margens do rio algumas espécies altamente resistentes ao estresse hídrico, como o Algarrobo (Prosopis spp.) e o (Huarango Acacia macracantha).

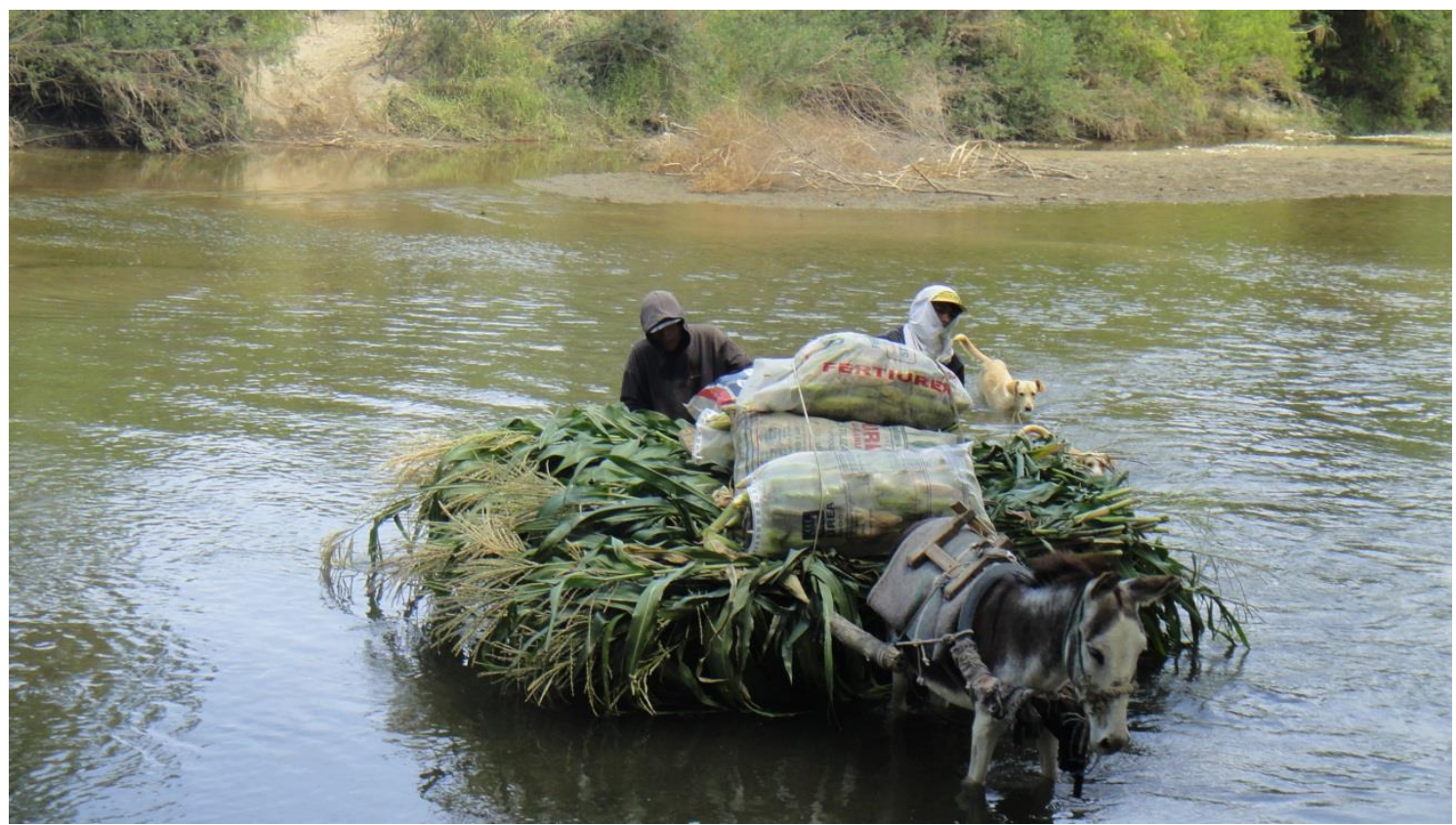

(FIGURA III.II.a) Trabalhadores rurais atravessam o rio Reque com carga de milho (zea mays). (foto do autor, 2015)

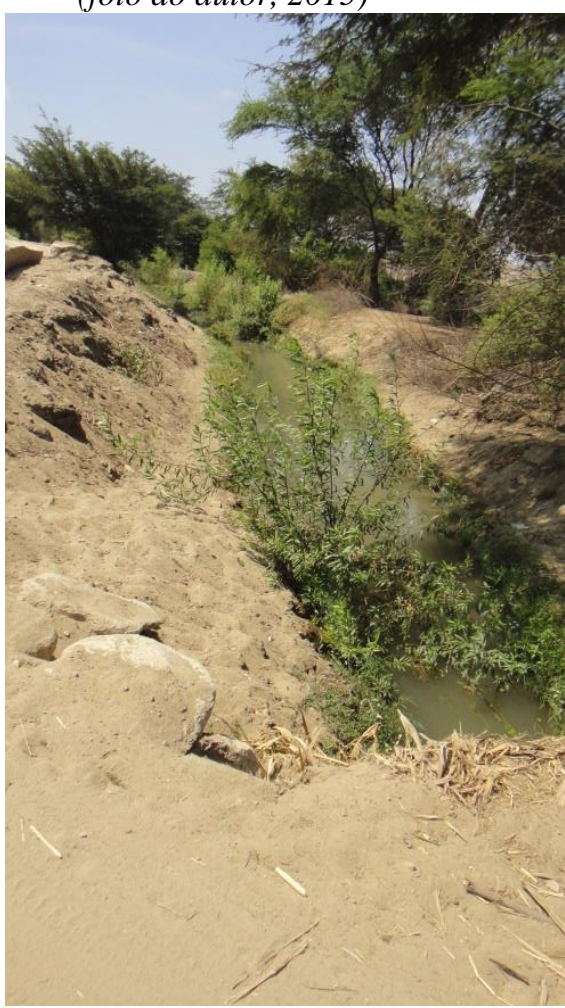

(FIGURA III.II.B) Provável canal pré-hispânico ainda em uso ao lado do rio. Às suas margens árvores de algarrobo. (foto do autor, 2015) 
Mesmo não tendo sido possível visitarmos bosque de Pomac ou a reserva ecológica de Chaparri, importantes reservas de bosques secos, pudemos visitar o bosque ao redor da Huaca Rajada (figura III.II.c), no vale de Lambayeque. Apesar de muito menor, a visita certamente nos auxiliou na compreensão da paisagem e da flora típica destes bosques.

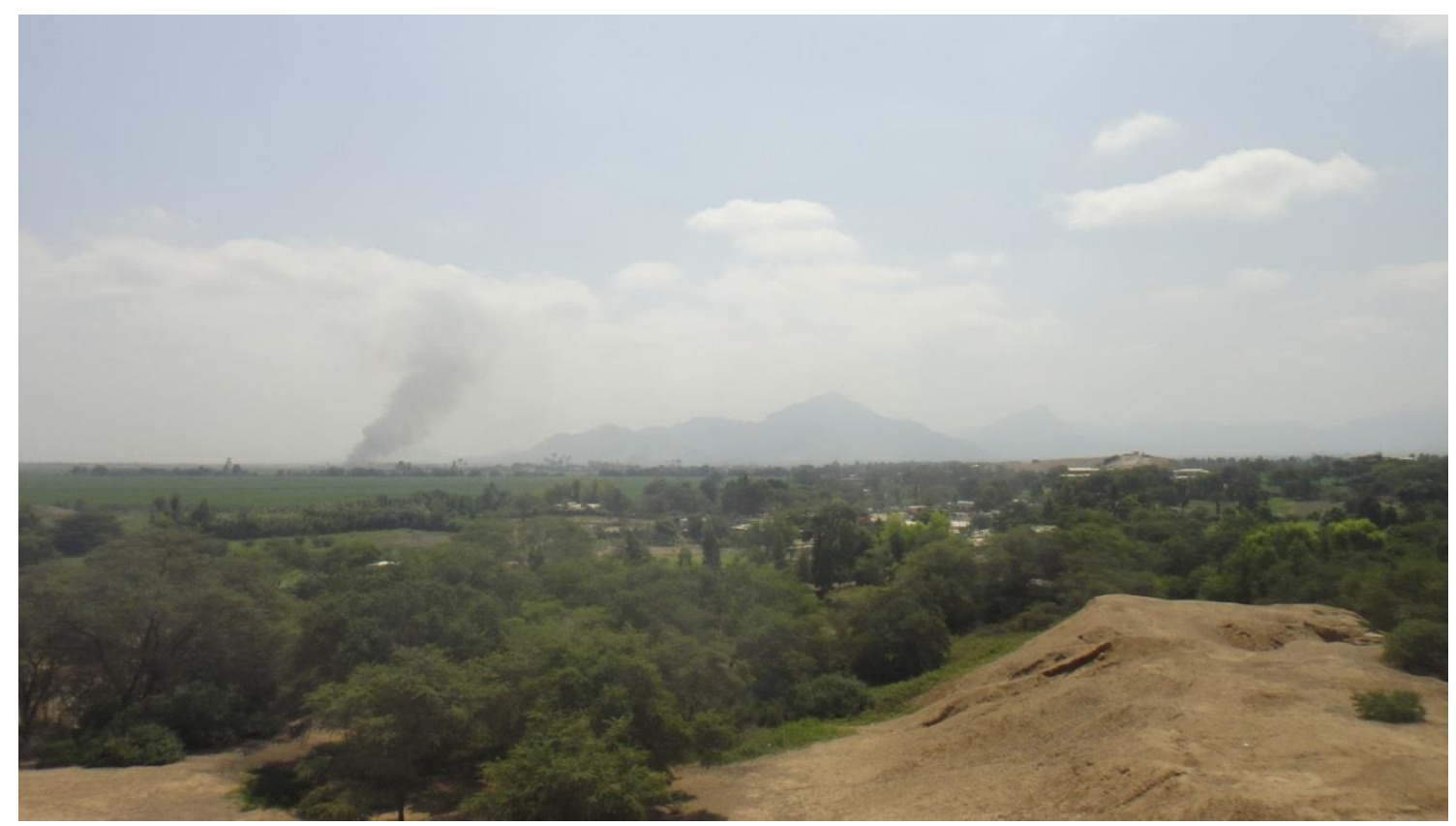

(FIGURA III.II.c) Pequeno bosque ao redor da Huaca Rajada. (Foto do autor, 2015)

Em nossas visitas ao Cerro Ventarrón, além da importância intrínseca que traz a Huaca Ventarrón localizada em sua base, pudemos fazer uma comparação visual da flora e paisagem com a de outras regiões visitadas, particularmente com a do cerro Campana. Uma vez que o cerro Ventarrón não é uma Loma, ou seja, não possue altitude e proximidade do mar suficientes para reter neblina nos meses de inverno, há uma diversidade específica bem menor se comparado ao cerro Campana, sendo apenas as espécies de zonas áridas como o cacto Neoraimondia arequipensis constantes em ambos os ambientes (figura III.II.d). 


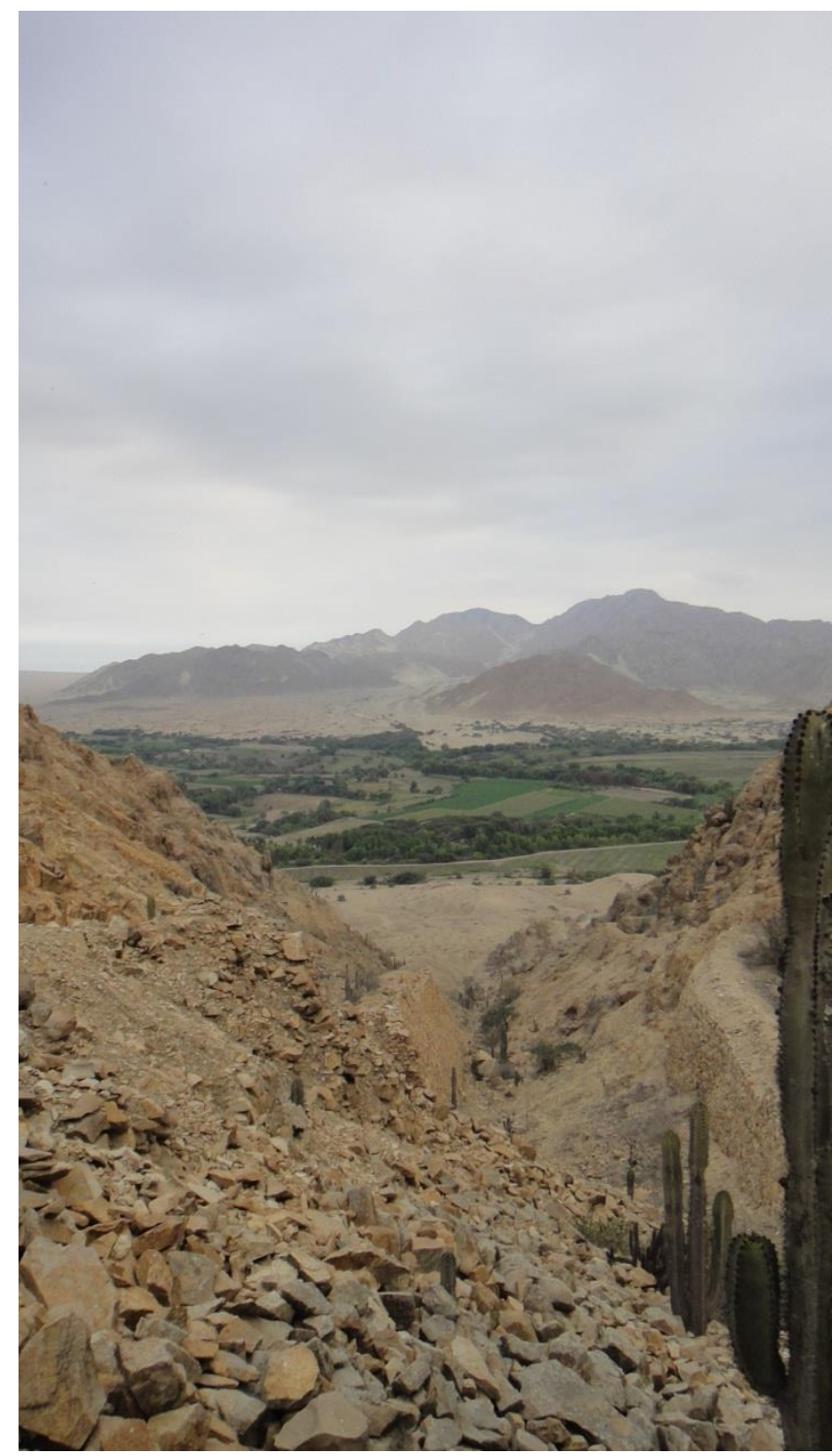

(Figura III.II.d) Zona da muralha Inca do Cerro Ventarrón com N. Arequipensis em primeiro plano e vale do rio Reque ao fundo (Foto do autor, 2015)

Todas as visitas tiveram grande importância mas, levando em conta que as lomas possuem uma considerável centralidade nas cenas com representações florísticas, nossa visita ao cerro Campana em 2017, uma loma, foi fundamental para a compreensão deste ecossistema delimitado e suas paisagens. $\mathrm{O}$ fato de a visita ter ocorrido em Julho, justamente no período seco dos vales e úmido das lomas, também trouxe um cenário de estudo particularmente rico.

Somado a isso há o destaque do Cerro Campana na região (figura III.II.e). Com altitude partindo de 80 até 996 metros e somando 1500 hectares de área (Leiva et.al, 2014) cerro Campana tecnicamente é uma montanha e não um cerro (morro), como popularmente conhecido. Fontes etnológicas recentes nomeavam a montanha de "Cipong" que, de acordo com Valladarez, 2012, significaria "Grande Pedra" em muchic, 
uma das línguas nativas da costa norte, enquanto Zavallos, (1992 apud Leiva et.al, 2014) baseado em fontes etnohistóricas nomeia o Cerro como "Rupipe".

Há vestígios de ocupações temporárias de caçadores a partir do fim do período lítico, cerca de 7.000 a.c (Valladares, 2012, Gálvez, 2004; Briceño, 1997 apud Leiva et. Al 2014). Ainda Valladares, descreve uma série de estruturas, provavelmente do período pré-cerâmico, incluindo uma pintura rupestre de veado mastigando folhas. Franco (2012) mapeia uma série de estruturas pré-hispânicas, Cupisnique, Salinar, Moche, Chimu e Inca, (figura III.II.f) incluindo altares sacrificiais do período mochica (figura III.II.g). Em nossa visita pudemos presenciar uma grande muralha supostamente Chimú ou chimú-inca, além de inúmeros vestígios cerâmicos, muito possivelmente também chimú.

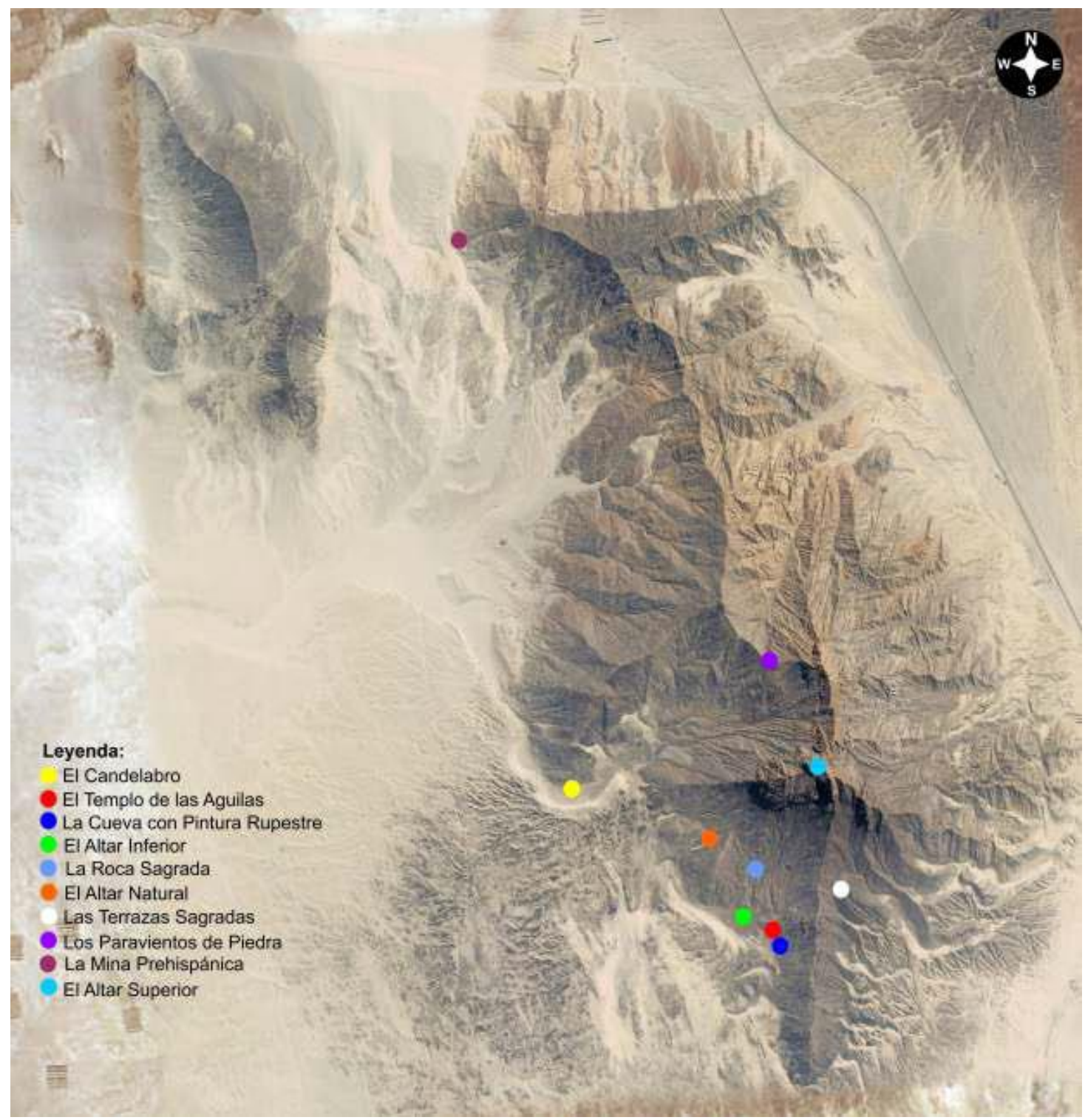

(Figura III.II.e) Pontos indicando estruturas pré-hispanicas no Cerro Campana(retirado de Franco, 2012) 


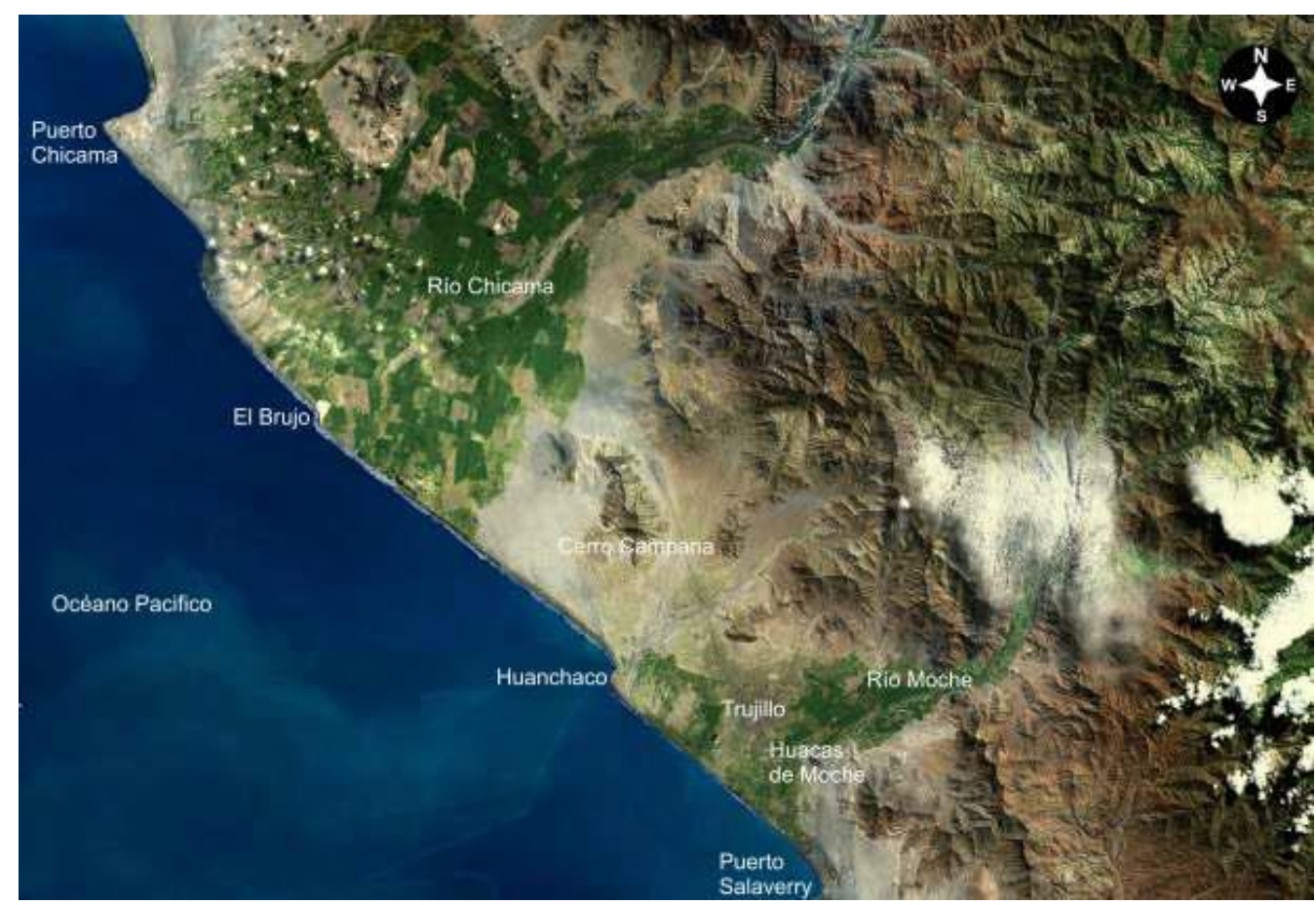

(Figura III.II.f) Localização do cerro Campana entre os vales de Moche e Chicama. (Retirado de Franco, 2012)

Leiva et. al (2014), e Valladares (2012) argumentam que há muitos indícios de que o Cerro tinha uma enorme importância regional no período pré-hispânico, mas é Régulo Franco Jordán quem faz as alegações de maior impacto para nosso trabalho. De acordo com Franco, há um recinto no cerro Campana com restos humanos desmembrados com padrões similares aos encontrados nos vestígios de sacrifício humanos no Cerro Blanco, ao lado das Huacas deL Sol e de la Luna (Franco, 2012: 279). Se o arqueólogo descobridor da Señora de Cao, importante líder moche encontrada no sítio de El Brujo, estiver correto, o Cerro Campana pode não ter sido apenas mais uma loma, mas o cenário no qual os sacrifícios cerimoniais apresentados nas cerâmicas mochica eram realizados. Aos vestígios humanos, Franco agrega outras evidências como formato da montanha, sua localização equidistante entre os vales de Chicama e Moche, e um impressionante altar escalonado encontrado no pico mais alto da montanha, com uma orientação leste-oeste. 


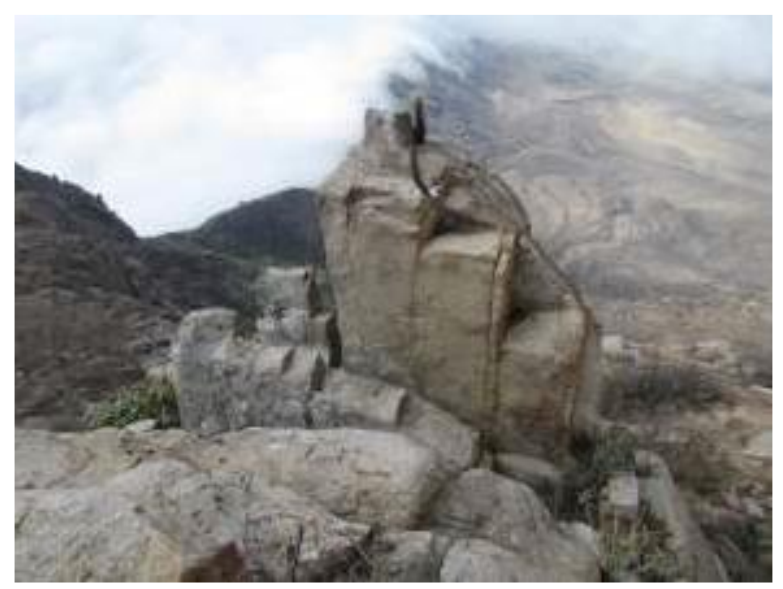

(Figura III.II.g) Altar escalonado encontrado em um dos picos do Cerro Campana (retirado de Franco, 2012).

De fato, a localização nos chamou atenção e pode ser uma das chaves favoráveis argumento de Franco. A montanha fica na fronteira entre as províncias de Trujillo e Ascope, na região de La Libertad, a $8 \mathrm{~km}$ do mar (figura 2.2.6). Está a $21 \mathrm{~km}$ da Huaca del Brujo, no vale de Chicama e a $22 \mathrm{Km}$ da Huaca de La Luna, vale de Moche (Valladares, 2012). Essa equidistância perfeita é um argumento eloquente em um contexto no qual haveria supostamente uma unidade política entre os dois vales. Dito isso, uma vez plausível que o Cerro Campana seja uma localização privilegiada no rito sacrificial, outros ritos registrados na cerâmica pictórica como a corrida dos feijões ou a coleta dos caracóis ou cenas do cânone mítico podem também ter sido desenvolvidos na montanha.

\section{III.II.I-Paisagem, possíveis ecótopos e espécies candidatas}

Buscamos identificar os habitats em que vivem as principais comunidades biológica abordadas e as possíveis espécies retratadas nos vasos pictóricos. De uma certa forma as espécies estão representando as paisagens e por isso eles devem ser explicados.

De acordo com Simpson (2006) taxonomia inclui descrição, identificação, nomenclatura e classificação. No caso da classificação, seu propósito específico o de "prover um sistema para catalogar e expressar as relações entre as entidades vivas" (Simpson 2006: 12). A classificação taxonômica é apresentada em níveis hierárquicos de modo que um nível superior e mais abrangente a abarca um ou mais níveis inferiores. Do mais abrangente ao mais específico temos Reino, Filo, classe, ordem, família, gênero e espécie. 
Como nossa preocupação vai principalmente no sentido de identificar as formas que aparecem nos vasos e relaciona-las com as plantas que existem in natura indicaremos a partir do nível da Família. Acreditamos que na maior parte dos casos pudemos fazer comparações sólidas no nível do gênero sendo o nível das espécies um tanto mais especulativo, uma vez que na maioria dos casos é o gênero que dita a morfologia geral e a diferença específica acaba sendo discreta demais para aparecer nas representações pictóricas. Não obstante, nos casos em que apenas uma espécie do gênero habita a região ou quando a diferença específica é grande o suficiente para ser notada e representada com certa recorrência, pudemos afirmar as espécies com grau maior de segurança.

Em suma nosso critério para apontar uma espécie passa por três crivos:

1. Compatibilidade morfológica: A figura produzida na cerâmica deve ser similar à espécie até o ponto em que o detalhamento da própria cerâmica permitir. Há casos em que o detalhamento é grande e há casos em que pouco se pode afirmar a partir das figuras.

2. Ocorrência nas regiões de ocupação Moche: Mesmo conscientes de que a ecologia de um local não é estática e teria variado desde o período mochica até hoje, há de se crer que exista estabilidade suficiente para correlacionarmos as espécies atuais com as existentes naqueles tempos. Em especial, buscamos ocorrência nas zonas alagadas, Lomas, bosques secos e mata ciliar localizados entre os vales de Chicama e Moche, uma vez que grande parte da cerâmica analisada provém dessa região.

3. Predominância na paisagem: Grande parte das espécies sugeridas possuem predominância nas paisagens que ocupam. Isso significa que dificilmente passam desapercebidas pelo olho humano observando a região. Em alguns casos a flora pode ser mais discreta, mas possui um vínculo intrínseco com a paisagem. As figuras de flores de plantas aquáticas, por exemplo, não têm grande distinção morfológica das flores terrestres, mas aparecem exclusivamente em ambientes aquáticos.

As identificações dos gêneros e espécies de floras e análise de seus ambientes naturais estão apresentadas no Capítulo V: Resultados I 


\section{III.III- Análise cerâmica}

A coleção do Museo Larco Herrera, localizado na capital peruana de Lima, foi escolhida como acervo a ser estudado por seu tamanho e acessibilidade. Como já comentamos no capítulo I e explicitado por La Chioma (2014) e Bars (2015), é uma coleção na qual grande parte das peças provém das fazendas Chiclin, e Chiquitoy, localizadas no vale de Chicama ou de sítios arqueológicos dos arredores.

O museu conta com um acervo online de 44.771 peças das quais disponibiliza 4 fotos de ângulos complementares. Como era necessário estreitar a busca para apenas os vasos com elementos pictóricos utilizamos o termo "pictórico" na busca o que reduziu os resultados para 1787 peças. Separamos todas as 1.787 peças por temas recorrentes, a maioria já com marcadores utilizados na catalogação do próprio museu, como caça, batalha ritual, geométricos etc. Destas foram identificadas representações de flora em apenas 191 delas. Em pesquisas complementares posteriormente foram identificadas mais 31 peças com representações florísticas somando um total de 222 peças. Importante ressaltar que não foram contabilizadas 20 peças nas quais apareciam a iguana junto a favas e sementes de algarrobo, uma vez que estas não possuíam diversidade.

De cada uma das 222 peças com flora, foram enviadas pelo Museo Larco 4 fotos de ângulos complementares em alta definição. Usando o programa de editoração Gimp, os 4 lados foram recortados e unidos em uma única imagem, simulando algo parecido com um roll out. Esta técnica serviu para identificar e quantificar todas as representações de flora nos vasos (Figuras III.III.A e III.III.B). Ela possui a vantagem de fornecer uma visão sequencial horizontal quase tão boa quanto a do roll out sem perder a tridimensionalidade do vaso, um fator muito criticado por Golte (2009) sobre a técnica de roll out. Entretanto ela não dá visão clara do setor do cume do corpo do vaso, entre as ascendências da alça asa estribo. Em alguns casos o professor Rui Murrieta pôde visitar o museu e produzir fotos deste ângulo vertical. Porém, na maioria dos vasos trabalhou-se com a visão parcial que os quatros ângulos tradicionais proporcionam.

Paralelamente, fizemos uma seleção de 10 peças pictóricas com flora selecionadas do acervo do Museu Etnológico de Berlin, visitado pelo professor dr. Rui Murrieta em 2016. Este pequeno estudo serviu como uma espécie de "grupo de controle" em busca de variações florísticas que fugissem das classificações criadas a 
partir da análise do acervo do Museu Larco. Importante notar que os padrões foram mantidos, não denotando nenhuma tendência particular do Museu Larco nesse sentido.

\section{ML13628}

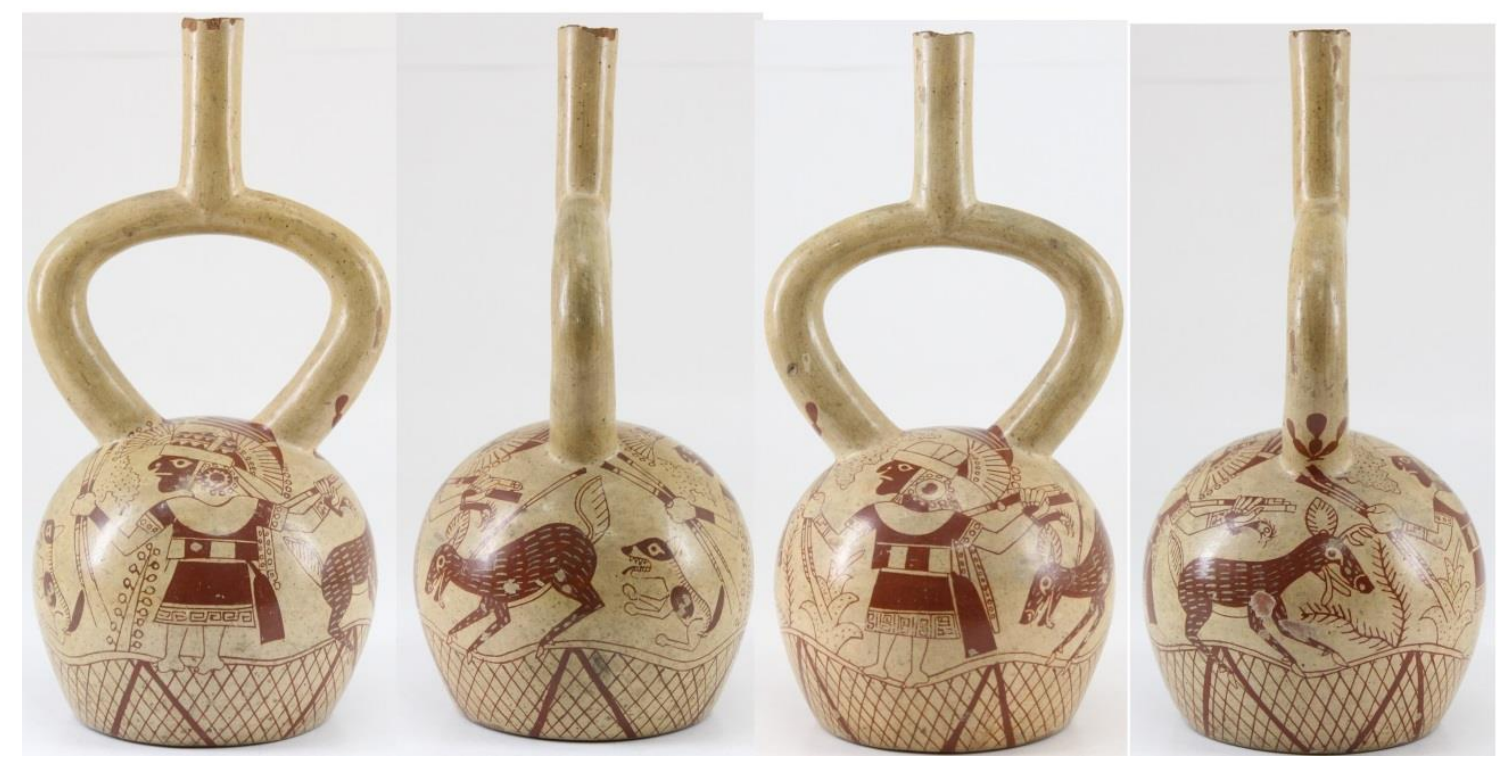

(Figura III.III.a) Exemplo de vaso nas 4 posições complementares. (Cortesia Museu Larco)

\section{ML13628}

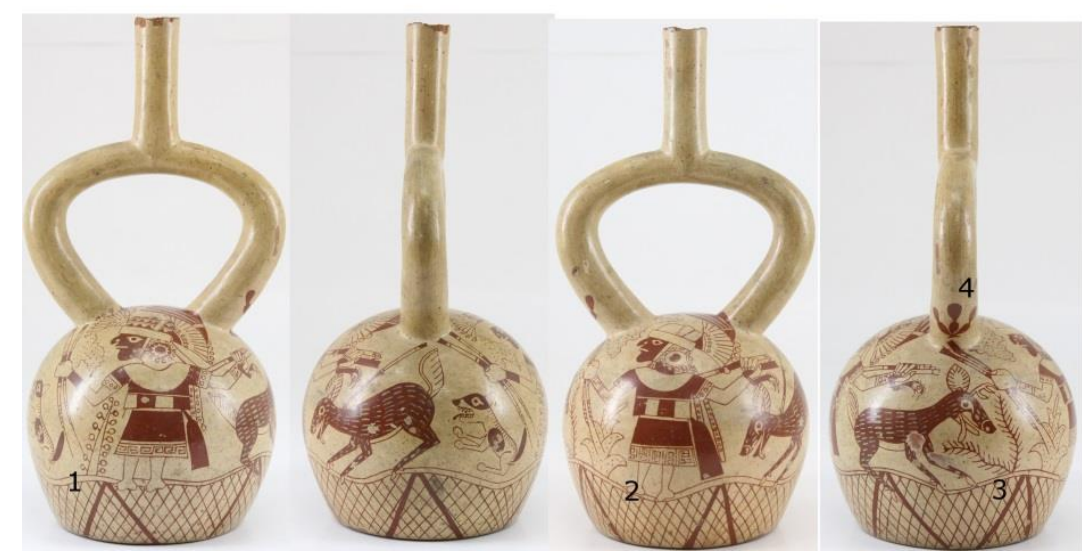

1. Cacto T5(colunar)

2. Furcraea (?)

3. Arbusto (algarrobo/ huarango)

4. Cacto T4 (opuntia)

(Figura III.III.b) Exemplo do mesmo vaso com flora quantificada e classificada. (Cortesia Museu Larco).

Além da contagem e classificação também foram contabilizadas características como espinhos, frutos, raízes, afloramentos e localização e associação dos elementos florísticos com personagens recorrentes das sequências canônicas. O objetivo, como explicaremos adiante em mais detalhes, era o de tentar encontrar padrões só percebidos quando observados de forma sistemática em um número considerável de peças. 
Posteriormente à classificação e numeração, utilizando as nomeações de personagem dadas pelo catálogo do Museu Larco, fizemos catálogos com amostras das imagens de cada tipo de flora retirada dos vasos. Assim temos o conjunto de flora que Aparece com o Veado, com Aia Paec (Anexo), com o Monstro Strombus etc. Este conjunto agrega todos os tipos de flora e serviu para identificarmos as tendências florísticas associadas a cada cena, juntamente com a planilha de quantificação.

De forma similar, produzimos também catálogos imagéticos que agregam amostras do conjunto de cada tipo de flora (anexo). Temos, portanto o catálogo das tillandsias, dos tipos de cactos etc. Estes em especial nos ajudam a explicitar a grande variação estilística sobre cada tipo de flora. Neste sentido, também fizemos catálogos agregando a flora dos cerca de 50 vasos que possuem origem indicada pelo museu. Aglutinando por vale pudemos observar a variação estilista dentro da produção do vale e compará-la com a de outros vales.

\section{II.III.I Análise de dados a partir da temática}

Intentou-se produzir uma análise configuracional dos vasos de linha fina a partir de seus temas. Como definiu Jackson (2008:134) “An individual artwork may present an entire scene, a partial scene, or just one specific element of a scene." Ou seja, muitas vezes, apenas com um elemento podemos identificar determinado tema.

No caso da atual pesquisa, o eixo dos temas seria o personagem principal indicado pelo catálogo do museu, sempre que possível. Dessa forma os mesmos personagens eram agrupados para que a flora que compõe a cena em conjunto com os personagens fosse classificada de acordo com os critérios apresentados no capítulo III e contabilizada por peça, agrupamento e totalidade.

Os personagens variam de seres míticos, como deidades antropomorfas, monstros e animais e plantas antropomorfizados a naturalistas como pessoas, e animais. Ambos os tipos se retroalimentam, com os seres míticos agregando traços dos seres naturais como presas, garras chifres ou cabeças e corpos inteiros semelhantes, enquanto os animais naturalistas recebem conotações derivadas da cosmologia andina, como o pertencimento da águia aos domínios do Deus Solar, rãs como símbolo da fertilização do mundo de abaixo, etc. Por isso, devido à diferente natureza das composições dividimos a totalidade dos grupos em quatro 
macrogrupos.

Os grupos variam no número total de peças de 1 a 31 e os Macro grupos podem ter de 2 a 9 grupos. São eles:

MACRO GRUPO 1 - SINGULARES: Mundo horroroso, Panóplia.

Incluímos neste macro grupo peças difíceis de encaixar na lógica implícita nos outros. Apenas dois grupos, o do "Mundo Horroroso" e em que figuram "Panóplias" estão neste Macro grupo.

MACRO GRUPO 2 - RITOS: Badminton, Sacrifício, Coca/Músico, Batalha, Corrida, Ave Guerreira, Guerreiro Vigilante

Também observamos cenas típicas de rituais conduzidos pelos mochica. Há também neste âmbito um fervilhante campo de discussões sobre a natureza dos ritos, as ações neles praticadas, seus objetivos os períodos em que eram realizados e as ligações entre si. Os ritos com certeza seguiam um calendário e eram essenciais na manutenção da coesão social. Para Hocquenghem:

The ceremonial calendar was thus the institution that actuated the cult of the ancestors and, by recalling the myths and reenacting them through ritual, assured the social production and reproduction of the central Andes. (Hocquenghem, 2008:26)

Incluímos as cenas em que importantes ritos da cultura mochica aparecem figurados no Macro Grupo 2.

MACRO GRUPO 3 - NATURALISTAS: flora, montanha,caça de aves, ave, pantano, raposa, veado, felino, caracois

Podemos observar cenas que não possuem seres humanos ou míticos em ação os que estes não estão em primeiro plano. Estas mostram, por exemplo, apenas animais como veados, felinos, raposas, garças ou caracóis, supostamente em seu habitat natural. Incluímos estas cenas 
no MACRO GRUPO 3.

MACRO GRUPO 4 - SERES MÍTICOS: Dragón, Ave Mítica, Monstro Strombus, Serpiente, Aia Paec

Há entre os estudiosos há algum consenso e muita discórdia sobre o nome identificação e ação dos seres míticos. Com efeito, algumas figuras que analisaremos têm grande semelhança com motivos iconográficos encontrados em têxteis provenientes da tradição religiosa Kotosh datada entre 3.000 e 1.800 A.C (Figura III.III.I.A).

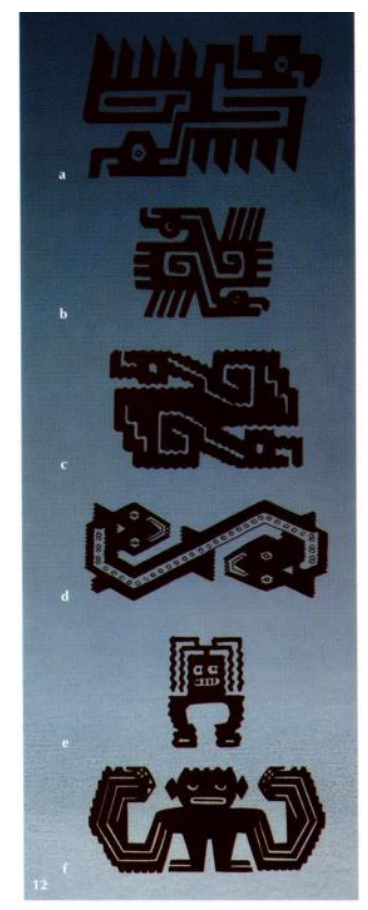

(Figura III.III.I.A) Motivos iconograficos de têxteis do pré-cerâmico tardio encontrados em LaGalgada $(a, b, f)$, Huaca Prieta $(c, e)$ Asia (d). Neles podemos observar figuras muito próximas da ave bicéfala ( $a, b$ e c) que aparece em ao menos um vaso analisado, a serpente bicélafa (d) e figura antropomorfica com cinturão de serpente bicefala (f) (Burger \& Salazar, 2000: 16)

No caso das deidades Moche foi utilizado principalmente Golte (2009), Hocquenghem (1987) e Makowsky (2000) como referência para os nomes e ações. Entre estes mochicólogos há uma identificação mais ou menos parecida das principais deidades, porém suas ações, posições hierarquicas e posições no cosmos são descritas 
de formas distintas. Parece haver, porém, um consenso sobre as divisões cosmológicas entre o mundo de acima e de abaixo e reinos complementares como céu, terra e mar, dia e noite. Como exemplo é indicado aqui um esquema proposto por Makowsky(2000) (figura III.III.I.B)

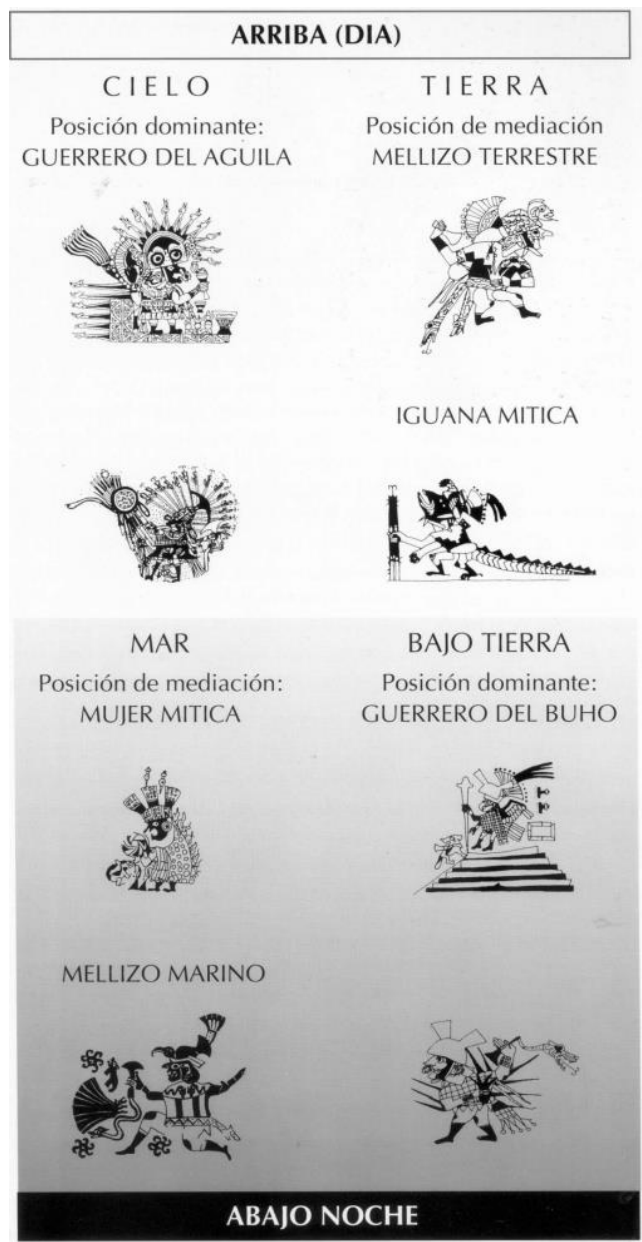

(Figura III.III.I.B) Esquema proposto por Makowsky (2000:148)

Os grupos em que estes seres míticos protagonizam foram incluídos no Macro Gupo 4.

\section{III.III.II - Análise da Flora}

A flora representada foi analisada e classificada a partir dos critérios dos Resultados I. Os exemplares arbóeros foram divididos entre arbustos ou algarrobos, as plantas aquáticas entre totoras e flores, as tillandsias e ulluchus foram identificados e os cactos divididos em 5 tipos. Há ainda a possibilidade de plantas nção catalogadas como desconhecidos, totalizando 13 possiveis indicadores específicos. 
Além da morfologia e identificação foram contabilizadas as seguintes variáveis:

Espinhos: se um cacto possui espinhos visíveis.

Frutos: se um cacto possui frutos visíveis

Raízes: se uma planta, cacto, tillandsia ou totora, possui raízes visíveis.

Localização: se as plantas encontram-se na metade de baixo, metade de cima, cume do corpo ou nas alças

Relação: se personagens de um grupo aparecem em outro grupo.

Fase: a provável fase em que o vaso foi produzido.

Vale: a origem do vaso, quando indicado em sua ficha museológica.

Sitio: origem do vaso quando houver identificação do sítio..

$\mathrm{Na}$ apresentação dos resultados abaixo incuímos a indentificação do grupo com os números de peças analisadas entre parênteses, seguidos de um verbete contextualizador de cada assunto.

Uma ficha simplificada está incluída na explicação de cada grupo com os tipos de plantas e seus percentuais. As outras variáveis serão apresentadas no final do capítulo juntamente com os totais. O conjunto observável das amostras de flora de cada grupo devera ser consultado nos anexos. Os resultados da análise cerâmica estão apresentados no Capítulo VI: Resultados II. 


\section{CAPÍTULO IV : RESULTADOS I -ESTUDO DE AMBIENTE E SUGESTÃO DE FLORA}

Como já dito, a função deste capítulo é a de sugerir o espécies ou gêneros florísticos naturais como fonte de inspiração para seus correlatos representados como localizadores. O modo de determinação das espécies ou gêneros está descrito mais detalhadamente no mais no capítulo III. A compreensão dos ambientes em que essas espécies ou gêneros ocorrem naturalmente também é essencial para a compreensão da função dos localizadores, portanto há uma breve descrição desses ambientes.

\section{IV.I - Ambientes aquáticos ou humedales}

Mesmo sendo ambientes presumivelmente bastante degradados por conta da rede de irrigação e cultivo intensivo de cana de açúcar, além do crescimento urbano, humedales, como são conhecidos localmente os ambientes alagados assim como mais especificamente os 'typhales', 'totorales' e espelhos d'água ainda são encontrados na costa nortenha, em específico para nosso estudo nos vales de Chicama e Moche (Leiva et al., 2018). Apenas na província de Trujillo encontramos 7 humedales, sendo 6 costeiros (figura IV.I.a).

Observamos que para os ambientes alagados, que possivelmente representam pântanos e margem de rios, apenas três ou quatro elementos florísticos são recorrentes : totoras, possivelmente (Schoenoplectus californicus [C.A.Mey.] Soják), a typha (Typha angustifolia) e flores provavelmente oriundas de dois tipos de ninféias (Nynphaeaceae), dos quais pudemos levantar a possibilidade de duas espécies: Nymphaea ampla (Salisb.) DC. e Nymphaea pulchella DC, esta última encontrada na zona alagada do complexo arqueológico de Chan Chan (Rodrigues, 2015). Não está descartada, entretanto, a possibilidade de flores de Tumbo (Passiflora foetida) estarem representadas, uma vez que um tipo de passiflora aparece em alguns vasos esculturados e pictóricos. Finalmente, há um pequeno montante de plantas difíceis de seres correlacionadas com espécies existentes, que não fomos capazes de identificar por falta de recorrência ou indeterminação mimética.

Há uma representação inter-estilística bastante homogênea, sendo que as flores aparecem apenas em vasos da fase IV em duas formas bastante inequívocas enquanto os 
"talos" ou juncos são apresentados em dois modos distintos: um deles presumivelmente da fase IV e inequivocamente análogo à totora e outro possivelmente fase III, onde não é possível distinguir entre totoras ou typhas.

Associados a estes ambientes aquáticos encontramos principalmente garças (ardeidae), patos (anatidae) (Angulo-Pratolongo, 2010) em menor frequência, sapos, provavelmente o bufón (rinella marina), e peixes, talvez um peixe comum da região (Dormitator latifrons), cujas características anatômicas geralmente são concordantes com as representações.

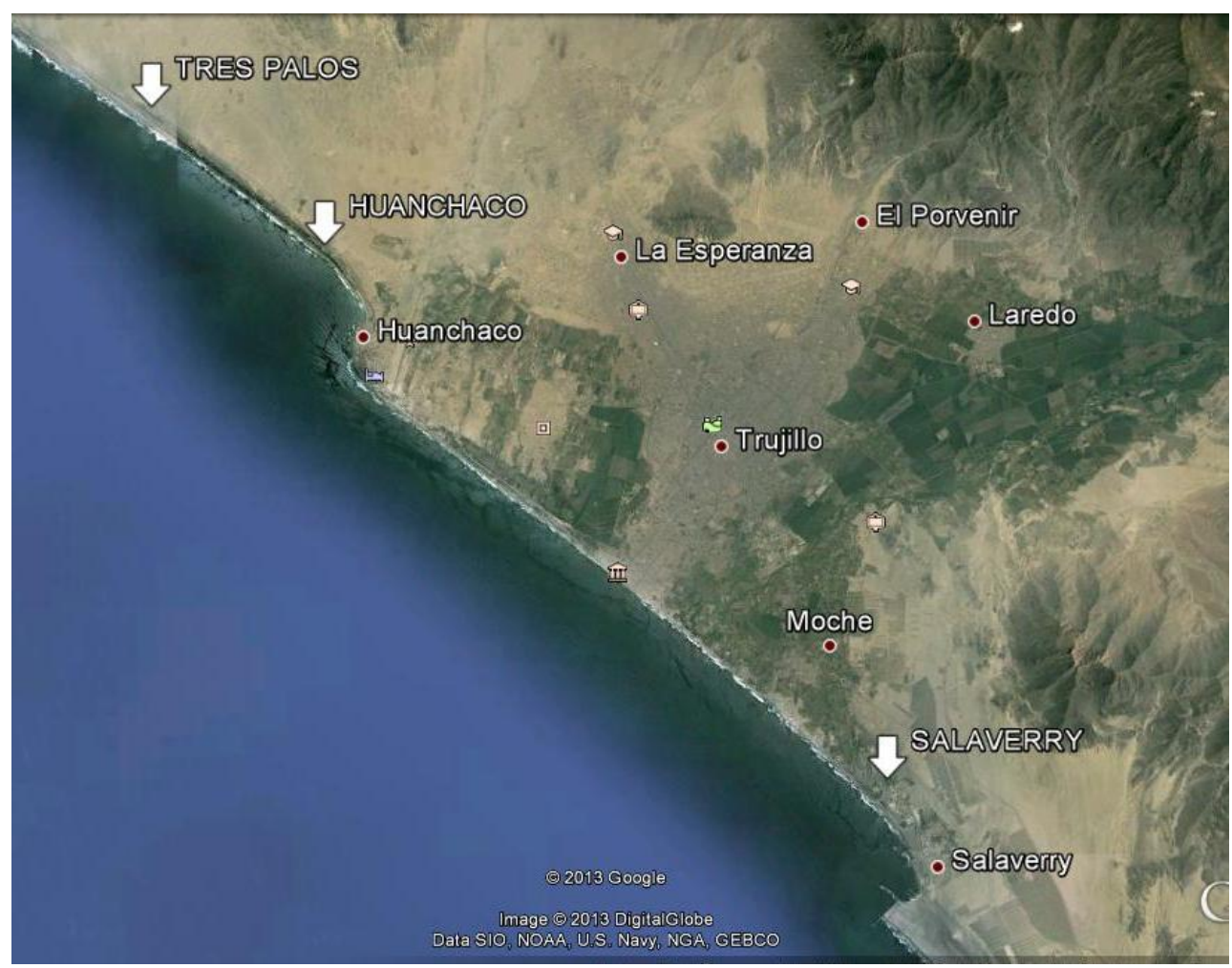

(FIGURA IV.I.a) localização de três humedales entre os vales de Chicama, Moche e Virú. Retirado de Altivez, 2012

\title{
IV.I.I- Totoras e Juncos
}

\author{
Família Cyperacea \\ Gênero Schoenoplectus \\ Espécie Schoenoplectus californicus sin. Scirpus californicus
}

Schoenoplectus californicus são plantas de regiões alagadas muito comuns nos andes, ocorrendo da costa norte a sul, além de cordilheira adentro, como o lago Titicaca. 
Foi uma planta muito importante para os Moche devido a seu uso na construção de tetos para as habitações e principalmente por serem a principal matéria prima da construção dos "cabalitos de totora", pequenas embarcações individuais utilizadas na pesca no oceano pacífico (Towle, 2007 :13[1961]). Ao contrário do junco (s. americanus) as totoras necessitam de ferramentas como uma foice para serem colhidas (Aponte, 2009) para serem colhidas.

Totoras são identificáveis por seu talo ereto, suas inflorecência na extremidade superior e, como veremos adiante, em grande parte das vezes, seus rizomas. (ver aponte, 2009) (figura IV.I.I.a e IV.I.I.b).. Na forma mais comum de representação da fase IV (figura IV.I.I.c) todas essas características são bastante naturalísticas e evidentes. Ocorre, porém, uma forma menos detalhada que podem também ser representações de totora.

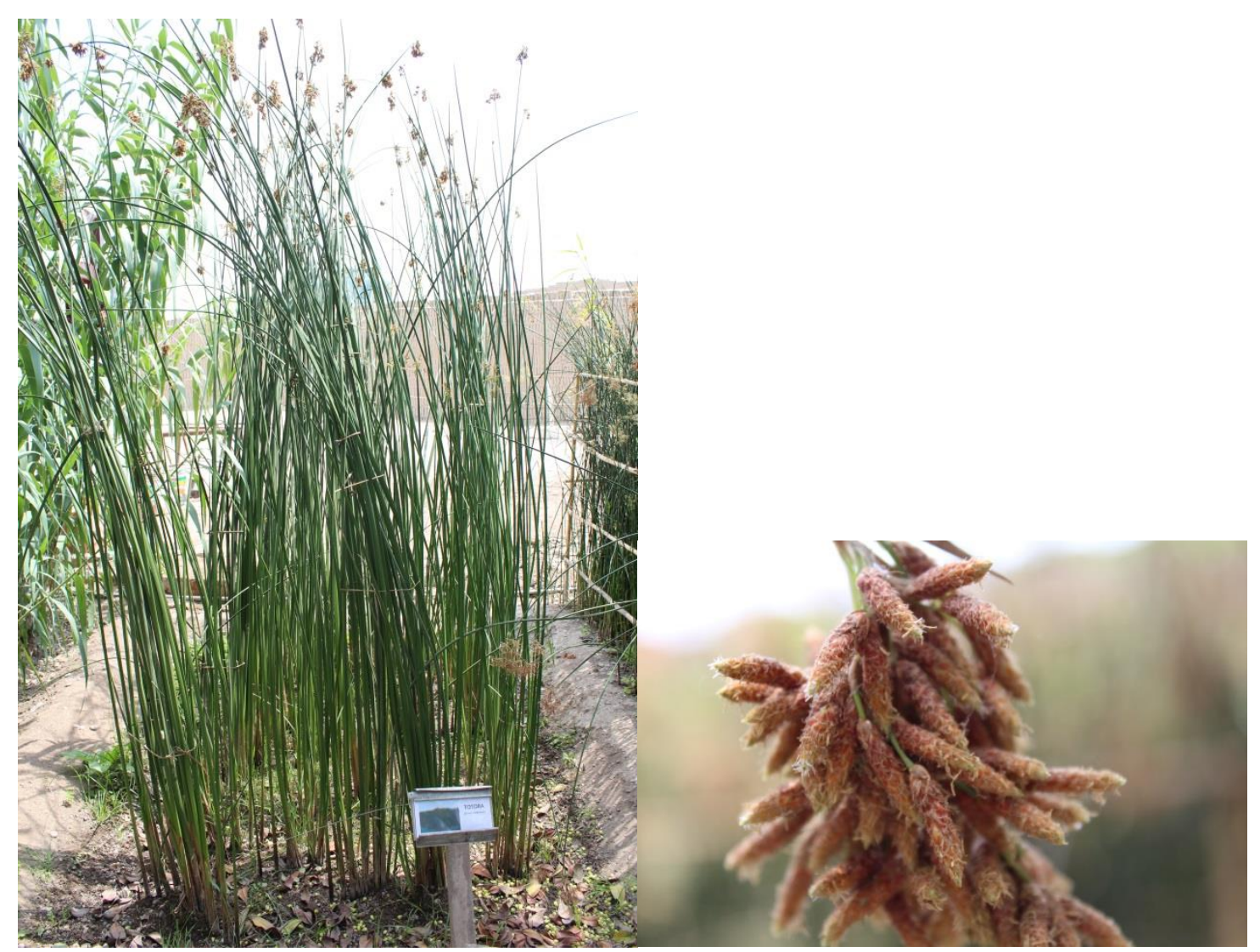

(FIGURAS IV.I.I.a e IV.I.I.b) Totoral em área alagada no complexo arqueológico de Chan Chan e detalhe, na foto da direita, de suas inflorecências distintivas, discerníveis nas representações cerâmicas mais detalhadas. (Fotos de Diego Mañas) 


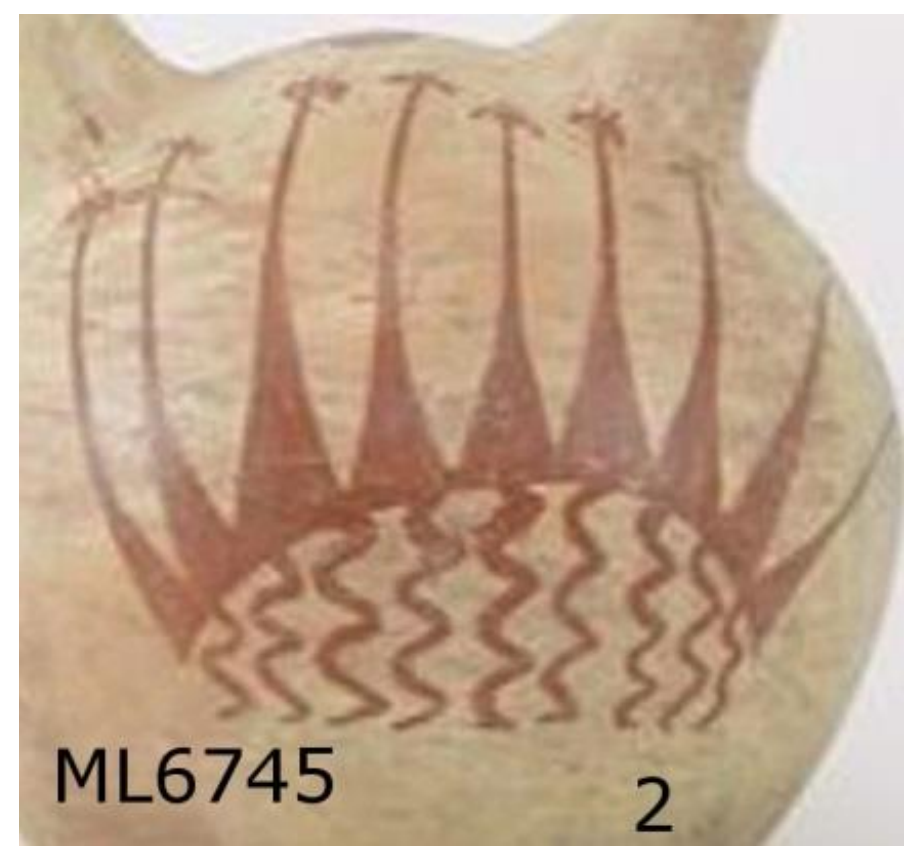

(FIGURA IV.I.I.c) Totoral em vaso da fase IV no qual são observáveis o corpo, os rizomas e as inflorecências das totoras (cortesia museu Larco).

\section{Família Typhaceae \\ Gênero Typha}

Espécie Typha angustifolia

Na segunda forma de representação os talos não são exibidos individualmente mas em grupo e as espiguelas também não aparecem. (figura IV.I.I.e). Por conta desse menor grau de naturalismo a confiança na identificação desta variação é menor. Essa segunda forma aparece constantemente junto a outros elementos de áreas alagadas, como garças, de um jeito semelhante aos da fase IV. Acreditamos ser mais provável estas serem representações de Schoenoplectus californicus, todavia, como as características morfológicas não são suficientemente claras consideramos a possibilidade de serem typhas, umas vez que são bastante comuns em ambientes alagados (figura IV.I.I.d). Além disso, ainda hoje as duas espécies são frequentemente confundidas entre si, ambas podendo ser comumente referidas por 'totoras' ou 'juncos' (Rodrigues, 2015), (Towle, 2007 [1961]) Não obstante as Typha angustifólia eram plantas bastante utilizadas pelos Moche, fornecendo fibras na produção de cordas, cestas, e tapetes (Towle, 2007: 13 [1961]). Daí também sua importância e possibilidade de representação. 


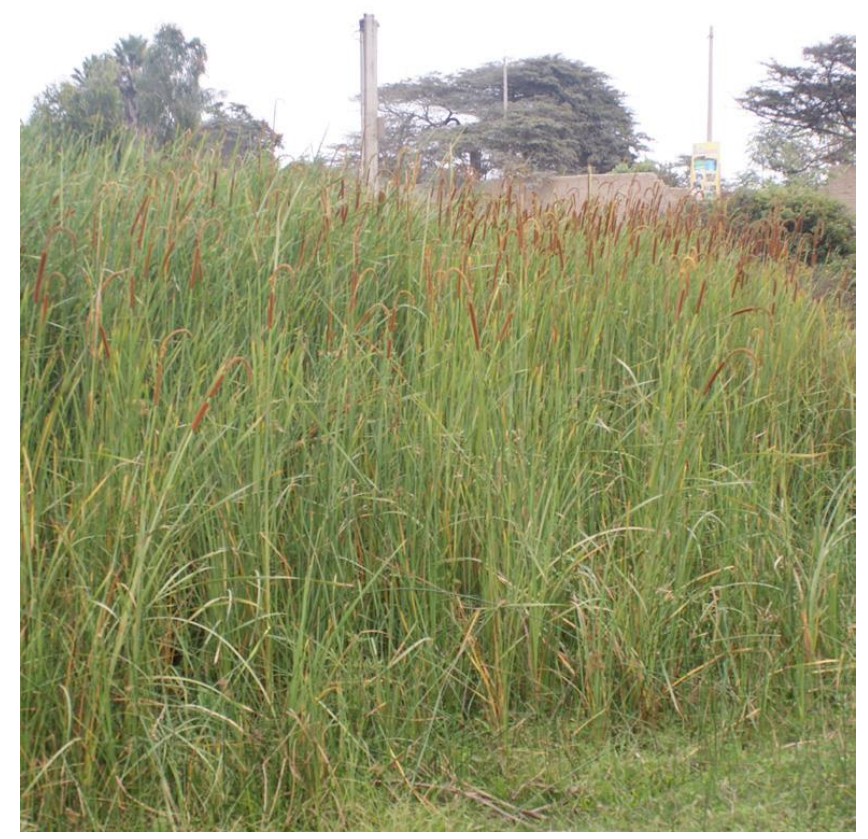

(FIGURA IV.I.I.d) “Typhales" próximos a Chan Chan.(Retirado de Rodriguez et al, 2014)

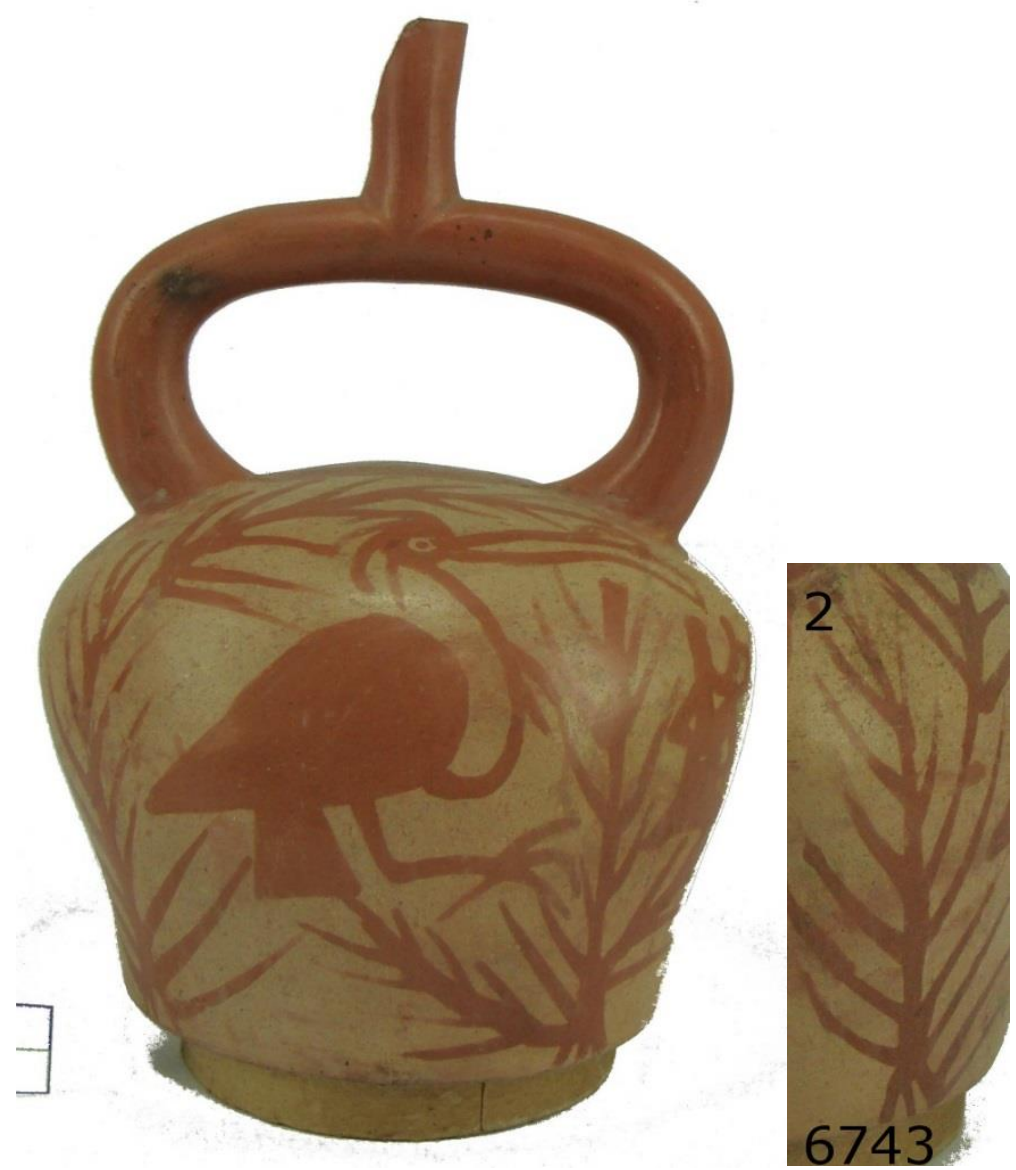

(Fgura IV.I.I.e) Vaso fase III com cenário de pântano associado à garça no qual a vegetação é indistinguível, podendo representar juncos (s. americanos), totoras (s. californicus) ou typhas (typha angustifolia). Ao lado, detalhe da vegetação. (Cortesia Museo Larco. Foto Rui Murrieta) 


\title{
$\underline{\text { IV.I.II- Flores }}$
}

Com uma frequência tão grande quanto a dos juncos e totoras os mochica inseriam flores em cenas aquáticas. Estas parecem ser um localizador de zonas alagadas tão incisivo quanto as totoras uma vez que aparecem apenas acompanhadas a outros elementos de pântano e muitas vezes por entre as totoras.

O discernimento dos gêneros ou espécies neste caso é difícil pois as flores das plantas aquáticas do gênero nymphaea não costumam ser radicalmente distintas entre si. As propostas aqui levantadas são principalmente baseadas nas espécies atuais que habitam os pântanos dentro da antiga área de habitação mochica-sul.

\author{
Família Nymphaeacea \\ Gênero Nymphaea \\ Espécie Nymphaea ampla \\ Espécie Nymphaea pulchella
}

Ambas as espécies correspondem à vegetação flutuante das zonas alagadas. As ninfeias estendem suas raízes até o leito dos pântanos ou espelhos d'água enquanto suas folhas e flores flutuam na superfície aquática. Por esta característica, suas folhas e frutos tornam-se bastante visíveis e destacam-se na paisagem aquática.

$\mathrm{Na}$ bibliografia pesquisada essas plantas não são tão comuns tendo sido identificadas em Lambayeque e Trujillo (Nymphaea ampla) (Llatas et al.,2010) e em Chan Chan a Nymphaea pulchella (Rodrigues, 2015). Todavia, por conta de sua forte associação aquática e grande visibilidade acreditamos ser grande a probabilidade de que as flores associadas à zonas úmidas sejam de ninfeias. 


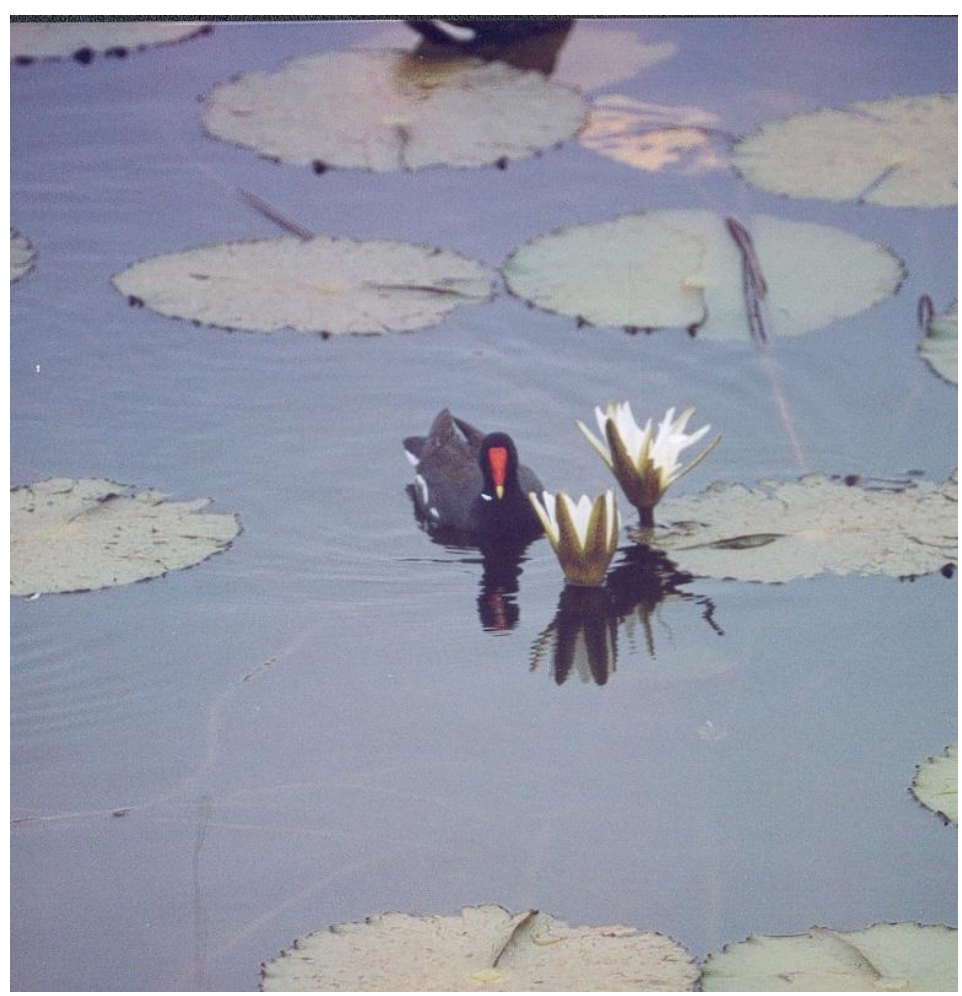

(FIGURA IV.I.II.a) Ave aquática ao lado de nymphaea pulchella (retirado de Rodríguez et. AL. 2014)

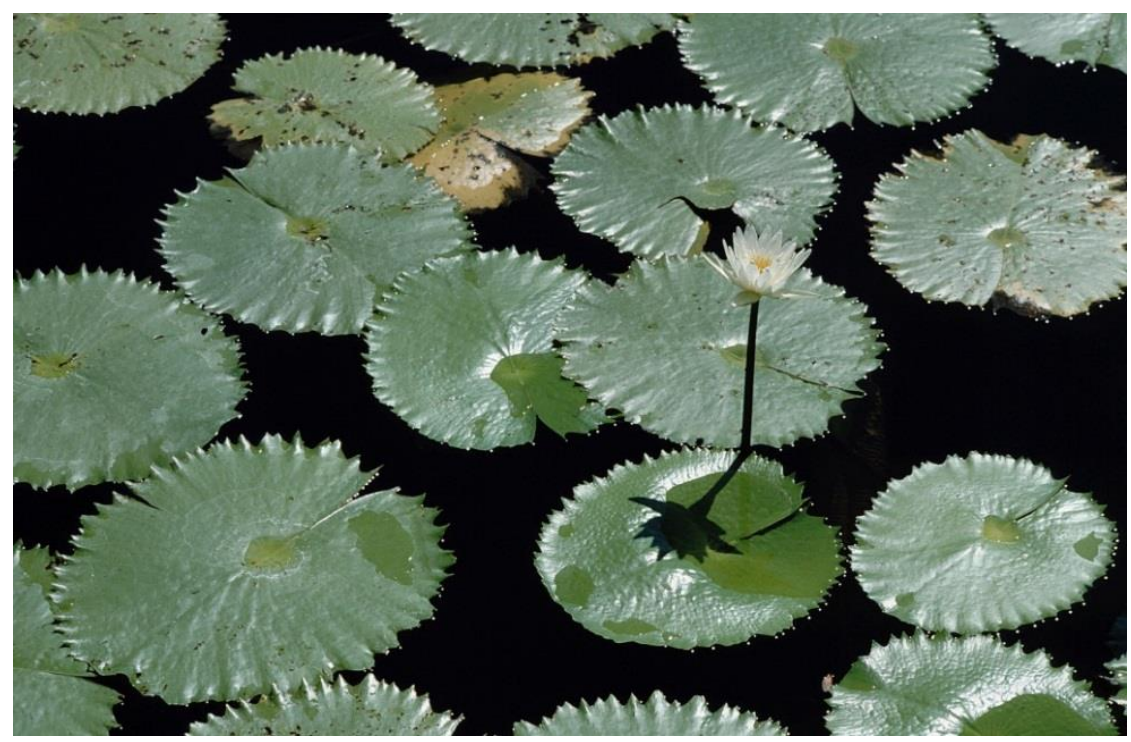

(FIGURA IV.I.II.b), Nymphaea ampla com flor (foto de Reinhard Jahn, retirado da Wikipédia. Acesso em 27/5/2018) 


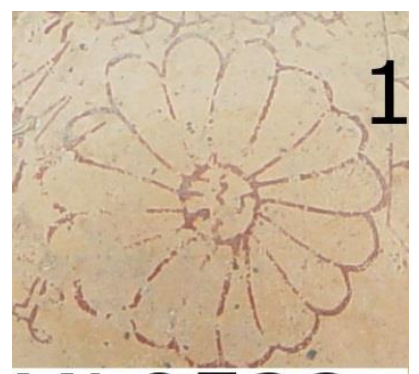

\title{
ML8523
}

(FIGURA IV.I.II.c) Flor aquática encontrada em vaso de linha fina fase IV associada a pato.

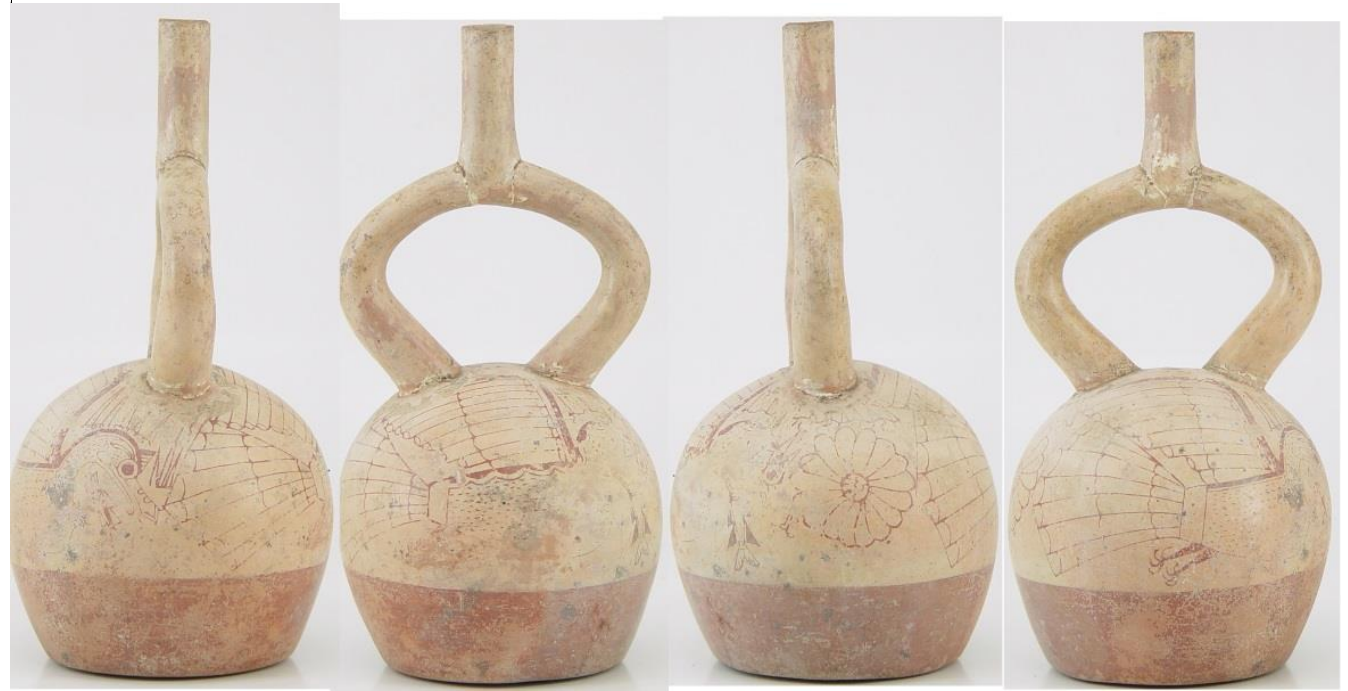

(FIGURA IV.I.II.d) Vaso de linha fina fase IV de pato com flor (Cortesia Museu Larco)

\author{
Família Passifloreacea \\ Gênero Passiflora \\ Espécie Passiflora foetida
}

Segundo (Rodrigues, 2015) o maracujá silvestre (Passiflora foetida) cresce em "gramadales" ou seja, zonas dominadas por gramíneas vizinhas às zonas úmidas em zona de alta salinidade. Apesar de não serem plantas aquáticas per se, consideramos a possibilidade de as flores representadas serem das passifloras após analisarmos dois vasos escultóricos e pictóricos em que figuram uma passiflora, identificada como “Tumbo" associada a um sapo ou rã (figura IV.I.II.e). 


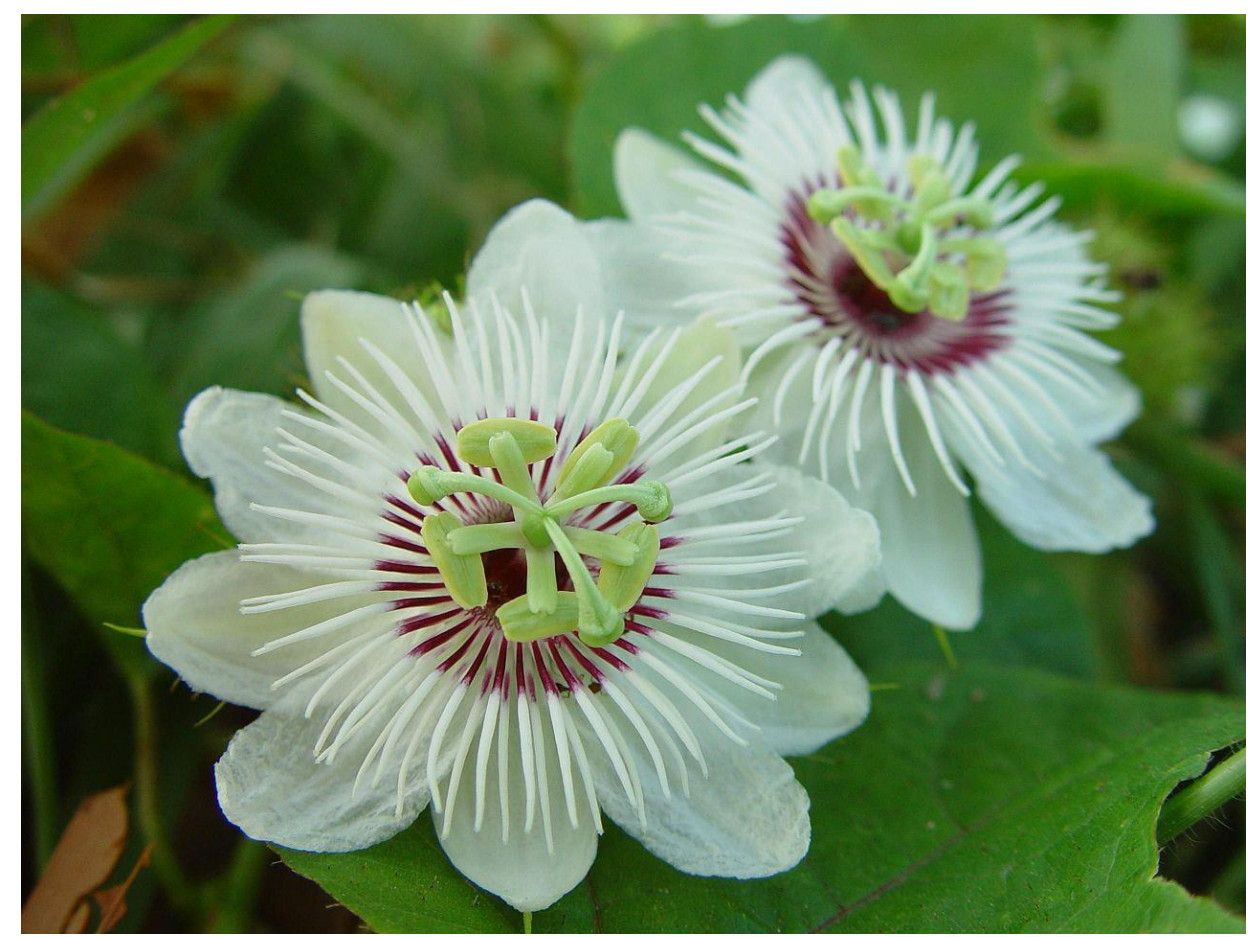

(FIGURA IV.I.II.f) Flor de Passiflora foetida. (Foto de Leon Brooks-retirada de Wikipedia. Acesso em 27/05/20018)

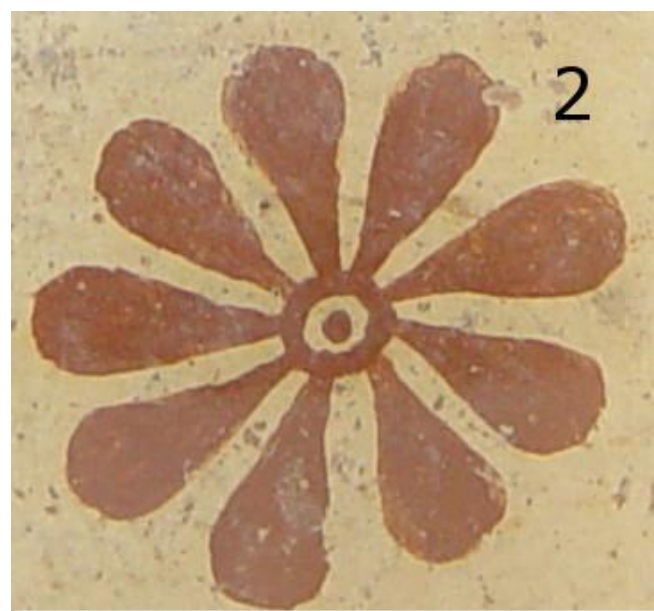

ML8719 


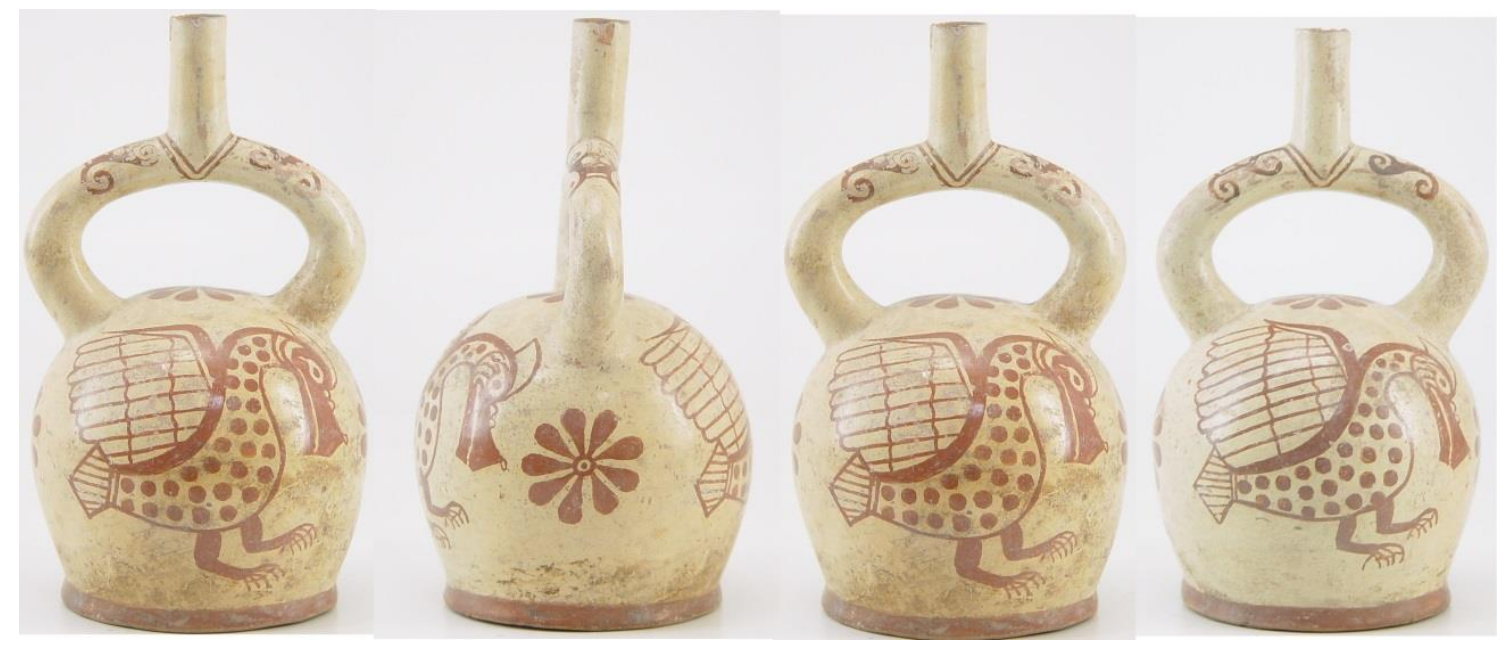

(FIGURA IV.I.II.g e IV.I.II.h) Outro vaso fase IV com variante de flor aquática novamente associada ao pato. Detalhe da Flor; (Cortesia Museu Larco)

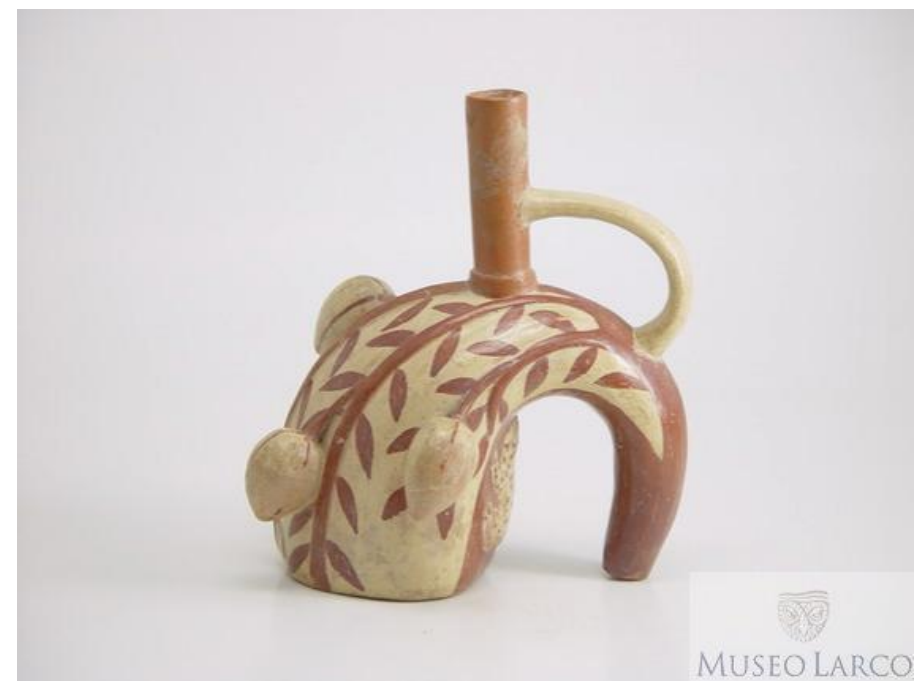

(FIGURA IV.I.II.i) Peça escultórica-pictórica com planta de passiflora foetida e sapo ou rã na base. (Cortesia do Museu Larco)

\section{IV.II - Lomas e zonas elevadas}

Como já dito no capítulo III, o deserto costeiro Peruano, no qual viviam os moche, é salpicados por lomas, ou seja, as áreas verdes sobre morros e montanhas costeiras das zonas desérticas do pacífico. Elas ocorrem porque parte da água de evaporação do oceano é condensada em forma de neblina ao ficar retida nessas montanhas costeiras. Segundo Rundel et. al, no deserto costeiro peruano "a vida vegetal é largamente encontrada em dois tipos de comunidades: ribeirinhas e lomas". (Rundel et al. 2007:158). Isso significa que a massa vegetal da região cresce largamente associada aos ciclos aquáticos, seja nos rios e seus vales (ribeirinhas), que em sua 
maioria dependem do degelo dos picos nevados andinos, seja na umidade sublimada das lomas. Estas, por sua vez possuem um ciclo oposto ao dos rios. Enquanto o período de chuvas e degelo vai de Novembro a Janeiro, o período em que as neblinas se tornam mais comuns nas lomas vai de julho a agosto.

Somadas as áreas das lomas do Perú (figura IV.II.a)e do Chile não passam de $4.000 \mathrm{~km}^{2}$ em seu máximo pós-chuvas de el-niño enquanto apenas o deserto costeiro peruano cobre uma área de 80.000 a $144.000 \mathrm{~km}^{2}$ (Rundel et. Al. 2007: 158). Isso significa que as lomas servem como oásis de vegetação no deserto abiótico entre os vales férteis, não por acaso foram nomemadas em 1950 de "oásis de neblina" (figura IV.II.b) pelo meteorologista alemão H. Ellenberg (Galán de Mera et. Al, 2010), alcunha ainda utilizada frequentemente (Engel, 1983; Rodriguez, 2012; Kalicki, 2014).

As lomas do norte peruano são as mais especificamente diversificadas de toda costa do pacífico sul americano (Rundell e Dillon, 1997) e há indicadores de que uma boa parte das espécies de sofreu alguma transhumância, isto é o transporte de espécies através de diferentes regiões por humanos, particularmente entre lomas e a cordilheira andina (Galán de Mera et. Al, 2010). Beresford-Jones et. al, 2015 advogam um papel central das lomas como refúgios contra oscilações climáticas e áreas de cultivo incipiente entre 8.000 e 4.500 anos antes do presente, em contexto de abundância, uma vez que ancestrais selvagens do tomate e batata (Solanum spp.) e papaya (Carica spp) além do Guanaco ocorreriam naturalmente nas lomas. (Beresford-Jones et. al, 2015 : 213) 


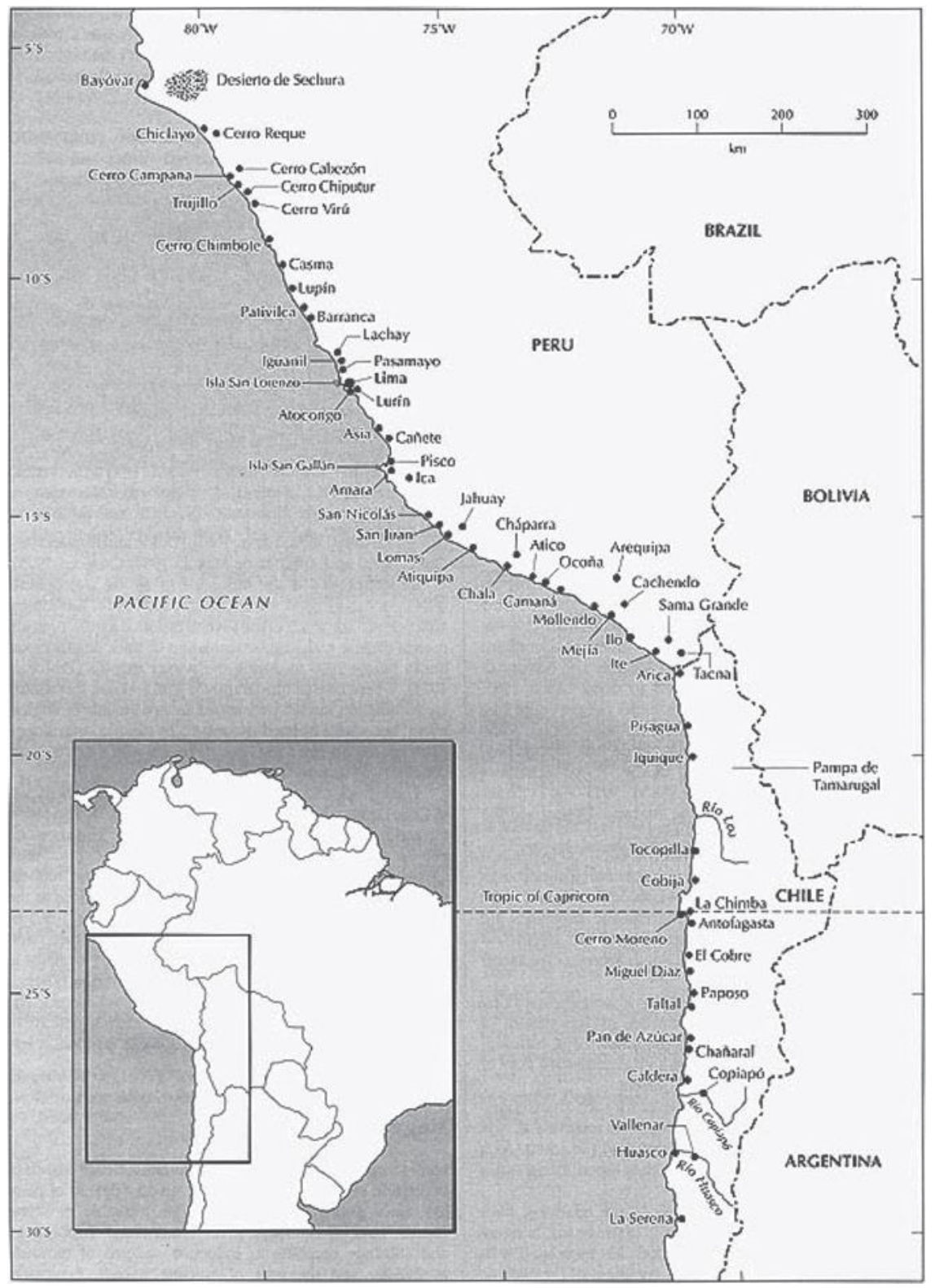

(FIGURA IV.II.a) Mapa das Lomas do Pacífico Sul Americano (retirado de Rundel et al, 2007) 


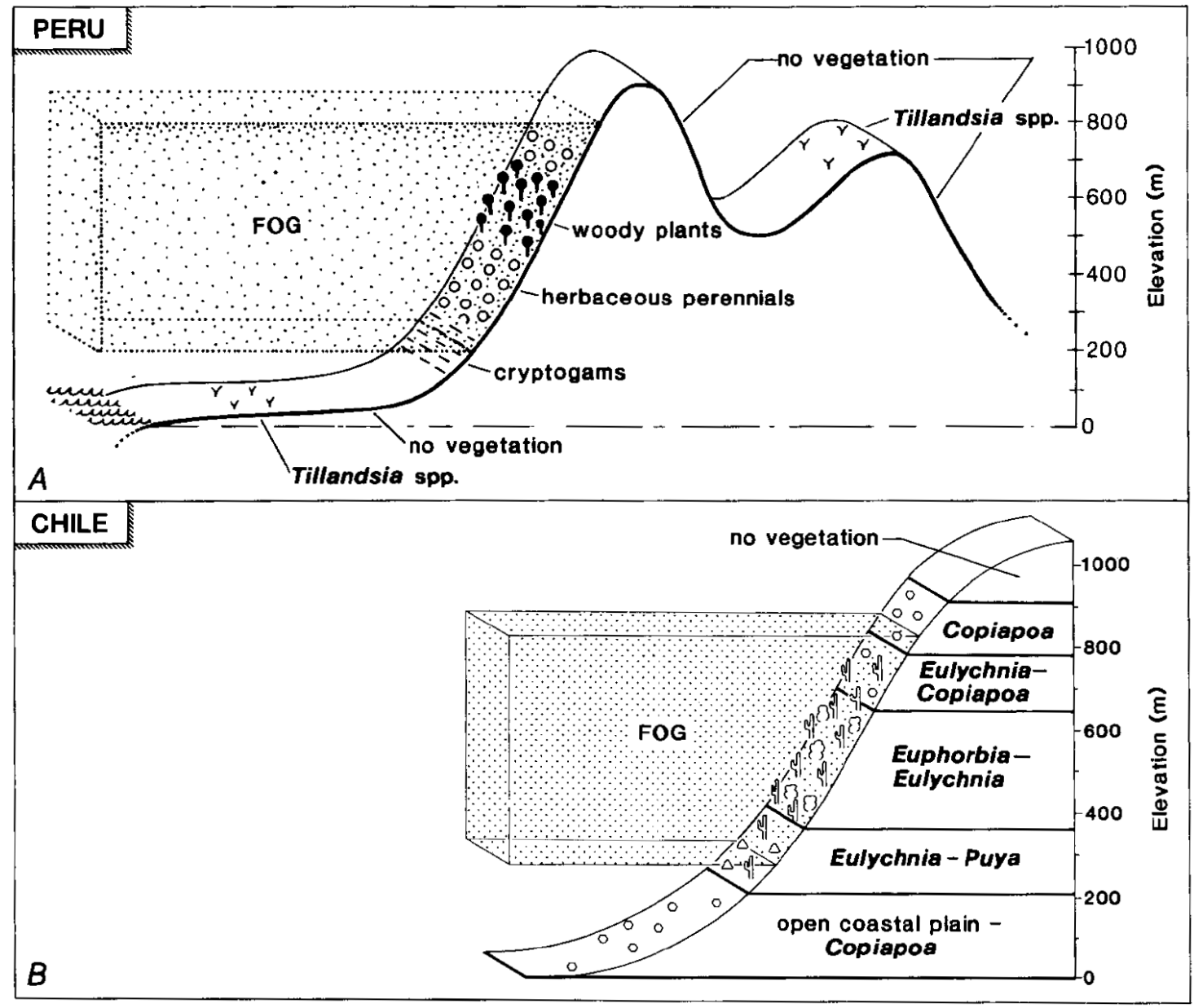

(FIGURA IV.II.b) Esquema de flora e umidade nas lomas peruanas e chilenas (retirado de Rundel et. al, 1991)

Segundo Benson (2012) líquidos possuem significado vital nos conceitos de fertilidade de todas as culturas conhecidas. Para os moche, um povo oriundo de regiões desérticas, o fluir das águas só pode adquirir uma importância destacada. Dentro desta lógica Golte afirma que as lomas possuem um lugar central nos cultos dos Moche direcionados à fertilidade. De acordo com sua visão da cosmologia Moche a "Divindade da Via Lactea" preside os céus noturno durante a época úmida (de novembro a janeiro) e vive nas lomas na época seca (de junho a agosto), e muitas vezes é representada sentada sobre uma pirâmide "rodeada de vegetação característica de modo que as próprias colinas formam seu corpo" (Golte, 2009 :74). Esta visão se coaduna com estudos etnohistóricos que apontam a importância central da observação da Via Láctea para os agricultores andinos no planejamento do plantio e na previsão da colheita. Além disso Golte apoia sua interpretação iconográfica no fato de que o período de verdejamento e abundância das lomas é justamente na época seca dos vales.

Em nosso estudo observamos que a representação das lomas pode ter uma certa 
variedade de apresentações florísticas mas há três grupos mais fortemente associados a elas. Em ordem decrescente na importância de associação temos as bromeliáceas, particularmente as Tillandsias, que são altamente associadas às cenas nas lomas; os cactos em sua maioria são associados porém em alguns casos sua associação pode ocorrem com zonas baixas e áridas; plantas xerófitas como árvores e arbustos em sua grande maioria estão associadas a zonas do vale mas podem também estar ligadas às faixas mais baixas das lomas ou aos desertos árido.

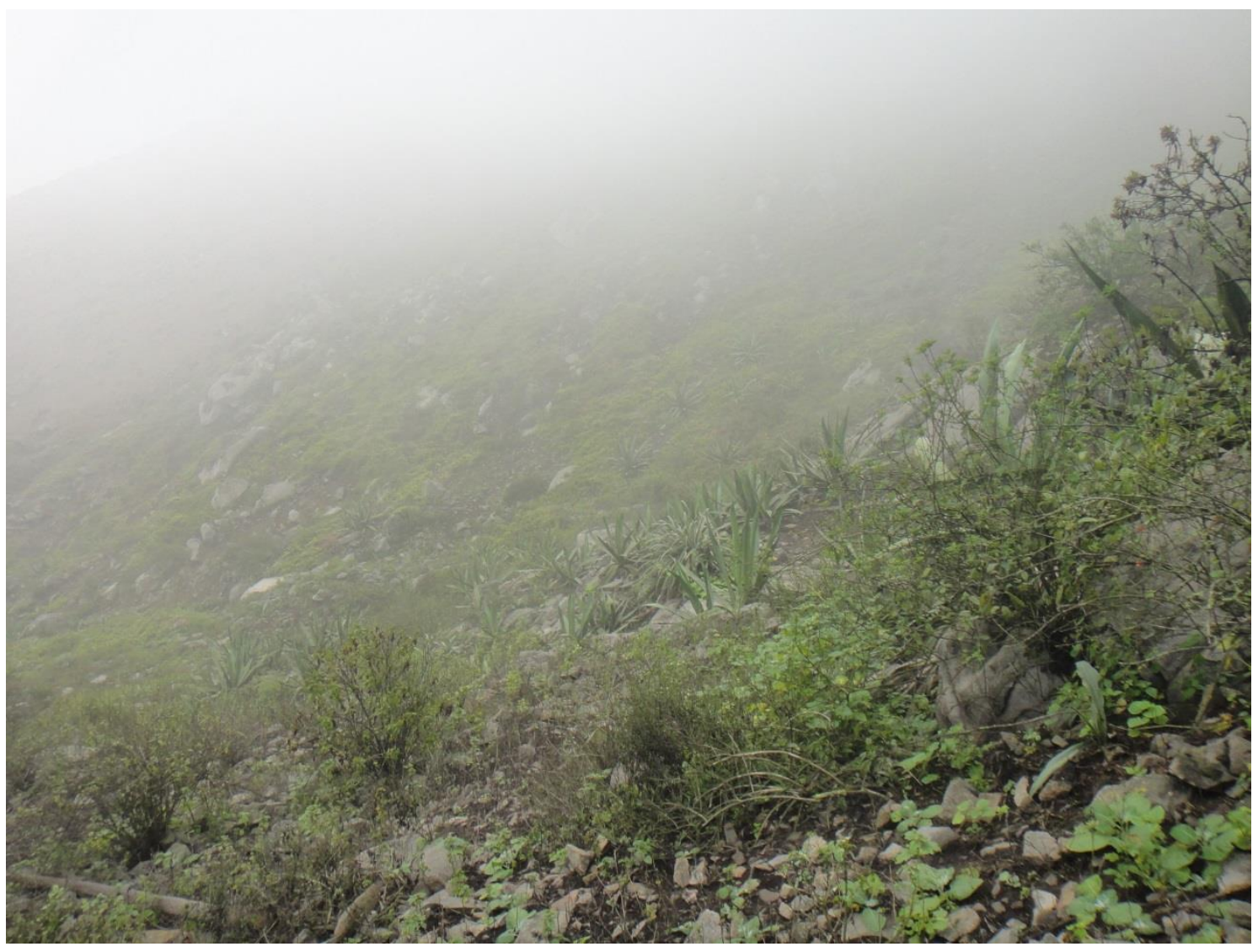

(FIGURA IV.II.c) Terceiro piso do Cerro Campana, a cerca de 900 metros de altitude, com vegetação verde sob densa neblina. (Foto do autor)

\section{IV.II.I: Familia Bromeliaceae}

A família das bromeliáceas assim como as cactáceas são oriundas do continente americano. Se estendem por zonas cálido-temperadas do sul dos Estados Unidos até o sul da Argentina e Chile. Existem 3.471 espécies divididas em 58 gêneros, sendo uma espécie nativa da África ocidental. Segundo Zanella et al. (2012) a família surge há cerca de 100 milhões de anos no planalto das Guianas e a partir de 19 milhões de anos se inicia uma explosão de diversificação a partir do norte dos Andes. 


\section{Gênero Tillandsia}

Muitas espécies do gênero Tillandsia são epífitas, ou seja, suas raízes servem para que a planta busque uma relação comensal apoiando-se em outras plantas. Por não precisarem das raízes na obtenção de água também conhecidas como plantas aéreas. Podem crescer sobre pedras e restos arqueológicos. Em zonas desérticas obtém sua água captando a humidade nas lomas, onde formam comunidades numerosas chamadas tillandsais (Aponte \& Flores, 2013), mas nas partes mais áridas e baixas não estabelecem relação comensal, em grande parte devido à falta de outras plantas nas zonas de grandes tillandsais.

\section{Espécie Tillandsia Latifolia}

Espécie endêmica muito comum por toda a costa peruana e chilena (figuras IV.II.I.a e IV.II.I.b). Habita principalmente as zonas mais baixas e secas das lomas e foi encontrada em grande quantidade em nossa visita ao Cerro Campana. São tillandsias de tamanho médio (até cerca de 30 centímetros) e são características suas folhas dispostas de forma de flor e seus pequenos ramos (rametos) que conduzem a reprodução clonal. (Aponte \& Flores, 2013). Entretanto, possuem um alto nível de plasticidade individual intracomunitária, com mais de $100 \%$ de variação em tamanho e, em geral com comunidades sobre areais sendo maiores do que aquelas estabelecidas sobre solo rochoso (Aponte, 2014). Sua morfologia é correspondente com a representada nos vasos pictóricos mochica que representa fielmente o formato das folhas (figuras IV.II.I.c e IV.II.I.d). Por isso, somado a sua ubiquidade, acreditamos que seja a principal espécie de tillandsia representada. 


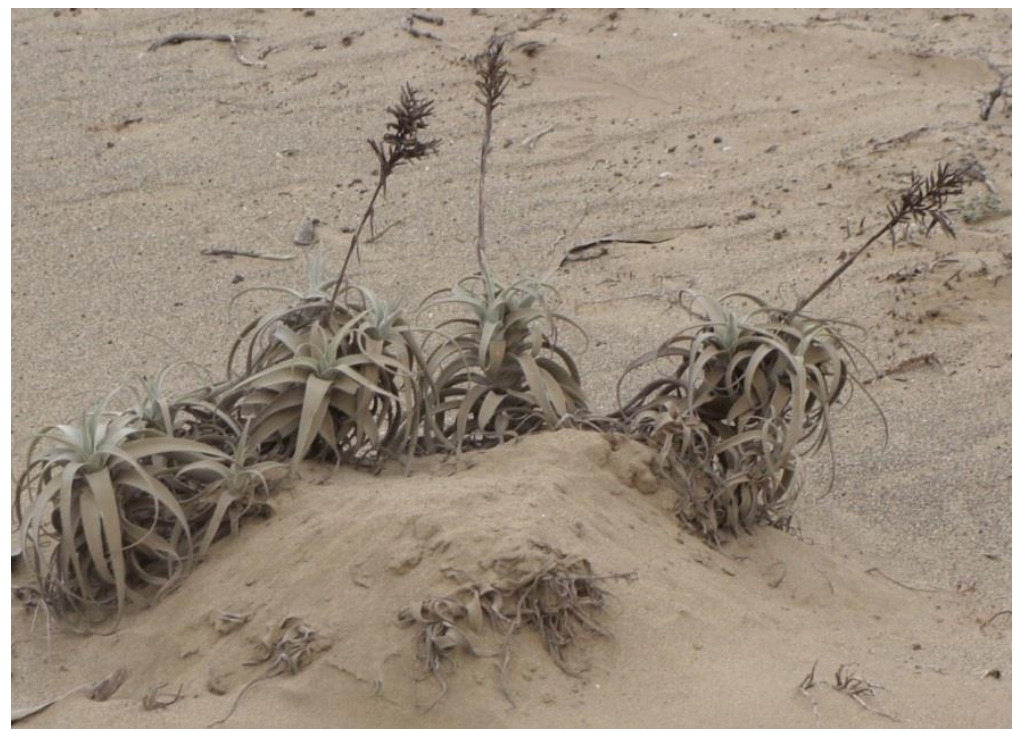

(FIGURA IV.II.I.a) Exemplares Tillandsias Latifolia em zona árida na base do Cerro Campana.

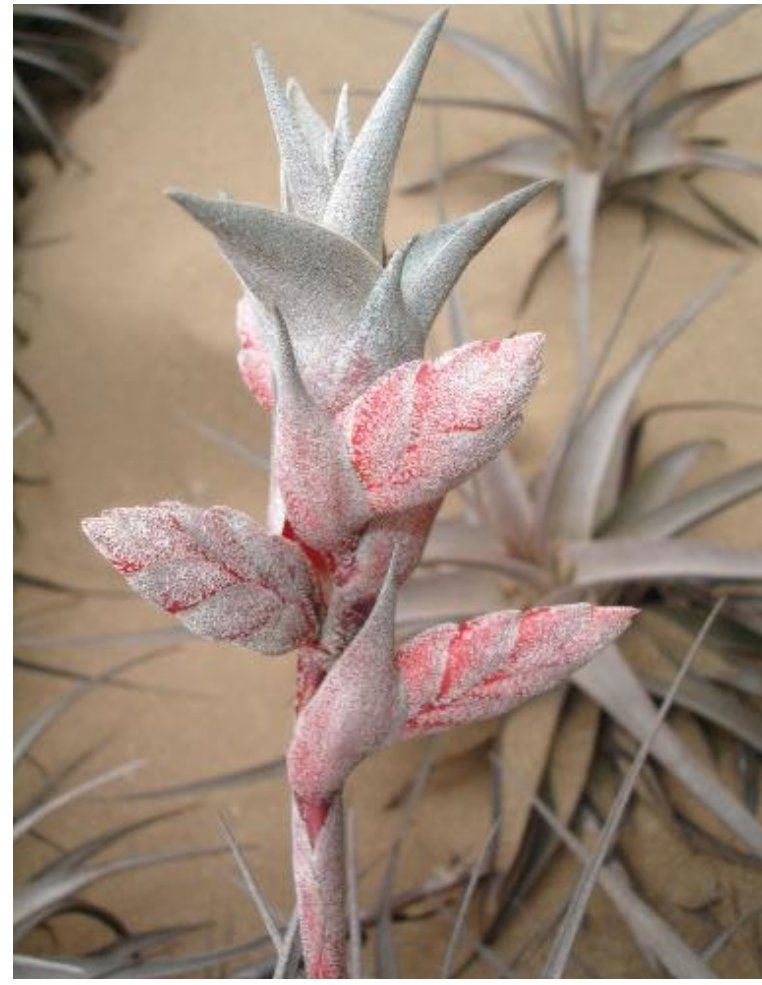

(FIGURA IV.II.I.b) Detalhe de rameto Tillandsia Latifolia (retirado de Leiva et. al, 2014) 


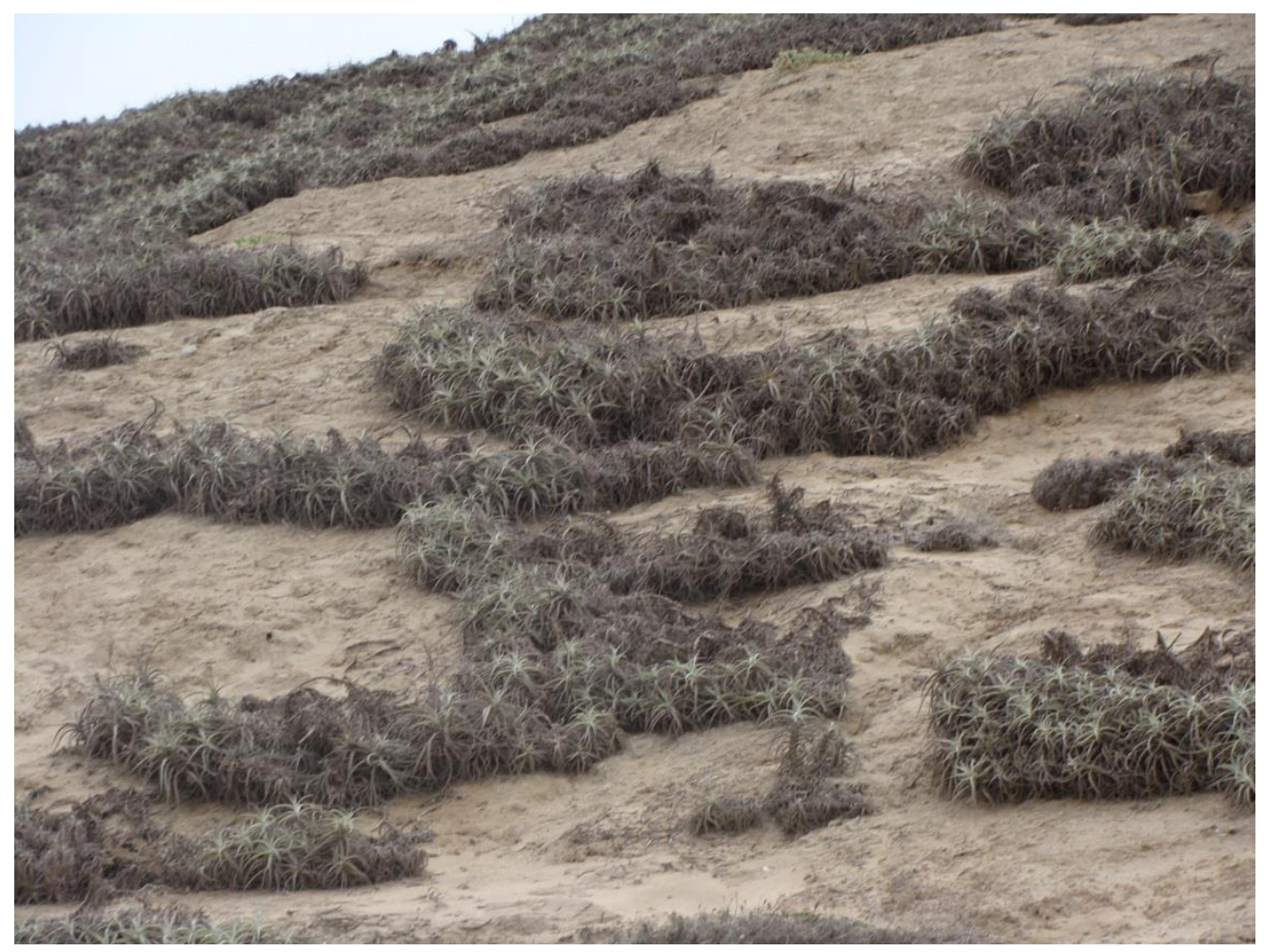

(FIGURA IV.II.I.c) Foto de tillandsal no primeiro piso do cerro Campana (foto do autor)

\section{Espécie Tillandsia purpúrea}

Juntamente com a T. Latifolia faz parte do grupo das Tillandsias "cinzas" ou aquelas que habitam as zonas mais baixas e secas das lomas e apresentam folhas mais acinzentadas do que aquelas em zonas mais elevadas e verdes. Possui tamanho e formato quase idênticos à latifólia e, apesar de constar nos levantamentos florísticos de Leiva et. Al (2014) e Corcuera (2017) não pudemos distingui-la da latifólia.

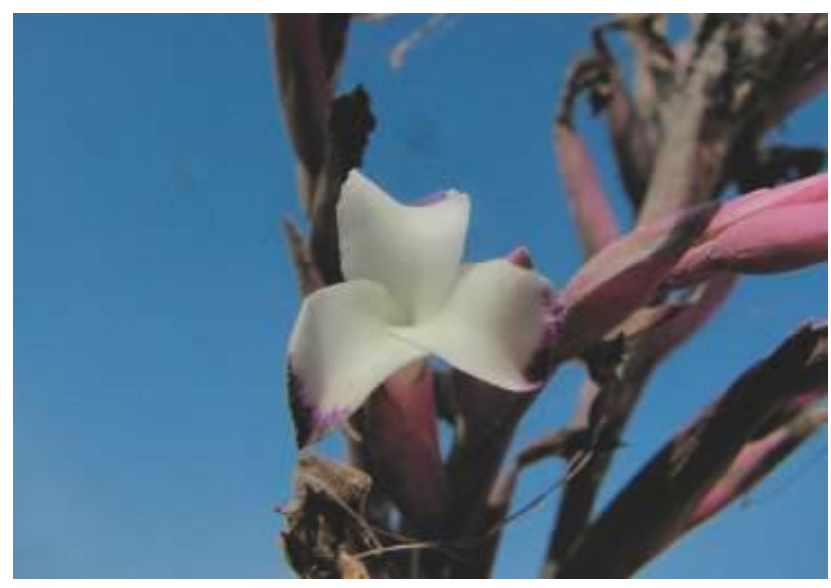

(FIGURA IV.II.I.d) Detalhe de flor T. Purpurea (retirado de Leiva et. al, 2014) 


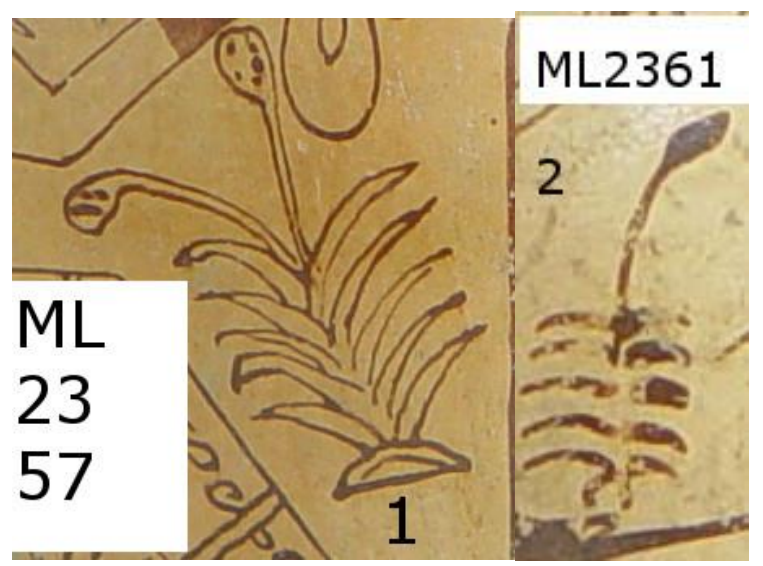

(FIGURA IV.II.I.e e IV.II.I.f) Tillandsias representadas em dois estilos distintos. Ambos, porém tem claramente delineados as folhas e os rametos.

\section{Espécie Tillandsia disticha}

Uma espécie de Tillandsia grande encontrada nas zonas mais elevadas e úmidas do cerro Campana. Consta em Leiva et al. (2014) e Corcuera (2017) Pode estar representada em um caso específico.

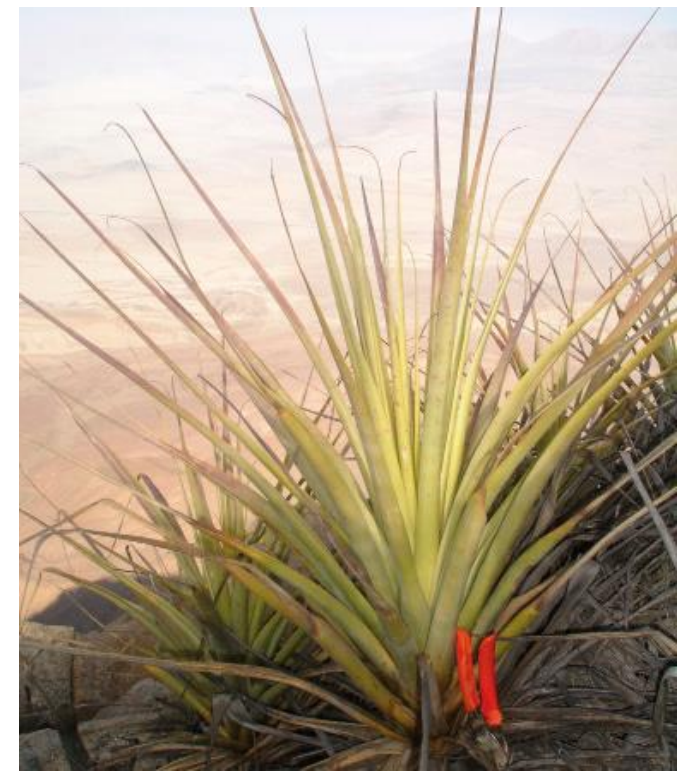

(FIGURA IV.II.I.g) Tillandsia Disticha. (Imagem retirada de Leiva et al. 2014)

Familia das Asparagaceae

\section{Gênero Furcraea}

\section{Espécie Furcraea occidentalis}

É uma planta da subfamília das asparagaceaes ou agaveáceas e a encontramos no segundo e terceiro pisos do Cerro Campana (cerca de 600 a 800 metros de altitude), em consonância com o levantamento de Leiva t. al, 2014. Corcuera, (2017) também a identifica no Cerro Ochiputur. Towle (2007 [1961]: 33) relata que cordas utilizadas em 
fundas feitas de fibras desta planta foram encontradas em uma necrópole Paracas. Acreditamos que em ao menos um caso esta planta esteja representada de forma consideravelmente naturalista (figura IV.II.I.i). Uma opção menos provável seria esta representação específica representar uma Tillandsia disticha, encontrada na mesma zona do cerro.

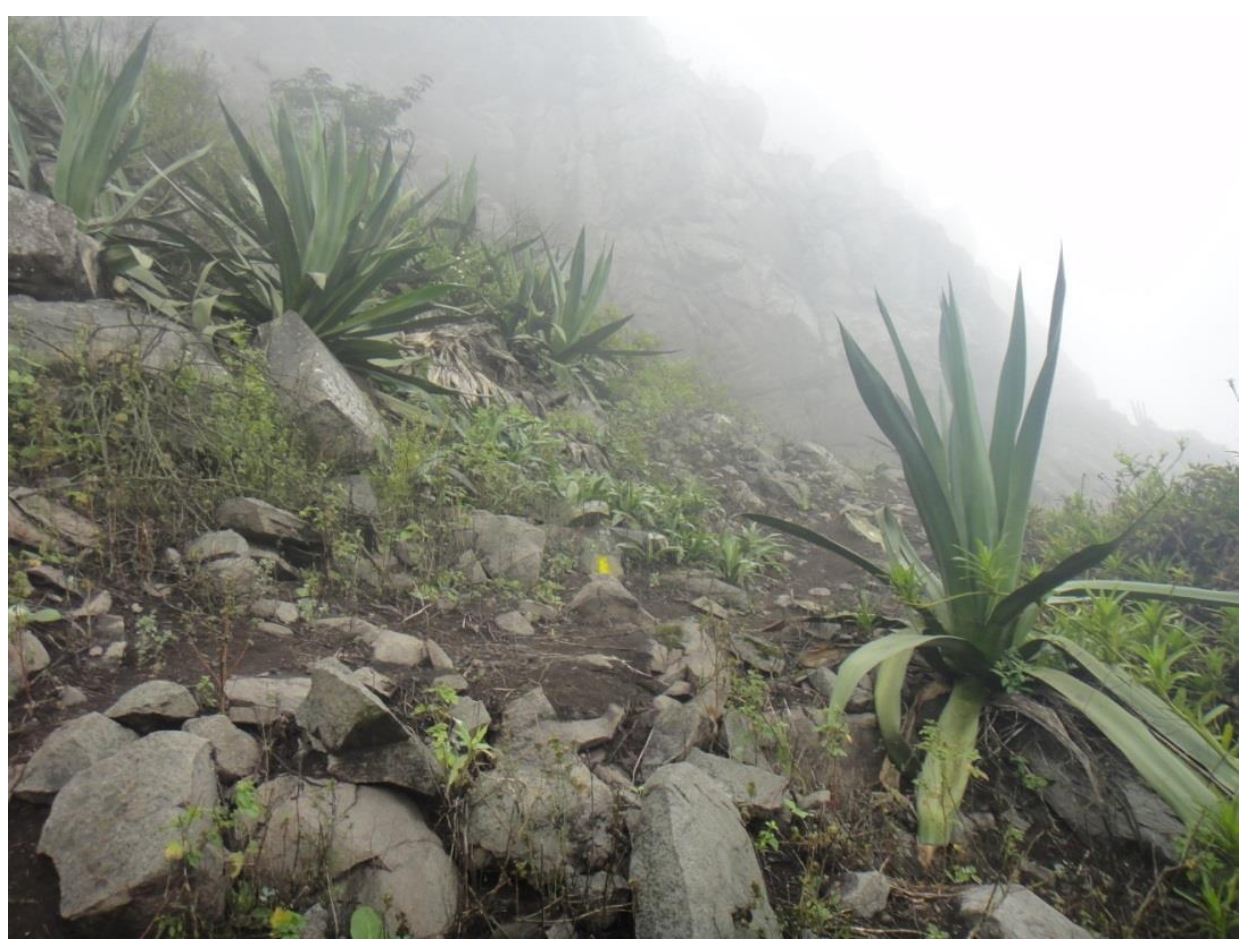

(FIGURA IV.II.I.h) Grupo de Furcraea occidentalis no terceiro piso do Cerro Campana, a cerca de 900 metros de altitude (Foto do autor) 


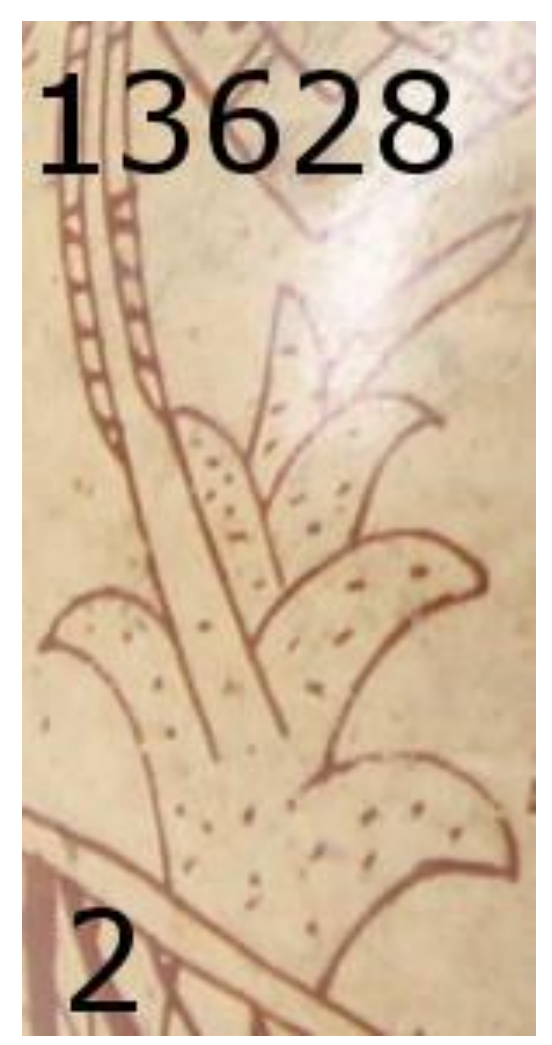

(FIGURA IV.II.I.i) Figura única sem recorrência que pode estar representando T. disticha ou F. occidentalis

\section{IV.II.II - Família das Cactaceas}

A família das Cactaceas é oriunda das américas com origem provável disputada entre 90 milhões e 30 milhões de anos atrás. Com cerca de 176 gêneros, estão distribuídos desde a região da Patagônia, no sul da Argentina até a província de Alberta no centro do Canadá (Ostalaza, 2014). Assim como no caso das bromeliáceas, encontramos uma espécie tanto no continente africano, a Rhipsalis bacífera cuja dispersão pode ter se dado por sementes levadas por pássaros ou correntes marítimas do Atlântico, uma vez que também é encontrada no continente americano. Também de forma similar às bromeliáceas acredita-se que a elevação da cordilheira andina entre 25 e 20 milhões de anos atrás tenha estimulado a diversificação dessa família.

São plantas adaptadas a climas diversos podendo ser encontradas desde a costa até altitudes maiores do que 4.000 metros, podendo resistir a temperaturas negativas e escorchantes (Ostalaza, 2011). São em geral suculentas que retém líquido por conta da adaptação a climas áridos. As cactáceas possuem diferenciação de ramos entre curtos e longos e suas folhas de ramos curtos são modificadas em espinhos, característicos de sua família. Os ramos longos costumam ser folhas de aspecto suculento que assumem a função produzir a fotossíntese (Cullman, Grotz e Groner, 1986) Algumas subfamílias 
como a Cactoideae não possuem folhas e são os caules que têm a função de realizar a fotossíntese. Além disso, esta família apresenta o caule segmentado verticalmente com protuberâncias e vales e permitem a absorção de água nas chuvas.

Os frutos dos cactos são do tipo baga com sementes internas. As raízes costumam ser muito ramificadas e superficiais para a absorção de chuvas superficiais ou grossas para o armazenamento de água (Ostalaza, 2001: 22). Todos os cactos possuem flores hermafroditas e em alguns casos como o dos melocactus as flores surgem no cefálio, estruturas de lã vegetal e cerdas feita em parte pela aglomeração de auréolas. As auréolas são estruturas exclusivas da família das cactáceas, felpudas em forma arredondada de onde surgem os órgãos importantes da planta como folhas, espinhos, cerdas, pelos, flores e fruto (Ostalaza, 2014: 28).

De acordo com Galán de Mera et. Al (2012) "as comunidades de cactos estão situadas nas lomas do deserto costeiro e nos pisos basais dos andes". O autor ainda aponta que a distribuição das comunidades de cactáceas acima do paralelo $8^{\circ}$ sul, que passa entre os vales de Chicama e Moche, são mais influenciadas pela umidade carregada pelas correntes de EL Niño enquanto abaixo desse paralelo as plantas seriam mais dependentes da umidade estival e invernal. Os mochica do sul, portanto, estariam em uma zona de fronteira climática que influenciaria no padrão distributivo das cactáceas.

As adaptações climatológicas fazem com que a família das cactáceas seja prolífica em variabilidade morfológica. Cullman, Grotz e Groner (1986) estressam o fato de que a morfologia geral reflete a estratégia evolutiva das plantas em relação a seu meio ambiente. Não entraremos nos detalhes das funções, vantagens e desvantagens de cada 'tipo' de cacto mas para nosso estudo precisaremos elencá-los. Como vemos na figura (figura IV.II.II.a) os autores propõem 11 tipos morfológicos conectados e graduais. Do maior para o menor temos os cactos arbóreos, arbustivos, colunares, colunares curtos, globulares e discoides. Derivados dos arbustivos temos os segmentados, epifíticos pendulares, escaladores e opuntioides. Derivado dos colunares temos o tipo rastejador ou prostrado. 


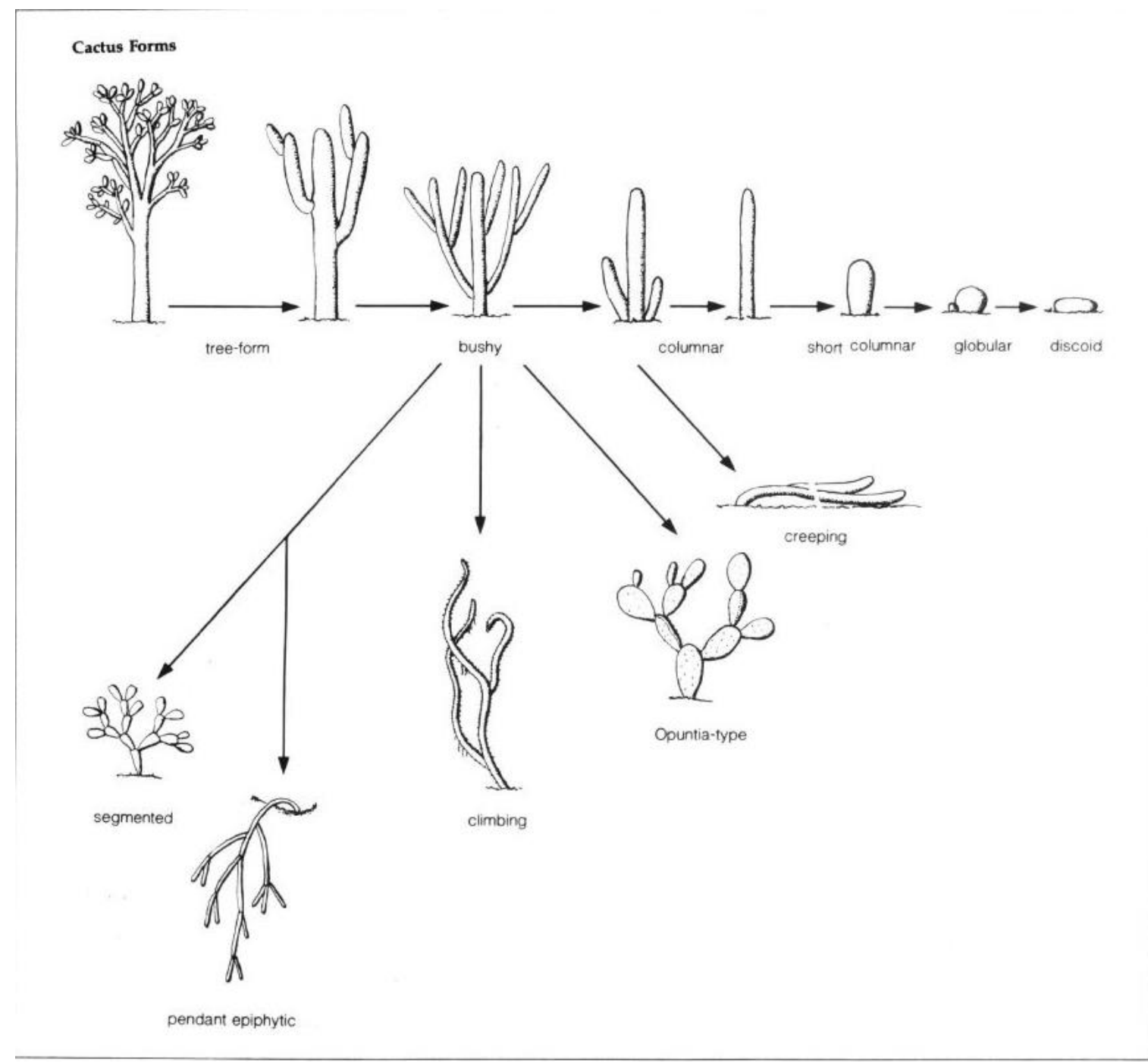

(FIGURA IV.II.II.a) Classificação dos Cactos de acordo com sua morfologia geral (Retirado de Cullman, Grotz e Groner, 1986)

Não por acaso as representações de cactos nos vasos pictóricos mochica refletem essa profusão de formas das cactáceas. Encontramos quase todos os tipos descritos por Cullman, Grotz e Groner com a exceção dos pendulares epífitos, mais comuns em zonas úmidas, e dos discoides. A variabilidade morfológica, a diversidade de gênero e os muitos estilos da cerâmica pictórica demandaram uma classificação mais complexa no estudo. Para tanto, constatamos as formas mais comuns e recorrentes e dividimos em cinco "tipos", sendo dois subdivididos: CT1A, CT1B, CT2, CT2B, CT3, CT4, CT5.

Os tipos e subtipos em geral podem representar uma ou mais espécies, mas mesmo nas peças mais bem acabadas o detalhamento geralmente nos permite ter uma certa segurança apenas do gênero representado. Além disso, como já foi dito, este não é um jogo de mimetismo detalhado e as espécies que sugerimos estarem sendo representadas são um produto do encontro de formas recorrentes na cerâmica com 
espécies recorrentes e dominantes na paisagem. Também é importante salientar que a divisão por tipos surgiu a partir da inferência dos dados da análise dos vasos antes de entrarmos em contato com a obra de Cullman, Grotz e Groner e levou a resultados convergentes com sua classificação. A seguir traremos uma breve explicação dos tipos de cactos.

\section{Cacto Tipo 1 subtipo A (CT1A):}

Este tipo reflete os cactos colunares eretos e prostrados. Difere-se do subtipo B por explicitar os espinhos. Criamos esta subdivisão por entender que existia alguma possibilidade de a explicitação dos espinhos trazer algum significado para os artistas mochica, principalmente no sentido de indicação de uma espécie particular. Os cactos representados no tipo 1A têm a base e a ponta do caule da mesma largura ou de larguras próximas. Alguns possuem frutos ou raízes. Com certa frequência eles se apresentam em afloramentos de três ou mais colunas porém são mais comumente representados apenas em uma coluna. Podem aparecer eretos ou inclinados horizontalmente. É uma forma de representação de cactos extremamente recorrente e se considerada juntamente com a forma CT1B torna-se a mais recorrente em todo o conjunto de vasos analisados.

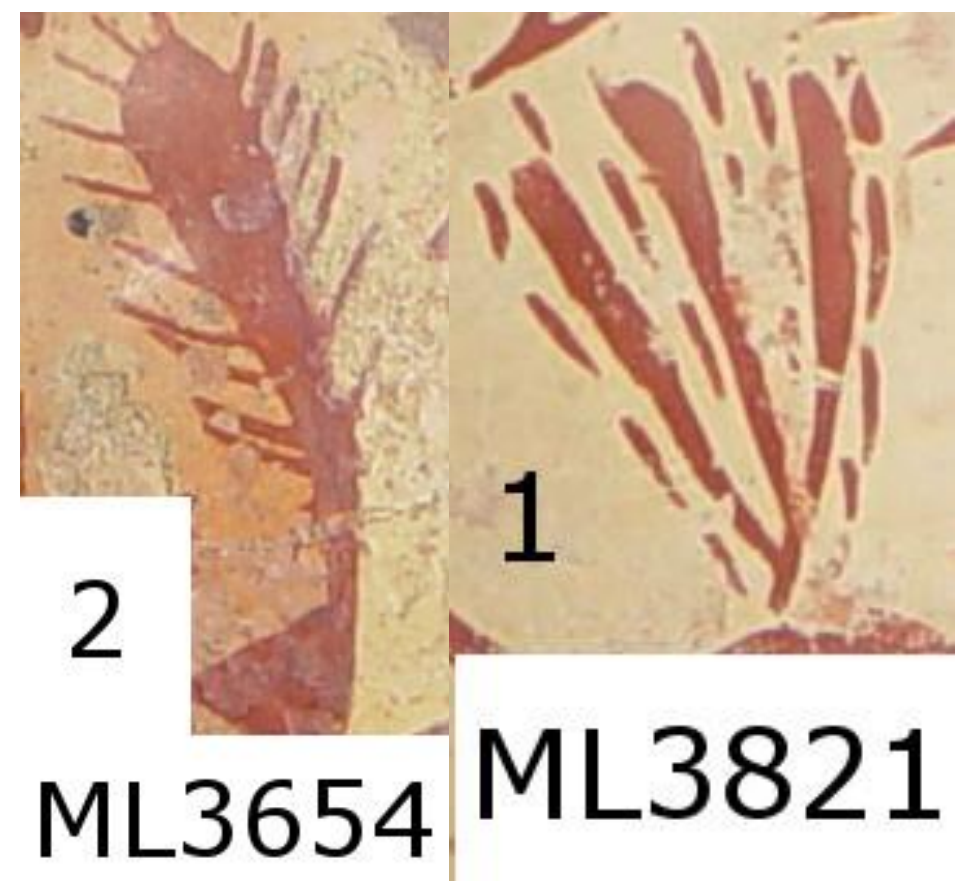

(FIGURAS IV.II.II.b e IV.II.II.c) Dois exemplos de CTIA. Notem que a largura da base não se distância demais da largura do fim da planta, trazendo o aspecto colunar. (cortesia do Museo Larco)

\section{Cacto Tipo 1 subtipo B (CT1B):}

Da mesma forma que o CT1A este tipo representa os cactos colunares eretos e prostrados. Entretanto neste subtipo os espinhos não são representados. Assim como no 
CT1A a largura da base e do fim dos talos são iguais ou próximas trazendo o aspecto colunar. São ainda mais recorrentes do que os CT1A podendo naturalmente apresentar frutos e raízes expostas. Além disso os "afloramentos" com ramificações basais de três colunas ou mais são mais comuns neste subtipo.
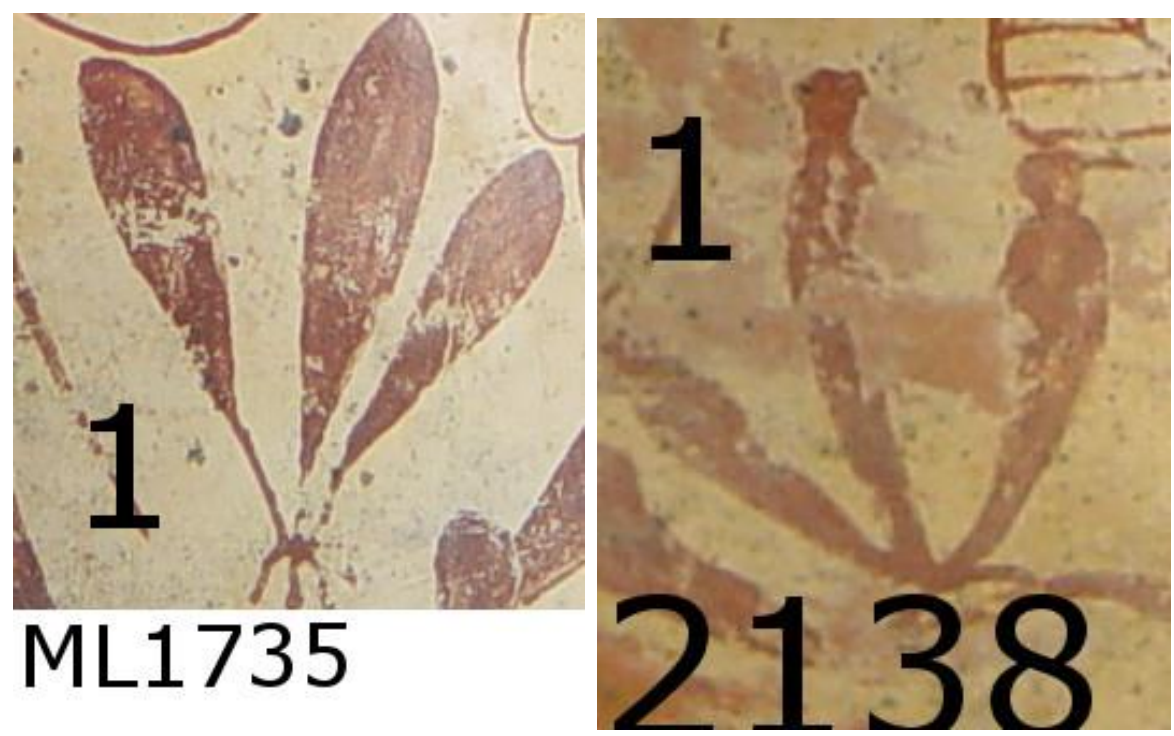

(FIGURA IV.II.II.d e IV.II.II.e) Exemplos de CTIB. O primeiro tem as raízes à mostra enquanto o segundo apresenta frutos. (Cortesia Museo Larco)

\section{Cacto Tipo 2 (CT2):}

Acreditamos que este tipo reflete as formas dos cactos colunares curtos, mas o grupo foi particularmente difícil de se tipificar. Mesmo não sendo arbitrária, a linha que separa este tipo com os tipos CT1A e CT1B muitas vezes é sutil. Buscamos incluir neste tipo formas com caules mais curtos e grossos e com uma razão entre a largura da base e a da ponta maiores. Apesar de algumas vezes aparecerem em aglomerações os CT2 aparecem pouco frequentemente surgindo de afloramentos basais como os CT1. Não diferenciamos neste tipo os com ou sem espinhos apesar de termos mantido registro desta diferenciação. Ainda neste tipo registramos alguns casos em que o artista parece registrar uma forma mais achatada. É difícil dizer se esta característica vem da vontade de representação de um objeto diferente ou simplesmente da diferença no estilo dos artistas. Por isso, a despeito de ainda mantermos estas formas como Tipo 2 produzimos uma nota diferenciada para as achatadas as indicando como "opuntioides". 


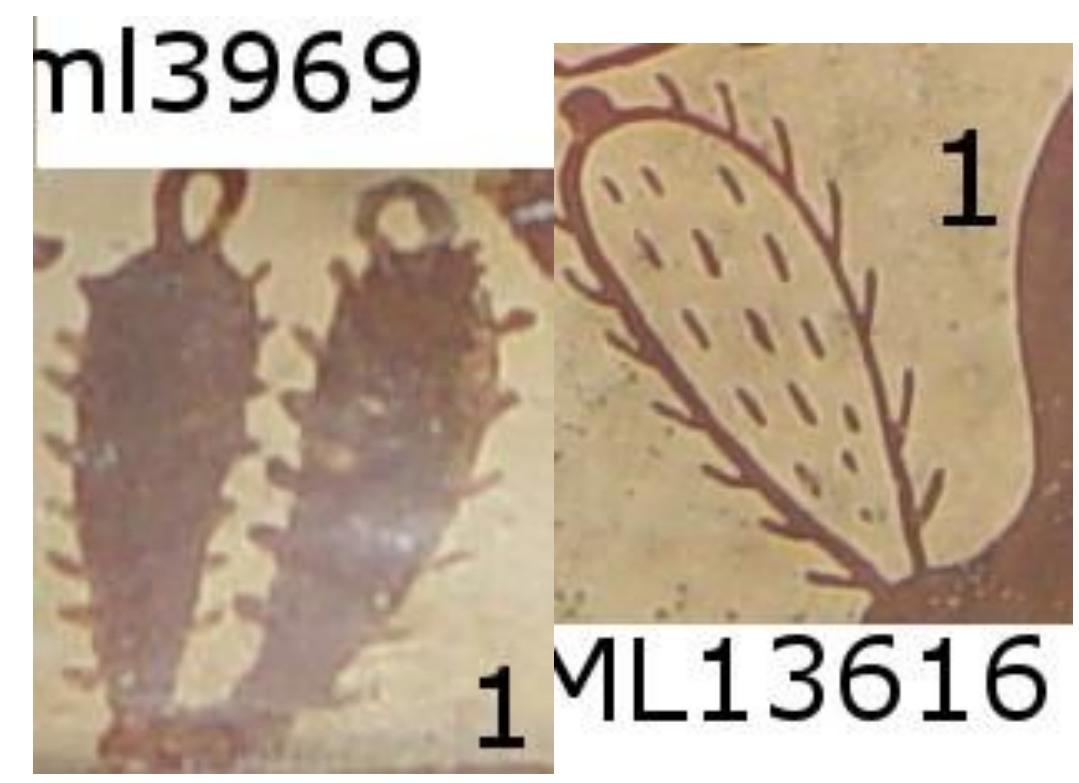

(FIGURA IV.II.II.f e IV.II.II.g) Dois exemplos de CT2, ambos com frutos e espinhos, sendo o segundo com características opuntioides (Cortesia Museo Larco)

Cactos Tipo 2 subtipo B (CT2B):

É um subtipo de cactos tipo 2 com caule ainda mais curto e grosso do que o tipo 2 comum. Acreditamos ser possível que neste tipo de cactos os artistas objetivassem a representação de Cactos globosos. Todavia este é um subgrupo limítrofe com poucas amostras e cujas intencionalidades artísticas de estarem buscando a representação de uma espécie ou gênero específicos são bem pouco perceptíveis.

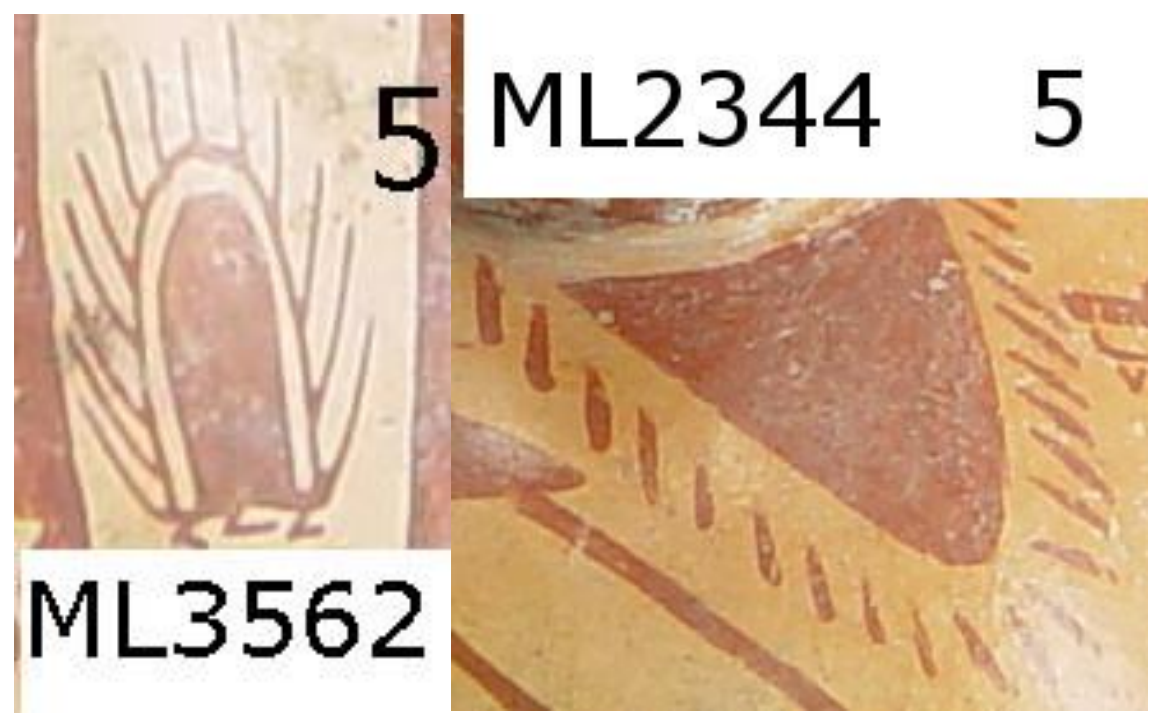

(FIGURA IV.II.II.h e IV.II.II.i.) Exemplos de CT2B. Sua forma mais atarracada pode ou não estar representado cactos globosos. (Cortesia Museu Larco) 


\section{Cactos Tipo 3 (CT3) :}

Os cactos tipo 3 (CT3) são raros com pouca recorrência na iconografia pictórica. É uma categoria transitória que engloba cactos do tipo segmentado, arbustivos ou colunares com algum tipo de segmentação.

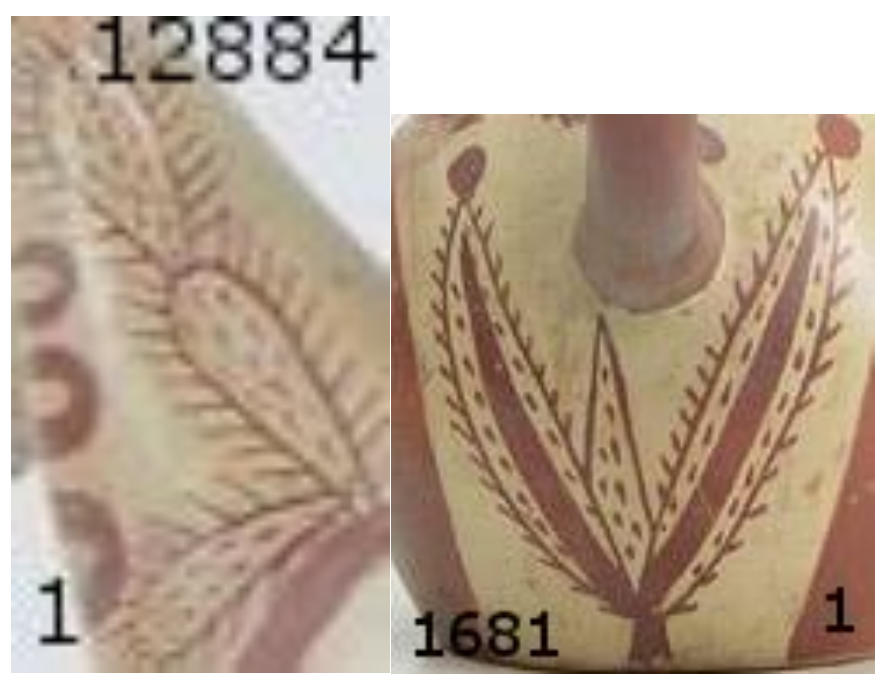

(FIGURAS IV.II.II.j e IV.II.II.k) Exemplos de CT3, ambos com espinhos mas com tipos diferentes de segmentação. (Cortesia Museu Larco)

Cactos Tipo 4 (CT4):

Nesta categoria buscamos incluir cactos com segmentos arredondados ou ovaloides. Esta é uma categoria bastante específica que pode marginalmente abarcar cactos do tipo segmentado, mas na prática é praticamente inteiramente representada pelos cactos opuntioides. Como atualmente nas regiões de habitação mochica encontramos apenas as espécies opuntia quitensis e, possivelmente opuntia macbridei, esta categoria é praticamente inteira dedicada a estas espécies. A frequência dos CT4 é pequena, mas constante em algumas cenas e sua forma inconfundível faz com que não haja dúvidas em sua identificação. 


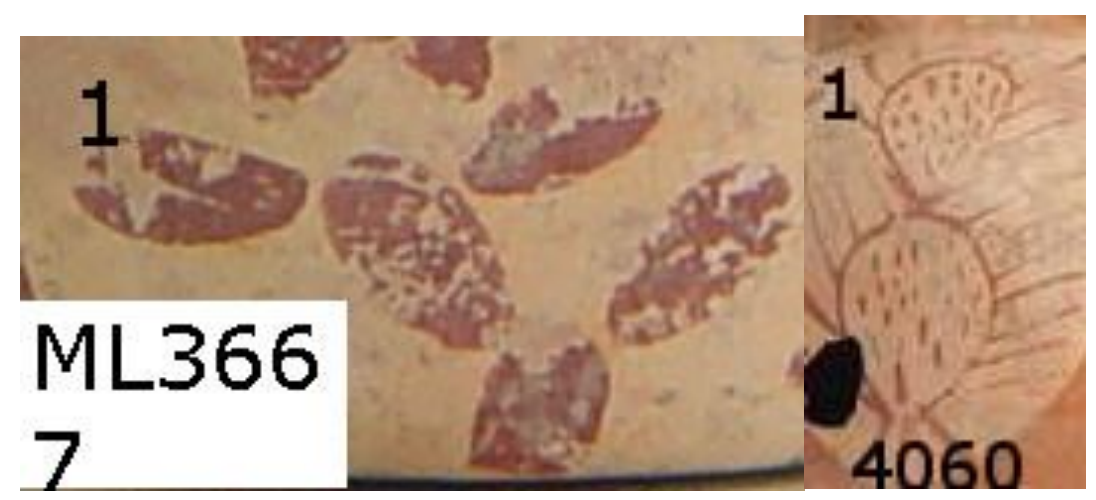

(FIGURA IV.II.II.l e IV.II.II.m) Exemplos de CT4. O primeiro preenchido e sem espinhos visíveis. $O$ segundo vazado, com espinhos e apenas uma ramificação segmentada. (Cortesia Museo Larco)

\section{Cacto Tipo 5 (CT5):}

Esta categoria tem a função de englobar as formas que aparecem apenas uma ou duas vezes e, portanto, não têm recorrência ou possuem recorrência irrisória. Acreditamos que a maioria dos casos são variações estilísticas de representações da espécie neoraimondia arequipensis. Entretanto, é possível que gêneros diversos como loxanthocereus e armatocereus apareçam ao menos uma vez nesta categoria, além de algumas formas de difícil identificação.

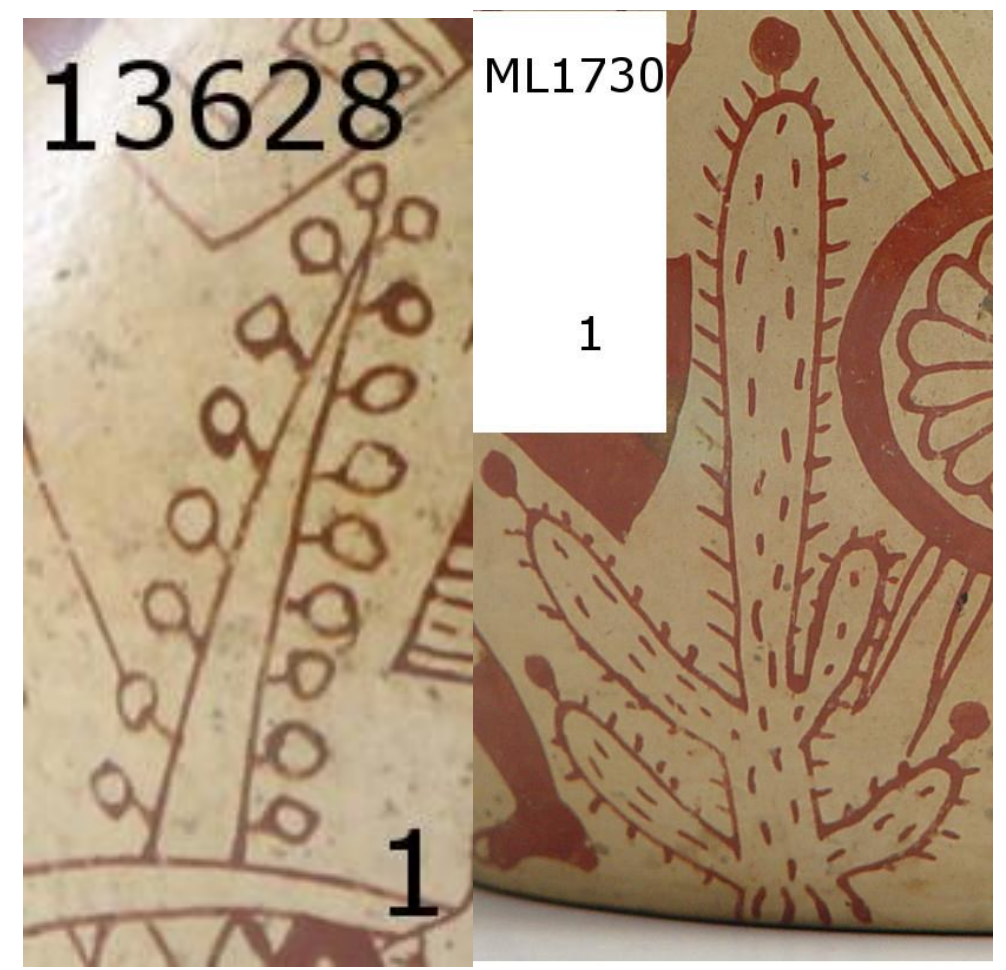

(FIGURA IV.II.II.n e IV.II.II.o). Exemplos de cactos agrupados no CT5. À direita uma forma naturalística de N. arequipensis. À esquerda um cacto colunar não identificado apresentando frutos. 
Cactos colunares e rasteiros de ramificação basal

Gênero Haageocereus:

É um gênero endêmico do Perú e, por ser muito comum na ecoregião do deserto pacifico da costa norte foram incluídas três espécies prováveis. Todas as espécies são colunares, multi-ramificadas e de ramificação basal (a partir da base), com talos em geral eretos ou semi prostrados (deitados). Por ser dominante nas paisagens de baixa altitude, principalmente o sopé das montanhas, além de compartilhar características amplamente recorrentes nas representações de cactos pictóricas mochica, este gênero é possivelmente um dos mais comumente representados na cerâmica na forma de CT1A e CT1B. É bastante parecido com o gênero esposotoa e pode ser confundido com este, sendo indistinguível na representação cerâmica. Para Ostalaza (2014: 291), o gênero possui 13 espécies e 10 subespécies. Aqui elencaremos 2 espécies que consideramos a representação crível de acordo com critérios de distribuição geográfica.

\section{Espécie Haageocereus Pacalaensis \\ subs repens:}

Devido o a seu formato e tendência à prostração (rasteiro) a espécie costuma ser identificada localmente como rabo-de-raposa (rabo de zorro), segundo Ostalaza (2011). É uma espécie seriamente ameaçada sendo que alguns exemplares foram plantados no Campus da Universidade de Trujillo para conservação. Atualmente é encontrada in natura em um raio de cerca de $12 \mathrm{~km}$ da cidade de Trujillo no vale de Moche, nas zonas desérticas costeiras (Ostalaza, 2014: 300). Chegam a cerca de 1,5 metros de altura e os talos pode ter até 10 centímetros de diâmetro. Têm a ponta alaranjada e os frutos avermelhados. Corcuera (2017) identifica esta espécie na loma do Cerro Ochiputur, no vale de Moche. É extremamente similar ao H. versicolor, podemos facilmente ser confundido com este. 


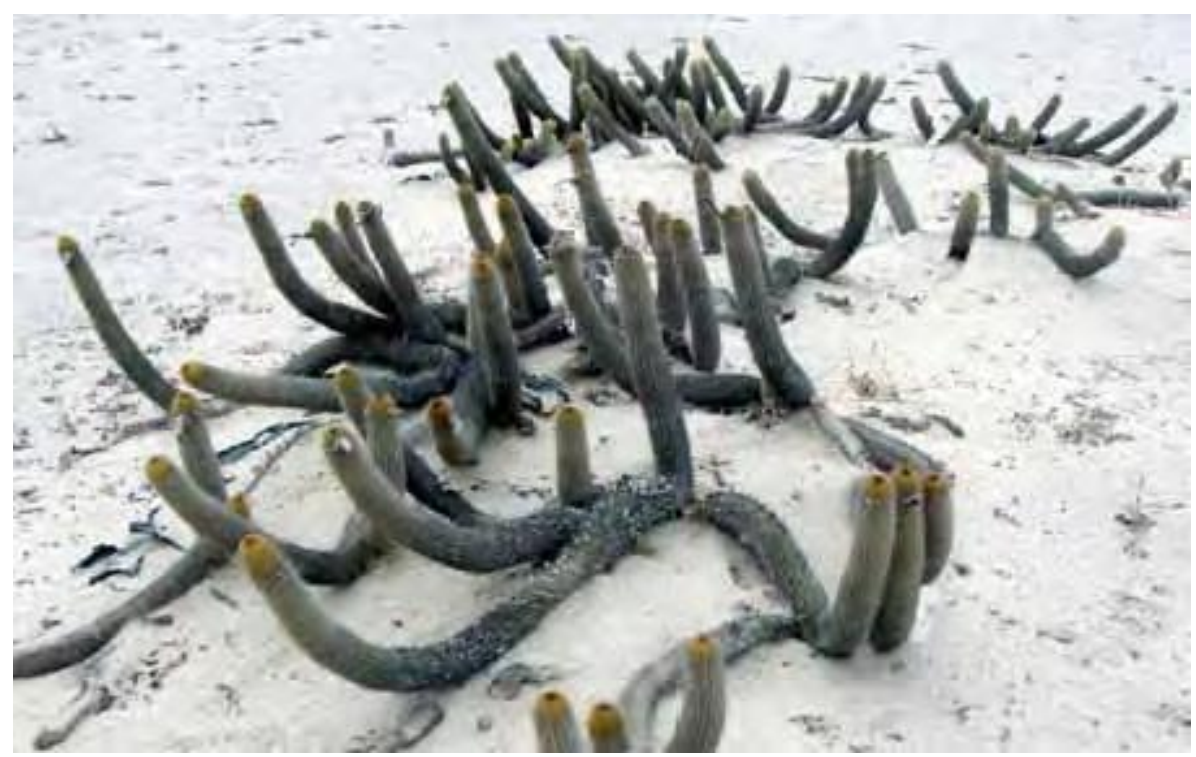

(FIGURA IV.II.II.p) H. Pacalaensis subs repens ao sul de Trujillo (retirado de Ostalaza, 2014)

\section{Espécie Haageocereus versicolor}

Ostalaza, (2014:40) aponta esta espécie como figurando em vasos moche que apresentam veados ou o temas da coleta de caracóis. No cerro Campana em o $H$. Versicolor era uma das espécies de cactos mais abundantes na paisagem, ao lado da Neoraymondia Arequipensis. Ostalaza ainda aponta que os frutos dessa espécie são comestíveis. São encontrados de 100 a 300 metros de altitude (Ostalaza:2014). Observamos que se concentram ao redor e no sopé das montanhas visitadas, de fato até cerca de 300 metros. Produzem frutos amarelados. Os talos têm cerca de 1,5 metro de altura mas são mais eretos do que o H. pacalensis. Em nossa análise este seria o cacto colunar de ramificação basal mais provável de estar sendo representado nos tipos CT1A e CT1B 


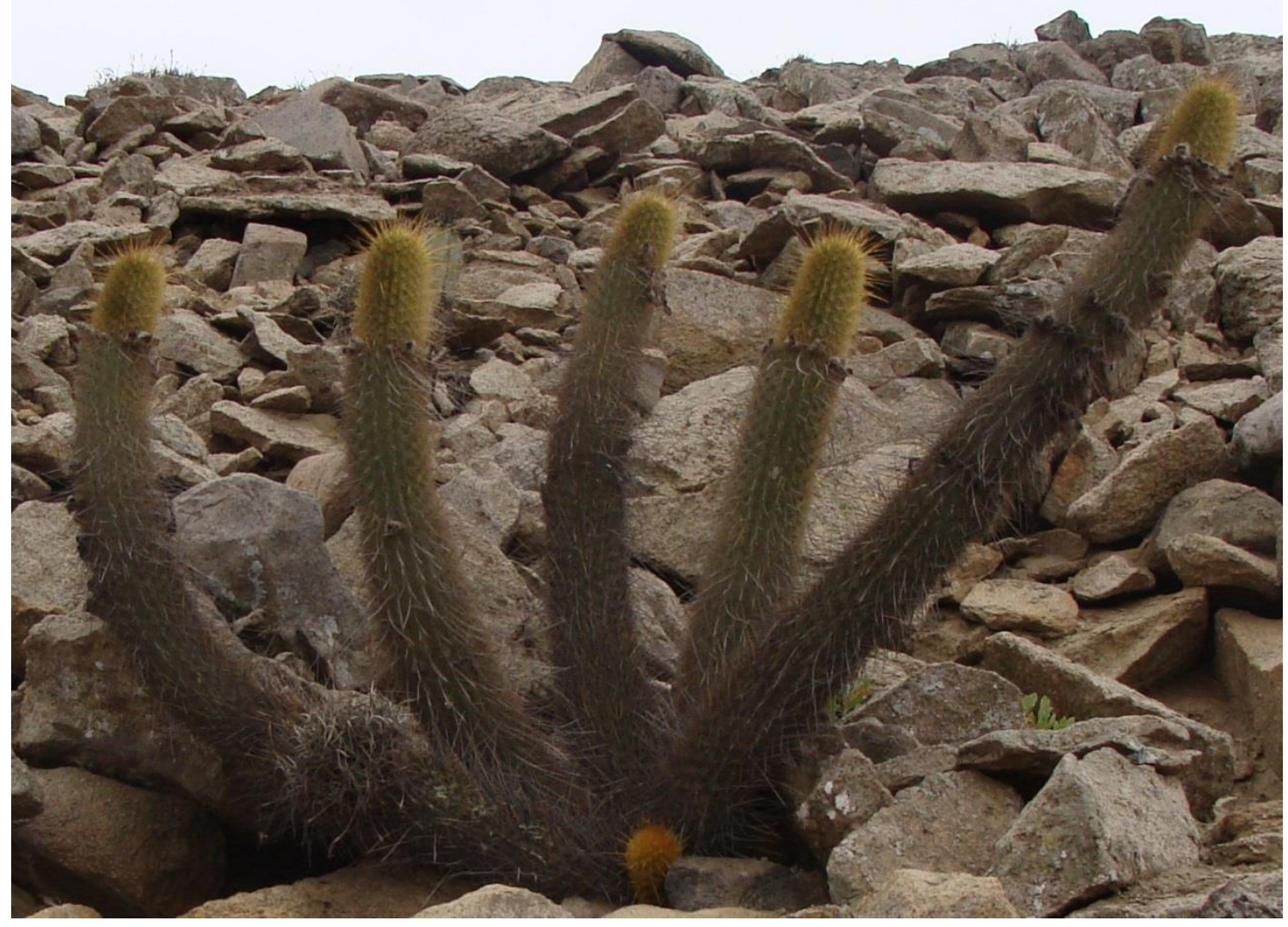

(FIGURA IV.II.II.q) H. versicolor com ramificação basal múltipla, típica das representações de tipo 1, crescendo sobre muralha Chimú. (Foto do autor)

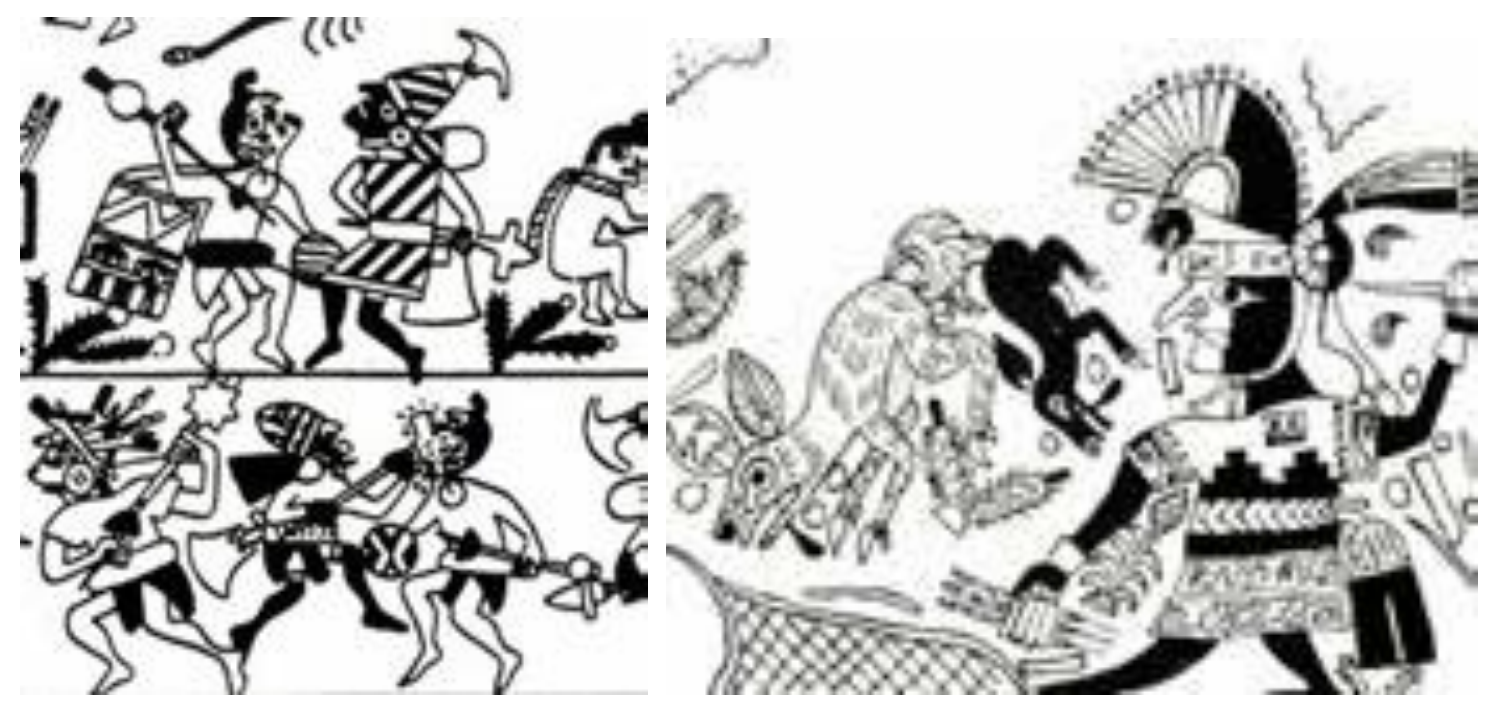

(FIGURA IV.II.II.r e IV.II.II.s) Cactos na cerâmica identificados como H. versicolor por Ostalaza. (Retirado de Ostalaza, 2014) 


\section{Gênero Espostoa}

\section{Espécie Espostoa Melanostele}

Esta espécie ocorre em zonas mais elevadas das lomas, cerca de 1.000 metros acima do nível do mar. É distinguível por seus pelos por todo o talo que lhe dão um ar "lanoso" e seu cefálio lateral. Possuem frutos alaranjados. Tem um formato estrutural parecido com o $H$. versicolor mas é maior e mais ereto, podendo chegar a 3 metros de altura (Ostalaza, 2014). É menos ubíquo nos pisos basais das lomas, mas torna-se mais comum na medida em que a altitude aumenta e o ar torna-se mais úmido. Observamos esta espécie no Cerro Campana e ela figura nos levantamentos de Leiva et. al (2014) e Corcuera (2017), este sobre o Cerro Ochiputur. Acreditamos ser possível que tenha sido representado nos vasos pictóricos principalmente às representações de cactos tipo CT1A e CT1B .

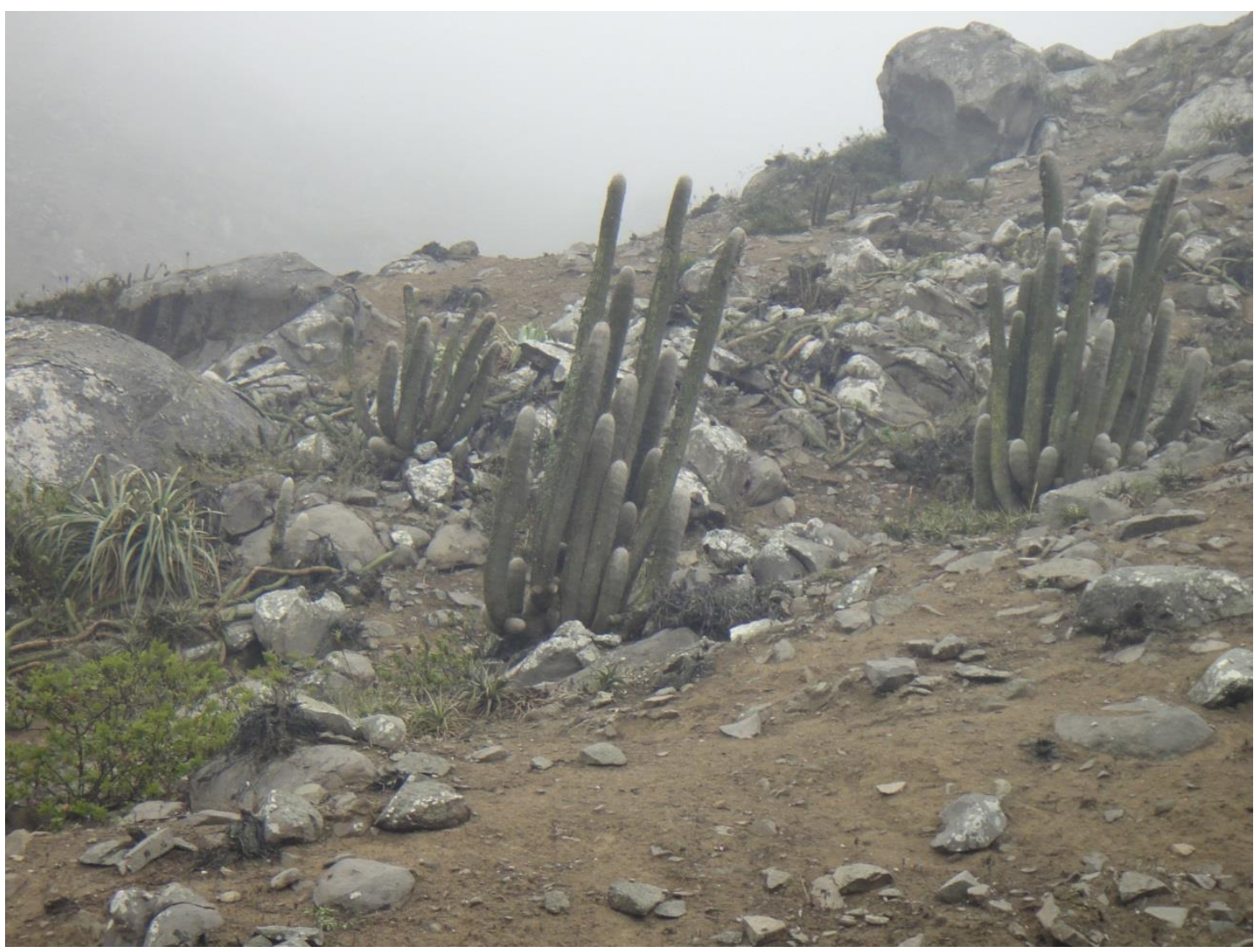

(FIGURA IV.II.II.t) E. Melanostele no segundo piso do Cerro Campana (cerca de 700 metros de altitude) (Foto do autor) 


\section{Gênero Loxanthocereus \\ Espécie Loxanthocereus trujilloensis}

Leiva et al (2014) identifica essa espécie de loxanthocereus no Cerro Campana e Corcura (2017) no Cerro Ochiputur. Também nos deparamos com um espécime a cerca de 700 metros (figura IV.II.II.u). Segundo Ostalaza (2014:331) trata-se de um gênero com grande semelhança com os haageocereus. Assim como estes últimos, são arbustivos com talos colunares, mas no caso do trujilloensis, o exemplar que pudemos observar possuía talos bastante prostrados. Essa morfologia característica nos faz acreditar que em ao menos um caso esta espécie pode ter sido representada em um caso particular na cerâmica mochica.

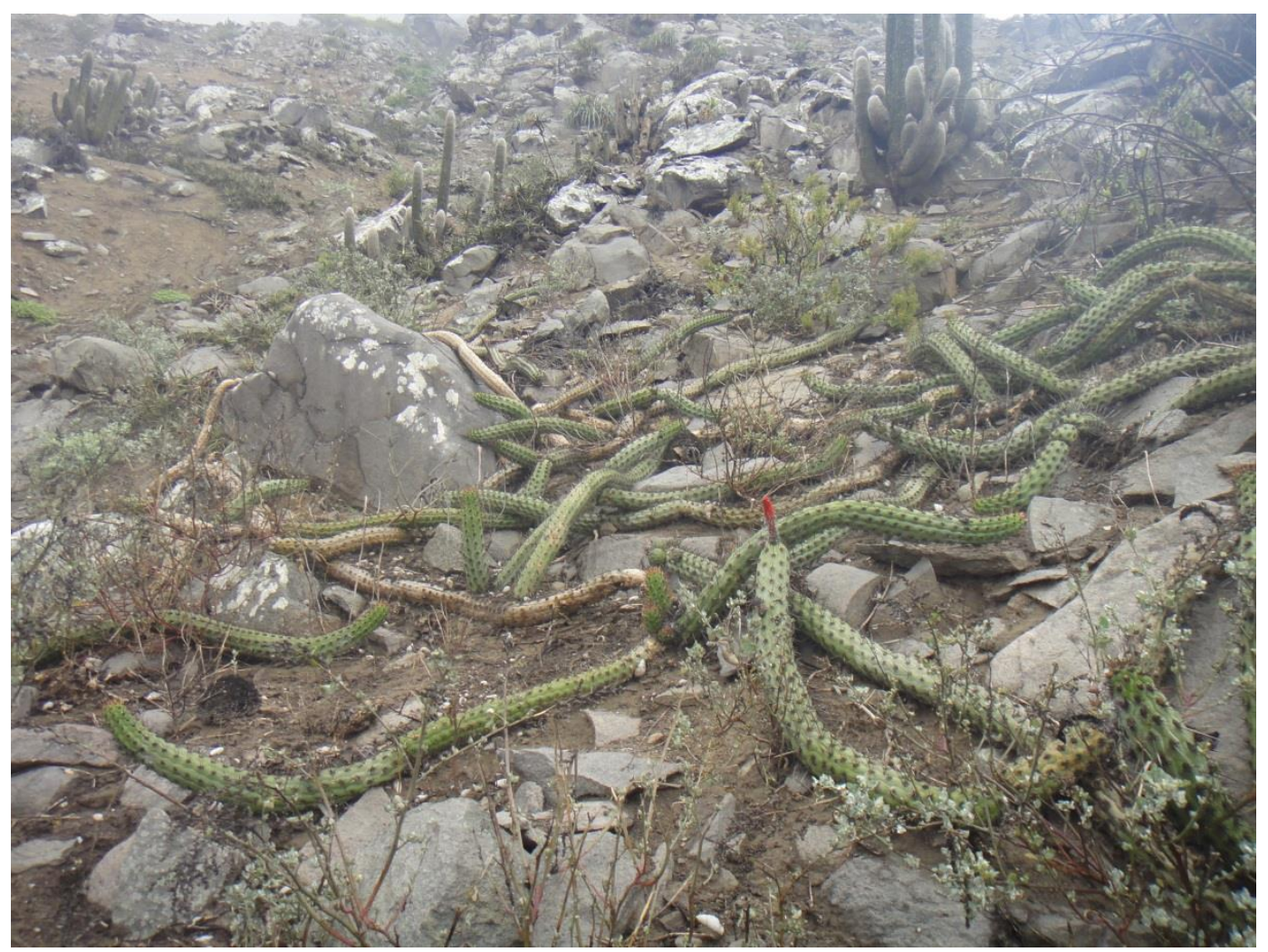

(FIGURA IV.II.II.u) L. trujilloensis a cerca de 700 metros de altitude do Cerro Campana com caules prostrados. (foto do autor) 


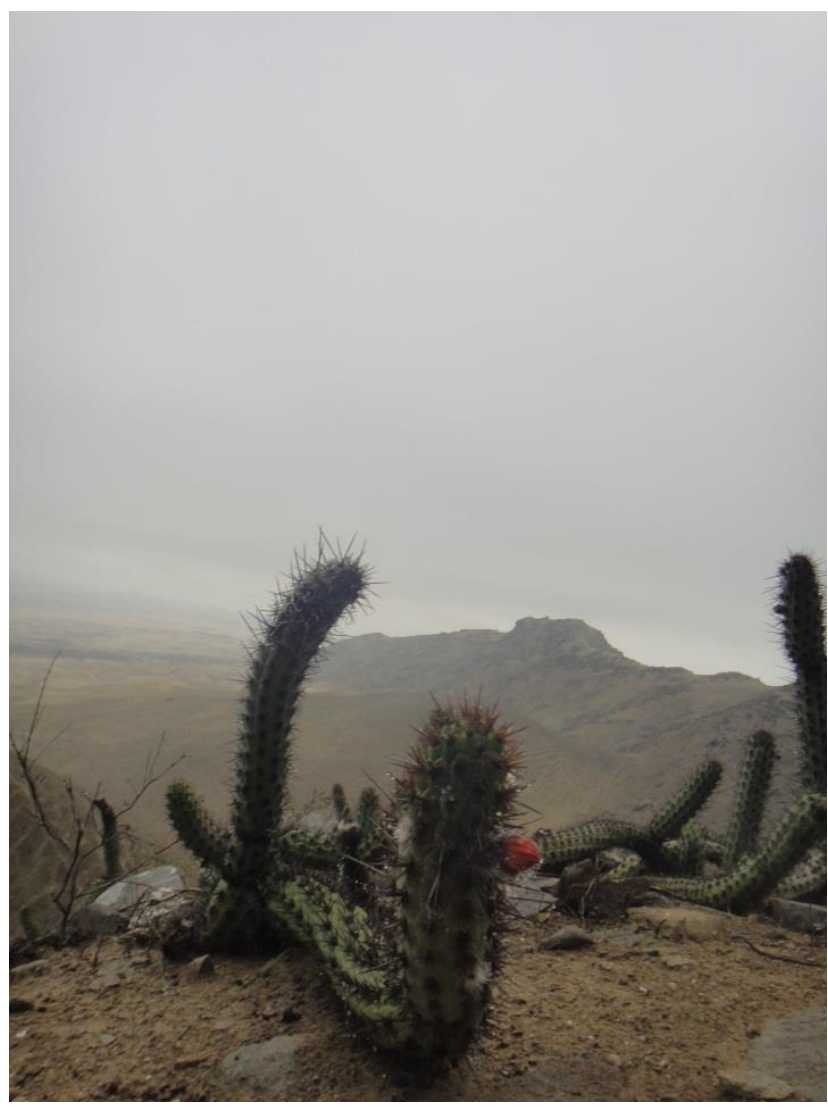

(FIGURA IV.II.II.v) Detalhe de flor do L. trujilloensis.(Foto do autor)

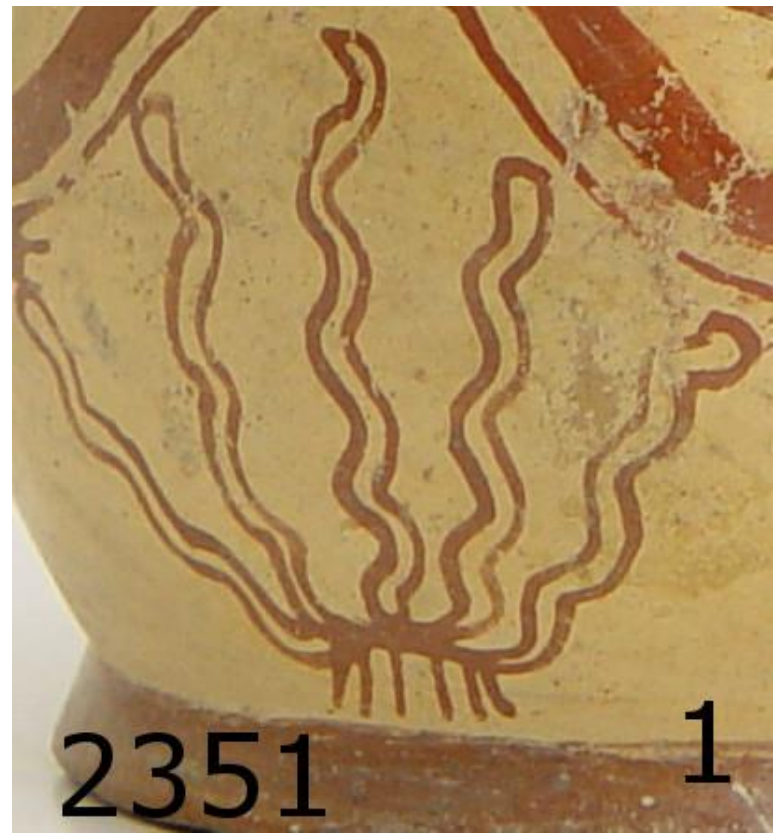

(FIGURA IV.II.II.x) Possível L. trujilloensis classificado como CT5 por ser um tipo não recorrente. O serpenteamento dos caules é único e pode estar simulando as formas do cacto. 


\section{Globosas}

Neste grupo incluímos uma espécie com características morfológicas atarracada e arredondada.. Isso confere a ela um tipo de morfologia bastante específica que pode ter sido representada pelos moche. Há também nessas características o gênero Matucana, mas como ocorrem mais para o interior dos vales nas montanhas andinas e não nas lomas, acreditamos ser ínfima a possibilidade de sua representação na cerâmica. Se bem que na cerâmica pictórica a representação de globosas é um pouco duvidosa, é quase certo que estas figuram na cerâmica escultórica, muito provavelmente na forma de melocactus (Towle, 2007 [1961]: 69).

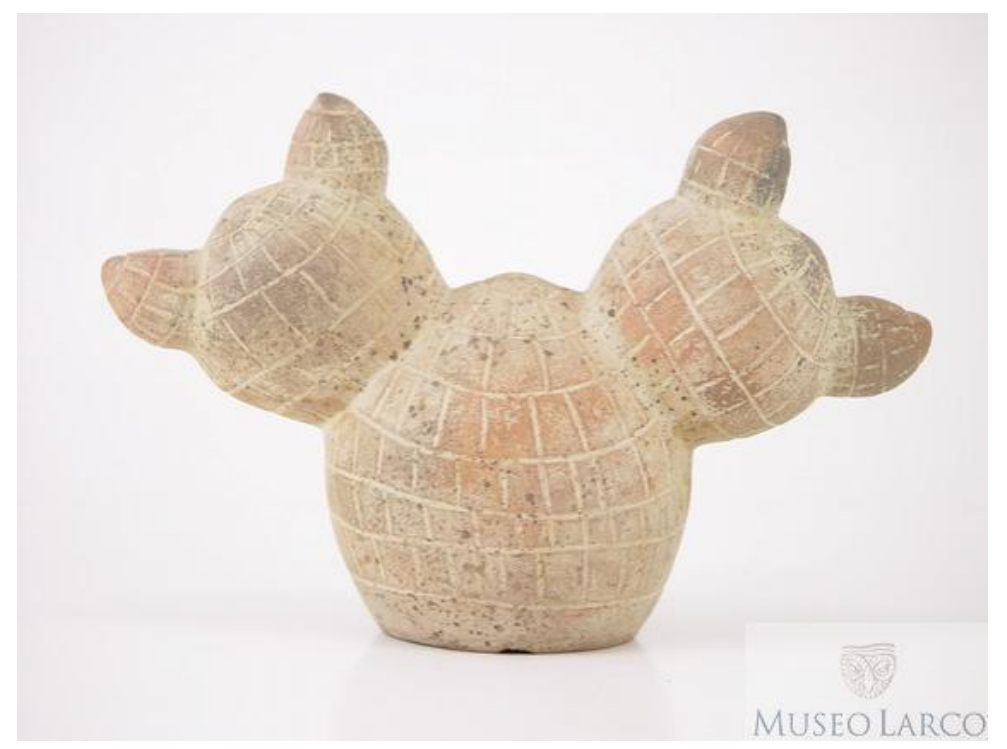

(FIGURA IV.II.II.z) Imagem de cacto escultórico (cortesia do Museu Larco) Espécie Melocactus peruvianus

O gênero Melocactus consiste em plantas compactas e globulares ( o prefixo melo significa maçã e foi empregado devido a semelhança deste tipo de cacto com os frutos)(Ostalaza, 2011). Os cefálios desenvolvidos são bem característicos do gênero, além do corpo coberto de espinhos bastante grandes (de 3 a $21 \mathrm{~cm}$ ). A espécie $M$. peruvianus é a mais comum em todo o Peru e pode ser encontrada em províncias costeiras e montanhosas, sendo mais comumente avistado entre 30 e 1.200 metros de altitude, com alguns relatos de avistamento a cerca de 3.400 metros de altitude (Ostalaza, 2014: 240). Observamos esta planta no Cerro Campana e ela também consta no levantamento de Leiva et. al (2014) e no de Corcuera (2017) no Cerro Ochiputur. Se estiver sendo representada, esta espécie estaria mais relacionada com o tipo 2 subtipo B. 


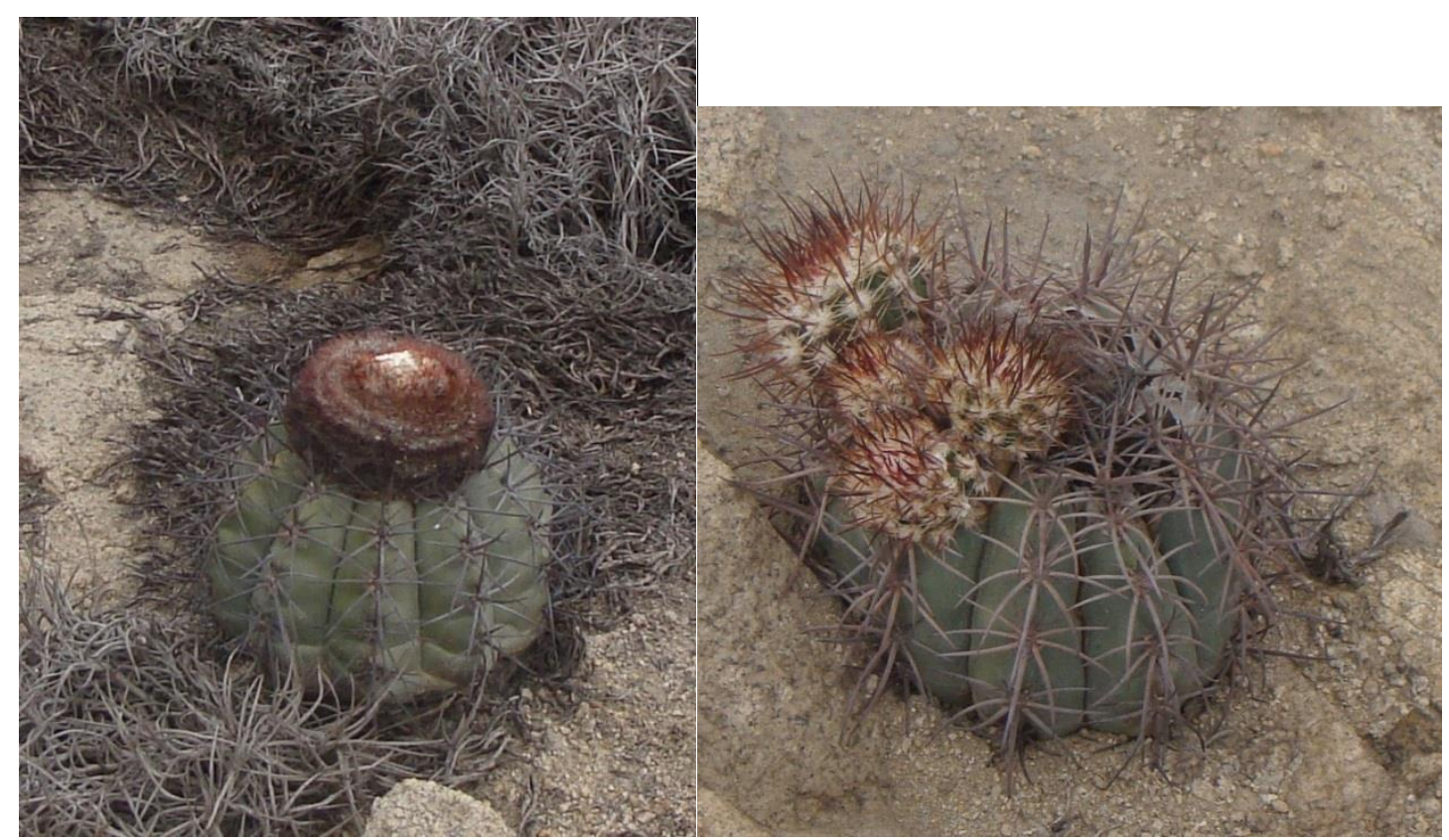

(FIGURAS V.II.II.al e V.II.II.b1) M.Peruvianus com cefálio em meio a um tillandsal (à esquerda) e com frutos (à direita) (Fotos do autor)

Segmentados arredondados

Espécies Opuntia quitensis / Opuntia macbridei

Há nas nos vasos pictóricos mochica representações de cactos segmentados com segmentos arredondados. Acreditamos que neste caso é grande a probabilidade de estarem representando uma ou, possivelmente duas espécies de cactos do gênero Opuntia: O. quitensis e O. macbridei. As plantas do gênero Opuntia são arbóreas e arbustivas, com seus talos segmentados achatados e tendendo para o arredondado ou ovalado. Entretanto existe uma confusão classificatória uma vez que apenas Ostalaza vê distinção entre Quitensis e Macbridei, esta última sendo menor (cerca de $60 \mathrm{~cm}$ de altura)e apresentando flores vermelhas enquanto a $O$. quitensis pode chegar a 2 metros de altura e apresenta flores laranjas. Segundo o próprio Ostalaza (2014) a maioria dos autores considera apenas $O$. quitensis como espécie. Tal divisão tem certa relevância uma vez que Ostalaza identifica O. Macbridei em um vaso pictórico Mochica (figura IV.II.II.c1). Entretanto o levantamento de Leiva (2014) sobre a flora no Cerro Campana indica a presença da $\mathrm{O}$. quitensis naquela loma. De fato, em nossa incursão observamos um cacto opuntia quitensis. Também é digno de nota que Ostalaza aponta que a O. Macbridei coloniza ambiente a cerca de 2.300 metros de altitude enquanto observamos o exemplar muito mais abaixo, a cerca de 700 metros da base do Cerro Campana. 
Portanto, neste caso utilizaremos O. Quitensis como contraparte natural das representações de cactos segmentados mais particularmente o cacto tipo 4. Consta no levantamento de Leiva et. al. (2014) sobre o cerro Campana e Corcuera (2017) sobre o Cerro Ochiputur.

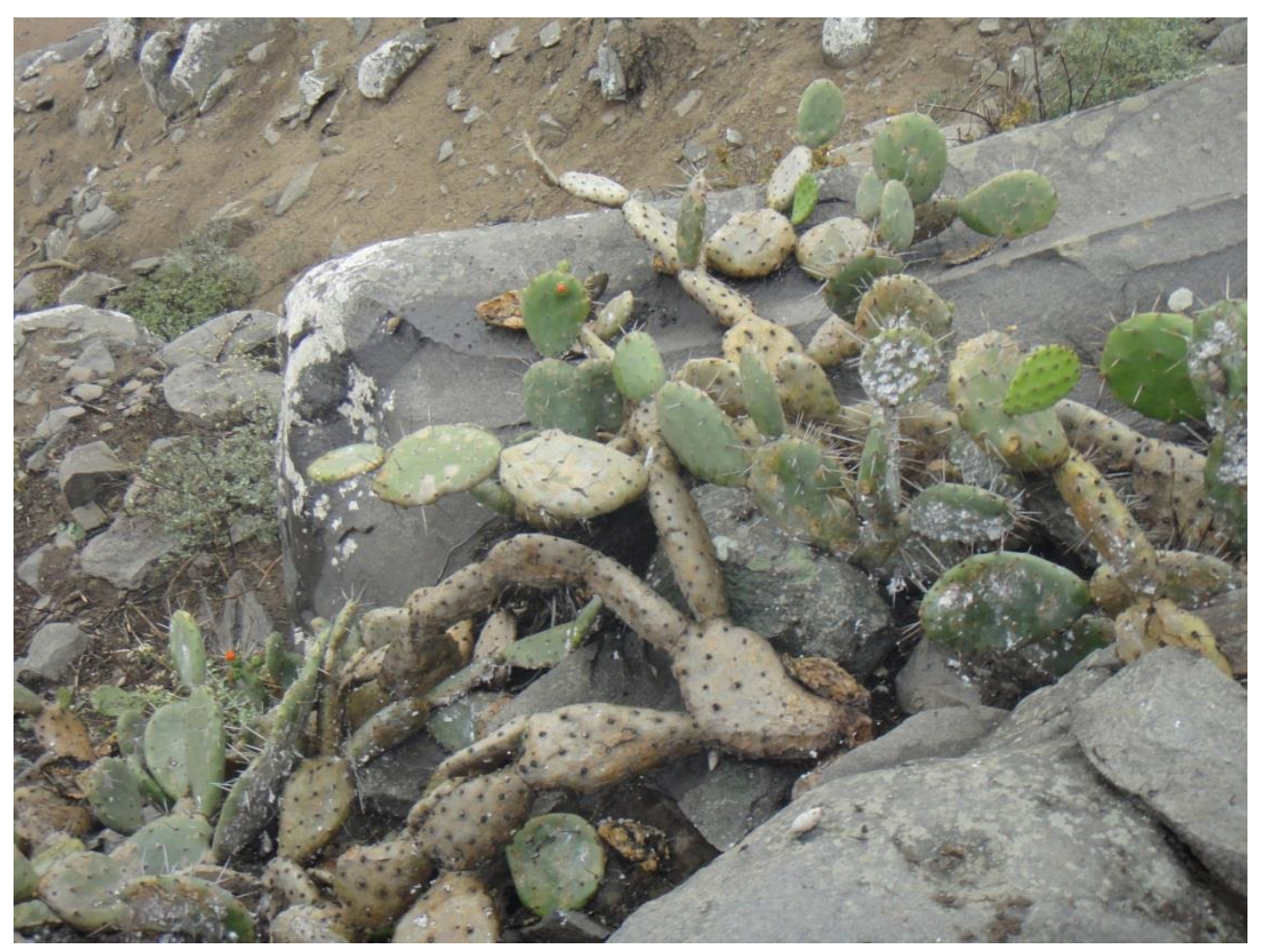

(FIGURA IV.II.II.c1) Opuntia Quitensis a cerca de 700 metros de altitude no Cerro Campana (Foto do autor)

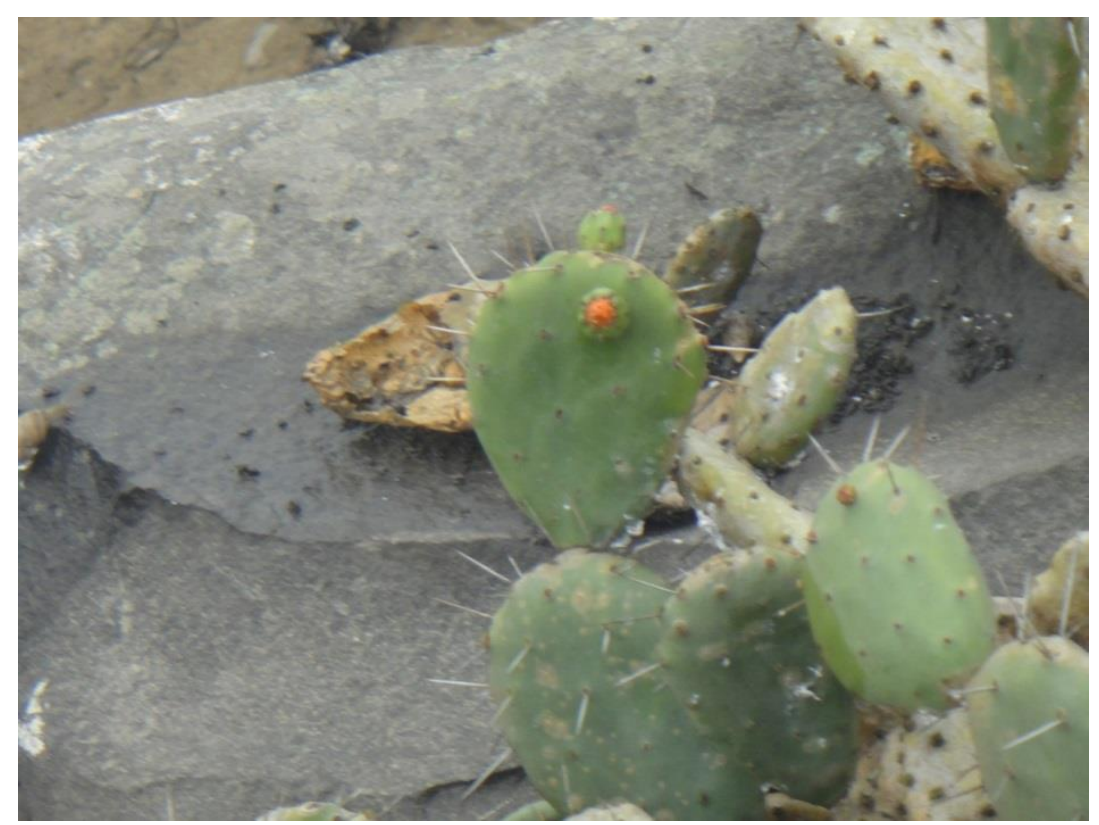

(FIGURA IV.II.II.d1) Detalhe dos frutos da O. Quitensis (Foto do autor) 


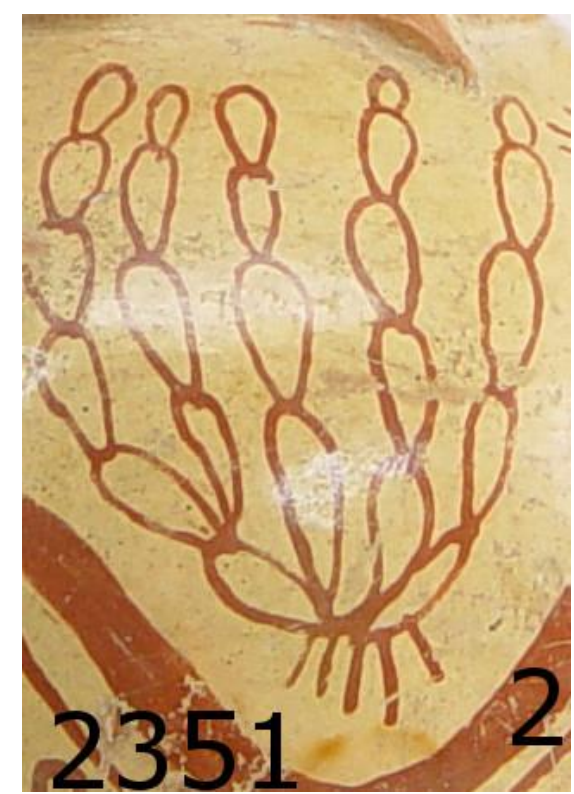

(FIGURA IV.II.II.e1) Cacto segmentado tipo CT4, possível representação de O. Quitensis. (Cortesia Museu Larco)

Grandes cactos colunares arbóreos e arbustivos:

Grandes cactos arbustivos não são incomuns nas representações pictóricas mochica. Aparecem frequentemente como colunas saindo do solo, ou cactos arbóreos com talos saindo do tronco principal. Menos frequentemente vemos colunas únicas surgindo do solo e algumas raras vezes observam-se talos colunares segmentados.

Gênero Neoraimondia

\section{Espécie Neoraimondia arequipensis subs gigantea}

Como a nomenclatura indica é um cacto de grande porte, podendo chegar a 8 metros de altura. Neoraimondia Arequipensis é uma espécie extremamente ubíqua na costa peruana, sendo a subespécie gigantea dominante na costa norte do Perú enquanto a subespécie Roseiflora domina a costa central peruana. Ostalaza (2014:58) indica a $N$. Arequipensis roseiflora como espécie representada na cerâmica da cultura Nasca, contemporânea aos Moche, associada a camelídeos que são representados se alimentado de seus frutos. Na cerâmica pictórica moche pretendo demonstrar que uma parte considerável dos cactos pictóricos são representações de Neoraimondia Arequipensis, algo condizente com sua predominância paisagística observada nos cerros.

Possui grandes espinhos de cerca de $7 \mathrm{~cm}$ (sabe-se que mais ao sul espinhos da N. Arequipensis eram utilizados como anzóis e agulhas)(Ostalaza:2014), auréolas 
grandes e frutos vermelho escuro. Shultes, (1967) apud De Rios (1989), reporta sobre um bebida alucinógena chamada cimora feita com uma espécie de Neoraimondia a $N$. Macrostibas, que atualmente é um sinônimo taxonômico para a neoraimondia arequipensis. Colonizam ambientes áridos de baixa altitude a cerca de 300 metros, mais evidentemente nos sopés dos cerros.

Burger (2000 :36) relata práticas de xamãs serranos que se utilizam dos caracóis para indução de uma viagem espiritual que identifica as aglomerações de cactos San Pedro. Segundo o autor, o alcaloide contido no N. Arequipensis seria absorvido pelos caracóis scutalus spp. que dele se alimentam e reabsorvidos pelas pessoas que os consomem, gerando um transe psicotrópico.

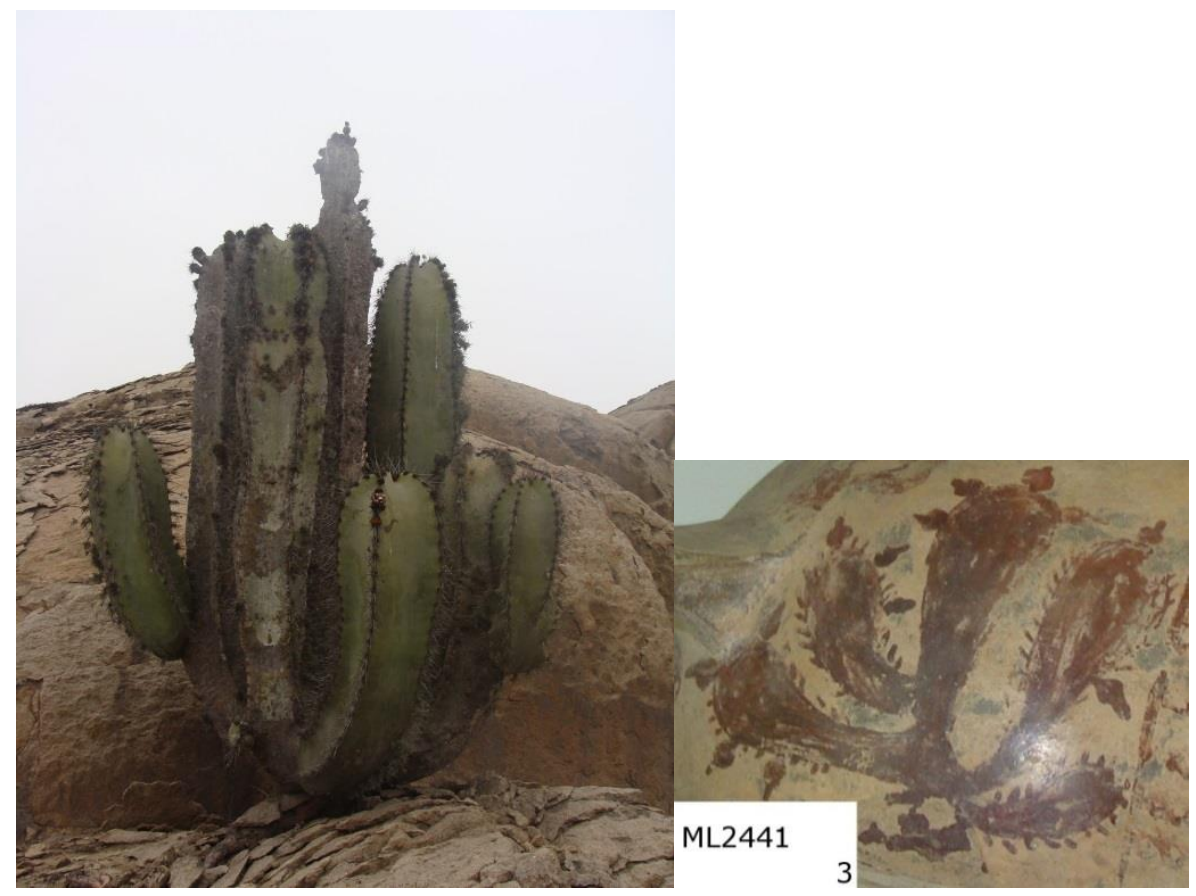

(FIGURA IV.II.II.fl e IV.II.II.g1) Espécime de N. arequipensis com muitas ramificações basais com aspecto arbustivo. (Foto do auto, 2017) Ao lado pintura cerâmica moche classificada como CT5 por ser não recorrente (cortesia Museu Larco) 


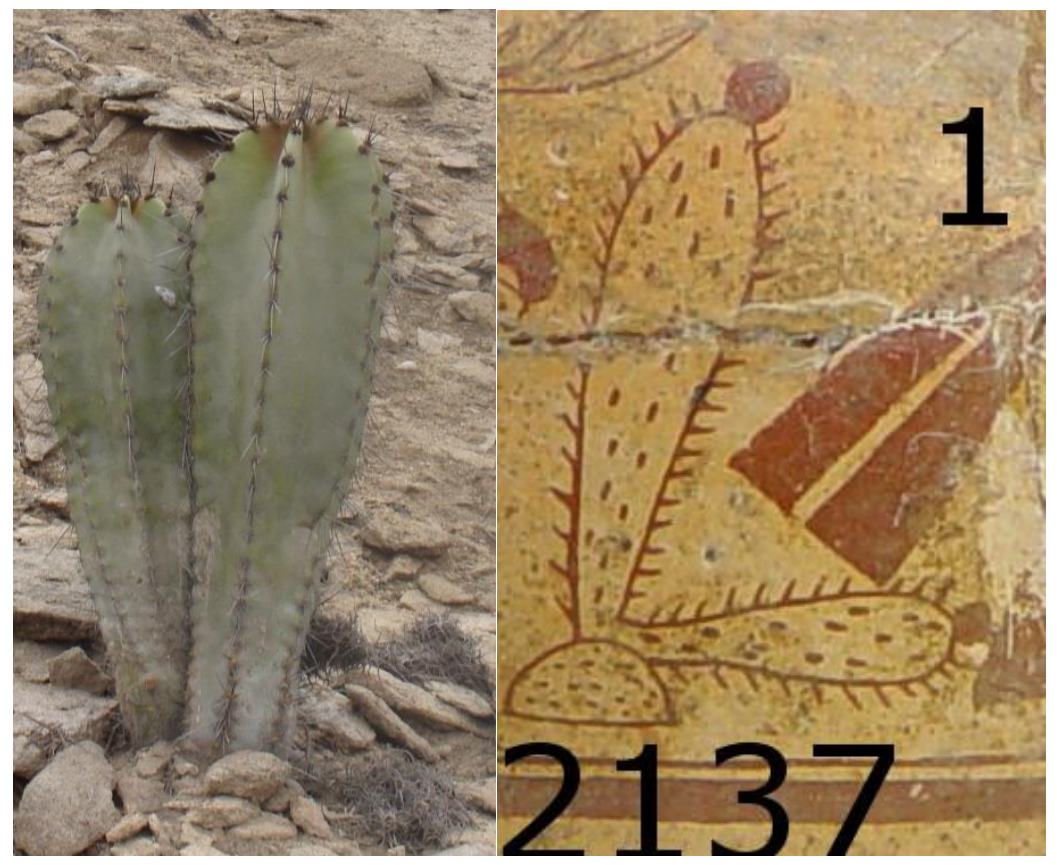

(FIGURA IV.II.II.h1 e IV.II.II.il) N. Arequipensis jovem no sopé do cerro Campana (Foto do autor, 2017) Ao lado, cacto CT2 com fruto. (Cortesia Museu Larco)

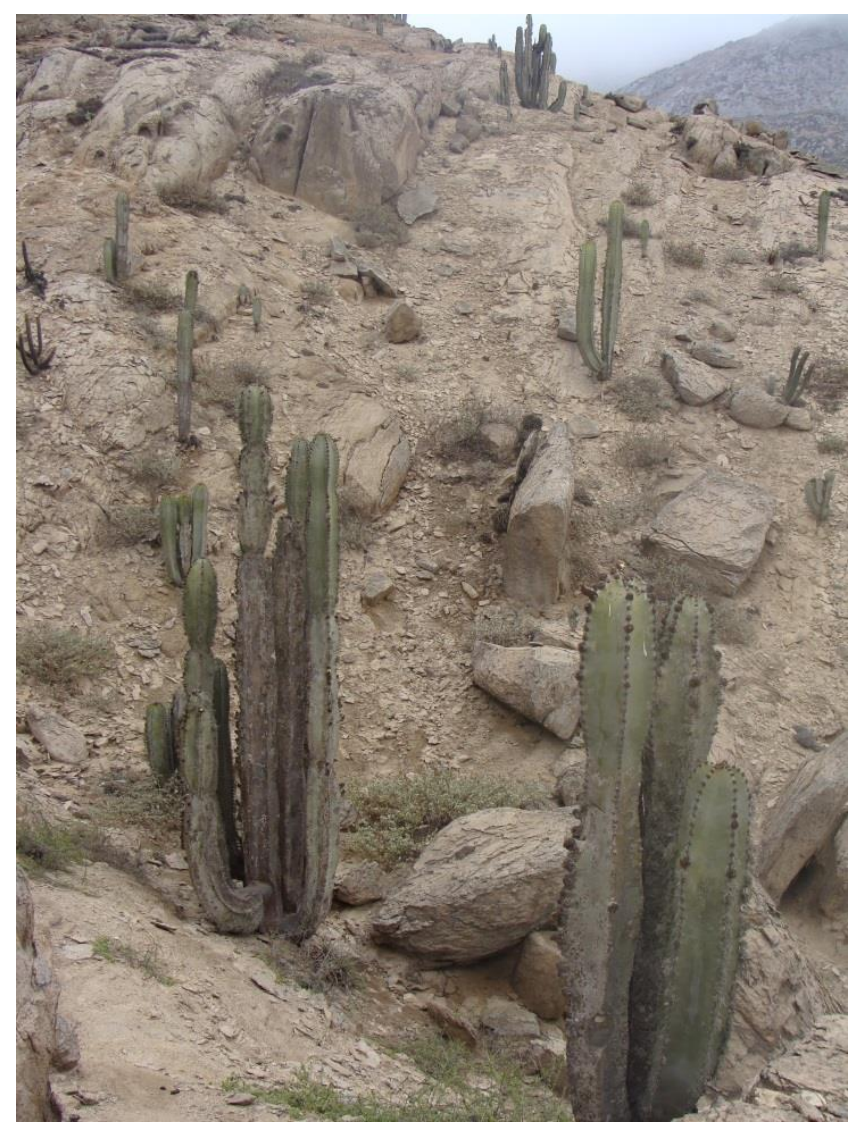

(FIGURA IV.II.II.j1) N. Arequipensis de aspecto colunar dominam a paisagem do primeiro piso do Cerro Campana. Também na foto exemplares de E. melanostele e H. versicolor. 


\section{Gênero Armatocereus}

\section{Espécie Armatocereus oligogonus}

Apesar de muito mais raro que a $N$. arequipensis, o armatocereus oligogonus atualmente pode ser avistado nas regiões habitadas pelos moche, em particular os Departamentos (divisão subprovincial peruana) de Lambayeque e Trujillo. O cacto colunar pode chegar a três metros de altura e é visivelmente distinto da Neoraimondia, principalmente pela segmentação de suas colunas. Habita as zonas baixas costeiras até regiões montanhosas cerca de mil metros acima do nível do mar. Apesar de provavelmente não ser de uma espécie ou gênero amplamente representado, acreditamos que em alguns casos o artista intenciona representar esta espécie ou ao menos uma espécie do mesmo gênero.

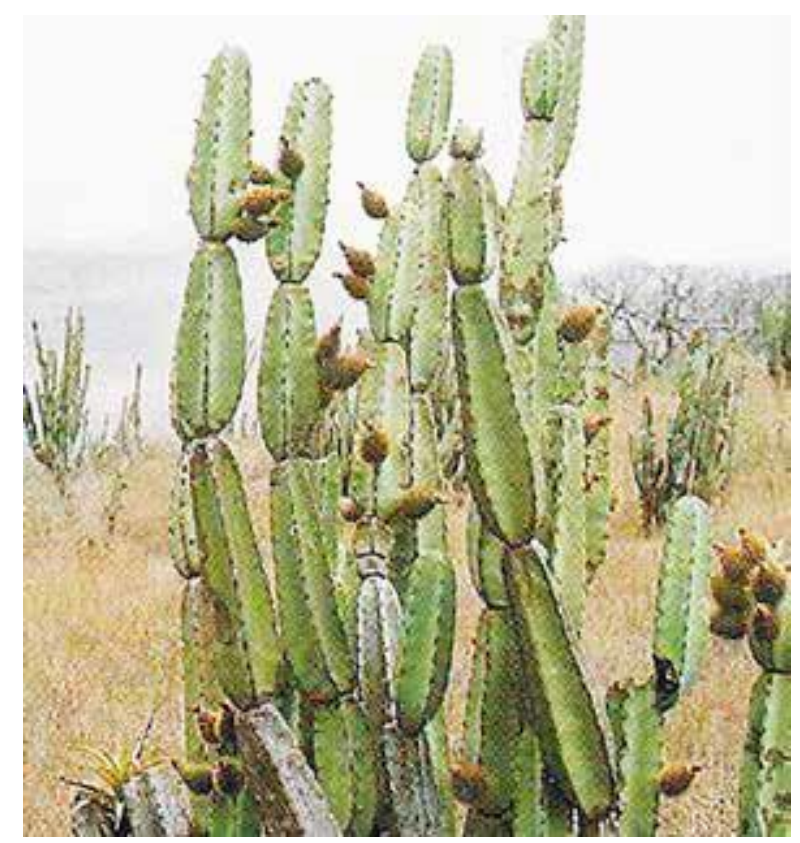

(FIGURA IV.II.II.k1) Armatocereus oligogonus na reserva de Chaparri em Lambayeque (Retirado de Ostalaza, 2014)

\section{Espécie Armatocereus procerus}

Galán de Mera et al (2012) associam fortemente esta espécie ao Haageocereus versicolor, uma vez que coabitam em comunidades de clima árido no vale de Jequetepeque, a cerca de 800 metros de altitude vale acima. Como dito acima, seria virtualmente indistinguível nas representações mochica da espécie oligogonus. Portanto mantém-se como candidato no exemplo. 


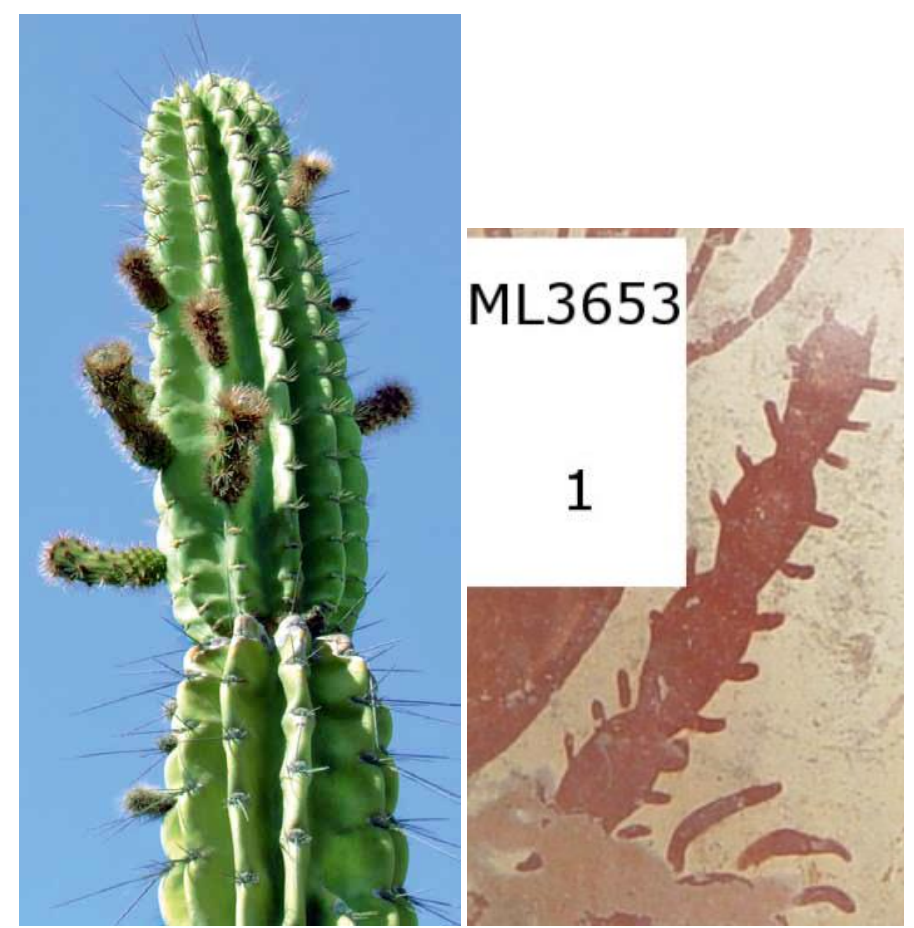

(FIGURA IV.II.II.l1 e IV.II.II.m1) Armatocereus Procerus (Retirado de Ostalaza, 2011). Ao lado, raro exemplo de cacto colunar segmentado classificado como CT5 (Cortesia Museu Larco)

Gênero Trichocereus

Espécie Trichocereus Pachanoi sin. Echinopis pachanoi

O Trichocereus ou Echinopis pachanoi (os nomes são sinônimos taxonômicos) é mais conhecido por sua alcunha popular "Cacto de San Pedro". A planta possui uma substância conhecida como mescalina (trimetoxi-feniletilamina), um alcaloide alucinógeno em quantidades ainda maiores do que o peyote (Lophophora williamsii) utilizado no méxico (Carod-Artal e Vázquez-Cabrera 2006)

Evidências de uso ritual do San Pedro são muito antigas e foram encontrados pedações secos da planta em altar cerimonial em Caral (3000 -2.500 a.c) Chavin de Huantar (1.200 a.c) (Soares, 2015: 147). Ostalaza (2014:54) identifica o T. pachanoi na cerâmica moche em representações que, como veremos adiante, classificamos como Cactos T2. Não obstante, alguns espécimes jovens podem ter ramificações basais (figura V.II.II.r1), adquirindo uma forma mais próxima do tipo 1B. Entretanto a atual distribuição dessa espécie não condiz exatamente com as zonas de habitação Moche. Apesar de atualmente ser encontrado nos departamentos de Trujillo e Lambayeque, o T. Pachanoi segundo o próprio Ostalaza (2013) habita regiões que estão entre 2 mil e 3.300 mil metros, altitude não atingida por nenhuma loma costeira da região. Ademais, o autor aponta a ocorrência natural do Cacto em Huancabamba (Departamento de Piura) e 
Quebrada Santa Cruz (Departamento de Áncash). Não obstante, há indícios de uso do San Pedro pelos mochica e sua representação associada a xamãs na cerâmica escultórica parece bastante clara.
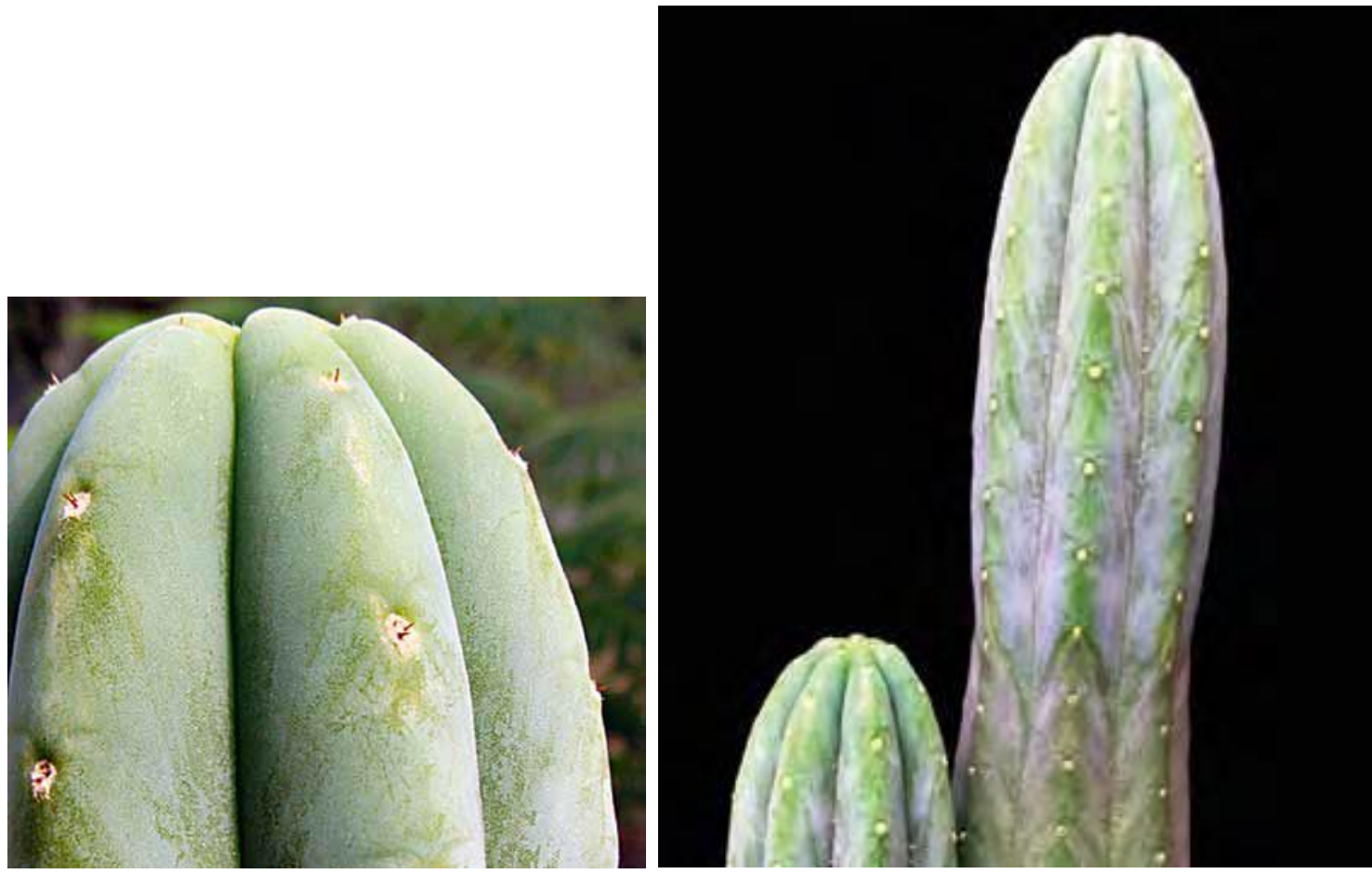

(FIGURA IV.II.II.n1 e IV.II.II.o1) Detalhe de T. Pachanoi evidenciando seus minúsculos espinhos e sulcos profundos. Ao lado uma visão um pouco mais abrangente do cacto (Retirado de Ostalaza, 2011)

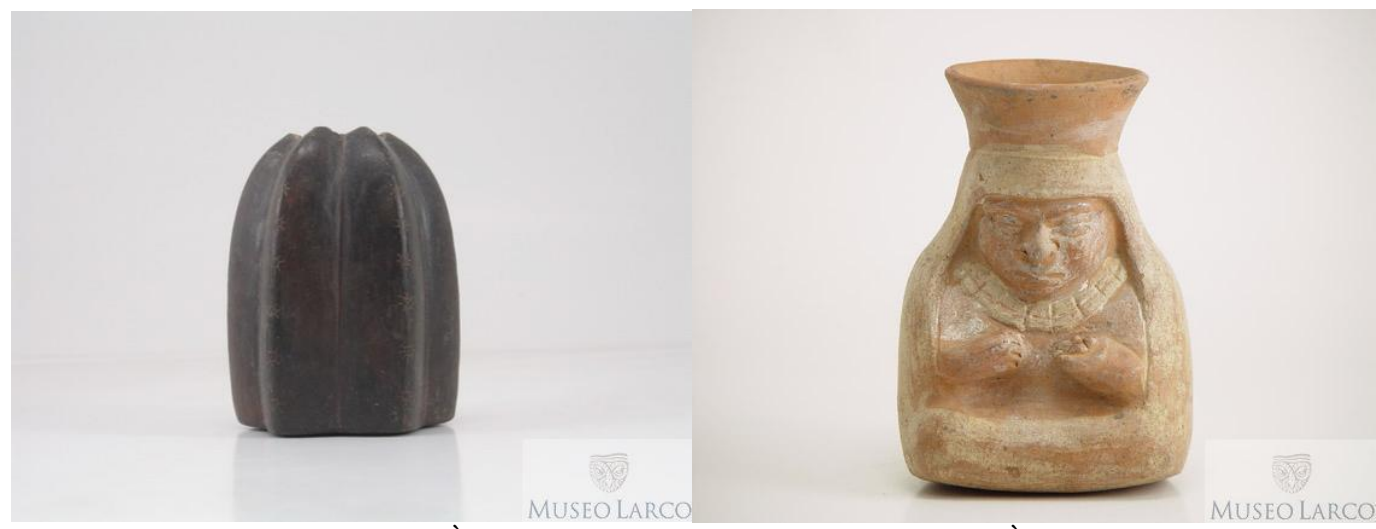

(FIGURA IV.II.II.p1 e IV.II.II.q1) À esquerda T. pachanoi escultulturado. À direita xamã segura o cacto (Cortesia Museo Larco) 


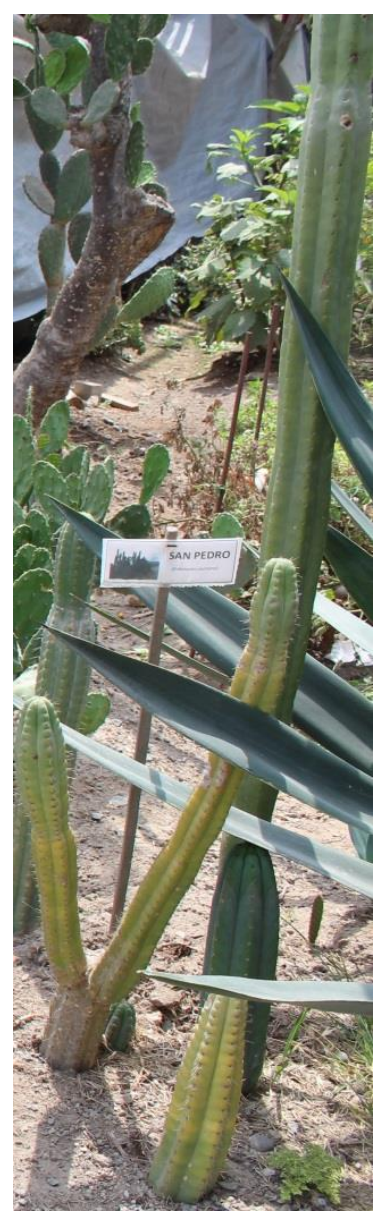

(FIGURA V.II.II.r1) San Pedros costumam ser unicolunares, mas alguns indivídos possuem ramificações.(Foto Diego Mañas)

\section{IV.III-Bosques, regiões desérticas e plantas xerófitas: árvores e arbustos}

Ocasionalmente observamos as representações de árvores e arbustos na cerâmica pictórica mochica. São aparições pouco frequentes, mas que provavelmente têm um alto teor significativo uma vez que aparecem de forma específica. Plantas arbustivas são comuns tanto na base das lomas quanto em suas partes mais altas além das margens dos rios e bosques secos. As consideradas xerófitas, isto é, adaptadas a climas áridos, podem ser encontradas também em zonas desérticas de clima punitivo demais para os demais vegetais. Acreditamos que árvores e arbusto representadas na cerâmica mochica são oriundas de não mais do que uma ou duas famílias de xerófitas muito bem adaptadas e abundantes nas regiões de antiga ocupação mochica. Por conta dessa versatilidade não é possível ter certeza se a representação desses arbustos indique necessariamente as zonas de bosque, de lomas ou desérticas. Todavia, como veremos no próximo capítulo, acreditamos ser mais provável que essas plantas sejam indicadores de bosques secos ou 
bosques ribeirinhos.

A família mais provável de estar sendo representada é a das fabaceas, sendo provavelmente as duas espécies de algarrobo (Prosopis pallida) e (Prosopis jutiflora), vulgo algarrobo macho, e o huarango (Acácia huarango), todas comuns na região e praticamente impossíveis de serem diferenciadas na cerâmica pictórica. A folhagem característica e as favas das três espécies são bastante parecidas e confundidas mesmo pela população local. Favas e sementes dos algarrobos também aparecem fortemente associadas à iguanas que se alimentam quando estes caem no chão abaixo da copa das árvores. Todavia como os vasos têm pouca variação, sempre apresentam a iguana rodeada por favas ou esferas, presumivelmente as sementes, os deixamos de fora da contabilidade principal uma vez que o objetivo desta era buscar variações significativas.

Há ainda a representação de arbustos que oferecem sinais morfológicos insuficientes para serem classificados assertivamente como algarrobos ou huarangos. Todavia, a pintura de suas folhagens é bastante semelhante à dos algarrobos ou huarangos. Nos arbustos com folhagem mais arredondada levantamos a possibilidade "Sapote" ou Capparis scabrida. Assim como os algarrobos e huarangos, o sapote é muito resistente ao clima árido e costuma formar ecossistemas de bosques combinados referidos como "zapotal-algarrobal" (Hocquenghem, 1989: 40). Por fim, em raras oportunidades aparecem árvores de Ulluchu que no nosso esquema classificatório entraram como "Ulluchu", juntamente com os frutos, muito mais comuns.

Família fabaceae

Gênero Prosopis

Espécie Prosopis juliflora, Espécie Prosopis pallida

O Algarrobo pode ser a denominação popular da prosopis pallida, prosopis juliflora. De acordo com Landeras et, al (2005) a Prosopis juliflora é nada menos que a espécie mais bem sucedida nas regiões áridas e semiáridas da américa do sul. No levantamento realizado por Galvéz et. Al (2006), as duas espécies de "algarrobo" assim como o sapote foram encontradas em uma área de deserto superárido tropical na região do deserto de Sechura, no departamento de Piura, o que testemunha a resistência e versatilidade dessas plantas. Sua adaptação ao clima árido é tão grande que podem resistir por décadas sem chuvas (Hocquenghem, 2002) e suas raízes podem descer a até 
25 metros abaixo do solo em busca de um lençol freático (Dias, 1995:65)

Tem uma função estabilizadora microclimática muito importante também por captar e conservar a umidade e uma função ecológica axial por colonizarem facilmente climas áridos e semiáridos e terem uma alta produtividade de sementes consumidas pela fauna local, incluindo os seres humanos. De acordo com Hocqueghem (2002:43) o algarrobo predomina ao lado do sapote (capparis scabrida) nos bosques secos em altitudes abaixo de 500 metros, mesmo estes dividem espaço com olmos, unha de gato, huarango e palo seco.

Ambas as espécies de prosopis coexistem nas regiões de antiga ocupação mochica sendo a prosopis pallida predominante nos vales de Chicama e Moche e a $P$. juliflora predominante de Lambayeque para cima. São espécies muito parecidas sendo a P. Pallida um pouco menor, chegando a 18 metros enquanto com arbustos de 3 a 4 metros enquanto a P. juliflora chega a 20 metros com arbustos de 3 a 6 metros. As folhas de P. pallida são mais numerosas por espinha, porém menores do que as da $\mathrm{p}$. juliflora (Díaz, 1995: 49-52). Dito isso, reforçamos que seria impossível discerni-las na cerâmica pictórica.

Os nativos da costa norte utilizavam sua madeira dura para a construção e para fazer um tipo de carvão mais eficaz (Shimada, 2013) essencial para a cozinha, cerâmica e metalurgia, de modo que era uma planta chave para a ecologia e economia da costa norte. Troncos de algarrobo presumivelmente aparecem na cerâmica pictórica mochica sustentando templos e tecelarias (Golte, 2009: 101; 119).Suas folhas e frutos serviram de alimento para o gado caprino colonial (Torres, 2016) e para os rebanhos de Lhamas dos mochica. Para Hocqueghem (2002: 46) no período mochica há uma retrocesso agudo dos bosques à margens dos rios devido a necessidade de espaço para agricultura e gado e uso de lenha. 


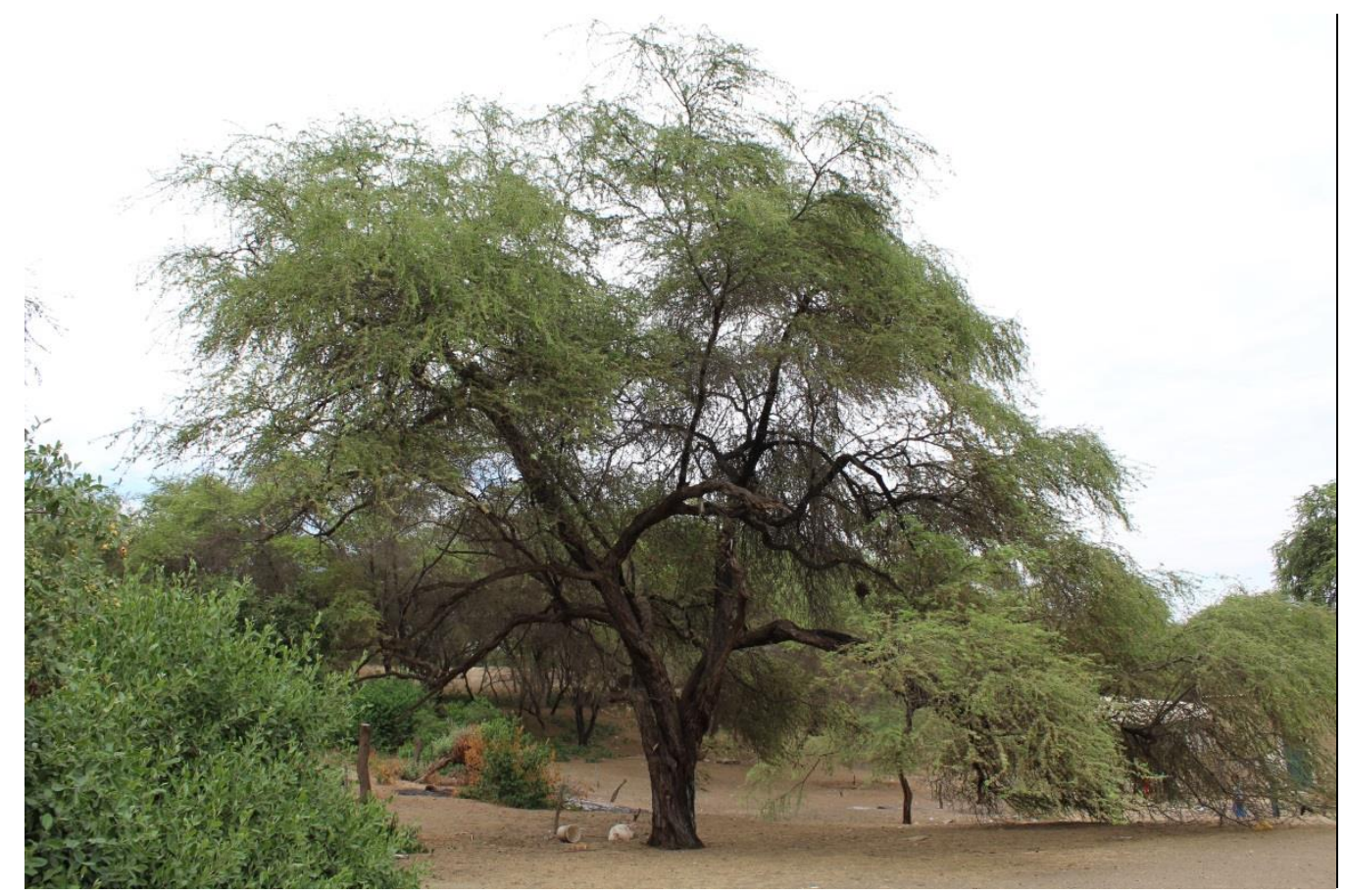

(FIGURA IV.III.a) Exemplar de algarrobo (Foto Diego Mañas)

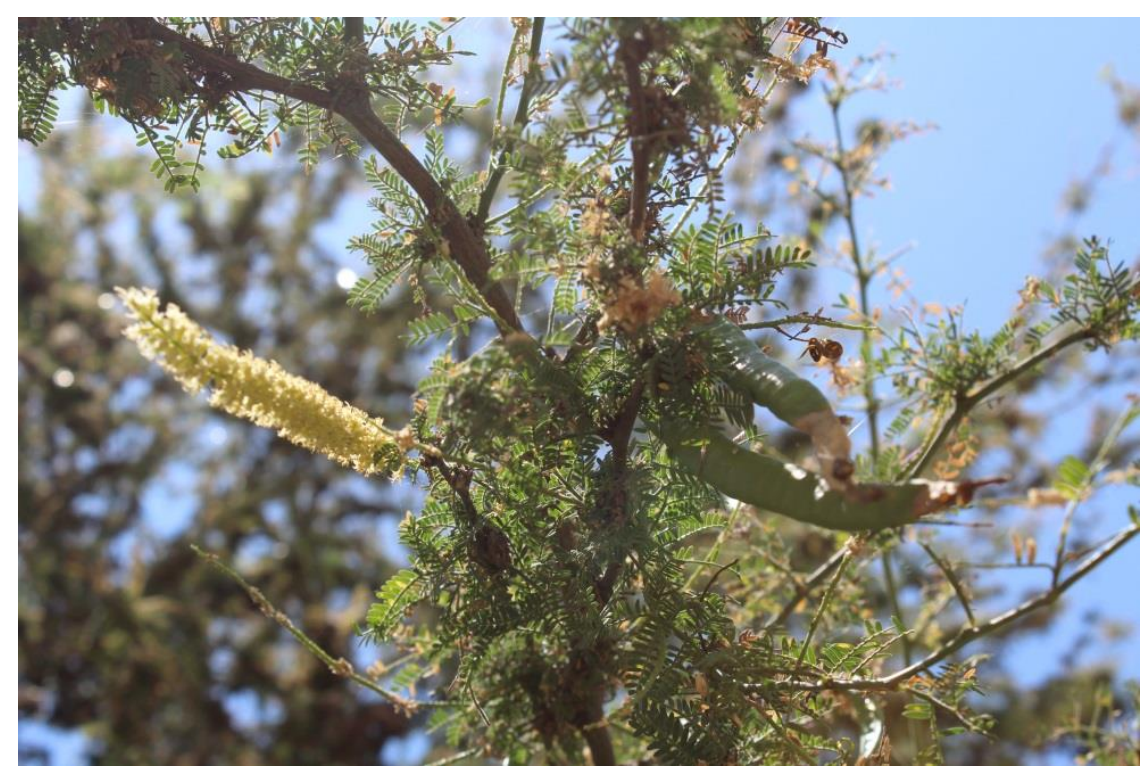

(FIGURA IV.III.b)Detalhe de flor e fava do algarrobo (foto Diego Mañas) 


\section{Espécie Acacia Huarango sin. Acacia macracantha}

Popularmente conhecida por Faique, cuja raíz mochica significa "espinho" ou huarango. Segundo Herrera (2004) o nome do huarango em quéchua é Taccu que se traduz apenas por "a árvore", algo muito indicativo de sua importância para os andinos da serra. O etnobiólogo Diego Mañas em comunicação oral aponta que atualmente a madeira do faique é bastante utilizada na construção de embarcações por ser resistente e mais leve do que a madeira do algarrobo. Ao mesmo tempo não é muito apreciado como lenha por conta da fumaça excessiva que sua queima libera. Sendo também uma fabácea, se parece muito com o algarrobo, com exceção de sua profusão de espinhos pelos galhos.

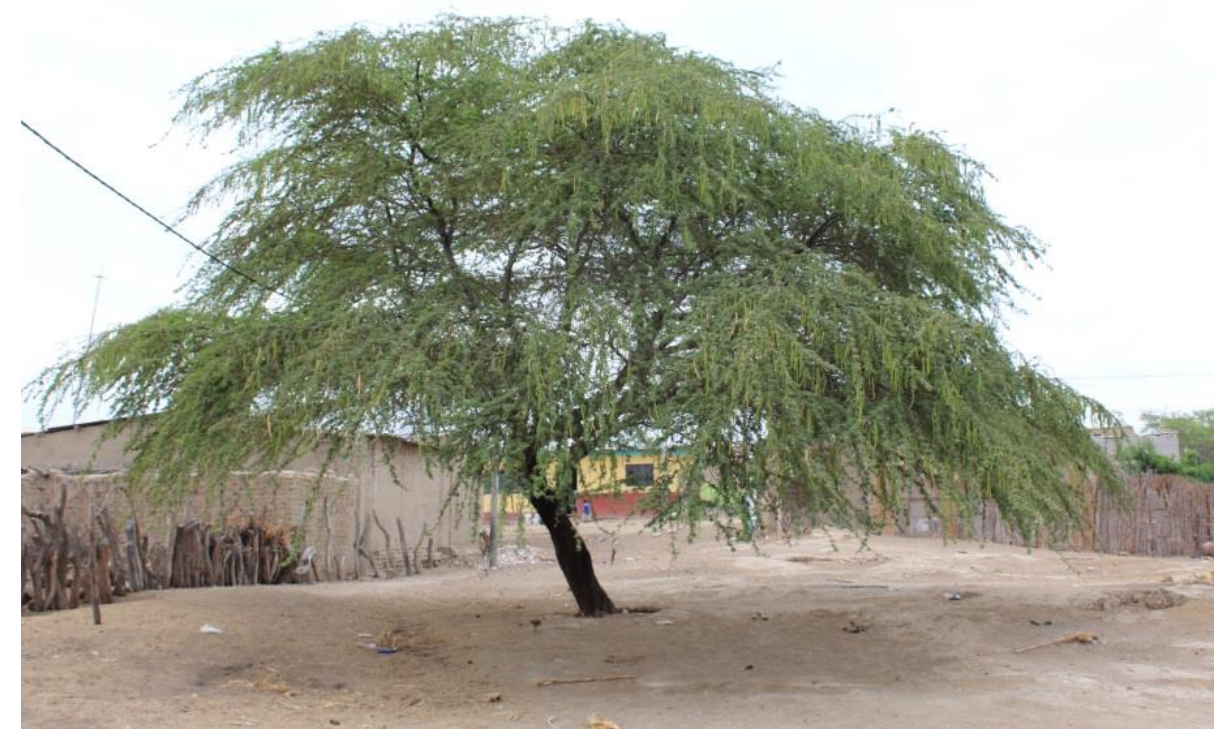

(FIGURA IV.III.c) Exemplar de faique (foto Diego Mañas) 


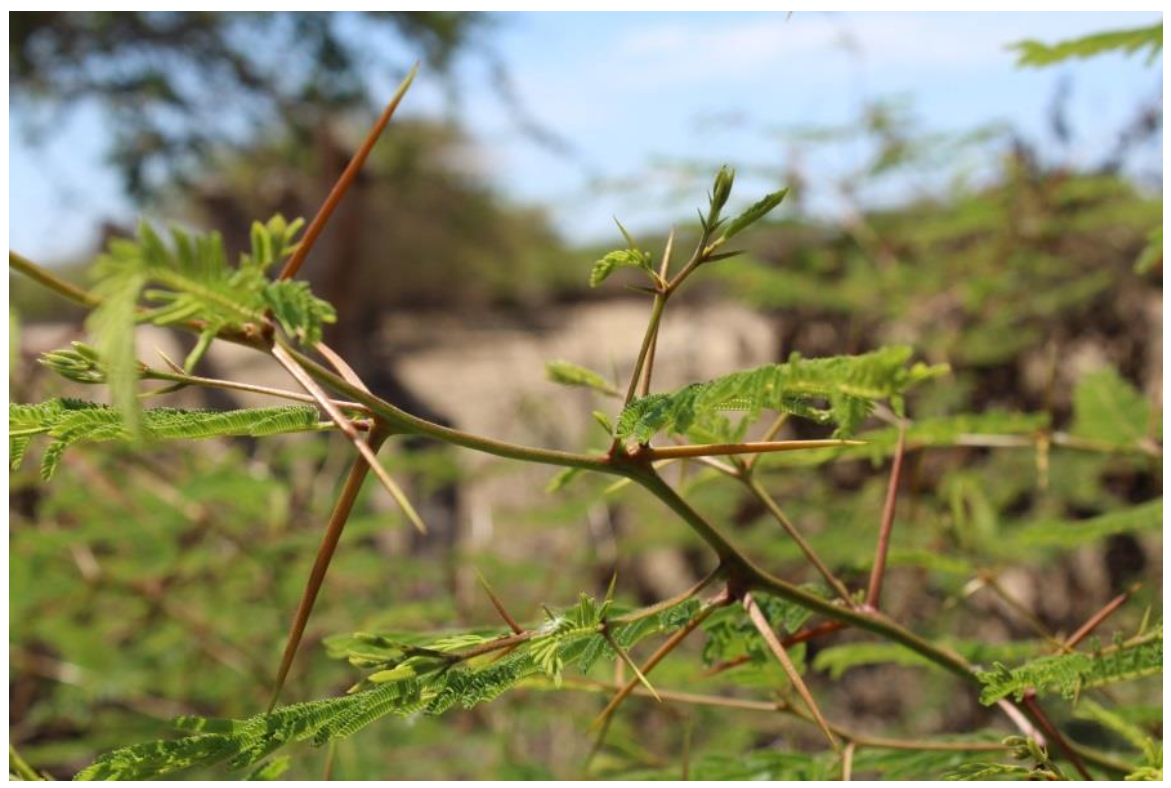

(FIGURA IV.III.d) Detalhe dos espinhos do faique (Foto Diego Mañas)

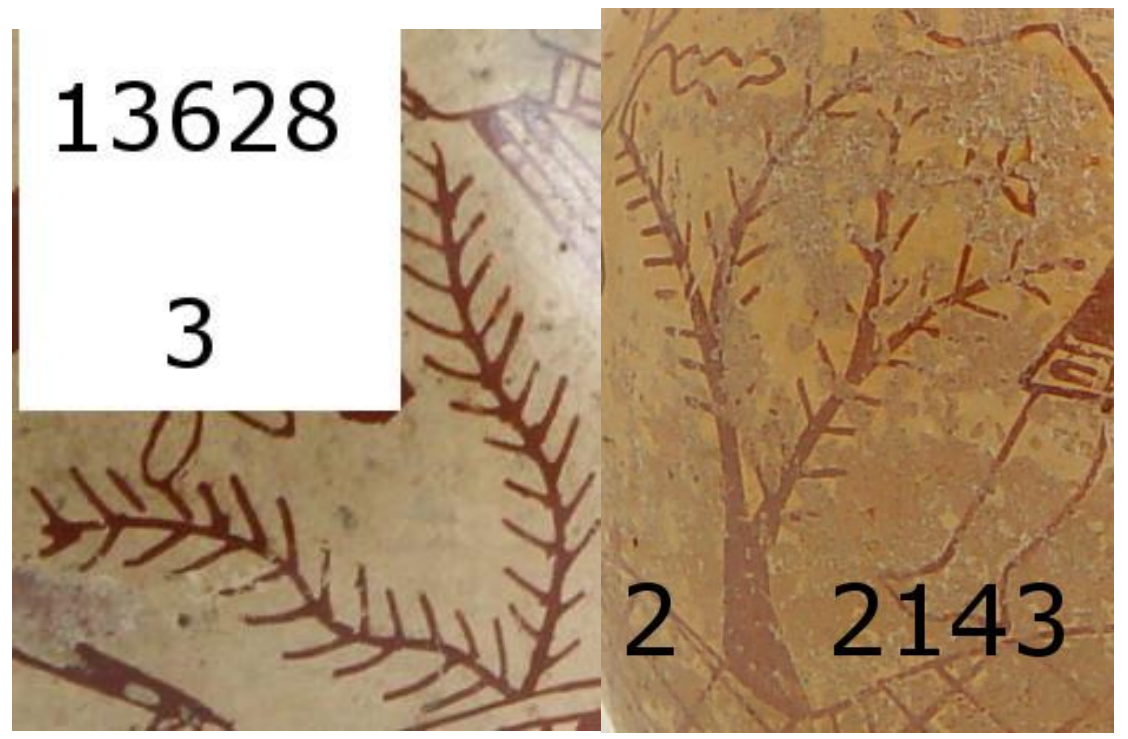

(FIGURA IV.III.e e IV.III.f) Arbusto em cena de cerâmica mochica com estrutura de espinhos ou folhagem pequena e fina como dos faiques e algarrobos. Na figura da direita podemos observar as favas típicas das fabáceas.

\section{Gênero Capparaceae}

\section{Espécie capparis scabrida}

O sapote, como é conhecido localmente a c. scabrida, assim como o algarrobo e o huarango é principalmente utilizada por sua madeira. Sendo de corte fácil e grande durabilidade Sua queima tem uma eficácia similar à do algarrobo e vestígios arqueológicos além de experimentos organizados por Shimada et. Al, 1994 indicaram que era tão utilizado quanto o algarrobo nos fornos para a queima de cerâmica (Rodrigues, 2007: 274). Apesar de ter pouco valor nutritivo é consumido pela raposa 
local do deserto e diversas aves da região, que dispersam suas sementes. Pode chegar a 9 metros de altura mas nos exemplos de cerâmica pictórica analisados aparece principalmente como arbusto. Podemos diferenciá-lo das fabaceas a partir de suas folhas, maiores, mais largas e ovais, em contraste com as folhas pequenas e finas das fabaceas. É bastante comum no sopé do Cerro Campana e em regiões áridas da costa norte em geral.

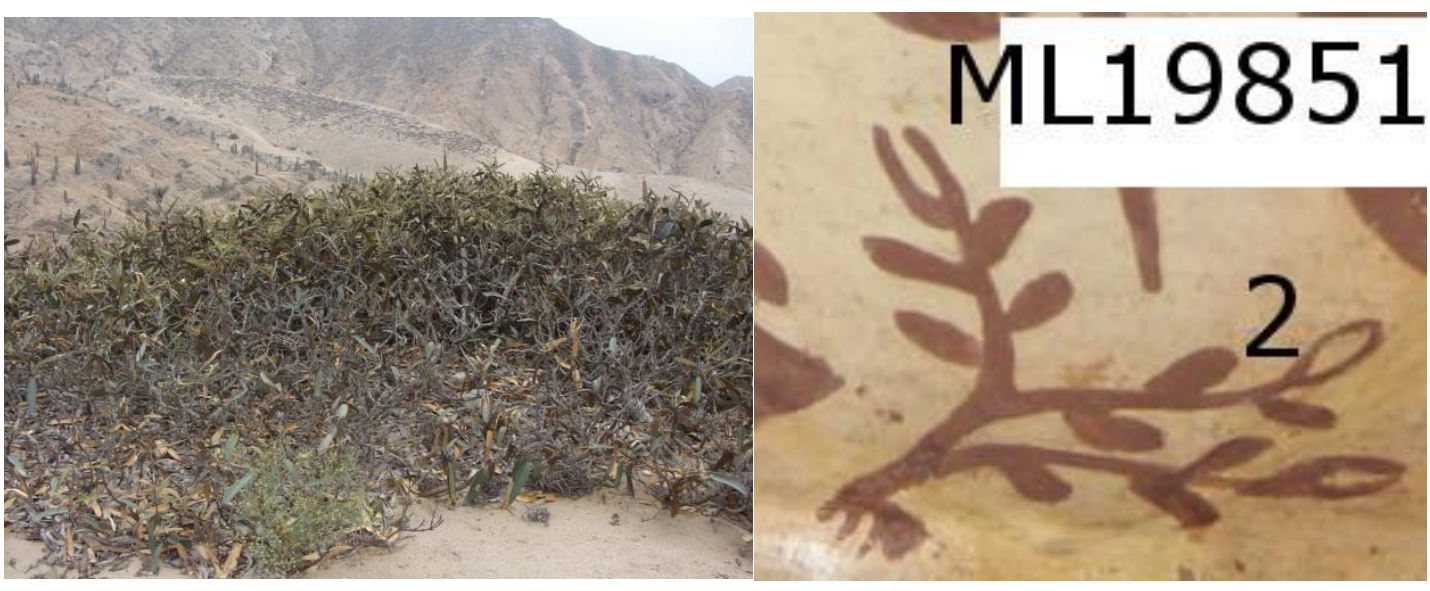

(FIGURA IV.III.g e IV.III.h) Exemplar de Sapote crescendo em morro de areia no sopé do Cerro Campana. (Foto do autor) Ao lado um raro arbusto com folhagem larga. (Cortesia Museo Larco)

\section{Ulluchu}

O Ulluchu é uma planta que aparece de forma recorrente na cerâmica Moche, tanto na pictórica quanto na escultórica. Ela aparece tanto como fruto em formato aberto semi-circular, com ranhuras no corpo, quanto como uma árvore carregada de frutos. Uma de suas associações mais comuns é com imagens de macacos que o colhem das árvores, mas suas associações são diversas, aparecendo "em todo aspecto da arte Moche da fase II à fase V. Ainda segundo a autora, mais de 50\% dos cintos usados pelos personagens das pinturas de linha fina são decorados com ulluchus (Mcclelland, 2008:43). Além dos cintos também encontramos ulluchus como toucados, sendo segurados a mão, flutuantes na obra ou dentro de cálices (Mcclelland, 2008:43). Golte (2009:66) associa a planta com a parte masculina e úmida do mundo de abaixo (hurin), essencialmente feminino. 


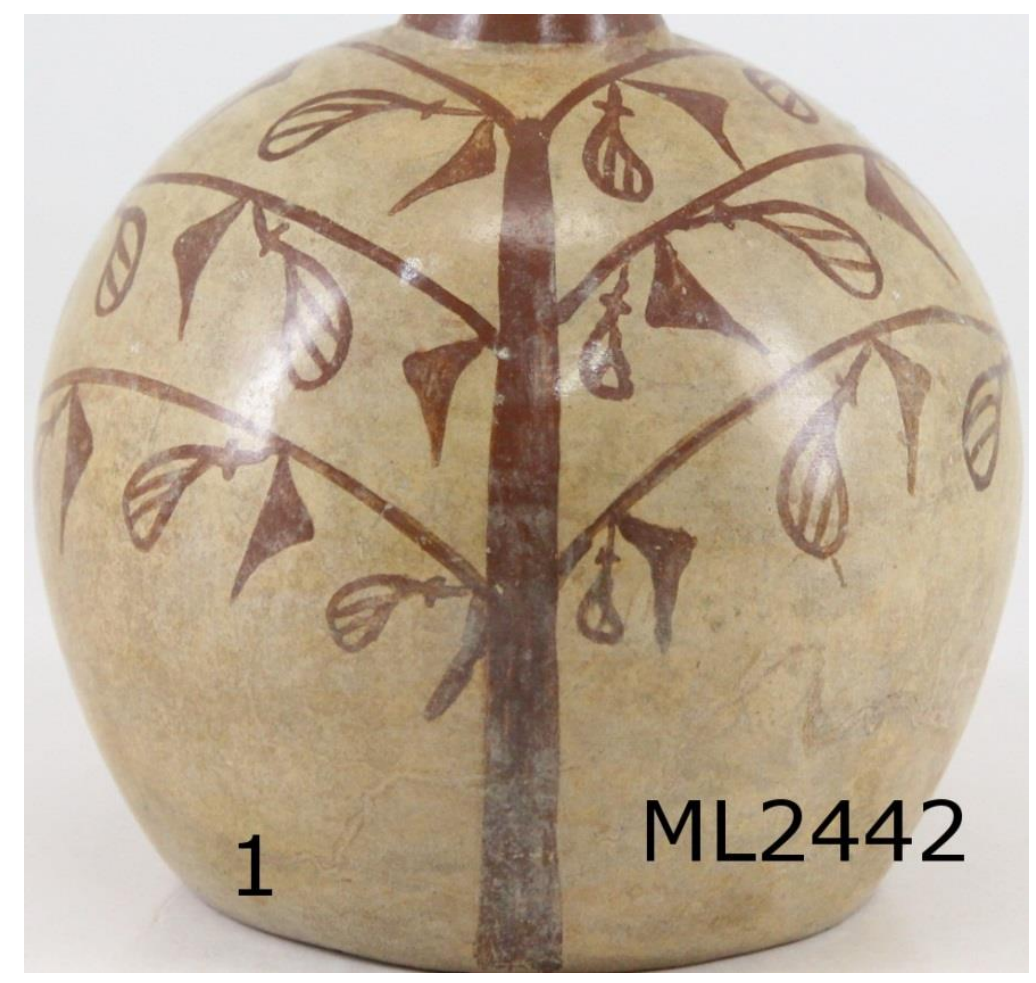

(FIGURA IV.III.i) Árvore de Ulluchu com frutos (Cortesia Museu Larco)

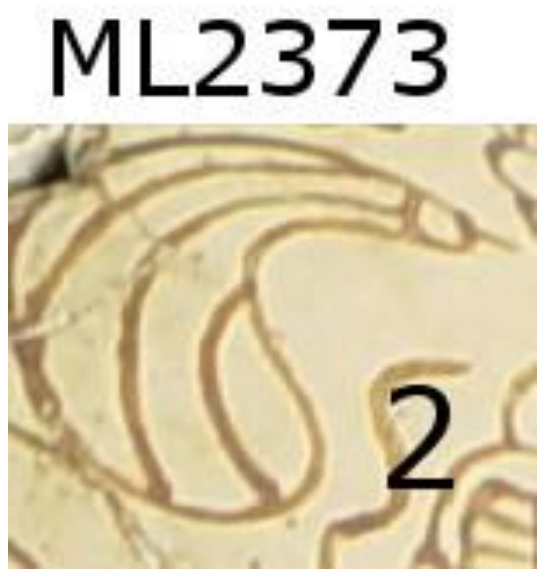

(FIGURA IV.III.j) Fruto do Ulluchu (cortesia Museu Larco)

Mesmo conspícua, a identidade botânica da fruta é disputada. Rafael Larco Hoyle nomeou a planta de Ulluchu partindo das identificações dos trabalhadores de origem muchic de sua fazenda (Golte, 2009:63), porém Bussman \& Sharon (2009:2) afirmam que não há evidências desta palavra no que se conhece de muchic ou yunga. Larco ainda propôs que o Ulluchu seria um tipo de representação de feijões (Phaseolus sp.), hipótese descartada por Donna MccLelland, que através da análise morfológica também descartou outras possibilidades como pepino (Solanum muricatum) e pimenta (Capsicum annum) (Mcclelland, 2008:43).

A hipótese de o ulluchu ser uma planta mitológica sem correspondente natural 
parecia cada vez mais provável quando, em 1987, o professor Henry Wassén da Universidade de Gotemburgo publicou um artigo afirmando se tratar de um tipo de mamão papaya da espécie Carica Candicans, cuja enzima papaína serviria de anticoagulante, possivelmente utilizável nos rituais de sacrifício (Mcclelland, 2008:58). Mccllelland todavia também descartou essa possibilidade, uma vez que, ao contrário dos mamoeiros, cujos frutos surgem do caule, nas representações da árvore de ulluchu os frutos estão pendurados nos galhos. Porém, de acordo com Bussman \& Sharon (2009), C. Candicans é um dos poucos tipos de papaia cujos frutos de crescem em galhos e cujas folhas de fato se parecem com as da iconografia. Logo, a C. candicans era um candidato promissor.

O impasse, entretanto, foi quebrado no fim dos anos 80 pelo arqueólogo Walter Alva ao anunciar que havia descoberto ulluchus escavando Huaca Rajada em Sipán. Em 1997 foi a vez de Cristopher Donnan encontrar os frutos escavando Dos Cabezas (Mcclelland, 2008:61). As frutas, embora ressecadas, eram idênticas às da iconografia, embora bem menores do que o esperado, variando de 1,5 a $5 \mathrm{~cm}$ (Bussman \& Sharon, 2009). A pergunta agora não era mais se o ulluchu seria uma planta mítica ou c. candicans, mas qual seria a planta encontrada nas escavações.

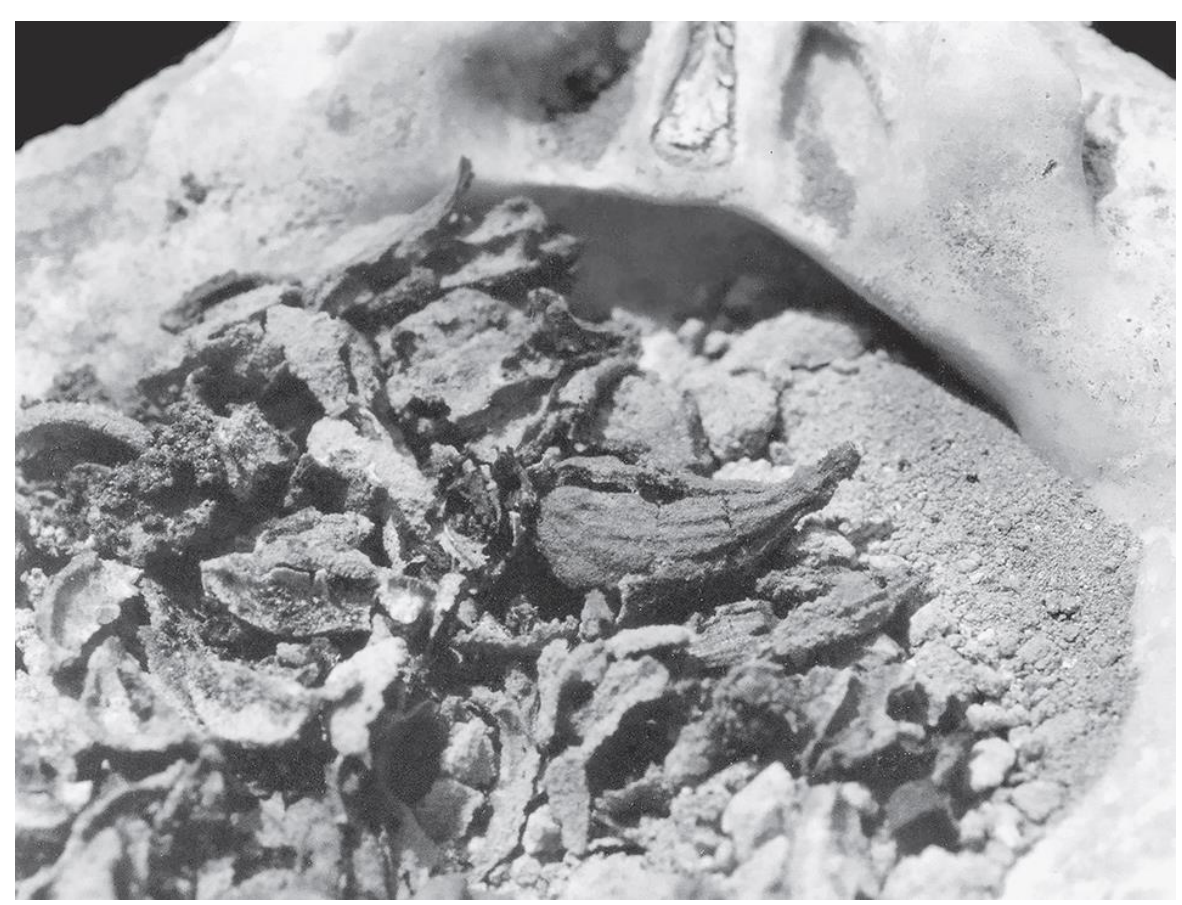

(FIGURA IV.III.k) Ulluchus ressecados em contexto escavado em Sipán (retirado de Mcllellan, 2008. Foto de Cristopher Donnan) 
Uma possível resposta veio com Bussman \& Sharon (2009) em um artigo que propõe o ulluchu como uma planta do gênero Guarea da família Meliaceae. Segundo os autores, as folhas das árvores desse gênero são semelhantes às encontradas nas representações mochica. Além disso, seus frutos de forma geral também são compatíveis com a morfologia das ilustrações e dos exemplares ressecados encontrados em contextos arqueológicos. De fato, a forte associação com macacos, que nas cenas aparecem colhendo os frutos da árvore, sugere uma origem selvática e, apesar de não ocorrerem na costa desértica do Peru, o gênero é abundante e diverso na floresta amazônica.

Os autores ainda afirmam que o consumo das sementes das plantas do gênero teria efeitos alucinógenos se inalado e, se ingerido, o fruto produziria um forte efeito vaso dilatador. Apoiados estes dois fatos Bussman \& Sharon interpretam os cálices dentro dos quais o fruto é muitas vezes representado como pilões onde a semente seria triturada antes de inalada. $\mathrm{O}$ efeito vaso dilatador da planta ingerida poderia explicar, por sua vez, os pênis eretos que apresentam os supliciados nas cenas de sacrifício.

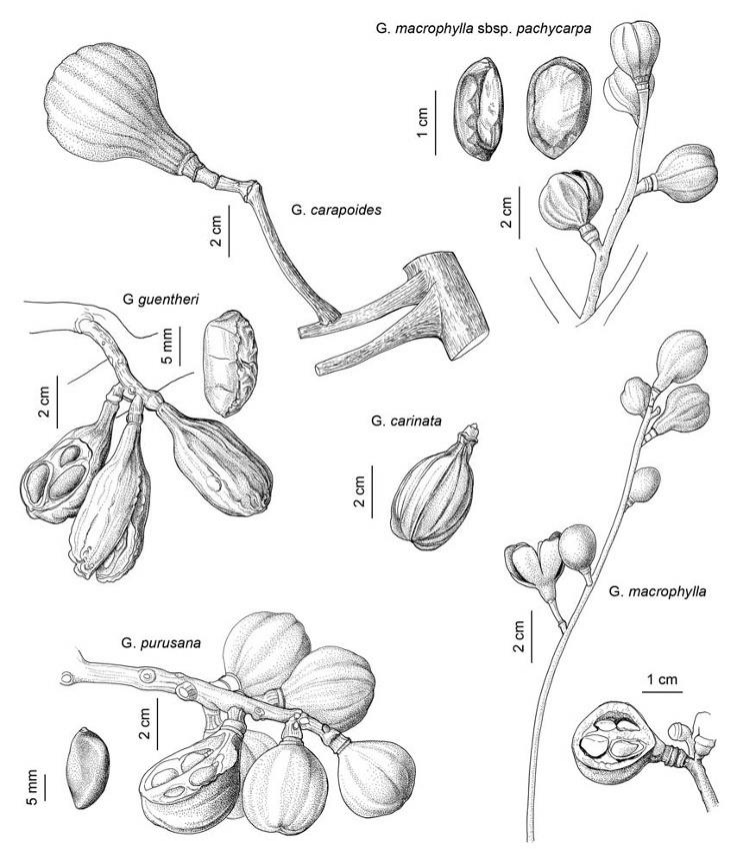

(FIGURA IV.III.l) Frutos de várias espécies do gênero Guarea (retirado de Bussman \& Sharon, 2009) 


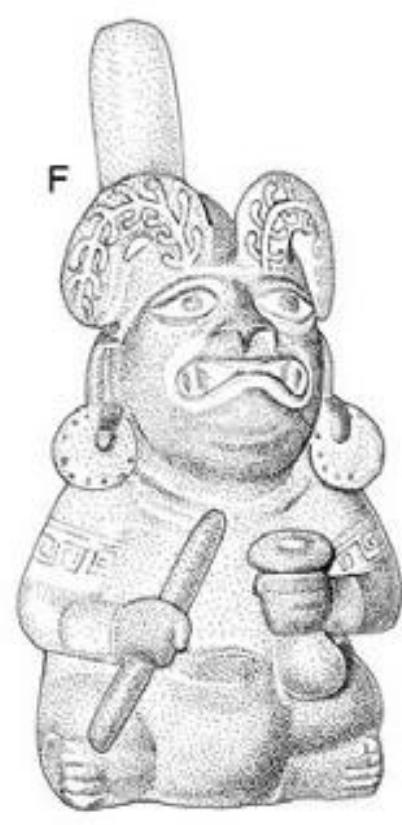

(FIGURA IV.III.m) Cerâmica escultórica mochica com personagem com toucado de ulluchu segurando o que Bussman \& Sharon considera um pilão (retirado de Bussman \& Sharon, 2009) 


\section{CAPÍTULO V - RESULTADOS - II : ANÁLISE ICONOGRÁFICA}

Como foi assinalado no capítulo III, a segunda parte dos resultados tem a função de trazer a análise iconográfica agregando os dados do estudo ambiental. Também já citados no capítulo foram as divisões em Macro grupos e grupos e método utilizado. Além de serem discutdas as tendências e significados dos personagens, cenas grupos e marcogrupos no final da seção traremos gáficos de apoio apontando grandes tendências de grupo.

\section{V.I -MACRO GRUPO SINGULARES: Mundo horroroso, Panóplia}

\section{MUNDO HORROROSO (1)}

A peça 7275 é a única classificada pelo museu como "Mundo Horroroso" com flora pictografada. São vasos que têm um formato geral "disforme" no qual elementos díspares se mesclam sem uma ordem clara. Golte se utiliza deste termo e classifica as peças do mundo horroroso como pertencentes da "ordem surrealista" (Golte, 2009:131). São peças sempre ligadas ao mundo de abaixo e muito frequentemente em forma de tuberculos com fortes associações a leões marinhos e ao período úmido (ibid:131-135).

Soares pensa que a associação com o mundo de abaixo deve ser considerada sob a chave da transformação e geração. A associação de cadáveres e tubérculos a este mundo nos lembra de que no mundo de abaixo nada é gerado por si, mas do encontro entre âmbitos diferentes (Soares, 2015:244).

Benson (2012:36) utiliza-se do termo "collage" aplicado por Donnan para descrever este tipo de vasilha. Sem adentrar muito específicamente na natureza das vasilhas, a autora considera três possíveis razões para a mescla dos elementos no vaso: pode estar relacionada à vida essencial dos objetos, ao mundo visto a partir das lentes de uma visão distorcida pelo uso de drogas alucinógenas ou pode espelhar o mundo distorcido por uma viagem subaquática para o infra-mundo.

Flora e peças:

A peça em específico (Figura V.I.a) mostra um homem com pintura facial segurando um artefato. Seu corpo em formato não específico (talvez montanha?) parece 
ser suporte para o crescimento de flores e o que lembra cactos tipo 2 opuntióides em um estilo que aparece em outra peça (ML4001_Ave Guerreira), surgindo sobre possíveis montículos de areia. Além disso vemos o que parecem ser flores pelo corpo da obra. Também vemos formações afinadas que podem ser plantas mas estas são indeterminadas demais para inlcuirmos como flora. Os cactos tipo 2 relacionam-se mais frequentemente com a espécie N. Raimondia e no caso dos opuntioides pode-se tratar também das O. Quitensis. Todavia, toda a flora classificada nessa peça tem uma morfologia e contexto diferentes do "normal". As flores, que em todos os outros casos, salvo uma excessão, aparecem em contexto aquático aparecem aqui no corpo do vaso sem outra associações com lagos. Pelo contrário, a serpente-felino ascendente costuma estar associada a peças representando zonas elevadas.

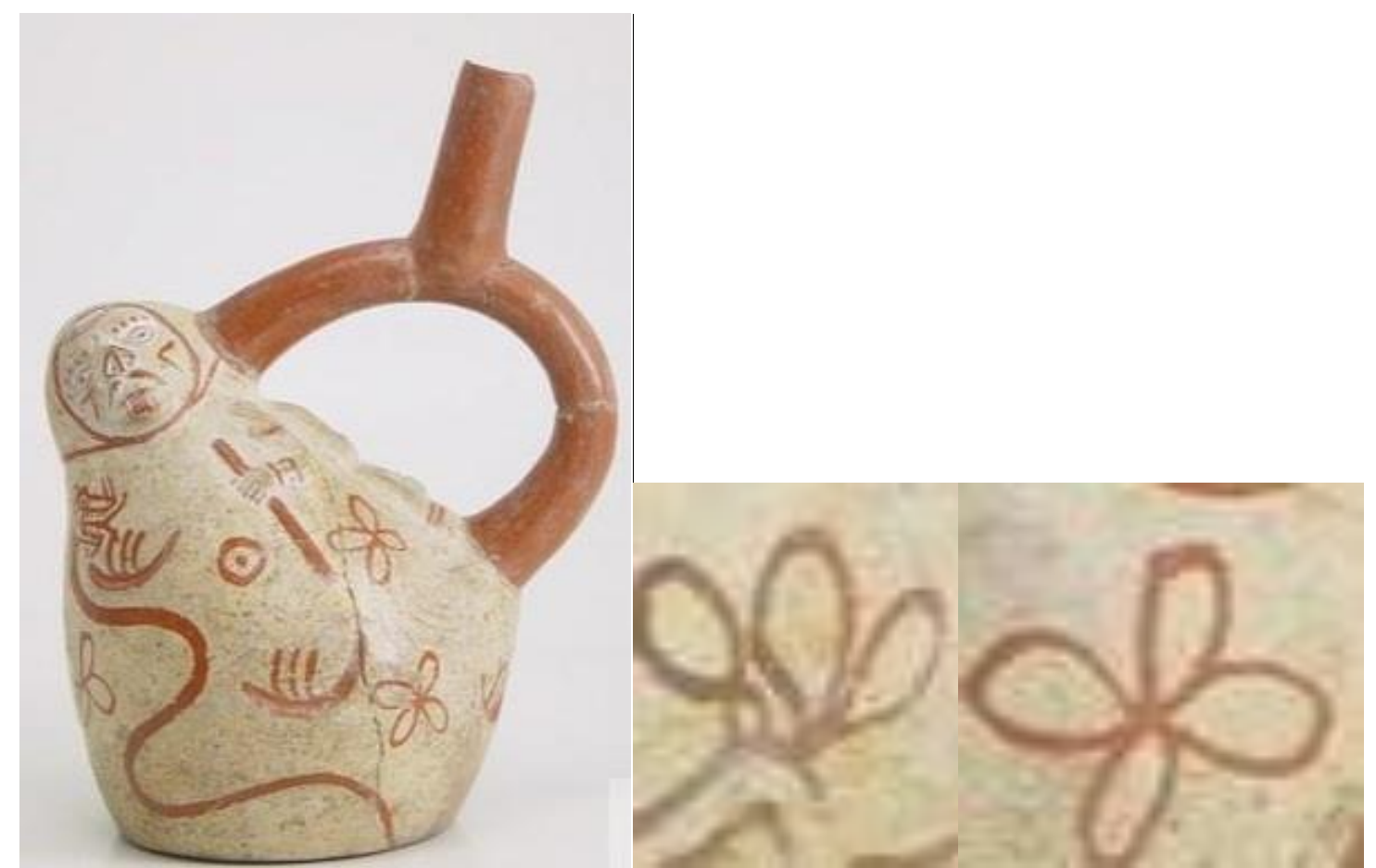

(FIGURA V.I.a) Peça ML7275 com exemplares da flora em evidência à direita: cacto tipo 2 opuntioide e flor) (Cortesia Museu Larco)

Ficha Simplificada

\begin{tabular}{|l|l|l|l|l|l|l|}
\hline PEÇA & CENA & TIPO DE VASO & FASE & CACTO T2 & FLORES & $\begin{array}{l}\text { LOCALIZAÇÃO DA } \\
\text { FLORA }\end{array}$ \\
\hline ML7275 & $\begin{array}{l}\text { MUNDO } \\
\text { HORROROSO }\end{array}$ & $\begin{array}{l}\text { Asa Estribo } \\
\text { lateral escultórico }\end{array}$ & III/IV & 3 & 5 & $\begin{array}{l}\text { FLORES: 3AC-2AB / CT2: } \\
\text { 2AB }\end{array}$ \\
\hline
\end{tabular}

\section{$\underline{\text { PANÓPLIA (3) }}$}


Nesta categoria buscamos agregar o conjunto de armas utilizadas nos combates compostos de escudo, porrete e estólica denominados de Panóplias. Panóplias são muito comuns na cerâmica pictórica mochica, mas neste grupo em epecífico separamos apenas as panóplias que figuram como motivo principal ao lado da flora. Sobre o motivo da Panóplia Benson afirma:

The bundle can be the center of a ritual scene or the only motif on a bottle; many of the fineline bottles that appeared in Late Moche at San José de Moro have a weapons bundle on the spout above the primary design (......) It seems to be a kind of logo for that site in the late period. Indeed, it may be a logo for the Moche. (Benson, 2008:10)

Não temos a origem das peças analisadas neste grupo mas consideramos improvável que se originem de San Jose de Moro devido ao histórico de formação da coleção do Museu Larco. Os vasos são, entretanto, quase certamente todos fase IV.

Cabeças de porrete eram comuns nos tetos de determinados prédios cerimoniais. Há evidências de pavilhões decorados com cabeças de porrete na Huaca de La Luna e Huaca Cao Viejo (Benson, 2008:6). Steve Bourget encontrou porretes de madeira com vestígios de sangue como se o objeto houvesse sido banhado em sangue por diversas vezes (Bourget, 2008) e Hocquenghem aponta que indícios de golpes de porrete foram encontrados em diversos crânios das vítimas sacrificiais escavadas na Huaca de La Luna (Hocquenghem 2008:38).

Em vista dessas evidências Benson, (2008:7) considera que os porretes podem também ser um símbolo para sacrifício. Golte crê na associação dos porretes com o mundo de abaixo, uma vez que o combate visa cativar os guerreiros opositores para depois oferecê-los como sacrifício ao mundo de abaixo e ao céu noturno (Golte, 2009 : 191-233).

Flora e Peças:

Os três vasos analisados são bastante semelhantes, muito provavelmente do mesmo período e os dois últimos possivelmente oriundos do mesmo sítio ou vale. No primeiro ML1863 (Figura V.I.b) o porrete e o escudo estão acompanhados por estruturas indefinidas parecidas com cordas ou panos. Quatro afloramentos de cactos tipo 2 opuntióides sem espinhos e com as raízes à mostra estão bastante evidêetes na 
parte superior do corpo. Estes cactos estão mais próximos morfologicamente com indivíduos jovens de Neoaimondia arequipensis.

O segundo vaso ML1864 (Figura V.I.c) mostra panóplias com porrete, escudo e estólicas. Os porretes tem cabeça zoomorfa, talvez de raposa, e os escudos possuem símbolos, possivelmente de hanan hurin, e as estólicas parecem dentadas. A flora surge exclusivamene de montículos de areia com topo escuro e triangular, provavelmente como símbolo de lomas. Os cactos consistem em quatro afloramentos de cacto tipo 2 , sendo dois com espinhos e frutos e dois lisos. Novamente, este tipo corresponde morfologicamente à $N$. Arequipensis.

Por último temos a peça ML1871 (Figura V.I.d), com a panóplia composta de porrete, escudo e o que parecem ser estólicas. O escudo está decorado com um quadrado, forma mais associada ao mundo de acima. A flora surge de linhas em meia lua e está composta de cactos tipo $1 \mathrm{~B}$ com raízes à mostra. A forma como são apresentados os cactos é peculiar e lembra as representações de totorais. Entretanto os cactos são morfologicamente compativeis aos haageocereus, esposotoa ou neoraimondia.

No geral o padrão de flora associada com as panóplias parecem ser cactos de ambiente árido, principalmente a espécie N.arequipensis. Essa associação (se levarmos em conta os padrões florísticos atuais) possivelmente vem dos sopés das lomas onde ritos como batalha ou sacrifício ritual eram performados.

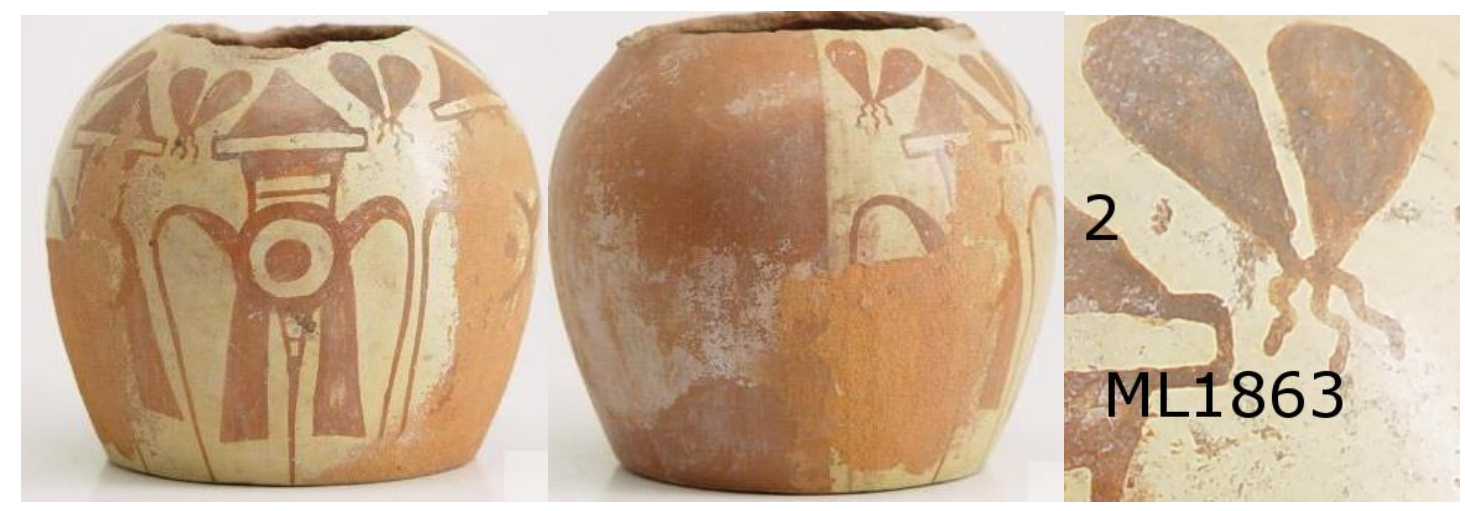

(FIGURA V.I.b) Peça M11863 com cactos 2 com raízes à mostra.( Cortesia Museu Larco) 


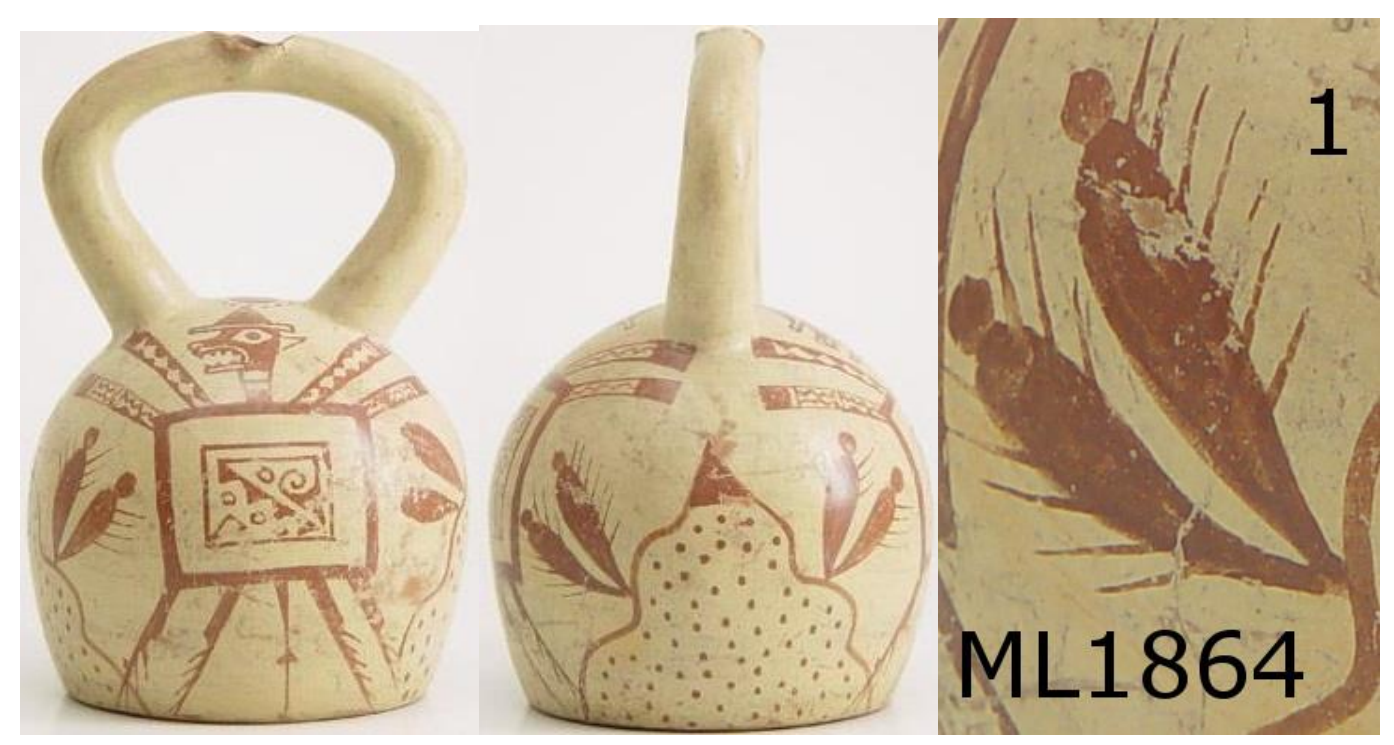

(FIGURA V.I.c) Peça ML1864 com CT2 e Panóplia antropomorfa (Cortesia Museu Larco)

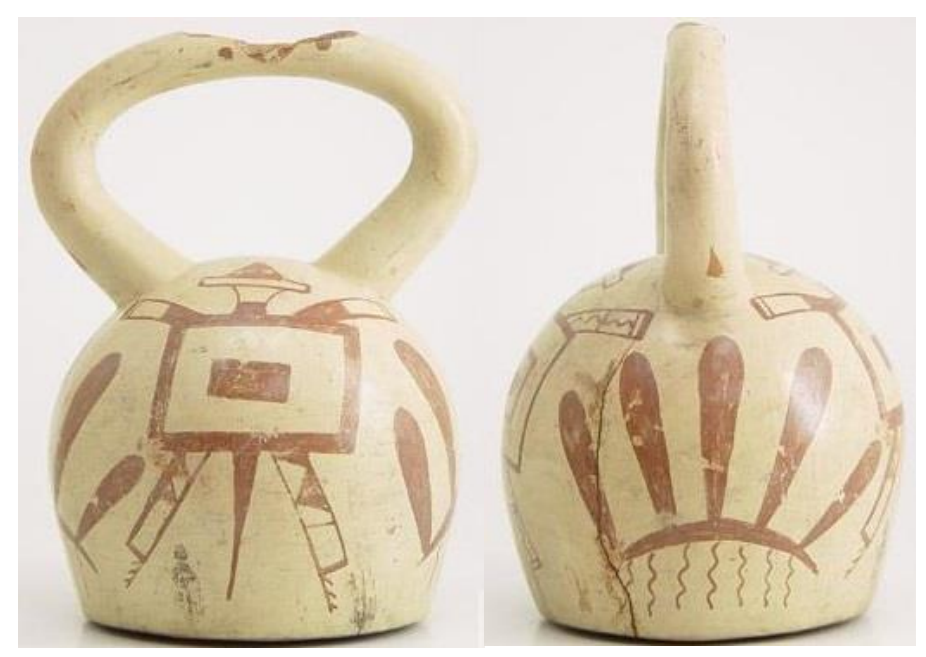

(FIGURA V.I.d) Peça ML1871 com CT2

Ficha simplificada:

\begin{tabular}{|l|l|l|l|l|l|l|l|l|l|}
\hline PEÇA & CENA & $\begin{array}{l}\text { TIPO } \\
\text { DE } \\
\text { VASO }\end{array}$ & FASE & VALE & SítIO & RELAÇão & $\begin{array}{l}\text { CACTO } \\
\text { T1B }\end{array}$ & $\begin{array}{l}\text { CACTO } \\
\text { T2 }\end{array}$ & LOCALIZAÇÃO \\
\hline ML1863 & PANOPLIA & $\begin{array}{l}\text { Asa } \\
\text { Estribo }\end{array}$ & IV & & & & & 4 & CT2: 4 AC \\
\hline ML1864 & PANOPLIA & $\begin{array}{l}\text { Asa } \\
\text { Estribo }\end{array}$ & IV & & & & & 4 & CT2: 4 AC \\
\hline ML1871 & PANOPLIA & $\begin{array}{l}\text { Asa } \\
\text { Estribo }\end{array}$ & IV & & & & 3 & & CT1B: 2AB \\
\hline
\end{tabular}




\section{V.II - MACRO GRUPO RITOS: Badminton, Coca/músico, Sacrifício,, Batalha, Corrida, Ave guerreira, Guerreiro vigilante}

\section{BADMINTON (1)}

O museu Larco classifica a cena da peça ML13660 como "Badminton" seguindo, a nomenclatura fornecida por Kuchter (1955) que, por sua vez, se referia a um jogo com raquetes muito popular na Inglaterra. Nesta cena, guerreiros mochica, alguns paramentados outros apenas com toucados e tapa-rabos, lançam dardos com flores (estas comparadas por Kuchter às petecas utilizadas no Badminton) atadas por cordões. Tanto Hocquenghem (1987) quanto Golte (2009) parecem concordar que as flores utilizadas são flores de "lóuts" (nymphea spp.) enquanto Benson levanta a possibilidade de não serem flores, mas penas (Benson, 2012:98).

Hocquenghem, compara o jogo de Badminton ao rito inca Cituia, descrito pelo cronista peruano do século XVI Guamán Poma de Ayala, no qual guerreiros paramentados, após um banho purificador em agua doce, lançavam flores para o ar utilizando fundas, com o intuito de purificar o ar e se livrarem de enfermidades. (Hocquenghem, 1987:52). Para ela, também os mochica lançavam flores com seus lançadores para a "purificação do ar" e "regeneração do tempo" (ibid:55-61).

Segundo a Hocquenghem, o rito Inca era performado durante o mês de Coya Raymi, no equinócio da primavera, no fim de setembro (ibid: 52). Golte concorda com o posicionamento temporal proposto pela autora (equinócio de setembro) e afirma que o propóstio do rito seria o de proporcionar é época de chuvas (Golte, 2009:172). Ademais:

Assim se compreenderia porque o lançamento de flores de lotus com estólica e seu regresso com para-quedas ao solo para o mundo de cima abre uma comunicação com o mundo de abaixo e, com ele, a úmidade da água (Golte, 2009: 172)

Flora e peças:

Encontramos apenas duas cenas pictóricas com a cerimônica do Badminton no catálogo do Museu Larco e apenas uma delas, a peça ML13660 (figura V.II.a), possuia flora como localizadores. Aqui as flores não estão sendo utilizadas como localizadores, mas como parte do aparato do jogo. Surpreendentemente a flora associada à cena se 
compõe de seis afloramentos de cactos tipo 1B localizados nas alças. Este tipo de cactos estão mais associados a cactos colunares semi-prostrados como o $H$. Pacalensis ou o $H$. Versicolor ou então mais eretos como o E. Melanostelis. Existe uma aparente contradição na associação de um rito aquático a cactos típicos de áreas áridas. É possivel que, seguindo a lógica de análise de Golte, haja um possível tinku (encontro de opostos complementares) entre as plantas e a cerimônia. Em geral, porém, encontramos associações de plantas de clima árido com cenas que provavelmente se passam nas mesmas localizações. Se for assim, teríamos de localizar o rito em uma região árida onde ocorram cactos T1 naturalmente. A quantidade de peças e a falta de evidências complementares, porém, não nos permite afirmar nenhuma hipótese.

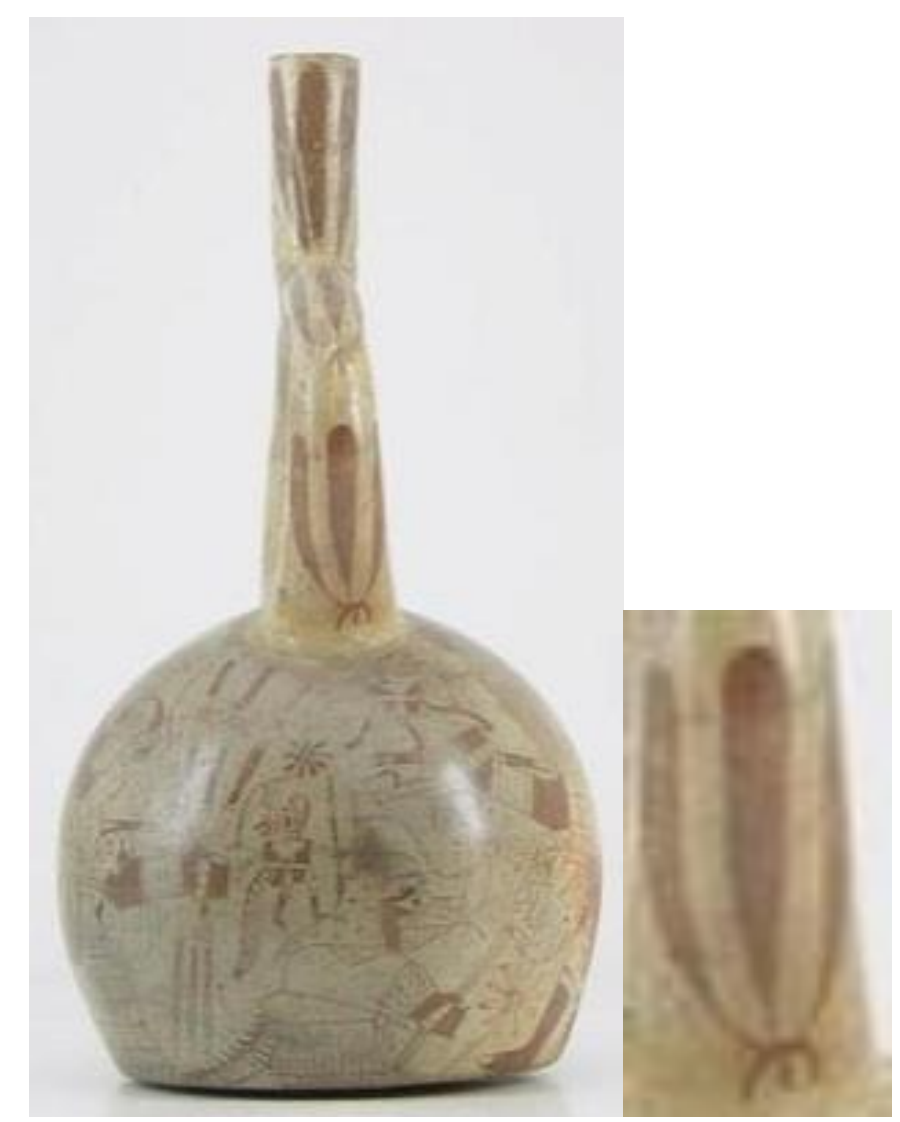

(FIGURA V.II.a)Cerimonia de badminton com flores e cactos CT1B nas alças. À direita detalhe dos cactos (Cortesia Museu Larco)

Ficha simplificada

\begin{tabular}{|l|l|l|l|l|l|}
\hline PEÇA & CENA & $\begin{array}{l}\text { TIPO DE } \\
\text { VASO }\end{array}$ & FASE & CACTO T1B & LOCALIZAÇ̃̃O DA FLORA \\
\hline ML13660 & Badminton & $\begin{array}{l}\text { Gollete Asa } \\
\text { Estribo }\end{array}$ & IV & 6 & CT1B: 6 alças \\
\hline
\end{tabular}




\section{TOMADORES DE COCA/MÚSICO (1)+(1)}

A peça ML4112 (Figura V.II.b)apresenta uma cena de tomadores de coca. Neste tipo de cena homens ou personagens míticos parecem mascar e oferendar a coca, tipicamente sob um céu noturno e a serpene bicéfala, que parece representar a via láctea. Os homens carregam uma chuspa, bolsa que até hoje serve para o transporte de amuletos e folhas de coca (Hochenghem, 1987:110). Hochenghem compara esta cena ao rito inca do Capacocha, no qual eram oferecidos sacrifícios ao deus Viracocha. Para ela, o rito de oferenda da coca servia como um ritual de entronização de forças ocorrido no solstício de inverno, quando se pedia à divindade da Via Lactea a potência necessária para a época de colheitas (ibid:114)

A cena noturna se passa num vaso alça estribo com estilo de pintura típico da fase IV. Golte (2009:93) acha provável o ser com presas suplicante da cena ser a divindade intermediadora.

De fato arqueólogo Santiago Uceda separa os tomadores de coca que acredita serem indivíduos ligados às clases religiosas dos adoradores, representados nas cenas do vaso ML4112 como a divindade intermediadora, os quais cria serem personagens da elite mochica (Uceda, 2008:173). Suas escavações na Huaca de La Luna encontraram uma chuspa em formato felínico, em perfeita concordância com a iconografia, com uma série de itens associados à tumba 18 cujo indíviduo teria a persona fortemente ao ritual, provavelmente como adorador. Uceda ainda levanta a hipótese de uma ligação sequêncial entre as cenas dos tomadores de coca e as de batalha ritual, possivelmente também com ritos de sacrifício (Uceda, 2000:97; 2008: 160).

Além da cena dos tomadores de coca também temos a peça ML12778 que mostra um flautista escultórico sentado sobre o topo do vaso. No centro do corpo da peça há uma linha composta de Cactos T4 envolta a esferas escuras. Abaixo dessa faixa estão representadas pessoas de mãos dadas, porovavelmente em um rito de dança.

Em sua tese de doutorado a arqueóloga Daniela La Chioma analisou as representações de músicos na iconografia mochica, na qual os divide em três grandes categorias: Oficiais, sobrenaturais e mediadores. Ao analisar a peça ML12778 La Chioma classifica o flautista sentado como um oficiante "tomador de coca com funções de músico" (La Chioma, 2016: 118), por conta de seu toucado de duas mãos típicos dos tomadores de coca. Além disso, as esferas escuras envolvendo os cactos indicam um 
céu noturno, como na cena dos tomadores de coca. São vasos, portanto, essencialmente interligados.

Flora e peças:

La chioma (2016:118) afirma que todas as cenas dos consumidores de coca estão associadas ao cacto san pedro (Trichocereus pachanoi). De fato, na peça ML4112 (figura V.II.c) além dos dois cactos T1B pode-se observar dois cactos colunares longos e vazados no canto da cena. Esse cactos colunares longos, sem espinhos aparentes e vazados foram classificados como CT5 e encaixam perfeitamente com a morfologia de um San Pedro. Apesar de termos apenas uma amostra no nosso catálogo, La Chioma elenca três vasos de linha fina onde músicos estão associados aos tomadores de coca (Pranchas 22, 23 e 24). Neles, apenas a prancha 22, a mesma peça ML4112 apresenta cactos com morflogia típica de San Pedro. Na prancha 23 (ML12778) temos cactos CT4, provavelmente opuntias e na prancha 24 temos cactos tipo CT1A, mais provavelmente relacionados à espécies de clima árido encontradas nas bases das lomas como Haageocereus.

De todo modo, não deixa de ser interessante termos cactos com morfologia compatível à do San Pedro na cena dos tomadores de coca, uma vez que não se trata de um tipo de cacto muito recorrente. Além disso é importante lembrarmos que de acordo com Ostalaza (2014:420) os San Pedro não são encontrados naturalmente em zonas costeiras, mas nas serras a partir de 2 mil metros de altitude, inclusas as regiões de ocupação da cultura Recuay, intrínsicamente atadas aos ritos com coca (Makowsky, 2000: )

Quanto à peça do músico tomador de coca (Figura V.II. ) os cactos T4, como já dito no capítula anterior, está exclusivamente relacionado à espécie Opuntia Quitensis, ocorrente nas zonas mais úmidas e altas das lomas. Apesar da peça não ter um formato escultórico de montanha pode estar indicando um rito envolvendo o uso da coca, música e dança nas lomas. 


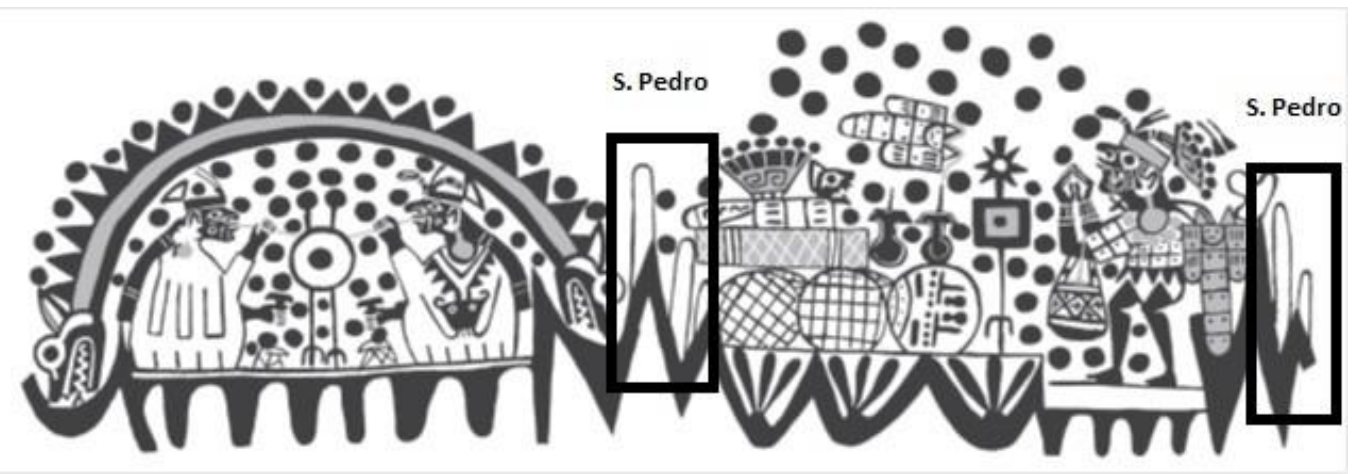

(FIGURA V.II.c) Roll out de peça ML4112 com cactos com morfologia muito próxima à do San Pedro (T. Pachanoi) são indicados. (Desenho de Donna Mclelland, retirado de Uceda,2008:154)

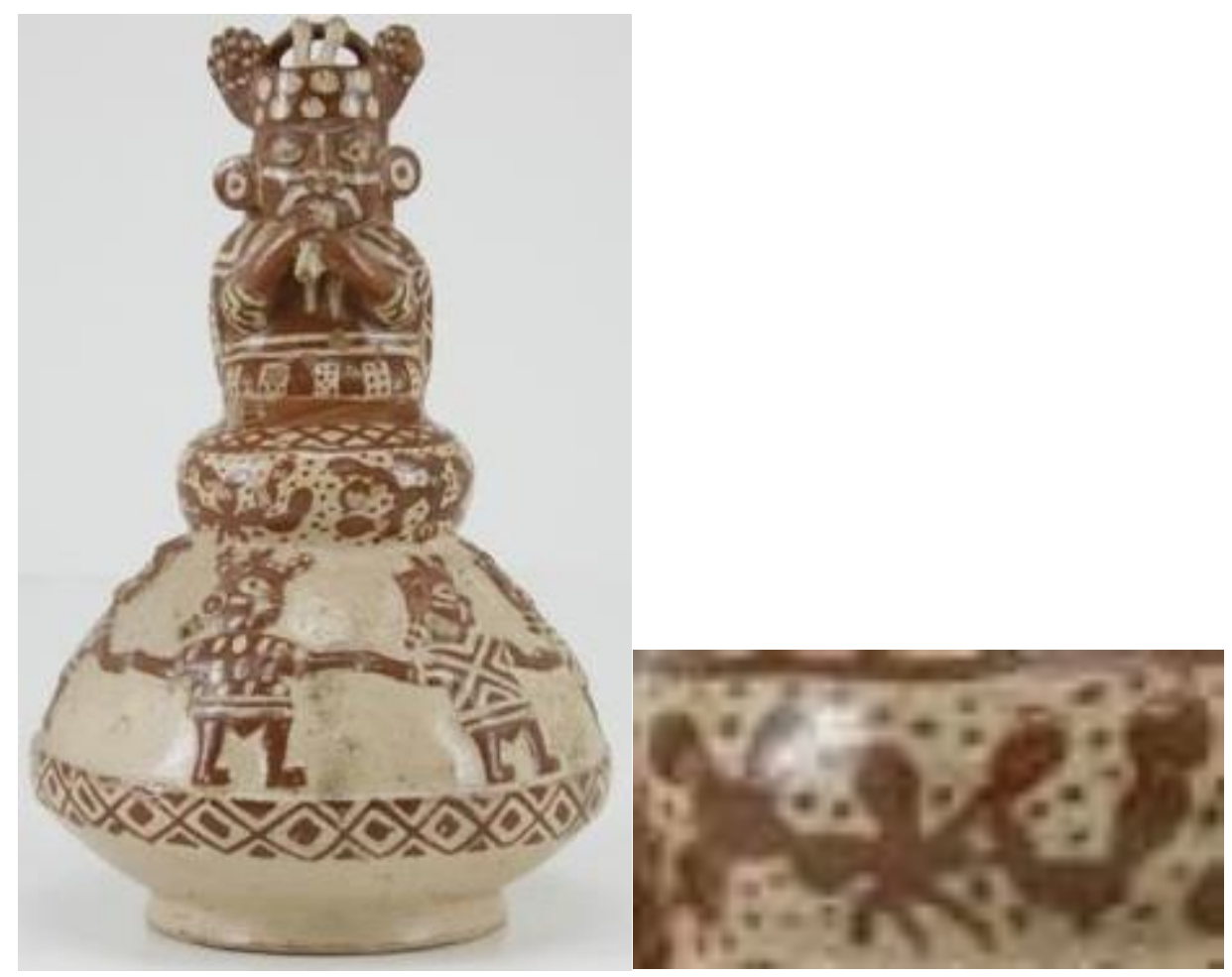

(FIGURA V.II.d) Peça ML12778 com detalhe de cacto T4.

Ficha Simplificada

\begin{tabular}{|l|l|l|l|l|l|l|l|l|l|}
\hline PEÇA & CENA & $\begin{array}{l}\text { TIPO } \\
\text { DE } \\
\text { VASO }\end{array}$ & FASE & VALE & SÍTIO & RELAÇÃO & $\begin{array}{l}\text { CACTO } \\
\text { T1B }\end{array}$ & $\begin{array}{l}\text { CACTO } \\
\text { T5 }\end{array}$ & LOCALIZAÇÃO \\
\hline ML4112 & COCA & $\begin{array}{l}\text { Asa } \\
\text { Estribo }\end{array}$ & IV & & & AIA PAEC & 2 & 3 & $\begin{array}{l}\text { CT1B: 2AB- CT5: } \\
\text { 3AB }\end{array}$ \\
\hline
\end{tabular}

\begin{tabular}{|l|l|l|l|l|l|l|l|}
\hline PEÇA & CENA & $\begin{array}{l}\text { TIPO DE } \\
\text { VASO }\end{array}$ & FASE & VALE & SÍTIO & CACTO T4 & LOCALIZAÇÃO \\
\hline
\end{tabular}




\begin{tabular}{|l|l|l|l|l|l|l|l|}
\hline ML12778 & MUSICO & $\begin{array}{l}\text { Asa Estribo } \\
\text { lateral } \\
\text { escultórico }\end{array}$ & III/IV & Virú & Pur Pur & 4 & CT4: 4AC \\
\hline
\end{tabular}

\section{SACRIFÍCIO (3)}

O tema do sacrifício é bastante complexo e difícil de se resumir em um verbete. Há evidências de sacrifício nas Huacas, como a Huaca de La Luna (Verano, 2016), (Bourget, 2008) em cerro "secos" como cerro Blanco e nas lomas como cerro Campana (Franco, 2012: 297). Apesar de termos apenas encontrado três peças com a figura central do sacrifícios, há outras três em que supliciados aparecem nas cenas dos caracóis e uma associada ao personagem "Aia Paec". Todas estas são peças de asa estribo escultóricas em formato de "montanha". Há ainda três peças nas quais o personagem "Dragão", relacionado à Via Láctea, segura cabeças decapitadas. Não apenas o Dragão está relacionado ao sacrifício. Golte (2009) e Benson (2012) indicam uma estreita relação da serpente bicéfala (possivelmente uma representação da Via Láctea) de Aia Paec (Divindade Intermediadora em Golte e Snake Belt God [Deus do cinturão de serpente] em Benson), seu companheiro iguana, a Divindade Coruja (que para Golte é um auxiliar do Deus da Via Lactea).

A quantidade aqui indicada não significa que o sacrifício seja uma cena pouco representada. Pelo contrário. Donnan e Mccllellan (1999) afirmam que o tema é um dos mais presentes na iconografia mochica. Uma razão para a quantidade escassa de peças com o tema "sacrifício" que contenham flora seria que apenas um ou dois "tipos" de sacrifício eram performados em montanhas ou zonas as abertas enquanto os outros seriam conduzidos dentro de recintos construídos.

Hocquenhem propõe dois tipos diferentes de rituais sacrificiais: os de propiciação e os de expiação. Propiciação serve para a transmissão do camay (uma espécie de energia vital animadora de todas as coisas) e a reprodução social (Hocquenghem, 2008:26-32) enquanto expiação, apesar de ter a mesma finalidade dos primeiros, serviria para compensar eventuais quebras na ordem de reprodução social, evitando assim desastres sociais e naturais, que por sua vez, interroperiam a transmissão de camay. Bourget (1994) divide em 4 "tipos": cerimônia das taças, sacrifício por degolamento, cenas de suplício ou sacrifício por descarnamento por abutres e sacrifício da montanha. 
Dos quatro "tipos" de rituais sacrificiais, dois estariam sendo conduzidos em espaços cerimôniais, cerimônia das taças, sacrifício por degolamento, nos quais vemos seres divinos performando os ritos, uma vez que para apenas a deuses seria permitido tomar a vida humana (Uceda, 2000:99), e dois ao ar livre: os suplícios por descarnamento e o sacrifício da montanha, nos quais não vemos o condutor da ação. Hocquenghem associa fortemente os ritos de expiação às lomas e ao equinócio de primavera. Para ela:

Estos ritos tendrian entónces el sentido de purificación, de restauración del orden. Las escenas de iconografia mochica que representan a personajes desbarrancados desde o alto de cimas ya a prisioneros sacrificados, estarián también relacionadas con los ritos de equinócios de primavera. En estas escenas están presentes animales que pueblan las lomas de la costa entre junio y noviembre: cievos, zorros, caracoles. Puesto que los días que precededen a los equinóccios son todavía hoy en día considerados propicios para las ofrendas, etas escenas podrian ilustrar los sacrifícios presentados antes del equinoccio de primavera, en agosto, cuando la tierra esta abierta. (Hocquenghem, 1987: 61)

Para Golte, os sacrifícios humanos são realizados nas Lomas no período geral "seco" quando essas zonas elevadas estão envoltas em neblina. Além da flora típica, uma evidência disso seriam os caracois (Bulimus sp.) estreitamente associados às cenas de sacrifício (Golte, 2009:177). De fato, não temos esta associação nos vasos na classificados como "sacrifício", mas temos dois vasos no tema dos caracóis (quase 1/3 da amostra de sete) com supliciados. Ainda para o autor, "o mundo de baixo requer sacríficios humanos" (Golte, 2009:177), mas estes não são feitos "apenas para o mundo de noturno e úmido, mas também às divindades da época seca" (Golte, 2009:198), com ritos usando cordas, que também aparecem na cerâmica ritual, "com a finalidade de estabelecer uma comunicação entre a terra úmida e o rio da via láctea" (Golte, 2009:203). Ainda nesta lógica, os sacrifícios seriam feitos ao fim da época seca, de neblinas em agosto quando já começa a ser possível ter uma boa visualização da Via láctea, uma vez que o objetivo dos sacrifícios seria o de "destapar" os mundos de abaixo e fortalecer as divindades noturnas, em especial o Deus da Via Láctea. 
Flora e peças:

Assim como Hocquenghem e Golte, Benson (2012) afirma que tillandsias estão associadas às cenas de sacrifício. Entretanto neste recorte específico de peças não há representações claras de tillandsias. Apesar de todas as peças serem alça estribo esculturadas em forma de montanha, cada peça possui peculiaridades. Todos os supliciados que aparecem nas peças estão com cabelo solto o que para Golte(2009) indica sua redução a condição de humanos sem status.

A peça ML13030 (figura V.II.e ) mostra um uma montanha de sete picos. Nela, observam-se três supliciados, um no pico principal e outrso dois nas partes mais baixas enquanto um grupo de seis pessoas estão sentadas abaixo de cada pico, exceto o em quem paira o supliciado. Por todo o corpo da peça aparecem cactos colunares de ramificação basal Tipo1A e um cacto $\mathrm{T} 3$, todos com espinhos evidentes e raízes à mostra. Morfologicamente estes tipos estão mais próximos de gêneros como haageocereus, esposotoa ou até, possivelmente, neoraimondia.

A peça ML3099 (Figura V.II.f) emula uma montanha de três picos na qual um supliciado encontra-se no topo do pico central. A flora é do tipo CT1B, onde os espinhos não são evidentes, mas no caso dos cactos da metade de cima podemos ver raízes. Na metade de baixo, os cactos crescem a partir de pirâmides que podem estar simbolizando huacas, montes de areia ou outras elevações. Os gêneros relacionados à flora representada são os mesmo da peça anterior.

A última peça ML3101 (Figura V.II.g) também mostra uma montanha de três picos na qual um supliciado encontra-se no topo do pico central. No centro do vaso podemos ver outro supliciado deitado. Em um dos picos há uma serpente felina ascendente e abaixo vemos uma figura que lembra o Dragão Lunar ou Dragão Recuay (ver. Dragão). No outro pico vemos um tipo de flora pouco comum, possivelmente representado exemplares arbóreos ou gramíneas. Não é impossível que sejam tillandsias. Vemos flora semelhante em algumas cenas de serpente e em outras cenas em montanhas escultóricas que, como esta, possivelmente são fase III ou se algum sitio específico com uma tradição de produção pictórica pré-linha fina.

No geral os cactos das duas primeiras peças parecem ser mais associados a tipos de ambientes mais áridos ou de sopés das lomas enquanto na última peça temos enfase em um flora que possivelmente está mais associada a regiões mais úmidas e altas das 
lonas.

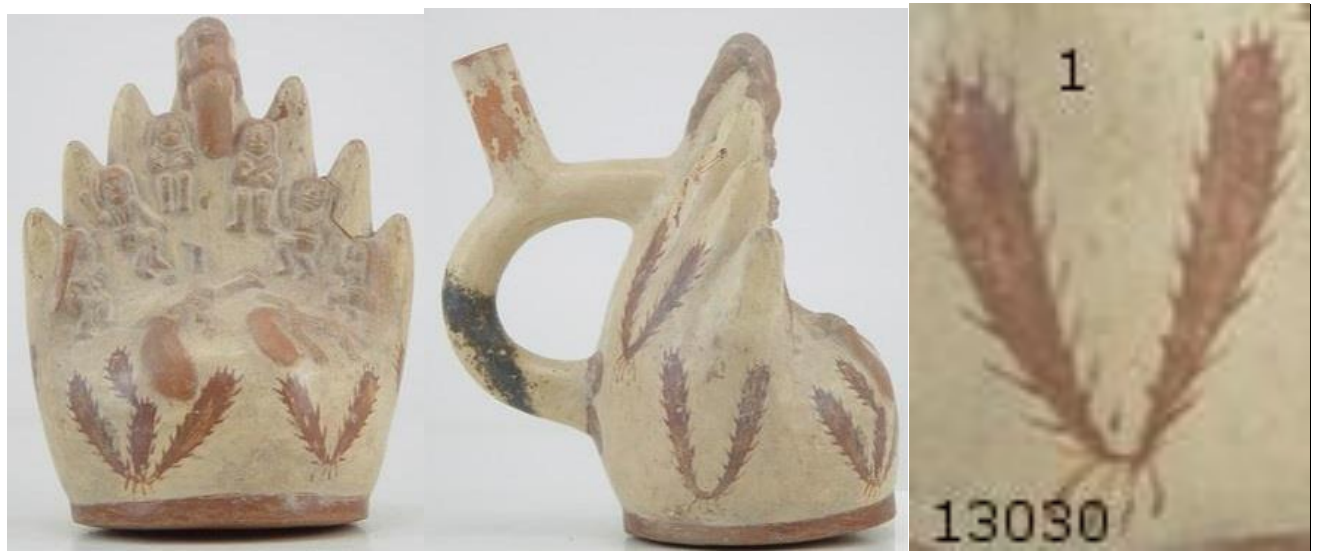

(FIGURA V.II.e) Peça M13030 com três supliciados esculturados

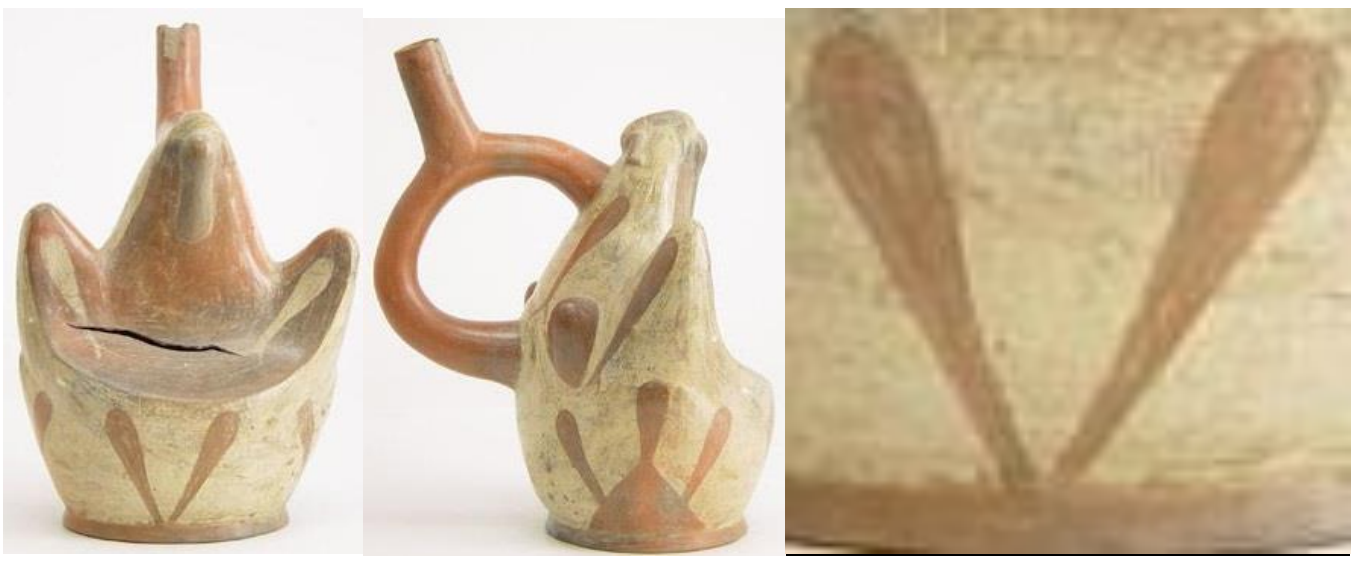

(FIGURA V.II.f) Peça ML3099 com pirâmides semelhantes a huacas (Cortesia Museu Larco).

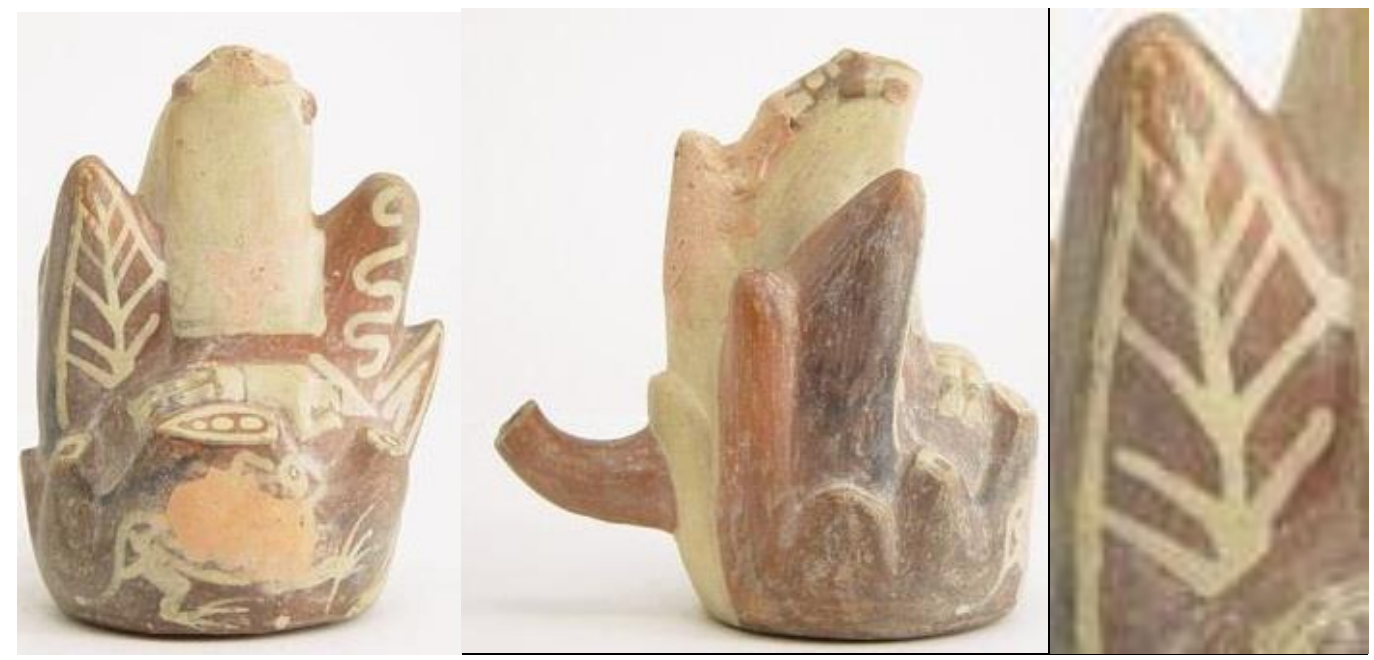

(FIGURA V.II.g) Peça ML3101com Dragão (Cortesia Museu Larco) 
Ficha simplificada

\begin{tabular}{|c|c|c|c|c|c|c|c|c|c|c|c|}
\hline PEÇA & CENA & $\begin{array}{l}\text { TIPO DE } \\
\text { VASO }\end{array}$ & $\begin{array}{l}\text { FAS } \\
\text { E }\end{array}$ & VALE & SÍTIO & RELAÇÃO & $\begin{array}{l}\text { CACTO } \\
\text { T1A }\end{array}$ & $\begin{array}{l}\text { CACT } \\
\text { O T1B } \\
\end{array}$ & $\begin{array}{l}\text { CACTO } \\
\text { T3 }\end{array}$ & DESC. & 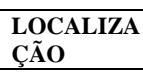 \\
\hline ML13030 & $\begin{array}{l}\text { SACRIF } \\
\text { ICIO }\end{array}$ & $\begin{array}{l}\text { Asa } \\
\text { Estribo } \\
\text { escultóri } \\
\text { co }\end{array}$ & IV & $\begin{array}{l}\text { Chica } \\
\text { ma }\end{array}$ & $\begin{array}{l}\text { Mocollo } \\
\text { pe }\end{array}$ & MONTAÑA & 7 & & 1 & & $\begin{array}{l}\text { CT1A: } \\
\text { 2AC- } 5 \mathrm{AB}\end{array}$ \\
\hline ML3099 & $\begin{array}{l}\text { SACRIF } \\
\text { ICIO }\end{array}$ & $\begin{array}{l}\text { Asa } \\
\text { Estribo } \\
\text { escultóri } \\
\text { co }\end{array}$ & IV & & & MONTAÑA & & 14 & & & $\begin{array}{l}\text { CT1B:6 } \\
\text { AC- } 8 \text { AB }\end{array}$ \\
\hline ML3101 & $\begin{array}{l}\text { SACRIF } \\
\text { ICIO }\end{array}$ & $\begin{array}{l}\text { Asa } \\
\text { Estribo } \\
\text { escultóri } \\
\text { co }\end{array}$ & III & & & $\begin{array}{l}\text { MONTAÑA+ } \\
\text { DRAGÓN } \\
\text { +SERPIENTE }\end{array}$ & & & & 1 & desc. 1AC \\
\hline
\end{tabular}

\section{BATALHA (11)}

As cenas de batalha costumam mostrar guerreiros em pares enfrentando-se com porretes, escudos, armaduras e toucados. Para compor este grupo ainda inserimos uma peça onde os guerreiros vencedores levam os vencidos para o sacrifício amarrado a uma corda e duas cenas onde há guerreiros paramentados, mas não há batalha aparente.

Baseados em relatos etnológicos, etnohistóricos e em lutas cerimoniais que ocorrem ainda nos dias de hoje como o ritual de povos tradicionais bolivianos e peruanos conhecidos por Tinku, a maioria dos estudiosos parece concordar que os vasos retratam batalhas rituais, muito provavelmente entre guerreiros representando as duas metades sociais, hanan e hurin ou acima e abaixo (Benson, 2012). Muito provavelmente uma das funções da batalha seria o de fornecer os perdedores como vítimas para algum dos titos de sacrifício sazonal.

Quilter (2008) crê que, ao menos parcialmente, os vasos poderiam estar representando guerras de conquista entre unidades polítcas Moche e seus vizinhos de outras culturas e etnias. Verano (2001) parece reforçar a hipótese ao conduzir um estudo que indica a origem estrangeira de uma parte das vítimas sacrificadas. Todavia não foram encontradas evidências consistentes de guerras de larga escala nas zonas de habitação mochica.

Flora e Peças:

O grupo é composto de 11 peças que explicitam guerreiros paramentados. O 
primeiro vaso ML1730 (figura V.II.h) mostra um guerreiro paramentado segurando um guerreiro inimigo pelo cabelo enquanto o outro segura um homem nu atado pelo pescoço, talvez o mesmo guerreiro capturado, sangrando como em um sacrifício. É uma cena cheia de elementos com duas panoplias, uma antropomorfizada, e dois pássaros na parte superior do corpo. A flora se compõe por uma Neoraimondia arequipensis extremamente naturalista, classificada como CT5, com espinhos e frutos e tillandsias na parte superior e finferior do vaso.

O vaso ML1745 (figura V.II.i) também é interessante por sua peculiaridade. Provavelmente um vaso da fase III o combate se trava entre guerreiros moche, um deles com uma pequena serpente bicéfala no toucado, e o que parecem ser guerreiros estrangeiros, muito possivelmente da cultura Recuay. A flora também é de um estilo diferente da padronizada na fase IV, compondo-se do que parecem ser dois cactos arbóreos ou até mesmo dois arbustos. A peça ML1085 também parece ser fase III e mostrar um engajamento entre mochicas e estrangeiros e apresenta a rara representação de um arbusto sem características de fabáceas, possivelmente um sapote (Capparis scabrida). Apesar de ter características morfologicas de peças da fase IV o vaso ML12783 possui uma estética no desenho bastante peculiar. O vaso é dividido por uma linha horizontal e guerreiros parecem correr na parte de baixo enquanto outros parecem estar caídos na parte de cima. Em ambas as divisões estão representadas tillandsias peculiares, cujo formato lembra o de uma planta de milho.

O grupo é inteiro formado por vasos de alça estribo, o que denota seu valor cerimonial específico para este tipo de vaso, com 9 vasos da fase IV e apenas dois da fase III. Cactos T1A, T1B, mais relacionados com haageocareus e esposotoas aparecem em 4 vasos enquanto cactos T2, 2B, T3 e T5, mais próximo do $N$. arequipensis, aparecem em 3 vasos, totalizando sete vasos com cactos. Tillandsias aparecem seis peças e há uma peça com arbusto representado. Parece um conjunto bastante equilibrado que provavelmente sinaliza a ação nos sopés ou niveis mais baixos das lomas, uma vez há uma representatividade bastante grande de tillandsias. 


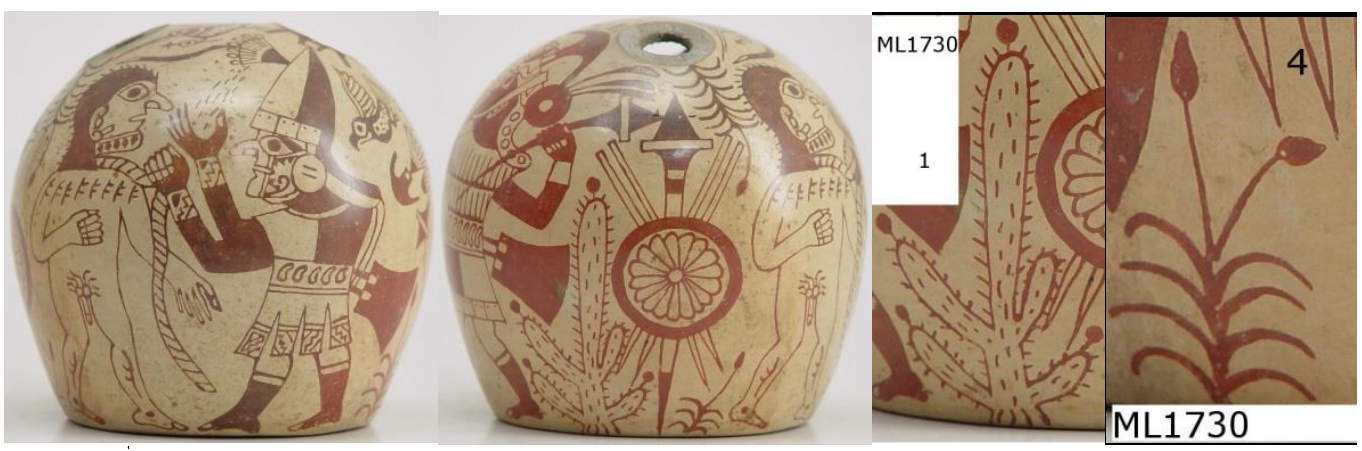

(FIGURA V.II.h)_Peça ML1730 com N.arqeuipensis (Cortesia Museu Larco)

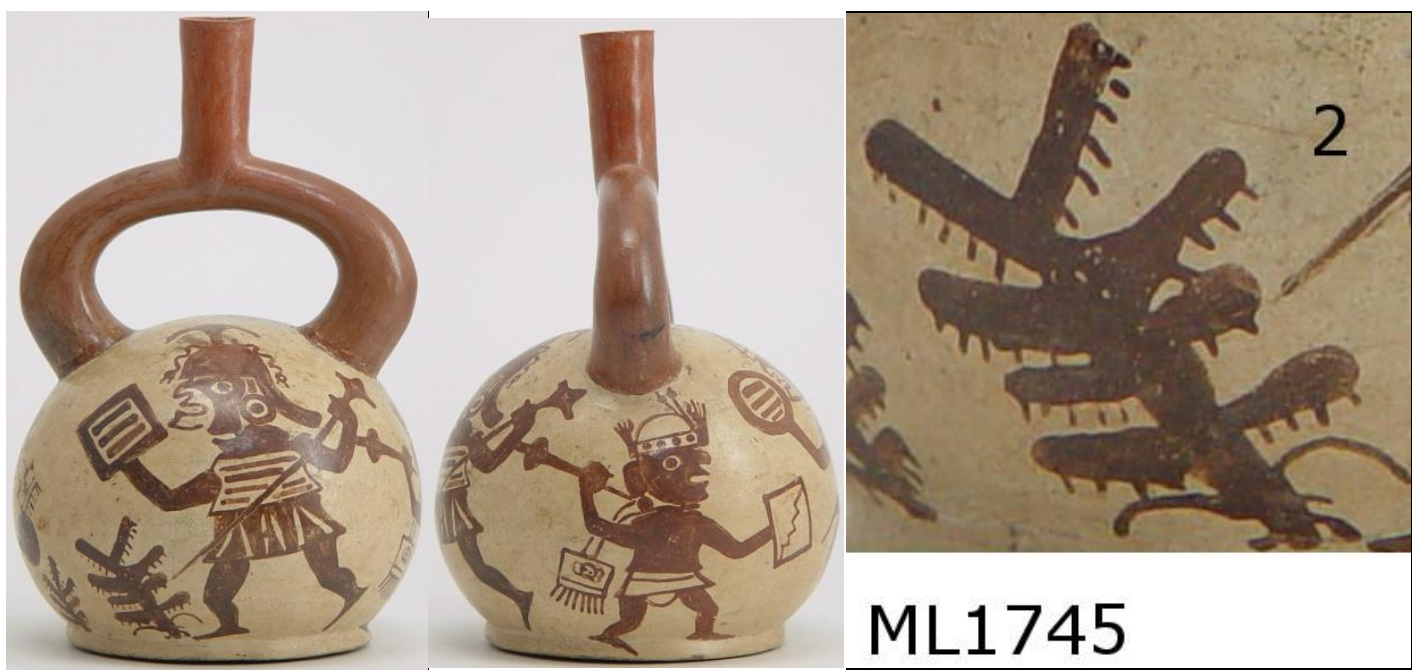

(FIGURA V.II.i) Peça ML1745 com guerreiro Recuay(Cortesia Museu Larco)

Ficha simplificada:

\begin{tabular}{|c|c|c|c|c|c|c|c|c|c|c|c|c|c|}
\hline PEÇA & $\begin{array}{l}\text { TIP } \\
\text { O } \\
\text { DE } \\
\text { VAS } \\
\text { O }\end{array}$ & FASE & $\begin{array}{l}\text { VAL } \\
\text { E }\end{array}$ & $\begin{array}{l}\text { SÍTI } \\
\text { O }\end{array}$ & $\begin{array}{l}\text { CA } \\
\text { CT } \\
\text { O } \\
\text { T1A }\end{array}$ & $\begin{array}{l}\text { CAC } \\
\text { TO } \\
\text { T1B }\end{array}$ & $\begin{array}{l}\text { CA } \\
\text { CT } \\
\text { O } \\
\text { T2 }\end{array}$ & $\begin{array}{l}\text { CAC } \\
\text { TO } \\
\text { T2B }\end{array}$ & $\begin{array}{l}\text { CA } \\
\text { CT } \\
\text { O } \\
\text { T3 }\end{array}$ & $\begin{array}{l}\text { CAC } \\
\text { TO } \\
\text { T4 }\end{array}$ & $\begin{array}{l}\text { CACTO } \\
\text { T5 }\end{array}$ & $\begin{array}{l}\text { TILLA } \\
\text { NDSIA } \\
\text { S }\end{array}$ & $\begin{array}{l}\text { ARBU } \\
\text { STO }\end{array}$ \\
\hline $\begin{array}{l}\text { ML17 } \\
30\end{array}$ & $\begin{array}{l}\text { Asa } \\
\text { Estri } \\
\text { bo }\end{array}$ & IV & & & & & & & & & 1 & 4 & \\
\hline $\begin{array}{l}\text { ML17 } \\
31\end{array}$ & $\begin{array}{l}\text { Asa } \\
\text { Estri } \\
\text { bo }\end{array}$ & IV & $\begin{array}{l}\text { Chica } \\
\text { ma }\end{array}$ & $\begin{array}{l}\text { Cerro } \\
\text { de } \\
\text { Cabra } \\
\text { s } \\
\end{array}$ & & & 3 & 3 & 2 & & & & \\
\hline $\begin{array}{l}\text { ML17 } \\
32\end{array}$ & $\begin{array}{l}\text { Asa } \\
\text { Estri } \\
\text { bo }\end{array}$ & IV & $\begin{array}{l}\text { Chica } \\
\text { ma }\end{array}$ & $\begin{array}{l}\text { Cerro } \\
\text { de } \\
\text { Cabra } \\
\text { s }\end{array}$ & & & & & & & & 3 & \\
\hline $\begin{array}{l}\text { ML17 } \\
35\end{array}$ & $\begin{array}{l}\text { Asa } \\
\text { Estri } \\
\text { bo }\end{array}$ & IV & & & & 2 & & & & & & & \\
\hline $\begin{array}{l}\text { ML17 } \\
45\end{array}$ & $\begin{array}{l}\text { Asa } \\
\text { Estri } \\
\text { bo }\end{array}$ & III & & & & & & & & & 2 & & \\
\hline $\begin{array}{l}\text { ML17 } \\
46\end{array}$ & $\begin{array}{l}\text { Asa } \\
\text { Estri } \\
\text { bo }\end{array}$ & IV & & & & 1 & & & & & & 1 & \\
\hline $\begin{array}{l}\text { ML17 } \\
47\end{array}$ & $\begin{array}{l}\text { Asa } \\
\text { Estri } \\
\text { bo }\end{array}$ & IV & & & & & & & & & & 6 & \\
\hline $\begin{array}{l}\text { ML17 } \\
48\end{array}$ & $\begin{array}{l}\text { Asa } \\
\text { Estri }\end{array}$ & IV & $\begin{array}{l}\text { Chica } \\
\text { ma }\end{array}$ & & & & & & & & & 8 & \\
\hline
\end{tabular}




\begin{tabular}{|l|l|l|l|l|l|l|l|l|l|l|l|l|l|}
\hline & bo & & & & & & & & & & & & \\
\hline $\begin{array}{l}\text { ML10 } \\
851\end{array}$ & $\begin{array}{l}\text { Asa } \\
\text { Estri } \\
\text { bo }\end{array}$ & III & & & 2 & & & & & & & & 1 \\
\hline $\begin{array}{l}\text { ML12 } \\
783\end{array}$ & $\begin{array}{l}\text { Asa } \\
\text { Estri } \\
\text { bo }\end{array}$ & IV & & & & & & & & & & 4 & \\
\hline $\begin{array}{l}\text { ML13 } \\
657\end{array}$ & $\begin{array}{l}\text { Asa } \\
\text { Estri } \\
\text { bo }\end{array}$ & IV & & & & 6 & & & & & & & \\
\hline $\begin{array}{l}\text { TOTA } \\
\text { L DE } \\
\text { VASO } \\
\text { S: } 11\end{array}$ & $\begin{array}{l}\text { Asa } \\
\text { Estri } \\
\text { bo }\end{array}$ & & & & 2 & 9 & 3 & 3 & 2 & & 3 & 26 & 1 \\
\hline
\end{tabular}

\begin{tabular}{|l|l|}
\hline PERCENTUAL TOTAL DE VASOS COM & TOTAL: 7 \\
CACTOS: $63.6 \%$ & \\
\hline PERCENTUAL DE VASOS & TOTAL: 6 \\
TILLANDSIAS: $54.5 \%$ & \\
\hline PERCENTUAL DE VASOS ARBUSTO: & TOTAL: 1 \\
$9.0 \%$ & \\
\hline
\end{tabular}

CORRIDA (20)

São comuns as cenas de pessoas ou animais antropomorfizados correndo morro acima segurando um tipo de saco. Esta cena foi nomeada por Raphael Larco Hoyle de corrida dos feijões. Para ele, os sacos continham feijões de lima, que aparecem nas cenas de forma naturalistica ou antropomorfizada, com caracteres que seriam "lidos" pelos corredores (Larco, 1939 apud Benson, 2012). A sequência parece aceita pela maioria dos pesquisadores exceto que acredita-se que os feijões não seriam lidos mas possivelmente fariam parte de um rito divinatório (Benson, 2012: 99).

Deste modo, a sequência da corrida seria a dos corredores, sejam humanos, animais ou feijões antropomorfizados, sentado jogando os feijões no chão. Este possivel rito divinatório poderia estar ligado indicações premonitórias relacionadas aos sacrifícios a serem realizados (ibid.100).

Bourget (2012:205) crê que apenas indivíduos específicos participavam deste tipo de ritual ou de outros com marcadores sociais importantes como a cerimonia de badminton. De fato, há um esforço dos artistas mochica em apresentar claramente os toucados dos corredores em todas as cenas analizadas. 
Golte crê que a corrida se dirigia ao senhor do mundo de abaixo e oferndava os feijões ao Deus Coruja. Para ele a forte associação as tilllandisias indicaria mais do que a localização da cena nas zonas altas e úmidas das lomas. Seria também um indicadore de temporalidade:

(...)el ciclo de crecimiento de las tilandsias de la costa peruana es contrario al ciclo de las plantas en los valles irrigados. (...) Para los moche este ciclo de crecimiento invertido debe de haber sido algo notorio, más aún porque empiezan a desarrollar sus flores al final de la época seca en agosto. Sus flores son por lo general de un color rojo intenso, algunas veces anaranjado, y apuntan hacia la dirección de la cual provenía la humedad, es decir el mar. Todo ello, y el hecho de que dejan de crecer en la época húmeda de los valles, para los moche no solo debe de haber sido un indicador espacial, sino uno que circunscribía una época muy específica comprendida entre agosto y octubre, en otras palabras: la época de transición del período seco al período húmedo. Es altamente probable que esta sea la razón por la cual se muestra una asociación tan marcada entre corredores y tilandsias, de forma que algunas veces uno puede dudar si eran los unos o los otros que querían mostrar los pintores. (...) los pintores indican plantas con varias generaciones de crecimiento, separadas por intervalos sin hojas u hojas reducidas.(Golte,2009:238-239)

Flora e peças:

A cena da corrida é grande com 20 peças agregadas. Além de pessoas correndo morro acima estão inclusas cinco peças em que pássaros antropomorfizados (possivelmente coruja e beija-flor) fazem o mesmo. Além disso estão incluídas cenas em que personagens sentados jogam feijões, a ver pássaros antropomorfizados ML2359, feijões antropomorfizados M12454 e um veado, um felino e uma raposa antropomorfizados, ML13609 (figura V.II.k).

Há algumas constantes interessantes no conjunto das peças. Apenas as três peças em que os personagens estão sentados não possuem ao menos um corredor com toucado de raposa. Em quatro peças temos uma divisão do corpo em espiral, como que se para enfatizar a subida dos corredores. Também como recurso enfático para o ambiente, em 
seis peças estão presentes desenhos de montículos de areia e linhas representando o solo em mais três. Panóplias são comuns aparecendo em quatro vasos, a serpente felina aparece em três e em duas peças aparecem lagostas na alça. Não surpreendentemente, feijões são comuns, aparecendo em sete vasos.

Em nenhum outro grupo há uma predôminância tão grande de tillandsias, sendo que estas aparecem em 17 peças ou $85 \%$ dos vasos. Em 9 casos ou $45 \%$ das vezes são representadas apenas tillandsias sem cactos, algo também único neste grupo. Há um vaso em espiral, ML2363 (figura V.II.j), em que são representadas 62 tillandsias, o maior número de plantas registradas neste trabalho. Nas três peças em que os indivíduos estão sentados jogando os feijões não há tillandsias representadas, apenas cactos. Isso parece curioso, uma vez que eles estariam supostamente jogando em áreas altas das lomas, onde os cactos não seriam tão dominantes na paisagem.

O vaso ML 2364 (Figura V.II.l) também é interessante uma vez que é dividido em três seções horizontais. Na baixa estão árvores morfologicamente muito próximas com o algarrobo e arbustos, na seção média aparecem tillandsias e cactos e no topo são representados feijões. A divisão parece didática ao mostrar as zonas de arbóreos nos vales e sopes das lomas, seguidas das zonas de tillandsias e cactos seguidas do local de jogo.

Outra planta que tem um índice alto de aparição nesta cena é o ulluchu, ocorrendo em 4 vasos, ou $20 \%$ do total. O ulluchu aparece de fato em poucas cenas e ter $20 \%$ dos vasos indica uma associaão bem alta da cena com a planta ou seu uso. Ela aparece tanto em vasos com corredores "normais" quanto "zoomorfizados". Parece indicativo também que no único vaso da fase III da cena, ML2379 (figura V.II.m) os corredores apareçam apenas rodeados de ulluchu, sem outra flora.

No geral a cena parece indicar ação nos pisos baixos e médios das lomas enfatizando anormalmente as tillandsias e os montículos de areia, com forte ação no uso dos ulluchus tanto pela referenciação das plantas quanto, indiretamente, pelos participantes "zoomorfizados". 

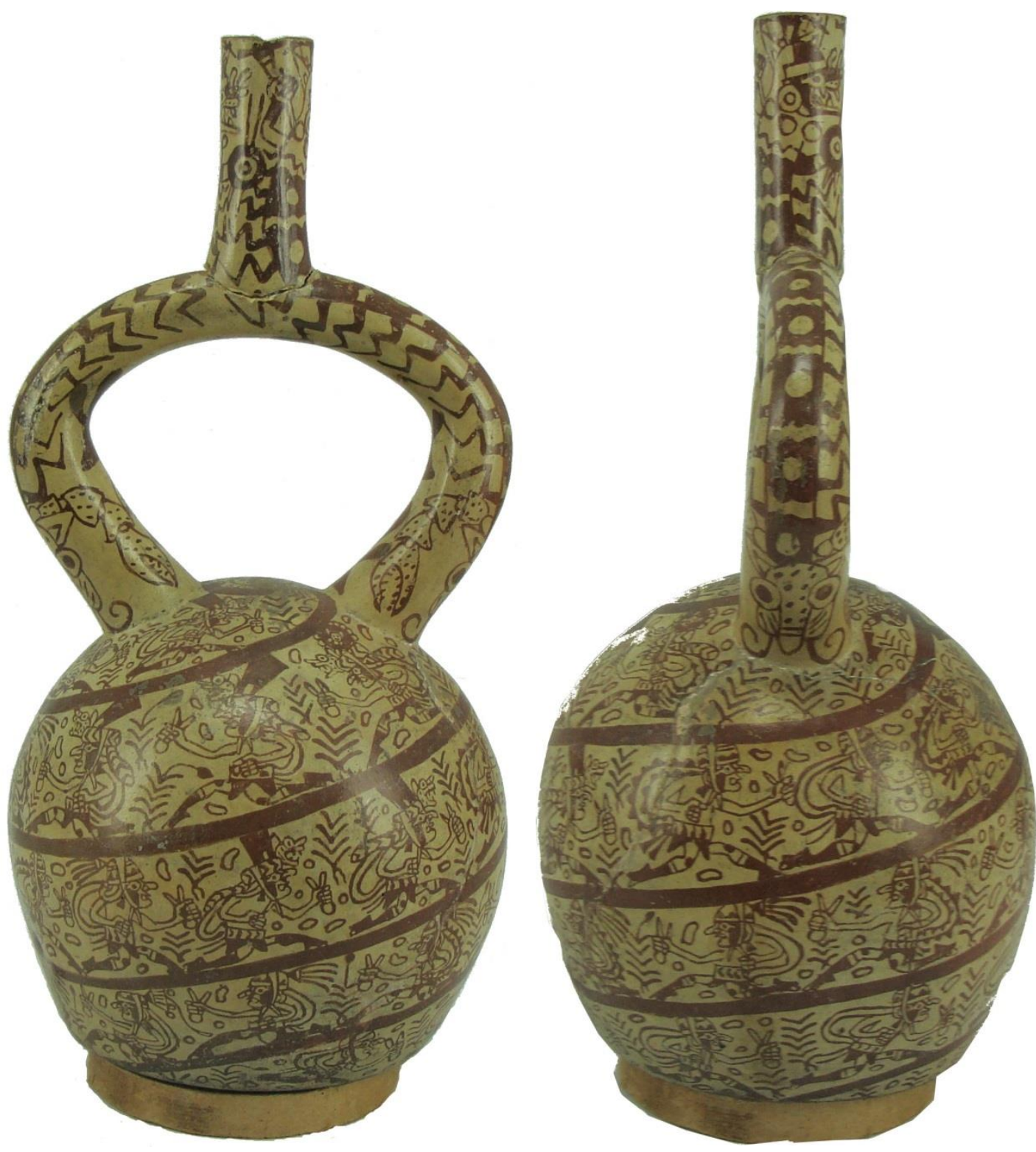

(FIGURA V.II.j) PeçaML2363 com 62 plantas contabilizadas( Foto Rui Murrieta)

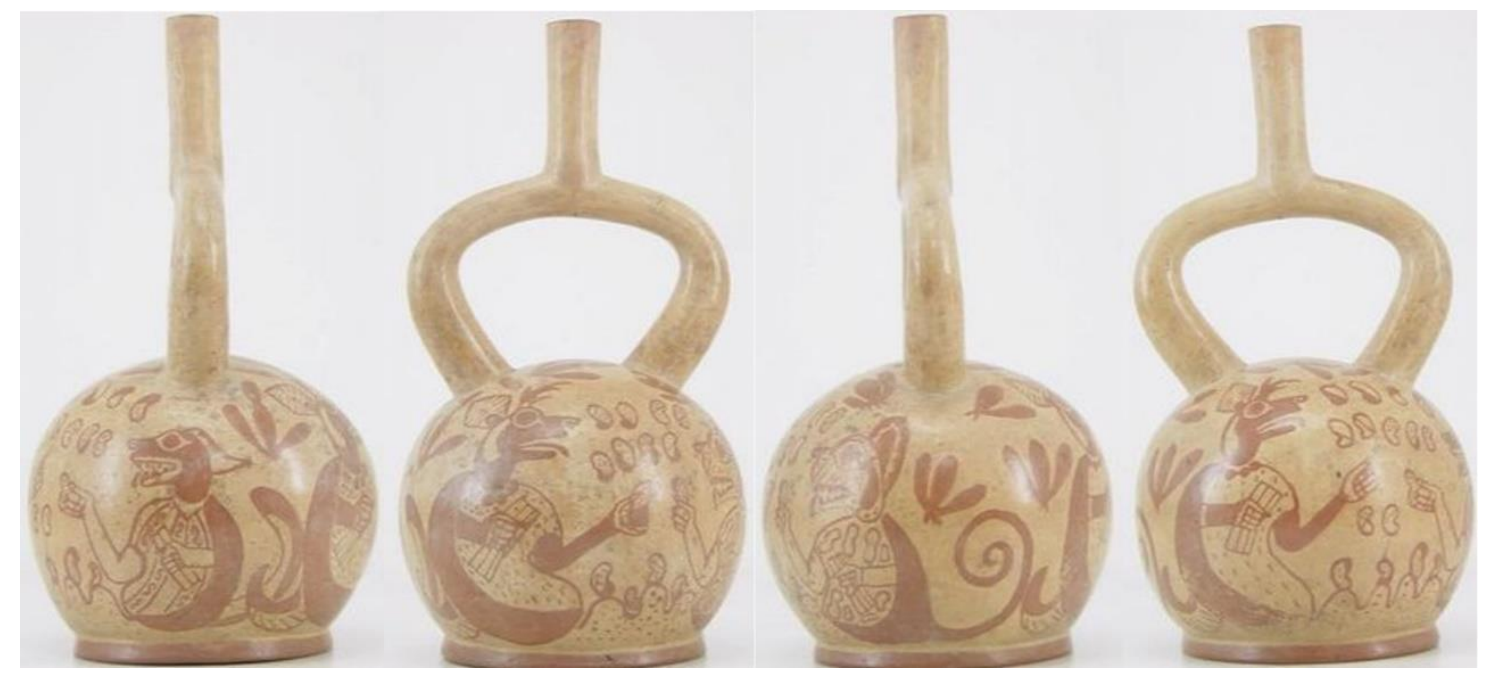

(FIGURA V.II.k) Peça ML13609 com raposa, felino e veado antropomorfizados (Cortesia Museu Larco) 

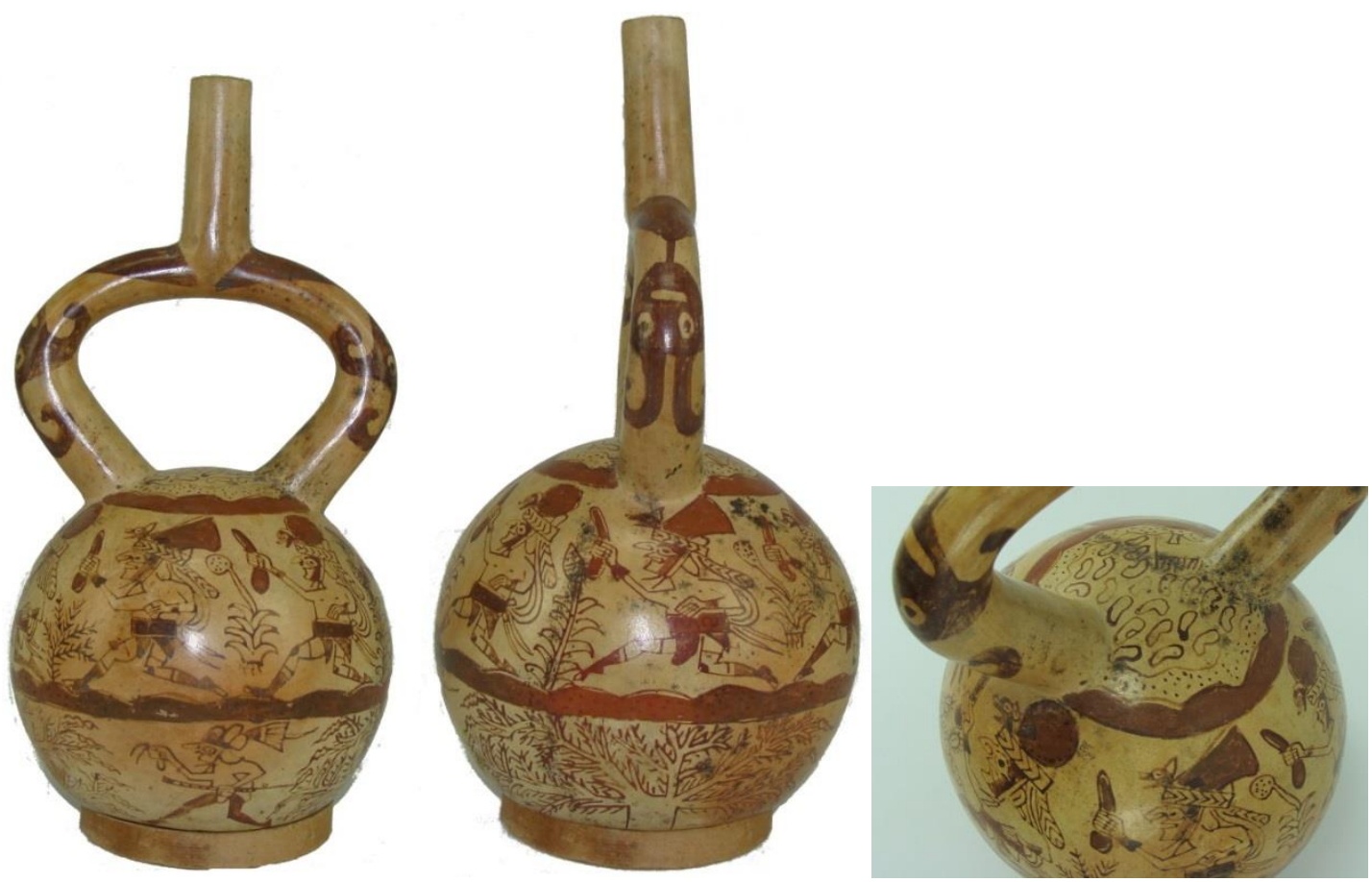

(FIGURA V.II.l) Peça ML2364 dividida em três cortes horizontais (Foto Rui Murrieta)

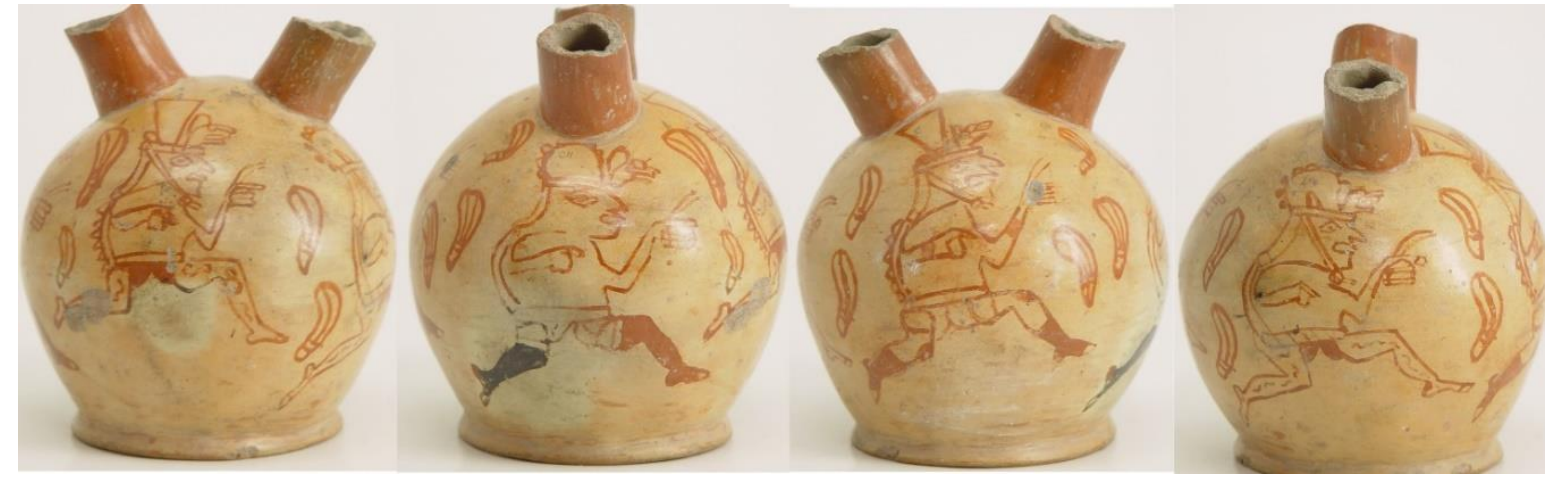

(FIGURA V.II.m)Peça ML2379 fase III com Ulluchus (Cortesia Museu Larco)

\begin{tabular}{|l|l|l|l|l|l|l|l|l|l|l|l|l|l|l|l|}
\hline $\begin{array}{l}\text { PEC } \\
\text { A }\end{array}$ & $\begin{array}{l}\text { TIPO } \\
\text { DE } \\
\text { VASO }\end{array}$ & $\begin{array}{l}\text { FA } \\
\text { SE }\end{array}$ & VALE & SíTIO & $\begin{array}{l}\text { CAC } \\
\text { TO } \\
\text { T1A }\end{array}$ & $\begin{array}{l}\text { CAC } \\
\text { TO } \\
\text { T1B }\end{array}$ & $\begin{array}{l}\text { CAC } \\
\text { TO } \\
\text { T2 }\end{array}$ & $\begin{array}{l}\text { CAC } \\
\text { TO } \\
\text { T2B }\end{array}$ & $\begin{array}{l}\text { CAC } \\
\text { TO } \\
\text { T3 }\end{array}$ & $\begin{array}{l}\text { CAC } \\
\text { TO } \\
\text { T4 }\end{array}$ & $\begin{array}{l}\text { CAC } \\
\text { TO } \\
\text { T5 }\end{array}$ & $\begin{array}{l}\text { TILLAN } \\
\text { DSIAS }\end{array}$ & $\begin{array}{l}\text { ARBU } \\
\text { STO }\end{array}$ & $\begin{array}{l}\text { ALGAR } \\
\text { ROBO }\end{array}$ & $\begin{array}{l}\text { ULLU } \\
\text { CHU }\end{array}$ \\
\hline $\begin{array}{l}\text { ML2 } \\
331\end{array}$ & $\begin{array}{l}\text { Asa } \\
\text { Estrib } \\
\text { o }\end{array}$ & IV & & & & & 8 & & & 1 & & & & & \\
\hline $\begin{array}{l}\text { ML2 } \\
336\end{array}$ & $\begin{array}{l}\text { Asa } \\
\text { Estrib } \\
\text { o }\end{array}$ & IV & $\begin{array}{l}\text { Chic } \\
\text { ama }\end{array}$ & $\begin{array}{l}\text { Facal } \\
\text { á }\end{array}$ & & & & & & & & 1 & & & \\
\hline
\end{tabular}




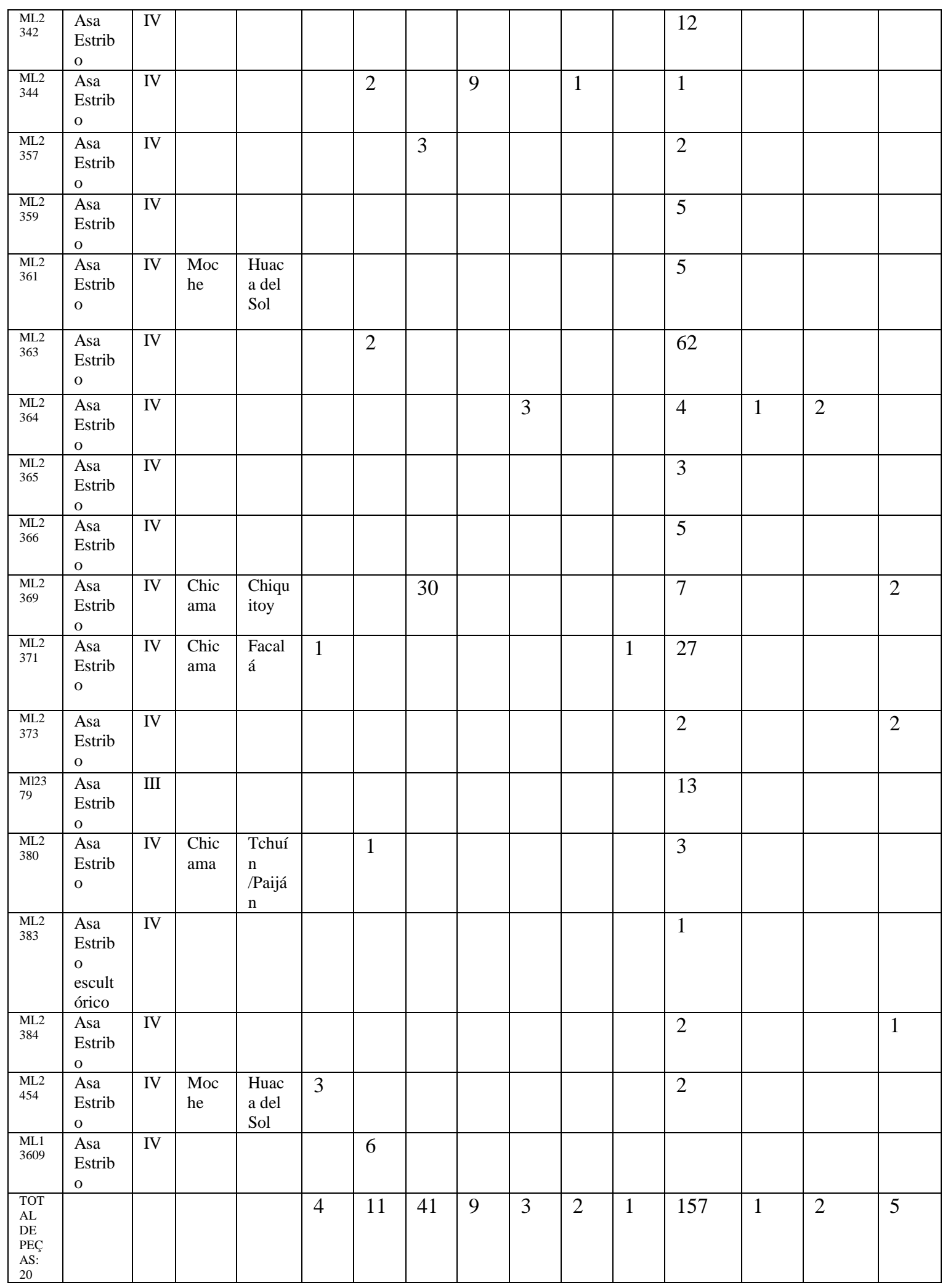

\begin{tabular}{|c|c|c|c|}
\hline PERCENTUAL & & & \\
VASOS & TOTAL: 17 & PERCENTUAL & TOTAL : 4 \\
TILLANDSIAS: & VASOS & VASOS & VASOS \\
$85.0 \%$ & & ULLUCHU: $20.0 \%$ & \\
\hline
\end{tabular}




\begin{tabular}{|c|c|c|c|}
\hline & & PERCENTUAL & \\
PERCENTUAL & TOTAL: 9 & VASOS & TOTAL: 2 \\
VASOS CACTOS: & VASOS & ARBÓREOS: & VASOS \\
$45.0 \%$ & & $5.0 \%$ & \\
& & & \\
\hline
\end{tabular}

\section{AVE GUERREIRA (8)}

Na catalogação do Museu Larco aparecem vasos cujos principais personagens são chamados de "aves guerreiras". Elas parecem estar relacionadas à cena da corrida, mas levam armas e estão paramentadas, portanto podem também estar relacionadas às cenas da batalha.

Flora e Peças:

Apesar de provavelmente os personagens de ave guerreira estarem relacionados com a cena da corrida, as indicações florísticas parecem ambíguas (anexos). Por um lado há uma grande prevalência de cactos (Figura V.II.n), a maioria tipo 1 e 2, relacionados à ambientes áridos, constando em 6 vasos, 87,5\% do total. Um perfil mais próximo ao da cena da batalha. Por outro há uma grande proporção de vasos com ulluchus (Figura V.II.o), três, ou 37,5\% do total. Essa alta percentagem aproximaria as aves guerreiras mais da cena de corrida do que da cena de batalha, onde ulluchus não aparecem. 


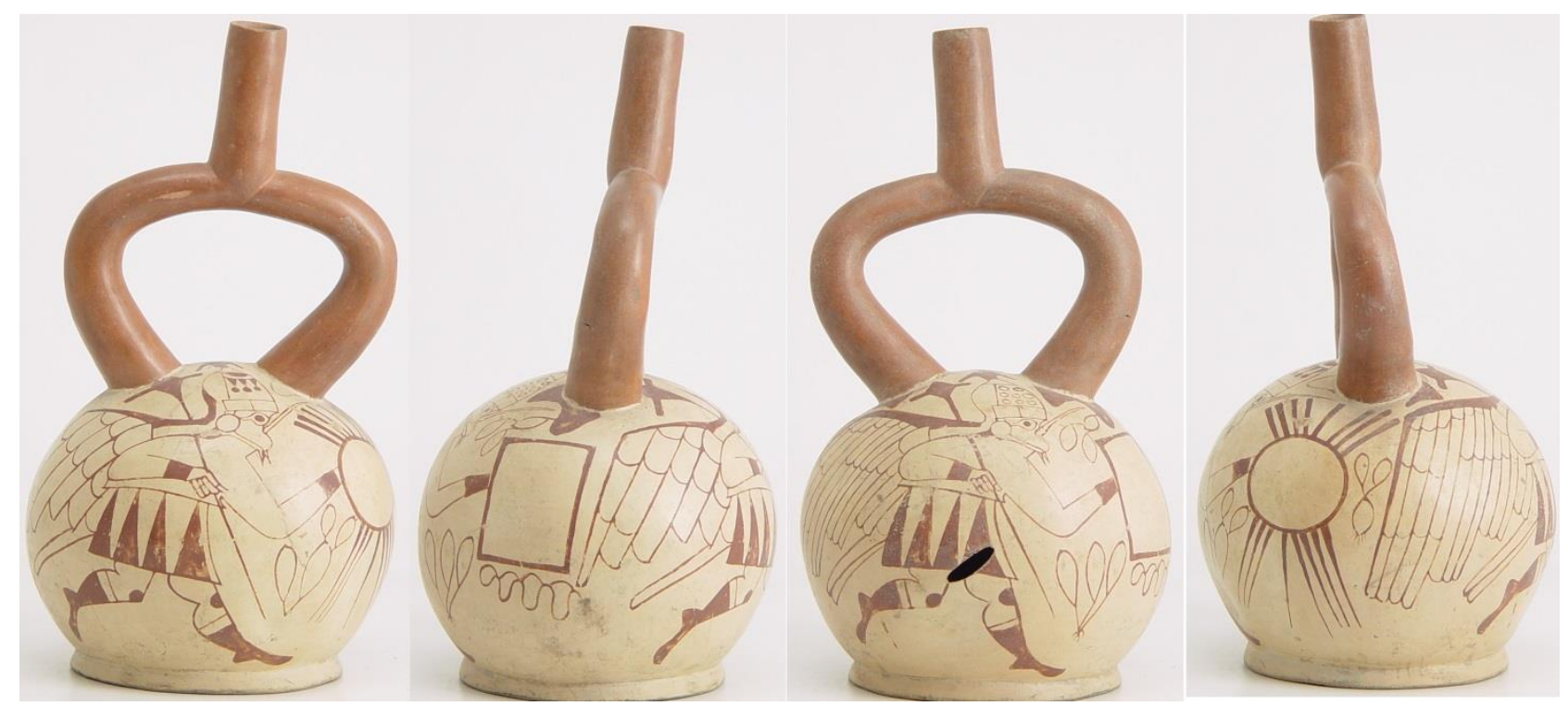

(FIGURA V.II.n) Peça ML4001 com Cactos Tipo 4(Cortesia Museu Larco)

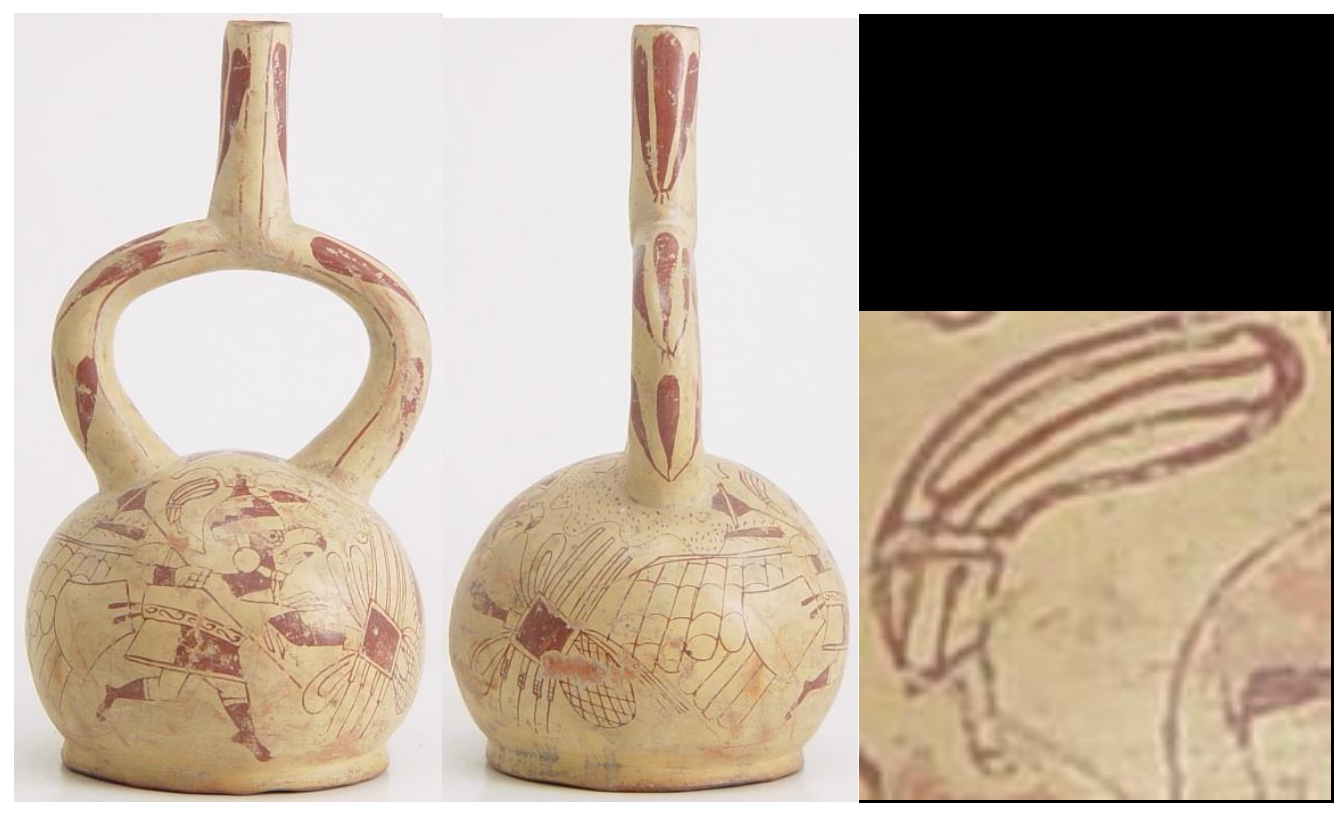

(FIGURA V.II.o) Peça ML4003 com ulluchus (Cortesia Museu Larco)

\begin{tabular}{|l|l|l|l|l|l|l|l|l|l|l|l|}
\hline PEÇA & $\begin{array}{l}\text { TIP } \\
\text { O } \\
\text { DE } \\
\text { VAS } \\
\text { O }\end{array}$ & $\begin{array}{l}\text { FAS } \\
\text { E }\end{array}$ & VALE & SÍtIO & $\begin{array}{l}\text { CACT } \\
\text { O T1A }\end{array}$ & $\begin{array}{l}\text { CACT } \\
\text { O } \\
\text { T1B }\end{array}$ & $\begin{array}{l}\text { CACT } \\
\text { O T2 }\end{array}$ & $\begin{array}{l}\text { CACT } \\
\text { O T3 }\end{array}$ & $\begin{array}{l}\text { CACT } \\
\text { O T4 }\end{array}$ & $\begin{array}{l}\text { TILLANDSI } \\
\text { AS }\end{array}$ & $\begin{array}{l}\text { ULLUC } \\
\text { HU }\end{array}$ \\
\hline $\begin{array}{l}\text { ML397 } \\
9\end{array}$ & $\begin{array}{l}\text { Asa } \\
\text { Estri } \\
\text { bo }\end{array}$ & IV & $\begin{array}{l}\text { Chica } \\
\text { ma }\end{array}$ & $\begin{array}{l}\text { Chiquit } \\
\text { oy }\end{array}$ & & 4 & & & & & \\
\hline $\begin{array}{l}\text { ML399 } \\
5\end{array}$ & $\begin{array}{l}\text { Asa } \\
\text { Estri } \\
\text { bo }\end{array}$ & IV & & & & & & & & 2 & 3 \\
\hline $\begin{array}{l}\text { ML400 } \\
0\end{array}$ & $\begin{array}{l}\text { Asa } \\
\text { Estri } \\
\text { bo }\end{array}$ & IV & $\begin{array}{l}\text { Chica } \\
\text { ma }\end{array}$ & $\begin{array}{l}\text { Chiquit } \\
\text { oy }\end{array}$ & 5 & 6 & & & & 1 & \\
\hline
\end{tabular}




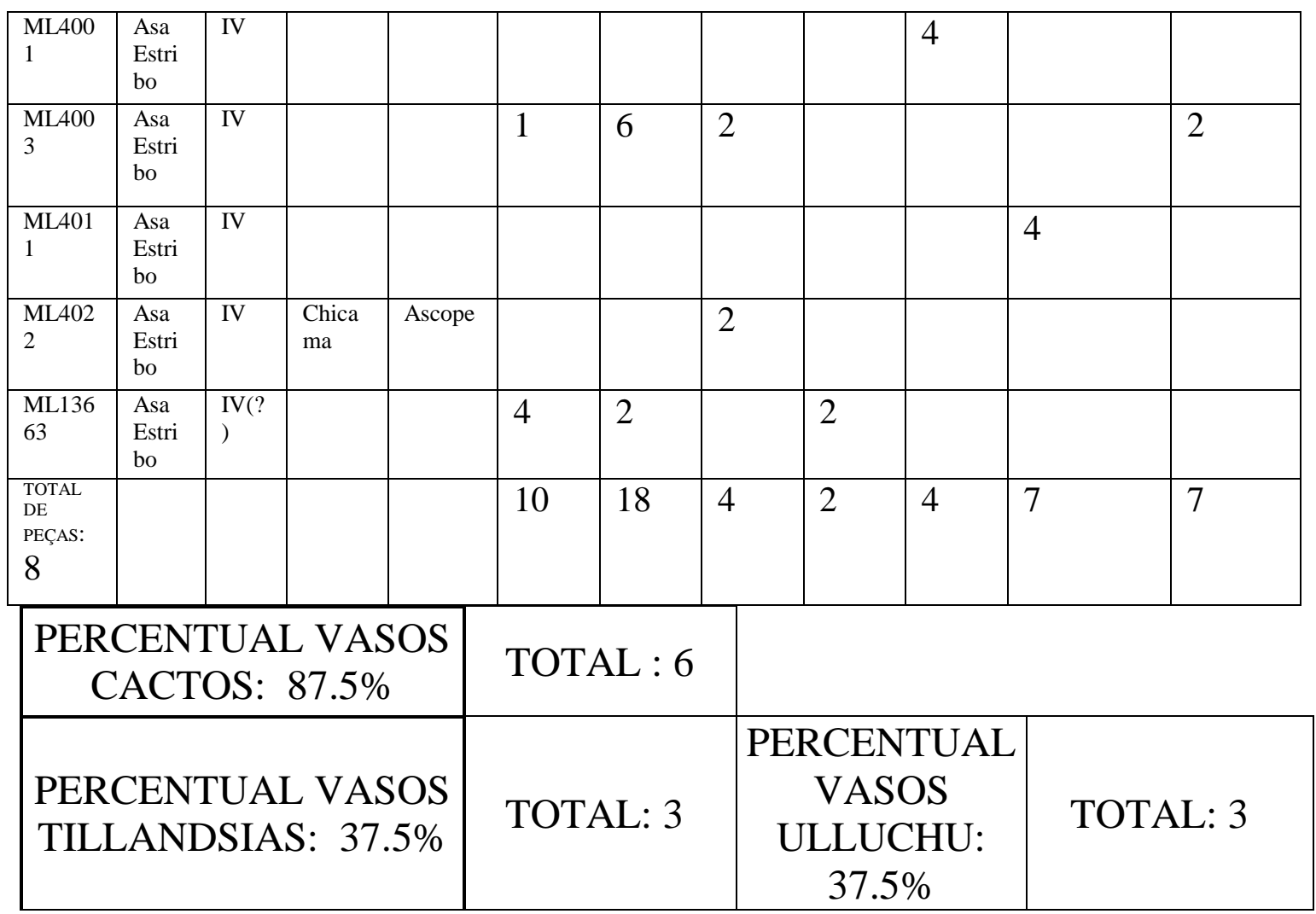

\section{GUERREIRO VIGILANTE (7)}

Em um grupo de peças podemos ver guerreiros esculturados sentados no topo do corpo do vaso, paramentados e segrando porretes. Abaixo deles, no corpo dos vasos pode-se ver floras pictóricas. Estas figuras estão marcadas no catálogo do museu larco como "guerreiro vigilante" ou "guerrerio vigiando" e podem estar reoresentando uma cena cotidiana.

Flora e Peças:

Os guerreiros deste grupo de fato parecem estar vigiando a partir de um ponto alto, pois estão todos sentados segurando seus porretes. Dois dos guerreiros são animais antropomorfizados, uma ave, possivelmente coruja e uma raposa. A coruja e mais três guerreiros possuem toucados em meia lua enquanto a raposa e mais dois possuem toucado cônico e vestes pontilhadas por esferas escuras. Talvez essas sejam indicações de pertencimento a diferentes metades, a ver hanan e hurin, de uma possível divisão social comum nos andes. 
Este conjunto, como o da ave guerreira não é grande, mas traz um perfil de flora pouco anbíguo (anexos). Há uma predominancia grande de cactos, ocorrendo em 6 vasos ou 87,5\% dos vasos. Em dois vasos aparecem raros cactos tipo 4, morfologicamente relacionados à Opuntia quitensis que nasce em zonas húmidas e altas das lomas. Novamente, a composição da peça parece fazer o vaso como um substituto para montanha, com o guerreiro sentado e a flora ao longo do corpo. A peça ML4060 (figura V.II.p) mostra morros e cactos e outra Ml6744 (figura V.II.q) desenha a cena completa com cactos, tillandsias, montanhas e até lagartos.

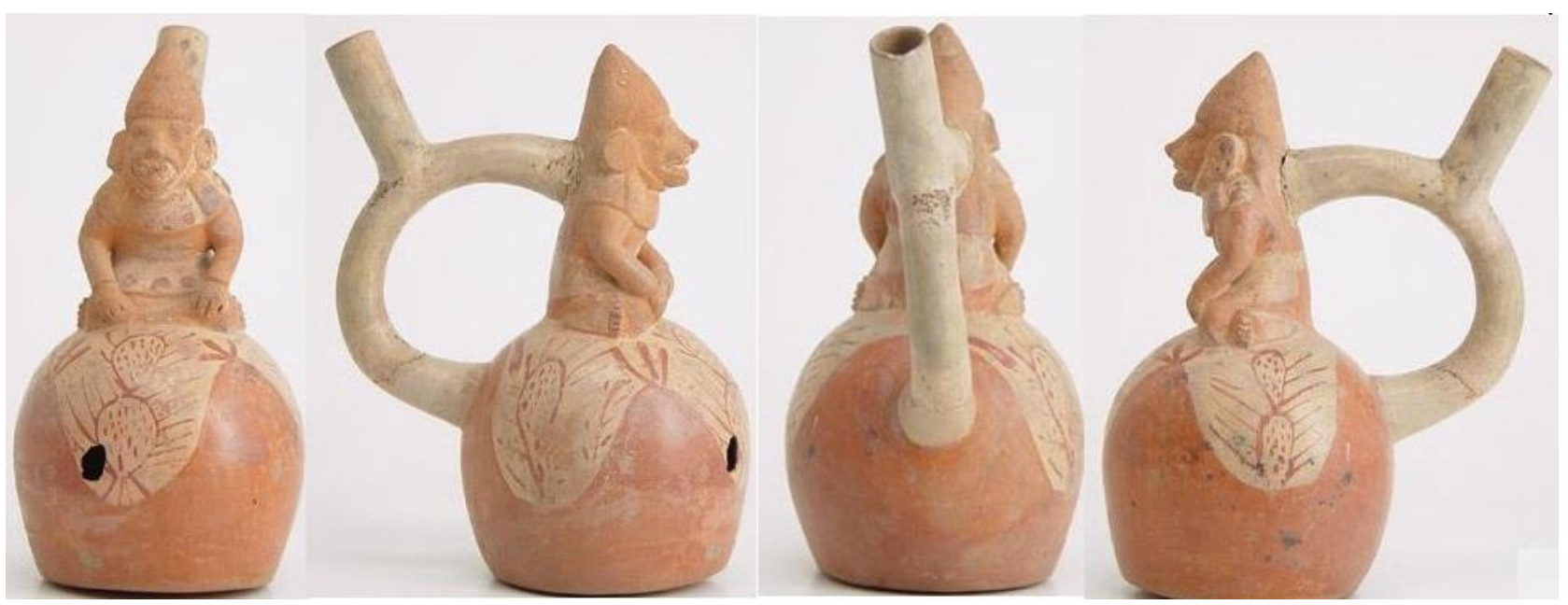

(FIGURA V.II.p) Peça ML4060 com guerreiro raposa e cacto tipo 4.(Cortesia Museu Larco)

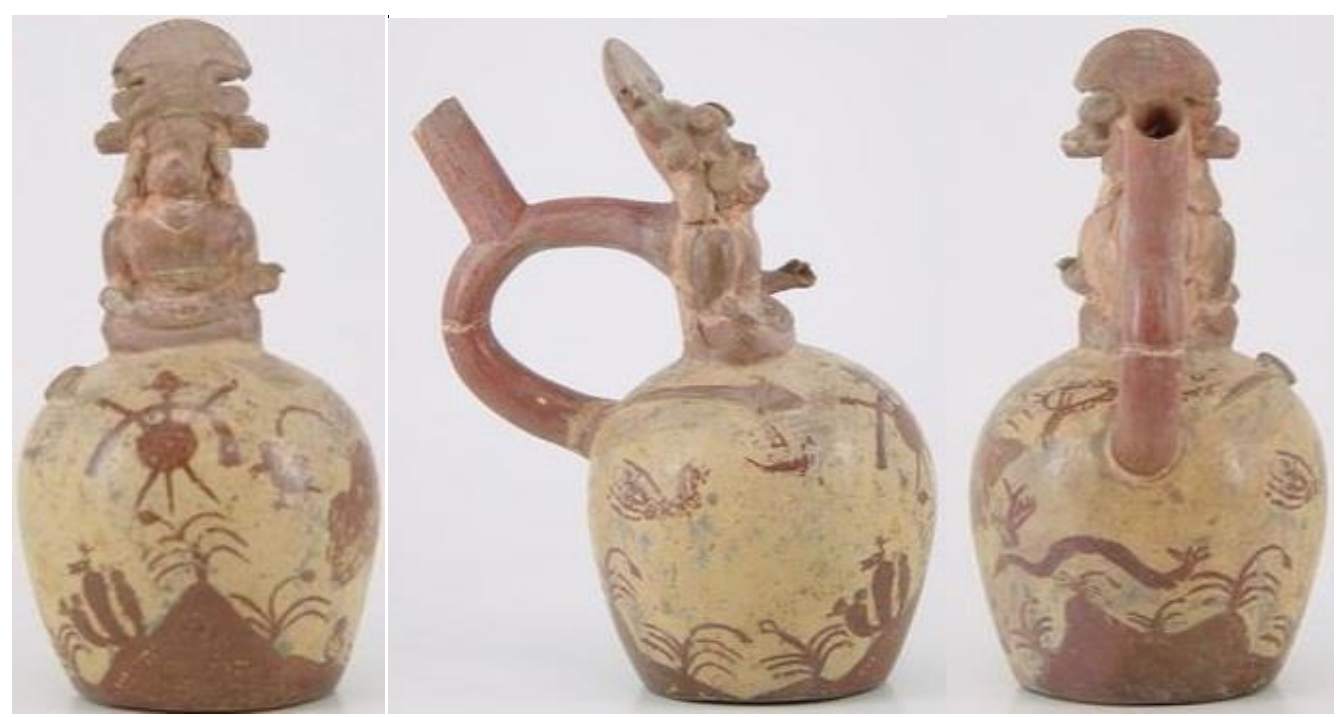

(FIGURA V.II.q) Peça ML6744 com paisagem completa (Cortesia Museu Larco) 


\begin{tabular}{|c|c|c|c|c|c|c|c|c|c|c|c|c|}
\hline PEÇA & $\begin{array}{ll}\text { TIPO } & \text { DE } \\
\text { VASO }\end{array}$ & $\begin{array}{l}\text { FAS } \\
\text { E }\end{array}$ & $\begin{array}{l}\text { VAL } \\
\text { E }\end{array}$ & $\begin{array}{l}\text { SÍTIO } \\
\end{array}$ & $\begin{array}{l}\text { CACT } \\
\text { O T1A }\end{array}$ & $\begin{array}{l}\text { CACT } \\
\text { O T1B }\end{array}$ & $\begin{array}{l}\text { CACT } \\
\text { O T2 }\end{array}$ & $\begin{array}{l}\text { CACT } \\
\text { O T2B }\end{array}$ & $\begin{array}{l}\text { CACTO } \\
\text { T3 }\end{array}$ & $\begin{array}{l}\text { CACT } \\
\text { O T4 }\end{array}$ & $\begin{array}{l}\text { CACTO } \\
\text { T5 }\end{array}$ & $\begin{array}{l}\text { TILLAND } \\
\text { SIAS }\end{array}$ \\
\hline ML1681 & $\begin{array}{l}\text { Asa Estribo } \\
\text { lateral } \\
\text { escultórico }\end{array}$ & IV & & & & & & & 2 & 3 & & \\
\hline ML1689 & $\begin{array}{l}\text { Asa Estribo } \\
\text { lateral } \\
\text { escultórico }\end{array}$ & IV & & & & & 1 & & & & & \\
\hline ML1694 & $\begin{array}{l}\text { Asa Estribo } \\
\text { lateral } \\
\text { escultórico }\end{array}$ & IV & & & & & & & & & 1 & \\
\hline ML1704 & $\begin{array}{l}\text { Asa Estribo } \\
\text { lateral } \\
\text { escultórico }\end{array}$ & IV & & & & & & & & & & 2 \\
\hline ML3877 & $\begin{array}{l}\text { Asa Estribo } \\
\text { lateral } \\
\text { escultórico }\end{array}$ & IV & & & 3 & & & & & & & \\
\hline ML4060 & $\begin{array}{l}\text { Asa Estribo } \\
\text { lateral } \\
\text { escultórico }\end{array}$ & IV & & & 1 & 2 & & & & 3 & & \\
\hline ML6744 & $\begin{array}{l}\text { Asa Estribo } \\
\text { lateral } \\
\text { escultórico }\end{array}$ & $\overline{\text { IV }}$ & & & & & & 1 & & & 1 & 11 \\
\hline $\begin{array}{l}\text { TOTAL } \\
\text { PEÇAS: } 7\end{array}$ & & & & & 4 & 2 & 1 & 1 & 2 & 6 & 2 & 13 \\
\hline
\end{tabular}

\begin{tabular}{|c|c|}
\hline PERCENTUAL & \\
VASOS CACTOS: & TOTAL: 6 \\
$85.7 \%$ & \\
\hline PERCENTUAL & \\
VASOS & TOTAL: 2 \\
TILLANDSIAS : & \\
$28.5 \%$ & \\
\hline
\end{tabular}

V.III-MACRO GRUPO NATURALISTAS: flora, montanha, caça de aves, ave, pantano, raposa, veado, felino, caracois

\section{FLORA (11)}

Encontramos na coleção peças cujo motivo principal é a propria flora. Segundo Donnan \& Mclelland isso começa a acontecer na fase III. Neste grupo a flora não atua como cenário mas como motivo principal do vaso.

Flora e Peças:

Neste conjunto de 11 peças encontramos uma leve predominância de representações de flora aquática, particularmente flores, com todas as quatro peças, 
36,6\%, de tema aquático contendo flores e, em uma delas, flores e totoras, ML6745 (figura V.III.a). Ulluchus também são bastante representados, aperecendo em 3 vasos, ou $27,2 \%$. Em dois desses vasos a árvores é prepresentada no corpo e macacos escultóricos aparecem no gargalo e no outro vemos apenas as frutas. Vagens de fabáceas, possivelmente algarrobo, são representadas em dois vasos. No vaso ML2441(figura V.III.b) temos um algarrobo associado a uma neoraimondia bastante naturalista com frutos. Não à toa é um vaso da fase III, com um estilo menos padronizado. Há ainda a peça ML6697 (figura V.III.c) que mostra uma planta desconhecida. A ficha do Museu Larco parece errada descrevendo uma batalha com decapitação, mas é possivel que a planta esteja relacionada com o "tumbo" encontrado na cena do pantano ou uma forma particular que ocorre em algumas cenas do dragão.

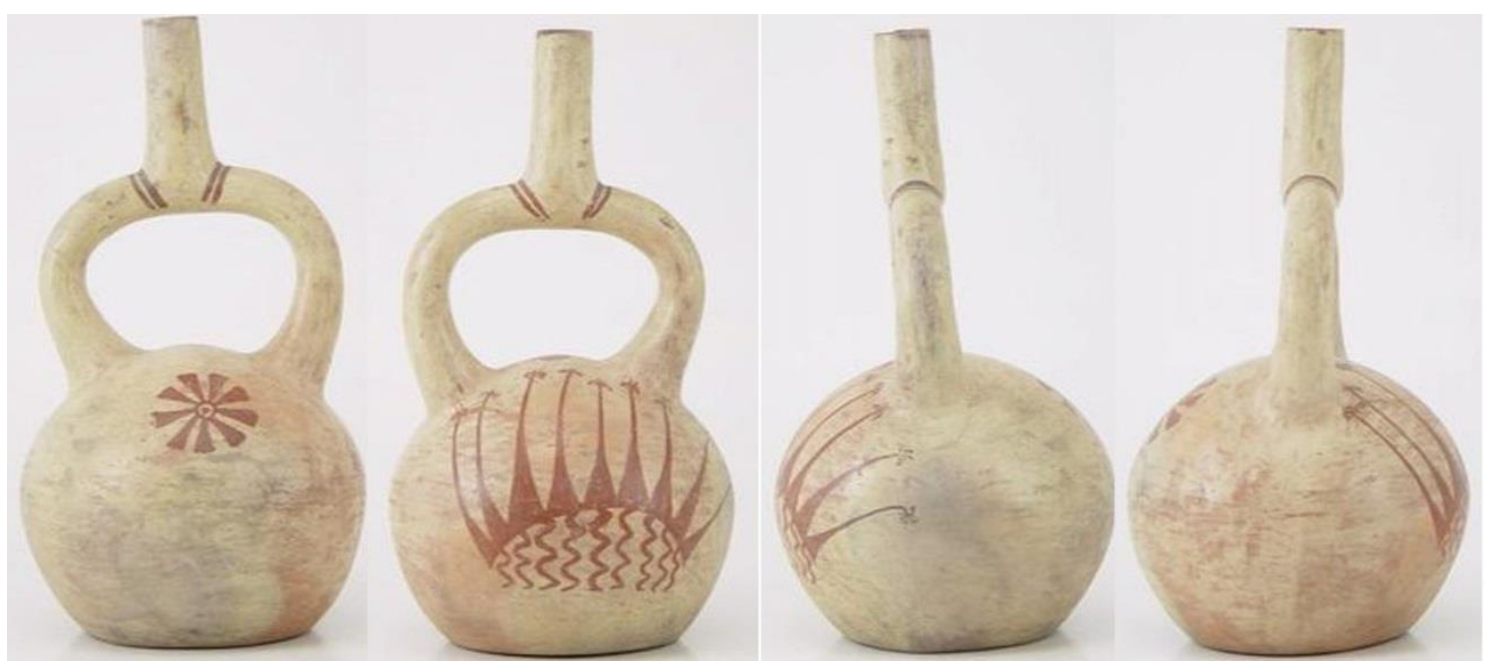

(FIGURA V.III.a) Peça ML6745 fase IV com totorais (Cortesia Museu Larco)

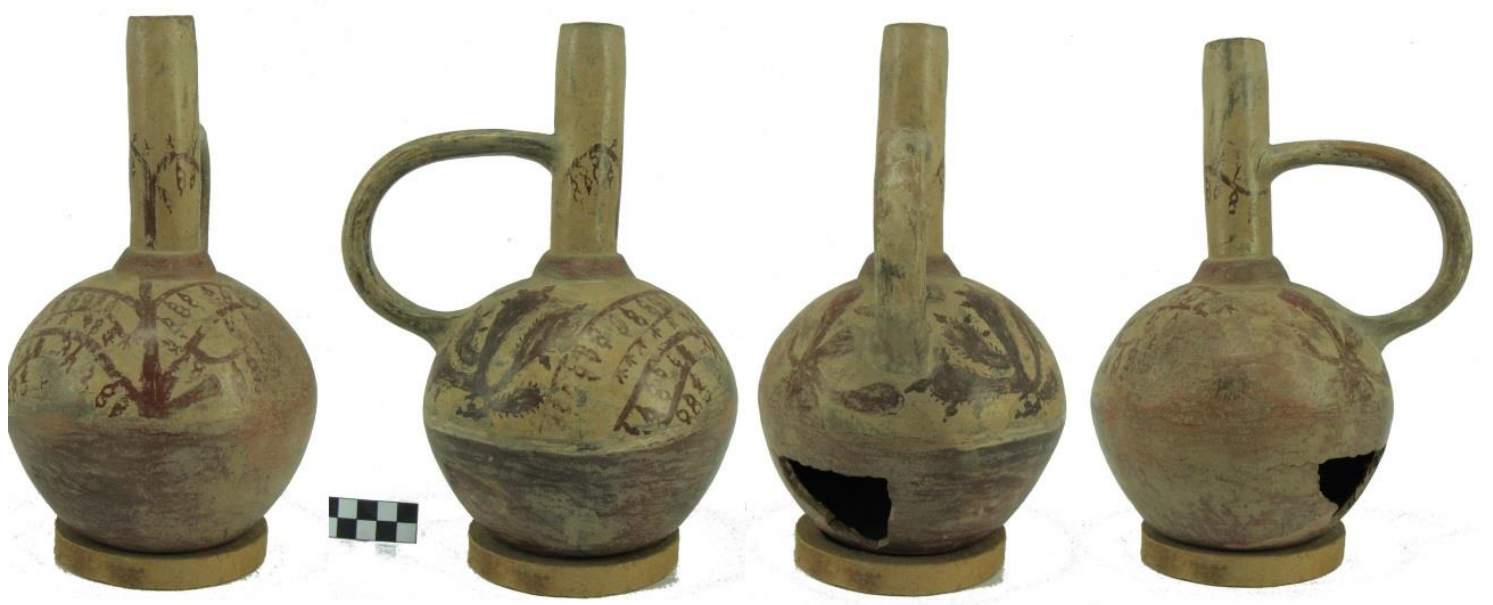

(FIGURA V.III.b) Peça ML2441 com N. Arequipensis e Algarrobo (Cortesia Museu Larco) 


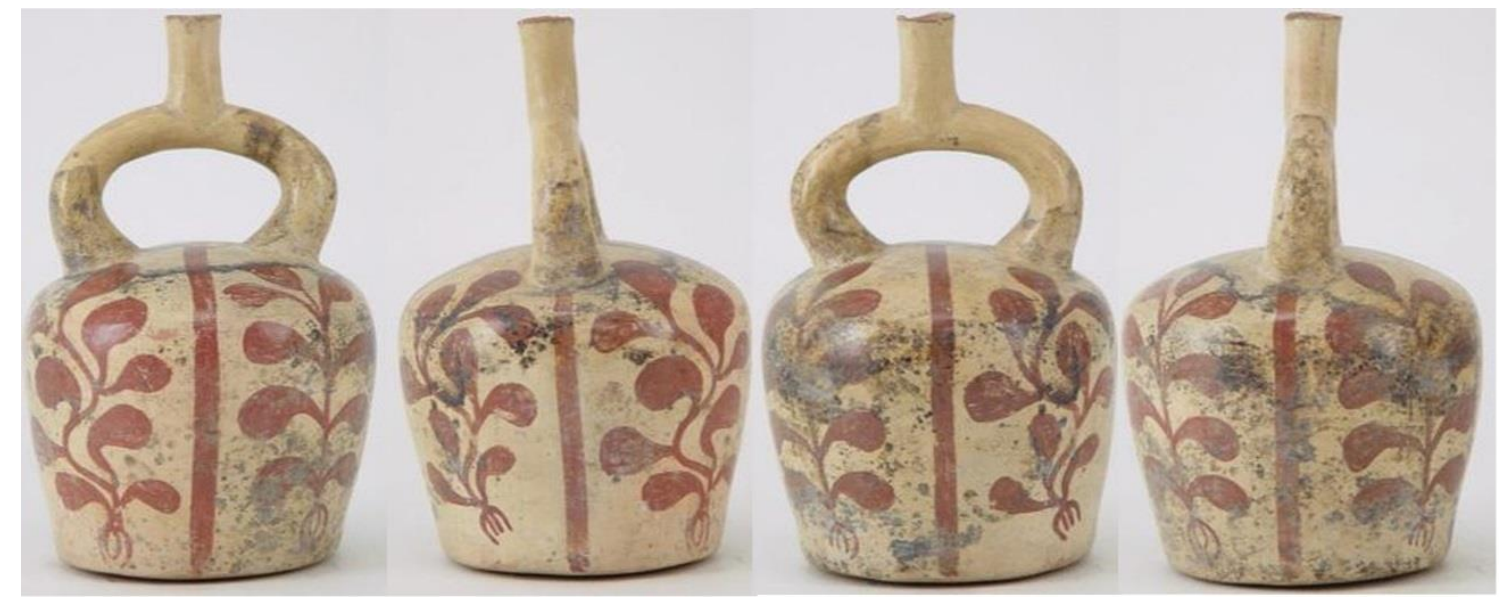

(FIGURA V.III.c) Peça ML6697 com pantas desconhecidas.(cortesia Museu Larco)

\begin{tabular}{|c|c|c|c|c|c|c|c|c|c|c|}
\hline PEÇA & $\begin{array}{l}\text { TIPO } \\
\text { DE } \\
\text { VASO }\end{array}$ & $\begin{array}{l}\text { FAS } \\
\text { E }\end{array}$ & VALE & SÍTIO & $\begin{array}{l}\text { CACT } \\
\text { O T5 }\end{array}$ & $\begin{array}{l}\text { TOTOR } \\
\text { AS }\end{array}$ & $\begin{array}{l}\text { FLORE } \\
\text { S }\end{array}$ & $\begin{array}{l}\text { ALGARRO } \\
\text { BO }\end{array}$ & $\begin{array}{l}\text { ULLUCH } \\
\text { U }\end{array}$ & $\begin{array}{l}\text { DESCONHECI } \\
\text { DO }\end{array}$ \\
\hline ML2441 & $\begin{array}{l}\text { Asa } \\
\text { lateral }\end{array}$ & III & & & 2 & & & 1 & & \\
\hline ML2442 & $\begin{array}{l}\text { Asa } \\
\text { lateral } \\
\text { escultóri } \\
\text { ca }\end{array}$ & IV & & & & & & & 1 & \\
\hline ML2443 & $\begin{array}{l}\text { Asa } \\
\text { lateral } \\
\text { escultóri } \\
\text { ca }\end{array}$ & IV & & & & & & & 1 & \\
\hline ML6504 & $\begin{array}{l}\text { Asa } \\
\text { Estribo }\end{array}$ & IV & & & & & & & 3 & \\
\hline ML6697 & $\begin{array}{l}\text { Asa } \\
\text { Estribo }\end{array}$ & IV & Virú & $\begin{array}{l}\text { San } \\
\text { Idelfons } \\
\text { o }\end{array}$ & & & & & & 4 \\
\hline ML6738 & $\begin{array}{l}\text { Asa } \\
\text { Estribo }\end{array}$ & IV & $\begin{array}{l}\text { Chicam } \\
\text { a }\end{array}$ & Sausal & & & 2 & & & \\
\hline ML6745 & $\begin{array}{l}\text { Asa } \\
\text { Estribo }\end{array}$ & IV & $\begin{array}{l}\text { Chicam } \\
\text { a }\end{array}$ & & & 2 & 1 & & & \\
\hline $\begin{array}{l}\text { ML1012 } \\
6\end{array}$ & $\begin{array}{l}\text { Asa } \\
\text { Estribo }\end{array}$ & IV & & & & & 2 & & & \\
\hline $\begin{array}{l}\text { ML1012 } \\
7\end{array}$ & $\begin{array}{l}\text { Asa } \\
\text { Estribo }\end{array}$ & IV & & & & & 2 & & & \\
\hline $\begin{array}{l}\text { ML1060 } \\
3\end{array}$ & $\begin{array}{l}\text { Asa } \\
\text { Estribo }\end{array}$ & IV & & & & & & & & $\begin{array}{l}\text { VAGENS DE } \\
\text { ALGARROBO }\end{array}$ \\
\hline $\begin{array}{l}\text { ML1073 } \\
2\end{array}$ & $\begin{array}{l}\text { Asa } \\
\text { Estribo }\end{array}$ & IV & & & & & & & & $\begin{array}{l}\text { VAGENS DE } \\
\text { ALGARROBO }\end{array}$ \\
\hline $\begin{array}{l}\text { TOTAL } \\
\text { DE } \\
\text { PEÇAS: } \\
11\end{array}$ & & & & & 2 & 2 & 7 & 1 & 5 & 4 \\
\hline
\end{tabular}




\begin{tabular}{|c|c|l|c|}
\hline $\begin{array}{c}\text { PERCENTUAL VASOS } \\
\text { AQUÁTICOS: } 36.3 \%\end{array}$ & TOTAL: 4 & $\begin{array}{l}\text { PERCENTUAL } \\
\text { VASOS } \\
\text { ALGARROBO: } \\
36.3 \%\end{array}$ & $\begin{array}{c}\text { TOTAL: } \\
3\end{array}$ \\
\hline $\begin{array}{c}\text { PERCENTUAL VASOS } \\
\text { ULLUCHU: } 27.2 \%\end{array}$ & TOTAL: 3 & $\begin{array}{l}\text { PERCENTUAL } \\
\text { VASOS: } 9.0 \%\end{array}$ & TOTAL:1 \\
\hline
\end{tabular}

MONTANHA (2)

Em duas peças encontramos montanhas escultóricas sem personagem, mas com flora representada. Estas peças podem estar referindos-se metonímicamente às cenas de sacrifício de montanhas ou podem ser elas mesmo oferendas aos deuses relacionados às montanhas. Makoswky relaciona o deus representado nos murais da huaca de la Luna, comumente chamado de Aia Paec, com um deus coruja, tectônico por natureza e dominante no mndo de abaixo (Makowsky, 2000, 148). Golte concorda que o Deus Coruja e Aia Paec, que ele nomeia de Divindade Intermediadora, estajam recebendo os sacrifícios na montanha, mas acredita que ambos são subordinados ao Deus da Via Láctea (Golte, 2009:193).

Flora e Peças:

Ambas as peças compartilham alguns traços morfológicos importantes. Têm alça lateral, algo incomum na coleção analisada, possuem aparentemente quatro picos dos quais dois estão em coloração diferente do resto do corpo e estão divididas verticalmente por uma linha horzontal sob a qual a flora é apresentada. Isso dito, na primeira, ML6770 (figura V.III.d), observamos um padrão de flora parecido com as peças de sacrifício; cactos tipo 1B, mais relacionados com gêneros e espécies colunares de ramificação basal, no geral comuns em áreas mais áridas como nos sopés das lomas. Na segunda ML6772 (figura V.III.e) a flora adquire um formato curioso. Apesar de classificado como desconhecido, suspeitamos que esta forma que se repete algumas vezes em contextos diversos esteja retratando o milho (Zea mays). É certo que o milho era plantado nos sopés da montanha e este pode ser um dos raros casos em que o milho é representado de forma pictórica. Não obstante, não é impossível que sejam representações de algum tipo de bromeliácea. 


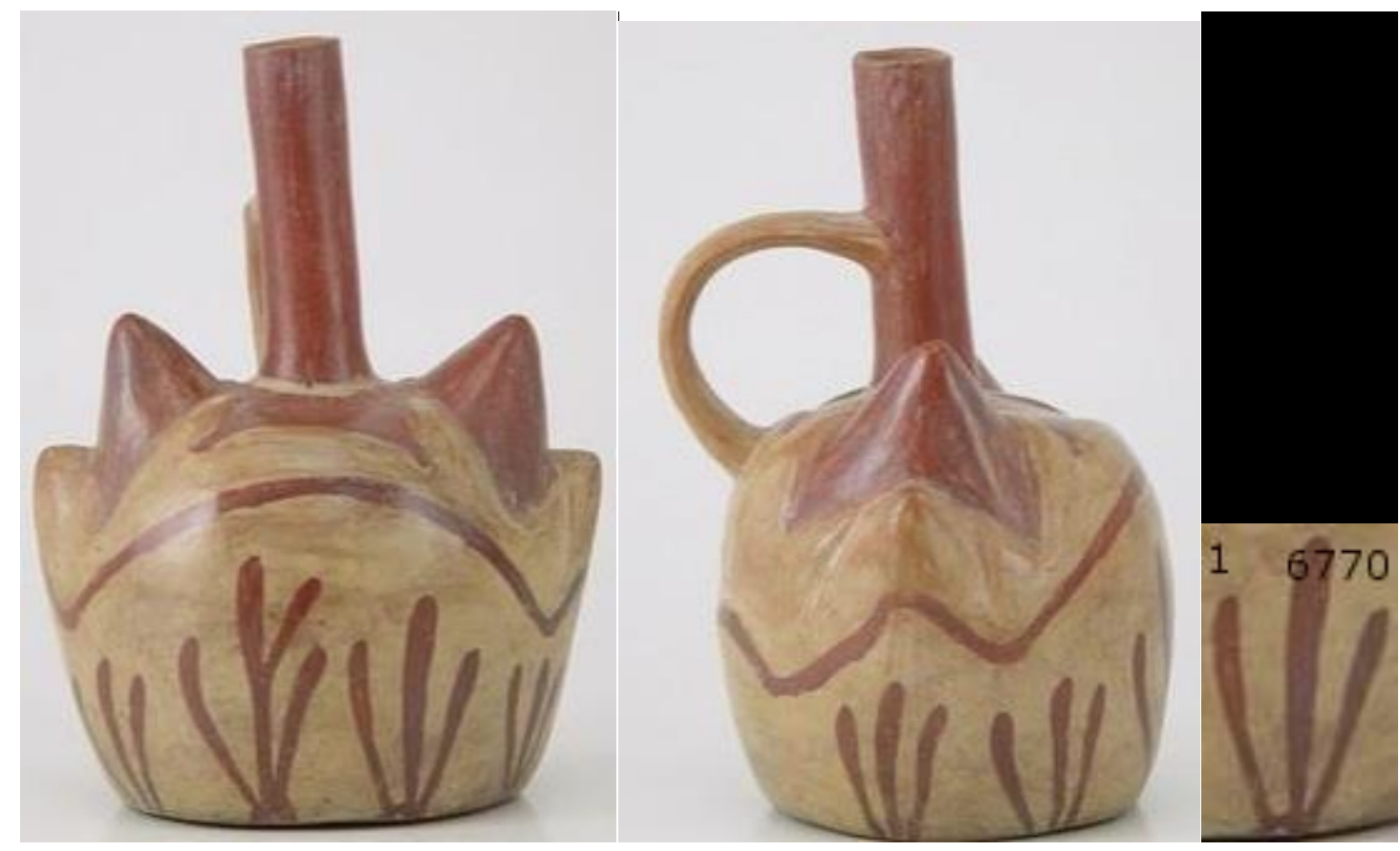

(FIGURA V.III.d) Peça Ml 6770 com CT1B (Cortesia Museu Larco)

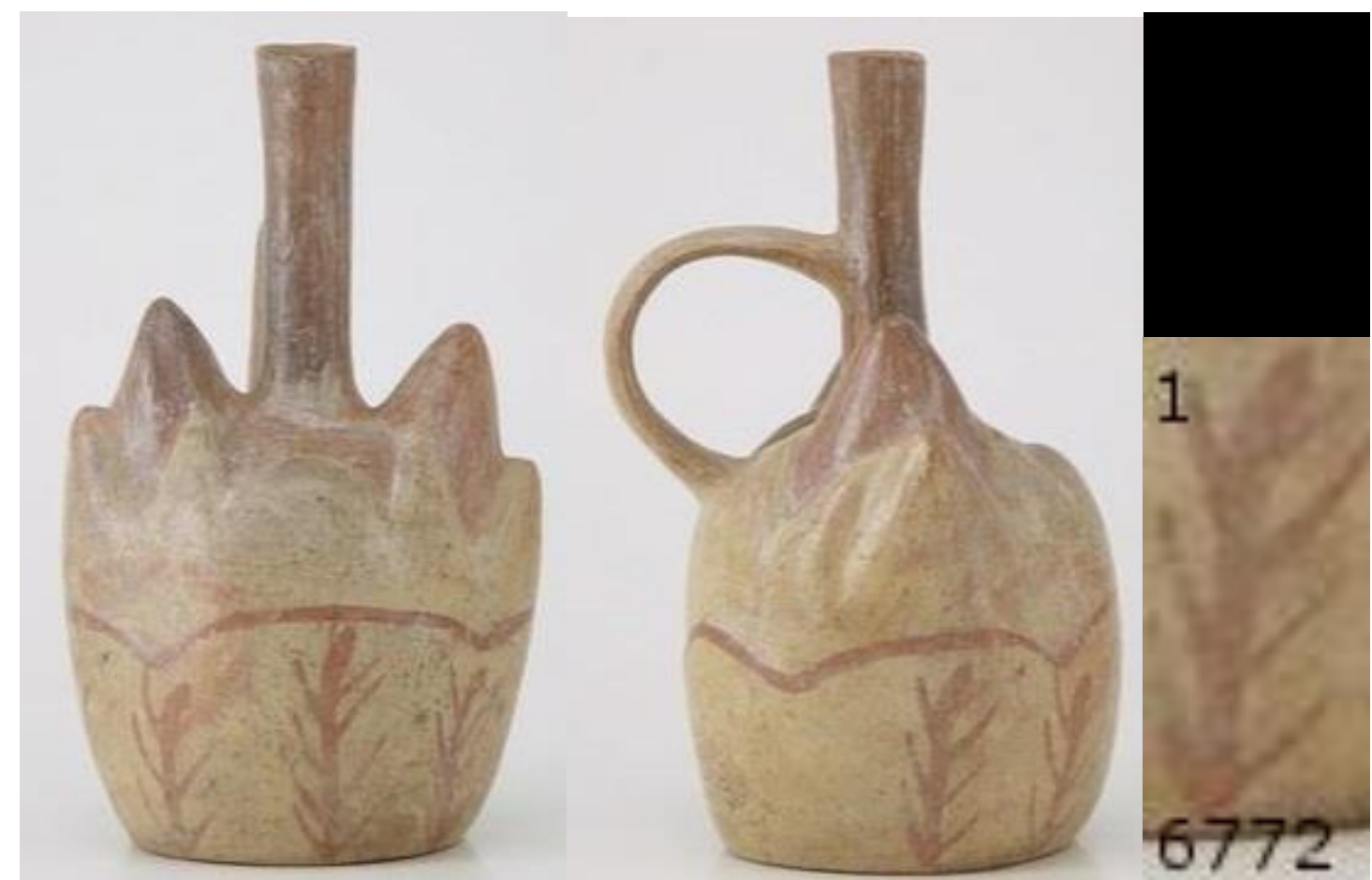

(FIGURA V.III.e) Peça Ml6772 com flora ambígua (cortesia Muesu Larco)

Ficha Simplificada

\begin{tabular}{|l|l|l|l|l|l|l|l|l|}
\hline PEÇA & CENA & $\begin{array}{l}\text { TIPO DE } \\
\text { VASO }\end{array}$ & FASE & VALE & SÍTIO & $\begin{array}{l}\text { CACTO } \\
\text { T1B }\end{array}$ & DESCONHECIDO & LOCALIZAÇÃO \\
\hline ML6770 & MONTAÑA & $\begin{array}{l}\text { Asa } \\
\text { lateral }\end{array}$ & IV & & & 7 & & CT1B: 7AB \\
\hline
\end{tabular}




\begin{tabular}{|l|l|l|l|l|l|l|l|l|}
\hline & & escultórico & & & & & & \\
\hline ML6772 & MONTAÑA & $\begin{array}{l}\text { Asa } \\
\text { lateral } \\
\text { escultórico }\end{array}$ & IV & & & & 4 & $\begin{array}{l}\text { DESCONHECIDO: } \\
\text { 4AB }\end{array}$ \\
\hline
\end{tabular}

\section{CAÇA DE AVES (2)}

A única referencia à caça de aves entre os mochica que pudemos encontrar foi em Larco (1937:149) quando afirma que os mochica caçavam com zarabatanas. É certo que há muitas peças em que o personagem "Aia Paec", ou sua versão de "gêmeo marinho, segura aves marinhas pelo pescoço. Porém cenas de caça a aves parecem raras. De fato este é um grupo que não esperávamos encontrar mas não seria possível encaixalo em nenhum outro.

Flora:

As duas peças encontradas também são bem diferentes entre si. Uma, aparentemente precoce, Moche II ou III, é extremamente peculiar e mostra uma figura humana caçando uma ave (ambos esculturados) com um tipo de zarabatana longa. É uma peça escultórica de montanha e muito provavelmente associada à caça nas lomas e a flora pictórica tem um estilo único, e por ser não recorrente podemos apenas deduzir que possivelmente seja uma representação de exemplares arbóreos.

A segunda peça já tem a morfologia asa estribo tradicional e é pintada em linha fina, no estillo clássico da fase IV. Os caçadores utilizam armamentos parecidos com os usados na caça ao veado mas sem porretes, com apenas a estólica e dardos. Estão apenas de taparrabos, brincos e alguns usam toucados que parecem ser de pano com penas e têm a faze pintada. Parecem lançar os dardos em direção a uma ave de rapina, provavelmente um falconídeo que está representado no cume do corpo e nas alças. A flora que compõe o vaso é bastante complexa, sendo composta de cactos T2 e um afloramento de cacto T1B. Todos os cactos parecem ter frutos e têm os espinhos visíveis. Os cactos T2 são mais próximos geralmente da espécie $N$. Arequipensis e mesmo o Cacto T1A apresentado na peça pode estar representando essa espécie uma vez que suas colunas são bem grossas.

Apesar de peças muito distintas entre si ambas parecem se passar nas lomas, sendo a primeira ML2136 (Figura V.III.f) escultórica com formato de montanha de três picos e a segunda, ML13613 (Figura V.III.g) possui inúmeros montículos de areia e 
linhas de solo, indicando o solo arenoso dos primeiros picos das lomas. Além disso, as aves representadas possuem traços de falconídeos e ambas podem estar representando a mesma espécie podendo ser o falconídeo Falco spacerius, encontrado em levantamento faunístico no cerro Campana (Zelada, 2014) ou, a águia pescadora (Pandion halietus) comum na costa, sendo esta última mais provável por conta de sua recorrência na iconografia mochica (ver o verbete Ave Mítica).

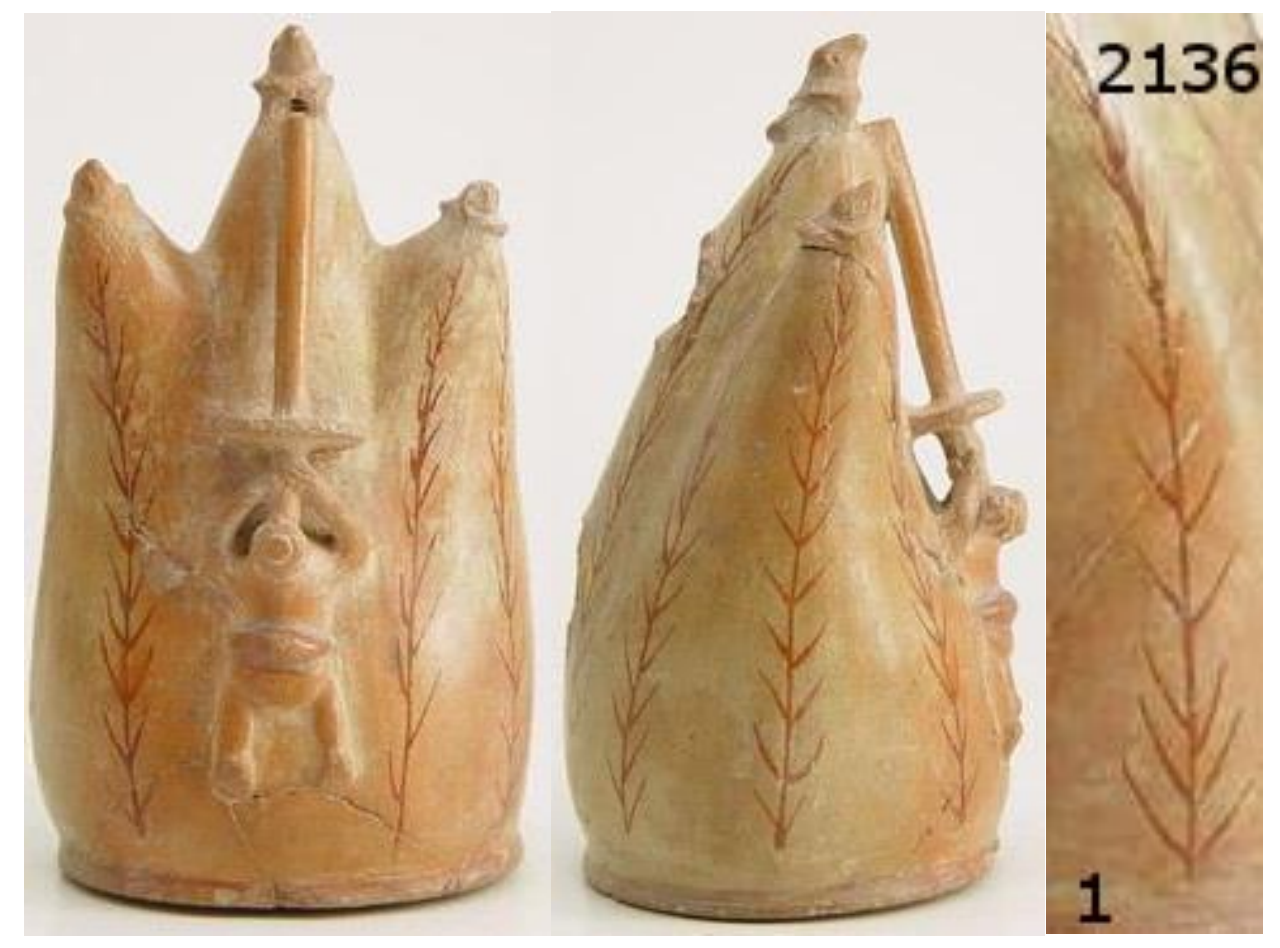

(FIGURA V.III.f) Peça ML2136 mostra homem esculturado caçando ave esculturada. À direita, close na flora pictórica. (Cortesia Museu Larco) 


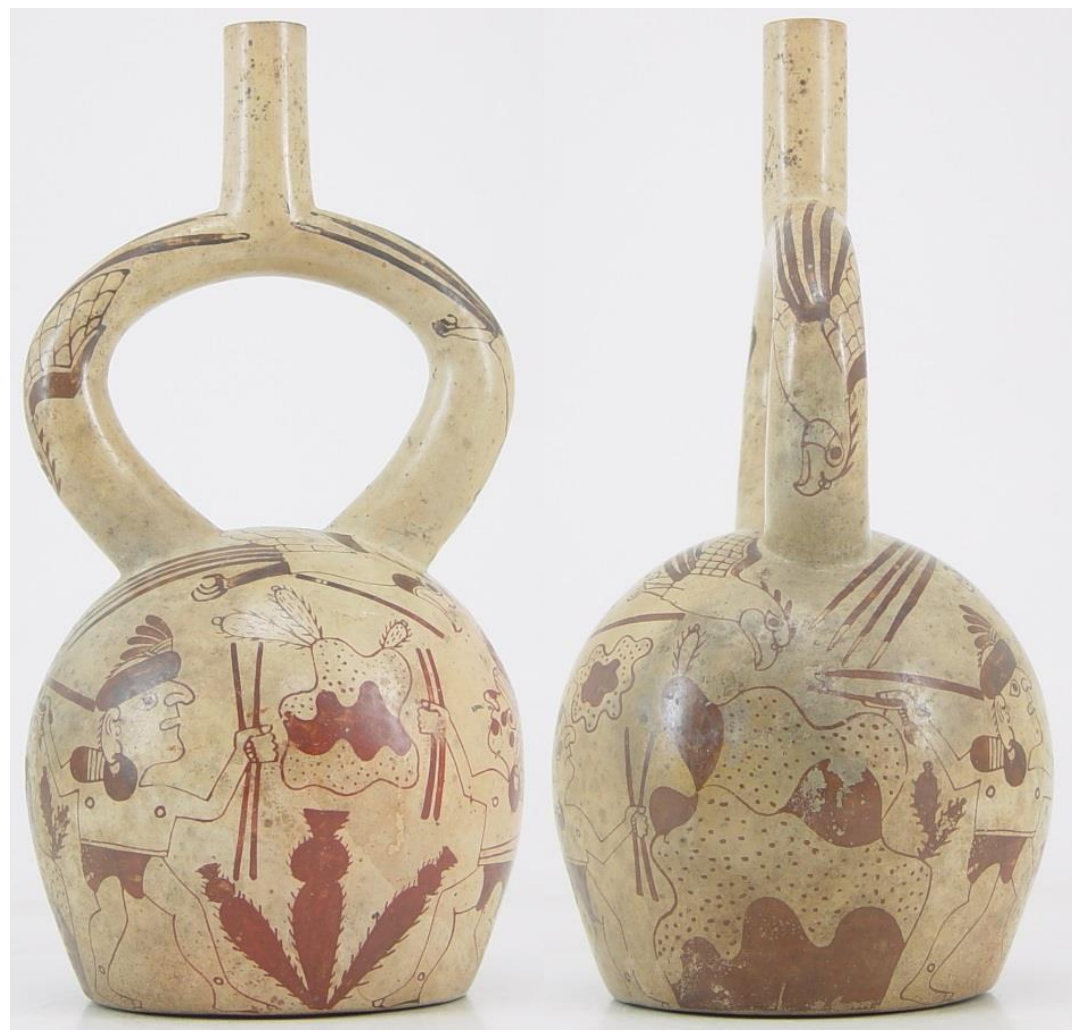

(FIGURA V.III.g ) Vaso ML13613 com caçadores e ave falconica. (Cortesia Museu Larco)

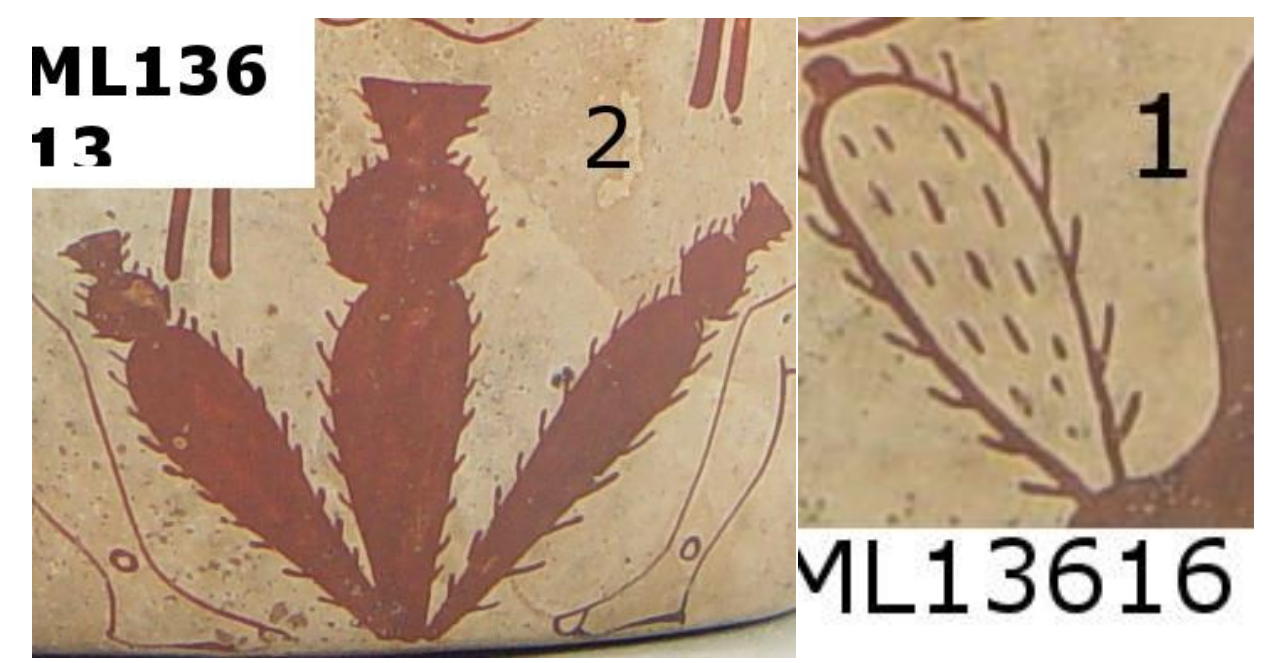

(FIGURA V.III.h) À esquerda um afloramento de Cactos T1A, com espinhos, talvez com frutos ou cefálio. À direita um Cacto T2 com fruto e espinho. É possível que ambos os tipos estejam representando a $N$. Arequipensis.

Planilha simplificada

\begin{tabular}{|l|l|l|l|l|l|l|l|l|}
\hline PEÇA & CENA & $\begin{array}{l}\text { TIPO DE } \\
\text { VASO }\end{array}$ & FASE & VALE & $\begin{array}{l}\text { CACTO } \\
\text { T1A }\end{array}$ & $\begin{array}{l}\text { CACTO } \\
\text { T2 }\end{array}$ & DESCONHECIDO & LOCALIZAÇÃO \\
\hline ML2136 & $\begin{array}{l}\text { CAZA } \\
\text { DE } \\
\text { AVES }\end{array}$ & $\begin{array}{l}\text { Asa } \\
\text { Estribo } \\
\text { lateral } \\
\text { escultórica }\end{array}$ & III & & & & 5 & DESC. 5 AB \\
\hline ML13613 & $\begin{array}{l}\text { CAZA } \\
\text { DE } \\
\text { AVES }\end{array}$ & $\begin{array}{l}\text { Asa } \\
\text { Estribo }\end{array}$ & IV & & 1 & 5 & & $\begin{array}{l}\text { CT1B: } 1 \mathrm{AB} / \mathrm{CT} 2: \\
2 \mathrm{AC}-3 \mathrm{AB}\end{array}$ \\
\hline
\end{tabular}




1

\begin{tabular}{|l|l|}
\hline 5 & 5
\end{tabular}

\begin{abstract}
AVES (22)
Este é um grupo artificial que criamos para tentar rastrear a flora associada à representação de aves representadas de forma naturalista em geral. Incluiríamos aqui as peças onde as aves estariam apenas em interação com o ambiente, sem humanos realizando alguma ação específica.
\end{abstract}

Flora e peças:

Este é um grupo de tamanho considerável, com 22 peças, e nos surpreendeu a grande predominância de cenas aquáticas. De fato, plantas aquáticas aparecem em 21 vasos, ou 95,4\% das peças. A ave mais representada é a garça ( há ao menos 7 espécies de garças na região segundo Altivez, 2012), como na peça M16743 (figura V.III.i) aparecendo em 14 vasos e, logo depois patos ou marrecos, em cinco vasos. Temos o que parecem ser mergulhões em dois. A flora é composta tipicamente de totoras acompanhadas de flores aquáticas. Peixes aparecem em alguns casos.

Apenas duas cenas mostram falconídeos esculturados, possivelmente a águia pescadora (Pandiom halietus) com flora representada no corpo do vaso. Somente uma delas ML8512 (figura V.III.j) mostra uma flora de lomas enquanto a outra apresenta uma cena aquática. Falconídeos naturalistas aparentemente também são representados nas cenas de caça de aves.

O tema aquático provavelmente influencia também a morfologia das peças uma vez que, mesmo que as peças de alça estribo ainda sejam maioria, somando 12 no total, há um grande quantidade de floreros, 4, como a peça ML6735 (figura V.III.k), e cinco vasos com a alça lateral, quatro delas simulando cântaro e uma um cântaro verdadeiro. Também é notável a grande quantidade de peças da fase III, podendo chegar a nove vasos ( temos algumas dúvidas com relação à datação de alguns). 

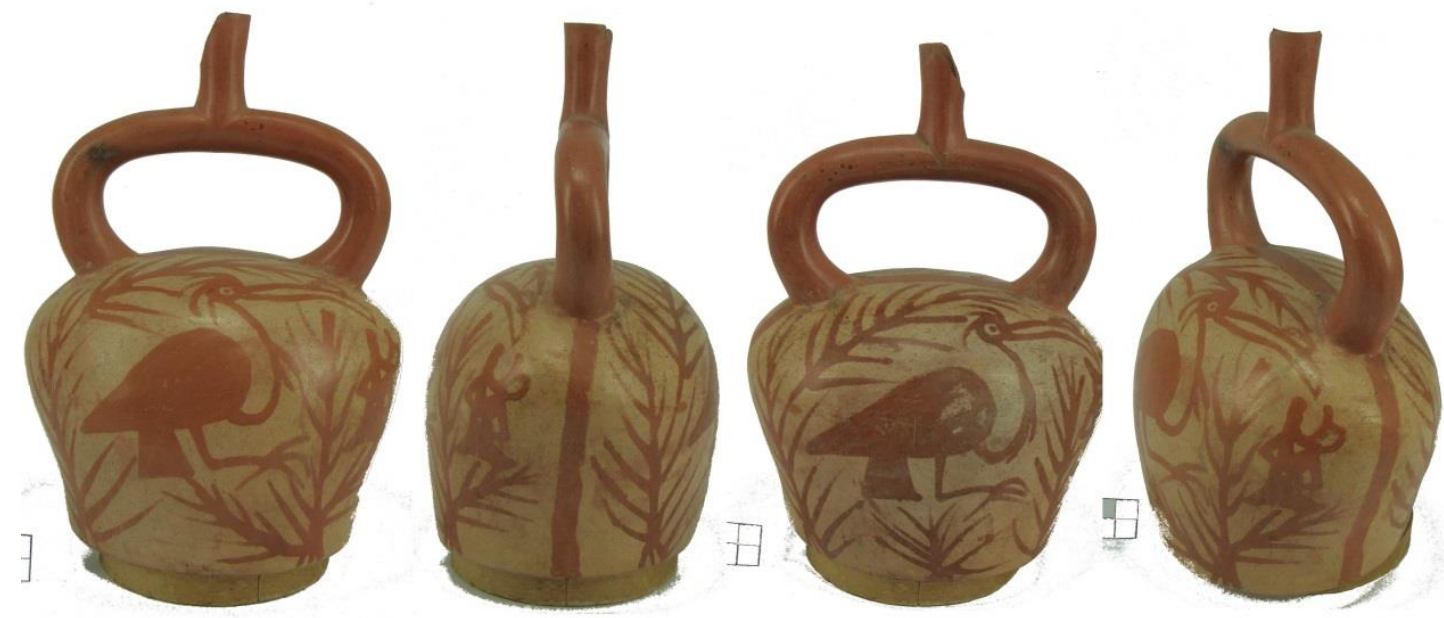

(Figura V.III.i) Peça ML6743 fase III com garça em pântano (cortesia Museu Larco)

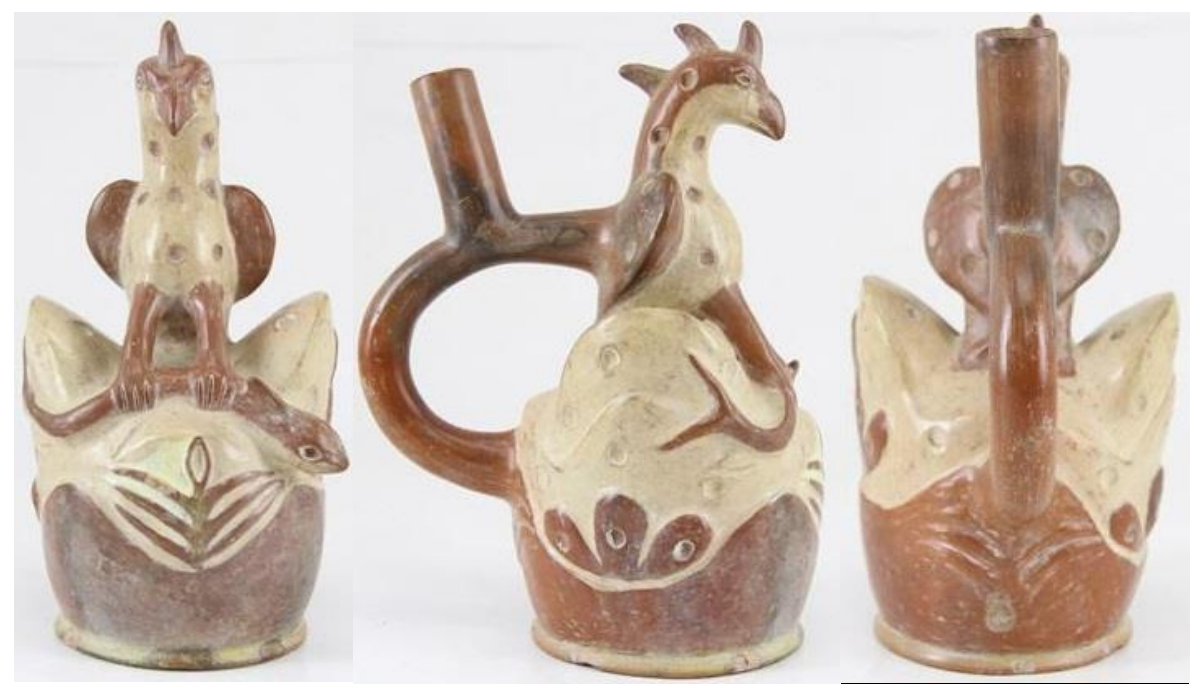

(FIGURA V.III.j) Peça ML 8512 com falconídeo esculturado segurando presa. (cortesia Museu Larco) 


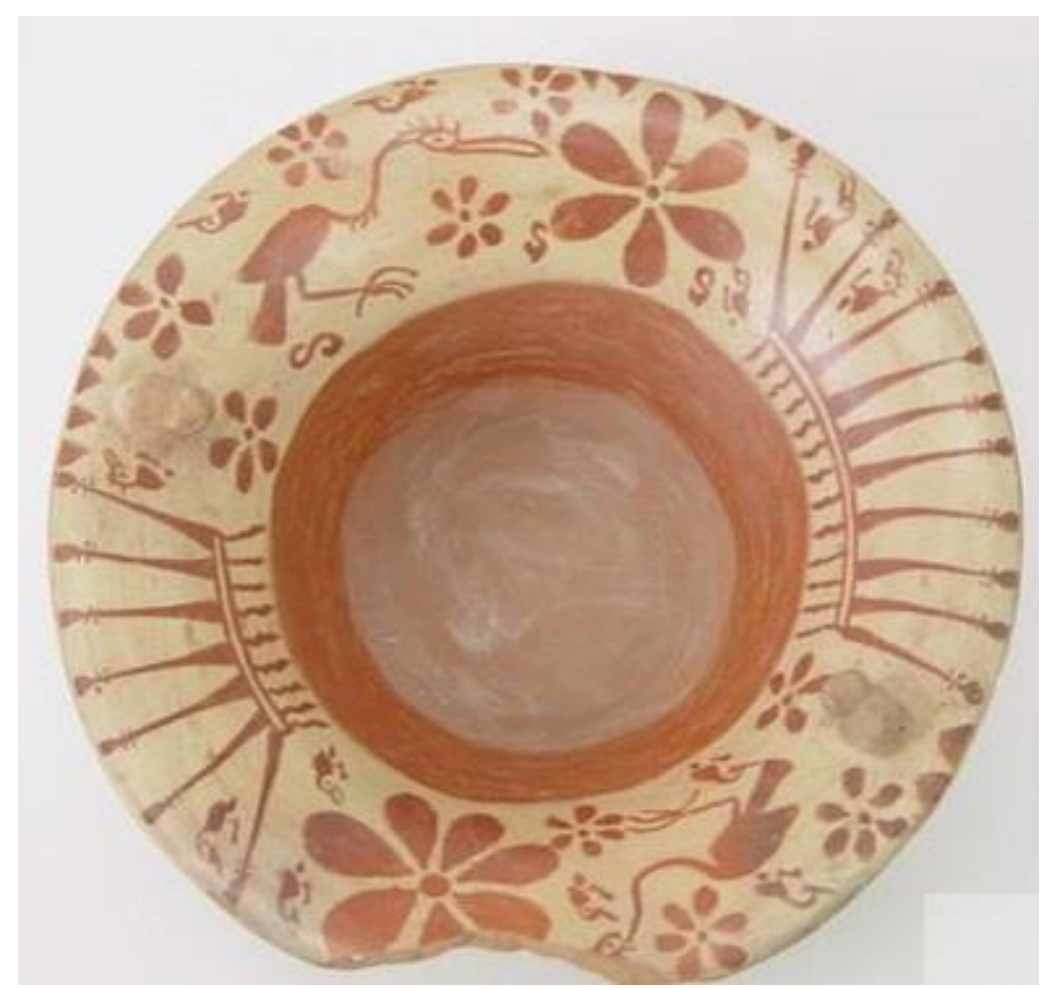

(FIGURA V.III.k) Peça Ml6735 com totoras, aves e flores. (Cortesia Museu Larco)

\begin{tabular}{|c|c|c|c|c|c|c|c|c|}
\hline PEÇA & $\begin{array}{l}\text { TIPO DE } \\
\text { VASO }\end{array}$ & FASE & VALE & SÍTIO & $\begin{array}{l}\text { CACTO } \\
\text { T2 }\end{array}$ & TILLANDSIAS & TOTORAS & FLORES \\
\hline ML6735 & FLORERO & III & & & & & 2 & 11 \\
\hline ML6741 & Asa Lateral & IV & SANTA & TANGUCHE & & & 2 & 6 \\
\hline ML6743 & $\begin{array}{l}\text { Asa } \\
\text { Estribo }\end{array}$ & III & & & & & 4 & \\
\hline ML6744 & $\begin{array}{l}\text { Asa } \\
\text { Estribo }\end{array}$ & III & & & & & 2 & 3 \\
\hline ML6746 & Cantaro & $\begin{array}{ll}\text { III } & - \\
\text { IV }\end{array}$ & & & & & 1 & 2 \\
\hline ML6747 & FLORERO & IV & MOCHE & $\begin{array}{l}\text { HUACA } \\
\text { DEL SOL }\end{array}$ & & & 3 & 3 \\
\hline ML6752 & $\begin{array}{l}\text { Botella } \\
\text { Gollete } \\
\text { Asa } \\
\text { Estribo }\end{array}$ & IV & Chicama & & & & 6 & 6 \\
\hline ML6753 & $\begin{array}{l}\text { Asa } \\
\text { Estribo } \\
\text { Lateral } \\
\text { Escultórica }\end{array}$ & IV & Chicama & Facalá & & & 1 & 1 \\
\hline ML6755 & $\begin{array}{l}\text { Asa } \\
\text { Estribo } \\
\text { Lateral } \\
\text { Escultórica } \\
\text { Cántaro }\end{array}$ & IV & & & & & 2 & \\
\hline
\end{tabular}




\begin{tabular}{|c|c|c|c|c|c|c|c|c|}
\hline ML6757 & $\begin{array}{l}\text { Asa } \\
\text { Estribo } \\
\text { Lateral } \\
\text { Escultórica } \\
\text { Cántaro }\end{array}$ & IV & & & & & 1 & \\
\hline ML6759 & $\begin{array}{l}\text { Asa } \\
\text { Estribo }\end{array}$ & IV & Chicama & Facalá & & & 2 & 2 \\
\hline ML7609 & Florero & III & & & & & & 4 \\
\hline ML7618 & FLORERO & III & & & & & 4 & \\
\hline ML8512 & $\begin{array}{l}\text { Asa } \\
\text { Estribo } \\
\text { escultórico }\end{array}$ & IV & & & 2 & 2 & & \\
\hline ML8518 & $\begin{array}{l}\text { Asa } \\
\text { Estribo } \\
\text { escultórico }\end{array}$ & IV & Chicama & Chiquitoy & & & 2 & \\
\hline ML8521 & $\begin{array}{l}\text { Asa } \\
\text { Estribo }\end{array}$ & $\begin{array}{l}\text { III- } \\
\text { IV (?) }\end{array}$ & & & & & & 4 \\
\hline ML8523 & $\begin{array}{l}\text { Asa } \\
\text { Estribo }\end{array}$ & IV & & & & & & 1 \\
\hline ML8707 & $\begin{array}{l}\text { Asa } \\
\text { Estribo }\end{array}$ & III & & & & & 3 & 6 \\
\hline ML8719 & $\begin{array}{l}\text { Asa } \\
\text { Estribo }\end{array}$ & IV & MOCHE & $\begin{array}{l}\text { HUACA } \\
\text { DEL SOL }\end{array}$ & & & & 3 \\
\hline ML8721 & $\begin{array}{l}\text { Asa } \\
\text { Estribo }\end{array}$ & $\begin{array}{l}\text { III(?) } \\
\text { IV (?) }\end{array}$ & & & & & & 5 \\
\hline ML8926 & $\begin{array}{l}\text { Asa } \\
\text { Estribo }\end{array}$ & III & Chicama & $\begin{array}{l}\text { Casa } \\
\text { quemada/ } \\
\text { Sausal }\end{array}$ & & & & 2 \\
\hline ML9214 & $\begin{array}{l}\text { Asa } \\
\text { Estribo }\end{array}$ & III & Chicama & Chiquitoy & & & 1 & \\
\hline $\begin{array}{l}\text { TOTAL } \\
\text { DE } \\
\text { PEÇAS: } \\
22\end{array}$ & & & & & 2 & 2 & 36 & 59 \\
\hline
\end{tabular}

\begin{tabular}{|c|c|}
\hline & \\
PERCENTUAL & \\
VASOS & TOTAL: 21 \\
AQUÁTICAS: & T5.4\% \\
& \\
\hline
\end{tabular}




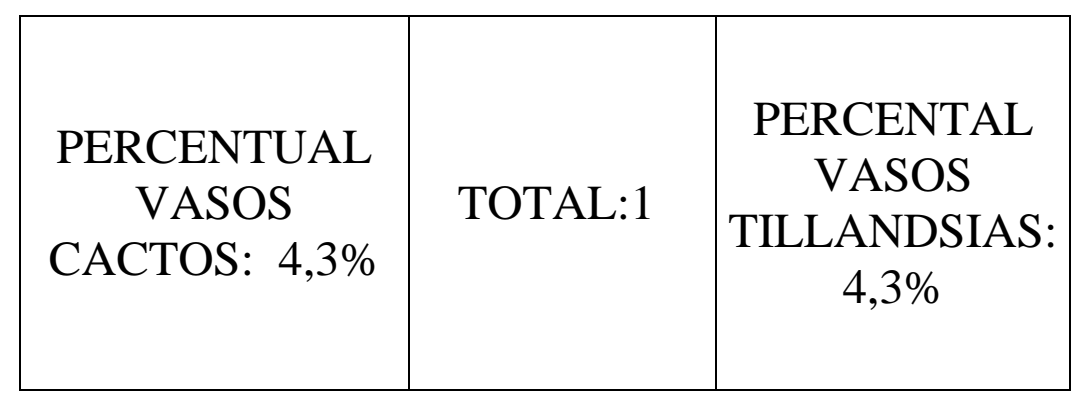

\section{PÂNTANO (5)}

Quase todas as cenas que representam zonas alagadas contém aves naturalistas, principalmente garças. Entretanto, umas poucas, (5) aparecem sem as aves. Nestas temos uma associação com rãs ou sapos, peixes e uma lagosta.

Como já discutido na cena de Badminton, para Hocquenghem (1987: 56) as plantas aquáticas e a água doce são relacionadas a rituais de purificação inca e atuais. As rãs parecem ter uma forte relação com mitos de fertilidade, umidade e terra úmida em todo mundo andino (idid.) e Golte ainda as associa a flores de lótus ou ninpheias (2009: 172). Lagostas, para o autor estariam associadas ao limiar entre o mar e a terra e o peixe, por fim com o mundo subaquático.

Flora e peças:

O conjunto da flora deste grupo é bastante simples. Por um lado temos duas peças, M16544 e M16545 (figura V.III.1) na qual sapos ou rãs esculturados aparecem abaixo de uma planta classificada pelo museus como "tumbo" (Passiflora spp), cuja natureza já foi discutida no capítulo passado. Importante lembrar que as peças também possuem alça lateral.

Do outro lado temos três peças que mostram totoras associadas a uma lagosta em um caso e a peixes em outros dois. Seguindo a tendência do grupo das aves, duas dessas peças têm alça estribo lateral e uma simula uma boca de cântaro. A peça ML6742(figura V.III.m) é possivelmente fase III ou de origem diversa das outras. 


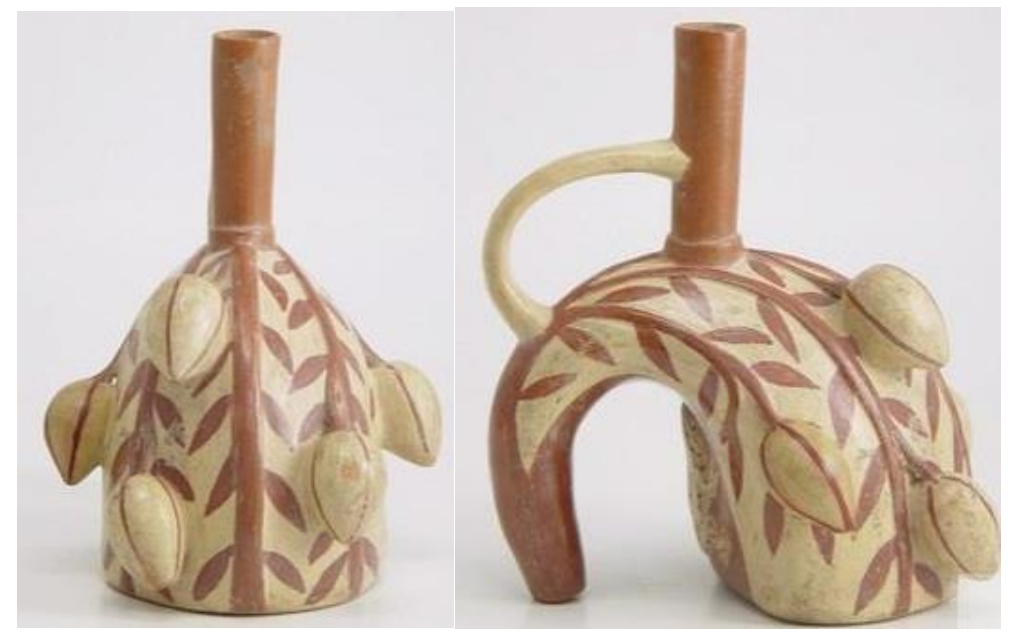

(FIGURA V.III.l) Peça ML6545 em formato de tumbo (cortesia Museu Larco)

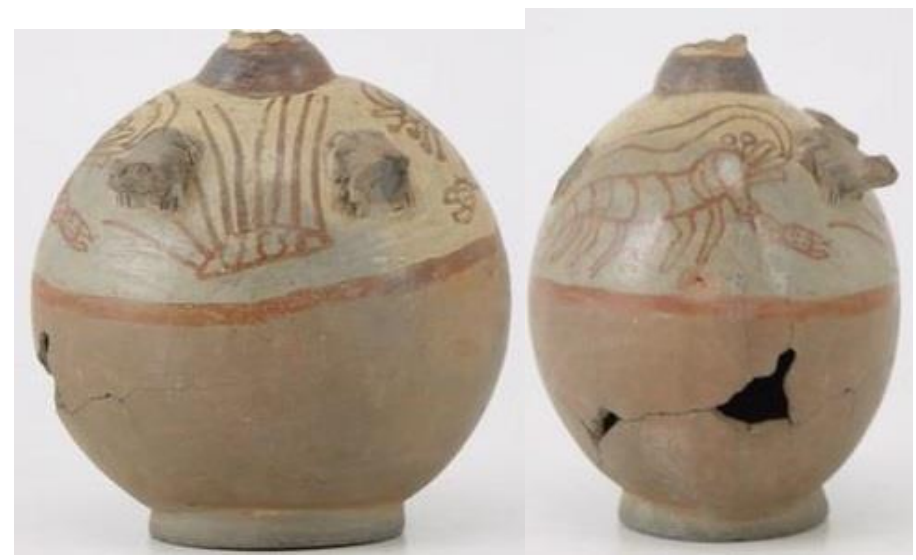

(FIGURA V.III.m) Peça ML6742 figurando lagosta. (Cortesia Museu Larco)

\begin{tabular}{|c|c|c|c|c|c|c|c|}
\hline PEÇA & $\begin{array}{ll}\text { TIPO } & \text { DE } \\
\text { VASO } & \end{array}$ & FASE & VALE & SÍTIO & TOTORAS & FLORES & DESCONHECIDO \\
\hline ML6544 & $\begin{array}{l}\text { Asa Estribo } \\
\text { lateral } \\
\text { escultórico }\end{array}$ & IV & & & & & 1 TUMBO \\
\hline ML6545 & $\begin{array}{l}\text { Asa Estribo } \\
\text { lateral } \\
\text { escultórico }\end{array}$ & IV & & & & & 1 TUMBO \\
\hline ML6742 & $\begin{array}{ll}\text { Asa } & \text { Estribo } \\
\text { lateral } & \end{array}$ & III & & & 1 & & \\
\hline ML6749 & Asa Estribo & IV & & & 2 & & \\
\hline ML6758 & $\begin{array}{l}\text { Asa Estribo } \\
\text { Cantaro }\end{array}$ & IV & & & 2 & & \\
\hline $\begin{array}{l}\text { TOTAL DE } \\
\text { PEÇAS: } 5\end{array}$ & & & & & 5 & & 2 \\
\hline
\end{tabular}




\section{FELINO (6)}

Temos um pequeno conjunto de peças (6) em que um animal carnívoro aparece de forma naturalista e é apresentado no catálogo do museu como "felino". Como discutido por Cassia Bars em sua tese de mestrado (2009) a exatidão de muitas características consideradas oriundas de felinos é contextável. Em nosso pequeno conjunto há animais que podem ser possivelmente onças, jaguatiricas, pumas e principalmente raposas. Entretanto buscamos aqui seguir a classificação do museu para seguir uma coerência metodológica.

Possivelmente influenciados pela profusão de relatos etnológicos e etnohistóricos provenientes das terras baixas amazônicas e da américa central, os arqueólogos estudiosos dos andes, incluindo Larco, classificaram as presas quase onipresentes nas divindades andinas do período inicial até o horizonte tardio, como traços felídeos. Todavia, estes traços, como demonstrou Bars podem ser oriundos de associações com caninos de canídeos ou, talvez o mais provável, pinípedes como o lobo marinho (Bars, 2009).

De qualquer forma, pela pesquisa atual é possível constatar que, ao menos quando de forma naturalística e associada a flora em vasos pictóricos, representações de felínos são consideravelmente raras.

Flora e Peças:

Este é um grupo pequeno e bastante homogêneo. A começar, todos os vasos são alça estribo. Dois são aparentemente fase III enquanto os outros quatro são fase IV. Em três vasos temos felinos com manchas, M17685, ML7691 e ML7694, o que pode estar caracterizando onças ou jaguatiricas e em outros dois, ML8225 e M18546 (figura V.III.n) os felinos possuem uma faixa escura nas costas. Estas figuras são exatamente iguais às classificadas como "raposa", mas preferimos mantê-las no grupo dos felinos. Neste último o felino aparece acompanhado de uma coruja com uma face levemente antropomorfizada.

O padrão da flora é bem claro no grupo: $100 \%$ de cactos, sendo a grande maioria deles tipo 1, 2 e 5, que correspondem às espécies colunares de ramificação basal como os gêneros haageocereus, esposotoa ou neoraimondia. A associação com climas áridos parece bastante enfática uma vez que três desses vasos ainda trazem linhas de solo e montículos representado solos arenosos. Um excessão seria o vaso da fase III ML6775 (figura V.III.o) que mostra um vaso tipo 4, associado à opuntia quitensins, cujo habitat 
é a parte úmida das lomas e a um caracol, também típico das partes altas desses ecosistemas.
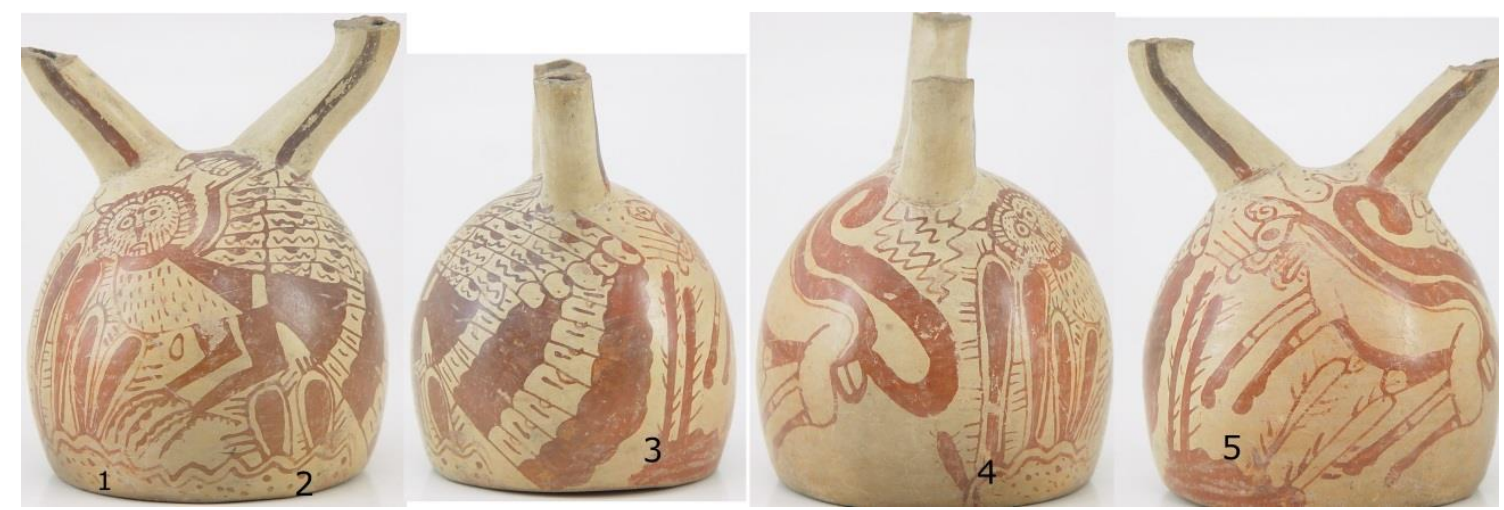

(FIGURA V.III.n) Peça ML8546 com "felino" e coruja. (cortesia Museu Larco)

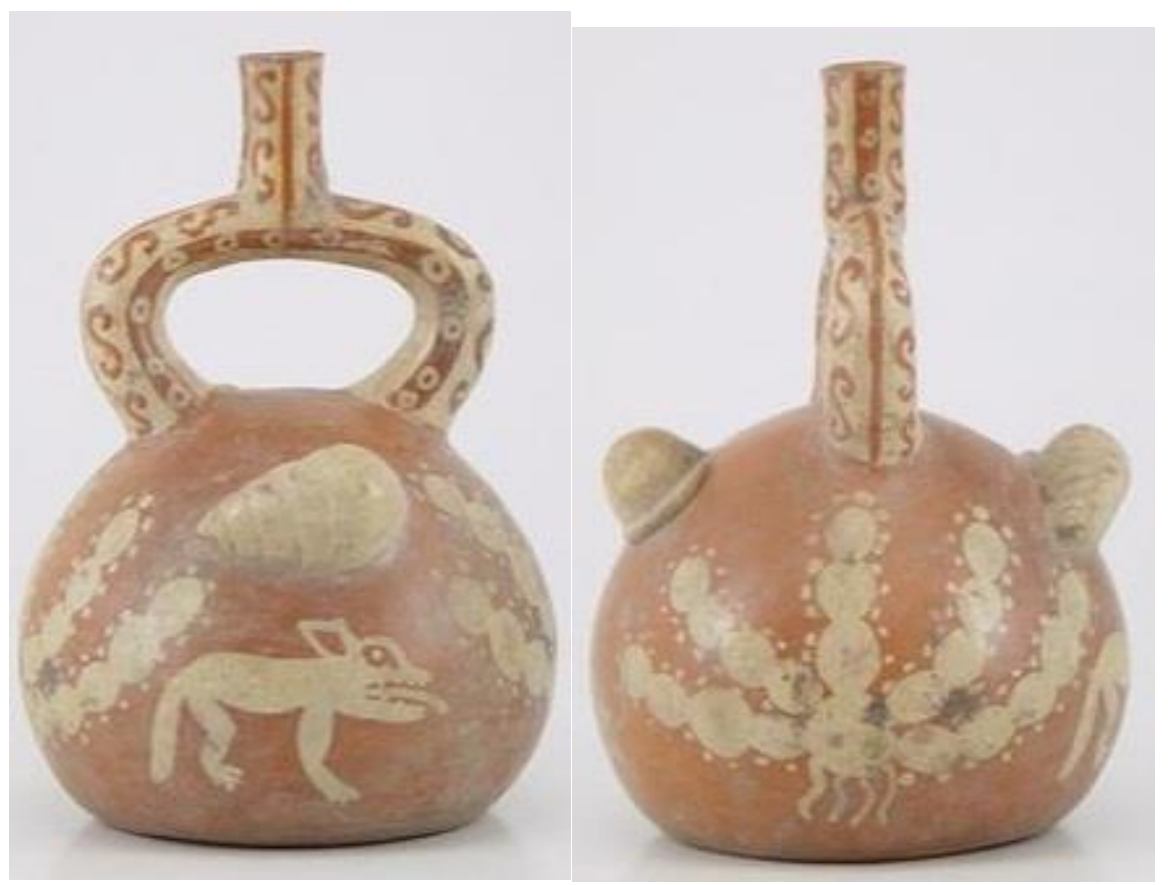

(FIGURA V.III.o) Peça ML6775 com CT4. (Cortesia Museu Larco)

Ficha simplificada:

\begin{tabular}{|l|l|l|l|l|l|l|l|l|l|l|}
\hline PEÇA & $\begin{array}{l}\text { TIPO } \\
\text { DE } \\
\text { VASO }\end{array}$ & FASE & VALE & SÍ́TIO & $\begin{array}{l}\text { CACTO } \\
\text { T1A }\end{array}$ & $\begin{array}{l}\text { CACTO } \\
\text { T1B }\end{array}$ & $\begin{array}{l}\text { CACTO } \\
\text { T2 }\end{array}$ & $\begin{array}{l}\text { CACTO } \\
\text { T2B }\end{array}$ & $\begin{array}{l}\text { CACTO } \\
\text { T4 }\end{array}$ & $\begin{array}{l}\text { CACTO } \\
\text { T5 }\end{array}$ \\
\hline ML6775 & $\begin{array}{l}\text { Asa } \\
\text { Estribo }\end{array}$ & III & & & & & & & $\mathbf{2}$ & \\
\hline ML7685 & $\begin{array}{l}\text { Asa } \\
\text { Estribo }\end{array}$ & III & Chicama & Facalá & & $\mathbf{2}$ & & & & \\
\hline ML7691 & $\begin{array}{l}\text { Asa } \\
\text { Estribo }\end{array}$ & IV & Virú & Salinas & $\mathbf{2}$ & & & & & \\
\hline
\end{tabular}




\begin{tabular}{|l|l|l|l|l|l|l|l|l|l|l|}
\hline ML7694 & $\begin{array}{l}\text { Asa } \\
\text { Estribo }\end{array}$ & IV & Chicama & $\begin{array}{l}\text { El } \\
\text { Brujo }\end{array}$ & & $\mathbf{9}$ & & & & $\mathbf{2}$ \\
\hline ML8225 & $\begin{array}{l}\text { Asa } \\
\text { Estribo }\end{array}$ & IV & & & & $\mathbf{1}$ & & & & \\
\hline ML8546 & $\begin{array}{l}\text { Asa } \\
\text { Estribo }\end{array}$ & IV & Chicama & & $\mathbf{2}$ & & $\mathbf{5}$ & $\mathbf{2}$ & & \\
\hline $\begin{array}{l}\text { TOTAL } \\
\text { DE } \\
\text { PEÇAS: } \\
6\end{array}$ & & & & $\mathbf{4}$ & $\mathbf{1 2}$ & $\mathbf{5}$ & $\mathbf{2}$ & $\mathbf{2}$ & $\mathbf{2}$ \\
\hline
\end{tabular}

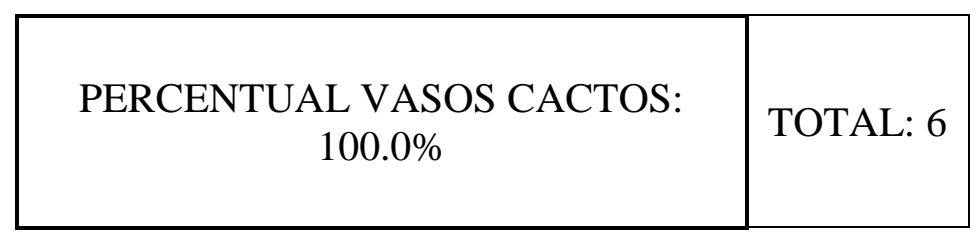

\section{RAPOSA (15)}

Frequentemente encontramos raposas representadas nos vasos de linha fina associadas à flora. Benson (2012:25) identifica a raposa costeira (Pseudalopex sechurae) como provável candidata à inspiração mochica. Raposas são associadas à cena da corrida dos feijões (ver corrida) e também podem ser guerreiros antropomorfizados (ver guerreiro vigilante) e a cenas de sacrifício (Benson, 2012:45).

Como já dito no tópico do felino, raposas estão muito próximas iconograficamente dos felinos e podem ter sido vistas como pertencente a família dos felinos pelos mochica. Golte(2009: 36) pensa que os mochica os viam como animais liminais que caminhavam entre a fronteira do dia e da noite, sendo a faixa escura sobre sua cauda em contraste com o resto do corpo um sinal dessa divisão.

Flora e peças:

É um grupo de tamanho considerável, com 15 peças, nas quais podemos ver, tal qual nas peças com felino, uma grande associação com cactos, principalmente tipo $1 \mathrm{e}$ 2. Porém, talvez por ser um grupo maior, também encontramos um percentual minoritário de vasos com tillandsias, 6 vasos ou $40 \%$ do total. Há ainda plantas que não puderam ser classificadas em dois casos, mas ao menos no caso da peça ML8065 (figura V.III.q) é provável que sejam tillandsias representadas de forma mais livre, já 
que se trata de um vaso da fase III.

Há um grande número relativo (5) de vasos que são provavelmente fase III o que pode indicar uma preferência deste tema nesta fase. Ainda é possível ver reforçada a associação com a cena da corrida, mais especificamente com o momento do jogo dos feijões, pois no vaso ML2437 (Figura V.III.r) vemos um feijão antropomorfisado sentado ao lado de uma raposa naturalista.

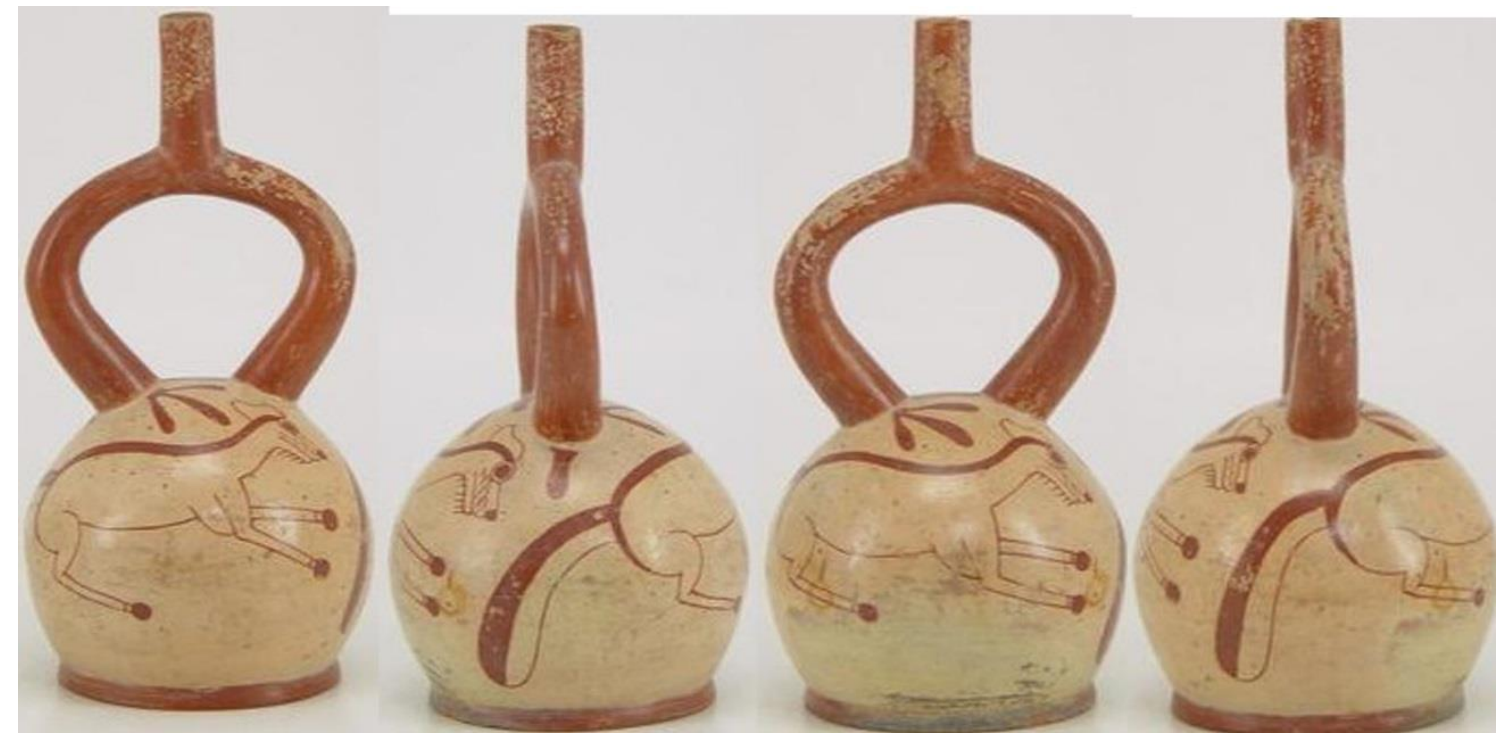

(FIGURA V.III.p) Peça ML8063 com cactos TIB ( Cortesia Museu Larco)

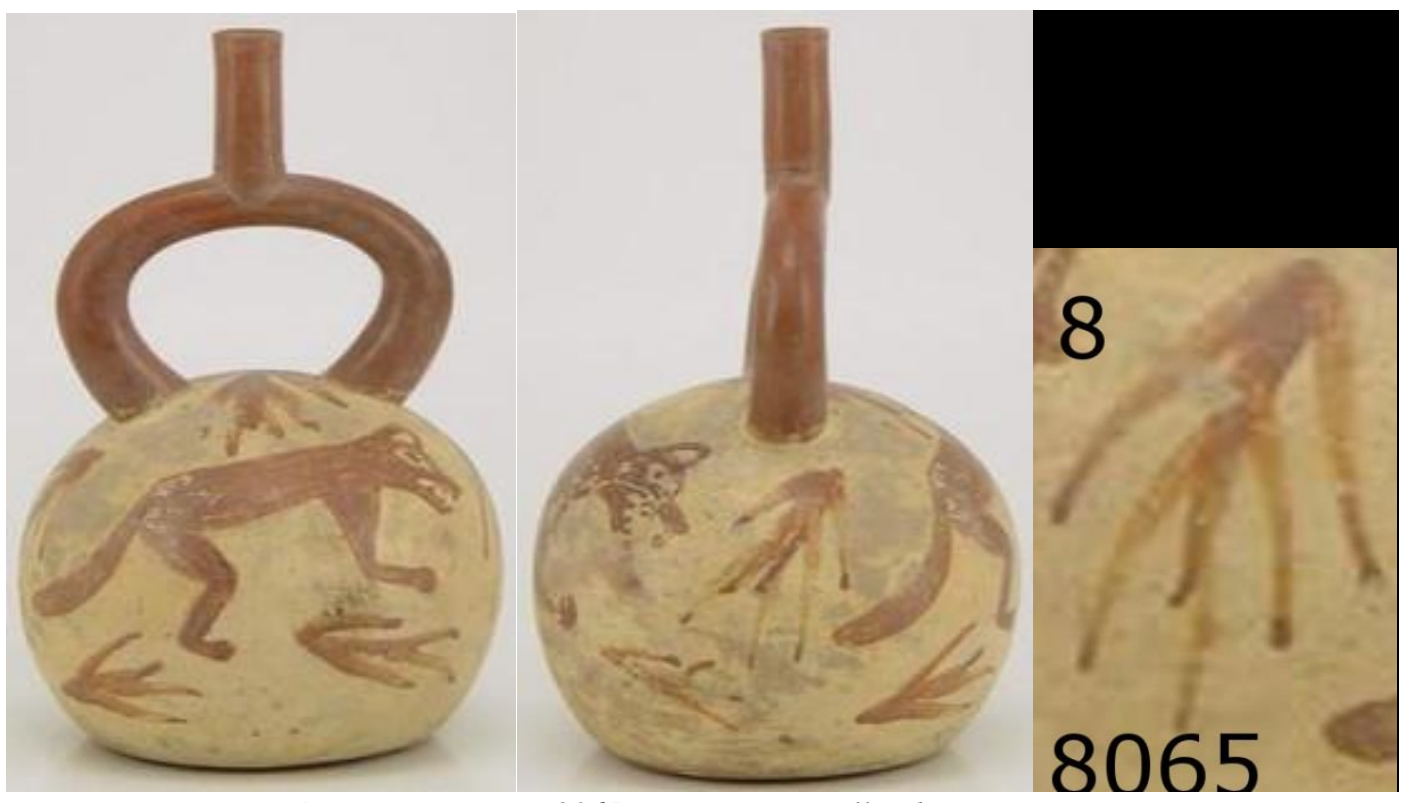

(FIGURA V.III.q) PeçaML8065 com possíveis tillandsias (cortesia Museu Larco) 


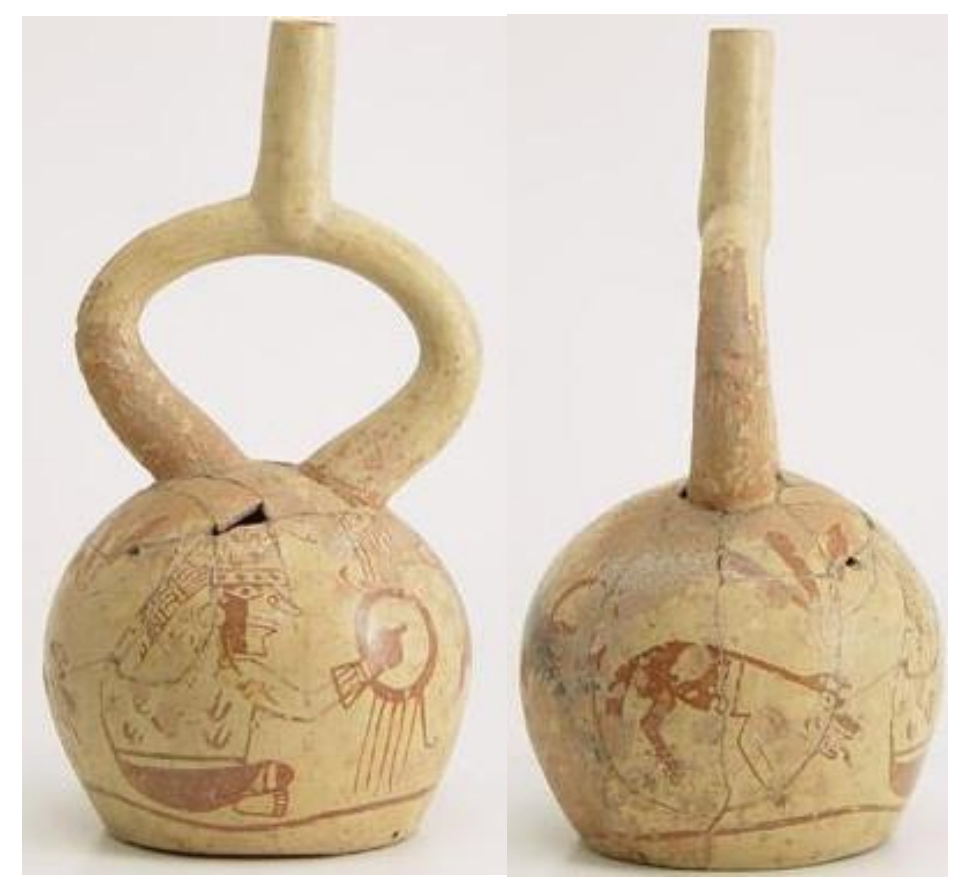

(FIGURA V.III.r) Peça Ml2437 com feijão antropomorfo (cortesia museu larco)

Ficha Simplificada:

\begin{tabular}{|c|c|c|c|c|c|c|c|c|c|c|}
\hline PEÇA & TIPO & FASE & $\begin{array}{l}\text { VAL } \\
\text { E }\end{array}$ & SÍTIO & $\begin{array}{l}\text { CACT } \\
\text { O T1A }\end{array}$ & $\begin{array}{l}\text { CACTO } \\
\text { T1B }\end{array}$ & $\begin{array}{l}\text { CACTO } \\
\text { T2 }\end{array}$ & $\begin{array}{l}\text { CACTO } \\
\text { T4 }\end{array}$ & $\begin{array}{l}\text { TILLA } \\
\text { NDSIA } \\
\text { S }\end{array}$ & $\begin{array}{l}\text { DESCON } \\
\text { HECIDO }\end{array}$ \\
\hline $\begin{array}{l}\text { ML219 } \\
7\end{array}$ & $\begin{array}{l}\text { Asa } \\
\text { Estribo }\end{array}$ & III & & & & 2 & & & 2 & \\
\hline $\begin{array}{l}\text { ML243 } \\
7\end{array}$ & $\begin{array}{l}\text { Asa } \\
\text { Estribo }\end{array}$ & IV & $\begin{array}{l}\text { Chica } \\
\text { ma }\end{array}$ & $\begin{array}{l}\text { Mocollo } \\
\text { pe }\end{array}$ & & 2 & & & & \\
\hline $\begin{array}{l}\text { ML398 } \\
7\end{array}$ & $\begin{array}{l}\text { Asa } \\
\text { Estribo }\end{array}$ & IV & $\begin{array}{l}\text { Chica } \\
\text { ma }\end{array}$ & Facalá & & & & & 2 & \\
\hline $\begin{array}{l}\text { ML805 } \\
8\end{array}$ & $\begin{array}{l}\text { Asa } \\
\text { Estribo }\end{array}$ & IV & & & & & & 1 & & \\
\hline $\begin{array}{l}\text { ML805 } \\
9\end{array}$ & $\begin{array}{l}\text { Asa } \\
\text { Estribo }\end{array}$ & IV & & & & & & & 2 & 2 \\
\hline $\begin{array}{l}\text { ML806 } \\
2\end{array}$ & $\begin{array}{l}\text { Asa } \\
\text { Estribo }\end{array}$ & IV & & & & 3 & & & 3 & \\
\hline $\begin{array}{l}\text { ML806 } \\
3\end{array}$ & $\begin{array}{l}\text { Asa } \\
\text { Estribo }\end{array}$ & IV & $\begin{array}{l}\text { Chica } \\
\text { ma }\end{array}$ & Facalá & & 3 & & & & \\
\hline $\begin{array}{l}\text { ML806 } \\
5\end{array}$ & $\begin{array}{l}\text { Asa } \\
\text { Estribo }\end{array}$ & III & $\begin{array}{l}\text { Chica } \\
\text { ma }\end{array}$ & $\begin{array}{l}\text { Chiquito } \\
\mathrm{y}\end{array}$ & & & & & & 8 \\
\hline $\begin{array}{l}\text { ML815 } \\
9\end{array}$ & $\begin{array}{l}\text { Asa } \\
\text { Estribo }\end{array}$ & III & & & 8 & & & & & \\
\hline $\begin{array}{l}\text { ML816 } \\
2\end{array}$ & $\begin{array}{l}\text { Asa } \\
\text { Estribo }\end{array}$ & IV & $\begin{array}{l}\text { Chica } \\
\text { ma }\end{array}$ & Roma & 2 & & & & & \\
\hline $\begin{array}{l}\text { ML816 } \\
4\end{array}$ & $\begin{array}{l}\text { Asa } \\
\text { Estribo }\end{array}$ & IV & Virú & Pur Pur & & & 4 & & 1 & \\
\hline $\begin{array}{l}\text { ML822 } \\
4\end{array}$ & $\begin{array}{l}\text { Asa } \\
\text { Estribo }\end{array}$ & III & Virú & & & & & & 2 & \\
\hline $\begin{array}{l}\text { ML823 } \\
9\end{array}$ & $\begin{array}{l}\text { Asa } \\
\text { Estribo }\end{array}$ & III & & & & & 3 & & & \\
\hline
\end{tabular}




\begin{tabular}{|l|l|l|l|l|l|l|l|l|l|l|}
\hline $\begin{array}{l}\text { ML824 } \\
0\end{array}$ & $\begin{array}{l}\text { Asa } \\
\text { Estribo }\end{array}$ & IV & & & & 2 & & & & \\
\hline $\begin{array}{l}\text { ML824 } \\
1\end{array}$ & $\begin{array}{l}\text { Asa } \\
\text { Estribo }\end{array}$ & IV & & & & 3 & & & & \\
\hline $\begin{array}{l}\text { TOTAL } \\
\text { PEC } \\
: 15\end{array}$ & & & & & $\mathbf{1 0}$ & $\mathbf{1 5}$ & $\mathbf{7}$ & $\mathbf{1}$ & $\mathbf{1 2}$ & $\mathbf{1 0}$ \\
\hline
\end{tabular}

\begin{tabular}{|c|c|c|c|}
\hline PERCENTUAL & \multicolumn{2}{|c|}{} \\
VASOS CACTOS: & TOTAL: 11 & \multicolumn{2}{|c|}{} \\
$73.3 \%$ & & $\begin{array}{c}\text { PERCENTUAL } \\
\text { VASOS }\end{array}$ & TOTAL: 2 \\
PERCENTUAL \\
VASOS \\
TILLANDSIAS: & TOTAL:6 & $\begin{array}{c}\text { DESCONHECIDO: } \\
13.3 \%\end{array}$ & \\
$40.0 \%$ & & & \\
\hline
\end{tabular}

VEADO (19)

O mural encontrado de cerca 4 mil anos que compõe a segunda parte mais antiga da Huaca Ventarrón, um dos centros cerimoniais mais antigos do Peru, atesta de forma bastante gráfica a importância primordial da interação entre homem e veado nos vales da costa norte do país. Polígonos vermelhos, amarelos, azuis e negros formam, em um estilo muito particular, a imagem expressiva de um cervídeo com olhos e dentes à mostra, imobilizado por uma rede de caça. A boa sorte preservou para a atualidade a imagem quase intacta uma cena arquetípica da região que veremos ser estruturalmente reproduzida até pouco antes da chegada dos europeus; a da caça ao veado.

Se não devemos ignorar a importância nutricional do veado para as populações humanas da região, principalmente antes da consolidação agrícola, é no campo simbólico que a caça ao veado encontrou papel central por milhares de gerações. Segundo o antropólogo peruano Luis Millones, a caça deve ter orientado os primeiros rituais já que ao "compor mimeticamente a repetição de seu andar (o da caça) ou a imitação de seus gritos, etc., se podia entender como um esforço para exercer poder sobre os seres assim reproduzidos.”(Millones, 1987:22). Deste modo, os rituais proporcionavam a "catarse necessária em uma sociedade possuída pela angústia de uma luta desigual com o meio ambiente" (idem). 
Ainda de acordo com Millones, os condutores de tais rituais "capazes de projetar esta imagem de paternidade difusa" e de "explicar a vida cotidiana em termos compreensíveis" seriam recompensados com prestígio pela comunidade. Vásques (2012) acredita que o princípio basilar de "reciprocidade mística" da caça é incorporado às religiões posteriores valorizando o sacrifício da presa e empoderando os chefes de caça (Vásques 2012:40). Assim, as comunidades agrícolas emergentes da costa norte peruana se organizariam ao redor de rituais baseados principalmente na atividade da caça, basilar para a subsistência humana por centenas de milhares de anos e ainda muito presente no imaginário dos povos produtores de alimentos. $\mathrm{O}$ veado aparece como personagem do mundo sobrenatural em todas as grandes civilizações da América (Millones, 2012:49), figurando em importantes registros escritos como no Popol Vuh e no manuscrito de Huarochiri. Neste último, compilação de lendas dos andes centrais feitas no início do período colonial espanhol, o veado aparece como um ser primordialmente comedor de humanos até que em uma virada de perspectiva causada por um momento de dúvida, tornam-se eles os alimentos dos humanos. O ciclo de perda e renascimento de seus chifres o tornaram um importante símbolo dos ciclos naturais (Vasques, 2012:40).

O veado de rabo branco, maior herbívoro nativo da região teria reservado um papel importante nos primeiros rituais e em seus desenvolvimentos subsequentes. Tratase do Odoicoileus peruanus, antes considerado uma das 39 subespécies de Odocoileus virginianus distribuídas por todas as Américas (Millones, 2012), porém atualmente classificado como uma das sete espécies nativas do Peru (Barrios, 2006). Enquanto a maioria das espécies habita a região amazônica o Odocoileus peruvianus e o Hippocamelus antisensis habitam a parte ocidental andina. O virginianus porém se distingue por ocupar zonas mais baixas enquanto o Hippocamelus prefere altitudes acima de 2.000. Deste modo são encontrados em regiões distintas (Barrios, 2006) e quase certo que a espécie representada na costa norte seja o Odocoileus peruvianus.

A arqueóloga Anne-Marie Hocquenghem (1983), aponta que o veado de rabo branco desce e lomas, zonas elevadas e úmidas que ocorrem nos desertos costeiros peruanos, no fim da estação seca, quando as chuvas começam a cair e a neve derreter e formar os rios sazonais. Nestes vales o animal se alimenta das vegetações dos bosques secos principalmente dos frutos de uma importante árvore da região, o Algarrobo (Prosopis Spp). Lá as fêmeas também dão à luz a um único filhote com a pelagem pontilhada de branco. Hocquenghem ainda considera-o habitante e viajante de mundos 
limiares entre o mundo dos mortos e o mundo de acima pois habita também uma zona limiar entre o cultivo e o não cultivo que são os bosques secos (Hocquenghem 1983: 79) além de transitar entre a montanha (acima) e os vales (abaixo).

O mural de Ventarrón demonstra a precocidade com que o veado ganha destaque nas representações dos povos nativos do Peru, mas é principalmente na cerâmica que observamos sua recorrência nos períodos posteriores. As culturas ceramistas herdeiras dos muralistas pré- cerâmicos que habitaram aqueles vales como Kotosh, Cupisnique e Salinar representam os veados em seus vasos. Todavia, no período do florescimento da cultura arqueológica dos Mochica das representações parece atingir seu apogeu, ao menos na cultura cerâmica.

Ou seja, o veado é, como a coruja, a raposa e lobo marinho um animal 'bom para pensar' como diria o antropólogo Levi-Strauss (1964), ao considerar a frequência maior de alguns animais do que de outros no sistema totêmico. Goepfert (2009) parece concordar pois para ele o veado deve ser considerado "uma figura ligada a aspectos totêmico do ponto de vista social e a ritos shamânicos do ponto de vista ritual" Goepfert (2009: 34). Aqui sociedade deve ser vista como uma sociocosmologia onde o ser humano não se aparta dos outros animais pela cultura, mas pela natureza, e mantém relações sociais intensas com forças não humanas. (Leonel, 2015)

A caça do veado (Figura V.III.s) faz parte de uma cena recorrente nos vasos mochica de linha fina como foi demonstrado Donnan (1982a) e Hocquenghem (1983). A cena mostra personagens da elite mochica armados com lançadores de dardos e maças acompanhados de servos munidos de redes e cães de caça. Devido às poucas evidências de vestígios de veados nas unidades domésticas mochica, Donnan propôs que a caça era restrita aos membros das classes altas das sociedades mochicas e o objetivo aparentemente não era o consumo da carne puro e simples mas o abatimento ritual do animal para oferendá-lo em sacrifícios.

Porém, se a caça ritual era restrita à população comum não se sabe de proibição, mesmo com o exemplo etnográfico posterior dos Incas seguindo neste sentido. Além disso, segundo Goepfert (2009), enquanto vestígios de veado foram encontrados apenas três vezes em contextos funerários, podendo inclusive ser intrusivos, restos do animal ocorrem com frequência baixa, mas constante nos vestígios domésticos desde os períodos iniciais até o período Moche. Hocquenghem acredita que não se encontram partes carnudas nos vestígios porque a carne era dedicada aos ancestrais Hocquenghem (1983:78). Logo, a afirmação de Donnan ainda não pode ser comprovada ou refutada, 
mesmo sendo bastante reforçada pela iconografia.

Para Hocquenghem (1983), o veado é essencialmente uma presa arquetípica, no que faz o papel de "oposto complementar assimétrico" com o jaguar, uma ideia estruturante em todo pensamento andino cuja dualidade assimétrica está sempre em ação. A autora ainda acredita que as cenas de Caça ao veado aparecem em dois mundos distintos, o "fantástico" e o "realista". A primeira vista o vaso analisado seria diretamente classificado como parte de um mundo realista. Entretanto, se considerarmos o pensamento perspectivista a pintura ritual poderia ser algum indicativo sobre a metamorfose do caçador ocupando o lugar do jaguar, a divisão entre realista e fantástico torna-se um tanto mais perene. Além disso, mesmo no caso da peça com o "veadoserpente- jaguar", ML3534, pode ser considerado participante da categoria quimera "híbridos fantásticos", uma espécie de realismo fantástico onde seres perfeitamente detalhados se fundem ao formar híbridos, dos quais Hocquenghem considera o exemplo mais extremo o "Veado-serpente-jaguar" e representação que os outros vasos "realistas", sem qualquer elemento "não natural" com exceção do próprio veadoserpente-jaguar.).

Em 2 peças o veado aparece antropomorfizado, ambas relativas à cena da corrida. Na peça ML2351 (Figura V.III.t) um veado esculturado com toucado senta sobre o vaso com desenhos de cactáceas em sua maioria. Uma possibilidade seria o veado representar uma entidade quintessencial. Para Golte os veados aparecem nas representações Mochica como "os que mais se assemelham a humanos e aparecem tanto como guerreiros como também cativos" (Golte, 2009:161). O antropólogo associa os veados guerreiros a uma Divindade Intermediadora que cumpre a função de trânsito e diálogo entre os mundos e os deuses do panteão mochica e ao que chama Deus Diurno ( Golte 2009 :214).

Lau (2004 ) adventa a possibilidade de os mochica representarem como veados os recuay, um povo fronteiriço da região serrana com quem os mochica mantinham relações de disputa e cooperação. O toucado tem uma função importante no vaso, pois como aponta Figueiredo (2014), a costa norte peruana tem uma longa tradição na representação de atributos de poder concentrada nos toucados. Ou seja, a interpretação correta do toucado poderia nos apontar qual entidade estaria sendo representada.

Flora e peças:

O vasos com iconografia de linha fina são predominantes neste grupo já que 17 dos 19 a possuem, enquanto os outros 3 mantém algum tipo de representação 
pictográfica. Em um dos vasos o caçador do veado é um felino pintado podendo ser um jaguar ou jaguatirica. Este é apenas um de inúmeros vasos que mostram o veado sendo caçado pelo jaguar. É importante notar que o jaguar ou a jaguatirica não ocorrem naturalmente no lado ocidental dos andes sendo o puma o felino endêmico da região que, no entanto, não possui pintas. Assim, seria improvável que a cena do jaguar caçando o veado, ainda que tão comumente representada fosse presenciada pelos mochica na natureza. Existem representações de senhores mochica com jaguatiricas amansadas (Bars, 2009) e não podemos descartar a hipótese de que esses felinos pudessem participar de determinadas caças ao veado.

Em duas peças os veados antropomorfizados aparecem em uma cena da iconografia mochica conhecida por "cenas dos feijões". Nestas cenas os veados aparecem nas mesmas condições que os outros animais, não na condição de presas (Bars 2009:209). Há também cenas em que aparecem feijões antropomorfizados e aparelhados como guerreiros. Mas esses feijões guerreiros combatem apenas os veados guerreiros (Golte 2009:222). Para Golte há uma possível ligação ecológica entre os veados e os feijões já que "os veados das lomas e dos bosques de algarrobo devem ter sido uma ameaça constante para a colheita de feijões dos moche".

Mesmo sendo um grupo relativamente grande, composto de 19 peças, a flora que o compõe parece ser a mais equilibrada de todas. Dois dados chamam a atenção aqui. Os exemplares arbóreos, entre arbustos e árvores, aparecem em seis peças, somando um total de 31,5\% dos vasos do grupo. Este é um número extremamente alto, uma vez que em toda coleção analizada els aparecem em apenas 9 vasos. Mesmo não sendo surpreendente, a associação dos veados com bosques secos e ribeirinhos parece ser reforçada pelos dados.

Há também uma quantidade anômala de cactos tipo 4, também bastante raros nos outros grupos. Com 10 exemplares distribuídos em quatro vasos, eles somam quase um terço do total registrado. Este tipo de cacto é morfologicamente próximo da espécie Opuntia quitensis encontrada nas zonas mais altas e úmidas das lomas. Apesar da ênfase aqui ser um pouco mais fraca, os dados parecem também reforçar a associação do veado com as lomas. 


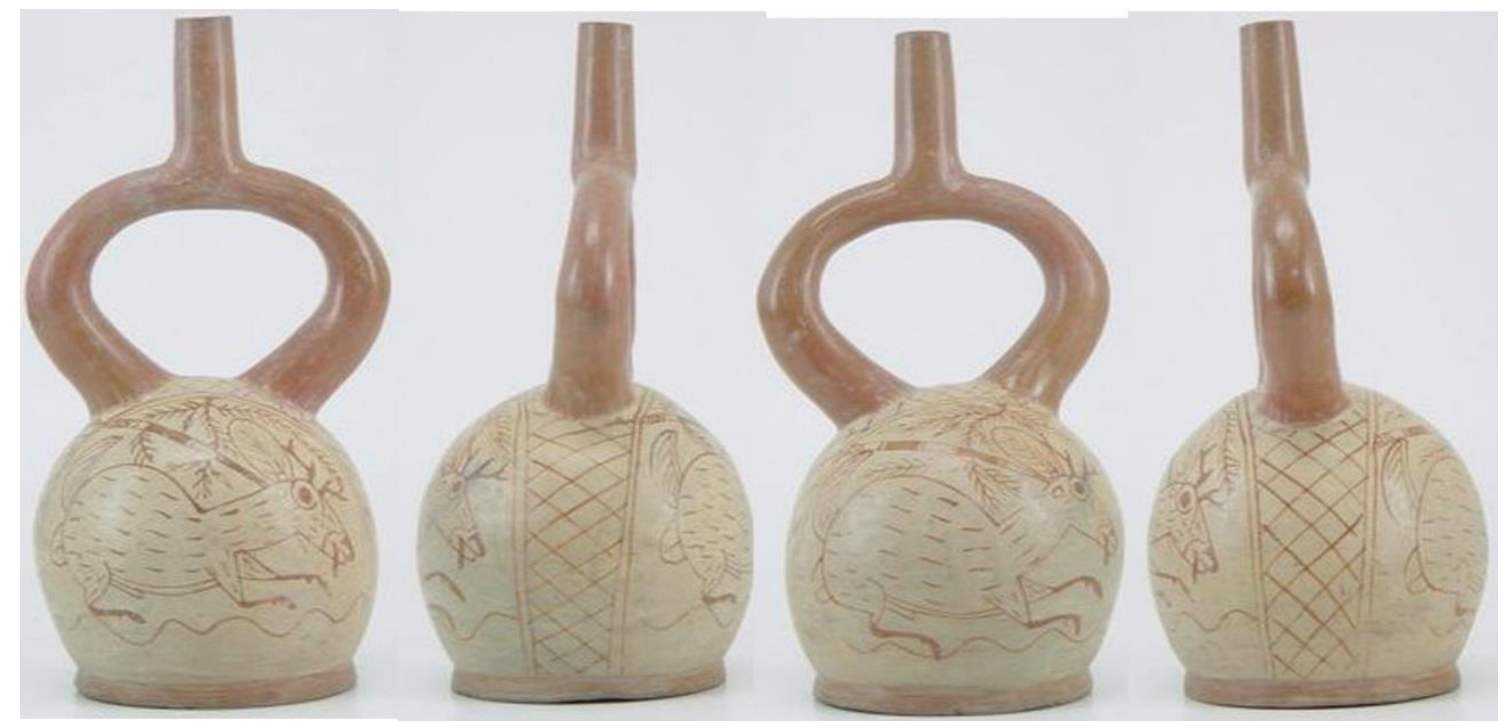

(FIGURA V.III.s) Peça ML12881 Cena comum de caça ao veado com ambiente arbóreo (cortesia Museu Larco)

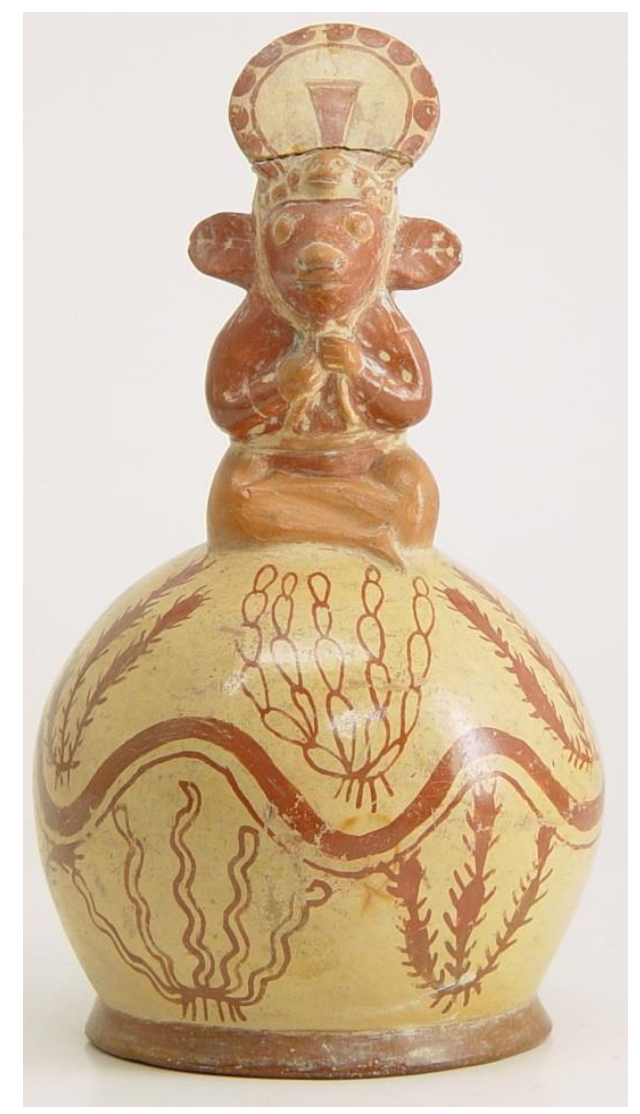

(FIGURA V.III.t) Veado antropomorfizado sentado sobre cactots tipo 4. (Cortesia Museu Larco) 


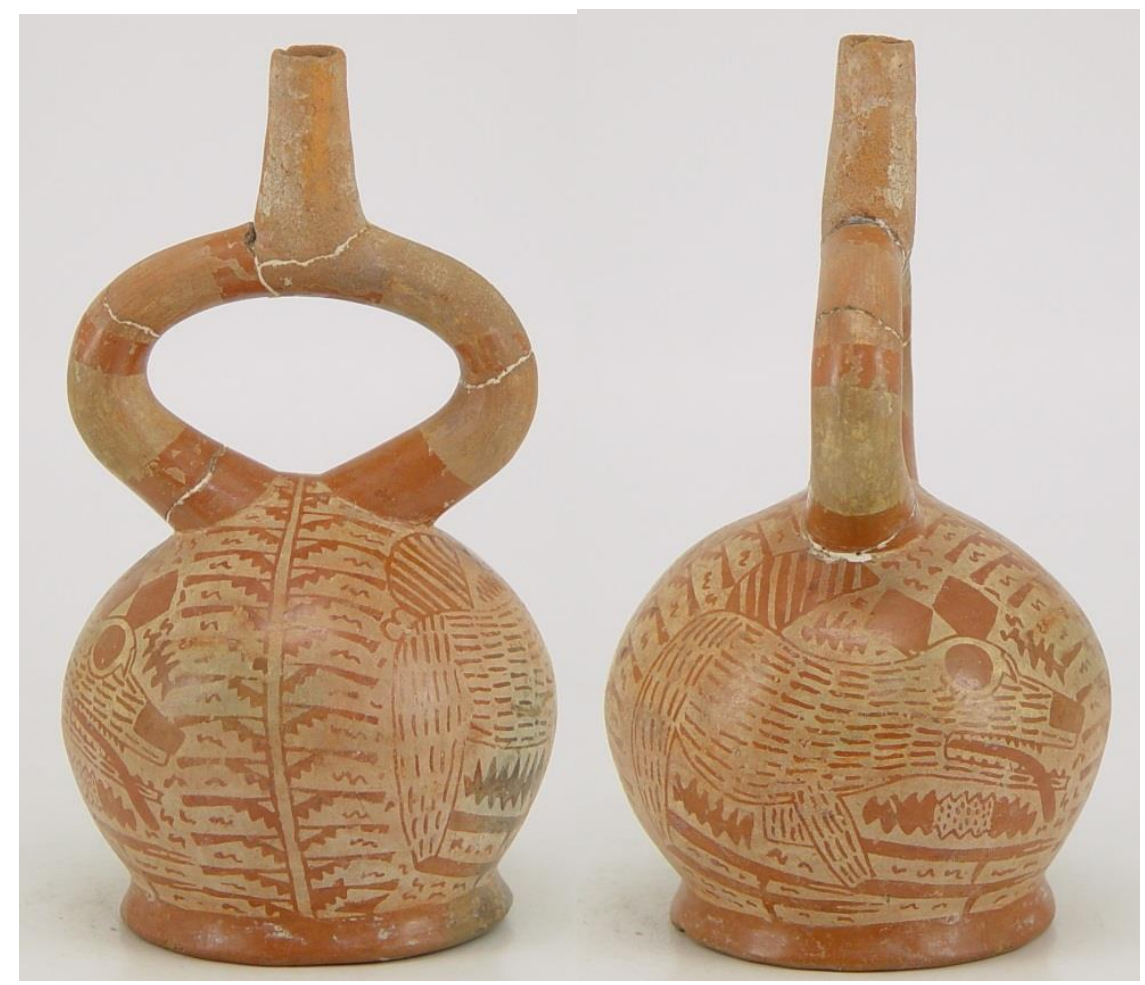

(FIGURA V.III.u) Peça ML8120, raríssima fase V que mostra o veado sendo perseguído. (Cortesia Museu Larco)

\begin{tabular}{|c|c|c|c|c|c|c|c|c|c|c|c|c|c|c|}
\hline PEÇA & TIPO & $\begin{array}{l}\mathbf{F} \\
\mathbf{A} \\
\mathbf{S} \\
\mathbf{E}\end{array}$ & $\begin{array}{l}\text { VAL } \\
\text { E }\end{array}$ & $\begin{array}{l}\text { SÍTIO } \\
\end{array}$ & $\begin{array}{l}\text { CA } \\
\text { CT } \\
\text { O } \\
\text { T1 } \\
\text { A }\end{array}$ & $\begin{array}{l}\text { CAC } \\
\text { TO } \\
\text { T1B }\end{array}$ & $\begin{array}{l}\text { CA } \\
\text { CT } \\
\text { O } \\
\text { T2 }\end{array}$ & $\begin{array}{l}\text { CAC } \\
\text { TO } \\
\text { T3 }\end{array}$ & $\begin{array}{l}\text { CAC } \\
\text { TO } \\
\text { T4 }\end{array}$ & $\begin{array}{l}\text { CAC } \\
\text { TO } \\
\text { T5 }\end{array}$ & $\begin{array}{l}\text { TILLA } \\
\text { NDSIA } \\
\text { S }\end{array}$ & $\begin{array}{l}\text { ARB } \\
\text { UST } \\
\text { O }\end{array}$ & $\begin{array}{l}\text { ALG } \\
\text { ARR } \\
\text { OBO }\end{array}$ & $\begin{array}{l}\text { DESCON } \\
\text { HECIDO }\end{array}$ \\
\hline $\begin{array}{l}\text { ML213 } \\
7\end{array}$ & $\begin{array}{l}\text { Asa } \\
\text { Estribo }\end{array}$ & $\begin{array}{l}\mathrm{I} \\
\mathrm{V}\end{array}$ & $\begin{array}{l}\text { Chica } \\
\text { ma }\end{array}$ & $\begin{array}{l}\text { Palenq } \\
\text { ue / } \\
\text { Sausal }\end{array}$ & & & & 3 & & & & & & \\
\hline $\begin{array}{l}\text { ML213 } \\
8\end{array}$ & $\begin{array}{l}\text { Asa } \\
\text { Estribo }\end{array}$ & $\begin{array}{l}\mathrm{I} \\
\mathrm{V}\end{array}$ & $\begin{array}{l}\text { Chica } \\
\text { ma }\end{array}$ & $\begin{array}{l}\text { Sausal } \\
/ \quad \text { El } \\
\text { Encant } \\
\text { o }\end{array}$ & 2 & 1 & & & & & & & & \\
\hline $\begin{array}{l}\text { ML214 } \\
0\end{array}$ & $\begin{array}{l}\text { Asa } \\
\text { Estribo }\end{array}$ & $\begin{array}{l}\text { I } \\
\text { V }\end{array}$ & & & 3 & 1 & & & & & 1 & & & \\
\hline $\begin{array}{l}\text { ML214 } \\
3\end{array}$ & $\begin{array}{l}\text { Asa } \\
\text { Estribo }\end{array}$ & $\begin{array}{l}\mathrm{I} \\
\mathrm{V}\end{array}$ & & & & & & & & & 1 & 1 & 2 & \\
\hline $\begin{array}{l}\text { ML215 } \\
0\end{array}$ & $\begin{array}{l}\text { Asa } \\
\text { lateral }\end{array}$ & $\begin{array}{l}\mathrm{I} \\
\mathrm{V}\end{array}$ & & & & & & & & & & & & 1 \\
\hline $\begin{array}{l}\text { ML215 } \\
1\end{array}$ & $\begin{array}{l}\text { Asa } \\
\text { Estribo } \\
\text { lateral }\end{array}$ & $\begin{array}{l}\mathrm{I} \\
\mathrm{V}\end{array}$ & & & & & 5 & & & & & & & \\
\hline $\begin{array}{l}\text { ML215 } \\
2\end{array}$ & $\begin{array}{l}\text { Estribo } \\
\text { lateral } \\
\text { Cantaro }\end{array}$ & $\begin{array}{l}\mathrm{I} \\
\mathrm{V}\end{array}$ & & & & & 2 & & & & & & & \\
\hline $\begin{array}{l}\text { ML219 } \\
6\end{array}$ & $\begin{array}{l}\text { Asa } \\
\text { Estribo }\end{array}$ & $\begin{array}{l}\mathrm{I} \\
\mathrm{V}\end{array}$ & & & & & 2 & & & & & 4 & & \\
\hline
\end{tabular}




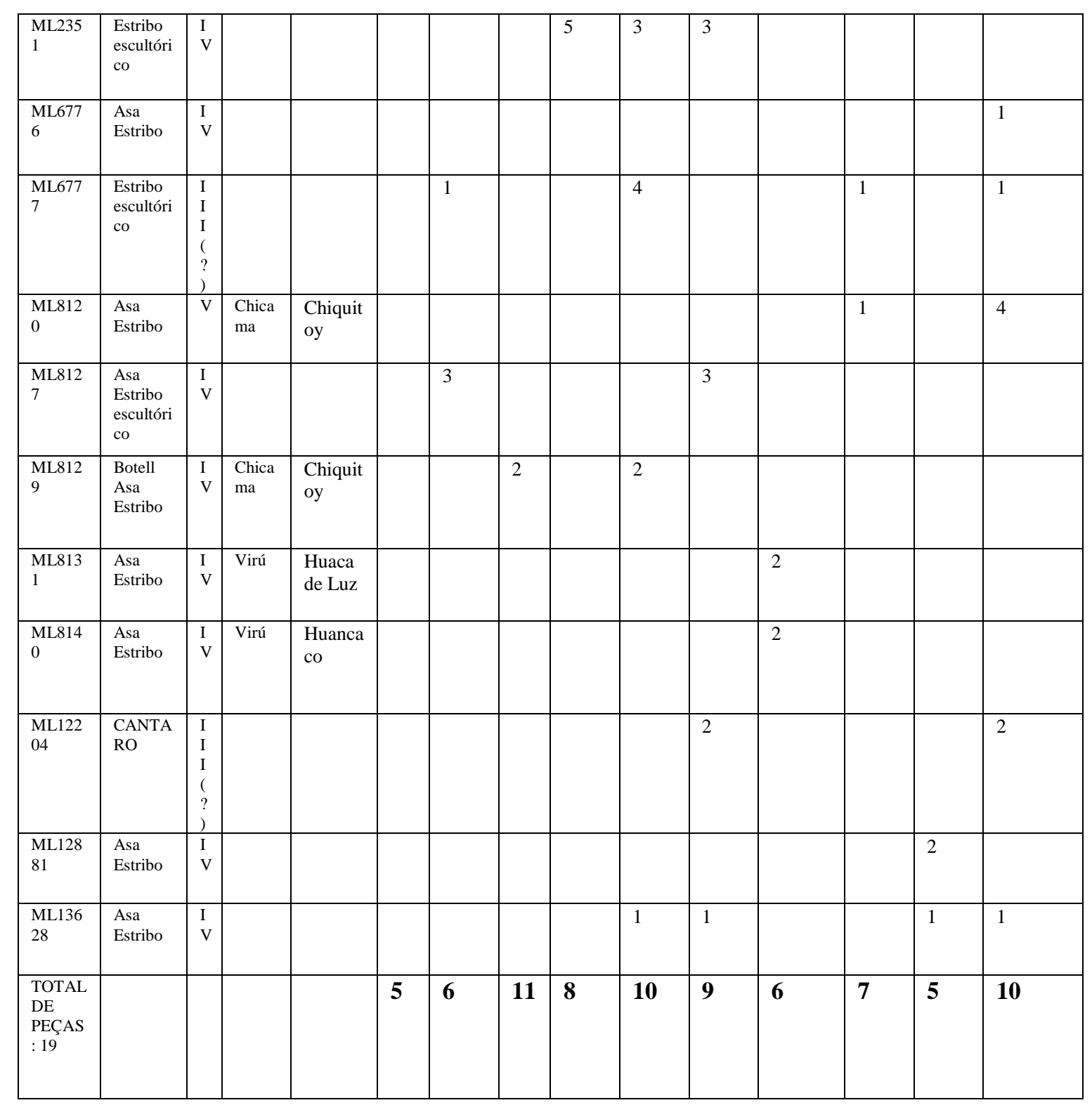

\begin{tabular}{|c|c|c|c|}
\hline $\begin{array}{c}\text { PERCENTUAL VASOS } \\
\text { CACTOS: } 63.1 \%\end{array}$ & $\begin{array}{c}\text { TOTAL: } \\
12\end{array}$ & $\begin{array}{c}\text { TOTAL DE } \\
\text { VASOS } \\
\text { DESCONHECIDO: } \\
6\end{array}$ & TOTAL:6 \\
\hline $\begin{array}{c}\text { PERCENTUAL VASOS } \\
\text { TILLANDSIAS: } 21.0 \%\end{array}$ & TOTAL: 4 & $\begin{array}{c}\text { PERCENTUAL } \\
\text { VASOS }\end{array}$ & TOTAL: 6 \\
& & $31.5 \%$ & \\
\hline
\end{tabular}




\section{CARACÓIS (7)}

Caracóis costumam ser apresentados na iconografia mochica associados à montanhas, geralmente sendo coletados, em cenas de sacrifício ou outras cenas relacionadas às lomas. As espécies representadas são muito provavelmente esculatus spp.

Golte $(1985,2009)$ pensa que os caracóis e, especialmente a cena de sua coleta, esteja intimamente ligada a rituais de fertilidade agrícola. Para ele, é possível que as lomas sejam um locus de reminiscência coletiva de um tempo pré-agrícola, quando a caça e a coleta nessas regiões eram essenciais para a sobrevivência humana nos períodos secos (ibid.362)

Burger (ver capítulo IV) adventa a possibilidade de o alcalóide contido nos cactos Neoraimondia Arequipensis serem absorvidos pelos caracóis consumidos pelos humanos, transformando possivelmente o ato de consumo em um rito fomentado por estados alterados da mente causados pelos alcalóides psicotrópicos.

Flora e peças:

Este é um grupo pequeno, mas bastante heterogêneo. Além dos caracóis há apenas um grande elemento comum que o formato de montanha de quase todos os vasos analisados, exceto pelo ML9661, que é alça estribo. Este parece apresentar caracóis naturalistas sem outra ação concorrente, assim como ML12884 (figura V.III.v) e Ml 6780. Temos uma cena de coleta de caracóis ML2134(Figura V.III.x) e duas cenas de sacrifício com caracóis, ML13040 e M13093. Por fim, há uma cena do mundo horroroso, ML17293 (Figura V.III.y), com o que parece ser uma raposa ou felino surgindo de uma montanha.

Nas cenas de sacrifício e do mundo horroroso podemos ver tillandsias ou plantas classificadas como desconhecidas, mas que muito possivelmente são representações heterodoxs de tillandsias. Nas outras cenas, excetuando o vaso de alça estribo, a flora é composta de cactos Tipo 2,3 e 5, todos muito próximos morfologicamente da $N$. Arequipensis, o que, de certa forma, reforça a associação dos caracóis com estas plantas. 


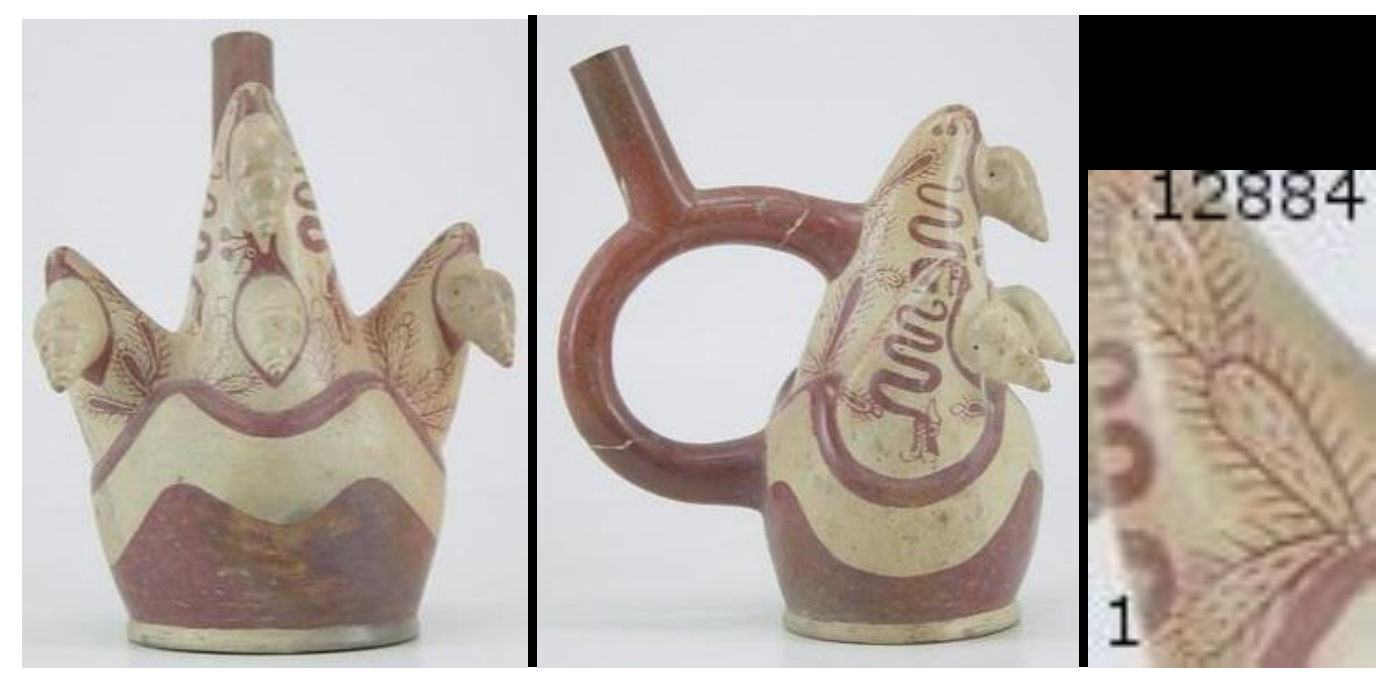

(FIGURA V.III.v) Peça ML12884 com possíveis N. Raimondias ou O. Quitensias
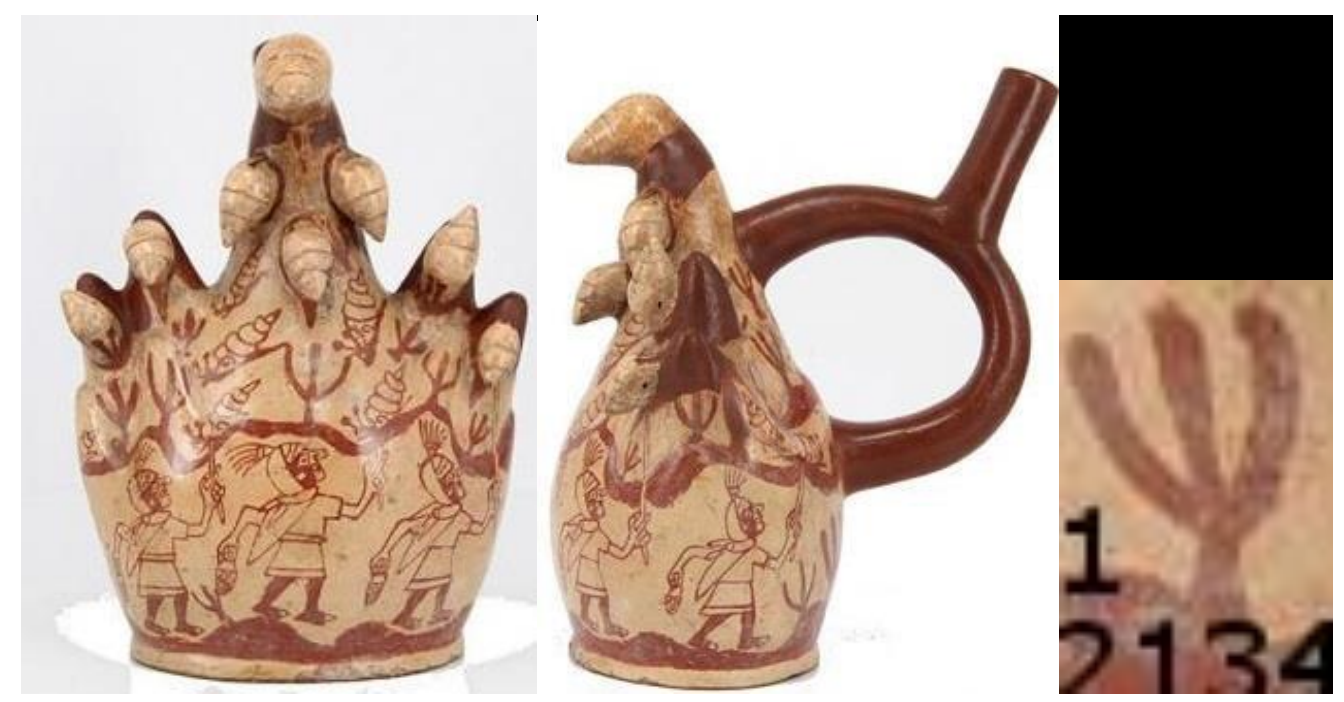

(FIGURA V.III.x) Peça ML2134 mostrandoa coleta de caracóis

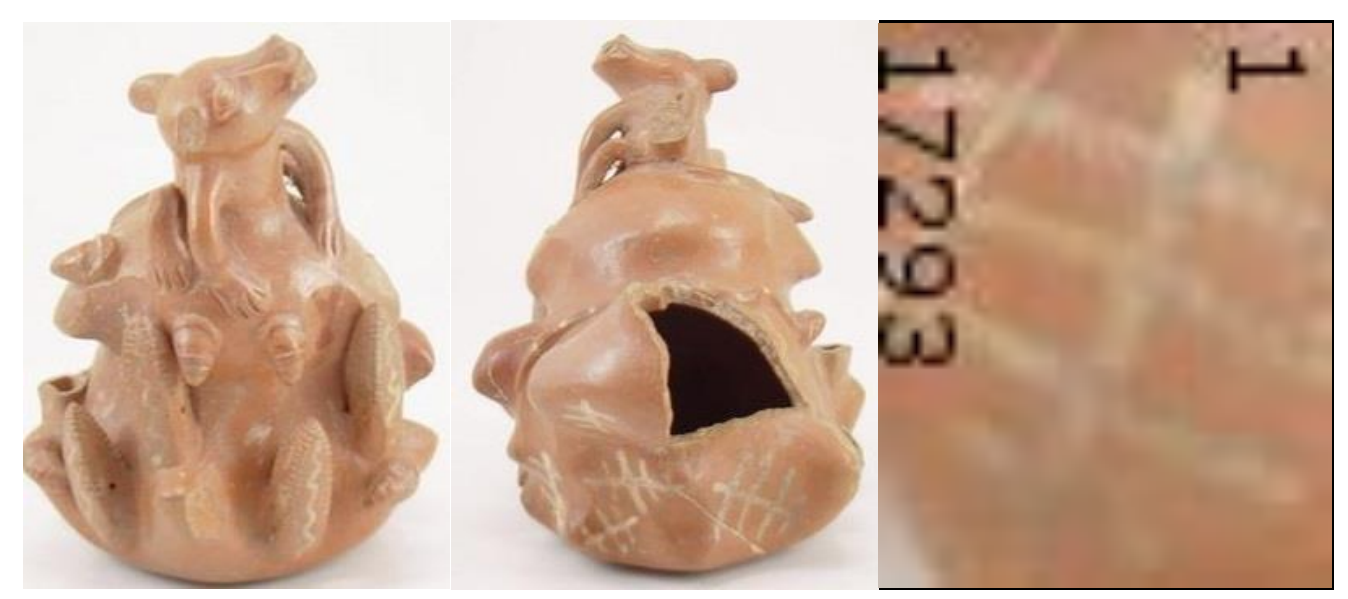

(FIGURA V.III.y) Peça ML17293 com possível tillandsia 


\begin{tabular}{|c|c|c|c|c|c|c|c|c|c|c|}
\hline PEÇA & $\begin{array}{l}\text { TIPO } \\
\text { DE } \\
\text { VASO }\end{array}$ & $\begin{array}{l}\text { FAS } \\
\text { E }\end{array}$ & $\begin{array}{l}\text { VAL } \\
\text { E }\end{array}$ & SÍTIO & $\begin{array}{l}\text { CACT } \\
\text { O } \\
\text { T1B }\end{array}$ & $\begin{array}{l}\text { CACT } \\
\text { O T2 }\end{array}$ & $\begin{array}{l}\text { CACT } \\
\text { O T3 }\end{array}$ & $\begin{array}{l}\text { CACT } \\
\text { O T5 }\end{array}$ & $\begin{array}{l}\text { TILLANDSI } \\
\text { AS }\end{array}$ & $\begin{array}{l}\text { DESCONHEC } \\
\text { IDO }\end{array}$ \\
\hline $\begin{array}{l}\text { ML213 } \\
4\end{array}$ & $\begin{array}{l}\text { Asa } \\
\text { Estribo } \\
\text { lateral } \\
\text { escultori } \\
\text { co }\end{array}$ & IV & & & & & & 21 & & \\
\hline $\begin{array}{l}\text { ML309 } \\
3\end{array}$ & $\begin{array}{l}\text { Asa } \\
\text { Estribo } \\
\text { lateral } \\
\text { escultori } \\
\text { co }\end{array}$ & IV & & & & & & & & 6 \\
\hline $\begin{array}{l}\text { ML678 } \\
0\end{array}$ & $\begin{array}{l}\text { Asa } \\
\text { Estribo } \\
\text { lateral } \\
\text { escultori } \\
\text { co }\end{array}$ & IV & Santa & $\begin{array}{l}\text { Tambo } \\
\text { Real }\end{array}$ & 2 & & & & & \\
\hline $\begin{array}{l}\text { ML966 } \\
1\end{array}$ & $\begin{array}{l}\text { Asa } \\
\text { Estribo }\end{array}$ & IV & & & & & & & & 2 \\
\hline $\begin{array}{l}\text { ML128 } \\
84\end{array}$ & $\begin{array}{l}\text { Asa } \\
\text { Estribo } \\
\text { lateral } \\
\text { escultori } \\
\text { co }\end{array}$ & IV & $\begin{array}{l}\text { VIR } \\
\text { Ú }\end{array}$ & $\begin{array}{l}\text { HUANCA } \\
\text { CO }\end{array}$ & & 5 & 4 & & & \\
\hline $\begin{array}{l}\text { ML130 } \\
40\end{array}$ & $\begin{array}{l}\text { Asa } \\
\text { Estribo } \\
\text { lateral } \\
\text { escultori } \\
\text { co }\end{array}$ & III & & & & & & & 2 & \\
\hline $\begin{array}{l}\text { ML172 } \\
93\end{array}$ & $\begin{array}{l}\text { Asa } \\
\text { Estribo } \\
\text { lateral } \\
\text { escultori } \\
\text { co }\end{array}$ & III & & & & & & & 6 & \\
\hline $\begin{array}{l}\text { TOTA } \\
\text { L DE } \\
\text { PEÇAS } \\
: 7\end{array}$ & & & & & 2 & 5 & 4 & 21 & 8 & 8 \\
\hline
\end{tabular}

\begin{tabular}{|c|c|c|c|}
\hline $\begin{array}{c}\text { PERCENTUAL VASOS } \\
\text { CACTOS: } 42.8 \%\end{array}$ & TOTAL: 4 & & \\
\hline $\begin{array}{l}\text { PERCENTUAL VASOS } \\
\text { TILLANDSIAS: } 28.4 \%\end{array}$ & TOTAL: 2 & $\begin{array}{c}\text { PERCENTUAL } \\
\text { VASOS } \\
\text { DESCONHECIDOS: } \\
28.4 \%\end{array}$ & TOTAL: 2 \\
\hline
\end{tabular}

V.IV-MACROGRUPO SERES MÍTICOS: aia paec, serpiente, monstro strombus, dragón, ave mítica. 


\begin{abstract}
AIA PAEC (13)
Aia Paec é conhecido como uma das principais personagens sobrenaturais da cultura Mochica. Segundo Benson (2012) é uma particularização tardia da divindade com presas cupisnique. É uma figura que aparece com bastante frequência na cerâmica cerimonial, principalmente Moche Sul, particularmente nas fases III, IV. É supostamente sua face que aparece repetidas vezes nos murais da Huaca de La luna, centro cerimonial do possível estado de Moche-sul. Além das presas, seu traço mais característico seria seu cinturão com duas serpentes, ou uma serpente bicéfala.

De acordo com Golte o termo AiApaec é equivocado, uma vez que significa "o fazedor" ou "criador" em muchik:

"AiApaec efectivamente es una voz muchik utilizada en la cristianización temprana de los habitantes de la costa norte para denotar al Dios cristiano como un"hacedor"o'creador". Los rezos de los predicadores cristianos (de la Carrera) utilizaban este vocablo para referirse a la Divinidad de los españoles de forma que en lo subsiguiente se convirtió en una palabra genérica para"Dios". Larco pensó que el vocablo era fruto de una larga tradición muchiky asumió que todos los seres que sus trabajadores llamaban con esta voz eran una misma divinidad"(Golte, 2009: 69)
\end{abstract}

Ainda de acordo com Golte (2009: 757) todos os seres vivos, incluindo aqui os que consideramos naturais e os supra naturais, que Golte indica como portadores de grandes quantidades de Kamaq, um tipo de força vital que anima o mundo, teriam sido criados pela união de duas entidades primordiais andrógenas, uma celeste e outra ligada à terra. Bars (2009: 136) aponta que Aia Paec apresenta características de ambos os seres, representando sua união.

Hocquenghem (1987) divide Aia Paec em dois gêmeos; um marinho que enfrenta monstros aquáticos e um terrestre, que aparece agindo contra monstros terrestres.

Makowski adota tal divisão. Além disso separa o Deus terrestre que aparece nas cenas enfrentando monstros e servindo a Divindade Solar superior do Deus com presas que figura nas paredes da Huaca de La Luna. Segundo ele, este último seria uma 
entidade tectônica ligada a montanhas e ao mundo de abaixo. A entidade que combate monstros também estaria ligado à montanhas, pois viveria sobre elas, mas serviria como aliado hierarquicamente inferior ao Deus Águia ou Deus Solar. (Makowski, 2000:200).

Golte não divide Aia Paec em Gêmeos. Para ele, trata-se de uma Divindade que chama de Intermediadora porque, apesar de essencialmente se relacionar com o dia e a superfície terrestre ela transita pelos quatro quadrantes do cosmos, isto é, os dois do mundo de acima e os dois do mundo de abaixo (Golte, 2009:70)

De fato, se for apenas um, este seria um dos personagens mais ubícuos da cultura material mochica, além de ser, com certeza, o que mais aparece se relacionando com outros personagens.

\section{Flora e peças:}

O grupo pode ser dividido em três: as peças em Aia Paec luta com monstros do mar, as em que luta contra monstros terreno e nas que incorpora montanha.

A proposta inicial deste trabalho excluiría as cenas marinhas. Incluímos as as cenas aquáticas porque elas trazem a flora lacustre analisada nas cenas de pântano. Nos vasos M13137 (figura V.IV.a), ML3141, ML3697 e ML13656 o deus ou seu gêmeo marinho enfrentam monstros aquáticos. A incorporação de elementos da flora de água doce pode estar indicando um cenário de água doce, nos rios, lagos e humedales, o pântanos de água salobra.

Nas peças ML3430 (figura V.IV.b), M13449, M13451 e M13667 Aia Paec luta contra o dragão lunar(ver Dragão). Na peça M13451 além do Dragão o deus tem de enfrentar o Monstro Strombus assim como na peça ML3430 e M128662. Por fim, na peça M13562 Aia Paec segura a serpente-felina (ver serpente).

O deus é apresentado sentado sob um tipo de gruta na montanha na peça M12965 e "sendo" a montanha na peça M13369(figura V.IV.c). A peça M13433 na qual além das serpentes saem aves, aparentemente condores ou urubus de sua cabeça parece estar associada tambpem à montanha.

No geral, as peripécias de Aia Paec acabam criando o grupo de flora mais diversificado de todos. Há uma dominância de cactos, em $69.2 \%$ dos vasos, mas também uma presença considerável de tillandsias, totoras e mesmo ulluchus que aparecem nas peças M13430 e M128662. 


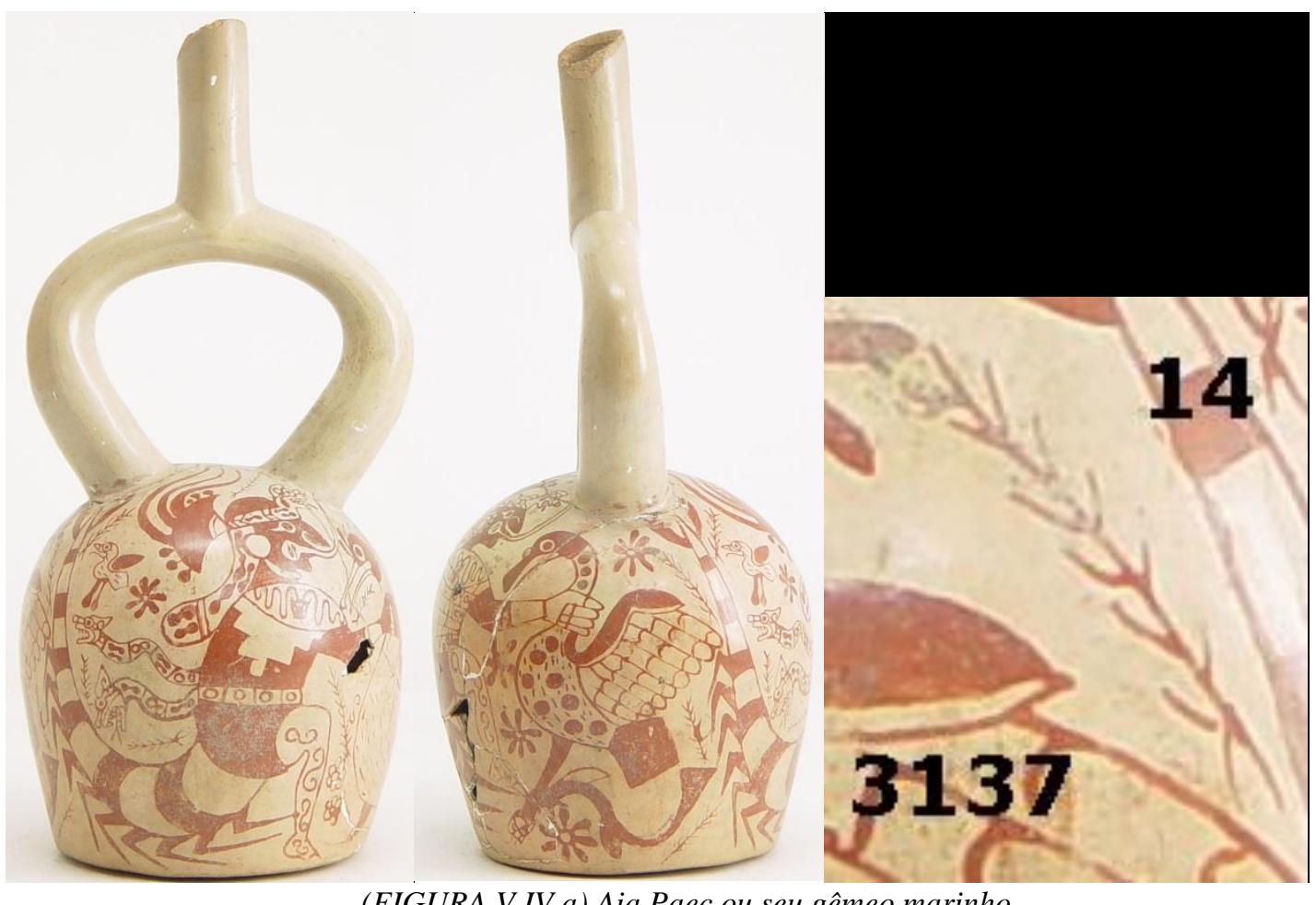

(FIGURA V.IV.a) Aia Paec ou seu gêmeo marinho

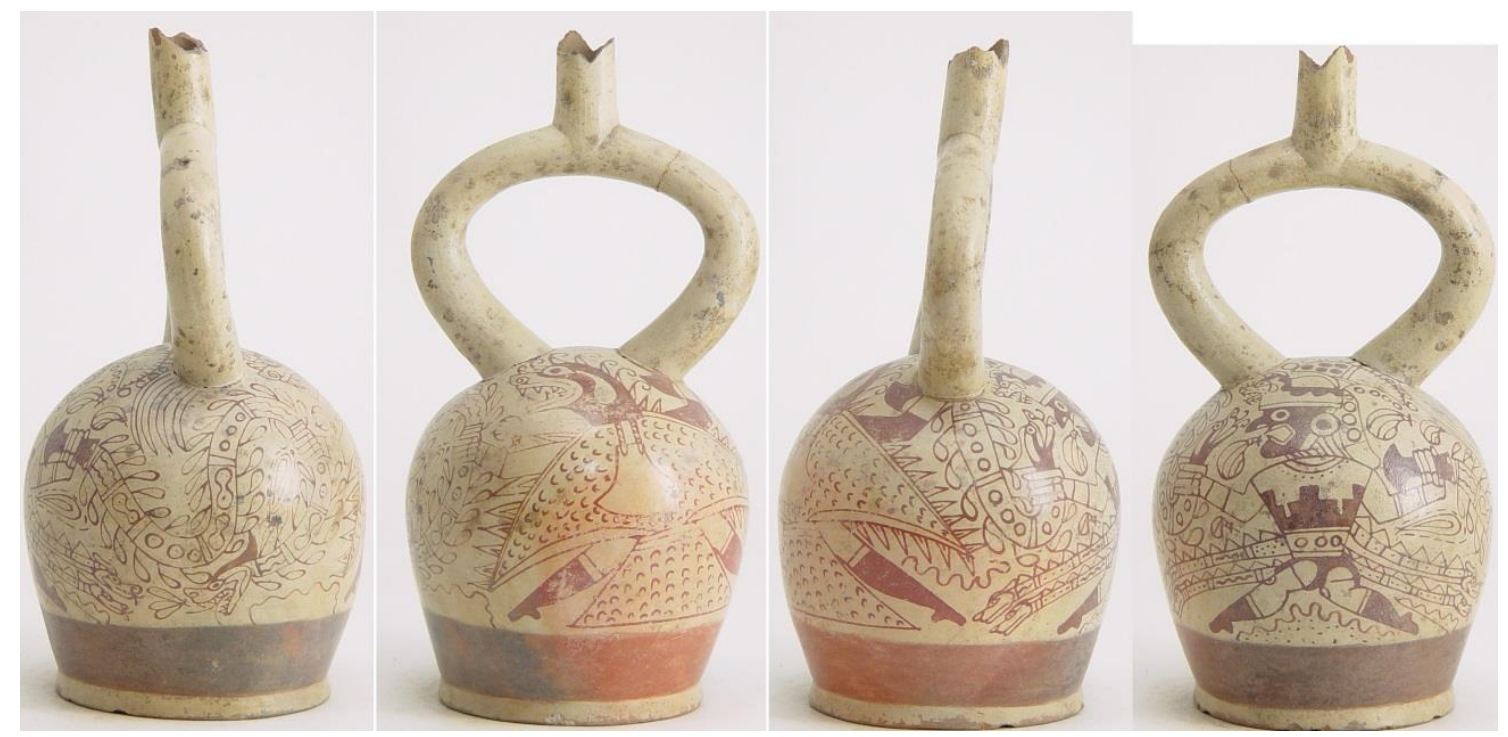

(FIGURA V.IV.b) Aia Paec Luta com Dragão antropomorfo 

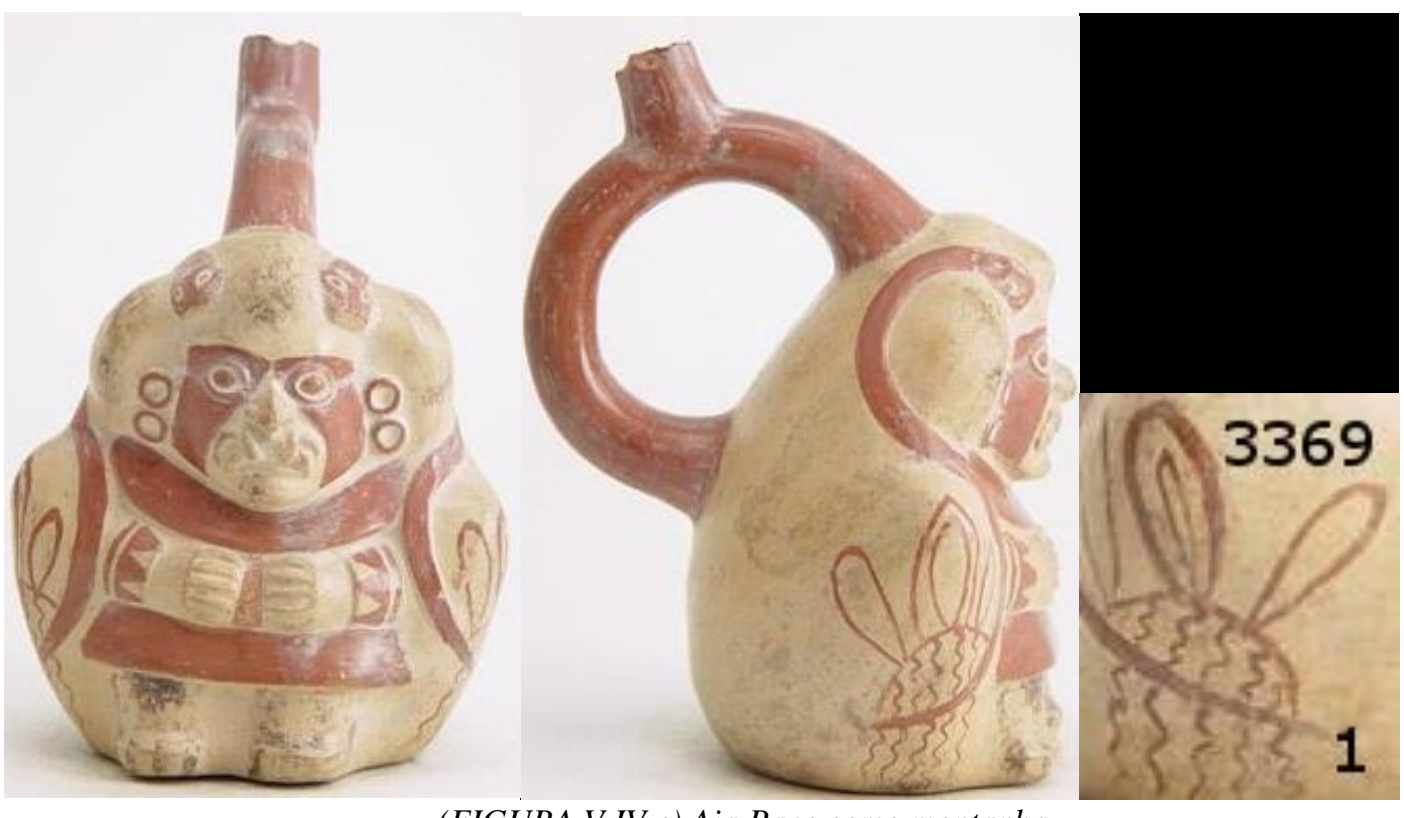

\section{9}

(FIGURA V.IV.c) Aia Paec como montanha

Ficha simplificada:

\begin{tabular}{|c|c|c|c|c|c|c|c|c|c|c|c|c|c|}
\hline PEÇA & TIPO & $\begin{array}{l}\text { FAS } \\
\text { E }\end{array}$ & VALE & SÍTIO & $\begin{array}{l}\text { CAC } \\
\text { TO } \\
\text { T1B }\end{array}$ & $\begin{array}{l}\text { CAC } \\
\text { TO } \\
\text { T2 }\end{array}$ & $\begin{array}{l}\text { CAC } \\
\text { TO } \\
\text { T2B }\end{array}$ & $\begin{array}{l}\text { CACT } \\
\text { O T3 }\end{array}$ & $\begin{array}{l}\text { CAC } \\
\text { TO } \\
\text { T4 }\end{array}$ & $\begin{array}{l}\text { TILLA } \\
\text { NDSIA } \\
\text { S }\end{array}$ & $\begin{array}{l}\text { TOT } \\
\text { ORA } \\
\text { S }\end{array}$ & $\begin{array}{l}\text { FLO } \\
\text { RES }\end{array}$ & $\begin{array}{l}\text { ULL } \\
\text { UCH } \\
\text { U }\end{array}$ \\
\hline $\begin{array}{l}\text { ML29 } \\
65\end{array}$ & $\begin{array}{l}\text { Escultu } \\
\text { rado } \\
\text { asa } \\
\text { estribo }\end{array}$ & III & & & & 4 & & & & & & & \\
\hline $\begin{array}{l}\text { ML31 } \\
37\end{array}$ & $\begin{array}{l}\text { Asa } \\
\text { Estribo }\end{array}$ & IV & & & & & & & & & 10 & 11 & \\
\hline $\begin{array}{l}\text { ML } \\
3141\end{array}$ & $\begin{array}{l}\text { Asa } \\
\text { Estribo }\end{array}$ & III & $\begin{array}{l}\text { CHIC } \\
\text { AMA }\end{array}$ & $\begin{array}{l}\text { FACA } \\
\text { LÁ }\end{array}$ & & & & & & & 1 & & \\
\hline $\begin{array}{l}\text { ML33 } \\
69\end{array}$ & $\begin{array}{l}\text { Escultu } \\
\text { ral asa } \\
\text { estribo }\end{array}$ & III & & & & 2 & & & & & & & \\
\hline $\begin{array}{l}\text { ML } \\
3430\end{array}$ & $\begin{array}{l}\text { Asa } \\
\text { Estribo }\end{array}$ & IV & & & & 2 & & & & & & & 5 \\
\hline $\begin{array}{l}\text { ML34 } \\
33\end{array}$ & $\begin{array}{l}\text { Asa } \\
\text { Estribo }\end{array}$ & IV & $\begin{array}{l}\text { CHIC } \\
\text { AMA }\end{array}$ & $\begin{array}{l}\text { CASA } \\
\text { GRAN } \\
\text { DE }\end{array}$ & 2 & & & & & & & & \\
\hline $\begin{array}{l}\text { ML34 } \\
49\end{array}$ & $\begin{array}{l}\text { Asa } \\
\text { Estribo }\end{array}$ & IV & $\begin{array}{l}\text { CHIC } \\
\text { AMA }\end{array}$ & $\begin{array}{l}\text { FACA } \\
\text { LÁ }\end{array}$ & & & & 1 & & & & & \\
\hline $\begin{array}{l}\text { ML34 } \\
51\end{array}$ & $\begin{array}{l}\text { Asa } \\
\text { Estribo }\end{array}$ & IV & & & 8 & & & & & 1 & & & \\
\hline $\begin{array}{l}\text { ML } \\
3562\end{array}$ & $\begin{array}{l}\text { Asa } \\
\text { Estribo }\end{array}$ & IV & & & 3 & & 2 & & & 3 & & & \\
\hline $\begin{array}{l}\text { ML } \\
3667\end{array}$ & $\begin{array}{l}\text { Asa } \\
\text { Estribo }\end{array}$ & IV & $\begin{array}{l}\text { CHIC } \\
\text { AMA }\end{array}$ & & & & & & 1 & & & & \\
\hline $\begin{array}{l}\text { ML36 } \\
97\end{array}$ & $\begin{array}{l}\text { Asa } \\
\text { Estribo }\end{array}$ & IV & & & & & & & & & 4 & & \\
\hline $\begin{array}{l}\text { ML13 } \\
656\end{array}$ & $\begin{array}{l}\text { Asa } \\
\text { Estribo }\end{array}$ & IV & & & 3 & & & & & & & & \\
\hline $\begin{array}{l}\text { ML28 } \\
662\end{array}$ & $\begin{array}{l}\text { FLOR } \\
\text { ERO }\end{array}$ & IV & & & & & & & & & & & 2 \\
\hline
\end{tabular}




\begin{tabular}{|l|l|l|l|l|l|l|l|l|l|l|l|l|}
\hline TOTA \\
L DE \\
PEÇA \\
S: 13
\end{tabular}

\begin{tabular}{|c|c|c|c|}
\hline $\begin{array}{c}\text { PERCENTUAL VASOS } \\
\text { CACTOS: } 69.2 \%\end{array}$ & TOTAL: 9 & $\begin{array}{c}\text { PERCENTUAL } \\
\text { VASOS } \\
\text { ULLUCHU: } \\
15.3 \%\end{array}$ & TOTAL:2 \\
\hline $\begin{array}{c}\text { PERCENTUAL VASOS } \\
\text { TILLANDSIAS: } 15.3 \%\end{array}$ & TOTAL: 2 & $\begin{array}{c}\text { PERCENTUAL } \\
\text { VASOS } \\
\text { AQUÁTICAS: } \\
23.0 \% \\
\end{array}$ & TOTAL:2 \\
\hline
\end{tabular}

\section{SERPENTE (9)}

Agregamos neste grupo as serpentes naturalísticas, a serpente- felino, que aparece com uma cabeça de raposa ou felino, e a serpente veado-raposa-felino, que acrscenta galhadas de veado a sua composição. Sobre este tipo de composição nos diz Bars:

\footnotetext{
"Os seres supranaturais são compostos de modo a confirmarem a possibilidade de uma 'mescla intencional' de animais e de formas. Sob um olhar diferenciado e especial para a natureza, os mochica enxergavam relações de semelhanças entre espécies que em nossa visão moderna estariam muito distantes umas das outras. Esse olhar, pautado pelos preceitos ditados pela cosmovisão, mistura o comportamento natural dos animais em seus ambientes com seus 'papéis' por eles assumidos no 'universo supranatural' mochica. ’(Bars, 2009:135)
}

Hocquenghem argumenta que em grande parte das culturas ameríndias serpentes estão relacionadas a rios, portadores de vitalidade. Há uma relação entre os rios que correm montanha abaixo, a bruma das lomas, consideradas como rios e a via láctea, também vista como um rio celeste. (Hocquenghem, 1987).

No caso da serpente-veado-jaguar, a autora encontra um exemplo de ser com as mesmas características chamado Amaru, registrado nas crônicas do século XVII sobre as crenças de povos que viviam próximos das lagoas de regiões elevadas do andes. Este 
ser teria a "potência do felino, a vitalidade da serpente e a majestado do veado", manifestando sinchi, callpa e capac, ou seja, potência física, vitalidade e poder político (Hocquenghem, 2008:35).

\section{Flora e peças:}

O grupo da serpente não é grande, com 9 peças, mas o personagem da serpentefelino ou serpente raposa é comum nas outras cenas, aparecendo em 12 dos 16 grupos aqui apresentados. Em apenas um caso, M13439 (figura VI.IV.d) a serpente aparece vista de cima de forma naturalistica. A flora, classificada como desconhecida, parece ser uma representação de gramíneas, mas é semelhante a representações precoces de totoras e pode ser até mesmo uma versão fase III de tillandsias.

O veado-serpernte-felino aparece em uma ocasião (figura V.IV.e) rodeado de cactos. Em uma peça M13744 (figura V.IV.f) a serpente-felino aparece ao lado de tillandsias na parte inferior do corpo enquanto totoras estão representadas no cume do corpo do vaso. Este é o único exemplo de plantas aquáticas e terrestres associadas no mesmo corpo, apesar de haver casos em que cactos apareçam nas alças de temas com tema aquático.

No geral a flora mais comum é a de cactos, mas tanto a peça ML3744 quanto a peça com a serpente naturalísica parecem desafiar o padrão.

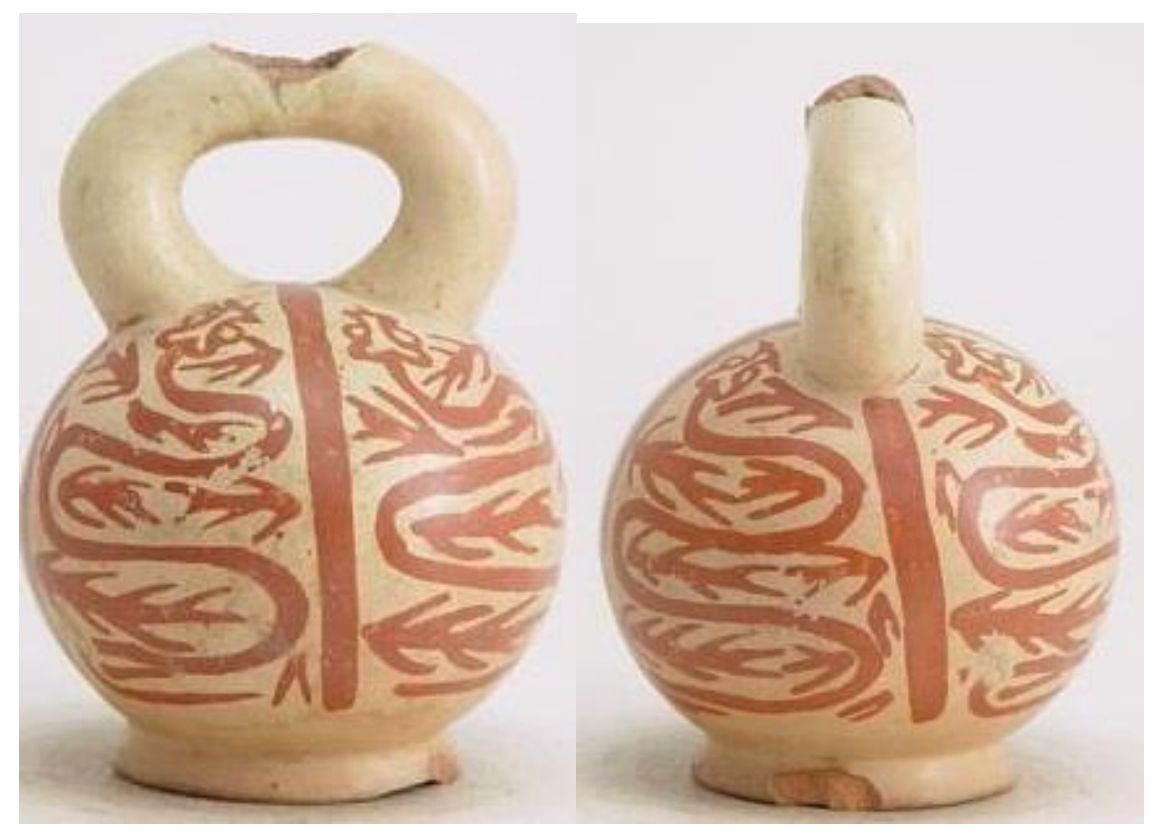

(FIGURA V.IV.d) rara seprente naturalista fase III 


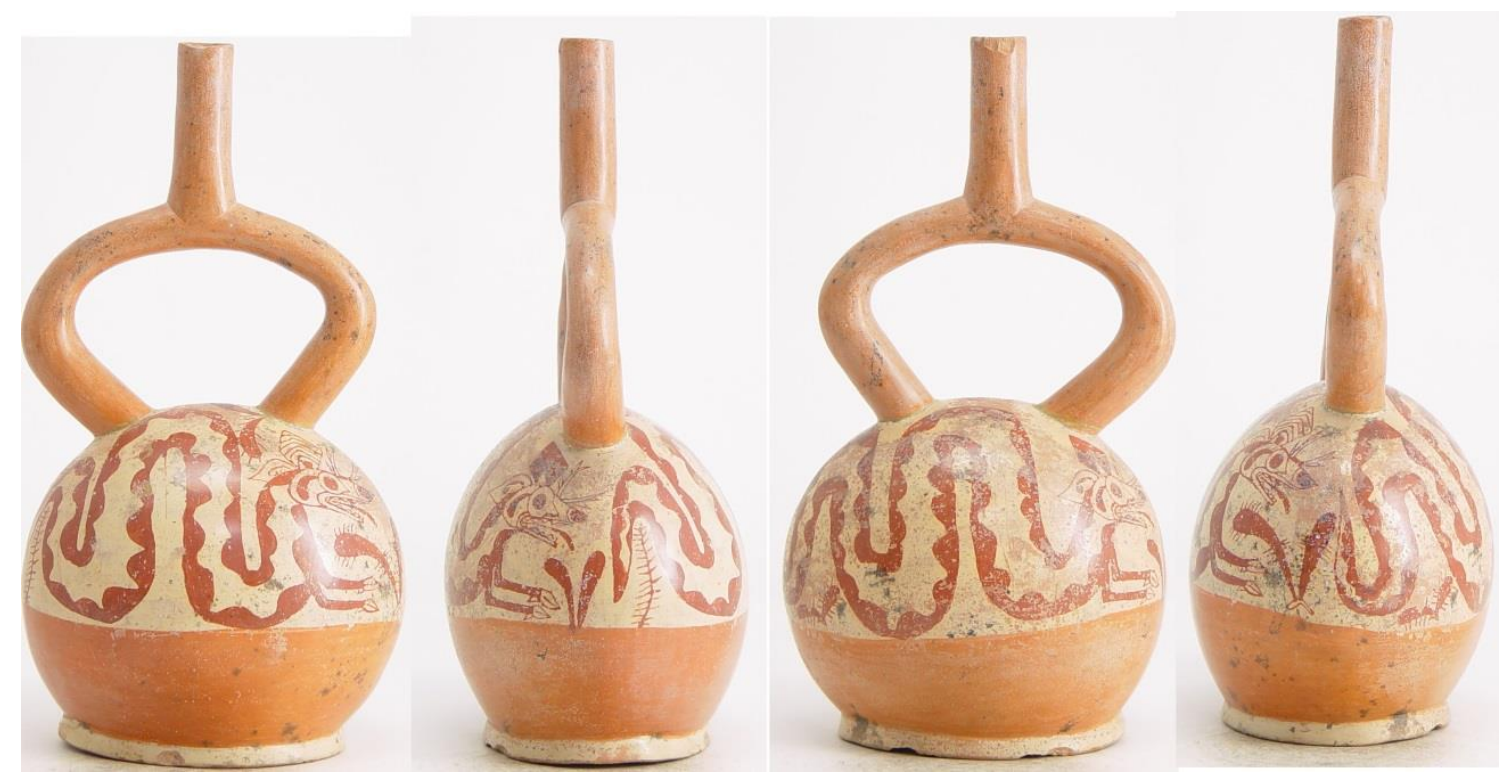

(Figura V.IV.e) Serpente Veado felino

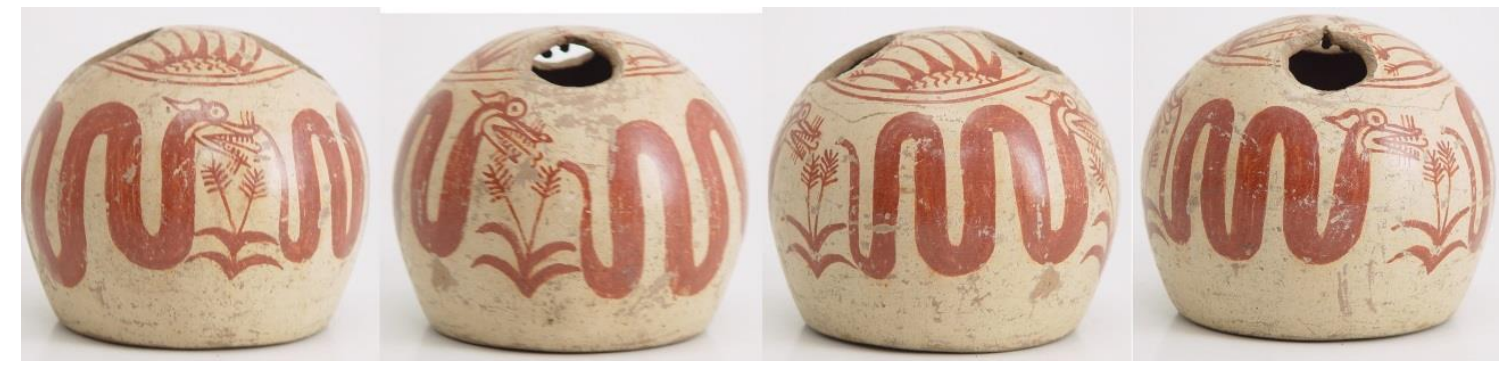

(FIGURA V.IV.f) Tillandsias na base e totoras no cume do corpo

Ficha Simplificada:

\begin{tabular}{|c|c|c|c|c|c|c|c|c|c|c|c|}
\hline PEÇA & $\begin{array}{l}\text { TIPO } \\
\text { DE } \\
\text { VASO }\end{array}$ & $\begin{array}{l}\text { FAS } \\
\text { E }\end{array}$ & VALE & SÍTIO & $\begin{array}{l}\text { CACT } \\
\text { O T1A }\end{array}$ & $\begin{array}{l}\text { CACT } \\
\text { O } \\
\text { T1B }\end{array}$ & $\begin{array}{l}\text { CACT } \\
\text { O T2 }\end{array}$ & $\begin{array}{l}\text { CAC } \\
\text { TO } \\
\text { T2B }\end{array}$ & $\begin{array}{l}\text { CACTO } \\
\text { T3 }\end{array}$ & $\begin{array}{l}\text { TILL } \\
\text { ANDS } \\
\text { IAS }\end{array}$ & $\begin{array}{l}\text { TOTOR } \\
\text { AS }\end{array}$ \\
\hline ML3439 & $\begin{array}{l}\text { Asa } \\
\text { Estribo }\end{array}$ & III & & & & & & & & & \\
\hline ML3534 & $\begin{array}{l}\text { Asa } \\
\text { Estribo }\end{array}$ & IV & & & 3 & 1 & & & & & \\
\hline ML3545 & $\begin{array}{l}\text { Asa } \\
\text { Estribo }\end{array}$ & IV & & & & 2 & 2 & & & & \\
\hline ML3557 & $\begin{array}{l}\text { Asa } \\
\text { Estribo } \\
\text { cantaro }\end{array}$ & IV & & & & 1 & 1 & & & & \\
\hline ML3744 & $\begin{array}{l}\text { Asa } \\
\text { Estribo }\end{array}$ & IV & Virú & & & & & & & 2 & 2 \\
\hline ML3857 & $\begin{array}{l}\text { Asa } \\
\text { Estribo }\end{array}$ & IV & Virú & $\begin{array}{l}\text { San } \\
\text { Idelfonso }\end{array}$ & 1 & & & 1 & 4 & & \\
\hline ML3859 & $\begin{array}{l}\text { Asa } \\
\text { Estribo }\end{array}$ & IV & & & & 1 & & & & & \\
\hline $\begin{array}{l}\text { ML1098 } \\
8\end{array}$ & $\begin{array}{l}\text { Asa } \\
\text { Estribo }\end{array}$ & III & & & & & & & & & \\
\hline $\begin{array}{l}\text { ML1362 } \\
9\end{array}$ & $\begin{array}{l}\text { Asa } \\
\text { Estribo }\end{array}$ & IV & $\begin{array}{l}\text { Chica } \\
\text { ma }\end{array}$ & Facalá & & & 1 & & 3 & & \\
\hline
\end{tabular}




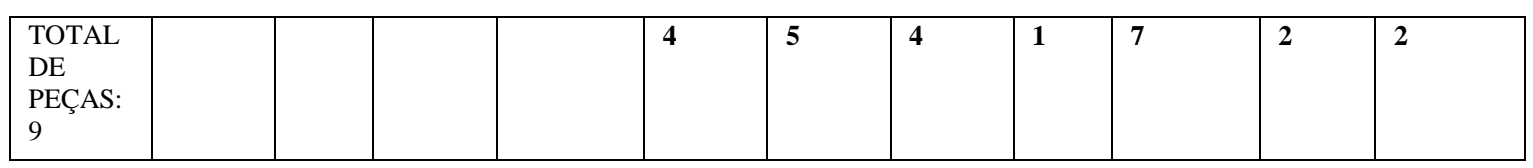

\begin{tabular}{|c|c|c|c|}
\hline $\begin{array}{c}\text { PERCENTUAL } \\
\text { VASOS CACTOS: } \\
77.7 \%\end{array}$ & TOTAL: 7 & $\begin{array}{l}\text { PERCENTUAL } \\
\text { VASOS } \\
\text { DESCONHECID } \\
\text { O: } 33.3 \%\end{array}$ & $\begin{array}{l}\text { TOTAL: } \\
3\end{array}$ \\
\hline $\begin{array}{c}\text { PERCENTUAL } \\
\text { VASOS TILLANDSIA } \\
: 11.1 \%\end{array}$ & TOTAL: 1 & $\begin{array}{c}\text { PERCENTUAL } \\
\text { VASOS } \\
\text { TOTORAS: } \\
11.1 \%\end{array}$ & TOTAL: 1 \\
\hline
\end{tabular}

\section{MONSTRO STROMBUS (9)}

O Museu Larco chama de "Monstro Strombus" um animal mítico bicéfalo com garras e dentes à mostra. Sua principal característica seria a grande concha de caracol Strombus que carrega nas costas.

Mackey \& Vogel crêem que assim como as bestas mitológicas do velho mundo, os monstros do novo mundo possuem; corpo composto por partes de vários animais, elementos imaginários complementados por não imaginários, habitam um lugar específico e possuem múltiplas funções culturais (Mackey \& Vogel, 2003: 329). Assim, talvez a característica mais marcante e "fantástica" deste ser, a concha, pode conter uma importante chave interpretativa.

O gastrópode marinho strombus ocorre em águas tropicais próximas da costa do equador. Sua concha chegava aos moche principalmente por meio de comércio, mas mudanças na corrente marítima durante os fenõmenos de el niño podem ter trazido estes animais às costas peruanas (Benson, 2012:64).

As conchas eram muito valorizadas no período Inca e muito provavelmente também o eram entre os mochica. Delas eram produzidos "trompas" rituais, além de serem muito utilizadas como oferendas nas quais se trocava a concha por água com os ancestrais (Hocquenghem, 1987:82).

Segundo Golte, o Monstro Strimbus tinha se associava ao lado masculino do mundo submarino e propiciava a reprodução masculina (Golte, 2009:135). Bourget(1994) acredita que os monstros marinhos poderiam personificar os perigos do mar, principalmente durante os períodos de El Niño. Benson crê que eles poderiam demonstrar animismo uma vez que a concha dura continha um ser vivo úmido dentro de 
si(Benson, 2012:63)

\section{Flora e Peças:}

Benson, (2012:64) pensa que o Monstro Strombus tenha emergido na cultura mochica tardiamente, já na fase IV. De fato, todos os nove vasos que compõe nossa análise são alça estribo e fase IV.

É um grupo homogêneo em todos os aspectos. O monstro aparentemente não realiza ação alguma apesar de aparecer em uma peça do grupo de Aia Paec lutando contra a divindade. Cactos aparecem em oito dos nove vasos enquanto tillandsias em apenas dois. Ulluchus aparecem também em dois vasos. No geral o cenário parece ser árido apesar das tillandsias.

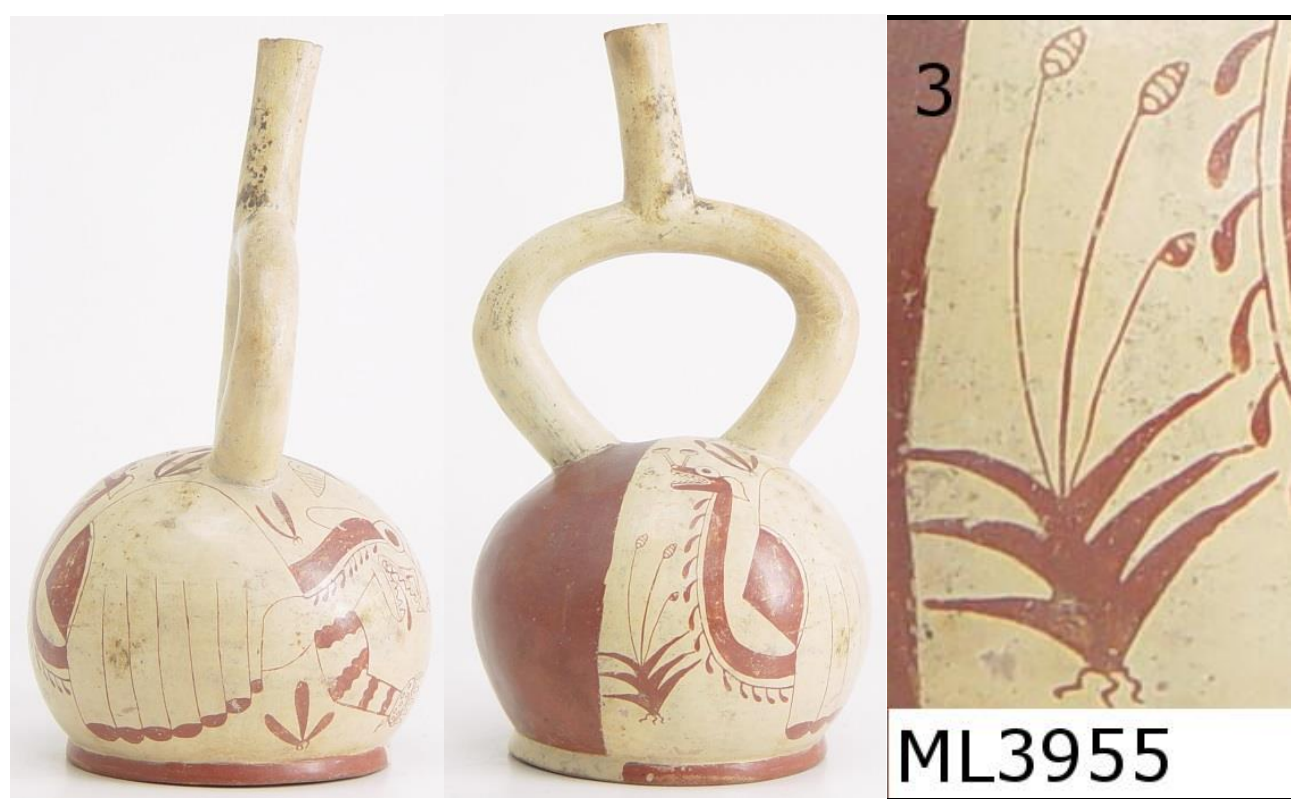

(FIGURA V.IV.g) Monstro Strombus ao lado de cactos e tillandsias

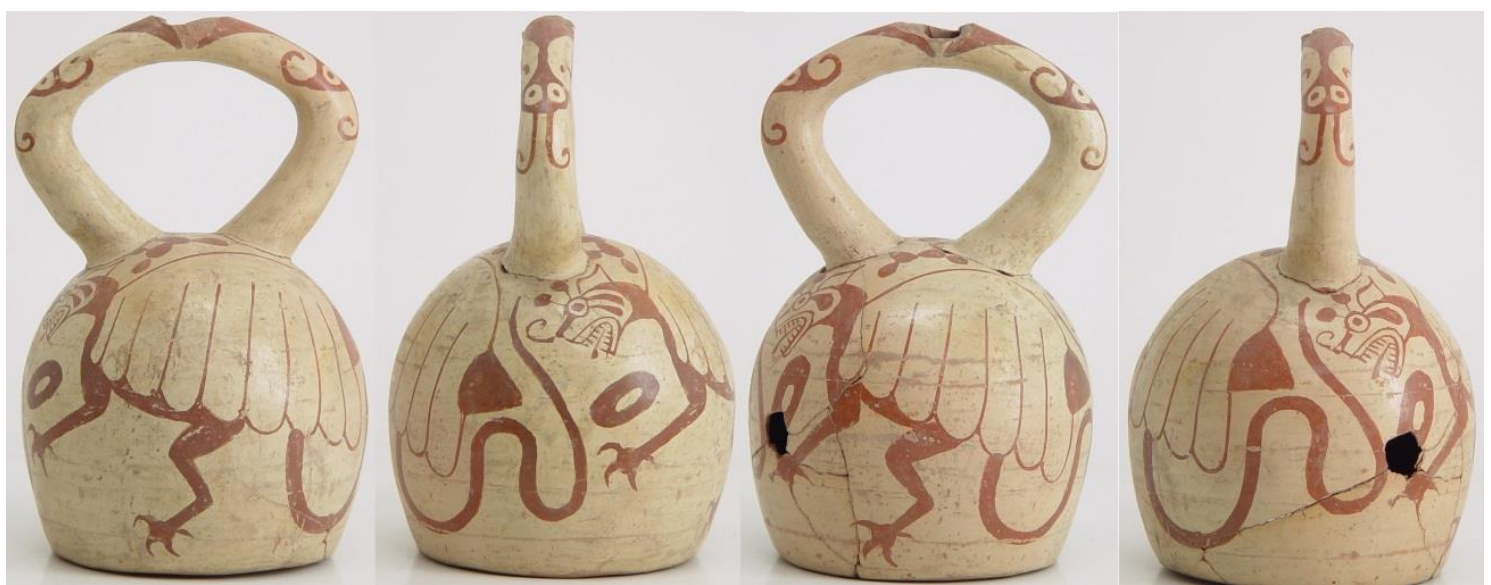

(FIGURA V.IV.h) Monstro Strombus com cacto T4 no cume do vaso 


\begin{tabular}{|c|c|c|c|c|c|c|c|c|c|c|c|c|}
\hline PEÇA & $\begin{array}{l}\text { TIPO } \\
\text { DE } \\
\text { VASO }\end{array}$ & $\begin{array}{l}\mathbf{F} \\
\mathbf{A S} \\
\mathbf{E}\end{array}$ & VALE & $\begin{array}{l}\text { SíTI } \\
0\end{array}$ & $\begin{array}{l}\text { CACT } \\
\text { O T1A }\end{array}$ & $\begin{array}{l}\text { CAC } \\
\text { TO } \\
\text { T1B }\end{array}$ & $\begin{array}{l}\text { CACT } \\
\text { O T2 }\end{array}$ & $\begin{array}{l}\text { CAC } \\
\text { TO } \\
\text { T2B }\end{array}$ & $\begin{array}{l}\text { CACT } \\
\text { O T4 }\end{array}$ & $\begin{array}{l}\text { CACT } \\
\text { O T5 }\end{array}$ & $\begin{array}{l}\text { TILLAN } \\
\text { DSIAS }\end{array}$ & $\begin{array}{l}\text { ULLUC } \\
\text { HU }\end{array}$ \\
\hline $\begin{array}{l}\text { ML39 } \\
44\end{array}$ & $\begin{array}{l}\text { Asa } \\
\text { Estribo }\end{array}$ & IV & & & & & 1 & & & & & \\
\hline $\begin{array}{l}\text { ML39 } \\
45\end{array}$ & $\begin{array}{l}\text { Asa } \\
\text { Estribo }\end{array}$ & IV & & & & & & & & 2 & & \\
\hline $\begin{array}{l}\text { ML39 } \\
54\end{array}$ & $\begin{array}{l}\text { Asa } \\
\text { Estribo }\end{array}$ & IV & $\begin{array}{l}\text { Chica } \\
\text { ma }\end{array}$ & $\begin{array}{l}\text { Chiq } \\
\text { uitoy }\end{array}$ & & 4 & & & & & & 9 \\
\hline $\begin{array}{l}\text { ML39 } \\
55\end{array}$ & $\begin{array}{l}\text { Asa } \\
\text { Estribo }\end{array}$ & IV & & & & 3 & & & & & 1 & \\
\hline $\begin{array}{l}\text { ML36 } \\
56\end{array}$ & $\begin{array}{l}\text { Asa } \\
\text { Estribo }\end{array}$ & IV & $\begin{array}{l}\text { Chica } \\
\text { ma }\end{array}$ & $\begin{array}{l}\text { El } \\
\text { Bruj } \\
\text { o }\end{array}$ & 3 & & & & & 2 & & \\
\hline $\begin{array}{l}\text { ML39 } \\
61\end{array}$ & $\begin{array}{l}\text { Asa } \\
\text { Estribo }\end{array}$ & IV & & & & 2 & & 2 & & & & 9 \\
\hline $\begin{array}{l}\text { ML39 } \\
64\end{array}$ & $\begin{array}{l}\text { Asa } \\
\text { Estribo }\end{array}$ & IV & $\begin{array}{l}\text { Chica } \\
\text { ma }\end{array}$ & $\begin{array}{l}\text { Saus } \\
\text { al }\end{array}$ & & & 6 & & & & & \\
\hline $\begin{array}{l}\text { ML39 } \\
71\end{array}$ & $\begin{array}{l}\text { Asa } \\
\text { Estribo }\end{array}$ & IV & Moche & $\begin{array}{l}\text { Lare } \\
\text { do }\end{array}$ & & & & & & & 1 & \\
\hline $\begin{array}{l}\text { ML39 } \\
74\end{array}$ & $\begin{array}{l}\text { Asa } \\
\text { Estribo }\end{array}$ & IV & & & & & & & 2 & & & \\
\hline $\begin{array}{l}\text { TOTA } \\
\text { L DE } \\
\text { PEÇA } \\
\text { S: } 9\end{array}$ & & & & & 3 & 9 & 7 & 2 & 2 & 4 & 2 & 18 \\
\hline
\end{tabular}

\begin{tabular}{|c|c|c|c|}
\hline & \multicolumn{2}{|c|}{} \\
$\begin{array}{c}\text { PERCENTUAL VASOS } \\
\text { CACTOS: } 88.8 \%\end{array}$ & TOTAL: 8 & \multicolumn{2}{|c|}{} \\
& & & \\
& & $\begin{array}{c}\text { PERCENTUAL } \\
\text { VASOS } \\
\text { PERCENTUAL VASOS } \\
\text { TILLANDSIAS: } 22.2 \%\end{array}$ & TOTAL: 2 \\
& & $\begin{array}{c}\text { TLUU: } \\
22.2 \%\end{array}$ & TOTAL: 2 \\
\hline
\end{tabular}


Um monstro quadrupede bicéfalo aparece em um ambiente árido, muitas vezes segurando uma cabeça decapitada. A este personagem o museu Larco denomina Dragão, mas recebe diversos nomes como Animal Lunar, Monstro Lunar ou Animal Cristado (Benson, 2012).

Mackey \& Vogel listam uma série de características associadas à maioria das representações do personagem como corpo arqueado, dentes e garras à mostra e crista proeminente (Mackey\&Vogel, 2003:326). Para elas, o animal já é representado em Galinazzo e segue aparecendo até os Chimú (idem: 330).

Benson vê o Dragão como semelhante a vários animais como felino, raposa e cão, com características felinas e garras parecidas com as das aves (Benson, 2012: 61). Segundo a autora, ao contrário dos outros "monstros", o animal jamais confrota Aia Paec (ver Aia Paec) ou Deus do Cinturão de Serpente (ibdi:62), mas na mesma obra ela publica uma imagem de um vaso do Museu Etnológico de Berlin onde o Deus luta com o monstro.

Apesar de fortemente associado à cultura serrana Recuay, contemporânea dos moche, cujas únicas divindades representadas parecem ser o Dragão e a Serpente bicéfala, Mackey \& Vogel advogam por uma origem costeira, possivelmente inspirada no gato montês andino (Oncifelis cololo) (Mackey \& Vogel, 2003:339).

Golte(2009), Makosky (2000), Benson (2012) e Mackey \& Vogel (2003) associam o animal ao céu noturno, a corpos celestes e mais fortemente à lua. Mackey \& Vogel (2003: 338) distinguem o Dragão de um outro animal praticamente similar o qual chamam de "Jaguar de Miranda". Não encontramos, entretanto, esta divisão em nenhum outro autor consultado. Se ela de fato existe, é provável que a classificação do Museu Larco abarque ambos os seres.

\section{Flora e Peças:}

O Dragão é uma figura de grande presença na iconografia Moche e isso se reflete na coleção, ao constituir o maior grupo, com 31 peças. Também é um grupo bastante homogêneo com 30 peças alça estribo e apenas uma com alça lateral simulando cântaro. Do mesmo modo, apenas uma peça parece ser fase III com todas as outras indicando ser da fase IV. 
A associação com a serpente-felino parece bem comum aparecendo em 12 peças. Em três vasos o Dragão aparece segurando uma cabeça decapitada (figura V.IV.j). A divisão vertical também parece comum, ocorrendo em 20 das peças (figura V.IV.k). Esferas, possivelmente indicando uma cena noturna, aparecem em 5 vasos.

A composição florística da cena é alvez a mais assertiva de todos os grupos. Cactos são representados em $100 \%$ dos vasos, com uma ênfase em cactos do tipo 2 , mais próximo morfologicamente do cacto $N$. arequipensis, resistente à aridez.

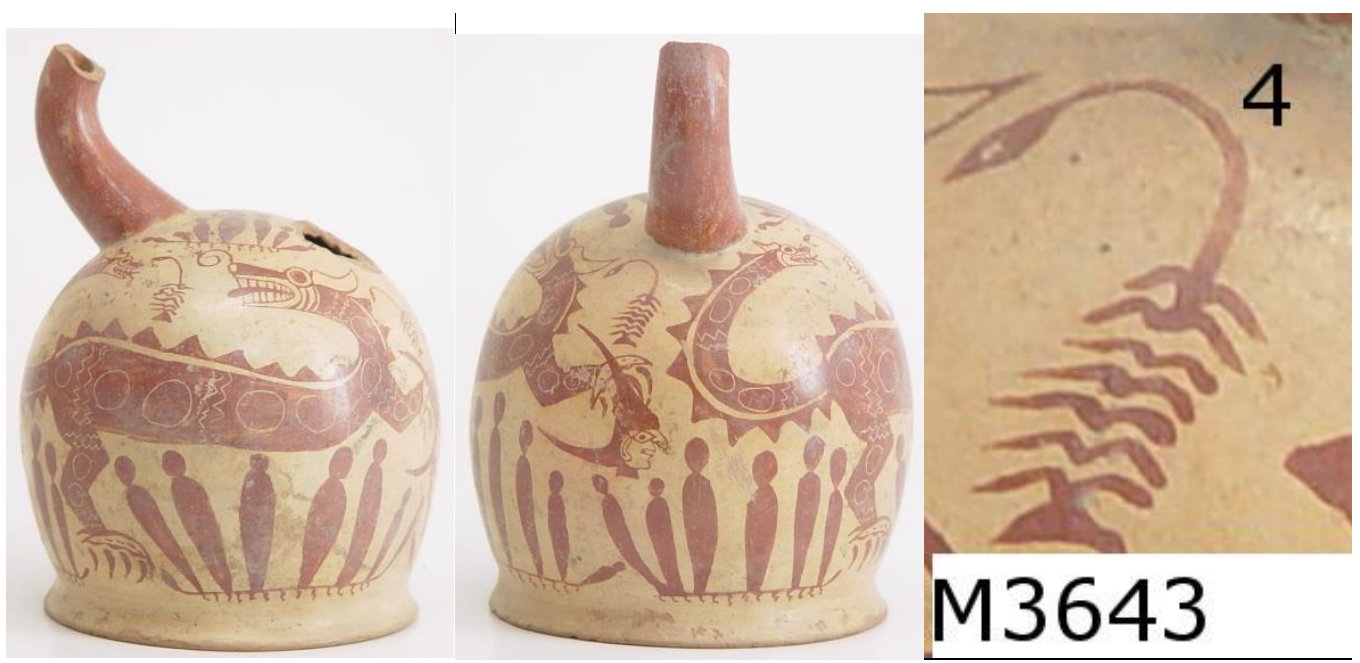

(FIGURA V.IV.j) Dragão com segurando cabeça decapitada

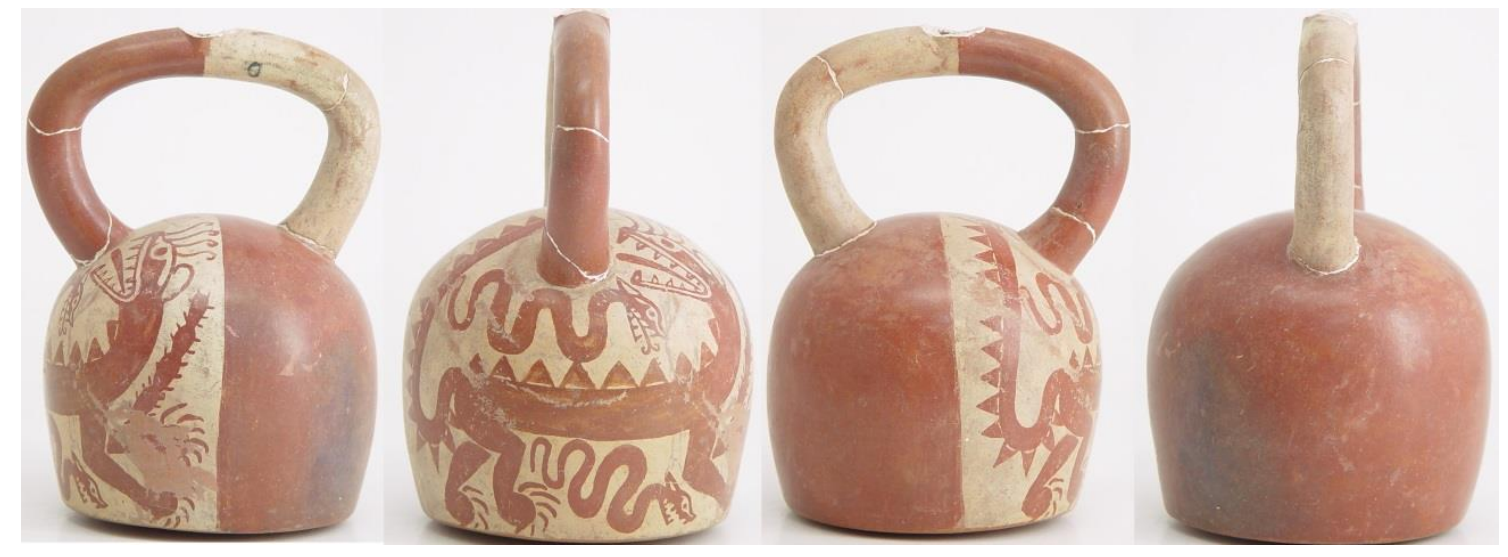

(FIGURA V.IV.k) Dragão com serpente associação comum.

\begin{tabular}{|c|c|c|c|c|c|c|c|c|c|c|c|c|c|c|}
\hline $\begin{array}{l}\text { PEÇA } \\
\end{array}$ & $\begin{array}{l}\text { TIPO } \\
\text { DE } \\
\text { VASO }\end{array}$ & $\begin{array}{l}\mathbf{F A} \\
\mathbf{S E}\end{array}$ & VALE & SÍTIO & $\begin{array}{l}\text { CAC } \\
\text { TO } \\
\text { TIA }\end{array}$ & $\begin{array}{l}\text { CAC } \\
\text { TO } \\
\text { T1B }\end{array}$ & $\begin{array}{l}\text { CAC } \\
\text { TO } \\
\text { T2 }\end{array}$ & $\begin{array}{l}\text { CAC } \\
\text { TO } \\
\text { T2B }\end{array}$ & $\begin{array}{l}\text { CAC } \\
\text { TO } \\
\text { T3 }\end{array}$ & $\begin{array}{l}\text { CAC } \\
\text { TO } \\
\text { T4 }\end{array}$ & $\begin{array}{l}\text { CAC } \\
\text { TO } \\
\text { T5 }\end{array}$ & $\begin{array}{l}\text { TILLAND } \\
\text { SIAS }\end{array}$ & $\begin{array}{l}\text { FLO } \\
\text { RES }\end{array}$ & $\begin{array}{l}\text { DESCONHE } \\
\text { CIDO }\end{array}$ \\
\hline $\begin{array}{l}\text { ML35 } \\
35\end{array}$ & $\begin{array}{l}\text { Asa } \\
\text { Estribo } \\
\text { escultó } \\
\text { rico }\end{array}$ & IV & & & & & 1 & & 1 & & & & & \\
\hline
\end{tabular}




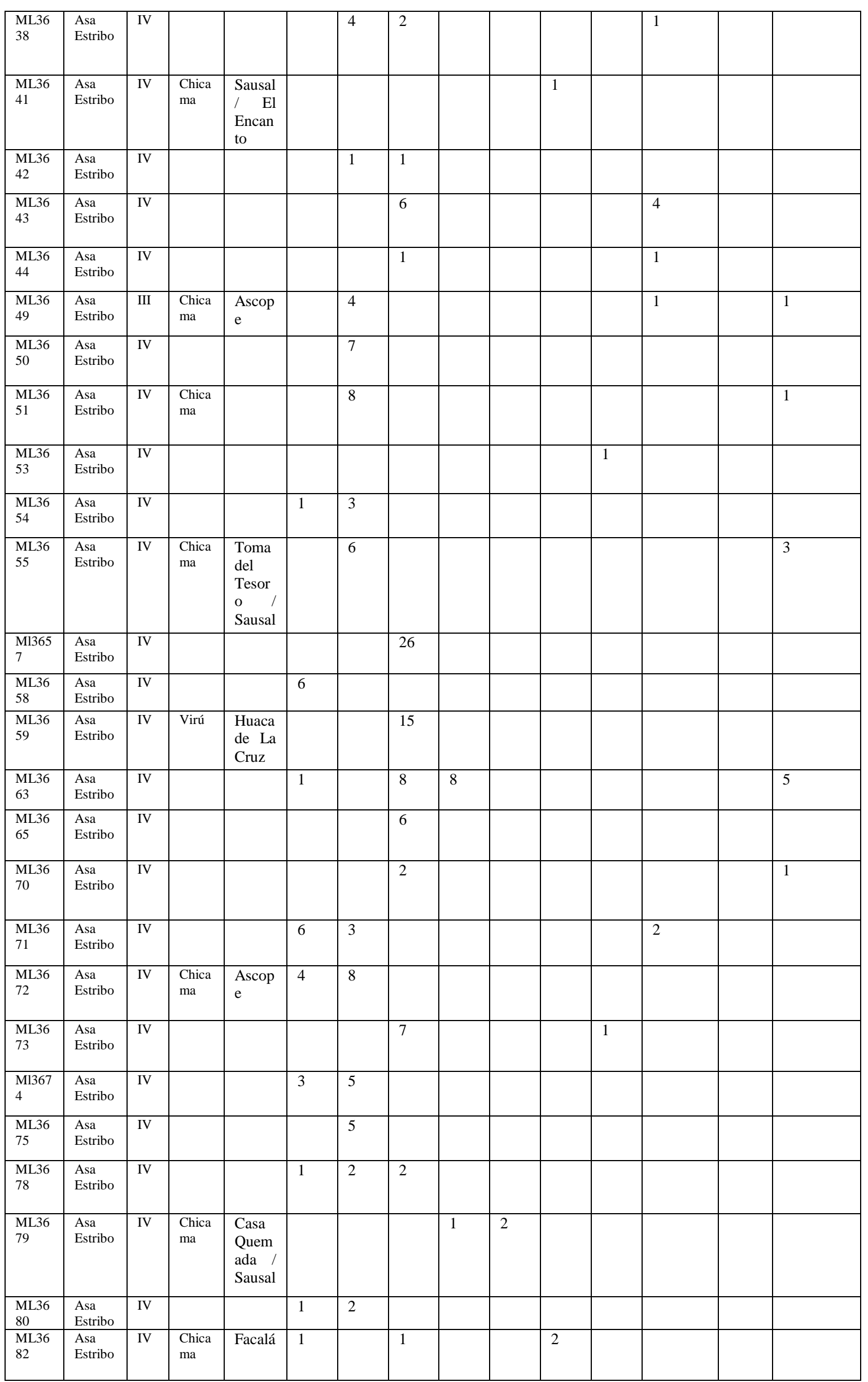




\begin{tabular}{|l|l|l|l|l|l|l|l|l|l|l|l|l|l|}
\hline $\begin{array}{l}\text { ML36 } \\
83\end{array}$ & $\begin{array}{l}\text { Asa } \\
\text { Estribo }\end{array}$ & IV & & & & & 2 & & 17 & & 2 & & \\
\hline $\begin{array}{l}\text { ML41 } \\
75\end{array}$ & $\begin{array}{l}\text { Asa } \\
\text { Estribo }\end{array}$ & IV & & & & 4 & & & & & & & \\
\hline $\begin{array}{l}\text { ML13 } \\
624\end{array}$ & $\begin{array}{l}\text { Asa } \\
\text { Estribo }\end{array}$ & IV & & & & 1 & 3 & & & & & & \\
\hline $\begin{array}{l}\text { ML13 } \\
626\end{array}$ & $\begin{array}{l}\text { Asa } \\
\text { Estribo }\end{array}$ & IV & $\begin{array}{l}\text { Chica } \\
\text { ma }\end{array}$ & & & & 9 & & & & & & 3 \\
\hline $\begin{array}{l}\text { TOTA } \\
\text { L: } 31\end{array}$ & & & & & $\mathbf{2 4}$ & $\mathbf{6 3}$ & $\mathbf{9 2}$ & $\mathbf{9}$ & $\mathbf{2 0}$ & $\mathbf{3}$ & $\mathbf{4}$ & $\mathbf{9}$ & $\mathbf{2}$ \\
\hline
\end{tabular}

\begin{tabular}{|c|c|}
\hline $\begin{array}{c}\text { PERCENTUAL VASOS } \\
\text { CACTOS: } 100.0 \%\end{array}$ & TOTAL:31 \\
\hline & \\
PERCENTUAL VASOS & TOTAL:5 \\
TILLANDSIAS: $16.0 \%$ & \\
\hline
\end{tabular}

AVE MÍTICA (18)

A definição "Ave mítica" dada pelo Museu Larco foi utilizada para a identificação de um falconídeo, talvez inspirado na águia pescadora (Pandion halietus) que aparece quase sempre alimentando-se em uma vasilhame ou huaco. É uma cena com pouquíssima variação, tanto na ação quanto no cenário.

É possível que seja uma herança ou linhagem de um culto ornitomorfo. Narváez (1995:109) indica que no sitio de Huaca Prieta, datado em cerca de 4.500 A.P, já se encontram ícones de adoração ornitomorfa. O autor ainda faz uma aproximação de base etnohistórica sobre a posição da aves na hieraquia inconológica Inca:

“(...)en la posición Hanan existe un una jerarquía de aves totémicas dentro de un esquema de tripartición y con connotaciones de caráter político y religioso: El Corenque o Halcón real de los Incas simbolizaba al hijo del sol o primera persona. La segunda persona estaba representada por el águila, símbolo de la guerra. La tercera persona ligada a administración del tributo y la producción estaba representada por el cóndor, símbolo del água, el mar y la fertilidad"'(Narváez, 1995:109)

De fato a ligação com o mundo de acima e com o Deus Rajado ou solar parece consenso. Makowsky considera a águia uma das manifestações do próprio Deus Solar a 
quem nomeia de "Guerreiro Águia". Segundo o autor, histórias de deuses transformados em aves eram muito comuns em tempos coloniais e não há porque pensar que as divindades mochica também não operariam pela mesma lógica (Makowsky, 2000:146)

Golte nomeia a Ave Mítica de Divindade Águia. Para ele, enquanto o Deus Coruja tem o papel de servir como intermediário da Divindade da Via Láctea, a Divindade águia serviria de intermediadora para o Deus Diurno, nomeado também de Deus rajado ou solar. A razão pela qual a Ave Mítica aparece em contextos tão limitados (quase sempre se alimentando no vaso) seria a de que o deus solar se vale de outro servo importante, o Deus intermediador (ver Aia Paec) (Golte, 2009:75). Todavia, como o próprio autor aponta, uma versão antropomofizada da Ave Mítica parece participar da cerimônia de Badminton (idb: 101).

Flora e Peças:

Apesar de ser grande, com 18 peças, o grupo da Ave Mítica é o mais homogêneo de todos quando considerados morfologia, período e composição de cena. Todas as peças são vasos alça estribo muito provavelmente da fase IV.

Do mesmo modo, quase todas as cenas, 16 peças, mostram a Ave se alimentando de um vaso acampanado em uma paisagem desértica (figura V.IV.l). Para Golte, trata-se de uma oferenda do mundo de abaixo para o mundo de acima no período seco, de junho à novembro ( Golte, 2009:101) O autor ainda aponta que uma das evidências de representação de ambos os mundos seria a divisão do vaso(ibd.). De fato, 12 vasos estão divididos horizontalmente, a maior proporção neste sentido do que qualquer outro grupo.

Dois vasos parecem sair um pouco da composição tradicional da cena. Em um deles ML3970, (Figura V.IV.m) a ave aparece se alimentado com presas. No outro, ML4013 (figura V.IV.n), a ave não apenas tem presas como possui pernas e braços e segura um panóplia.

A flora parece estar ligada à regiões áridas com uma predominância de cactos, 14 vasos, $77,7 \%$, e uma representação minoritária de tillandsias em 5 vasos, $27,7 \%$. O ulluchu aparece muito discretamente em um vaso próximo ao vaso, e é difícil que iso indique alguma associação forte da ave à planta. 


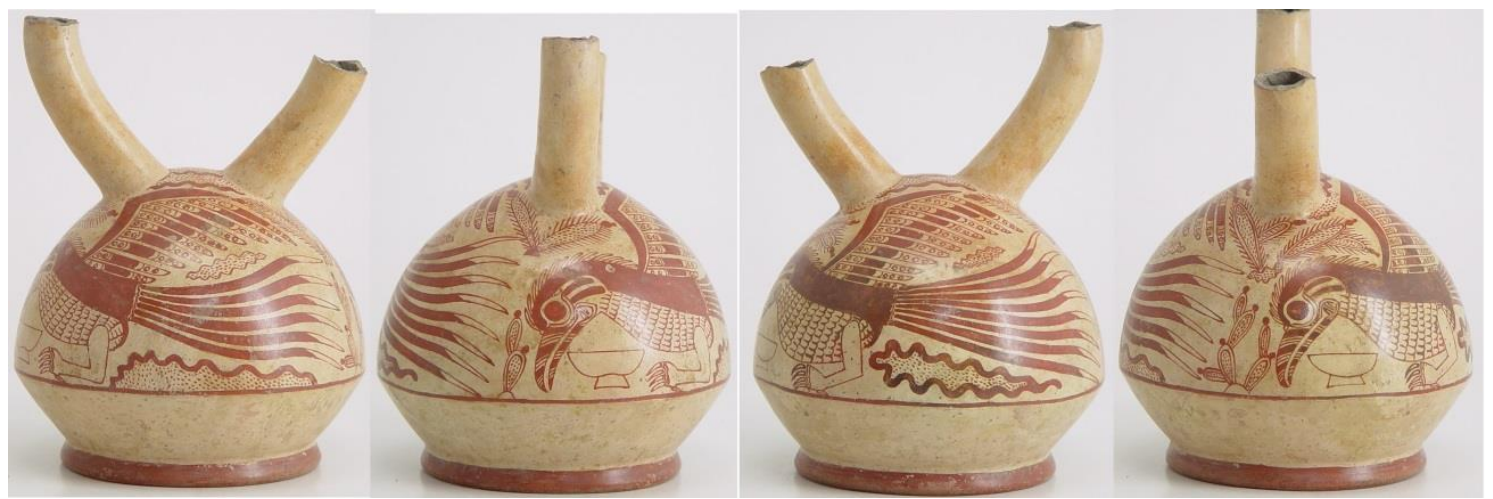

(FIGURA V.IV.l) Um exemplo de vaso típico do grupo

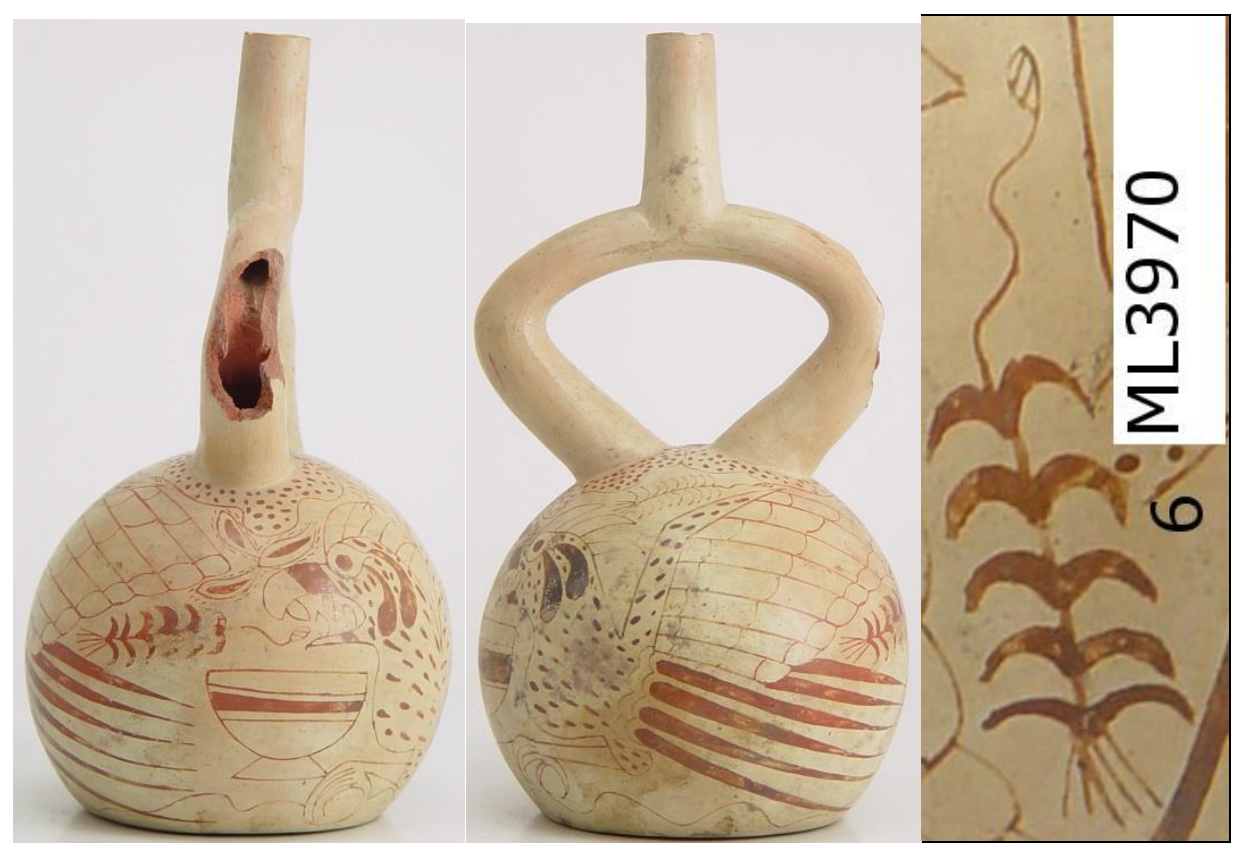

(FIGURA V.IV.m) ave Mitica com presas

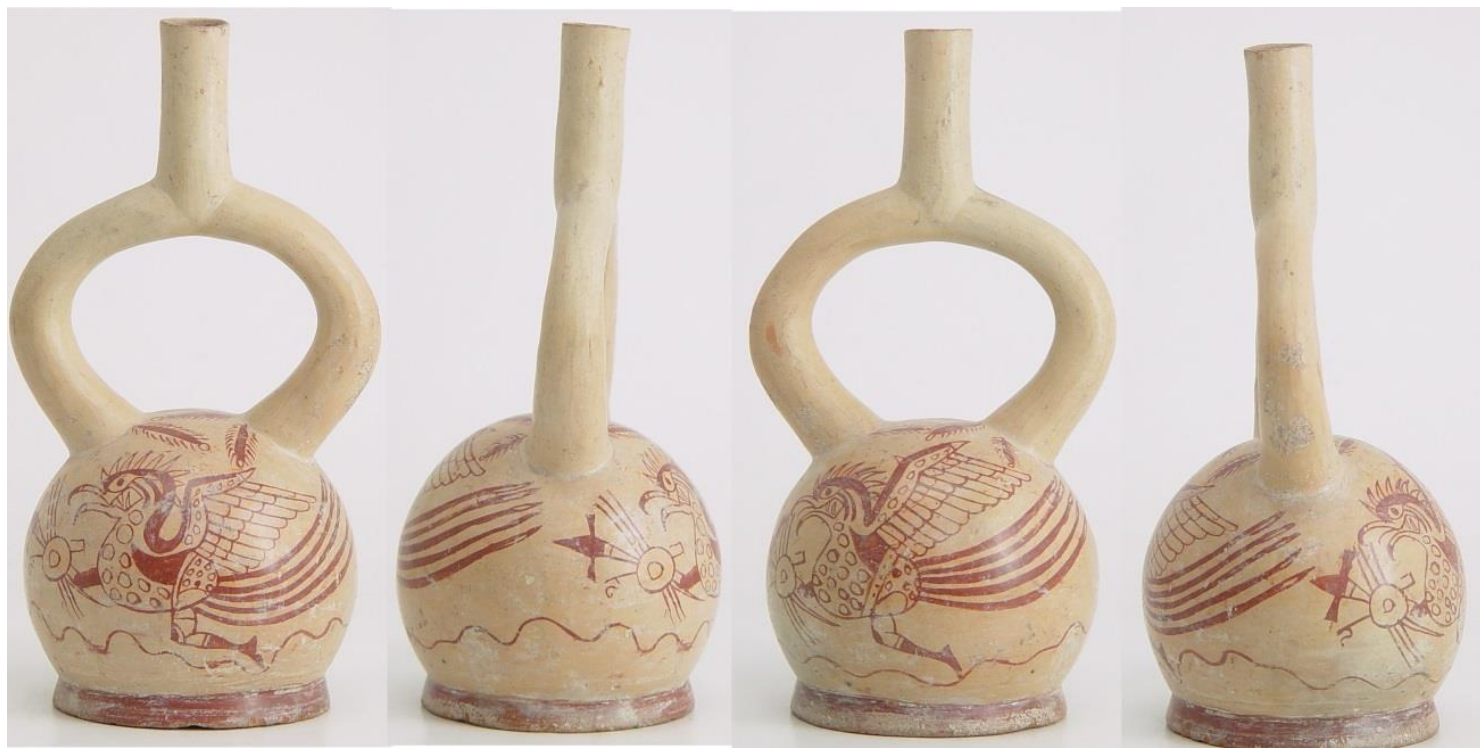

(FIGURA V.IV.n) Ave Mítica pistola com presas, pernas e panóplia 
Ficha Simplificada.

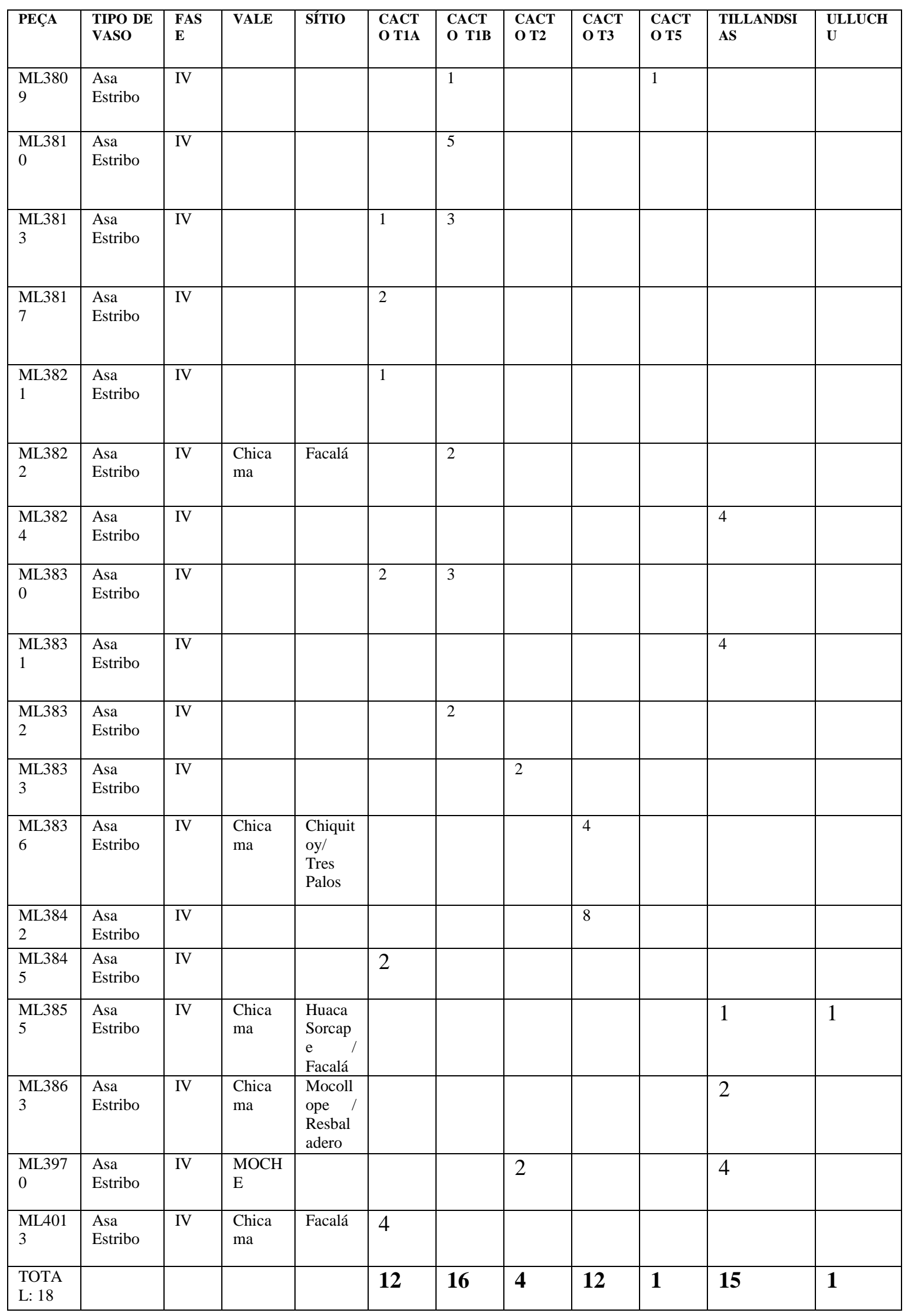




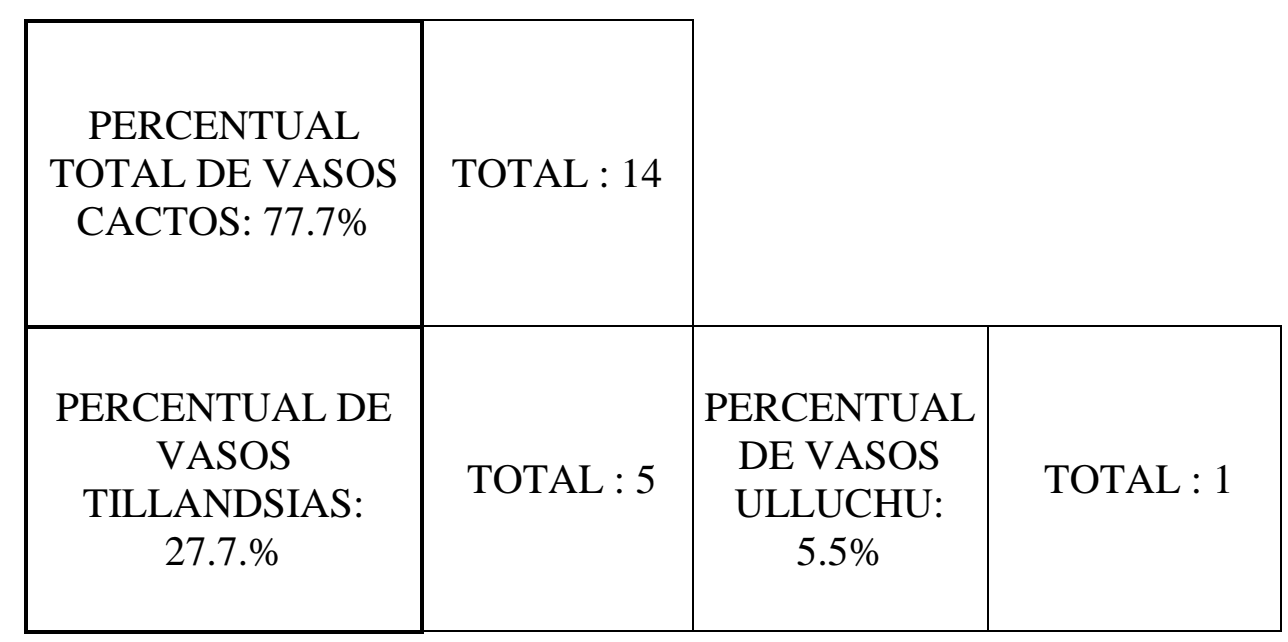

\section{V.V - TOTAIS}

No intuito de buscar padrões no conjunto total, os grupos serão analisados lado a lado. Para que a distorção causada pela variação de números de peças por grupo fosse amenizada foram excluídos os grupos de cinco ou menos peças. São eles Mundo Horroroso, Badminton, Caça de aves, Coca/Músico, Panóplia e Pântano. Os 15 grupos restantes foram distribuídos dentro de seus macrogrupos originais.

O Gráfico 1 (abaixo) mostra a divisão em números totais de todas as plantas contabilizadas no conjunto dos vasos, com cáctos, arbóreos e aquáticos unificados.

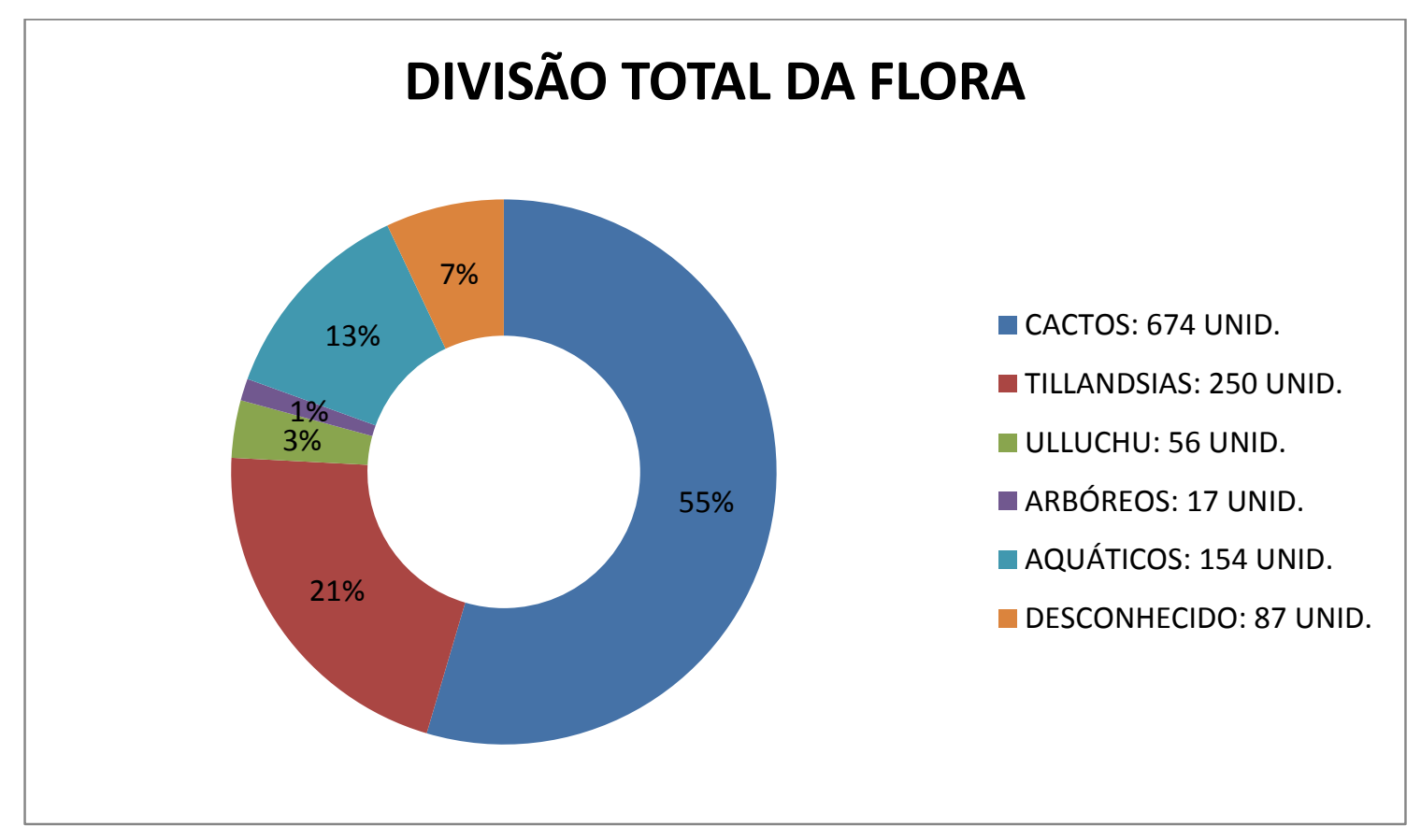

(Gráfico 1) Divisão total da flora 
No gráfico 2 (abaixo) está contabilizado o número total de plantas no conjunto de vasos.

\section{DIVISÃO TOTAL DA FLORA POR TIPO}

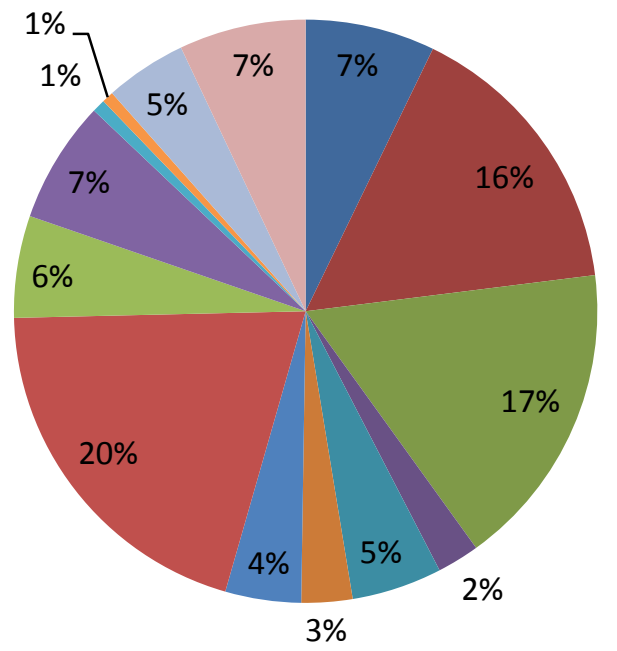

- CT1A: 89

- CT1B: 196

- CT2: 211

- CT2B: 29

- CT3:62

CT4: 35

- CT5: 52

- TILLANDSIAS: 250

- TOTORAS: 70

- FLORES :84

(Gráfico 2) Divisão total por tipo.

O Grafico 7, (abaixo) apresenta o percentual de vasos com cada tipo das 14 divisões florísticas propostas. A ficha de apoio mostra os percentuais das barras.

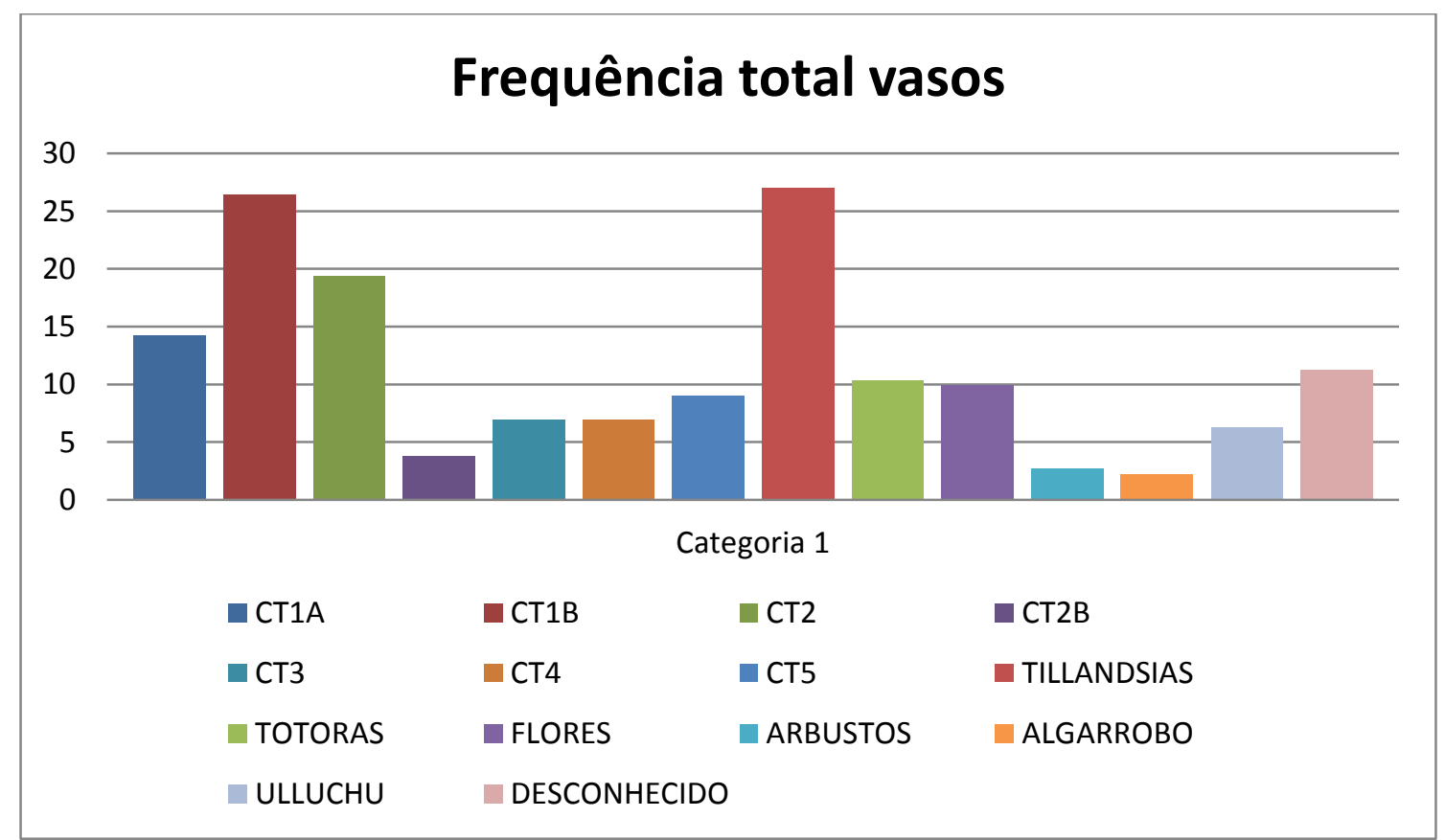

(Gráfico 3) Frequência nos vasos considerando-se o total do conjunto por divisão unitária.

Ficha de apoio (Gráfico 3) 


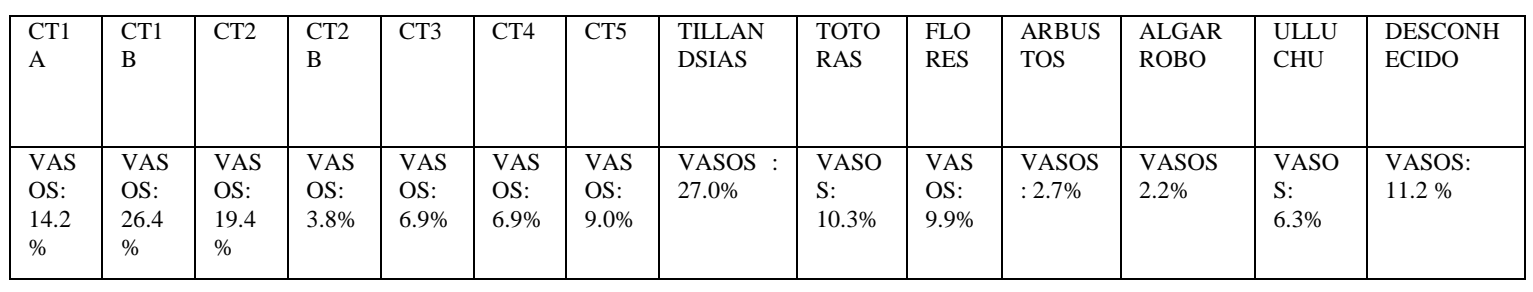

Variáveis: foram contabilizados os cactos que apareciam com frutos e os cactos, tillandsias e totoras que apareciam com raízes ou rizomas expostos

\begin{tabular}{|l|l}
\hline Cactos com frutos: 42 vasos & Plantas com raízes: 72 vasos
\end{tabular}

Localização das plantas: a tabela abaixo contabiliza a localização da flora na estrutura física do vaso.

\begin{tabular}{|l|c|c|c|}
\hline Alças: 4,2\% & Cume: $9,4 \%$ & Metade superior: & Metade Inferior: \\
& & $44,1 \%$ & $42,2 \%$ \\
\hline
\end{tabular}

Embora a amostra seja numericamente limitada, alguns padrões parecem despontar, mesmo que possivelmente válidos somente para a coleção do Museu Larco Herrera. Os gráficos apontam o percentual de vasos relativo ao grupo nos quais determinado topo de flora aparece.

No macrogrupo dos ritos (Gráfico 4) percebe-se uma associação média com cactos de $69,5 \%$, maior do que a do grupo naturalista (Gráfico 5) mas menor do que a do grupo dos seres míticos (Gráfico 6). As tillandsias aparecem em 50,5\% dos vasos, uma média bem acima dos outros dois macrogrupos. Isso se deve, em grande parte à participação da cena da corrida e em menor a da batalha, mas a cena da Ave guerreira também possui um percentual maior do que a média. Ulluchus aparecem nas cenas de Corrida e ave Guerreira, mas, mesmo não aparecendo nesta coleção são conhecidas cenas de batalha com a planta pictografada. No total somam $13,75 \%$ dos vasos, mais do que do macrogrupo naturalista e menos do que no macrogrupo dos seres míticos. Arbóreas ocorrem em duas cenas (corrida e batalha) somando apenas 3\% do total dos vasos. Não aparecem plantas aquáticas. 


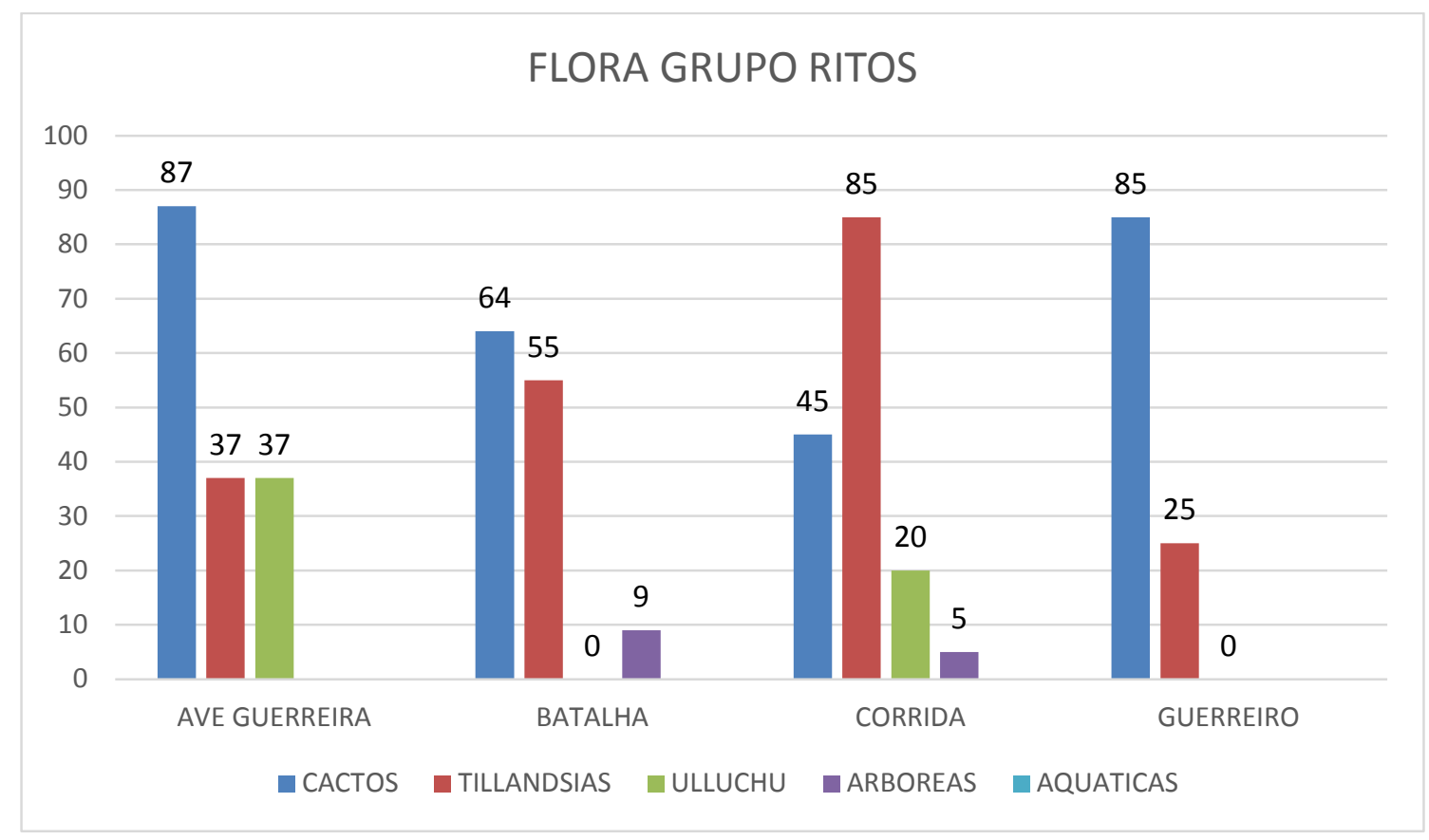

(Gráfico 4) Macrogrupo dos ritos(em percentual dos vasos relativos a cada grupo)

O macrogrupo dos naturalistas possui apenas 49\% de vasos com cactos. Há um padrão bem distintivo, com o grupo das aves apresentando um perfil quase completamente aquático, o grupo da flora bastante heterogêneo e os outros três grupos terrestres. O grupo dos felinos é o mais homogêneo de todos, tendo apenas cactos representados, mas como já comentado, é um grupo de identificação problemática que deve ser analisado junto ao grupo da raposa. As tillandsias somam 16,16\% devido também à bipartição aparente entre abientes terrestres e aquáticos. $\mathrm{O}$ grupo da raposa possui $40 \%$ de sua composição com tillandsias que seria um número alto. O ulluchu aparece apenas nos vasos de Flora e soma 4,5\% da composição da cerâmica. Arbóreas aparecem nas cenas do Veado e Flora e somam 6\% mais do que todos os macrogrupos. A cena do veado é anômala neste sentido com $31 \%$ de vasos apresentando exemplares arbóreos. Plantas aquáticas somam 21,6\% do total de vasos. A cena das aves apresenta 95\% de peças com estas plantas o grupo de Flora, com 36\%, também possui um percentual alto. 


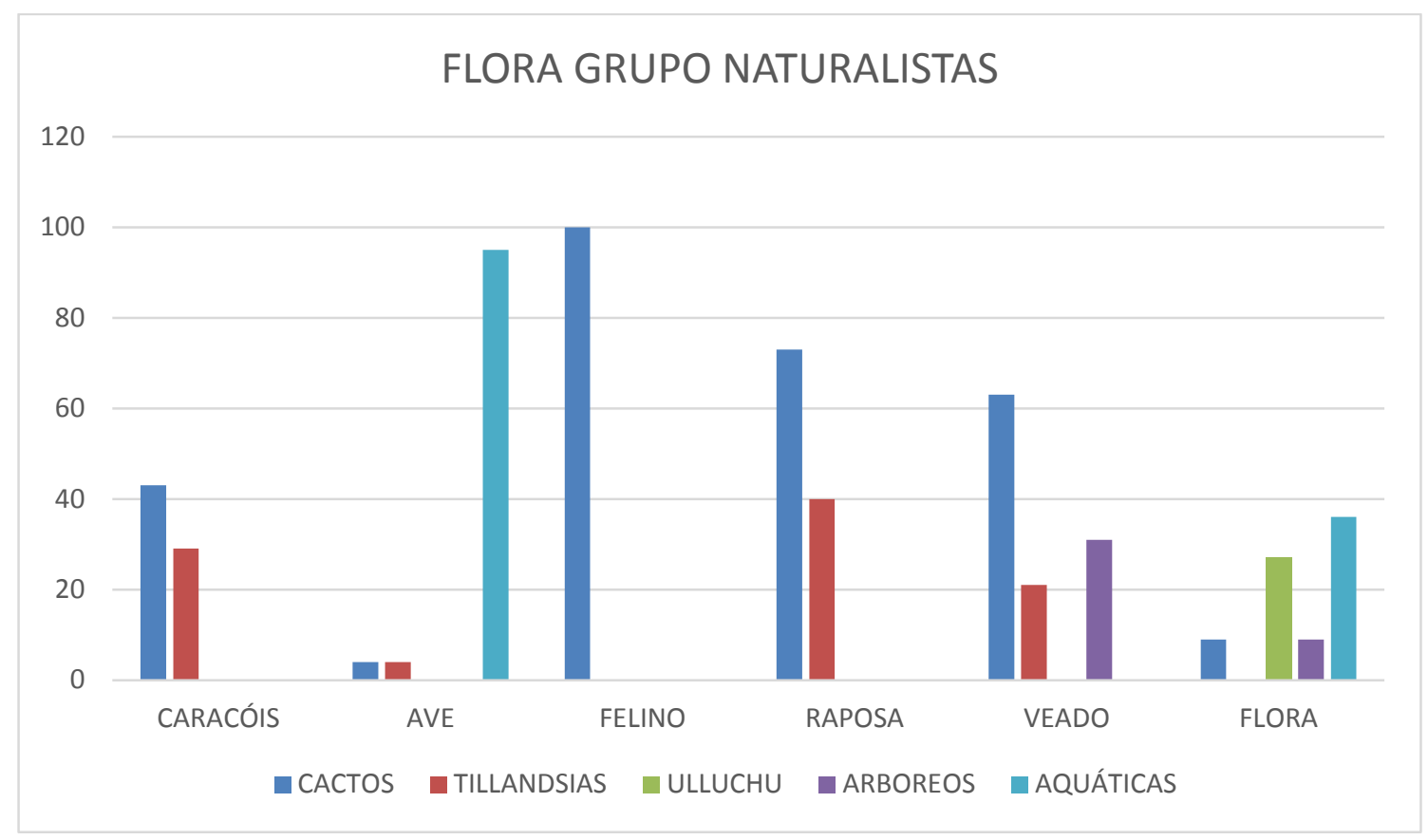

(Gráfico 5) Macrogrupo naturalistas(em percentual dos vasos relativos a cada grupo)

No macrogrupo dos Seres míticos temos uma clara tendência a maior representação de cactos com $82,6 \%$ dos vasos os contendo. Tillandsias tem uma média abaixo do grupo dos ritos e da média total, mas maior do que o grupo naturalista, com 18,4\%. O Ulluchu aparece com grande frequência, em 24, 4\% dos vasos. Não há exemplares arbóreos e os elementos aquáticos são minoritários, somando apenas $6,8 \%$.

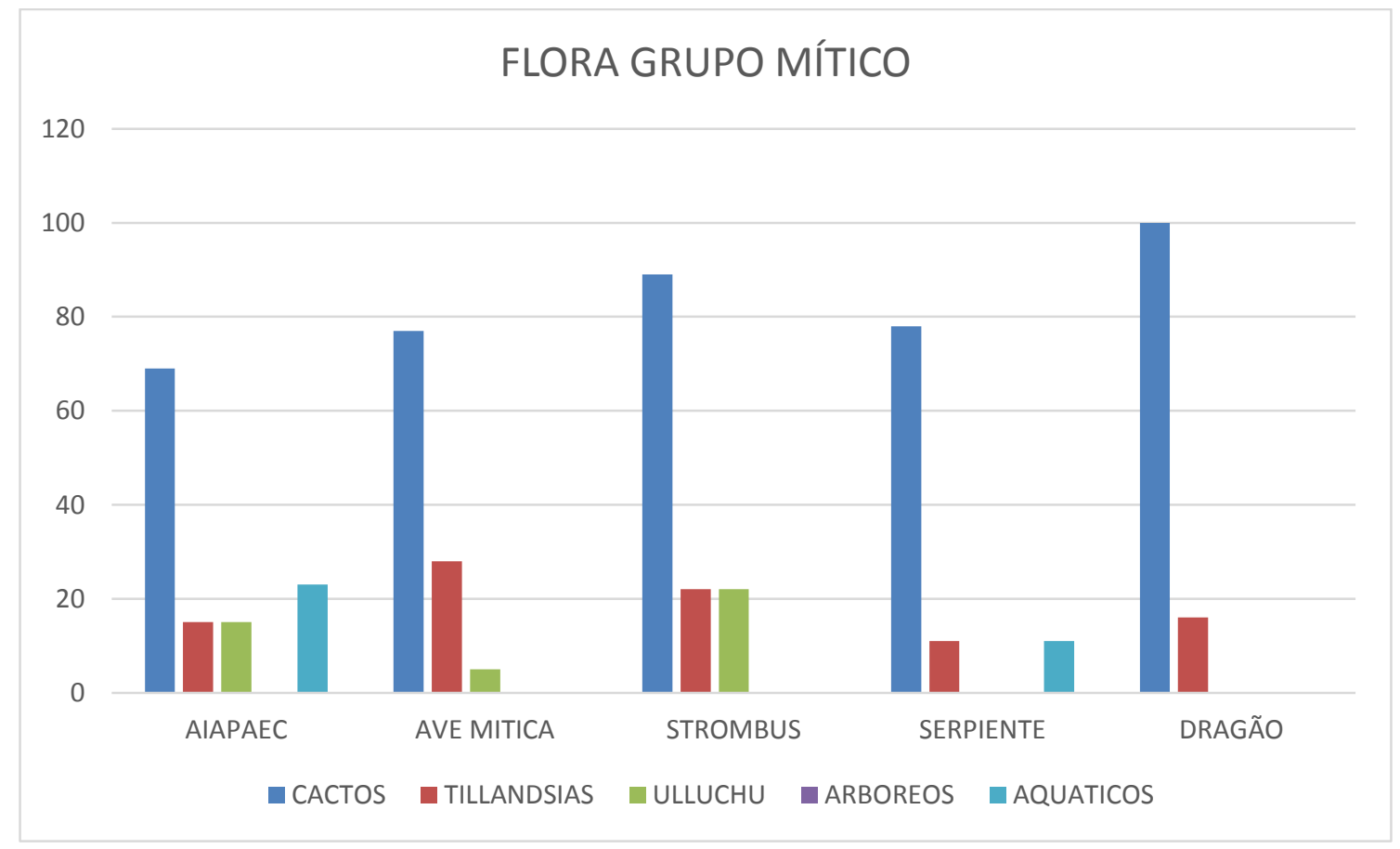

(Gráfico 6) Macrogrupo seres míticos (em percentual dos vasos relativos a cada grupo) 
No gráfico 4 podemos ver mais clararamente as tendências dos macrogrupos em relação uns aos outros. O grupo mítico lidera nos cactos e ulluchus. No grupo dos ritos temos um forte destacamento das tillandsias. No grupo naturalista as plantas aquáticas e arbóreas se destacam.

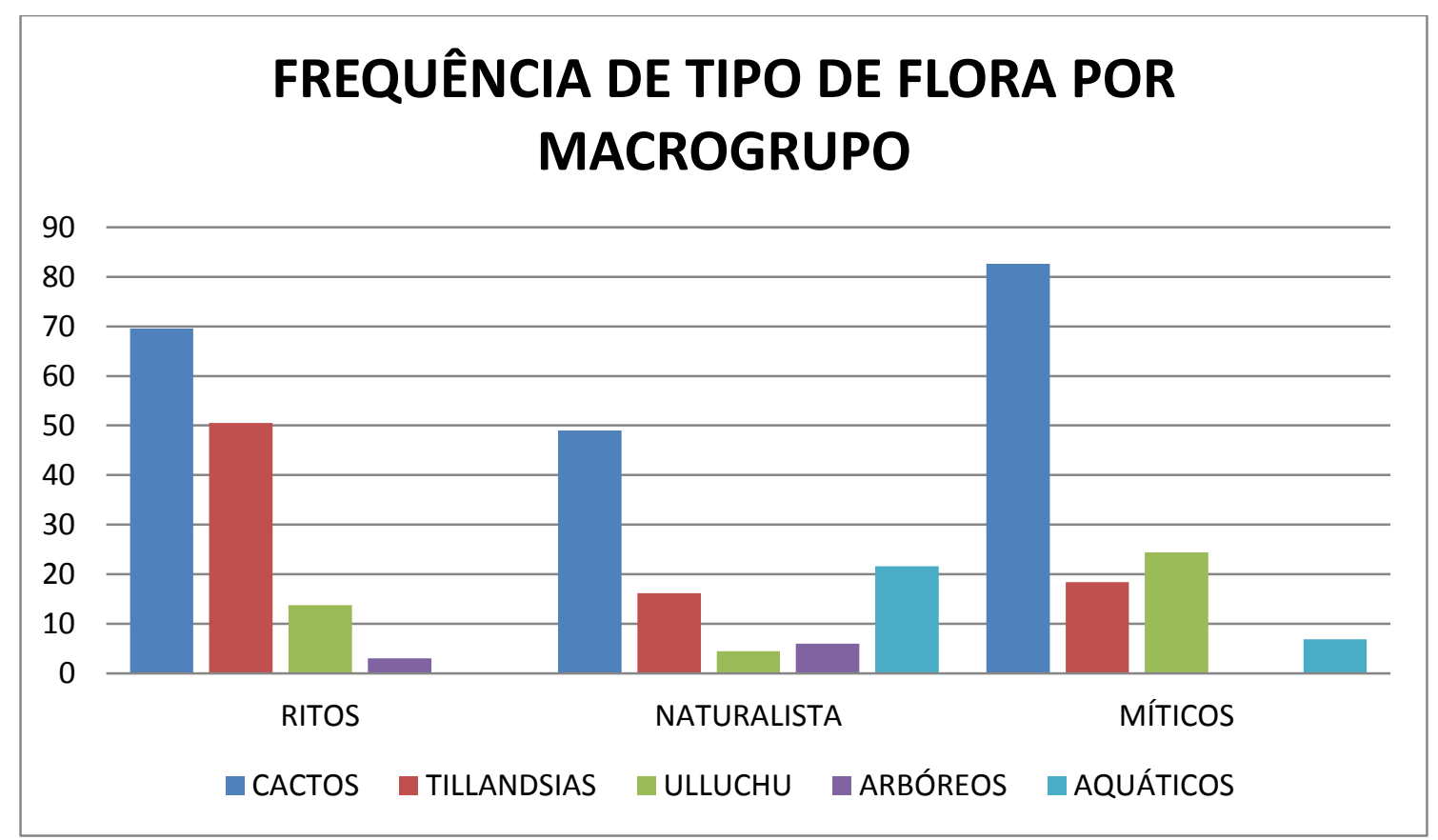

(Gráfico 7) Percentual de vasos com tipos de flora por macrogupo

A média percentual de frequência da flora por vasos (Gráfico 8) mostra uma frequência de $67 \%$ de cactos, mais do queo dobro de tillandsias, 28, $18 \%$. Estas por sua vez aparecem quase duas vezes mais do que o Ulluchu, 14,2\%. Aquáticos ocorrem em 9,48\% dos vaso e arbóreos em apenas 3\%. 


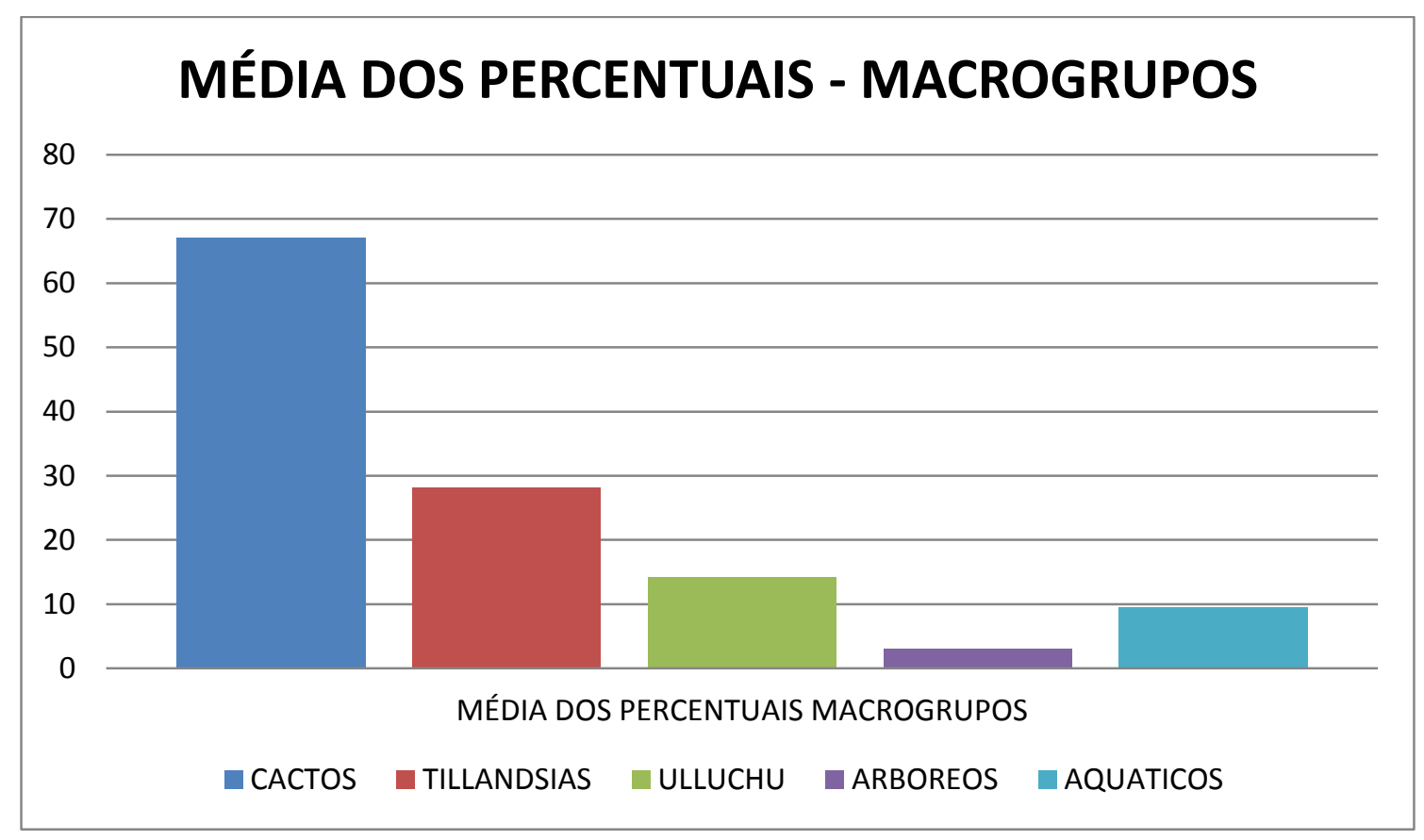

(Gráfico 5) Média dos percentuais dos macrogrupos somados.

No Gráfico 7 temos a média da ocorrencia de cada tipo de flora considerando o total da coleção. Os valores são muito próximos dos surgidos das somas dos macrogrupos, com $62,1 \%$ de vasos com cactos, $27 \%$ de vasos com tillandsias, $6,3 \%$ de vasos com uluchus, $4 \%$ de vasos com arbóreas e 15,3\% de vasos com plantas aquáticas.

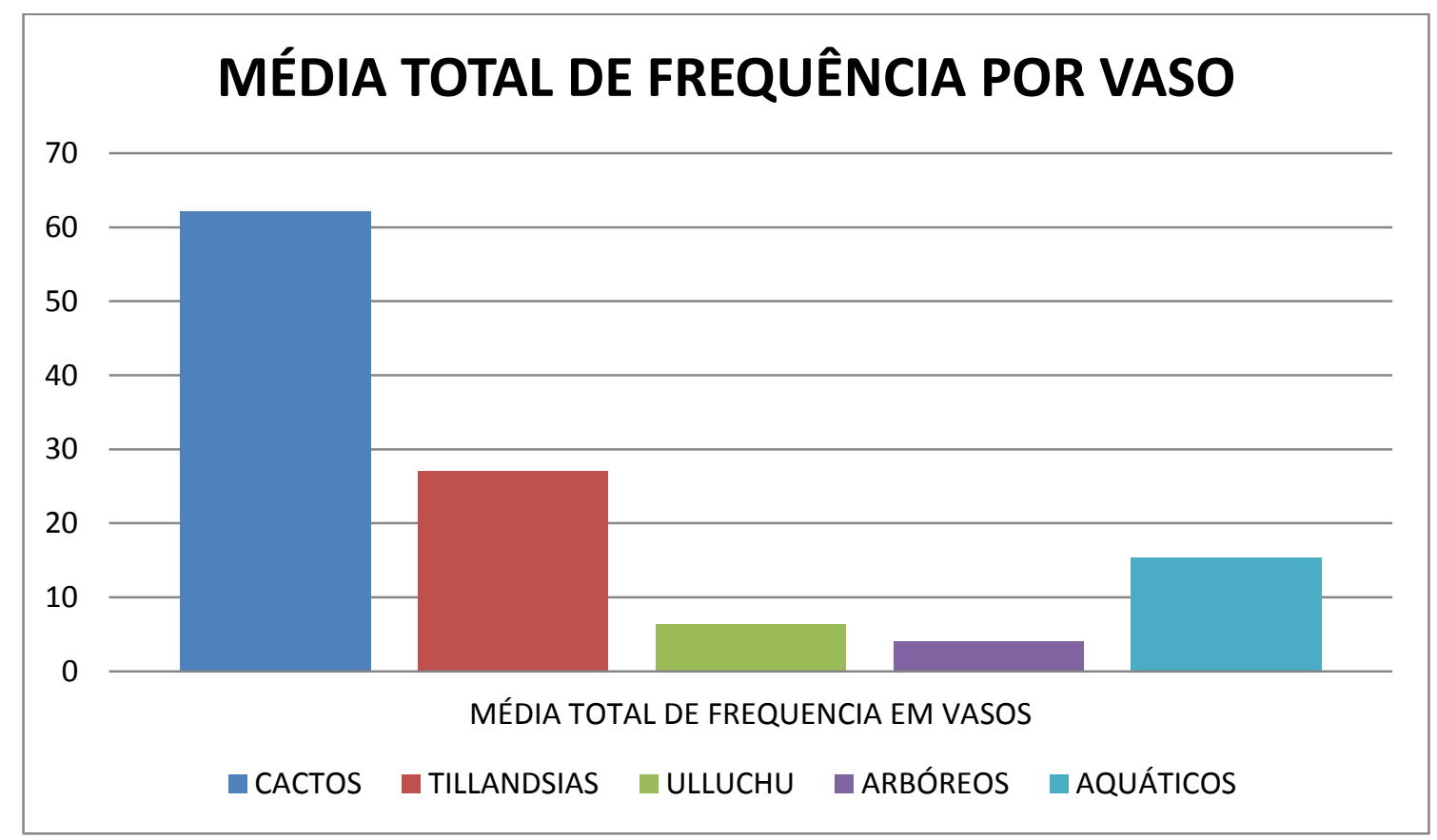

(Gráfico 7) Média de frequência em vasos considerando o total da coleção. 


\section{CAPÍTULO VI - INTERPRETAÇÃO DOS DADOS E CONCLUSÃO}

\section{VI.I- Interpretação dos dados}

Podemos ver pelo conjunto de gráficos que os cactos são dominantes. Mais precisamente cactos tipo 2 ao lado dos tipos 1B e 1A. Estas formas repetem-se em grande parte dos vasos com grande variação de origem e estilísticas. Não à toa, os cactos tipo 1 e 2 estão relacionados à gêneros como o Haageocereus e espécies cono a N. Arequipensis. Ambos são muito comuns nas paisagens áridas dos sopés das lomas. A N. Arequipensis em particular é a espécie mais ubíqua da região. Os tipos 1 e 2 são tão comuns que sua morfologia pode ter estruturado um tipo de "matriz genérica" de cactos, que eram desenhados a partir de suas formas.

Os dados também nos ajudam a responder algumas questões levantadas por alguns autores. Golte ( 2009:238-239) afirma que sabemos que a cena da corrida dos feijões se passa no fim de agosto pois coincide com o período de floração das tillandisias, que são efetivamente mostradas com sua inflorescência. Isso seria um marcador de tempo além do marcador espacial. Todavia, todas as tillandsias são representadas com inflorecências e todos os principais grupos possuem vasos com tillandsias. Nos parece mais provável que as tillandsias inflorescentes fossem o padrão de representação dessas plantas em qualuqer circunstância.

Também as variáveis nos ajudam a esclarecer algumas questões. Benson (2012:24) considera a possibilidade de as plantas com raízes à mostra serem um indicador de um ritual de purificação onde plantas eram arrancadas do solo e jogadas na água. Ela associa as raízes à mostra a cenas, de caça ao veado, combate e sacrifício. Porém, no total encontramos 72 vasos com plantas com raízes à mostra (cactos, tilandsias e totoras) em todos os grupos maiores. Não é impossível que raízes à mostra estejam ligadas a um significado de purificação, mas certamente não estão ligadas a cenas específicas. Em termos práticos, as raízes eram mostradas quando as plantas não estavam sobre um suporte, como montículos de areia.

Cactos com frutos aparecem em 42 vasos em todos os 15 grupos com mais de cinco peças e também não pudemos encontrar um padrão claro em sua aparição. Cactos tipo 4 parecem indicar zonas altas das lomas mas os dados foram insuficientes e o 
resultado ambíguo. As plantas aparecem quase de forma simetrica nas metades de cima e debaixo do corpo enquanto o cume do corpo, logo abaixo da alça estribo, é uma região de representação mais rara, assim como as alças.

Finalmente, notamos uma experimentação maior na flora dos vasos de fase III. Muitas plantas tiveram de ser deduzidas pelo contexto, mas nessa fase os cânones para a a representação de flora pareciam ainda em construção. Diferentemente do que afirmam, Donnan \& Mclelland (1999) parece haver um número pequeno de vasos que representam pântanos já na fase III. A garça já está convencionada apesar das plantas aquáticas não possuíerm características diagnósticas tão claras.

\section{VII.II -CONSIDERAÇÕES FINAIS}

Para que o conjunto dos dados agregados neste trabalho tenha um sentido amplo, é necessário voltar ao conceito de ecótopo. Retomando a definição de Jhonson \& Hunn “ecótopos são as menores unidades de paisagem", sendo a paisagem "percebida e imaginada pelo povo que nela vive": são "tipos de lugares" determinados pelos nativos. (Jhonson \& Hunt, 2010: 170-187).

Estes tipos de lugares incluem elementos bióticos, abióticos e antropogênicos “distribuídos de forma repetitiva ao longo da paisagem”.(Ibd. 189). Ecótopos aparecem em uma escala "perceptível a humanos no solo enquanto viajam por seus ambientes no curso de suas atividades normais". Dunas de areia são ecótopos enquanto a própria areia não; para ser um elemento da paisagem ela precisa estar configurada em uma forma espacial particular”.(Idib.202)

Ecótopos também têm uma razão de existir, uma vez que refletem aspectos da paisagem "com significância biológica e adaptativa", focando características úteis para as pessoas "extraírem sua subsistência da terra". Há, para os autores, uma retroalimentação entre a paisagem e sua classificação pelos nativos que leva em conta os potenciais da terra e as formas humanas de vivência, incluindo tecnologia, cosmologia e sistemas de conhecimento(Ibid. 212).

Segundo Hunn \& Meilleur, é esperado que os ecótopos sejam caracterizados por “associações distintivas de organismos, particularmente plantas", ja que sua imobilidade proporcionaria mais predicabilidade nas associações com outros elementos da paisagem. (Hunn \& Meilleur, 2010:449). A previsão de elementos bióticos na paisagem é possivelmente um dos principais propósitos adaptativos dos ecótopos. Segundo os 
autores, ecótopos são uma forma de maximizar a previsibilidade de certos recursos ao associar elementos paisagísticos em "tipos" que reunem maior probabilidade de abrigar tais recursos (ibid.468).

Esta forma de classificação está instrinsicamente relacionada à lingua e referentes comuns de uma cultura. Ao apontar evidências de que os humanos em média conseguem nomear 500 animais e 500 plantas na região nativa, os autores argumentam:

To appreciate this point, consider the following thought experiment. If we recognize 500 plants and 500 animals, that equals 1,000 kinds of organisms. If, in addition, we recognize 500 named places, we will have 500,000 $(1000 \times 500)$ bits of information about the environment to keep track of. On the other hand, if we were to define a few dozen ecotopes such that the organisms and places were evenly distributed among them (each plant and animal and each place uniquely associated with one and only one ecotope), the task of locating a particular organism at a particular place would be substantially simplified (Hunn \& Meilleur, 2010:449)

Logo, os ecótopos devem ser sintéticos o suficiente para não se multiplicarem em categorias pouco acessíveis e ao mesmo tempo ser eficientes na previsão de recursos que na natureza não estão sempre associados de formas simples.

Se retomarmos a definição de Donnan \& Mclelland para localizadores como "objetos que posicionam a atividade em uma localização específica" (Donnan \& Mclelland, 1999:59) veremos que ela se posiciona de maneira próxima ao conceito de ecótopos. A similaridade é ainda mais evidente quando levamos em conta a descrição dos autores para os localizadores da fase III.

- Peixes, carangueijos, moluscos, arraias ou ondas nas cenas indicam que a atividade está se passando no oceano.

- Montes de areia e vegetação desértica na cena indicam que a atividade está ocorrendo no terreno desértico entre os vales dos rios;

- arquitetura na cena mostra que a atividade está acontecendo em um edifício ou estrutura, provavelmente cerimonial; (Donnan \& Mclelland, 1999:59)

e em seguida os localizadores para a fase IV: 
- Matagais são indicados são indicados pela inclusão de vegetação, geralmente árvores inteiras ou simplesmente ramos. Isto posiciona a atividade nos arbustais e matagais ao longo dos vales dos rios.

- Pântanos são indicados por plantas de pântano e garças. Isto localiza a atividade nas áreas ribeirinhas dos delta dos vales dos rios. O ambiente pode ser distinguido dos oceanos pela vegetação que cresce nas águas paradas. (Donnan \& Mclelland, 1999:104)

Portanto, Donnan \& Mclelland possuem 5 "locais": oceano, deserto, edifícios, vales dos rios, áreas ribeirinhas. Estes "locais" possuem 4 tipos de indicadores: animais, formações abióticas naturais, como montes de areia e ondas, edifícios e plantas. Esta forma de categorização com o que Hunn \& Mellieur denominam "elementos salientes" da paisagem utilizados na construção dos ecótopos, uma vez que:

(...)named elements that partition space are predicated not only on botanical and zoological associations, but may also highlight geological, hydrological, and edaphic features (which in turn constrain biotic species associations), and reflect both the "natural" and the "built" environment.

(Hunn \& Meilleur, 2010:538)

Makowski também busca uma categorização interpretativa dos espaços representados na cerâmica mochica.

La subdivisión natural, tripartida, del espacio mochica entre el litoral marítimo, la ancha costa rodeada por el desierto, y el valle que se estrecha a medida que avanza hacia la sierra con refugios de bosque tropical húmedo en las alturas, se refleja directamente en las figuras fantásticas en forma de animales antropomorfos. Hay entre ellos, por un lado peces,crustáceos y aves marinas y por el otro iguanas, perros, zorros y picaflores. Los grande felinos, el puma y jaguar así como los venados, representam el tercer ambiente natural. (Makowski, 2000:138) 
Como se vê, o autor se vale categorias mais abrangentes e ligadas a conceitos cosmológicos e políticos. O espaço é natural tripartido entre litoral marítimo, costa rodeada pelo deserto e os vales de rios e serra, que para o autor são contínuos. São os animais antropomorfizados que "representam" estes ambientes com os peixes, crustáceos e aves marinhas relativos ao litoral, iguana, cães, raposas e beija-flores relativos à parte desértica e felinos e veados relativos à costa. Os animais antropomorfizados seriam como "embaixadores" de seus ambientes ao figurarem nos ritos em que são representados. Na condição de representantes de seus ambientes não seria absurdo darmos o passo lógico de que os animais "naturais" seriam previsivelmente encontraodos nestes ambientes e logo, poderiam servir como "localizadores".

Esta dimensão politica do espaço parece ainda mais evidente na descrição do autor dos ritos representados por humanos:

Entre los seres humanos que participan en los rituales se observa una subdivisión en tres grupos:

- los habitantes del litoral que pescan y cazan lobos marinos,

- los del valle costeño que realizan actividades guerreras, propias de la elite,

- y los del valle serrano, que cazan venados, cosechan los cultivos y recolectan plantas silvestres en las lomas altas. (Makowski, 2000:139)

Isto é, as cenas em cada ambiente são protagonizadas pelos habitantes destes ambientes, possivelmente de grupos etnicos, culturais ou políticos distintos. O que Makowski parece tentar fazer é amarrar o que se sabe da expansão político-cultural mochica, supostamente de caráter elistista (ver capítulo 1), às representações ambientais, onde as unidades políticas das regiões subjugadas da costa e serra participariam como subalternos complementares e os elementos da região desertica seriam apresentados como governantes tanto em representações "naturalísticas" quanto "fantasticas".

Há ainda uma forma de compreensão mais difusa na qual os autores utilizam-se de uma interpretação de base ritualística/simbólica para compreender os localizadores. Assim, como já visto, Benson ve a possibilidade de raízes à mostra estarem ligados a ritos de purificação ou uma associação da cena do veado a ritos sacrificiais. George Lau 
crê em um possível uso dos localizadores como insignias de origem.

Portanto, surgem três possibilidades interpretativas dos localizadores: o naturalístico, que da ênfase na função de indicar os ambientes, o político, que da ênfase nas dinâmicas de domínio e trocas populacionais e o simbólico, que dá ênfase nos significados cosmológicos trazidos pela flora.

Mesmo reconhecendo as limitações que o escopo limitado de se trabalhar com uma única coleção pode trazer, o propósito desta pesquisa foi $o$ de refinar $o$ conhecimento da flora que compõe os vasos pictóricos mochica para desta forma compreender melhor sua função na composição da cerâmica ritual. Para tanto, foi necessário pesquisar e compreender aspectos ecológicos, a fim de identificar as plantas endêmicas das regiões de habitação mochica, anatômicos, a fim de buscar similaridades entre as plantas e suas possíveis representações, etnobiológicos, a fim de tentar encontrar os usos e significados destas plantas para as populações tradicionais, além de conceitos paisagísticos, a fim de tentar identificar comunidades botânicas com características "salientes" na paisagem. Também foi necessario o estudo dos aspectos formais de uma composição e a compreensão básica da sociedade, cultura e cosmologia mochica.

Em nossa interpretação os resultados da pesquisa estariam mais de acordo com a visão de "localizadores" de Donnan \& Mclelland do que da grande visão tripartida de Makowski. Não negamos a validade desta visão e acreditamos que seja possivelmente complementar à nossa em muitos aspectos, mas ela parece trabalhar com uma escala ambiental de grandeza diferente e uma estruturação politica que demandaria um estudo focado na atuação de animais antropomorfos e naturalistas.

Consideramos a ideia de localizadores muito próxima a de "ecótopos" e na nossa visão a flora representada nos vasos pictóricos, a exceção do ulluchu, eram representações de ecótopos amplamente reconhecidos pelos mochica. O maior indício disso seria a pequena quantidade de "tipos" correlacionados a gêneros e espécies frente à profusão de estilos e origens da cerâmica. Com efeito, temos o ecótopo das zonas alagadas muito bem limitado por duas plantas características, ambas de carater paisagístico bastante "saliente".

Os ecótopos de terra seca, todavia, se mostram mais problemáticos. As árvores e arbustos parecem de fato estarem se referindo à zonas de bosques ciliares e bosques secos, uma vez que são bastante características. Porém, como é possível observar em algumas peças da cena de corrida, elas também podem ocorrer na base das lomas. Além 
disso, em regiões tão áridas onde nem cactos são encontrados como, plantas como o algarrobo e o sapote são comuns (Galvez, 2006). O que nos leva à questão das tillandsias.

Com exceção da cena do felino que, como já mencionado, é bastante problemática e não pode ser considerada isoladamente, todas as cenas que possuem um personagem fortemente associado a cactos, como o Dragão, também aparecem em ao menos um vaso associados à tillandsias. Cactos de clima árido como a $\mathrm{N}$. arequipensis ou os haageocereus podem ocorrer em zonas áridas e o tipo de espécie varia de acordo com o índice pluviométrico da região (Galán de Mera, 2012). As tillandsias, contudo, necessitam da hidratação fornecida pelas brumas das lomas para que florescam e nas lomas são tão numerosas que tornan-se quintesenciais daquele ambiente (Pinto et al, 2010). Ou seja, tillandsias são a característica mais saliente das lomas.

Em casos como o da cena corrida a associação obsessiva com tillandsias juntamente com as indicações de subida, montanha e montículos de areia parecem deixar poucas dúvidas de que o ecótopo é o das lomas. Porém em outros casos onde a grande maioria dos vasos traz apenas cactos e as tillandsias aparecem em apenas uma minoria dos vasos parecem deixar apenas três soluções lógicas.

1. Não havia consenso no significado das tillandsias ou elas significariam outra coisa que não ecótopos.

2. Os personagem estão em movimento.

3. A grande maioria ou mesmo a totalidade das cenas se passa nas lomas.

Quanto à primeira possibilidade, cremos, como já foi afirmado, que as plantas possuem muitas características de ecótopos, como sumarizar "tipos de lugares" com interesse na predicabilidade de recursos. Lomas neste caso são ecótopos perfeitos por serem um "oasis" úmido com uma rica biodiversidade cercada por desertos.

A segunda possibilidade parece ocorrer em tipos de personagens "móveis" como Aia Paec ou a Serpente. Todavia, estes personagens tem algumas características apontando sua mobilidade e também estão presentes em ambientes aquáticos. Personagens como o Dragão ou a Ave Mítica aparecem sempre na mesma pose e no mesmo cenário, sem indícios de movimento. A hipótese, entretanto, não é completamente descartável.

A última possibilidade resolveria a questão em termos ambientais. Lomas possuem algarrobos e matagais em seus sopés. Seus primeiros pisos possuem enormes 
comunidades de tillandsias e cactos de clima árido como Neoraimondia e Haageocereus que correspondem aos tipos de cacto mais comuns, 1 e 2 . Nos pisos mais altos, as lomas abrigam cactos mais raros, como a opuntia quitensis, relativa ao cacto tipo 4 além de espécies qua aparecem sem recorrência como as furchrea. Ademais, alguns rituais como o da corrida e sacrifício eram quase certamente performados nestes ambientes. Por fim, o cerro Campana (ver cap.2) possui indícios de diversas estruturas construídas em tempos pré-coloniais.

Por mais elegante que seja a solução número 3 devemos considerar que há outros aspectos além dos ambientais em jogo. Os cactos San Pedro são um bom exemplo. É claro que uma planta com potencial de uso psicotrópico intimamente ligada a ritos xamãnicos teria uma importância simbólica enorme. Há alguns casos em cenas como a do Dragão ou do Veado que detectamos cactos com o potencial de serem representações de San Pedro. Há um caso na cena dos tomadores de coca em que a representação é praticamente identica à de um San Pedro adulto. Seriam os San Pedro indicadores de que a cena estaria se passando nas serras acima de 2 mil metros onde nascem? Ou teriam um significado associando os personagens a princípios xamãnicos? Os estariam associando os personagens à serra ? Seriam um indicador de cultivo desses cactos na região costeira?

Questões como esta podem aparecer com toda flora representada. Lau (2004) cogita a possibilidade de que as plantas sobre as cabeças dos guerreiros sirvam como marcadores de origem. Golte (2009) afirma que todos elementos, incluindo a flora, na composição de um vaso possuem um significado cosmológico. Estes significados podem estar inacessíveis para sempre, além dos limites da pesquisa iconográfica. Mas a função do pesquisador é a de empurrar a membrana opaca do tempo para que, cada vez mais, os mundos perdidos, antes habitados por milhares de vidas, revelem-se. Mesmo que seja na beleza melancólica de uma sombra pálida. 


\section{BIBLIOGRAFIA}

ALTIVEZ, E.I, et al. Calidad ecológica de los humedales de la provincia de Trujillo, Perú, en base a la flora acuática. In: Revista Científica de la Facultad de Ciencias Biológicas Universidad Nacional de Trujillo. Trujillo. Perú 2012

ANGUlO-PATROLONGO, F. Las aves de los humedales de Eten, Lambayeque, Perú

- Departamento Académico de Biología, Universidad Nacional Agraria La Molina, Lima - Perú, 2010

APONTE, H; FLORES. J. Densidad y distribuición espacial de Tillandsia latifolia en el tillandsial de piedra campana. Departamento Académico de Biología, Universidad Nacional Agraria La Molina, Lima - Perú. 2013

APONTE, H; CANO, A. Estudio florístico comparativo de seus humedales de la costa de Lima (Perú) - 2013

ARCURI, M. M. El occidente no vio el Sol Nocturno: El papel de la dualidad complementaria de las fuerzas cósmicas en la organización política de las jefaturas amerindias. In: Los pueblos amerindios mas allá del estado, Ed. Rústica: 2011

Paysage y monumentalidad en Ventarrón: nuevos aportes al debate acerca del origen del Estado en el Formativo Inicial Andino In: Ventarrón Y Collud: origen y desarollo de la civilizatión em La Costa norte del Perú. Ed. Lambayeque: 2013:92

BARS, C. R. O felino na Iconografia Mochica: Análise dos padrões de estilização da cerâmica ritual. 2009. Dissertação (Mestrado em Arqueologia) - Museu de Arqueologia e Etnologia da cidade de São Paulo. 2009.

BENSON, E. P.The worlds of the Moche on the north coast of Peru. University of Texas Press.2012

Iconography Meets Archaeology In: The art and Archaeology of the Moche.

Bourget. (Edit).2008

BERNIÈRE, H. Craft Especialist at Moche: Organization, Affliations and Identities. In: Latin American Antiquity - 21: 2010

BERSFORDES-JONES, D. Re-evaluating the resource potential of lomas fog oasis environments for Preceramic hunteregatherers under past ENSO modes on the south coast of Peru. Quaternary Science Reviews 129. PP.196-215. 2015

BILLMAN, B R; HUCKLEBERRY, G. Deciphering the politics of prehistoric el niño events on the north coast of Peru. In: El Niño, Catastrophism, and Culture Change in Ancient America, Dumbarton Oaks Research and library collection: 2009. 
BILLMAN, B.R.How Moche Rulers Came to Power. Investigating the Emergence of the Moche Political Economy. In: CASTILlO, L. J. \& QUILTER, J. (Eds.), New Perspectives on Moche Political Organization. Washington D.C.: Dumbarton Oaks Research Library and Collection. 2010

BOCANEGRA, C. (org.) La Libertad. Estrategia Regional para la conservación y la utilización sostenible de La Diversidad Biológica.. Consejo Nacional del Ambiente. 1999

BOURGET, S. Sex, death and sacrifice in Moche religion and visual culture. Austin: University of Texas Press, 2006.

El Mar y la Muerte en la Iconografía Mochica. In: UCEDA, S.; MUJICA, E. (eds.). Moche: Propuestas y Perspectivas. Actas del Primer Coloquio sobre la Cultura Mochica (Trujillo, 12 al 16 de abril de 1993). Lima: Institut Français d'Etudes Andines, Vol. 79, 1994b: 425-477.

BOURGET, S.; JONES, K. (eds.). The Art and Archaeology of the Moche: An Ancient Andean Society of the Peruvian North Coast. Austin: University of Texas Press, 2008. BUSSMAN, R; SHARON, D. Naming a phantom - the quest to find the identity of Ulluchu, an unidentified ceremonial plant of the Moche culture in: Northern Peru. In: Journal of Ethnobiology and Ethnomedicine. March.2009

CAROD-ARTAL, F.J. Hallucinogenic drugs in pre-Columbian Mesoamerican cultures IN: Neurología. 30(1):42—49. 2015

CASTILlO, L.J.B; DONNAN, C.B. Los Mochicas del Norte y los Mochicas del Sur. In: Vicús. K. Makowski (edit.) pp. 142-181. Colección Arte y Tesoros del Perú. Banco de Crédito del Peru: 1994

CASTILLO, L.J.B; UCEDA, S. C.. The Mochicas. In: The Handbook of South American Archaeology. Springer: 2008

CASTILlO, L.J.B; UCEDA, S. C. Los Mochicas de la Costa Norte del Perú. In: The Handbook of South American Archaeology. 2007.

CASTILlO, L. J. Los rituales Mochicas de la Muerte. In: MAKOWSKI, K. (compilador). Los Señores de los Reinos de la Luna. Lima: Colección de Arte y Tesoros del Perú. Banco de Crédito del Perú. Pp. 103-135. 2000.

CARNEIRO, R. L. A Theory of the Origin of the state. In: Sience, Volume 169, Issue 3947: 1970.

CHILDE, G. The Urban Revolution. In. The town Planning Review. Vol.21. No 1. pp- 
3-17: 1951.

CONTRERAS,C. John V. Murra (1916-2006), intérprete de la economía andina. In. Histórica, [S.1.], v. 31, n. 2, p. 169-173, mar. 2007. ISSN 2223-375X. Disponible en: $<$ http://revistas.pucp.edu.pe/index.php/historica/article/view/47>. Data de acceso: 24 sep. 2018

CORCUERA, V.D.C La Loma del cerro Ochiputur: conociendo su flora y fauna.In: Pueblo Cont. Vol. 28[1] enero - junio 2017

CRUMLEY, C.L. Heterarchy and the Analysis of Complex Societies. University of North Carolina at Chapel Hill: 1986

CULMAN, W; GOTZ, E; GRONER,G. The encicplodeia of Cacti. Timberpres, Portland, Oregon.1984

D’ALTROY, T.N. The Incas. 2nd Edition. Wiley-Blackell, 2014

Dillehay,T; Monte Verde: Seaweed, Food, Medicine, and the Peopling of South America. 2008

DONNAN, C. B. Moche Fineline Painting. Its Evolution ans Its Artists. Los Angeles: Fowler Museum of Cultural History, University of California. 1999. FEINMAN, G; MARCUS, J. Archaic States. School of American Research, 1998 FIGUEIREDO, M.L.B. Política e religião no Tahuantinsuyu: evidências de relações centro x periferia de cusco na costa norte peruana, tese de mestrado, São Paulo, 2014 FRANCO, R.J. El Apu Campana, la montaña sagrada moche In. Publo Continente VOL. $23 \mathrm{~N}^{\circ} 2,2012$

GAGNON, C. M. Daily Life and the Development of the State in the Moche Valley of North Coastal Perú: A Bioarchaeological Analysis. Tese de Doutorado University of North Carolina at Chapel Hill: 2006

GALÁN DE MERA, A. Distribution patterns of cactus communities in the occidental slopes of the Peruvian Andes. In: Caldasia 34(2)- 257-275.2012

GÖLTE, J. Moche, Cosmología y Sociedad: una interpretación iconográfica. Cusco: Instituto de Estudios Peruanos, 2009.

La modelación de una cosmologia. In: Scientia 10(10)Centro de Investigaciónde la universidade Ricardo de Palma, Lima, 2008

Los recolectores de caracoles en la cultura Moche In: Indiana 10:355-369. (1985)

Las formas de generacion de sentido em los cuerpos de iconos mochica y nazca. In: Revista Utopia Moderna: 1998 
HOCQUENGHEM, A.M. Iconografía Mochica. Lima: PUCP; Fondo Editorial, 1987 Les cerfs et les morts dans l'iconographie mochica in: Journal de la société des américanistes, 69 pp. 71-83, 1983.

Sacrifices and Ceremonial Calendars in Societies of the Central Andes:

A ReconsiderationIn: The art and Archaeology of the Moche. Bourget. (Edit).2008

HUNN, E; MEILLEUR B.A.Toward a Theory of Landscape Ethnoecological Classification In: Landscape Ethnoecology: Concepts of Biotic and Physical Space (Environmental Anthropology and Ethnobiology). Berghahn Books, 2010. Kindle edition JACKSON,M; Moche Art and Visual Culture in Ancient Peru. Universitu of New Mexico Press. 2010

JHONSON, L.M; HUNN, E. Introduction.In: Landscape Ethnoecology: Concepts of Biotic and Physical Space (Environmental Anthropology and Ethnobiology). Berghahn Books, 2010. Kindle edition

KALICKY , P. A model of interregional contacts betewwn Highland and coastal groups in late pre-columbian periods in the lomas.In: Contributions in New World Archaeology 6: 83-110. 2014

KNIGHT, V. Iconographic method in new world prehistory. Cambridge university press, 2013

LA CHIOMA, D. Emissários do Vento: Um estudo dos toucadores de antaras representados na cerâmica ritual Mochica e Nasca. Dissertação (Mestrado em Arqueologia). Museu de Arqueologia e Etnologia da Universidade de São Paulo.2012.

O Músico na Iconografia da cerâmica Ritual Mochica: um estudo da correlação entre as representações dos instrumentos sonores e os atrobutos de poder. tese (doutorado em Arqueologia). Museu de Arqueologia e Etnologia da Universidade de São Paulo.2016.

LAU,G. Object of Contention: an Examination of Recuay-Moche Combat Imagery.In: Cambridge Archaeological Journal, Jan 1, 2004

LLATAS, S.S.(org). Estudio de La biodiversidade de Lambayeque. Govierno Regional de Lambayeque, VOL 1 e 2.2010

LEIVA, S.G.. Diversidad Florística de la Loma Cerro Campana, Provincia Trujillo, Departamento La Libertad-Perú In: Arnaldoa 21 (1): 187 - 220, 2014

LUMBRERAS, L. G. Arqueología y Sociedad. In: DEL ÁGUILA, C.; CARRÉ, E. G. (eds.). Arqueología y Sociedad. Lima: Instituto de Estudios Peruanos, 2005.

LUMBRERAS, Luis G. De los origenes del "Estado" en el Peru. Lima: Carlos Milla Batres, 
1972.

MAKOWSKI, K. Andean Urbanism. In: The Handbook of South American Archaeology. Springer: 2008

Las Divinidades en la iconografía Mochica. In: MAKOWSKI, K. et al. (eds.).

Los dioses del antiguo Perú. Lima: Banco de crédito del Perú, 2000.

MACKEY, C. VOGEL. La luna sobre los Andes:una revisión del animal lunar.2003

McCLELLAND, D. Ulluchu: an Elusive Fruit. In: BOURGET; S; JONES, K (eds.). The

Art and Archaeology of the Moche: an Ancient Andean Society of the Peruvian

North Coast. Austin: University of Texas Press, 2008: 43-65

MOSELEY, M. Introduction: human exploitation and organization on the North Andean

Coast. In: Chan Chan Andean desert City ed: Michael Moseley \& Kent C. Day. University of New Mexico Press. Albuquerque USA, 1982

NOBEL, P. Cacti biology and uses. UNIVERSITY OF CALIFORNIA PRESS

Berkeley Los Angeles.2001

OSTALAZA, C.N. 101 Cactus del Perú. Ministerio del Ambiente. Lima, Peru. 2011

Todos los Cactus del Perú. Ministerio del Ambiente. Lima, Peru. 2014

OSMICH, D. Atlas of cacti. Dino Osmic. May 2006, Tuzla, BiH. 2006

PEARSALL, D. M. Plant Domestication and the Shift to agriculture in the Andes. In: The Handbook of South American Archaeology. Springer: 2008

POZORSKI, S; POZORSKI, T, Early Cultural complexity on the coast of Peru, In; The Handbook of South American Archaeology. Springer: 2008

QUILTER, J. The narrative approach to Moche Iconography. In: Latin American

Antiquity, 8 (2), 1997: 113-133.

Art and Moche Martial Arts In: The Art and Archaeology in the Moche: An Ancient Andean Society of the Peruvian North Coast. Edited by Steve Bourget and Kimberly L. Jones. University Of Texas Press Austin: 2008.

The shinning dawn of American gold: Metallurgy in Ancient America. In: To Capture the Sun: Gold in Ancient Panama: 2011

The Moche revolt of objects. In: Latin American Antiquity, Vol. 1, No. 1. (Mar., 1990), pp. 42-65.

Moche Politics, Religion and Warfare. In Journal of World Prehistory, VOl.

16, No.2, June 2002

YAYA, I. Hanan y Hurin: historia de un sistema estructural inca. In: Bulletin de l'Institut français d'études andines [En línea], 42 (2): 2013. pp 173-202.

URL : http://journals.openedition.org/bifea/4049 ; DOI : 10.4000/bifea.4049 
YOFFE, N. Mitos do Estado Arcaico. Edusp, São Paulo: 2013

RODRIGUEZ, E.F. El cerro Campana, patrimonio natural y cultural de la Región La Libertad In: Pueblo cont. 23(2) 2012

RUNDEL, P.W.; DILLON, M. "The Phytogeography and Ecology of the Coastal Atacama and Peruvian Deserts," Aliso: A Journal of Systematic and Evolutionary Botany: Vol. 13: 1991

RUNDEL, P.W.; DILLON, M. Ecological patterns in the Bromeliaceae of the lomas formations of Coastal Chile and Peru. Springer-Verlag 1998

RUNDEL, P.W. Arid and Semi-arid Ecosystems.In: The Physical Geography of

South America. pp158-178.2007

Willey, G. R. (1953). Prehistoric Settlement Patterns in the Virú Valley, Peru. Bureau of American Ethnology Bulletin 155. Washington, D.C.

SANDWEISS, D.; III, R. Central andean Environments. In: The Handbook of South American Archaeology. Springer: 2008

SMITH, M.E; PEREGRINE, P. The comparative Archaeology of complex Societies, 2011, Cambridge University Press: 2011

SOARES, D. L. Xamanismo e Cosmovisão Andina: um estudo sobre práicas de curandeirismo expressas na cerâmica ritual. Dissertação (Mestrado em Arqueologia). Museu de Arqueologia e Etnologia da Universidade de São Paulo.2015

SHIMADA, I; New Perspectives on Moche Metallurgy: Techniques of Gilding Copper at Loma Negra, Northern Peru. In America Antiquity. 2013 Moche Sociopolitical Organization: Rethinking the Data, Approaches, and Models. In: ew perspectives on moche political organization. 2010 SOLIS, R.S. America's First City? The Case of Late Archaic Caral. In: Andean Archaeology III. Springer: 2006

TOWLE,M. The Ethnobotany of Pre-Columbian Peru. Routledege, Chicago 2007 (1961)

VALLADARES, P.M.H. R.J. Evidencia cultural en el cerro Campana.In. PuEblo Continente VOL. $23 \mathrm{~N}^{\circ} 2,2012$

VEGA-VERA N; LINARES-PALOMINO, R. Plantas vasculares de los Andes Occidentales. Universidad Nacional Mayor de San Marcos \& Smithsonian Conservation Biology Institute (SCBI, Washington D.C.)2016

VERANO, J. War and death in the Moche world: osteological evidence and visual discourse. In: PILLSBURY, J. (ed.) Moche Art and Archaeology in Ancient Peru. Washington: National Gallery of Art, 2006: 111-126. 
ZELADA-ESTRAVER.W. Vertebrados del Sistema lomal "Cerro Campana", Trujillo-La Libertad, Perú. In: ArnaldoA(21).2014 


\section{(ANEXO 1) FLORA CACTO TIPO 1 A}

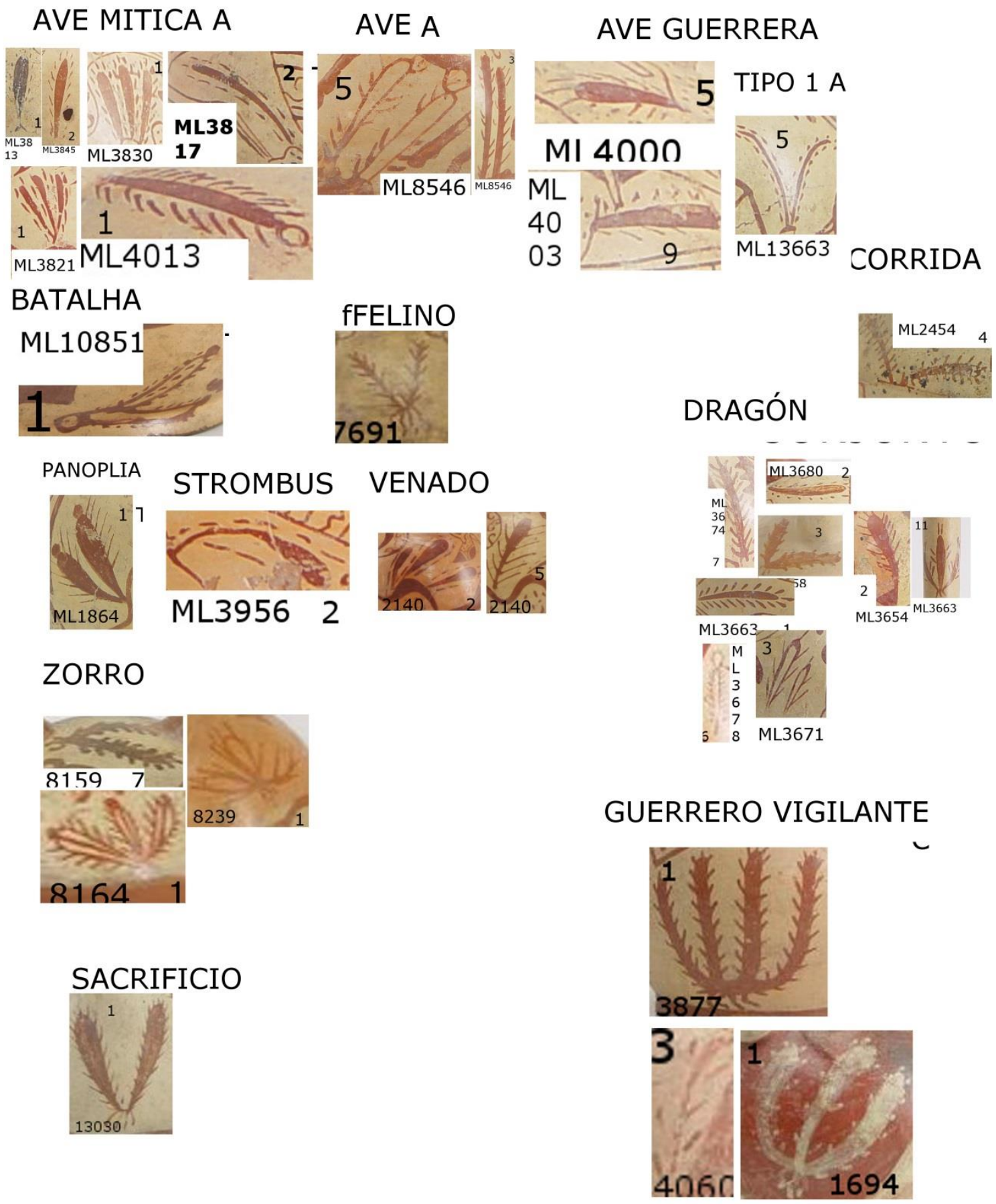




\section{(ANEXO 2)FLORA CACTO TIPO $1 \mathrm{~B}$}

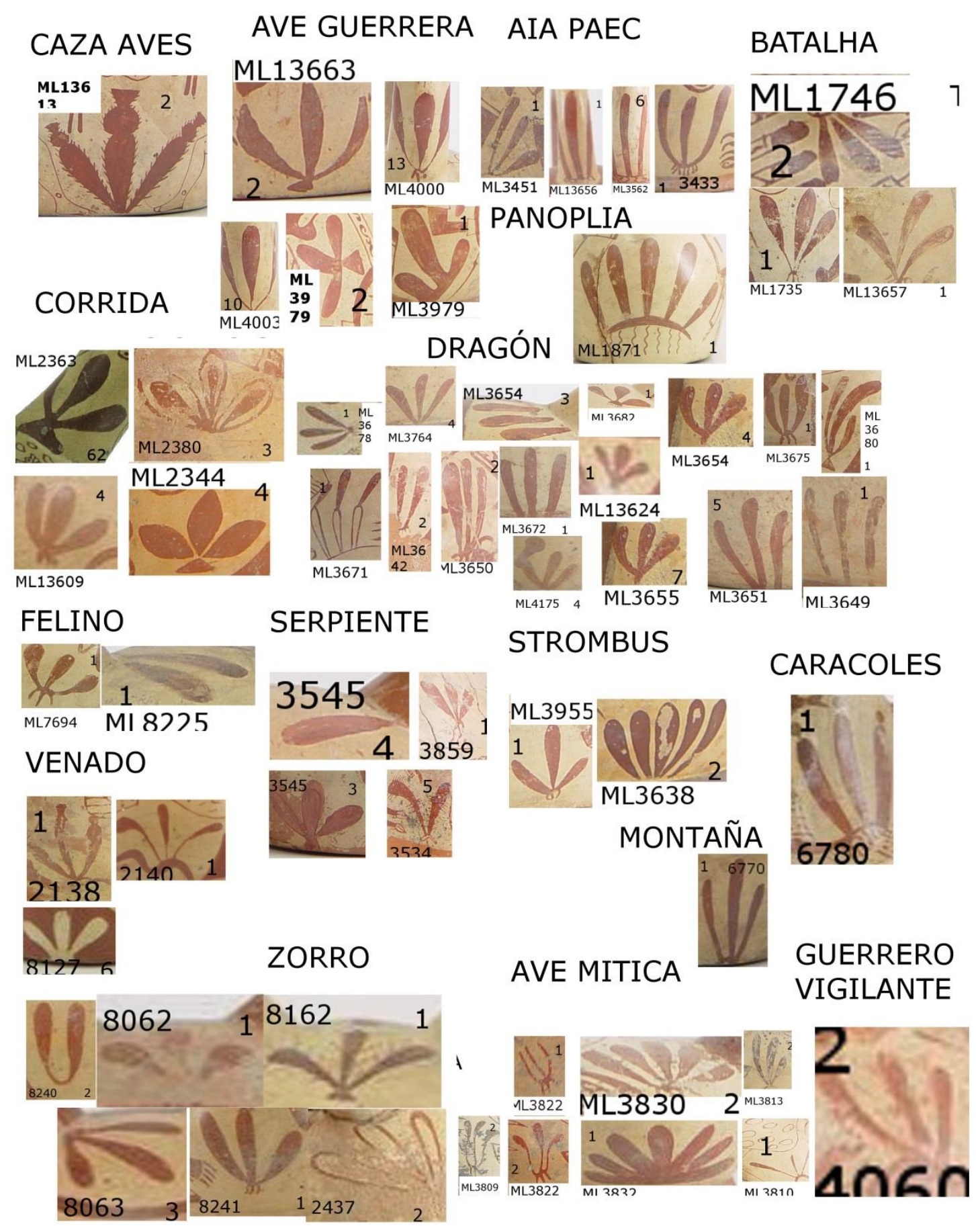




\section{(ANEXO 3) FLORA CACTO TIPO 2}

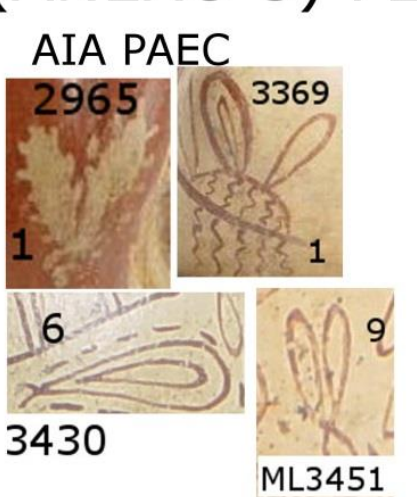

AVE GUERRERA

AVE MITICA CAZA DE AVE
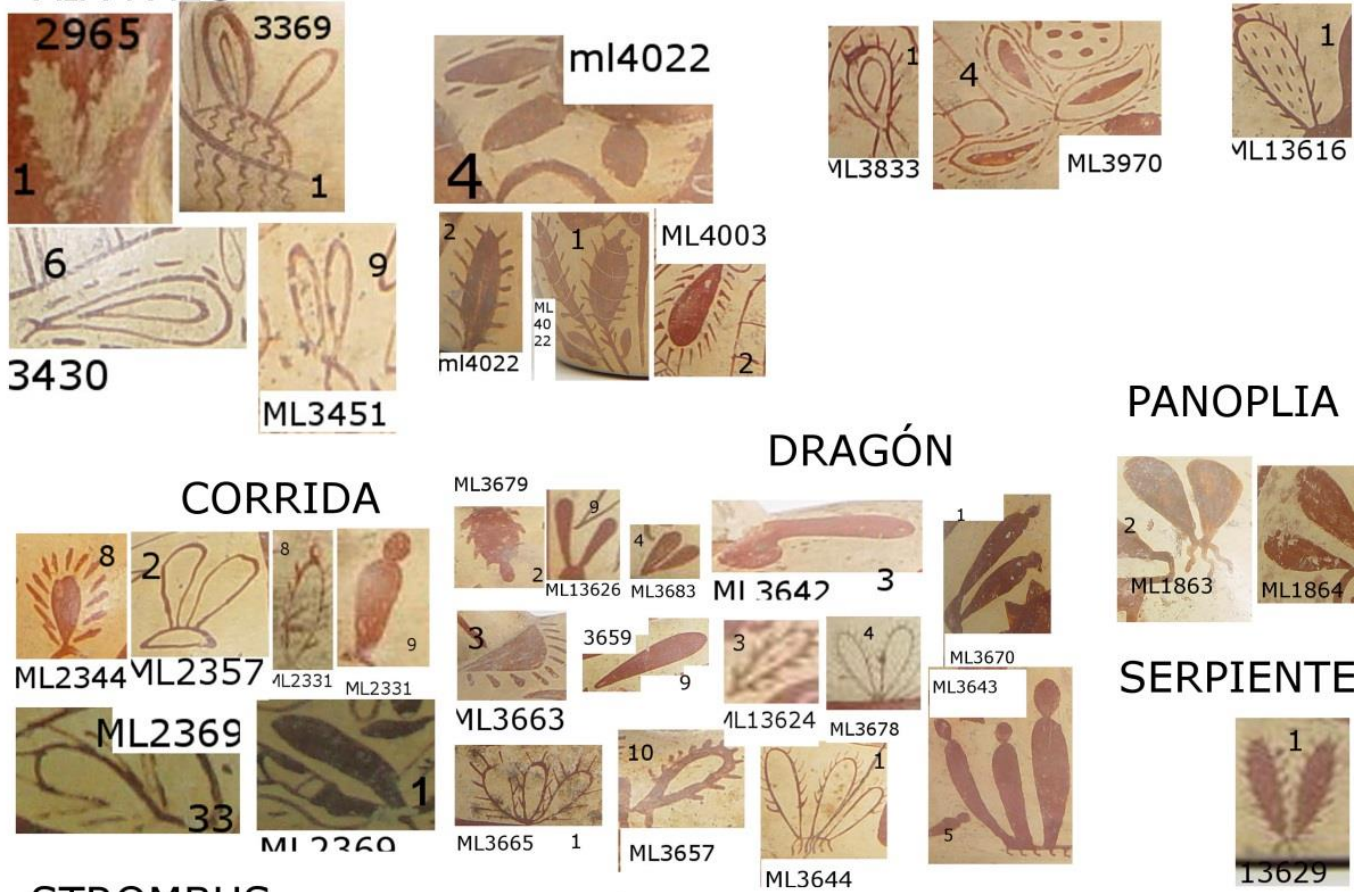

PANOPLIA

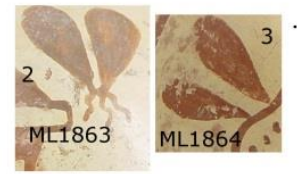

\section{SERPIENTE}
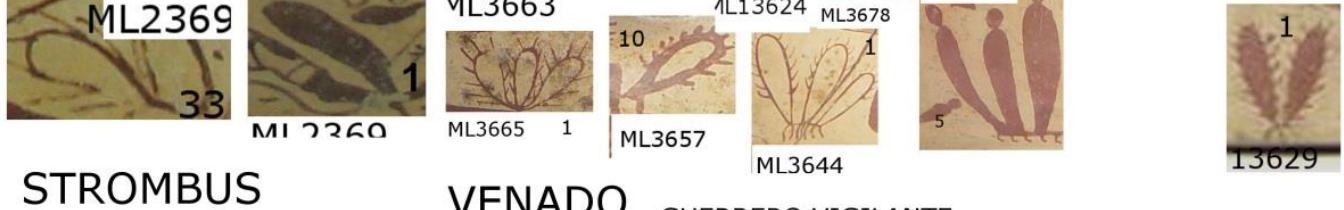

VENADO GUERRERO VIGILANTE
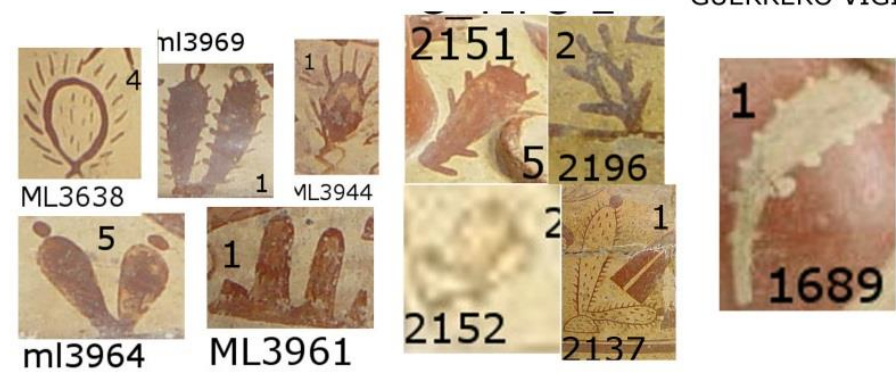

MUNDO HORROROSO

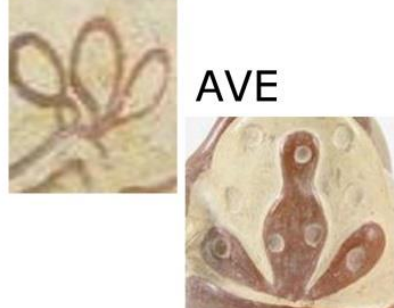

$2 B$

\section{AIA PAEC AVE}

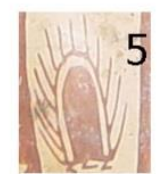

ML3562

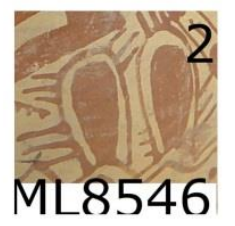

BATALHACARACOLES

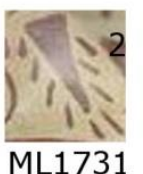

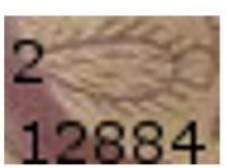

CORRIDA

ML2344 5

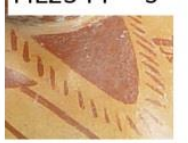




\section{(ANEXO 4)FLORA CACTO TIPO 3}

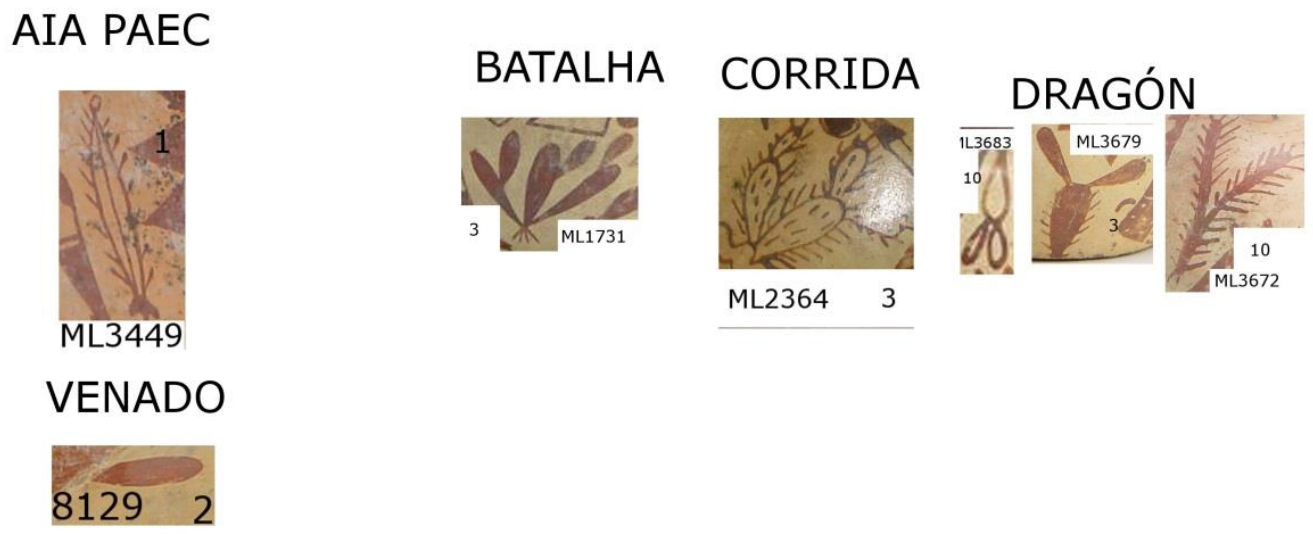

AVE MITICA

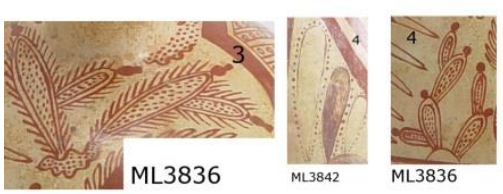

AVE GUERRERA

CARACOLES

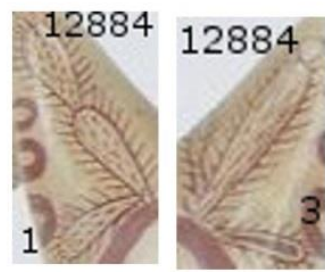

GUERRERO VIGILANTE

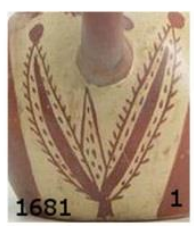




\section{(ANEXO 5) FLORA CACTO TIPO 4}
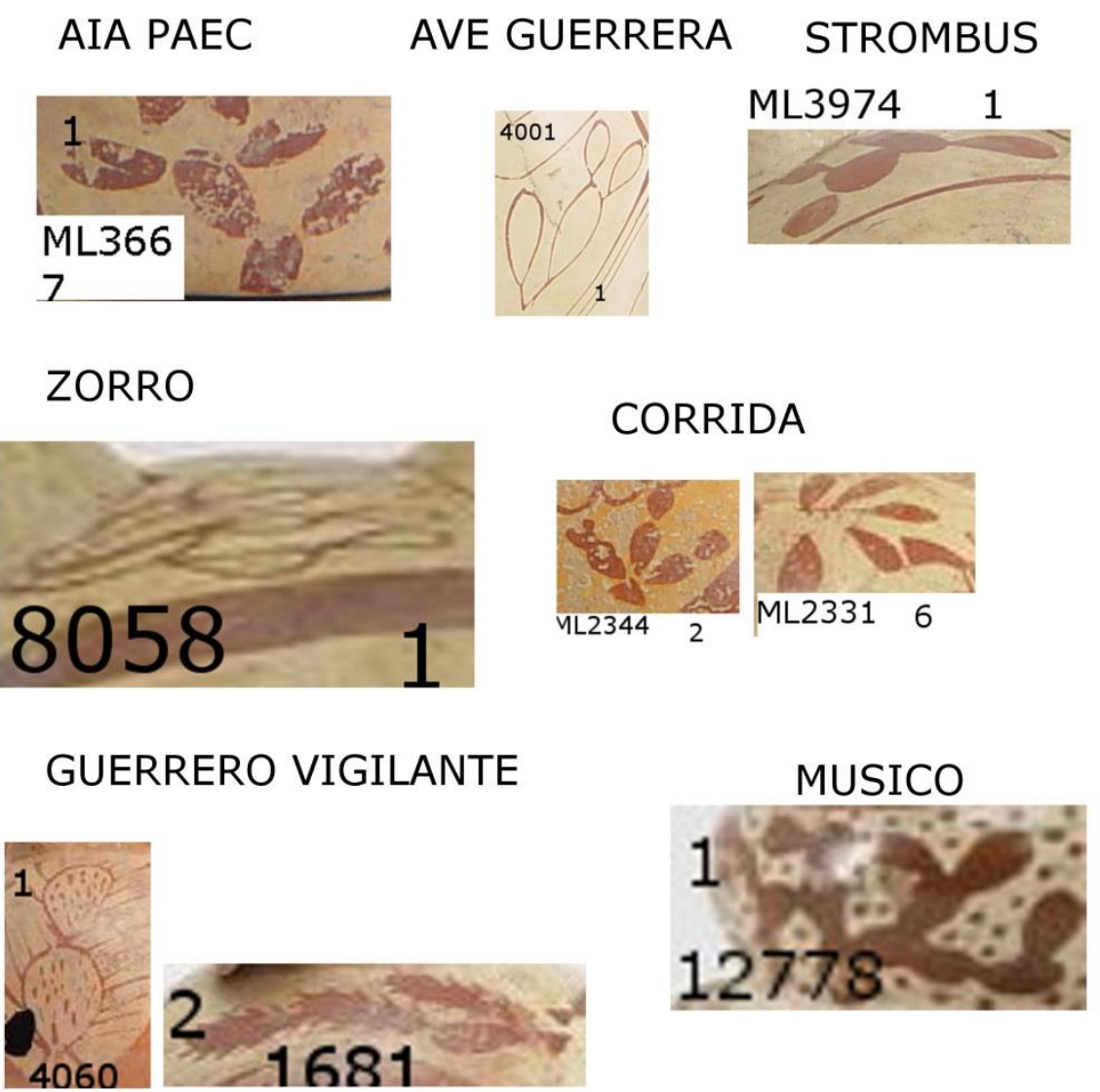


\section{(ANEXO 6) FLORA CACTO TIPO 5}

AVE MITICA

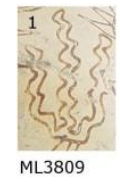

CARACOLES

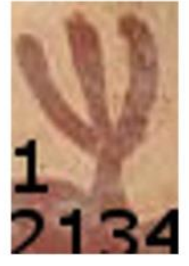

FELINO
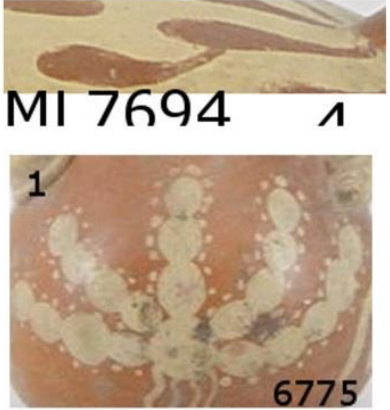

BATALHA

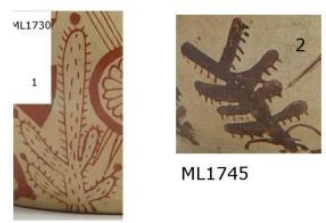

CORRIDA DRAGÓN
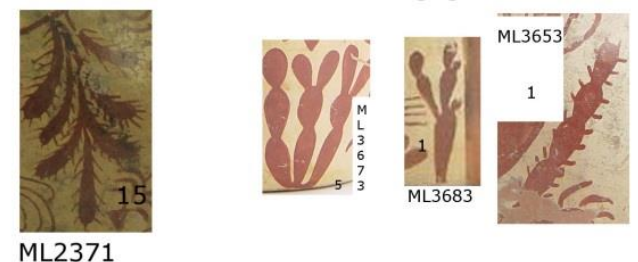

FLORA

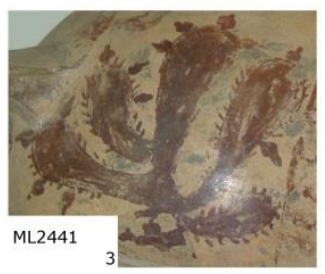




\section{(ANEXO 7)ARVORES E ARBUSTOS}

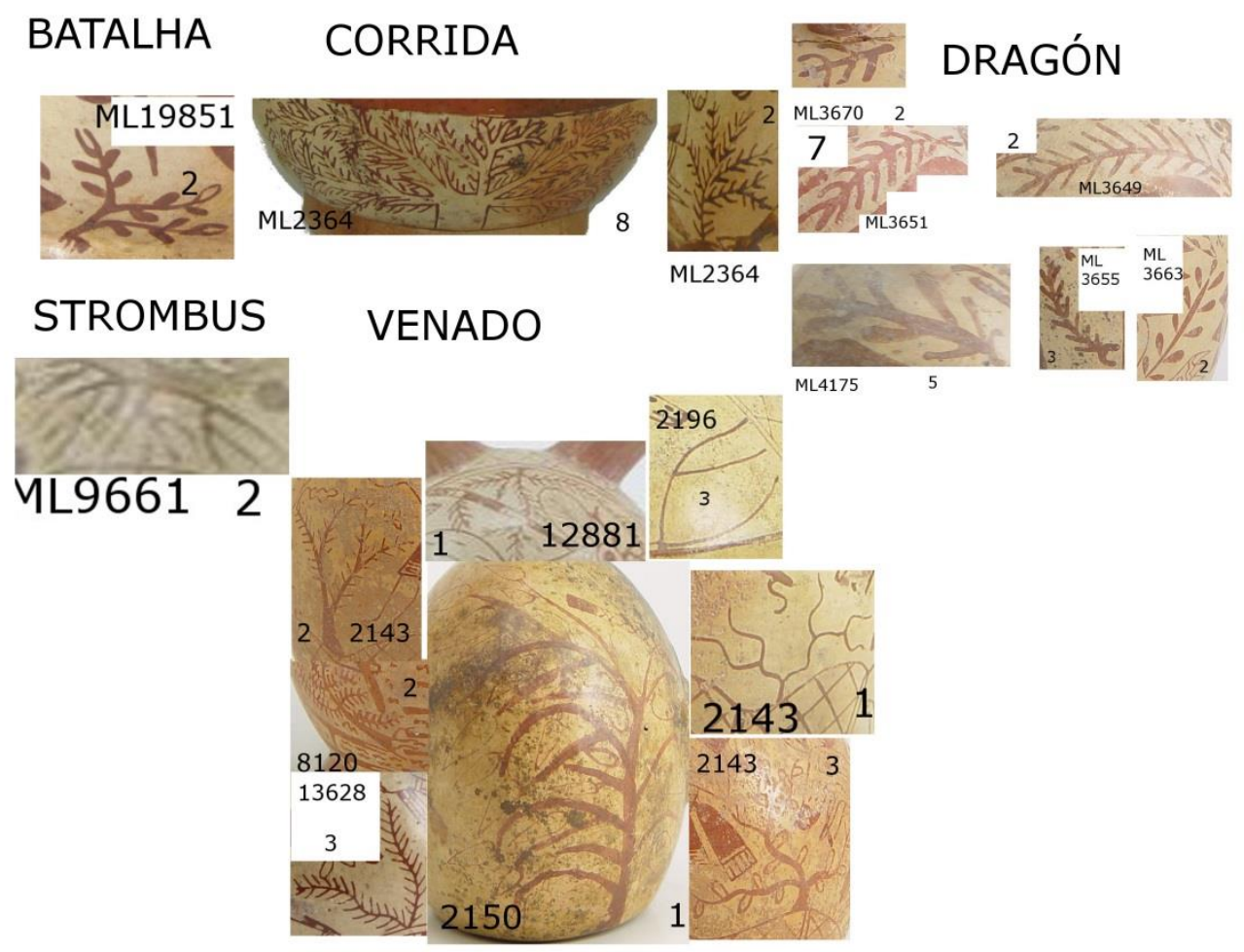

CAZA DE AVES MONTAÑA
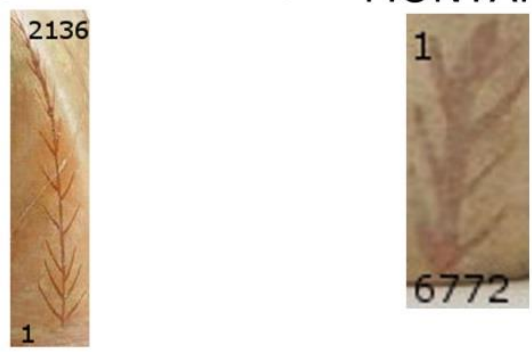


\section{(ANEXO 8) TILLANDSIAS}

AIA PAEC

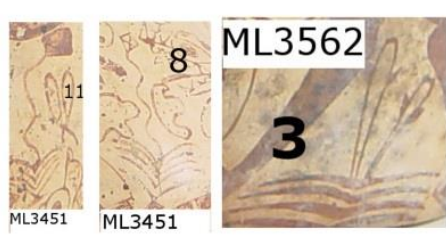

AVE MITICA
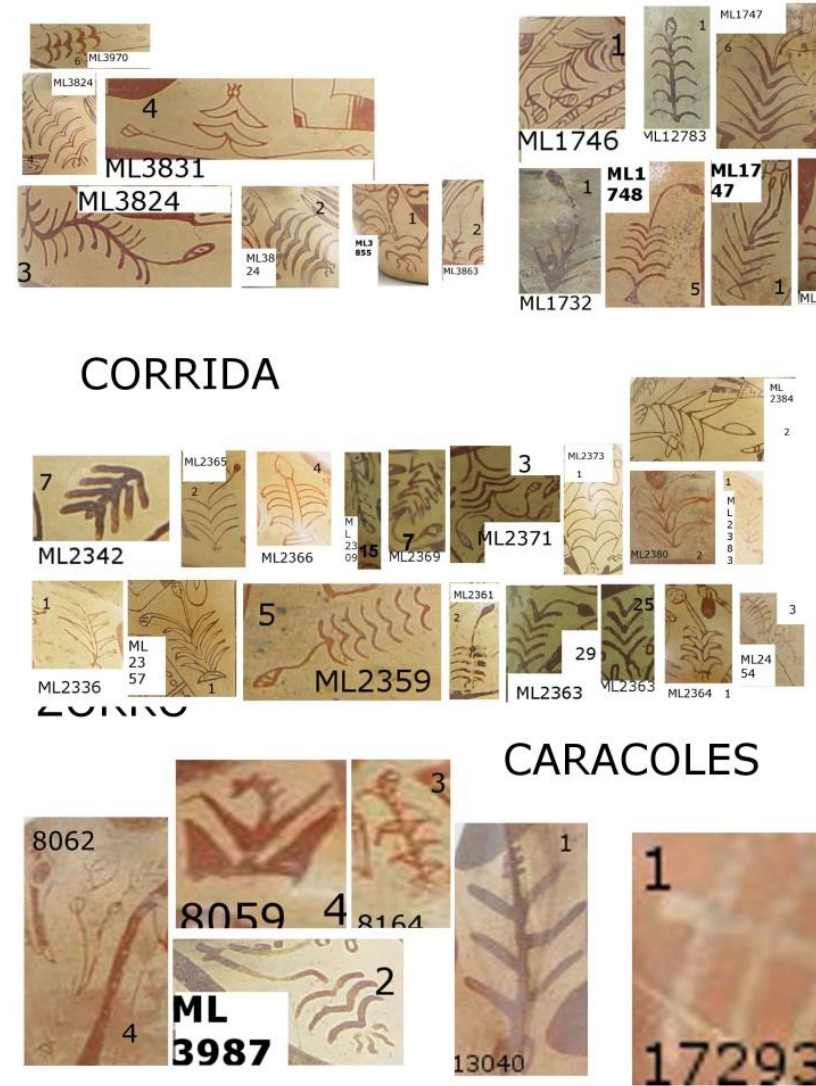

\section{CARACOLES}
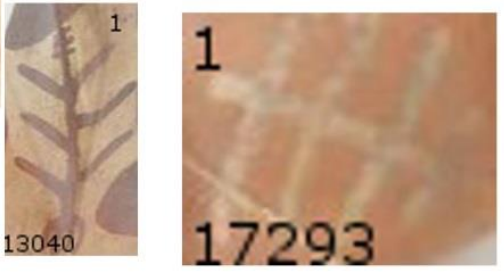

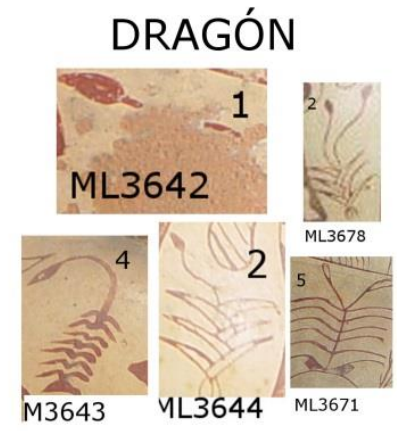

STROMBUS
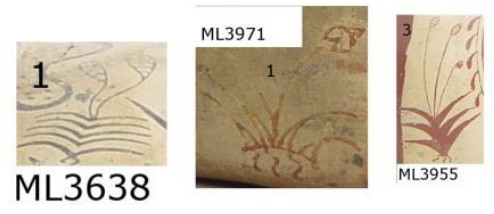

\section{VENADO}

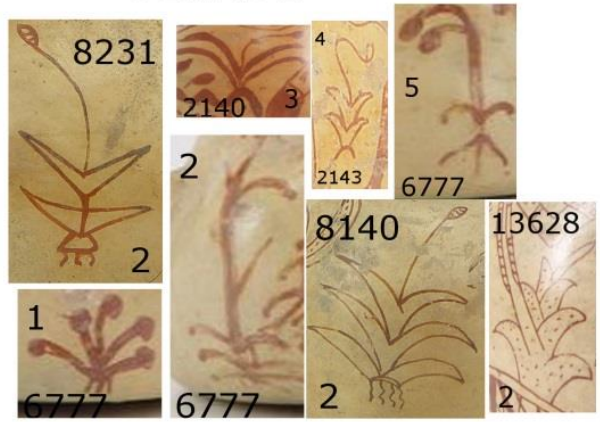

\section{AVE}

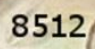

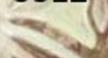

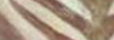




\section{(ANEXO 9) FLORES}

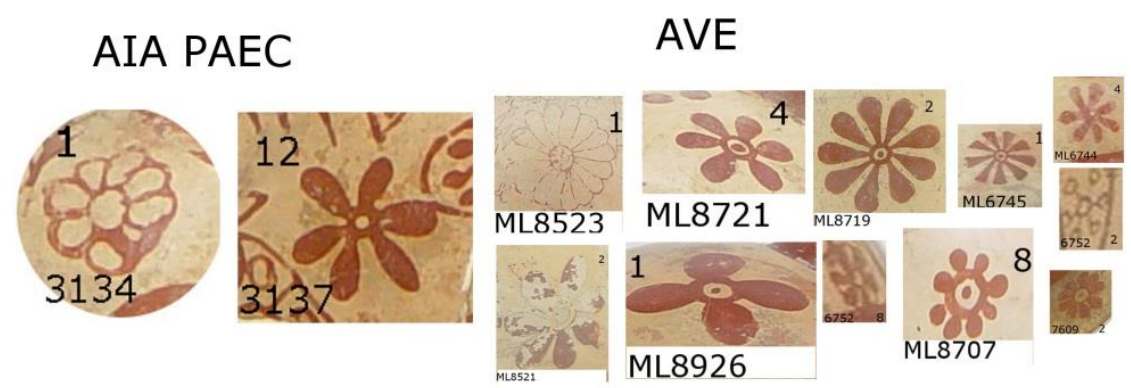

DRAGÓN

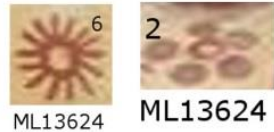

MUNDO HORROROSO

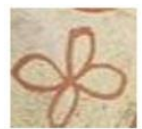


(ANEXO 10) TOTORAS

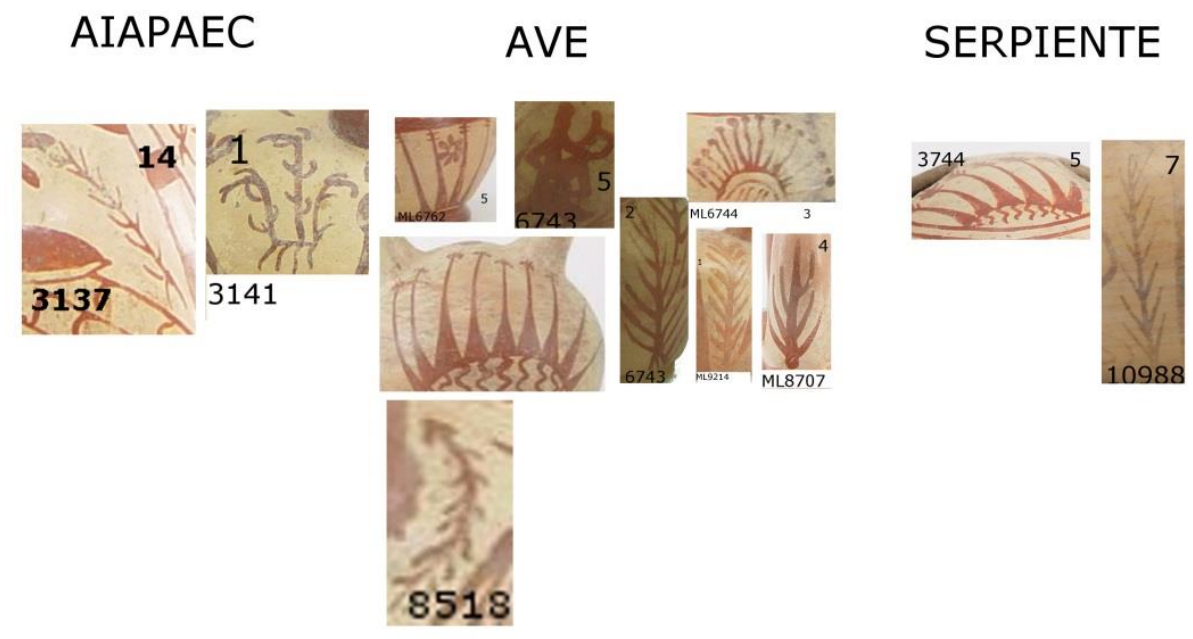


(ANEXO 11) ULUCHU

AVE GUERRERA

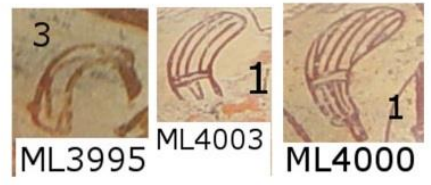

FLORA
AVE MITICA CORRIDA
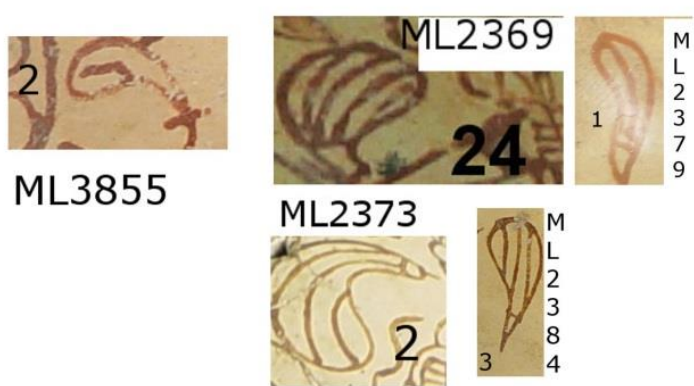
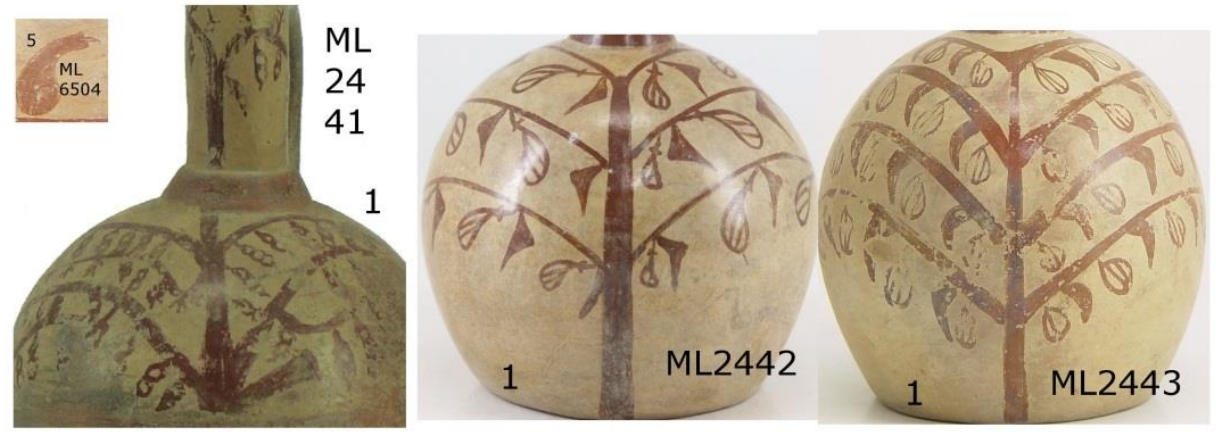

STROMBUS

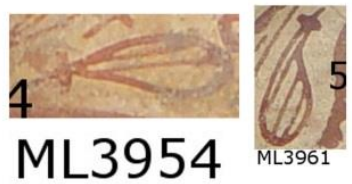



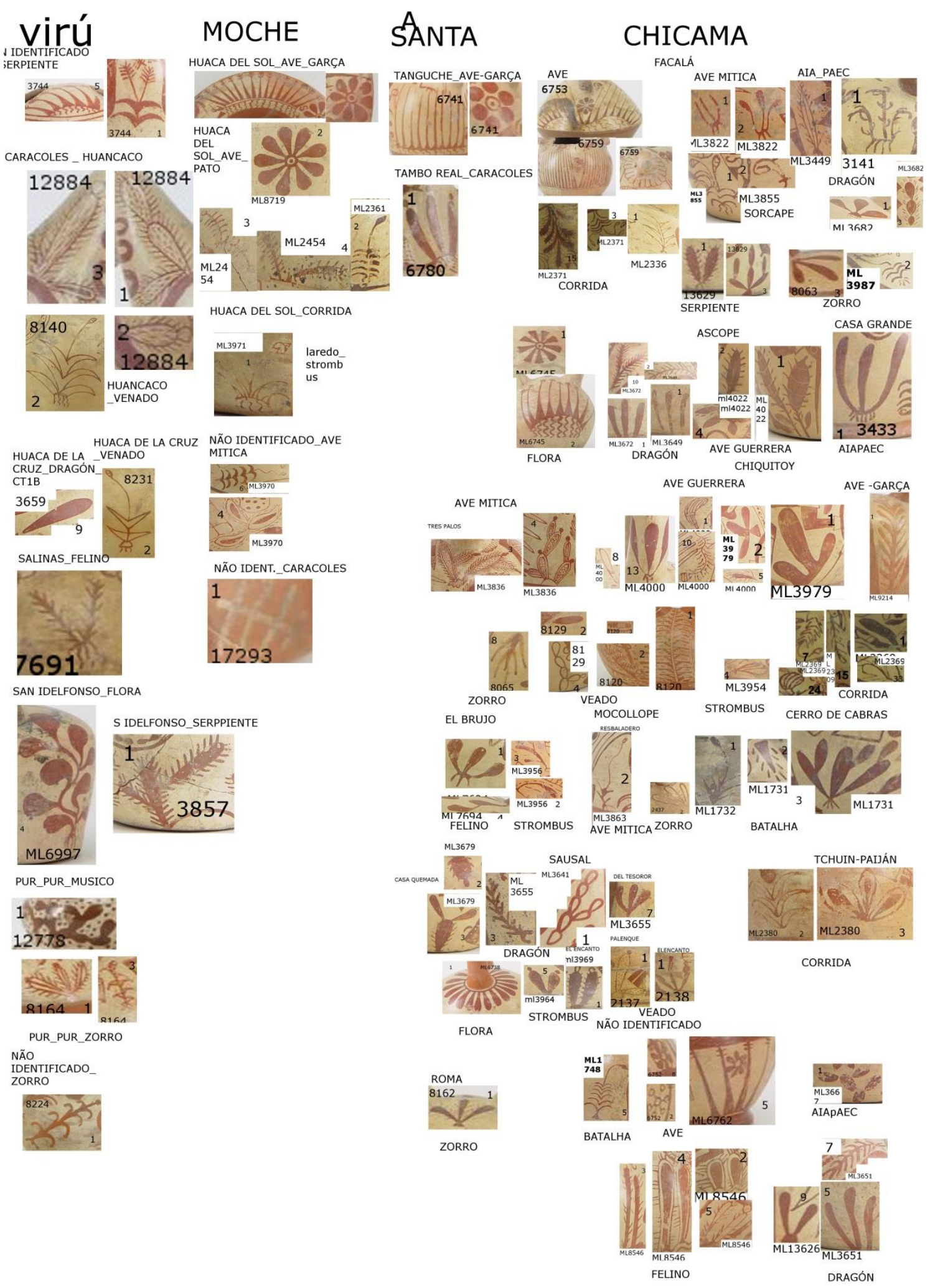


\section{(ANEXO 13)AIA - PAEC FLORA}
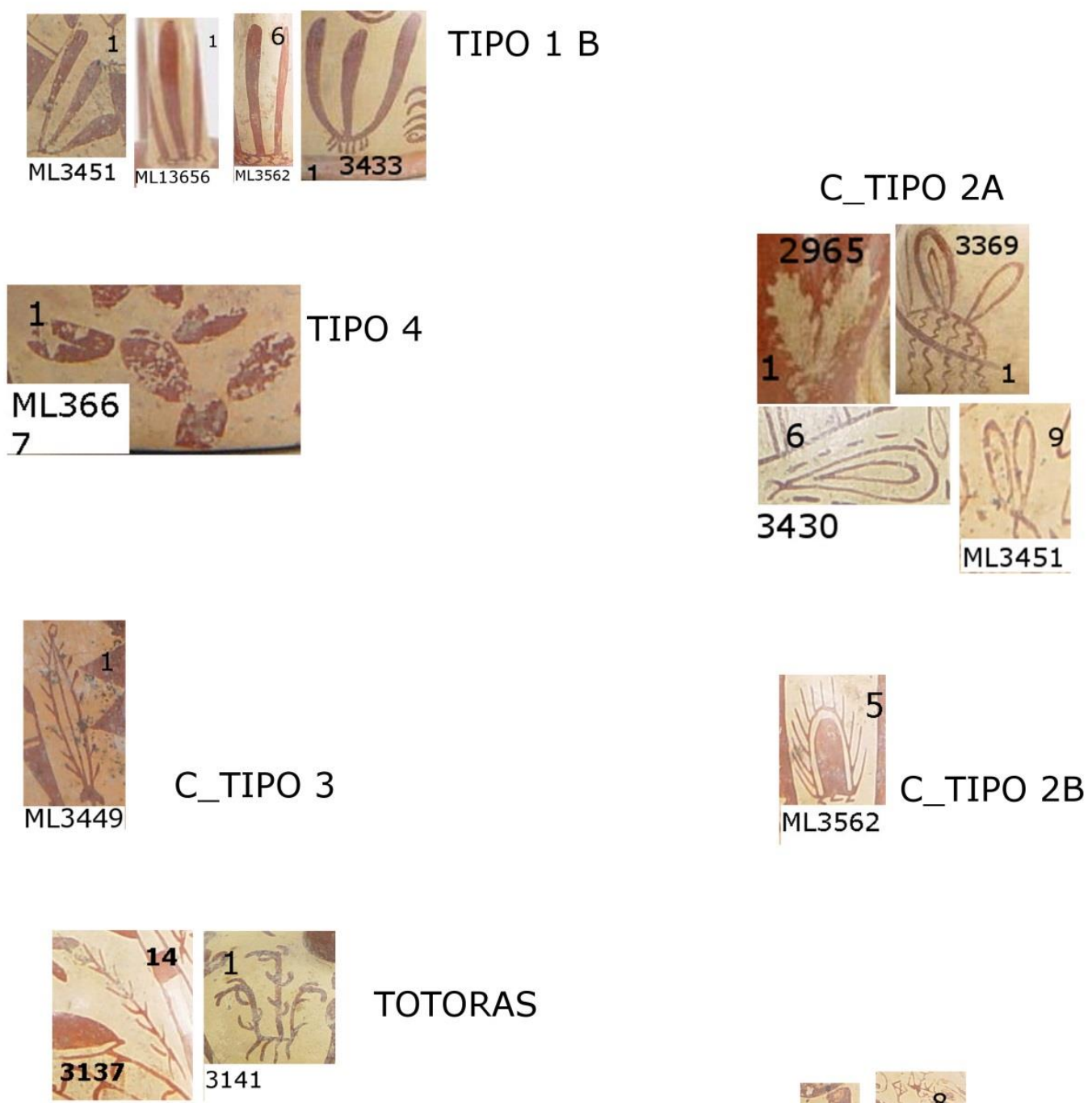

FLORES

TILLANDSIAS
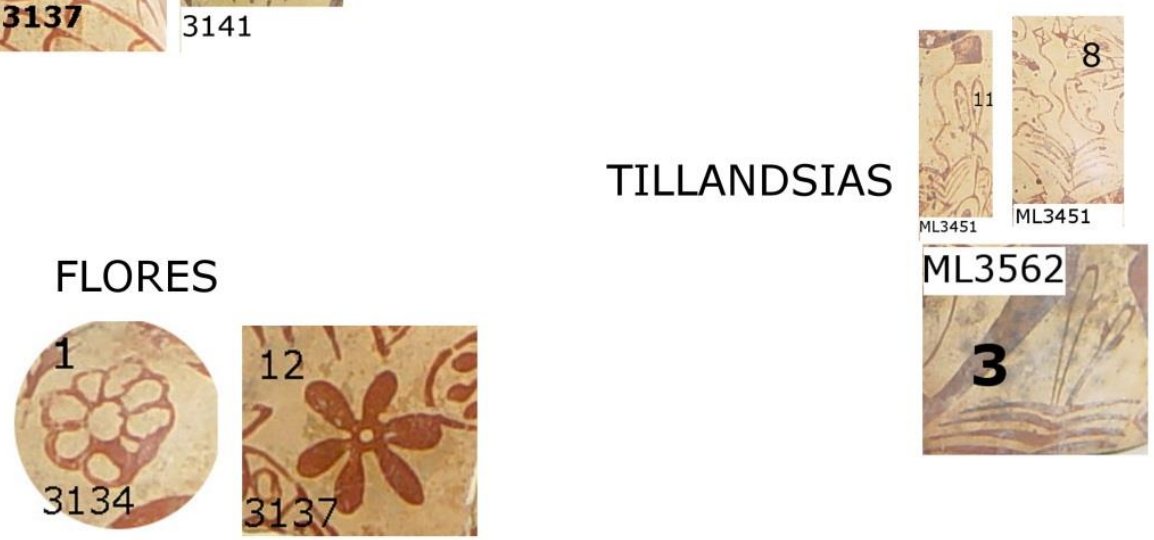


\section{(ANEXO 14)AVES- CONJUNTO FLORA}

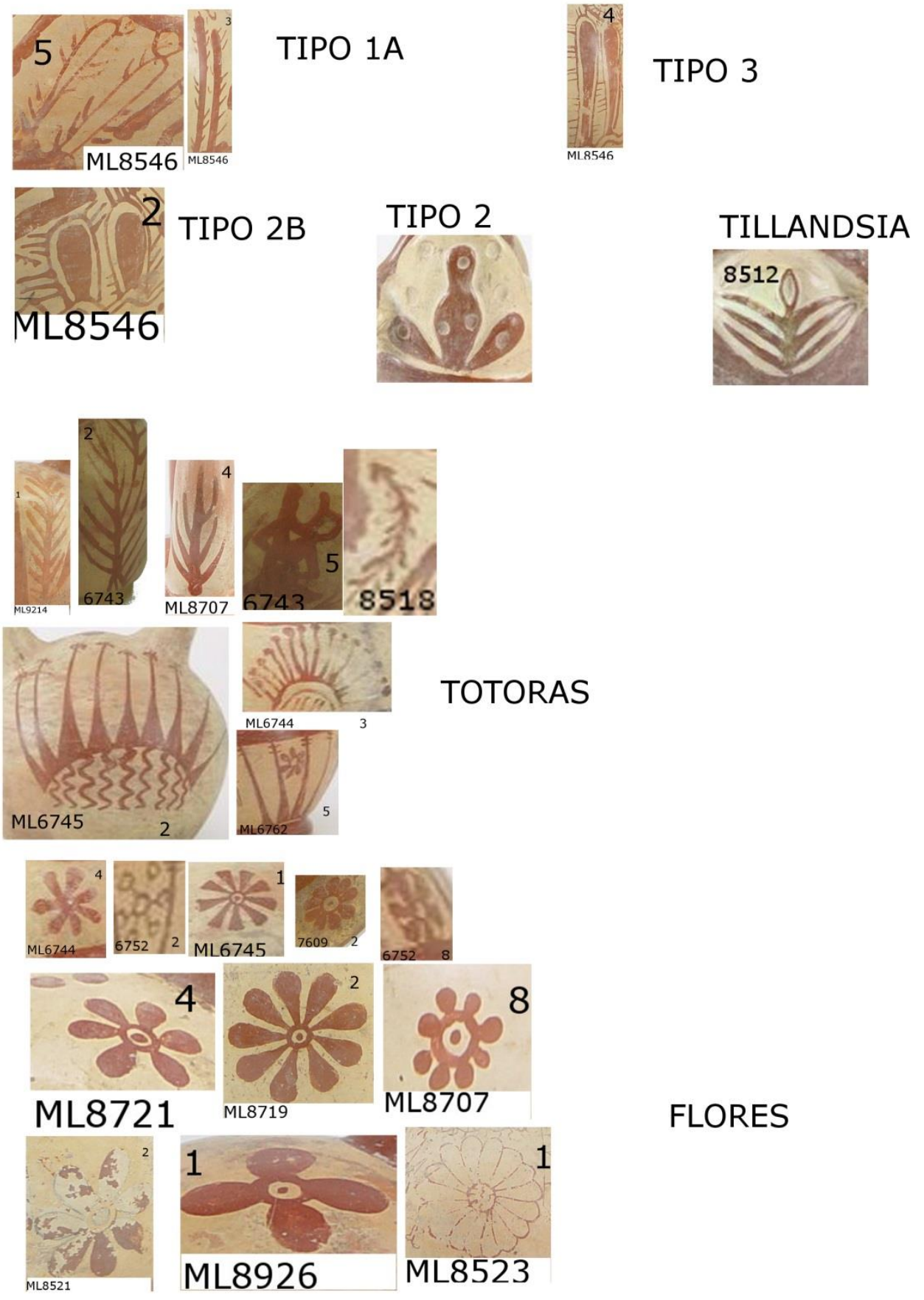




\section{(ANEXO 15) FLORA AVE GUERRERA}
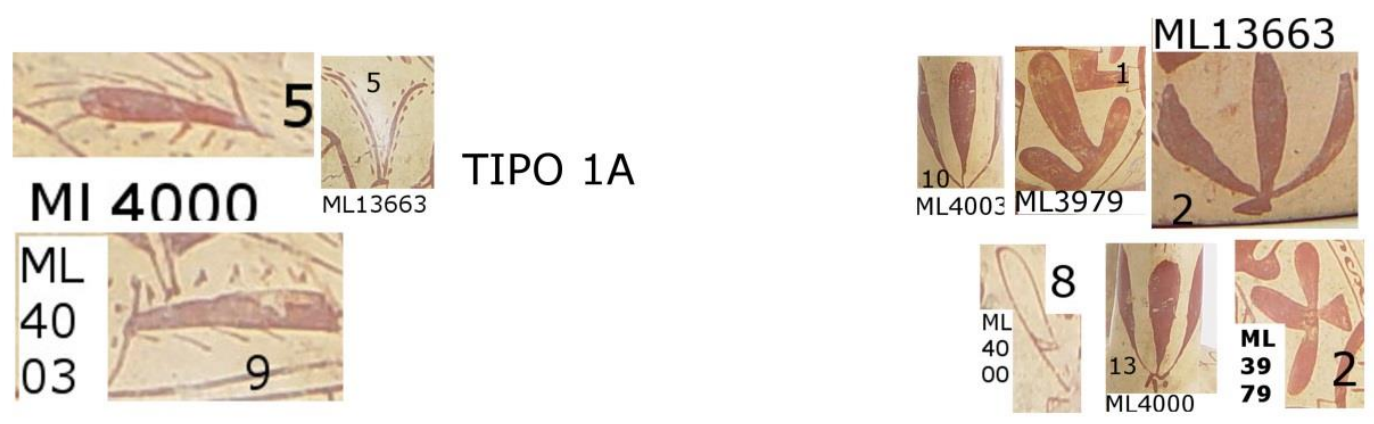

TIPO 1B

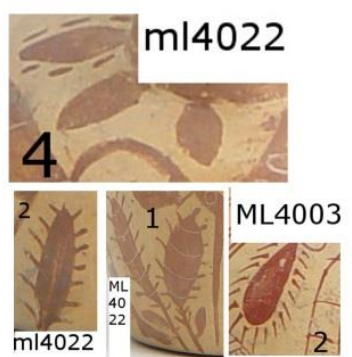

TIPO 2
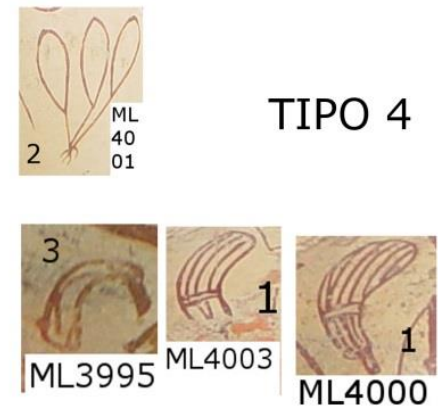

TILLANDSIAS

ULUCHU

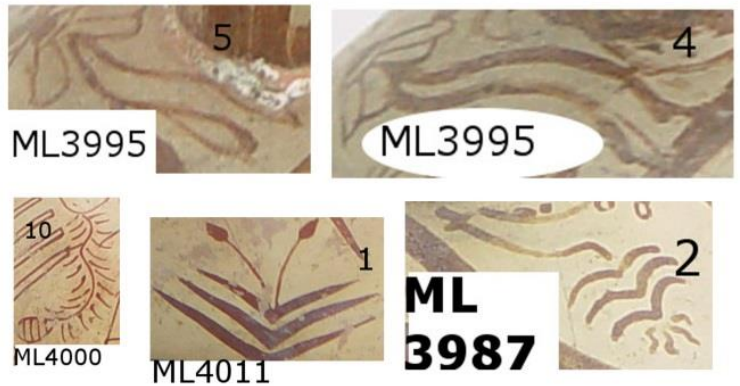




\section{(ANEXO 16) AVE MITICA FLORA}

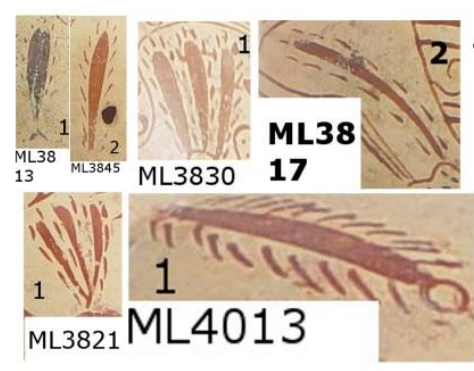

TIPO $1 \mathrm{~A}$
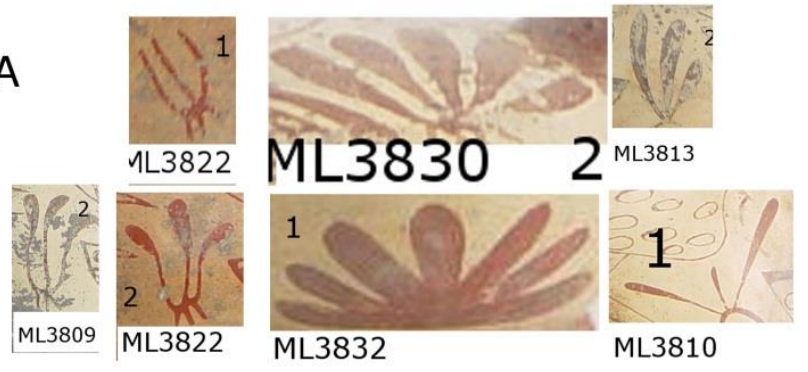

TIPO $1 \mathrm{~B}$
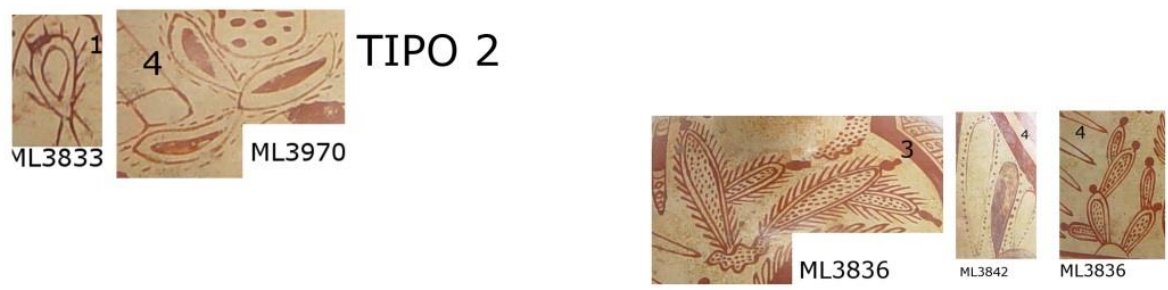

TIPO 3

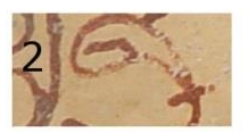

ML3855
ULUCHU

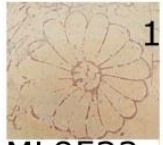

ML8523
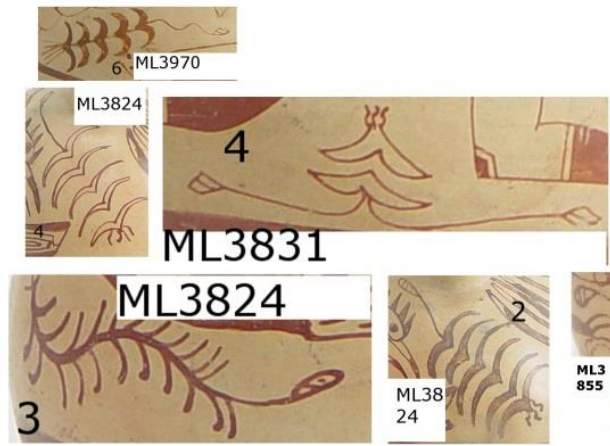

TILLANDSIAS

TIPO 5

FLOR_LARCO ERROU. CAT. CORRETA SERIA AVE
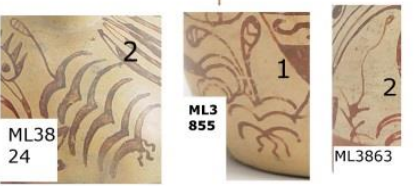


\section{(ANEXO 17) BATALHA RITUAL FLORA}

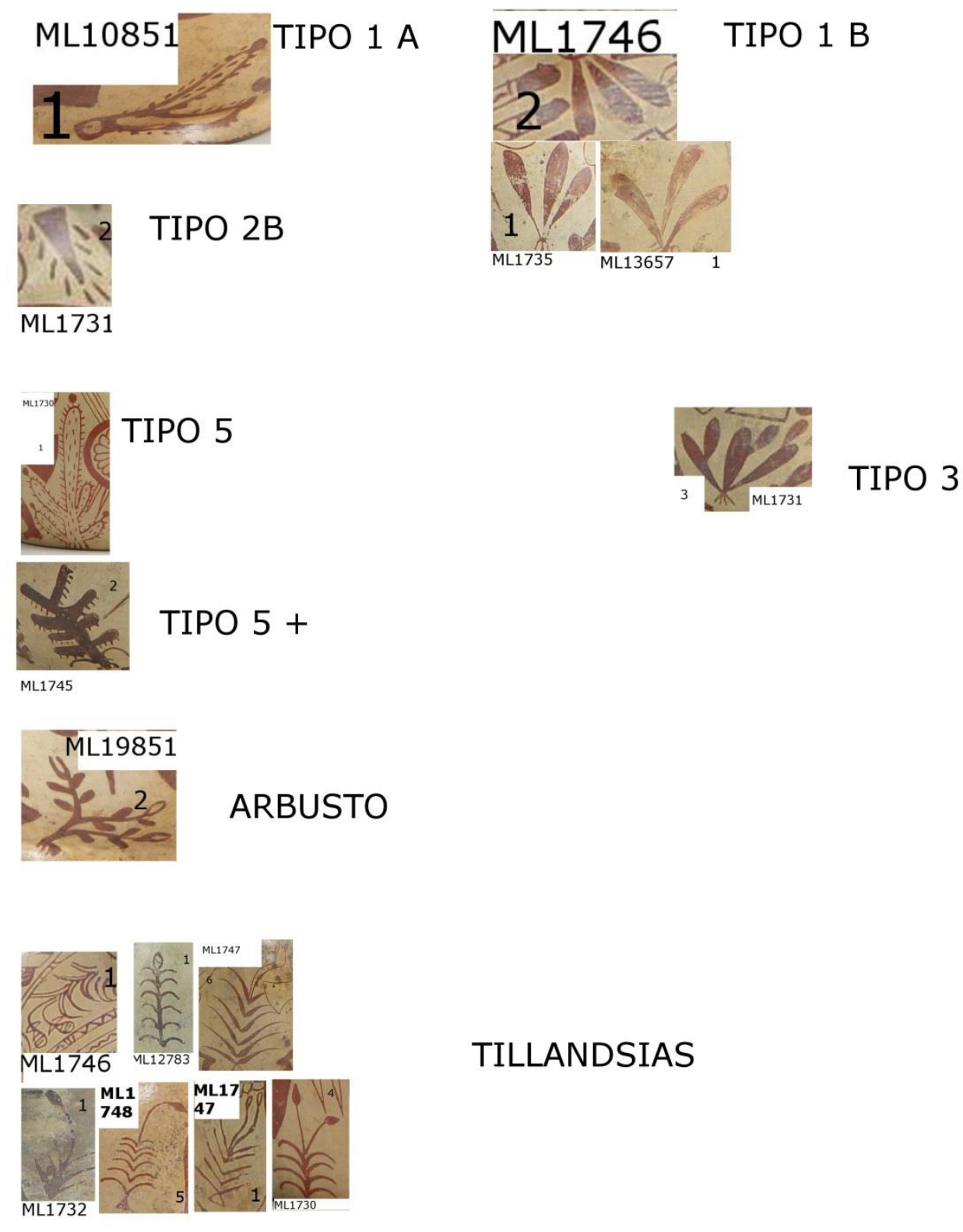




\section{(ANEXO 18)CARACOLES FLORA}

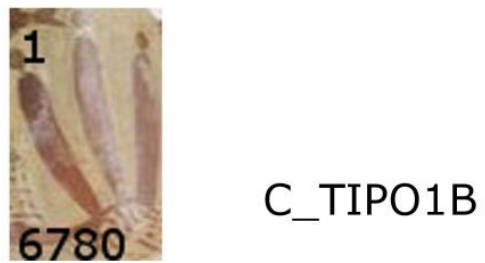

C_TIPO 3
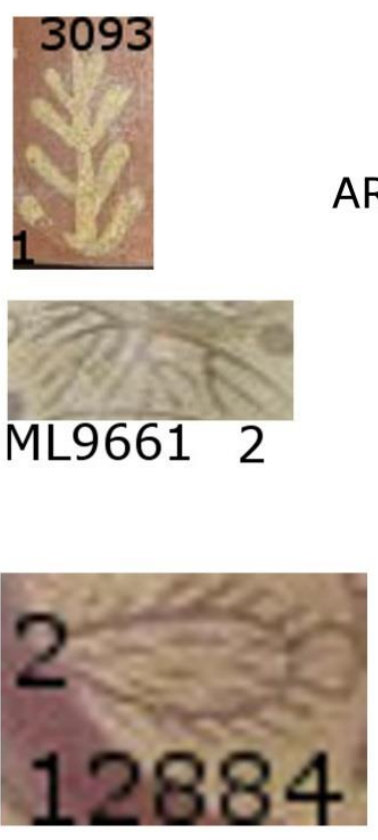

C_TIPO2B

1

2134

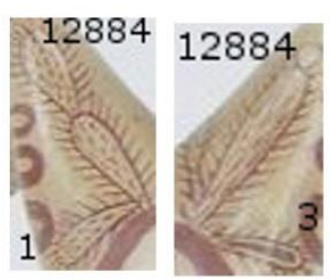

C_TIPO5

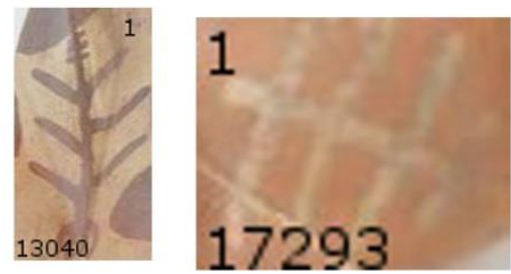

TILLANDSIAS 


\section{(ANEXO 19) FLORA CORRIDA}

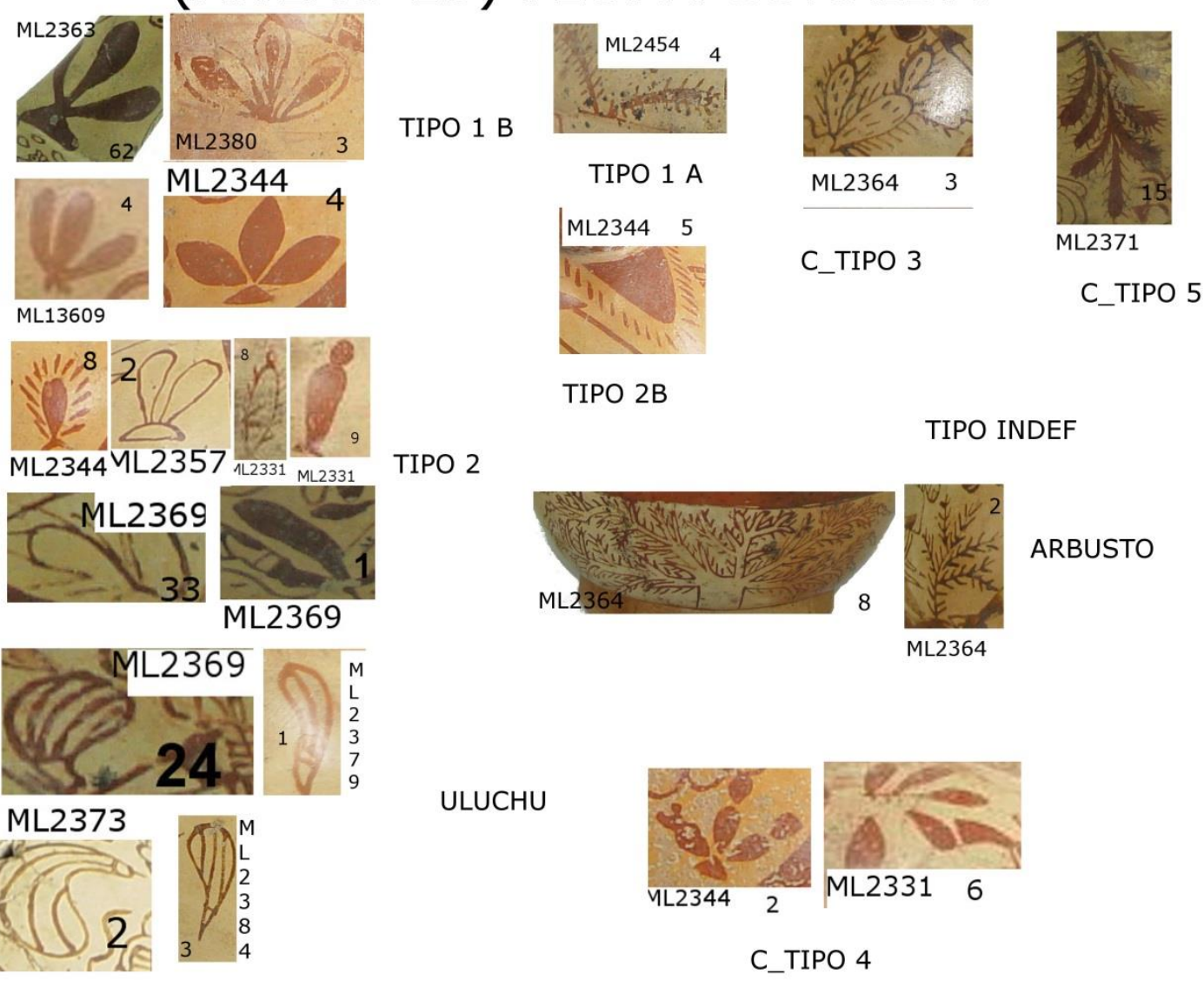

TILLANDSIAS

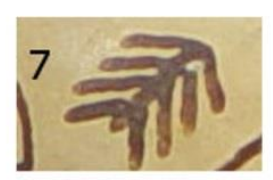

ML2342

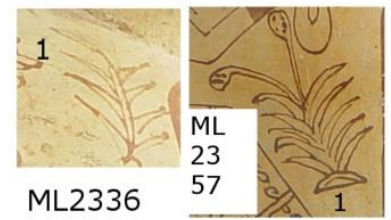

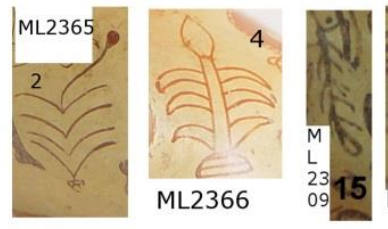

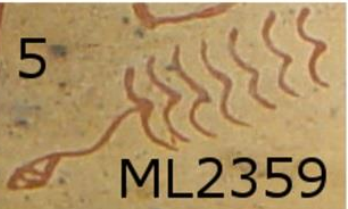

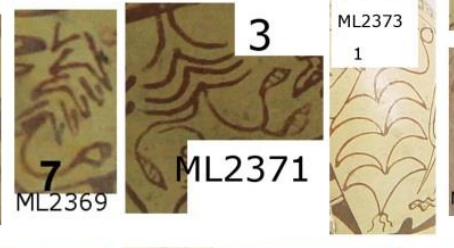
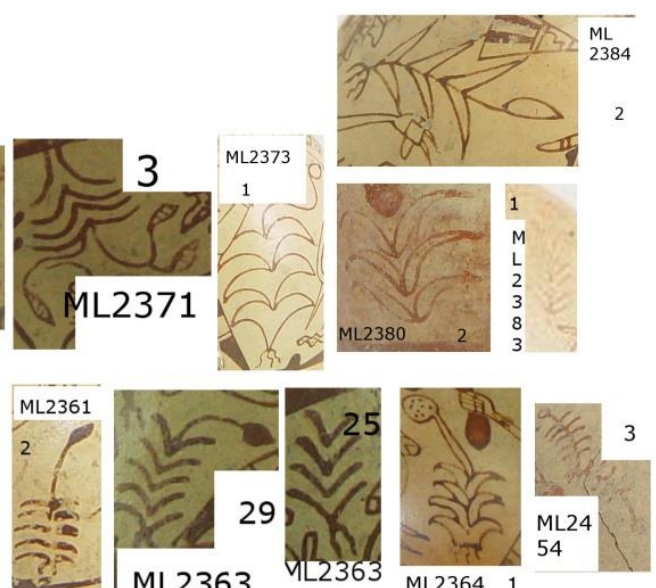


\section{(ANEXO 20) FLORA DRAGÓN}

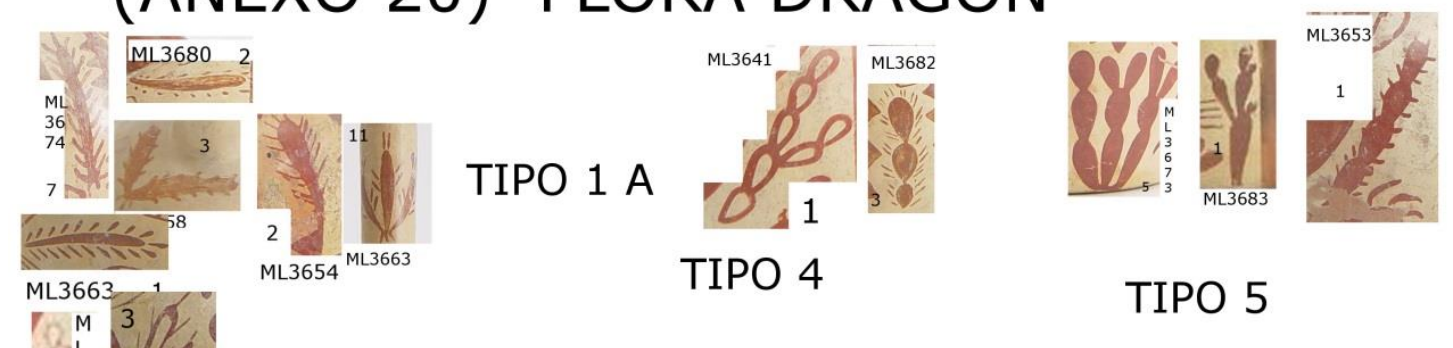

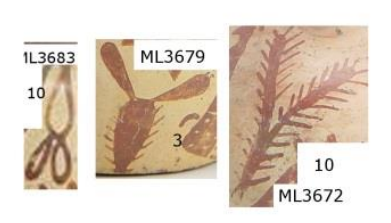

TIPO 3

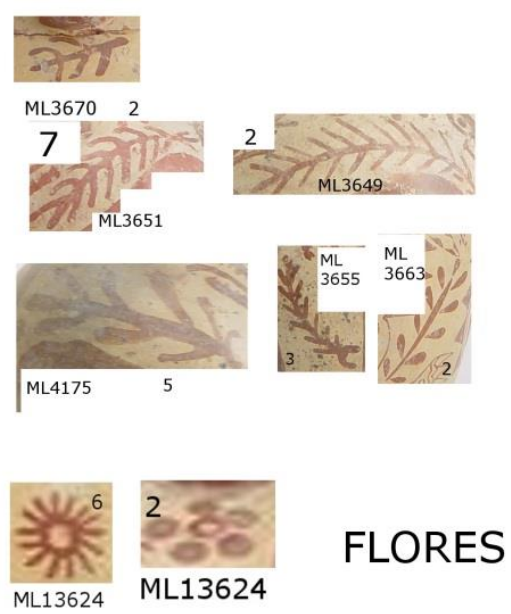

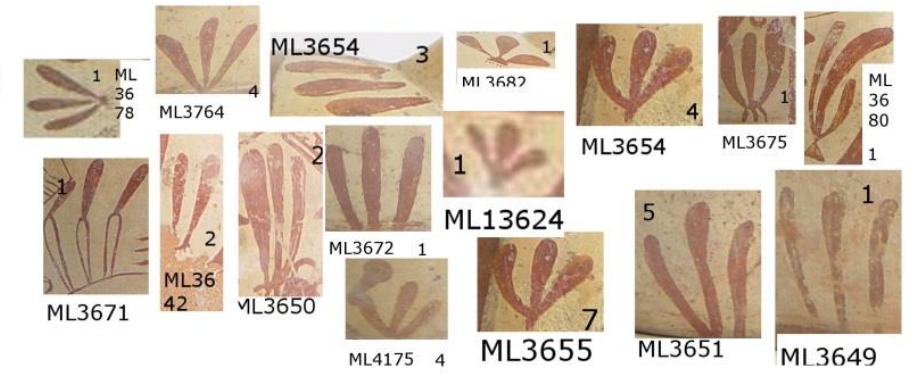

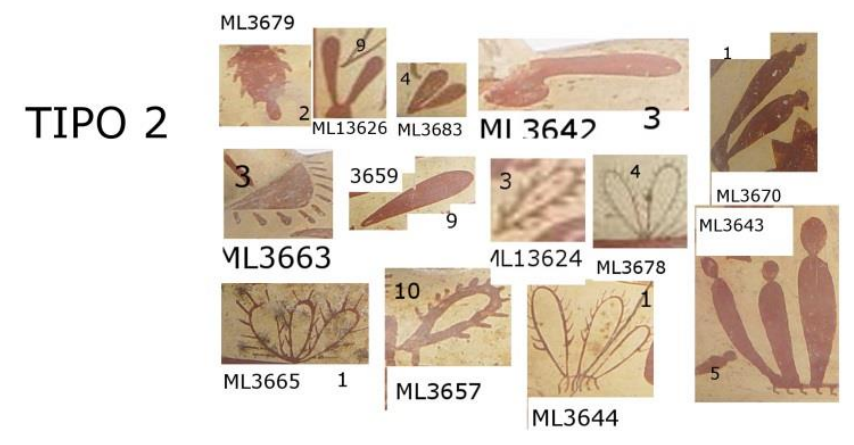

ARBUSTOS 


\section{(ANEXO 21)FELINO FLORA}

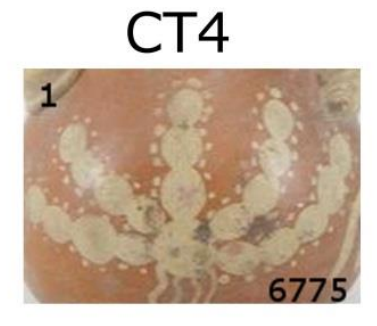

CT1B
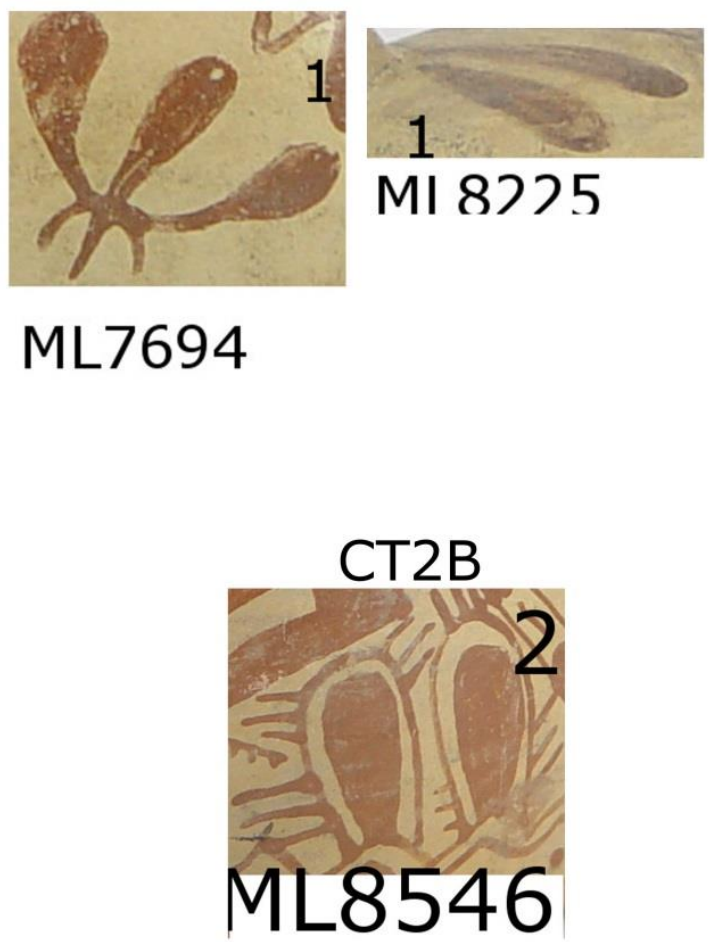

CT5

CT1A
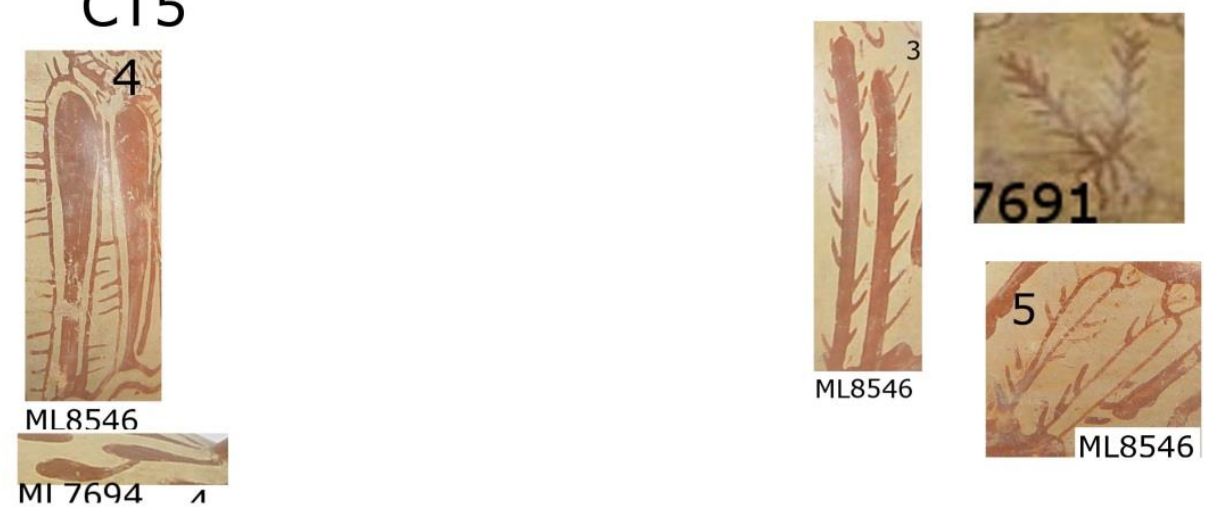


\section{(ANEXO 22) FLORA_FLORA}

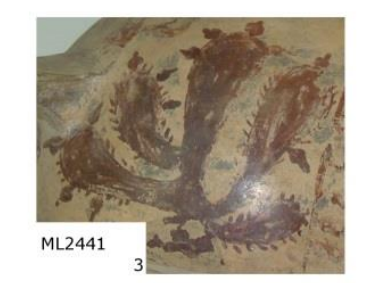

$$
\text { C_TIPO } 5
$$

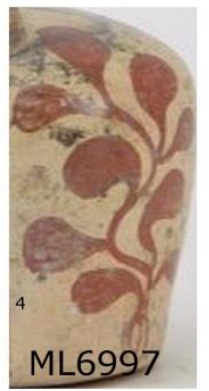

PLANTA INDEF

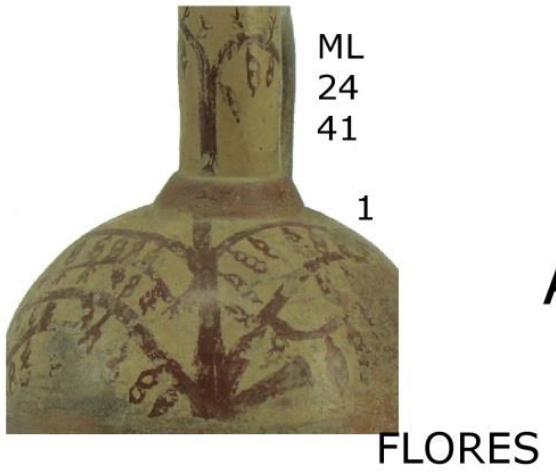

\section{ALGARROBO}

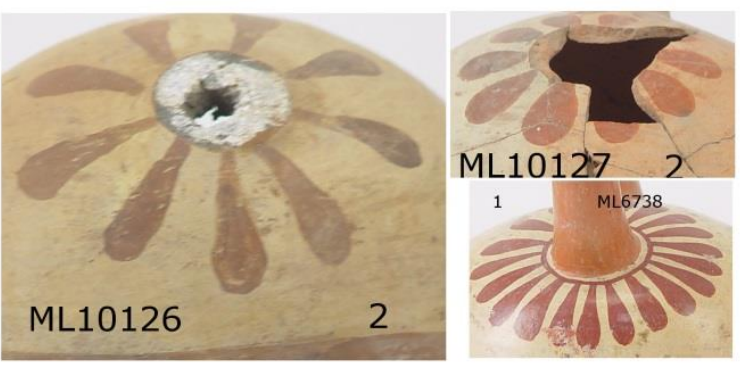

ULUCHU
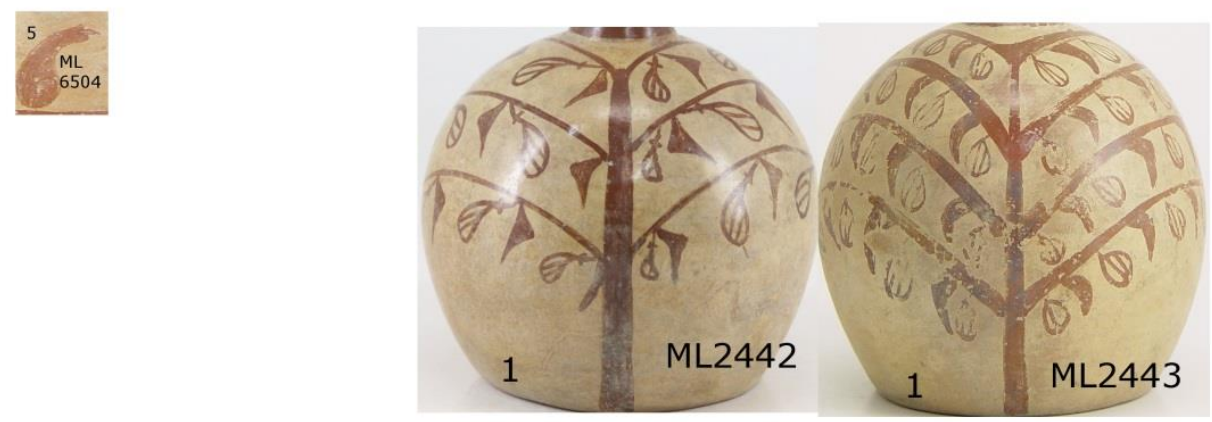
(ANEXO 23) GUERREIRO VIGILANTE FLORA
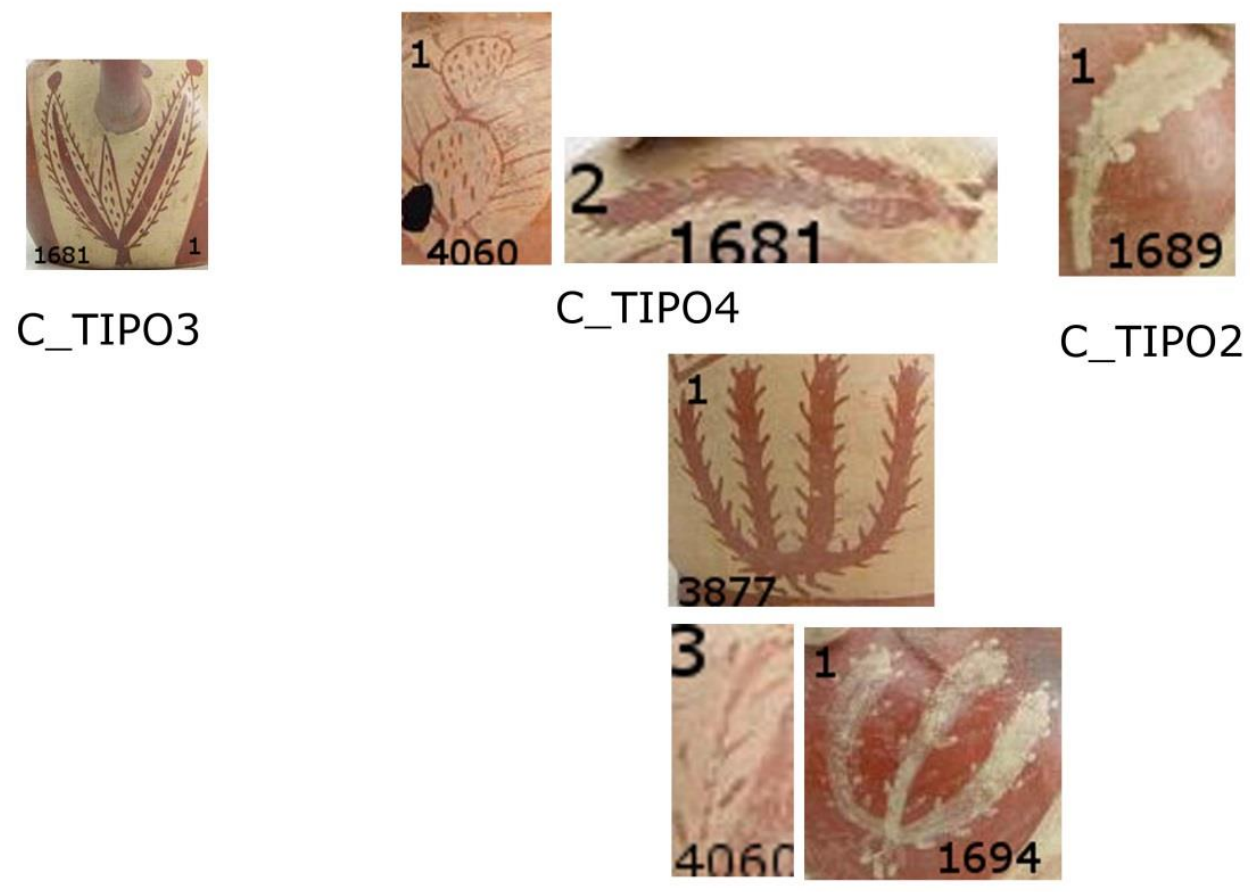

C_TIP01A

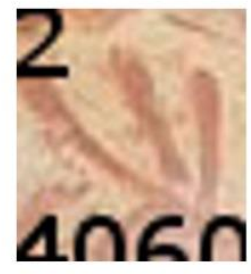

C_TIPO1B 


\section{(ANEXO 24) SERPIENTE_FLORA}
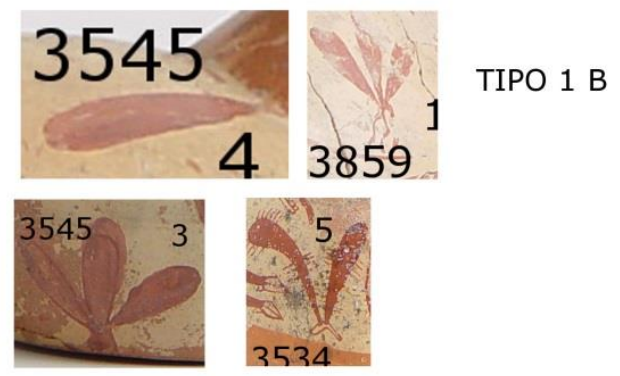

TIPO 2

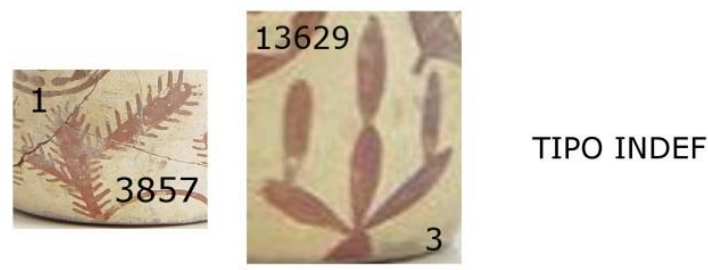

TIPO INDEF
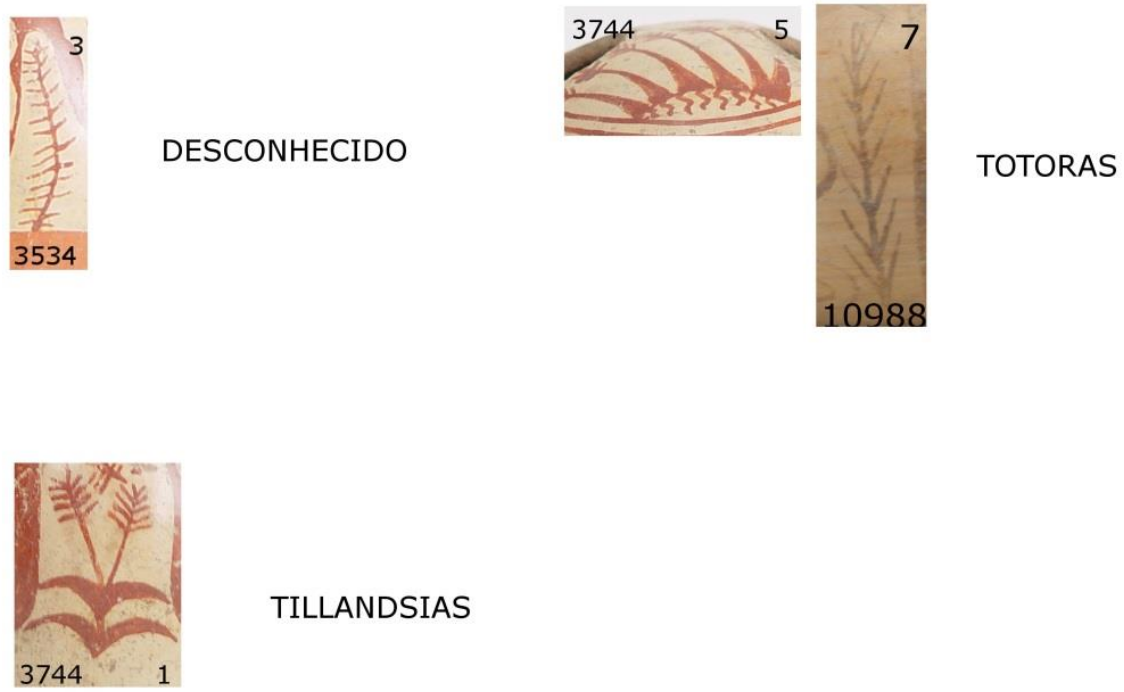

TILLANDSIAS 


\section{(ANEXO 25) FLORA STROMBUS}

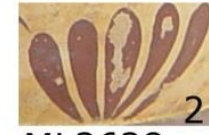

ML3638

ML3955

1

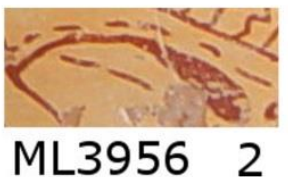

TIPO 1

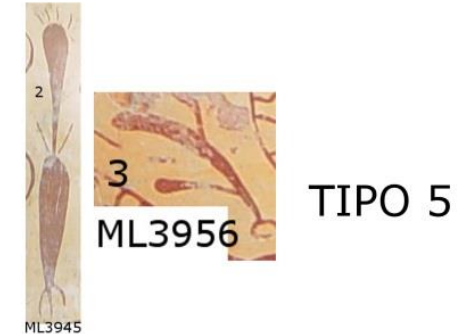

TIPO 2

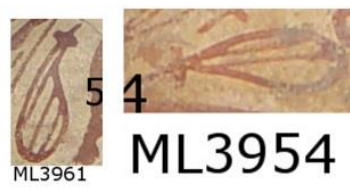

UULLUCHU

ML3954

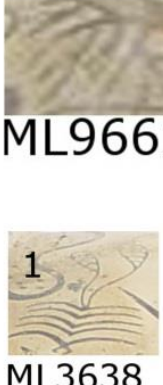

TIPO 4

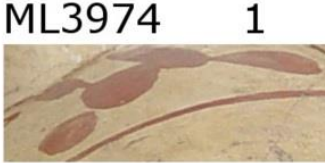

TIPO 4

ML3638

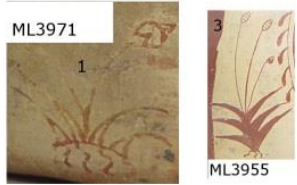




\section{(ANEXO 26) VEADO_FLORA}

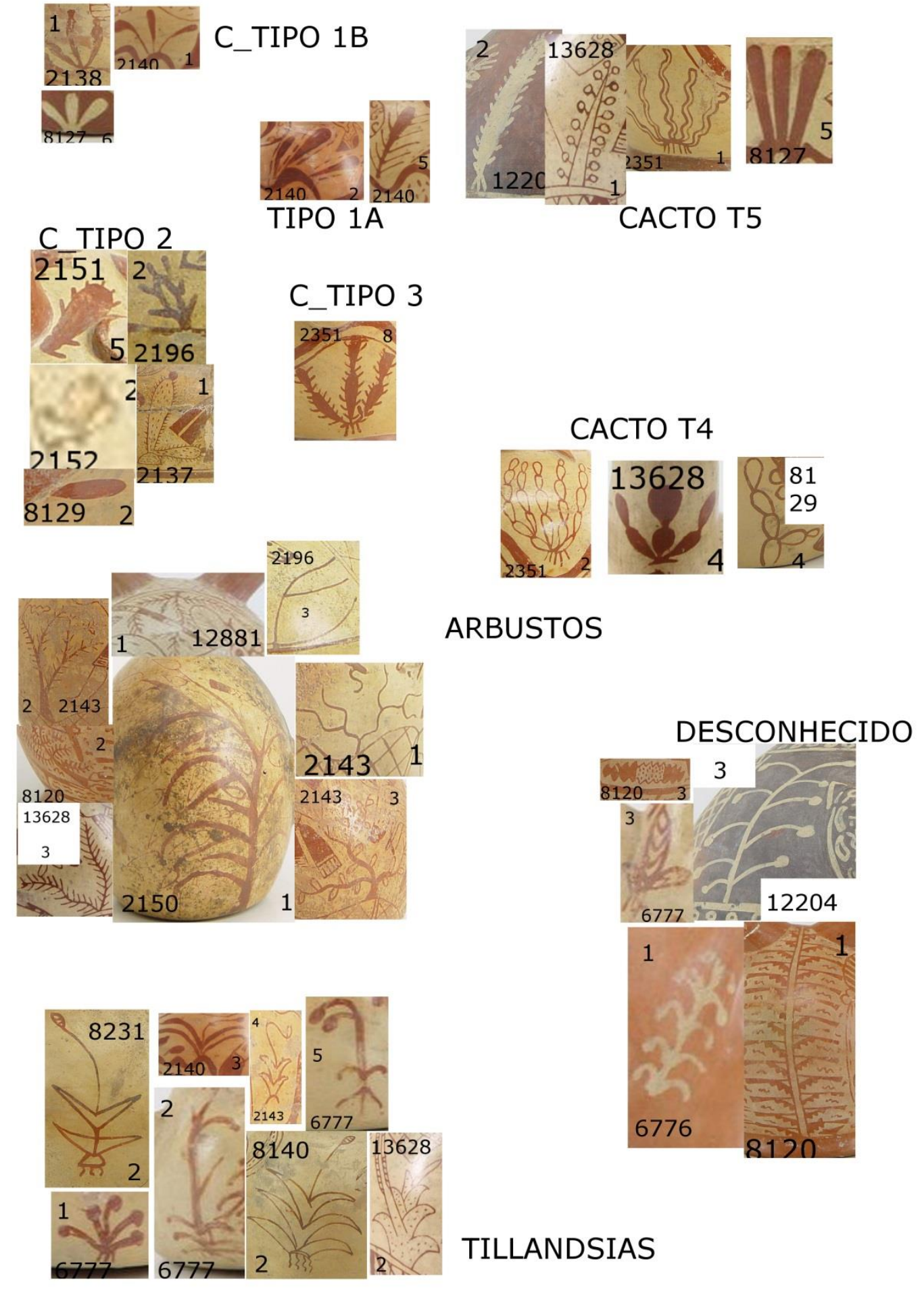




\section{(ANEXO 27) ZORRO_FLORA}
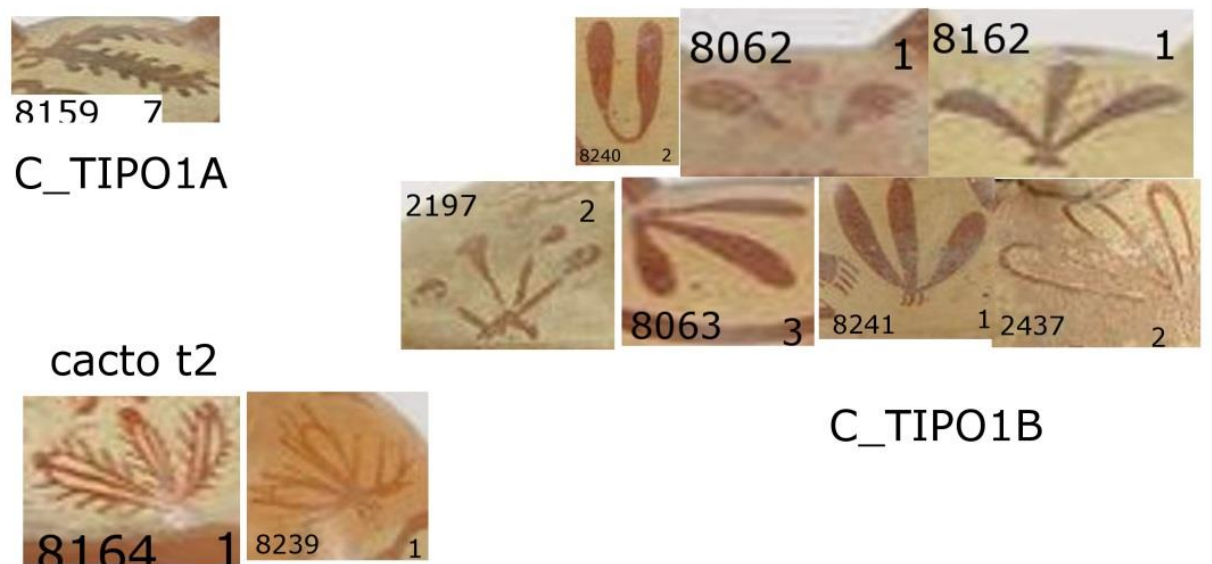

C_TIPO1B

DESCONHECIDO

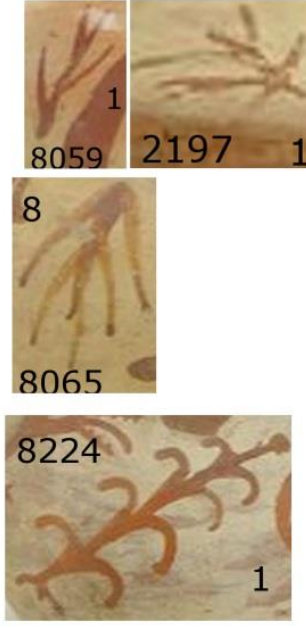

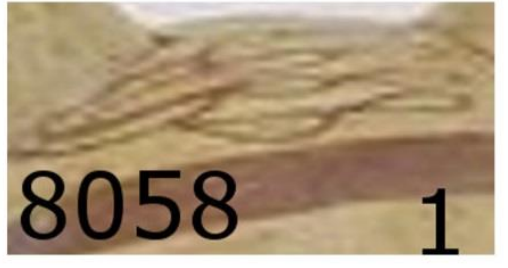

C_TIPO4

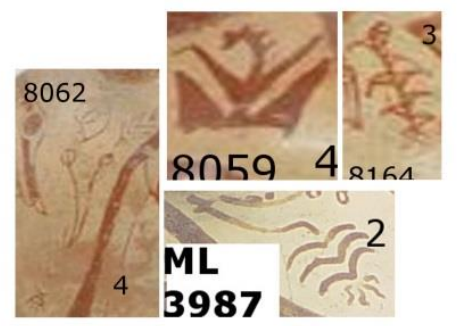

TILLANDSIAS 